European Union Liaison Committee of Historians

Wilfried Loth | Nicolae Păun (eds.)

\title{
Disintegration and Integration in East-Central Europe
}

1919 - post-1989

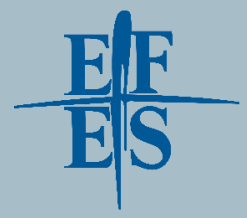


Veröffentlichungen der Historiker-Verbindungsgruppe bei der Kommission der Europäischen Gemeinschaften

Publications of the European Union Liaison Committee of Historians

Volume 16 
Wilfried Loth | Nicolae Păun (eds.)

\title{
Disintegration and Integration in East-Central Europe
}

\author{
1919 - post-1989
}

Nomos

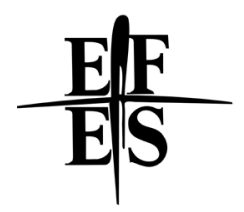


Die Deutsche Nationalbibliothek lists this publication in the Deutsche Nationalbibliografie; detailed bibliographic data is available in the Internet at http://dnb.d-nb.de.

ISBN 978-3-8487-1330-1 (Nomos Verlagsgesellschaft, Baden-Baden) 978-606-526-178-5 (Editura Fundației pentru Studii Europene)

1st edition 2014

(c) Nomos Verlagsgesellschaft, Baden-Baden 2014. Printed in Germany.

This work is subject to copyright. All rights are reserved, whether the whole or part of the material is concerned, specifically those of translation, reprinting, re-use of illustrations, broadcasting, reproduction by photocopying machine or similar means, and storage in data banks. Under $\S 54$ of the German Copyright Law where copies are made for other than private use a fee is payable to "Verwertungsgesellschaft Wort", Munich. 


\section{Table of contents}

INTRODUCTION

Wilfried $\mathrm{LOTH}$

The European Union as a Pan-European Project 13

Ioan-Aurel POP

Preliminaries to European Integration in the Transylvanian Area (Case Study on Unity and Diversity)

The End of Empires AND the AtTEMPts at

Creating a New Balance (1919-1945)

Lucian LEUŞTEAN

The Late Start of the Little Entente. Regional Cooperation within East-Central Europe in Times of Adversity (1920-1921)

Gérard BOSSUAT

L'Europe pour la paix: certitude et interrogations

Sylvain SCHIRMANN

Régionalisme agraire et crédit agricole en Europe Centrale autour de

l'année 1930

\section{Nicolae PÄUN}

Le paradigme du développement économique en Europe Centrale et Orientale pendant l'entre-deux-guerres. Des contributions françaises en Roumanie

Vladimír GONĚC

"New Central Europe" in Co-operating and United Europe. Czechoslovak Ideas in 1920s and 1930s and Attempts at Coordination with Austrian and Hungarian Ideas

Roumiana PRESHLENOVA

Uniting the Balkans: Common Desires and First Initiatives in the Interwar Period 
The End of the Nazi "Empire" in East-Central Europe and the Creation of a New “Empire” in the East (1945-1989)

Gergely FEJÉRDY

La Conférence du Mouvement Européen sur l'Europe Centrale et Orientale en janvier 1952

Nicolas BADALASSI

Un continent, deux blocs, trois idees. Le COMECON, la CEE et le processus d'Helsinki

Jerzy ŁAZOR, Wojciech MORAWSKI

Autarkic tendencies in the Council for Mutual Economic Assistance

Sara TAVANI

Muddling Through the European Bloc System: The Evolution of Italian-Polish Relations over the 1970's and 1980's

Janusz KALIŃSKI, Łukasz DWILEWICZ

The Transferable Rouble and 'Socialist Integration' - What Kind of

Relationship?

1989: THE END OF EUROPE's DIVISION. A NEW

EUROPE THROUGH INTEGRATION

Michael GEHLER

Austria. The Revolutions in Central and South Eastern Europe.

Austrian Perceptions and International Reactions 1989-90

186

Georgi DIMITROV

Ever Closer or Diverging: The Relationship between EC and the

Latecomers (Bulgaria and Romania) Seen Through the Prism of CVM 205

Ewa SZCZEPANKIEWICZ-RUDZKA

Coopération dans le cadre du Groupe de Visegrad à l'épreuve de l'integration européenne. Point de vue polonais.

Marius JUCAN

Rethinking Cultural Relations between the European Union and United States in Age of the Transatlantic Rift

Michael O'NEILL

Atlanticism and the Changing Dynamics of European Security in the 'New Global Order' 


\section{Valentin NAUMESCU}

Between the Economic Agenda and the Need of Strategic Security: East-Central Europe in the Context of the Transatlantic Relation's Disruption

\section{Benedetto ZACCARIA}

The European Community and Yugoslavia in the Late Cold War Years, 1976-1989

Branislav RADELJIĆ

Serbia's EU Future: Concerns and Perspectives

Western Europe's aPPROVAL of EUROPE's EASTWARD

ENLARGEMENT - A STARTING POINT FOR EUROPE'S NEW FUTURE

Antonio VARSORI

Italy's attempts at integrating East-Central Europe in a new continental balance: an early response to the crisis of the Communist bloc (1989-1991)

Wichard WOYKE

Germany and the EU-Eastern Enlargement

Georgiana CICEO

Hard Core Europe? Possible Scenarios for the Prospect of Differentiated Integration?

Iordan Gheorghe BĂRBULESCU, Andra-Maria POPA

A Crisis of the European Model? Reflections and Projections

Ovidiu PECICAN

Integration as Disintegration. Some Remarks on the Romanian Case viewed by Emil Cioran

Alberto GASPARINI

Future Scenarios for United Europe

TABle of Contributors 


\section{Introduction}

This volume is a collection of articles pertaining to the sinuous topic of European Construction in the East-Central European area, throughout the $20^{\text {th }}$ century and beyond, from a dual perspective, as decided by the intricate course of history: disintegration and integration. The contributions presented hereafter were upheld by their respective authors during the colloquium entitled "Disintegration and Integration in East-Central Europe (1919 - post-1989)", which was hosted by the Faculty of European Studies, Babeş-Bolyai University, in Cluj-Napoca, between the $20^{\text {th }}$ and the $23^{\text {rd }}$ of February 2013, in collaboration with the European Union's Liaison Committee of Historians of European Integration.

The 27 scientific papers cover a broad range of perspectives that make up the main topic, which have been divided into four major sections, following the configuration of the aforementioned colloquium. Hence, the introductory article, signed by Wilfried Loth, performs a thorough investigation into the avatars of the broader Pan-European project in this part of the continent. On the other hand, the Rector of Babeş-Bolyai University, PhD Professor and member of the Romanian Academy Ioan-Aurel Pop, aims to provide a historical framework for the area that hosted this scientific event, namely the culturally and linguistically affluent region of Transylvania. Surprising projects aimed at the ideal of European Integration stem from the history of this place, which render the city of Cluj-Napoca, located in the very heart of Transylvania, an optimal location for discussing the origins and outcomes of European Construction in the complex area of East-Central Europe.

The first section of the volume is designed under the auspices of the End of Empires, i.e. the tumultuous period surrounding the First World War and its aftermath, one that ultimately led to the creation of what we have referred to as "a new balance" on the stage of European affairs and beyond. The interwar period fostered numerous attempts at cooperation amongst states in Central and Eastern Europe, which our contributors have analysed from a plethora of viewpoints. Amongst the latter we should outline endeavours of regional cooperation, such as the "Little Entente", skilfully presented by Lucian Leuştean. The synergy between integration projects in the East and West relies on multiple similarities, one of which being the ideal of peace, promoted on both sides of the continent, as proved by Gérard Bossuat. An evident merit of this collection of ideas is not to have left aside the prominent economic perspective, which ultimately turned out to be the driving force of European Construction, albeit the balance between the political and the economic realms has always yielded controversy, in terms of primacy. Thus, Sylvain Schirmann takes the focus on the interwar period to the level of agricultural regionalism and investments, which played a major role in the development 
of East-Central Europe at the time, given the predominantly agrarian character of the vast majority of states in the area. Moreover, the undersigned identifies the principles of what we are entitled to call a genuine paradigm of economic development in the region, during the 1920s and 1930s, which relied massively on foreign investments, a veritable linker between the two sides of the continent, as it emerges from the case study presented on the topic of French capital in the Romanian economy. Last, but most certainly not least, two interesting contributions by Vladimír Goněc and Roumiana Preshlenova have the merit of explaining the framework for cooperation in East-Central Europe in the interwar period, whilst assessing the feasibility of projects stemming from the Czechoslovakian area and the Balkans, respectively.

The second section of the volume follows the course of history, moving beyond the atrocities of the Second World War and the dissolution of the so-called Nazi Empire, in order to focus its attention on the modelling of a new "Empire", in the Eastern part of the European continent. Its existence, spanning the interval between 1945 and 1989, triggered the particularly intricate phenomenon generally referred to as the Cold War, marked by the unnatural separation of the Eastern and Western sides of the continent by an Iron Curtain. The alternatives provided by the Soviet Bloc to the much more effective Marshall Plan nevertheless proved to be resourceful and definitely worthy of in-depth scientific analyses. Therefore, initiatives such as that of the European Movement in 1952 attempted to sketch valid perspectives for the future of this dynamic area, as outlined by Gergely Fejérdy. From an economic standpoint, the parallel development of the Comecon and the European Economic Community exhibits notable differences and approaches to successful integration, all of which are pertinently analysed by Nicolas Badalassi. Furthermore, the Council for Mutual Economic Assistance manifested a series of trends that can only be deemed autarkic, in the opinion of Jerzy Łazor and Wojciech Morawski, with complex economic consequences on the entire Eastern Bloc, whose prosperity and overall level of economic development began to lag behind the more dynamic Economic Community under construction in the West, beginning with the Treaties of Paris and, chiefly, Rome. As case studies illustrating the various levels of economic integration in the area of the continent that interests us, the volume boasts two interesting perspectives, namely the exchange between East and West resulting from the Italian-Polish relations, analysed by Sara Tavani, on the one hand, and the question of monetary integration, portrayed in the controversy over the transferable rouble, pictured by the research of Janusz Kaliński and Łukasz Dwilewicz, on the other hand.

The end of communism and the beginning of the so-called transition in EastCentral Europe have prompted us to include a separate section dedicated to the New Europe and its attempts at integrating into the European Union, thus marking the historic end of division on the continent. Several of the contributions paint the 
picture of accession endeavours by various states in the area, so as to underline the challenges arising in the process, as well as the contributions of the latter to a reunified Europe. A case in point is previewed by Michael Gehler, who performs an analysis of revolutions in East-Central Europe, from the viewpoint of the international community and, in particular, Austria, boasting the preliminary framework for comprehending the future course of action undertaken by the states in the region. The complex dossier engendered by Yugoslavia holds an esteemed place in this chapter, thanks to the research conducted by Benedetto Zaccaria, whilst Serbia's perspectives of European integration are weighed in the balance by the introspective study signed by Branislav Radeljić. Once the way to integration became paved, examples of more or less successful endeavours are provided in ample analyses, such as the one performed by Georgi Dimitrov, on the cases of both Romania and Bulgaria. An additional perspective lies within the framework of the Visegrád Group, whose contribution to the process of integration of not only Poland, but also the rest of its members, is pinpointed through numerous pertinent qualitative analyses performed by Ewa Szczepankiewicz-Rudzka. This context would be incomplete in the absence of the transatlantic partnership, which translates to cultural relations, as well as to the issue of security, in the view of Marius Jucan and Michael O'Neill, respectively. To elaborate on the subject, Valentin Naumescu brings into the equation current matters pertaining to the economic agenda and strategic security, so as to further this ample section dedicated to the relations between the European Union and the United States, with a particular focus on the role played by East-Central Europe in this mutually beneficial partnership.

Needless to say, the integration of East-Central Europe into the European Union would have been inconceivable without the support of the West and its willingness to pave the way for enlargement, in an ultimate feat of what we may perhaps call historical reparation. For this reason, the final section of the book is dedicated to the support provided by Old Europe to the newest member states of the $\mathrm{EU}$, albeit this endeavour has met with considerable hurdles, revolving around the institutional, economic and identity crises of modern European Construction. Our contributors have provided two important studies focusing on the Italian and German attitudes towards Eastern enlargement, thanks to the research of Antonio Varsori and Wichard Woyke, respectively. Nevertheless, in the intricate context fostered by Euroscepticism, opt-out mechanisms and institutional dysfunctions, the prospects of differentiated integration are looming on the horizon, as it has been accurately portrayed by Georgiana Ciceo in her original article, centred on the idea of "hard core Europe". The overview of the current state of affairs within the European Union would certainly be incomplete without a comprehensive approach to the crisis it is experiencing, whose roots may be traced to the very essence of the European Model. A welcome scientific contribution by Iordan 
Gheorghe Bărbulescu and Andra-Maria Popa explores the core of this peculiar phenomenon and paints a realistic picture of a potential outcome of the current crisis. Ovidiu Pecican then conducts an interesting exploration of the universe of Emil Cioran. The ending of this book has been entrusted to Alberto Gasparini, whose exploration of civil societies and social classes within the European Union at this time enables the author to propose a plethora of scenarios which are likely to draw the guidelines of future European Integration, moving along the sinuous and unpredictable path to political union.

This historical thread, pursued due to the research of reputable scholars in the area of European Integration, has the merit of providing a comprehensive insight into the state of integration of East-Central European countries. The chronological perspective adopted by the four sections of the book enables the reader to explore the roots of this phenomenon, the numerous obstacles that have arisen amid political and social turmoil, the various alternative models proposed by the dominant political class and, ultimately, the option for reconstructing a united continent. The thesis of the Two Europes, deeply rooted in the interwar period, witnesses a recalibration following the collapse of the dreaded Iron Curtain, with the emergence of a New Europe, in a quest for identity and recognition. The synergies between the latter and the more experienced Western part of the continent in terms of integration have enabled the European Union to become stronger, more united and more representative in a world driven by globalisation, with the fresh empowerment of a regained East-Central part, overflowing with ambition, eagerness to make a stand, but also with challenges and facing a long way ahead before it achieves its ambitions.

Dr. Nicolae Păun

Professor Jean Monnet Ad Personam of European Integration 


\title{
The European Union as a Pan-European Project
}

\author{
Wilfried LOTH
}

\begin{abstract}
In the first plans for European integration presented in the years after World War I a borderline between Eastern Europe and Western Europe was never envisaged. People from Middle and Eastern Europe articulated them in the same perspective as people from Western Europe, and this perspective was a pan-European one. As a consequence, overcoming the communist rule in the countries of the Soviet bloc in Europe remained one of the reasons of the process of European integration; and the inclusion of the countries of the former communist bloc in this process became inevitable as soon as the communist rule collapsed.

Keywords: European Movement, Governments in Exile, Marshall Plan, Plans for European Integration, Resistance
\end{abstract}

Contemporaries of the Cold War saw the European Union mostly as an element of Western integration and Western block building. As a consequence, the hostile attitude of the Soviet Union towards the efforts to integrate Western Europe seemed quite natural, and even if Soviet officials had great difficulties to explain the success of these efforts in terms of Marxist-Leninist theory, ${ }^{1}$ the enduring tensions between the European Communities and the Soviet Union could be easily understood. When after the collapse of the Soviet bloc former member countries aimed at becoming members of the EU this was usually interpreted as an expansion of the integrated West.

However, if we look more closely on the beginnings of European integration we can discover that the integrated Europe was much more than a consequence of the Cold War and that, as a consequence, the hostility of the Soviet Union towards the EU was not as inevitable as it seems to have been. Broadly speaking, four different driving forces can be recognized behind the process of European integration: the maintenance of peace among sovereign states in Europe; the resolving of the German question - that is the problem of a potentially dominant state in the middle of the European continent; the preservation of economic productivity in a time of national markets in Europe becoming too small for rational production methods; finally the self-assertion in the face of the new world powers, the US as well as the Soviet Union. ${ }^{2}$ It should be no surprise that such motives emerged not only in the Westerns parts of the European continent but in its Eastern parts as well.

1 See Wolfgang Müller, “The Soviet Union and Early West European Integration”, in: Journal of European Integration History 15 (2009/2), pp. 67-85.

2 For a general view, see Wilfried Loth, "Explaining European Integration: The Contribution from Historians”, in: Journal of European Integration History 14 (2008/1), pp. 9-26. 
In the first plans for European integration presented in the years after World War I a borderline between Eastern Europe and Western Europe was never envisaged. People from Middle and Eastern Europe articulated them in the same perspective as people from Western Europe, and this perspective was a pan-European one. The only dispute splitting the adherents of the European idea was if Great Britain should become a member of a united Europe or not. Richard Coudenhove-Kalergi in his book on "Paneuropa" did not envisage a British participation whereas the adherents of the "Union for a European Understanding" aimed at a strong connection with the Brits. The representatives of middle and east European countries had a considerable part in the activities and congresses of the European movement; their unions had their offices in Budapest and Prague as well as in Brussels, Paris and Vienna. The strongest groups of Coudenhove's "Pan-European Union" and the "European Customs Union" directed by the Hungarian economist Elmer Hantos were established in the capitals of Middle and Eastern Europe. The cartel of Western European steel producers established in 1926 due to the efforts of Emile Mayrisch was joined one year later by the steel producers of Austria, Hungary and Czechoslovakia. ${ }^{3}$ In the planning of European integration during the years of World War II ${ }^{4}$ the Eastern Europeans were also participating at the same degree as the Western Europeans. Even more: This time, the most specific and detailed planning was developed by the representatives of the exiles and resistance of Eastern Europe. As early as 11 November 1940, the Polish government in exile under General Wladysław Sikorski and the provisional Czech government under President Eduard Beneš had issued a joint declaration of their intention "to enter, as independent and sovereign states, into a closer political and economic association" which was to be joined by "other countries in that part of the European

3 Walter Lipgens, A History of European Integration 1945-1947. The Formation of the European Unity Movement, Oxford: Clarendon Press 1982, pp. 35-44; Anita Ziegerhofer-Prettenthaler, Botschafter Europas. Richard Nikolaus Coudenhove-Kalergi und die Paneuropa-Bewegung in den zwanziger und dreißiger Jahren, Vienna: Böhlau 2004; Oliver Burgard, Das gemeinsame Europa - von der politischen Utopie zum außenpolitischen Programm. Meinungsaustausch und Zusammenarbeit proeuropäischer Verbände in Deutschland und Frankreich 1924-1933, Frankfurt/Main, 2000; Włodzimierz Borodziej / Heinz Duchhardt / Małgorzata Morawiec / Ignác Romsics (eds.), Option Europa. Deutsche, polnische und ungarische Europapläne des 19.und 20. Jahrhunderts, 3 vols., Göttingen: Vandenhoeck \& Ruprecht, 2005; Vladimír Goněc, „Milan Hodža before Milan Hodža. His early schemes and concepts of Europe”, in: Vladimír Goněc (ed.), In Between Enthusiasm and Pragmatism: How to Construct Europe? Six Studies, Brno: Masaryk University, 2008, pp. 66-112.

4 See Wilfried Loth, "Sources of European Integration: The Meaning of Failed Interwar Politics and the Role of World War II", in: Ludger Kühnhardt (ed.), Crises in European Integration. Challenges and Responses, 1945 - 2005, New York / Oxford: Berghahn, 2009, pp. 19-32; Walter Lipgens (ed.), Documents on the History of European Integration. Vol. 1: Continental Plans for European Union, 1939-1945; Vol. 2: Plans for European Union in Great Britain and in Exile, 1939-1945, Berlin / New York: de Gruyter, 1985/1986. 
continent". ${ }^{5}$ On 23 January 1942, the two governments concluded a formal agreement in which they undertook to form a Polish-Czechoslovakian "confederation" after the war. They agreed that periodical meetings of the deputies and governments of both countries should provide a close coordination and the development of common policies of both countries.

Sikorski and the Polish government in exile wanted to go even further. Their plan for a union with Czechoslovakia envisaged the establishment of common ministries of Foreign affairs, Defense and Common Economic affairs as well as the organization of a common General Staff in times of war. The "Federal government" constituted in this way should be controlled by a Parliamentary Assembly and a "Highest Council". However, Beneš who was very skeptical on the federal idea and more interested in economic integration rather than in political-military unification could not be convinced to agree on more than on the confederative form of association. So, in the construction agreed in January 1942 the national governments preserved the last word in any case of conflict.

During the same time as the Polish and the Czechoslovakian governments in exile the governments of Yugoslavia and Greece negotiated a bilateral association, too; and the conflict lines between them were similar. In this case, it was the government in exile of Yugoslavia and especially the Foreign minister Ničič who aimed at a federative form of the planned Union of the Balkans - including a common chancellor and common authorities on political, military and economic questions based on the respective national ministries. The member countries of the Union should strive for an economic and monetary union and a common army; furthermore, they should coordinate their foreign policy. In contrast to this, the Greeks wanted to minimize the degree of integration. However, differently from the case of the Polish-Czechoslovakian Union it were the federalists who succeeded in these negotiations, due to an intervention by British Foreign minister Anthony Eden: The confederation agreement signed by both governments on 15 January 1942 included the organization of a "common office" charged to execute the decisions of the common authorities. Among the purposes of the Union both the creation of an economic and monetary union and the organization of a common General Staff were agreed. ${ }^{6}$

5 Text in The Times, 12 Nov. 1942. Cf. Walter Lipgens, "East European Plans for the Future of Europe: The Example of Poland", in: Documents, vol. 1, pp. 609-658; Feliks M. Goss and M. Kamil Dziewanowski, "Plans by Exiles from East European Countries", in: Documents, vol. 2, pp. 353-413; Feliks Gross, "Views of East European Transnational Groups on the Postwar Order in Europe", ibid., pp. 754-785; Jósef Łaptos and Marius Misztal, American Debates on Central European Union 1942-1944. Documents of the American State Department, Brussels: P.I.E. Peter Lang, 2002; Vladimír Goněc, Hubert Ripka: un Européen, Brno: Masaryk University, 2006, pp. 46-78.

6 Detlef Brandes, "Confederation plans in Eastern Europe during World War II", in: Michel Dumoulin (ed.), Wartime Plans for Postwar Europe 1940-1947, Brussels: Bruylant, 1995, pp. 83-94. 
The great majority of those belonging to the Eastern European resistance, drawn mostly from the ranks of the political center and the socialist left, saw in these agreements the prelude to a federalization of the Eastern European region within an overall European context. A number of figures turned their attention to a combination of Eastern-Central European federation, Danube federation, and Balkan federation; others, including Sikorski, wanted to gather the whole of Eastern-Central and South-Eastern Europe into one federation. At a meeting with King Peter II of Yugoslavia, immediately after the signature of the agreement between Yugoslavia and Greece, Beneš called the two confederations "the base for a more comprehensive treaty and a general peace settlement in Middle and Southeastern Europe". The King declared himself in favor of cooperation between his country and Czechoslovakia in the framework of an "international community of Europe". ${ }^{7}$ However, for the Greek government this connection between the Middle-European and the Southeastern European Confederation went too far, at least for the time being: The Greeks didn't want to be involved in the disputes of Poland with the Soviet Union. Within the Yugoslavian government even a possible extension of the Balkan confederation on Bulgaria met on opposition. As a consequence, the governments of Yugoslavia and Greece agreed in November 1942 to postpone negotiations on the possible inclusion of neighbor countries of the Soviet Union in the confederation after a settlement of territorial and political disputes of these countries with the Soviet Union.

The integration of the regional federations into a greater Europe was discussed for the first time at a round of meetings organized by Sikorski at the headquarters of most of the governments in exile in London. At his invitation, representatives of Poland, Czechoslovakia, Norway, Belgium, the Netherlands, Luxemburg, Greece, and Yugoslavia as well as the "Free France" Committee met to air their views on the organization of a "European community". The negotiations lasted for the whole of 1942, and in the process, it became apparent that there was considerable agreement on the need to surrender sovereignty to the community and for the participant states to be organized democratically. It was also clear, however, that it was no longer feasible to decide on the overall structure of Europe without the involvement of the new world powers and that the problem of securing peace could in any event no longer be solved predominantly on the European level. ${ }^{8}$

It is common wisdom in most of the literature that these federation or confederation plans for the Eastern region of Europe failed due to the veto of the Soviet Union. ${ }^{9}$ This is not entirely correct. When in December 1941 British foreign minister Eden negotiated with Joseph Stalin about the postwar settlement for

$7 \quad$ Ibid. p. 86.

8 See the report by Paul Henri Spaak, Memoiren eines Europäers, Hamburg: Hoffman und Campe, 1969, p. 117. A detailed reconstruction of these talks is still lacking.

9 See Lipgens, A History, pp. 68-72. 
Europe the Soviet leader declared to have "no objections against the founding of state federations in Europe". ${ }^{10} \mathrm{He}$ did not fundamentally reject Churchill's concept of a "European Council" in the framework of the United Nations. At the Tehran Conference in November of 1943 he only insisted that the United States as well as the Soviet Union should be members of the European Council, as well as of the Asiatic one. A European Council without Soviet participation seemed to him too insecure vis-à-vis the risk posed by Germany as well as the antiSoviet tendencies in Eastern Europe, and might even emerge as an instrument for the formation of an imperialist power block under British leadership. ${ }^{11}$ The first and most comprehensive war objectives programme of the Moscow leadership, edited by the chairman of the Commission for the Planning for Reparations to be Extracted from the Defeated Enemy States, Ivan Maiskii, and handed to Foreign Minister Vyacheslav Molotov on 11 January 1944, simply stated that it would not be "in the interest of the Soviet Union to promote the creation of federations of different kinds" in Europe, "at least during the first period after the war". ${ }^{12}$

At close look, the federation plans for Eastern Europe failed due to the PolishSoviet quarrel about the Eastern borderline of Poland. In order to avoid an involvement in this dispute Beneš declared in November of 1942 that he considered the time "not yet ripe" for the realization of the federation project with Poland. When Stalin broke off diplomatic relations with the Polish government in exile in May of 1943, Beneš likewise ended the negotiations with the Poles. ${ }^{13}$ After this break in the other circles of Eastern European exiles support for federation plans rapidly dwindled too; to pursue them in light of the Soviet-Polish dispute seemed neither sensible nor realistic. Following Sikorski's death in an air crash in July of 1943, discussions among the governments in exile in London were not pursued any further. ${ }^{14}$

10 Conversation Stalin - Eden 16 December 1941, Soviet minutes in: Georgij P. Kynin / Jochen Laufer (eds.), SSSR I germanskij vopros 1941-1949. Vol. 1: 22 ijunja 1941 g. - 8 maja 1945 g, Moskva: Meshdunarodnye Otnoscheija, 1996, pp. 124-135.

11 See Keith Sainsbury, The Turning Point. Roosevelt, Stalin, Churchill and Chiang-Kai-Shek, 1943. The Moscow, Cairo and Teheran Conferences, Oxford/New York: Oxford University Press, 1985.

12 Published in: Istocnik, 4/1995, pp. 124-144; reprinted in SSSR I germanskij vopros, Vol. 1, pp. 333-360. On the context see Geoffrey Roberts, Stalin's War. From World War to Cold War, 1939-1953, New Haven / London: Yale University Press, 2006; Wilfried Loth, Die Sowjetunion und die deutsche Frage. Studien zur sowjetischen Deutschlandpolitik von Stalin bis Chruschtschow, Göttingen: Vandenhoeck \& Ruprecht, 2007, pp. 27-47; Jochen Laufer, Pax Sovietica. Stalin, die Westmächte und die deutsche Frage 1941-1945, Köln: Böhlau, 2009.

13 Piotr S. Wandycz, Czechoslovak-Polish Confederation and the Great Powers 1940-1943, Bloomington: Indiana University Publications, 1956, pp. 75-88.

14 Gross, Views of East European Transnational Groups, p. 759. 
This end of official negotiations notwithstanding representatives of the democratic forces in the countries of Middle and Eastern Europe continued to look after possibilities to realize the federation plans and to engage themselves for these plans in public, as long as the completion of Communist power control did not yet prevent them to do so. For instance, in 1945-46 the Chairman of the Committee of Foreign Affairs in the Hungarian Parliament, Paul von Auer continuously propagated the creation of Danubian federation in the framework of "United States of Europe". The governments of Hungary and Romania worked for a comprehensive bilateral settlement and the preparation of a customs union. In April 1947 the Chairman of the European Union of Federalists, Henri Brugmans was invited to Prague to prepare the foundation of a Czechoslovakian section of this federalist movement. If in Poland the liberty of action for federalists was already much more restricted after the establishment of the Lublin committee, Polish politicians who had remained in exile or were forced to leave the country once again in 1947 were strongly in favor of the federalist idea. In a poll organized by Coudenhove-Kalergi 89 percent of them declared their support for the integration plans. ${ }^{15}$

Given these circumstances it was no surprise that the overwhelming majority of the organized European movement in the Western parts of the European continent didn't see their project in the first stance not as a Western project to contain the danger of Soviet expansionism but on the contrary as a means to avoid the division of Europe into East and West. As Brugmans said at his visit in Prague: "What European federalism can offer Czechoslovakia is the following: there will be no attempt to detach the country from the USSR or Slav solidarity", but "the object is to keep the Slavic world in Europe open in both directions and not confront these nations with a choice between Russia and the West. A United Europe will make it possible to work with both". ${ }^{16} \mathrm{~A}$ basic resolution issued by the enlarged Central Committee of the Union of Federalists stated in April 1947: "that a European Federation is essential to overcome bloc politics and thus to avoid a new conflict which would be the inevitable result of the division of the world into spheres of influence". ${ }^{17}$

During the years 1945 to 1947, only a few Europeans welcomed the concept of integrating Western Europe within a Western bloc. When Winston Churchill, in his Zurich speech of September 19, 1946 called for the creation of "a kind of United States of Europe" which was to defend against the "approach of some new peril, tyranny, or terror", - that is: a Western Europe which was to defend against Soviet expansionism - he reaped much more opposition than consent. ${ }^{18}$ This was

15 Lipgens, A History, pp. 444-457; Goněc, Ripka, pp. 79-90.

16 Lipgens, A History, pp. 448f.

17 Ibid. p. 381.

18 Text in: Walter Lipgens / Wilfried Loth (eds.), Documents on the History of European Integration, Vol. 3: The Struggle for European Union by Political Parties and Pressure 
the major reason why the Truman administration offered its Marshall Aid program not only to the countries of Western Europe but also to those of Eastern Europe and to the Soviet Union. The US didn't want to take over the burden of responsibility for the division of the European continent. ${ }^{19}$

By rejecting the Marshall offer Stalin who believed himself much cleverer than the degenerated imperialists, stepped into this trap. ${ }^{20}$ The numerous advocates of a Europe of the "Third force" between East and West could only react by opting for a "Begin in the West". However, it should be noted that they argued just in favor of a "begin". They took this decision hesitantly and with the conviction that even a union of the Western European countries only could and would work in favor of an overcoming of the blocs. As the Italian federalist Altiero Spinelli put it on the congress of the European Union of Federalists in August 1947 in Montreux: "A European federation, even a partial one, will possess that independence vis-à-vis America that the Western states can no longer achieve individually. Such a federation can further restrain and finally do away with the pernicious policy of spheres of influence [...] it can gradually bring back the values and institutions of democratic civilization to those countries which have departed from them". ${ }^{21}$

I must admit that not all supporters of real existing process of European integration since 1950 did share these long-term aims. Also, during the long experience of a bi-polar world the Pan-European perspective was simply forgotten by many of them. Nevertheless, overcoming the communist rule in the countries of the Soviet bloc in Europe remained one of the reasons of the process of European integration; and the inclusion of the countries of the former communist bloc in this process became inevitable as soon as the communist rule collapsed. Politicians and citizens of the EU had to admit that, as the Federalists in Montreux had stated in August 1947, "it is impossible in the final event to achieve a closely knit Europe for which life is possible unless all its constituent countries, north, south, east and west, pool their complementary qualities and economies", and that "the traditions and culture of each of these peoples are part and parcel of the common European heritage". ${ }^{22}$

Groups in Western European Countries 1945-1950, Berlin / New York: de Gruyter, 1988, pp. 662-666. On the reaction, see pp. Lipgens, A History, pp. 341-347.

19 See Wilfried Loth, "The Marshall Plan and European unification: Impulses and Restraints", in: John Agnew / J. Nicholas Entrikin (eds.), The Marshall Plan Today: Model and Metaphor, London / New York: Routledge, 2004, pp. 217-233.

20 See Scott D. Parish, "The Marshall Plan, Soviet-American-Relations, and the Division of Europe", in: Norman Naimark / Leonid Gibianski (eds.), The Establishment of Communist Regimes in Eastern Europe, 1944-1949, Boulder, Co., 1997, pp. 267-290; Mikhail M. Narinsky, "Sovětský svaz a Marshallûv plán. Ještě k otázce sovětského veta", in: Soudobé dějiny 4 (1997/3-4), pp. 479-491.

21 Lipgens, A History, p. 582.

22 Ibid. p. 583. 
Given this historical background, the Eastern enlargement of the EU in 2004 and the following years was in the first place not an expansion of the West but a long awaited completion of the beginnings in the late 1940's and early 1950's. When on the $1^{\text {st }}$ of May 2004 the heads of 25 states and governments and their Foreign Ministers met in Phoenix Castle near Dublin to celebrate the accession of 10 new member states, it was Lithuana's Foreign Minister Sandra Kalniete who coined the sentence of the day: "This is Europe's triumph over the $20^{\text {th }}$ century". ${ }^{23}$ It is important to see that she was right.

\section{Bibliography}

Borodziej, Włodzimierz / Heinz Duchhardt / Małgorzata Morawiec / Ignác Romsics (eds.). Option Europa. Deutsche, polnische und ungarische Europapläne des 19. und 20. Jahrhunderts, 3 vols., Göttingen: Vandenhoeck \& Ruprecht, 2005.

Brandes, Detlef: "Confederation plans in Eastern Europe during World War II", in: Michel Dumoulin (ed.), Wartime Plans for Postwar Europe 1940-1947, Brussels: Bruylant 1995, 83-94.

Burgard, Oliver: Das gemeinsame Europa - von der politischen Utopie zum außenpolitischen Programm. Meinungsaustausch und Zusammenarbeit proeuropäischer Verbände in Deutschland und Frankreich 1924-1933, Frankfurt/Main, 2000.

Goněc, Vladimír: Hubert Ripka: un Européen, Brno: Masaryk University, 2006.

Goněc, Vladimír: „Milan Hodža before Milan Hodža. His early schemes and concepts of Europe", in: Vladimír Goněc (ed.), In Between Enthusiasm and Pragmatism: How to Construct Europe? Six Studies, Brno: Masaryk University, 2008, 66-112.

Kynin, Georgij P. / Jochen Laufer (eds.): SSSR I germanskij vopros 1941-1949. Vol. 1: 22 ijunja 1941 g. - 8 maja 1945 g, Moskva: Meshdunarodnye Otnoscheija 1996.

Laptos, Jósef / Marius Misztal: American Debates on Central European Union 1942-1944. Documents of the American State Department, Brussels: P.I.E. Peter Lang, 2002.

Laufer, Jochen: Pax Sovietica. Stalin, die Westmächte und die deutsche Frage 1941-1945, Köln: Böhlau, 2009.

Lipgens, Walter: A History of European Integration 1945-1947. The Formation of the European Unity Movement, Oxford: Clarendon Press, 1982.

Lipgens, Walter (ed.): Documents on the History of European Integration. Vol. 1: Continental Plans for European Union, 1939-1945;Vol. 2: Plans for European Union in Great Britain and in Exile, 1939-1945, Berlin / New York: de Gruyter, 1985/1986.

Lipgens, Walter / Wilfried Loth (eds.): Documents on the History of European Integration, Vol. 3: The Struggle for European Union by Political Parties and Pressure Groups in Western European Countries 1945-1950, Berlin / New York: de Gruyter, 1988.

Loth, Wilfried: "The Marshall Plan and European unification: Impulses and Restraints", in: John Agnew / J. Nicholas Entrikin (eds.), The Marshall Plan Today: Model and Metaphor, London / New York: Routledge 2004, 217-233.

23 Günter Verheugen, Europa in der Krise. Für eine Neubegründung der europäischen Idee, Köln: Kiepenheuer \& Witsch, 2005, p. 63. - For an assessment of the enlargement of 2004/2007 see Antoine Marès, "Central Europe in the 'Fifth' Enlargement of the European Union”, in: Wilfried Loth (ed.), Experiencing Europe.50 Years of European Construction 1957-2007, Baden-Baden: Nomos, 2009, pp. 326-345. 
Loth, Wilfried: Die Sowjetunion und die deutsche Frage. Studien zur sowjetischen Deutschlandpolitik von Stalin bis Chruschtschow, Göttingen: Vandenhoeck \&Ruprecht, 2007.

Loth, Wilfried: "Explaining European Integration: The Contribution fromHistorians", in: Journal of European Integration History 14 (2008/1), 9-26.

Loth, Wilfried: "Sources of European Integration: The Meaning of Failed Interwar Politics and the Role of World War II", in: Ludger Kühnhardt (ed.), Crises in European Integration. Challenges and Responses, 1945 - 2005, New York / Oxford: Berghahn 2009, 19-32.

Marès, Antoine: "Central Europe in the 'Fifth' Enlargement of the European Union", in: Wilfried Loth (ed.), Experiencing Europe. 50 Years of European Construction 1957-2007, BadenBaden: Nomos 2009, 326-345.

Müller, Wolfgang: "The Soviet Union and Early West European Integration", in: Journal of European Integration History 15 (2009/2), 67-85.

Narinsky, Mikhail M.: "Sovětský svaz a Marshallûv plán. Ještě k otázce sovětského veta", in: Soudobé dějiny 4 (1997/3-4), 479-491.

Parish, Scott D.: "The Marshall Plan, Soviet-American-Relations, and the Division of Europe, in: Norman Naimark / Leonid Gibianski (eds.), The Establishment of Communist Regimes in Eastern Europe, 1944-1949, Boulder, Co., 1997, 267-290.

Roberts, Geoffrey: Stalin's War. From World War to Cold War, 1939-1953, New Haven / London: Yale University Press, 2006.

Sainsbury, Keith: The Turning Point. Roosevelt, Stalin, Churchill and Chiang-Kai-Shek, 1943. The Moscow, Cairo and Teheran Conferences, Oxford /New York: Oxford University Press, 1985.

Spaak, Paul Henri: Memoiren eines Europäers, Hamburg: Hoffman und Campe, 1969.

Verheugen, Günter: Europa in der Krise. Für eine Neubegründung der europäischen Idee, Köln: Kiepenheuer \& Witsch, 2005.

Wandycz, Piotr S.: Czechoslovak-Polish Confederation and the Great Powers 1940-1943, Bloomington: Indiana University Publications, 1956.

Ziegerhofer-Prettenthaler, Anita:Botschafter Europas. Richard Nikolaus Coudenhove-Kalergi und die Paneuropa-Bewegung in den zwanziger und dreißiger Jahren, Vienna: Böhlau, 2004. 


\title{
Preliminaries to European Integration in the Transylvanian Area (Case Study on Unity and Diversity)
}

\author{
Ioan-Aurel POP
}

\section{What is Transylvania?}

Through some of its most important characteristics, Transylvania may be considered (and it sometimes was) a smaller Europe. Although, due to its Latin resonance, the name Transylvania (initially Ultrasilvana) may seem rather exotic and old, it actually does not date back to the antiquity, but to the threshold of the first and the second millennia of the Christian era, meaning "over the forest" or "beyond the forest". ${ }^{1}$ Today, the name is given, in the common language, to a wide area (of almost 100,000 square kilometres), situated to the north of the Southern Carpathians (the Transylvanian Alps) and west of the Eastern Carpathians, an integrative part of Romania, accounting for approximately $40 \%$ of the surface area of the country. The current population of Transylvania is approximately 7 million (more than a third of Romania's population), of which over $75 \%$ are Romanians, approximately $17 \%$ are Hungarians, and the rest are Roma (Gypsies), Slavs, Germans etc.

\section{The image of Transylvania - the smaller Europe}

In the $21^{\text {st }}$ century, this Transylvania (Erdély in Hungarian, Siebenbürgen in German) still bears the marks of a troubled past considerably different from anything experienced by other regions of Europe. At first glance, quite striking in both rural and urban areas is the close proximity of various churches, from the Byzantine and Neo-Byzantine cupolas of the Orthodox churches to the Gothic towers piercing the urban skyline, from the round arches of the Romanesque churches to the Baroque façades of other places of worship. In some regions, on an area measuring barely a few hundred square meters, one can see Orthodox and Greek-Catholic churches standing beside Roman-Catholic, Calvinist, Lutheran or Unitarian ones, all not very far from a synagogue. For instance, in the city of Cluj-Napoca (Clus, Kolozsvár, Klausenburg, Claudiopolis), the traditional capital of the province, we find today five Christian prelates of episcopal rank or higher (an Orthodox metropolitan bishop, a Greek-Catholic bishop, a Calvinist bishop, a Lutheran bishop and a Unitarian one), as well as an episcopal vicar (RomanCatholic), while the local Babeş-Bolyai University (with approximately 42,000 undergraduate, postgraduate and doctoral students and faculty members) has four

1 See I.-A. Pop, Romanians and Hungarians from the 9th to the 14th Century. The Genesis of the Transylvanian Medieval State, Cluj-Napoca, 1996, pp. 5-11, 140-151. 
faculties of theology (two having Romanian as the language of instruction and two where the teaching is done in Hungarian), according to the main historical denominations of the country. Transylvania is the only place in Europe to have such a complex cultural and religious structure, the only place where Romanesque and Gothic monuments stand beside Byzantine, Renaissance, Baroque or even Secession (Modern Style, Jugendstil, Art Nouveau) ones. East of the Transylvanian border, the Romanesque style is completely absent and the Gothic blends into the Moldavian style devised in an old Romanian environment that spiritually vacillated between Constantinople (the New Rome) and Moscow (the Third Rome), following the path of "Byzantium after Byzantium" (to quote Nicolae Iorga) or of the Byzantine Commonwealth, as Dmitri Obolenski put it. ${ }^{2}$

During the Middle Ages, Transylvania brought together the models of Eastern (Orthodox) and Western (Catholic) spiritual life, while the modern era further diversified the landscape by adding Protestant, Hebrew, Neo-Protestant etc. components. For longer or shorter periods of time, all of these models were endangered, competed with and fought one another, threatened one another's existence, but eventually coexisted and exercised mutual influences, shaping this unique Transylvanian world that, for this very reason, came to be known in some circles as a world of tolerance. According to the reality, as well as to each one's interpretation, this Transylvanian "tolerance" meant acceptance and rejection, welcoming and exclusion, equality and segregation, giving its society a sui generis form and functioning.

Consequently, Transylvania's character of a smaller Europe refers to its habitat, to the aspect of the dwellings and of the architectonic styles, to its basic ethnical and linguistic groups (Romanic, German and Slavic, plus Finno-Ugric), to its main religions and cults (Orthodox, Catholic, Hebrew, Protestant and NeoProtestant etc.). All these elements personalise the continent, as Europe (along with Transylvania) reunites all these characteristics under its cupola.

\section{Transylvania - between medieval tradition and modernity}

Transylvania was also a nursery for European ideas concerning, at the same time, habitation and cohabitation, unity and segregation, integration and disintegration, acceptance and exclusion. This heritage and vocation come from ancient times, when the seal of Rome was affixed - two millennia ago - at the Carpathians and at the Danube. At that time, the Thraco-Dacian world was integrated into the tricontinental Roman Empire, a fact that created the premises for the birth - on that

2 Nicolae Iorga, Byzance après Byzance, Bucharest, 1971; Dmitri Obolensky, The Byzantine Commonwealth, Eastern Europe 500-1453, London, 1971; I.-A. Pop, „Bisanzio dopo Bisanzio: la realtà e l'eredità imperiale nell'Europa centro-orientale", in Andrea Piras (ed.), Imperia. Esperienze imperiali nella storia d'Europa, Rimini, 2008, pp. 29-42. 
land - of a Romanic people, i.e. the Romanians. Afterwards, Germanic, Turan (Turkic and Ural-Altaic), Slavic etc. migrants passed. The Slavic people were the most numerous and the most powerful, strongly influencing the Romanian's ancestors and leading to the establishment of neighbouring Slavic states (Bulgaria, Kievian Russia, Serbia, Croatia etc.). At the threshold between the millennia, the Hungarian Finno-Ugric people and the Szeklers appeared, as well as the Germanic "guests" - generically called Saxons (Saxones) - between the $12^{\text {th }}$ and $13^{\text {th }}$ centuries. The main Transylvanian populations in the Middle Ages were the Romanians, the Hungarians, the Saxons and the Szeklers, while the main religions were Orthodoxy and Catholicism. The conquest and integration of Transylvania into the Kingdom of Hungary $\left(11^{\text {th }}-12^{\text {th }}\right.$ centuries $)$, a Catholic state, led to the full acceptance of the Transylvanian Catholic ethnic groups (Hungarians, Saxons, Szeklers) and to the marginalization of the Byzantine or Orthodox communities (mainly Romanians). Initially, their marginalization had ethnic or confessional causes, as a result of the increasing competition between Rome and Constantinople, based on their rivalry over the monopoly of new followers. At a certain point, Hungary - a Catholic state, created within the Patrimonium Sancti Petri and the family of kingdoms within the Roman-German Empire - took very seriously its mission of fighting against "the pagans, the heretics and the schismatics", inside and outside its borders. Or, Romanians were irremediably placed among the "Schismatics" and, consequently, they were meant to be converted or removed from power, banished or even eradicated. It was not possible for those radical plans to be implemented as such, but they undoubtedly led to discrimination. Despite it, the Transylvanian civilisation was built through the common efforts of all aforementioned ethnoconfessional groups.

For many specialists, modern Europe begins with the Protestant Reformation, a movement for which Transylvania was an extremely important scene. The $16^{\text {th }}$ century reformation transformed Transylvanian Catholics into Protestants: the Saxons became Lutherans (Evangelical), the Hungarians and the Szeklers became (most of them) Calvinist and Unitarian, while Catholics largely decreased in number (being mostly concentrated among the Szeklers). As such, a new "constitutional" organisation was imposed in Transylvania, by which Catholics" place in the rule of the country was taken by Protestants. The entire process bears the name of "tolerance regime", meaning that the confessions newly founded through the Reformation were accepted - as a result of some fierce litigations, carried out quite peacefully, with a minimal number of casualties - through the decisions taken by the country's assembly (Diet). Consequently, in a period of approximately three millennia, along with Catholicism (which became weak and had no fortunes, as they had passed to the new authorities), the Lutheran, Calvinist and Unitarian religions became "receptae" (official). The Romanian's eastern Christian fate was still 
not recognized, similarly to the Romanian community that did not have the right to participate in the rule of the country.

During the process of the Protestant Reformation imposition in Transylvania, some generous ideas of freedom (which announced the new age of modernity) were affirmed. The first was that of accepting diversity among the ancient Catholics. As such, one at a time, Lutheranism, Calvinism and, last but not least, Unitarianism (Anti-Trinitarianism) became recognized. At a certain point, due to the general enthusiasm and despite the obvious and quite fierce rivalry existing between the new cults, the country's Diet actually accepted the right of each community (be it rural or urban) to choose their confession ( $16^{\text {th }}$ century). This was an absolute novelty in $16^{\text {th }}$ century Europe. Furthermore, certain approaches to convert Romanians to Protestantism also began. However, the radicalism of the Reformation in Transylvania stopped there and even regressed soon after. As such, at the beginning of the tenth decade of the $16^{\text {th }}$ century, any "religious innovation" was completely stopped by the Diet. Moreover, the permissive right to freely chose one's religion at the community (parish) level was entirely eluded and even prohibited. Catholicism, although formally maintained among the official religions, had no more power, especially as a result of the seizure of its entire fortune, including the possessions owned by the bishops of Alba Iulia and Oradea. Attracting the Romanians to the Reformation was seen with much doubt by Romanians themselves, as well as by the recognized classes and confessions, who felt that their monopolyon power was being threatened. As a result, the initiative failed, the Romanians remaining faithful to their Orthodox belief, but that failure marginalized them and they still lacked the right to participate in the rule of the country. In fact, practically, in certain periods of the $16^{\text {th }}$ and $17^{\text {th }}$ centuries, both the (Romanian) Orthodox and the (Hungarian speaking) Catholics suffered from discrimination, through serious limitations to the exercise of their cults, hierarchy, church properties, access to cities etc. The main difference was that the Romanians / Orthodox were excluded from the ruling of the country, as well as from the right to citizenship, through legally binding official decisions, according to which Catholics were temporarily de facto discriminated, whereas, legally, they were "recepti", i.e. accepted. That fact was extremely important, however, as after the imposing of Austrian domination (1688-1699), the Catholics were de facto resettled in their position of de iure privileged people, while the Romanians remained in the same submissive position of inferior inhabitants.

\section{New and old ideas}

The analysis of this enormous transformation of the Transylvanian society may lead to several useful conclusions for current European construction. In this approach, enthusiasm has to make room for realism, starting from the premise that 
the world in the past should not be assessed according to contemporary values and conceptions, but to the mentalities of the era in question. Or, in $16^{\text {th }}$ century Europe, the transformations occurring in Transylvania were customary and unusual at the same time.

Naturally, a great change manifested itself as a result of the official acceptance of the confessions born from the Reformation. It was undoubtedly a regime of tolerance, of accepting thy neighbour, who was different from you. Generally, that situation was produced without the use of armed force, something that cannot be said about other regions of Europe at the time, such as the more civilised France. If one takes a closer look, however, things do not seem so spectacular anymore. In fact, the ancient Catholic elite in Transylvania, i.e. the country's privileged class, who had mostly turned to Protestantism, had to choose between blaming themselves and continuing to rule the country. The non-recognition of confessions stemming from the Reformation process would have led to their marginalization, to their exclusion from the privileges. In Transylvania, unlike France or Germany, almost all important Saxon, Hungarian and Szekler leaders became, one way or another, the followers of Protestantism. Consequently, Transylvania's leading elite recognized itself, re-officialised itself in order to maintain its powers, i.e. its privileges. Any other solution would have been illogical, unrealistic, leading to self-destruction. As a result, the much simpler recognition of reformed confessions was carried out in Transylvania also due to a self-preservation spirit, in order to maintain the ancient elite as the ruler of the country, whose power was based on medieval autonomies and customs.

The process was, nevertheless, far from being calm and that was not because of Catholicism (which had almost been annihilated in Transylvania before 1570), but rather because of the rivalries existing between the new confessions. The latter, especially Calvinism (practiced by Hungarian speakers) and Lutheranism (mostly adopted by German speakers) fiercely fought for supremacy. A serious rival in this competition- at least in the $16^{\text {th }}$ century - was Unitarianism, the most radical of European Protestant currents, defined (as a new and accepted confession) even in Transylvania, in Cluj. However, the Anti-Trinitarian belief was not new (it was founded on the teaching of Arius, a priest from Egyptian Alexandria, in the $3^{\text {rd }}-4^{\text {th }}$ centuries A.D.) and wad timidly reiterated in the 1540s, in Venice and then Poland, with the help of Giorgio Blandrata, Laelio Socinus, Faustus Socinus, Francesco Stancarus, Mathias Vehe Glirius etc. The most radical Unitarian ideas (engendering several trends, among which the Judeo-Christian one of the Sabbatarians) enjoyed initial success but then lost some of their supporters, especially among the less wealthy Hungarian-speaking communities of Cluj, Turda/Torda/Thorenburg and Arieş/Aranyos. Its advocates supported the uniqueness of God's person and nature, the inexistence of the Holy Trinity, the human nature of Jesus Christ, the falsity of sacraments (sacramenti), of the church's traditions, of the cult of the Virgin Mary and the saints etc. Denying the divinity of Jesus Christ led to 
two radical precepts or principles, clearly stated as follows: 1) He should not be worshiped (nonadoramus); 2) He should not be invoked when in need (noninvocando). Such Unitarian ideas were rejected and criticised not only by Catholics, but also by other Protestant beliefs. Still, together with the other Anti-Trinitarian teachings, they were embraced for a while by the nobility elite, but mostly by the lower Hungarian class. Between 1566 and 1570, the city of Cluj became the world centre of Anti-Trinitarianism, the place where it was founded and affirmed.

\section{Religion and nation}

Confessions born from the Reformation are not specific to certain nations and are not based on ethnicities. On the contrary, they have been officially open to all "languages" (peoples). The fact was obvious in Transylvania as well, where Lutheranism was initially spread among Saxons and then, quite rapidly, among Hungarians, and even among Szeklers, while Unitarianism was embraced by Hungarians and Szeklers etc. Similarly, Hungarians were Lutherans, Calvinists and Unitarian etc. Still, gradually, things started to change, along with the emphasis on the role of ethnicity, as the age of modernity got closer. As such, the Lutheran "religion" or the "religion of Sibiu" gradually became associated with the German inhabitants of Transylvania and came to be known as "the Saxon religion", while the Calvinist "religion" or the "religion of Cluj" was called by some "the Hungarian religion". Many Hungarian nobles abandoned Lutheranism for the very purpose of adhering to a "religion" that was specific to their nation; hence these confessions are also based on ethnical criteria. For instance, the June 1654 Diet of Turda issued a document stating that "As the superintendents ${ }^{3}$ and the priests of the Church of Cluj, or indeed the Hungarian one, and those belonging to the Church of Sibiu, or the Saxon one, have had a lot or arguments, debates, conflicts and differences of opinion on religious matters and especially with regard to the Eucharist $t^{4}$, in order to put an end to differences, appease the conscience of both parties and bring peace to the inhabitants of the country, it has been decided that in future both sides will be allowed to profess and practice the religion and the faith of both Sibiu and Cluj, but no priest from a royal town or from a town in the plains shall be allowed to preach the religion and the faith of the Church of Cluj and forcefully try and persuade the people". ${ }^{5}$ We see that in the country assembly, the Calvinist faith (with its several trends) was dubbed "Hungarian" and

3 Rulers, acting as bishops, of initial Protestant churches.

4 Sacrament through which the believers' communion is performed using bread and wine, transformed, through the power of the Holy Spirit, into the body and blood of God. Martin Luther accepted this sacrament almost in an unaltered way (along with two more of the total seven), albeit Protestants generally rejected the Eucharist or accepted a merely spiritual presence of Jesus Christ amidst them (in Calvinism).

5 Monumenta Comitialia Regni Transylvaniae, redactor Szilágyi Sándor, vol. II (1556-1576), Budapest, 1877, pp. 231-232. 
the Lutheran one "Saxon". In the same spirit, starting with the $16^{\text {th }}$ century, amid the strong affirmation of the Calvinist principate, the overlap between this religion and the Hungarian nation became even more obvious. As such, Transylvanian religions were delineated, although not very sharply, on national criteria. And since Romanians had been synonymous to Orthodoxy for a very long time, in that same spirit, since the $16^{\text {th }}$ century, the word "Wallachian" became synonymous with Orthodox (of eastern or Byzantine belief), so that saying Romanian was the same as saying Orthodox and vice-versa. Step by step, despite certain attempts at reversion, on the Transylvanian scene, Calvinism became the Hungarian religion for a long time, Lutheranism was the German (Saxon) religion, while Orthodoxy was the Romanian religion ("law"). The ethnic pride was obvious: in 1556, after the banishment of Austrians, Francisc Davis became the bishop of not only the Hungarian Lutheran Church, but also the Szeklar Church; Szeklers, however, although they lived in their own enclave, welldelineated under the linguistic and confessional aspects, felt threatened by the proHungarian trend represented by David and elected a Saxon bishop (Matthias Hebler); in 1559, at the moment of his resignation from the position of Lutheran bishop (he had become Calvinist in the meantime), the same Francis David proclaimed himself "Bishop of the Hungarian Churches"; some exegetes believe that Lutheran Hungarians ran the risk of being nationally assimilated by the Saxons, but were saved by the "Helvetic orientation" (or Calvinism), which, from the very beginning, emphasized the promotion of values and national language ${ }^{6}$. As such, the political nations of Transylvania started to be defined according to religion, language, origin, traditions and even territory. The land dominated by the Saxons, given to them by the king (therefore named Fundus Regius), was more and more often called the "Land of the Saxons", the land dominated by the Szeklers was called the "Land of the Szeklers", while the land predominantly inhabited by the Hungarian nobles (the seven comitatus) was sometimes referred to as the "Hungarian Land". Thus, in the land of Transylvania at that time, a gradual strengthening of ethnicity, set against the background of the ancient medieval elitist spirit, partially converted into a modern meaning, with the help of the ideas of communities of origin, language, territory and confession. There, as well as in other regions, confession became an important brand of national identity.

The country of four (five) "religions", or the diversity of spiritual models in Transylvania

In the $16^{\text {th }}$ and $17^{\text {th }}$ centuries, located at the point of contact between the Eastern Byzantine and the Western Latin civilizations, Transylvania provided the example of a European country that was home to a diversity of ethnic groups, religious denominations, cultures and models of civilization. During this period, the political

6 Vígh B., Disputele sinodale..., pp. 70-71. 
nations (estates) gradually turned into modern nations, in the ethnic sense of the term, and the original two denominations (Orthodox and Catholic) were joined by several new ones (Lutheran, Calvinist, Unitarian, Greek-Catholic etc.). These changes were peaceful and violent, quiet and agitated, innovative and retrograde, open to modernity but preserving much of the medieval rigidity. During the modern era, the three political nations (the Hungarian nobles, the Saxons and the Szeklers) turned into two distinct national groups: the Hungarians (who presently also include the Szeklers) and the Germans. Without having been an officially recognized medieval nation, the Romanians nevertheless turned into a modern nation, aware of its role despite the discrimination it faced. The official religion Roman-Catholic - gave birth to the four legally accepted denominations: RomanCatholic, Lutheran, Calvinist and Unitarian. The religion of the Romanians Orthodox - was denied official recognition both before and after the Protestant Reformation. A largely failed attempt at granting them global recognition occurred a bit later, involving the union with the Church of Rome and the creation of the Greek-Catholic Church (around the year 1700).

This extremely diverse landscape witnessed a constant vacillation between acceptance and exclusion, between peaceful integration (assimilation) and ethnicreligious revolt, between privileges and the absence thereof, between tolerance and intolerance. For centuries on end, that was the normal and natural state of affairs, in the sense that a "Catholic and apostolic" kingdom like Hungary had the mission and obligation to protect and favour Catholics and to take discriminatory measures against the others.

Consequently, religious tolerance has to be understood in the context set by the era, within its limits, marked by the arsenal of a medieval heritage. Under no circumstances should tolerance be mistaken for full religious freedom or for absolute equality between religions. Hence, it is easy to see the great rivalries between the new Protestant religions and the periods of domination of one or another, as well as the hegemony of Calvinism in the $17^{\text {th }}$ century. Leaving aside the constantly inferior status of the Orthodox Church, one has to notice the persecution of Catholicism and its church, especially by the Unitarians (dominant between 1567 and 1571). So powerful was the assault that the Catholic Church almost disappeared from Transylvania or was forced to manifest itself cryptically.

In conclusion, it could be stated that, in Transylvania, the Reformation quickly changed the landscape of political nations, i.e. of the leading elite of the country. It transformed the latter from Catholic into Protestant. Power was collegially exercised by the Hungarians, the Saxons and the Szeklers, who, from that moment on, were the followers of four religions: Calvinist, Lutheran, Unitarian and Catholic. The inhabitants of the different nations and confessions lived separately and together at the same time. Therefore, from the political viewpoint, a regime of three official nations and four official religions ruled in Transylvania. The Romanians - the most numerous 
inhabitants of the country - were left outside of the equation of power, deemed inhabitants of the inferior class, yet being accepted to live usque ad beneplacitum principum et regnicolarum, i.e. until the good will of the princes and (lawful) citizens lasted.

Therefore, Transylvania was a melting pot of the new modern Europe, with all its freedoms and constraints, with its acceptance and rejection, with ideas for progress and bizarre perpetuations of medieval traditions. From certain points of view, the inhabitants of the Transylvanian Country provided Europe with lessons on generosity and tolerance, which, even though not constantly and generally applied, left in public awareness an imprint of cohabitation that remains valid even at present.

\section{Appendices:}

\begin{tabular}{|l|l|}
\hline Ideas of acceptance (tolerance) & Ideas of exclusion (discrimination) \\
\hline $\begin{array}{l}\text { Official recognition of Lutheranism, Calvin- } \\
\text { ism and Unitarianism }\end{array}$ & $\begin{array}{l}\text { Drastic limitation of Catholicism (expropria- } \\
\text { tion, seizures, interdictions) }\end{array}$ \\
\hline $\begin{array}{l}\text { Recognition of the communities' right to } \\
\text { freely choose their religion }\end{array}$ & $\begin{array}{l}\text { Unfair competition between the new reli- } \\
\text { gions; pressures to attract Christians }\end{array}$ \\
\hline $\begin{array}{l}\text { The collegial participation in the exercise of } \\
\text { power }\end{array}$ & $\begin{array}{l}\text { Exclusion from the collegial power of the } \\
\text { Romanian community; the leadership of the } \\
\text { Orthodox church was forced to convert to } \\
\text { Calvinism }\end{array}$ \\
\hline Acceptance of thy different neighbour & $\begin{array}{l}\text { Retraction of the communities' right to freely } \\
\text { choose their religion }\end{array}$ \\
\hline $\begin{array}{l}\text { The increased role of teaching, education and } \\
\text { culture }\end{array}$ & Contempt for unofficial confessions \\
\hline $\begin{array}{l}\text { Prevalence of the decision of the country's } \\
\text { Diet compared to local decisions (at the level } \\
\text { of comitatus, Land of the Saxons, Land of the } \\
\text { Szeklers) }\end{array}$ & $\begin{array}{l}\text { Limitation of the right to religious } \\
\text { "innovations" }\end{array}$ \\
\hline $\begin{array}{l}\text { Emphasis on the inhabitants' mobility in } \\
\text { Europe }\end{array}$ & $\begin{array}{l}\text { Maintenance of medieval privileges and } \\
\text { autonomies }\end{array}$ \\
\hline
\end{tabular}

\begin{tabular}{|l|l|}
\hline Ideas and means of unity (integration) & $\begin{array}{l}\text { Ideas and means of dividing (separation, } \\
\text { segregation) }\end{array}$ \\
\hline The prince, the prince's council & $\begin{array}{l}\text { Division of the country into different regions, } \\
\text { based on ethnic criteria }\end{array}$ \\
\hline Diet (country's assembly) & Exaggerated power of local autonomies \\
\hline $\begin{array}{l}\text { Representation of all recognised nations in } \\
\text { the central governing bodies }\end{array}$ & $\begin{array}{l}\text { Refusal to accept Romanian representatives } \\
\text { (and other ethnicities) in the central govern- } \\
\text { ing bodies }\end{array}$ \\
\hline $\begin{array}{l}\text { Representation of all "official religions" in } \\
\text { the central governing bodies }\end{array}$ & $\begin{array}{l}\text { Refusal to accept Orthodox representatives } \\
\text { (and other religions and cults) in the central } \\
\text { governing bodies }\end{array}$ \\
\hline Single foreign policy & Connections to rival foreign powers \\
\hline
\end{tabular}




\title{
The End of Empires and the Attempts at Creating a New Balance (1919-1945)
}

\author{
The Late Start of the Little Entente. Regional Cooperation \\ within East-Central Europe in Times of Adversity (1920-1921)
}

\author{
Lucian LEUŞTEAN
}

\begin{abstract}
During the first half of August 1920, it was a huge diplomatic battle where Romania had an important part, maybe a decisive one. The dispute was between a French plan that intended to set up a Polish-Romanian-Hungarian alliance with an apparent Anti-Bolshevik disposition, essential for France's interests in that moment, and a Czech plan for an AntiHungarian alliance of all the neighbors of Hungary. For the Romanian leaders both political designs were somehow unsatisfactory. Which proposal was picked up by Romania? And especially why? Did Romania forward its own scenario for regional cooperation in EastCentral Europe? Did the Romanian proposal succeed? Which were the bases of the Little Entente? Why regional cooperation had so many misfortunes in the first inter-war years? The responses for these questions represent the substance of our text, the core of our paper, even if some answers imply more questions.
\end{abstract}

Keywords: Romania, Little Entente, regional cooperation, great and small powers, East Central Europe, early inter-war years

When a state major structure, which has existed for centuries, is suddenly erased from the world map, it is quite natural that a high number of nostalgic voices appear afterwards. This number is not necessarily identical with the number of those whose interests were harmed by the radical transformation in question, but they are close. The manifestation of nostalgia could be benign - like a dream state, a recollection of a grand "golden age" when everything was "perfect" - or it could be active, trying to resurrect, by different means and in different forms, the state structure in question.

That is how things happened in the case of the Austro-Hungarian Empire's fall as well, in the autumn of 1918. Many of those for whom the double-headed monarchy had become a source of advantages - material, political, economic, cultural, psychological or prestige-related ones -started almost immediately to show their regrets, to compare the "nothingness" of the post-dualistic present's realities to the "exceptional" achievements of the Habsburg Empire's past and, some of them, to try even a "deconstruction" of the recently demolished edifice, that is a recomposition, from some of the constitutive elements of the former state structure, of something that should have at least looked like the defunct empire. 
There was a wide range of individuals showing discouragement, contempt or hate towards the Central and Eastern Europe's realities in the aftermath of World War I: from some of the Austrian or Hungarian politicians, who found themselves all of a sudden deprived of their capacity to influence the European politics, unless to an insignificant extent, to the Hungarian gendarme from some Transylvanian or Slovakian village, who was now "chased" by those who had been the targets of his anger not long before; from the Hungarian or Austrian aristocrat who saw his properties decimated by the agrarian reforms started by almost all the successor states, to the Jewish who had made major efforts to be assimilated to the dominant cultures of the Austro-Hungarian Empire and was now deemed an ethnic minority member, like any other; from Western statesmen and diplomats who had been accustomed to work with a significant influence and power factor in the region of Central Europe, and now had to deal with a multitude of States, none of them weak enough to be completely dominated, nor strong enough to replace the double-headed monarchy on the European geostrategic map, to the teacher or the civil servant who suddenly found out that he had to swear an oath to states once deemed hostile or, worse, to learn languages he once disregarded, unable to imagine until then - not in his worst nightmares - that he would be forced to revalue them; from the western businessman who quickly discovered that the benefits of a huge "Austro-Hungarian" market had evaporated, leaving behind a group of smaller and much more aggressive markets, as well as a frustrating increase of the number of kilometres of border in Europe and, implicitly, of the number of tariffs, protectionist ones in their majority, to some of the ordinary people for whom the transformation of their life savings from Austro-Hungarian kronen into the currencies of the successor states turned out to be ruining.

There was, obviously, a reverse of the medal: although those who regretted the dualistic monarchy were quite numerous, the ones who were satisfied with the disappearance of the multinational empire were even more numerous. In this case too, there was a marked diversity: from the Romanian, Czech, Slovakian, Polish, Serbian, Croatian and Slovenian politicians who had seen many of their national objectives fulfilled, to the peasants who, regardless of their nationality, when they received land, felt they had a purpose and a homeland, some of them for the first time; from some western statesmen and diplomats who thought the successor states were a better anti-Bolshevik "sanitary cordon" and a more effective obstacle in the way of the natural German domination upon the Central and Eastern Europe than the Habsburg Empire could have been, to the ordinary people who were sincerely happy about the possibility to send their children to study in their native language; from the businessmen and bankers form the Western Europe or the United States of America who quickly understood that the pressure they could put on the successor states were much easier than that on a major power like Austria-Hungary, to those for whom the identity needs of a national culture were 
eventually met; finally, from all those for whom the return to a situation that had seemed to be over would have meant a personal or community disaster, to those who had been long waiting for historical revenges.

Between the two categories of people, the conflict of interest was obvious, and it took place at several levels. From the standpoint of our research, we are only interested in that side of the conflict that is related to the field of international relations. In other words, we will try to present and analyse the opinions and actions of those political, military and economic leaders - of both the successor states and the great powers - who tried to modify the territorial arrangements made after World War I or to preserve the status quo in this issue. We will put forward and investigate the establishment and the initial evolution of a security structure - the Little Entente - whose primary purpose was this very one, to neutralize backwardlooking plans.

$*$

The leaders of Warsaw had decided, in the spring of 1920, to solve, by force of arms, the territorial conflicts with the Soviets: at the end of April, the Poles started an offensive in Ukraine, which initially enjoyed much success. ${ }^{1}$ At the beginning of May 1920, Hungary offered its military aid against the Bolsheviks and its support against Czechoslovakia, in exchange for the Polish assistance in the negotiations with the neighbours and the equipping of the army. ${ }^{2}$ The Poles, although cautious, promised military aid and contemplated the advantages of a Polish-RomanianHungarian alliance. ${ }^{3}$

The Russian counteroffensive against Poland, started in June $1920^{4}$, stimulated the Hungarian aid offers, as well as the French fears. As the Russians continued to move forward, Czechoslovakia declared its neutrality on August 7 and impeded the transportation of weapons to Poland ${ }^{5}$, providing thus arguments to those who said that Hungary was a better barrier in the way of communism and against Germany than Czechoslovakia was. ${ }^{6}$ On the other hand, the French were extremely wor-

1 Kalervo Hovi, Alliance derevers, Stabilization of France's Alliance Policies in East Central Europe, 1919-1921, Turku: Akateeminen kirjakauppa, 1984, p. 41.

2 Papers and Documents relating to the Relations of Hungary (P.D.F.R.H.), vol. 1, 1919-1920, Budapest: Royal Hungarian University Press, 1939, pp. 332-333.

3 Arhivele Ministerului Afacerilor Externe (Ministry of Foreign Affairs Archives, A.M.A.E.), Fund 71/1920-1944, Transilvania, vol. 348, f. 109.

4 Andrzej Garlicki, Józef Pilsudski, 1867-1935, Aldershot: Scolar Press, 1995, p. 101; K. Hovi (1984), p. 51.

5 Antoine Marès, "Mission militaire et relations internationales: l'exemple francotchécoslovaque, 1918-1925", Revue d'histoire moderne et contemporaine, XXX, 1983, pp. 575-576.

6 Raymond Poincaré was such an example (Cf. vol. Histoire politique, chronique de quinzaine, Paris: Plon-Nourrit, 1921, p. 18). 
ried about Poland's military situation; a desperate one in July-August 1920, when losing Warsaw was an actual possibility. ${ }^{7}$ France joined Great Britain and Italy in blaming the Polish "imperialism", but at the same time promised aid. The French assistance manifested itself in several forms. First, a military mission was sent, run by General Maxime Weygand, as well as several transports of war material. Second, the French adopted a diplomatic tactic meant to keep Germany away from the conflict. Finally, the promotion of a Polish-Romanian-Hungarian combination was attempted, the only one able to block, according to the French, the spreading of the Bolshevik plague towards Europe. This French wish matched very well the Hungarian-Polish affinities and contacts mentioned above. But Romania's inclusion in such an arrangement turned out to be much more difficult to make. ${ }^{8}$

As one can notice, in the summer of 1920 the Romanians showed a relative availability to talk to the Hungarians. It was probably an attitude promoted on the express request of France. ${ }^{9}$ In July 1920, the direct discussions between Romania and Hungary started on the normalization of the relations between the two countries. As far as Romania was concerned, it seems that King Ferdinand and General Averescu supported a rapprochement to Hungary ${ }^{10}$, while Take Ionescu was still oscillating, trying to reconcile the irreconcilable: his negotiations with Beneš on the Little Entente and the rapprochement to Hungary. This dilemma of the Romanian minister of Foreign Affairs was solved by the Hungarian Cabinet, who only had one preoccupation - the lost territory; so the negotiations failed quite quickly, as the antagonism was implacable. If Romania's only interest was to discuss juridical, economic and civic issues, the major topic of the Hungarian government was the rectification of the borders. The Romanians firmly rejected it. Romania - as well as Czechoslovakia and Yugoslavia - did not show, neither then nor later, any kind of availability in debating the territorial issue.

In spite of this failed attempt of Romanian-Hungarian rapprochement, one should notice that in the first half of August 1920, so in the most difficult moment for the Poles in their conflict with the Soviets, a major diplomatic duel took place, in which Romania played a significant, if not decisive part. The dispute did not occur between the supporters of a so-called "Danubian economic confederation" and those of a "Little Entente" as a project ${ }^{11}$, but between a French plan, aiming at the construction of a Polish-Romanian-Hungarian alliance of anti-Bolshevik nature, whose emergence seemed to be vital for Paris' interests at the moment,

7 Piotr S. Wandycz, Soviet-Polish Relations, 1917-1921, Cambridge Mass.: Harvard University Press, 1969, pp. 215-225.

8 Cf. A.M.A.E., Fund 71/1920-1944, Transilvania, vol. 348, f. 107-109.

9 Vasile Netea, "Budapesta", in vol. Reprezentanțele diplomatice ale României, II, 1911-1939, Bucureşti : Ed. Politica, 1971, p. 163.

10 Alexandru Marghiloman, Note politice, vol. III, Bucureşti: Scripta, 1995, p. 378.

11 I. Ciupercă, "Din istoria contemporană a unei idei: Confederaţia economică danubiană", in Românii în istoria universală, III/1, Iaşi: Univ. Al.I. Cuza, 1988, p. 672. 
and a Czech plan concerned with an anti-Hungarian alliance of all Hungary's neighbours. One can easily notice that the only common element of these two potential alliances was Romania. But for the leaders in Bucharest, none of the two schemes was completely satisfactory. On the one hand, the Romanian interest in a rapprochement to Poland was clear ${ }^{12}$, but not as solid as to determine the involvement of the country into a military anti-Soviet adventure ${ }^{13}$, or, even less, to cause the acceptance of any Hungarian territorial claim. On the other hand, the Czech alliance scheme was not very attractive for Romania because of the Slavonic obvious preponderance, considering that the main danger for the Romanian state was not the Hungarian, but the Eastern menace, even if it wore the Bolshevik ideological mask.

In these very complex circumstances, the Romanian government adopted an attitude of expectation, waiting for certain clarifications that were supposed to supply with substance the important decision that was going to be made. Consequently, the Romanian government paid attention to the French advice to get closer to Poland and to talk to the Hungarian officials, but these actions did not result in any significant commitment ${ }^{14}$; the authorities of Bucharest showed actually justified concerns towards the Polish-Hungarian effusions ${ }^{15}$ and they could not ignore the firm opposition of the governments of London and Rome with regard to the French plan. ${ }^{16}$ Meanwhile, the Hungarian activity during the Polish crisis precipi-

12 Cf. as well Florin Anghel, "O dilemă teritorială şi un debut diplomatic. Ocuparea Pocuției de către armata română (24 mai - începutul lunii august 1919) şi debutul relațiilor românopolone", in Revista istorică, VI, 9-10, 1995, pp. 761-771.

13 Cf. Desăvârşirea unității național-statale a poporului român. 1918, Documente interne şiexterne, VI, Bucureşti: Ed. Stiintifica si Enciclopedica, 1986, pp. 122-123.

14 G. Juhász (Hungarian Foreign Policy, 1919-1945,Budapest: Akadémia Kiádó, 1979, p. 56) sets forth that some military supplies had arrived in Poland coming from Romania, but there is no other confirmation for such an assertion. There is just a report, dated in April 1922, of colonel Bădulescu, the Romanian military attaché in Warsaw, in which it is stated that the Polish would have asked, on the 11th of August 1920, the Romanian government that the Hungarian troops to transit Romania. It seems that the Romanians would have accepted the request on the 5th of September 1920, but afterwards, with the military situation changed, the leaders of the Polish Army would have cancelled that demand, on the 23rd of September 1920 (A.M.A.E., Fund Dosare speciale, Problema 71/1920 - Polonia, Relații cu Ungaria, vol. 40/1, f. 40-42); Cf. as well Traian Sandu, "La coopération franco-roumaine face à la Russie lors du passage de Take Ionescu au Ministère des Affaires Étrangères (juin 1920-décembre 1921)", in Revue Roumaine d'Histoire, XXXIV, 3-4, 1995, pp. 369-371 (the author writes about delaying, with the Czech's approval, of the withdrawal of Romanian army from Carpatho-Ruthenia, which has facilitated the transit of military supplies to Poland).

15 A.M.A.E., Fund Dosare speciale, Problema 71/1920 - Polonia, Relații cu Ungaria, vol. 40/1, f. $2,4,8$.

16 Carlo Sforza, Diplomatic Europe since the Treaty of Versailles, New Haven: Yale University Press, 1928, passim; R. J. B. Bosworth, Italy and the Wider World, 1860-1960, London: 
tated the Czechoslovakian-Yugoslavian alliance, the first step of what was going to become the Little Entente. ${ }^{17}$ On 14 August 1920, in Belgrade, Edvard Beneš, the Czechoslovakian minister of Foreign Affairs, signed a defensive alliance with the Kingdom of Serbs, Croats and Slovenes, deeming Hungary a possible aggressor ${ }^{18}$. Immediately afterwards, Beneš came to Bucharest to talk to the Romanian officials. The Romanian minister of Foreign Affairs, Take Ionescu, approved then of the protocol of neutrality in the Soviet-Polish war only ${ }^{19}$, with an oral promise of mutual assistance in the case of a Hungarian attack. Therefore, this was, after all, the same expectant attitude. ${ }^{20}$ Furthermore, Take Ionescu put forward a proposition regarding a variant of alliance made of five states (Romania, Czechoslovakia, Yugoslavia, Poland, and Greece), which could be subsequently extended to other countries of the region. This was also the main motivation for postponing Romania's joining the scheme proposed by the Czechs: the decision was that Romania would adhere to the convention of alliance between Czechoslovakia and Yugoslavia, but not right away, only after all the possibilities to construct a larger alliance were exhausted. ${ }^{21}$

At that time there were records, and many of the Romanian, Czech and Serbian historians stated it afterwards, that even in that situation, with no full commitment from Romania, the system that would quickly be known as the Little Entente was actually working since the summer of 1920; and it was almost immediately said to be directed against the French patronage upon Hungary. This step was not well seen at Paris, being deemed an obstruction of the French politics related to the construction of an anti-Bolshevik combination made up of Poland, Romania and Hungary, that even Czechoslovakia and Yugoslavia could join. ${ }^{22}$

It seems that the Romanian leaders did not either accept or completely reject any of the two alliance plans proposed at that moment. Our standpoint is that the Little Entente was not established yet in August 1920. We should underline that the Beneš plan and the Ionescu plan with regard to the Little Entente were not complementary, as significant differences and only few resemblances existed between

Routledge, 1996, p. 34.

17 See Eliza Campus, Mica Îțelegere, Bucureşti: Ed. Academiei, 1997, p. 54.

18 D. Perman, "The Shaping of the Czechoslovak State. Diplomatic History of the Boundaries of Czechoslovakia, 1914-1920", in W. Philipp and P. Scheibert (eds.) Studies in East European History, VII, Leiden: E.J. Brill, 1962, pp. 263-264.

19 V. Moisuc, "Praga" in vol. Reprezentanțele diplomatice ale României, II, 1911-1939, Bucureşti: Ed. Politica, 1971, p. 193.

20 The Romanian reservations were probably encouraged by the presence of the French fieldmarshal Joffre in Bucharest when Beneš arrived (A.M.A.E., Fund Mica Ințelegere, vol. 4, f. 1, 210; Idem, Fund Dosare speciale, 71/1920-1944, vol. 47/3, passim; M. Ádám, The Little Entente and Europe (1920-1929), Budapest: Akadémia Kiádó, 1993, p. 91).

21 E. Campus (1997) 54.

22 See the report of the Romanian minister in Paris, Dimitrie Ghica, dated on the 27th of August 1920 (A.M.A.E., Fund Mica Ințelegere, vol. 3, f. 6); nor the French press was initially supportive to the project promoted by Beneš (Ibid., f. 33). 
the two. The Czech proposition was simply an expression of Prague's concerns in respect to Hungarian aggressiveness, which at the moment seemed to be focused on the young Czechoslovakian state. ${ }^{23}$ On the other hand, the leaders of Bucharest were not so frightened by the Hungarians, as the experience of the 1919 military confrontations was favourable to the Romanians, who seemed to be able to settle the conflicts with the Hungarians by themselves. But the Romanian worries were then much more visible in the relation with the eastern enemy. Consequently, Take Ionescu's project advocated the establishment of an alliance of five states directed against any aggression, a formula meant to provide Romania with a plus of security at the eastern border. But Beneš doubted the feasibility of the project put forward by the Romanian minister of Foreign Affairs, his hesitations concerning the possibility of a Polish-Czech rapprochement; furthermore, the Czech leader objected that Take Ionescu's plan would perpetuate the regime of the two armed camps before the war, would block the way to reconciliation and would place the new states under the diplomatic guardianship of the Allied Powers. ${ }^{24}$

Therefore, we could say that Edvard Beneš' visit to Bucharest, in August 1920, resulted mainly in a failure. The common declarations of collaboration, as well as the mutual promises made at the end of the discussions were only protocol formulas meant to cover a diplomatic lack of success.

Meanwhile, in the period between September-November 1920, an ample action of the Romanian diplomacy occurred, in the form of a tour the Romanian minister of Foreign Affairs, Take Ionescu, made in several European capitals, especially in the Occidental ones. The main part of this diplomatic journey took place in Paris, where Take Ionescu paid a long official visit, leaving later for Rome and London. After a short return to Bucharest, the head of the Romanian diplomacy left for Prague and Warsaw. Ionescu's European tour should have ended in Athens (or, the Greek Prime Minister Elephterios Venizelos should have come to Bucharest), but this last phase did not happen for various reasons.

The objectives of these Romanian sustained diplomatic activities aimed at solving issues suspended during the Paris Peace Conference (first of all, obtaining the international acknowledgment of Bessarabia's belonging to the Kingdom of Romania ${ }^{25}$ ), at getting some loans meant to cover, even if partially, the stringent financial needs that the Romanian State was confronted to, at calming down the French worries related to the transformation of the Czechoslovakian-Yugoslavian alliance into a central and eastern European combination beyond France's control and, eventually, at convincing different European chancelleries about the necessity and viability of the establishment of a Little Entente in an extended form (Take Ionescu's plan of an alliance "of five"). After the Paris phase of his tour,

23 Cf. Desăvârşirea unității național-statale ..., vol. VI, 57.

24 John O. Crane, The Little Entente, New York: Macmillan, 1931, p. 105.

25 See T. Sandu (1995) 372-373. 
the Romanian minister of Foreign Affairs was enthusiastic, but the London rain stopped the momentum, and the sun of Rome withered his hopes; finally, the visits to Prague and Warsaw confirmed his avatars of cooperation in Central and Eastern Europe, so he did not even go to Athens any more. The tour was a fiasco.

When Aristide Briand was invested Prime Minister of France, in January 1921, the French politics seemed clear, and the French leader expressed his "special sympathy" for the Little Entente ${ }^{26}$. This had been finalized in 1921, after the first attempt of Habsburg restoration; on 21 April 1921, Romania signed an agreement with Czechoslovakia and in August a similar one with Yugoslavia, the only difference being that the latter obliged the parties to defend not only the Treaty of Trianon, but also the Treaty of Neuilly. ${ }^{27}$

Romania eventually joined the Little Entente, but only in the international context of 1921, which was quite different from the summer of 1920. Moreover, the adherence to the anti-Hungarian scheme promoted by Edvard Beneš occurred only after the Polish-Romanian alliance was signed in March 1921. ${ }^{28}$ The latter one was a reminiscence of the French plan from the summer of 1920, concerning the achievement of an anti-Bolshevik Polish-Hungarian-Romanian alliance; as far as the form was concerned, it also resembled other documents issued Quai d'Orsay: the Franco-Belgian military agreement of September 1920 and the Franco-Polish alliance of February $1921 .^{29}$

Furthermore, in a period of recrudescent tension in the Romanian-Hungarian relations, in the spring of 1921, occured the first attempt to bring back on the throne of Hungary Charles IV, the last Habsburg that had been emperor of Austria and king of Hungary. Charles had never abdicated formally, but he had "relinquished the exercise of his functions" in November 1918 and was living in Switzerland ever since. ${ }^{30}$

26 Anne Orde, "France and Hungary in 1920. Revisionism and Railways", in Bela K. Kiraly, Peter Pastor and Ivan Sanders (eds.), War and Society in East Central Europe, vol.VI, Essays on World War I: Total War and Peacemaking, A Case Study on Trianon, New York: Columbia University Press, 1982, p. 194.

27 E. Campus (1997) 62-67.

28 A.M.A.E., Fund 71 - Polonia, Relații cu România, vol. 52, f. 8-18.

29 See Jonathan Helmreich, "The Negotiations of the Franco-Belgian Military Accord of 1920", in French Historical Studies, III, no. 3/1964, pp. 360-378; Robert J. Young, France and the Origins ofthe Second World War, New York: Macmillan, 1996, p. 17; Henryk Bulhak, "L'alliance franco-polonaise dans le système politique et militaire de Versailles en Europe de l'Est et du Sud-Est", in Pierre Aycoberry, Jean-Paul Bled, Istvan Hunyadi (eds.), Les consequences des traités de paix de 1919-1920, Strasbourg: Presses universitaires, 1987, pp. 323-332.

30 William M. Batkay, Authoritarian Politics in a Transitional State. István Bethlen and the UnifiedParty in Hungary, 1919-1926, Boulder: Columbia University Press, 1982, p. 113. 
Thus, although Hungary's domestic situation and the international context at the beginning of 1921 did not seem propitious to a Habsburg restoration in Budapest, such an attempt was going to occur at the end of March 1921. It seems that the ex-king Charles, discontent with the oscillating attitude of the Hungarian leaders, who theoretically were all monarchists and most of them legitimists too, as well as with the fact that the anti-Habsburg front initiated by Italy seemed to enjoy a great success, with real chances to be extended, decided to face his adversaries with a fait accompli. He could not have afforded to start an adventure that could have ended badly if he had not had promises of help from several political, military and religious Hungarian personalities, as well as the support of external circles. It seems that an important part in the attempt to bring Charles back on the Hungarian throne was played by some of the French leaders.

At the same time, there was an opinion in the Hungarian historiography, that the royal family in Romania would have helped Charles at that moment. The former emperor thought that Ferdinand owed him for having saved his throne in 1918, when Wilhelm II had intended to remove him in order to give Romania's Crown to a pro-German sovereign. Anyway, Charles had maintained good relations with the Romanian royal family, Queen Mary visiting him in Switzerland and even facilitating his getting closer to some circles in France. ${ }^{31}$

The divergent standpoints of the great powers, the firm attitude of Hungary's neighbours, catalysed by the government of Prague, as well as the disagreements between the different political and influential groups in Hungary led to the failure of the Habsburg restoration attempt; after a few days of peregrinations in Western Hungary and in Budapest, the former sovereign was forced to leave the Hungarian territory.

It had become clear that in April 1921, it was the best time for Romania and Czechoslovakia to materialize their rapprochement, because of their common enemy, in a bilateral treaty. This was the opportunity for the Romanian diplomacy to admit, in a discrete way, that the so-called "Take Ionescu plan" was no longer topical, but the "Beneš plan" could, at that moment, be materialized. Since the crisis, more precisely since April 4, the Romanian minister of Foreign Affairs communicated at Prague that he was ready to sign with Czechoslovakia and Yugoslavia defensive conventions in order to maintain the Trianon Treaty.

On 7 June 1921, at Belgrade, the convention of defensive alliance between the Kingdom of Romania and the Kingdom of Serbs, Croats and Slovenes is signed. Once the conventions of alliance between Romania and Czechoslovakia and Yugoslavia were signed, the Little Entente was established. At the same time, we should not forget that in the spring of 1921, in the Parliaments of France, Italy and Great Britain, a series of debates took place with regard to the ratification of the Trianon Treaty. Many voices asked for the revision of the treaty in Hungary's

31 M. Ádám (1993) 114; A.M.A.E., Fund 71/1914, E2, part II, Paris, 1914-1924, vol. 3, f. 511. 
favour. ${ }^{32}$ Even if the opinions of some parliamentarians did not influence the policies of the executive branch in the countries in question ${ }^{33}$, the hopes in Budapest, as well as the worries in Prague, Belgrade and Bucharest, could not but increase.

Finally, another important reason for the facilitation of the Romanian decision to join the Little Entente was the intensification, in the spring of 1921, of the Hungarian revisionist and irredentist activities, whether they were actions of the government of Budapest or "private" operations, carried out with the tacit or explicit consent of the Hungarian authorities. For instance, at the end of 1920 and in the first months of 1921, the Romanian government received stupefying pieces of information: more than two years after the union of Transylvania with Romania, the Romanian State's institutions in Transylvania (school departmental offices, schools, hospitals, city councils, notary offices, courts!!!) were exchanging official correspondence with the authorities in Hungary, enforcing the orders of Budapest ${ }^{34}$; on every envelope of this official correspondence were written, in Hungarian, the two cardinal slogans of the Hungarian irredentism: "Broken Hungary is no country / Hungary united is heaven!" and "I believe in one God, / I believe in one Homeland, / I believe in one divine eternal Truth, / I believe in the resurrection of Hungary. Amen" 35 ; on all the private telegrams and letters coming from Hungary, after the name of the place in Romania, the following text was written: "territory under occupation"; the Hungarian border authorities were stamping the travellers' passports with "Seen for passage in the occupied territory". ${ }^{36}$

In 1921, the states composing the Little Entente were also confronted to what was called the "Burgenland affair". This was a strip of territory in the west of the Hungarian part of Austria-Hungary; although formally it had belonged to the government of Budapest, the region was inhabited by a German majority, but there were also Hungarians, especially in the area of the city of Sopron (Ödenburg). ${ }^{37}$

Then, in the summer and autumn of 1921 the crisis of Burgenland grew graver, when Hungary should have evacuated the region in August, and Yugoslavia should have proceeded identically in the case of the regions of Baranya and Pécs in southern Hungary. As the Serbs did not obey the order of the Conference of Ambassadors

32 See The Hungarian Peace Treaty (British Statesmen about the Hungarian Question) (Budapest, 1921) 36-50; A.M.A.E., Fond 71/1920-1944, Ungaria, presă, 1920-1923, vol. 25 , f. 58-59.

33 Cf. Argus (2446/16 iunie 1921) 3.

34 A.M.A.E., Fund 71/1920-1944, Transilvania, Iridenta ungară, 1920-1921, vol. 31, f. 9, pp. 28-29.

35 Ibid., pp. 19-20.

36 Ibid., p. 46.

37 B. Hamard, "Le transfert du Burgenland à l'Autriche 1918-1922, un arbitrage international de l'après-guerre", Revue historique, CCXCIV, 2/1995, p. 285. 
but partially, the Hungarians did the same, refusing to withdraw their troops from the whole Burgenland. ${ }^{38}$

In September 1921, Beneš offered himself to be the mediator between Austria and Hungary, arousing thus the discontent of Rome, Belgrade and Bucharest. The Yugoslavian and Romanian leaders were vexed by the position of leader of the Little Entente that Beneš arrogated for himself and especially by the fact that sometimes he was acting in the name of the three countries without consulting the partners of alliance. But the Italians in particular felt disturbed by Edvard Beneš' claims - who had meanwhile become the Prime Minister of Czechoslovakia, keeping also the position of minister of Foreign Affairs - to control and influence the diplomatic evolutions in Central Europe. The Italian diplomacy, led since July 1921 by the Marquis DellaTorretta (Pietro Paolo Tomasi) - a former ambassador to Vienna who modified some of the directions of foreign policies established by his predecessor Carlo Sforza ${ }^{39}$ - managed to remove Beneš from the mediation of the Hungarian-Austrian conflict, succeeding in finding a solution to the crisis of Burgenland. On 15 October 1921, at Venice was signed a convention stipulating that the greatest part of Burgenland had to go to Austria, but in the area of Sopron a plebiscite was to take place, supervised by the great powers. ${ }^{40}$

The Italian involvement in the identification of the compromise meant to solve the crisis of the Burgenland demonstrated that the Little Entente, in spite of its aspirations, could not play the role of a great power in the Central and Eastern European region. ${ }^{41}$ Even if the Czechoslovakian-Yugoslavian-Romanian alliance represented 50 million people, it was not a great power. The lack of unity in terms of objectives, the interests that were sometimes distinct even if not necessarily contradictory, the vanities of the leaders of Prague, Belgrade and Bucharest, as well as the economic and military malfunctions in the alliance, indicated that the Little Entente was far from reaching its final purpose, that is to have a decisive word to say in the issues of the Central and Eastern Europe. ${ }^{42}$

\section{Bibliography}

\section{A. Archives}

Arhivele Ministerului Afacerilor Externe [Ministry of Foreign Affairs Archives, A.M.A.E.],

Fund 71/1920-1944, Transilvania, vol. 348; Fund Dosare speciale, Problema 71/1920 -

Polonia, Relații cu Ungaria, vol. 40/1; Fund Dosare speciale, 71/1920-1944, vol. 47/3; Fund

Mica Înțelegere, vol. 3-4; Fund 71 - Polonia, Relații cu România, vol. 52; Fond 71/1914, E2,

38 Ibid., pp. 292-293.

39 Christopher Seton-Watson, Italy from Liberalism to Fascism, 1870-1925, London: Methuen, 1967, p. 602.

40 B. Hamard (1995) 296-298.

41 A.M.A.E., Fond 71/1920-1944, Ungaria, presă, 1920-1923, vol. 25, f. 103.

42 See the commentaries in Democrația (IX, nr. 10/1921), pp. 486-488. 
partea a II-a, Paris, 1914-1924, vol. 3; Fund 71/1920-1944, Transilvania, Iridenta ungară, 1920-1921, vol. 31; Fund 71/1920-1944, Ungaria, presă, 1920-1923, vol. 25.

B. Published documents, newspapers, magazines

Argus, 2446/16 iunie 1921.

Democrația, IX, nr. 10/1921.

Desăvârşirea unității național-statale a poporului român. 1918, Documente interne şi externe, VI, (1986), Bucureşti : Ed. Stiintifica si Enciclopedica.

The Hungarian Peace Treaty (British Statesmen about the Hungarian Question), (1921), Budapest: Popular literary society.

Papers and Documents relating to the Relations of Hungary (P.D.F.R.H.), vol. 1, 1919-1920, (1939), Budapest: Royal Hungarian University Press.

C. Memoirs

Marghiloman, Alexandru, (1995), Note politice, vol. III, Bucureşti : Scripta.

Poincaré, Raymond, (1921), Histoire politique, chronique de quinzaine, Paris: Plon-Nourrit.

Sforza, Carlo, (1928), Diplomatic Europe since the Treaty of Versailles, New Haven: Yale University Press.

D. Books and articles

Ádám, M., (1993), The Little Entente and Europe (1920-1929), Budapest: Akadémia Kiádó.

Anghel, Florin, "O dilemă teritorială şi un debut diplomatic. Ocuparea Pocuției de către armata română (24 mai - începutul lunii august 1919) şi debutul relațiilor româno-polone", in Revista istorică, VI, 9-10, 1995, 761-772.

Batkay, William M., (1982), Authoritarian Politics in a Transitional State. István Bethlen and the Unified Party in Hungary, 1919-1926, Boulder: Columbia University Press.

Bosworth, R. J. B., (1996), Italy and the Wider World, 1860-1960, London: Routledge.

Bulhak, Henryk, "L'alliance franco-polonaise dans le système politique et militaire de Versailles en Europe de 1'Est et du Sud-Est", (1987), in Pierre Aycoberry, Jean-Paul Bled, Istvan Hunyadi (eds.), Les consequences des traités de paix de 1919-1920, Strasbourg: Presses universitaires, 323-332.

Campus, Eliza, (1997), Mica Îțelegere, Bucureşti: Ed. Academiei.

Ciupercă, I., (1988), "Din istoria contemporană a unei idei: Confederația economică danubiană”, in Românii în istoria universală, III/1, Iaşi: Univ. Al.I. Cuza, 667-684.

Crane, John O., (1931), The Little Entente, New York: Macmillan.

Garlicki, Andrzej, (1995), Józef Pilsudski, 1867-1935, Aldershot: Scolar Press.

Hamard, B., (1995), "Le transfert du Burgenland à l'Autriche 1918-1922, un arbitrage international de l'après-guerre", Revue historique, CCXCIV, 2/1995, 285-305.

Helmreich, Jonathan, (1964), "The Negotiations of the Franco-Belgian Military Accord of 1920", în French Historical Studies, III, no. 3/1964, 360-378.

Hovi, Kalervo, (1984), Alliance de revers, Stabilization of France's Alliance Policies in East Central Europe, 1919-1921, Turku: Akateeminen kirjakauppa.

Juhász, G., (1979), Hungarian Foreign Policy, 1919-1945, Budapest: Akadémia Kiádó.

Marès, Antoine, (1983), "Mission militaire et relations internationales: l'exemple franco-tchécoslovaque, 1918-1925", Revue d'histoire moderne et contemporaine, XXX, 1983, 559-586.

Moisuc, V., (1971), "Praga" in vol. Reprezentanțele diplomatice ale României, II, 1911-1939, Bucureşti: Ed. Politica. 
Netea, Vasile, (1971), "Budapesta", in vol. Reprezentanțele diplomatice ale României, II, 19111939, Bucureşti: Ed. Politica.

Orde, Anne, (1982), "France and Hungary in 1920. Revisionism and Railways", in Bela K. Kiraly, Peter Pastor and Ivan Sanders (eds.), War and Society in East Central Europe, vol.VI, Essays on World War I: Total War and Peacemaking, A Case Study on Trianon, New York: Columbia University Press.

Perman, D., (1962), "The Shaping of the Czechoslovak State. Diplomatic History of the Boundaries of Czechoslovakia, 1914-1920", in W. Philipp and P. Scheibert (eds.) Studies in East European History, VII, Leiden: E.J. Brill.

Sandu, Traian, (1995), "La coopération franco-roumaine face à la Russie lors du passage de Take Ionescu au Ministère des Affaires Étrangères (juin 1920-décembre 1921)", in Revue Roumaine d'Histoire, XXXIV, 3-4, 367-382.

Seton-Watson, Christopher, (1967), Italy from Liberalism to Fascism, 1870-1925,London: Methuen.

Wandycz, P., (1969), Soviet-Polish Relations, 1917-1921, Cambridge Mass.: Harvard University Press.

Young, Robert J., (1996), France and the Origins of the Second World War, New York: Macmillan. 


\title{
L'Europe pour la paix: certitude et interrogations
}

\author{
Gérard BOSSUAT
}

\begin{abstract}
This paper has been written to stress on the complexity of the well-known statement: "The Peace by Europe". We have to deconstruct it because it is too optimistic. In opposite to a Europhile stream which celebrates each event linked to European unity as a new way to the Federal Union, historians have to analyse the effects of each common decision made by the member states involved in the Union, and to wonder which kinds of processes of decision are fitted to any specific situation. Do we need to use the community system in each situation? Peace is a complex political and social state which requires the work of several organisations, the European Union indeed and others like World organisations agencies, or intergovernmental and even non governmental organizations. Peace by Europe means also that the political elites have considered the satisfaction of a revolutionary concept, the "European general interest. The Nobel jury said it has been done by the European Union since 1950!
\end{abstract}

Keywords: Union européenne; intérêt general européene, paix, système communautaire européen.

L'attribution récente du prix Nobel de la Paix (2012) à l'Union européenne a été justifiée ainsi par le Comité Nobel : « l'Union et ses ancêtres contribuent depuis plus de six décennies à l'avancement de la paix et à la réconciliation, la démocratie et les droits de l'homme en Europe ». Cette explication fait écho à la déclaration de Robert Schuman, ministre français des Affaires étrangères, le 9 mai 1950 : «Par la mise en commun de productions de base et l'institution d'une Haute Autorité nouvelle, dont les décisions lieront la France, l'Allemagne et les pays qui y adhéreront, cette proposition réalisera les premières assises concrètes d'une Fédération européenne indispensable à la préservation de la paix ».

L'unité européenne est donc étroitement associée au rétablissement de la paix en Europe de l'Ouest. Ce succès des années 50 justifiait que l'Union s'élargît rapidement à la partie orientale de l'Europe après la fin de l'Empire soviétique pour mettre un terme à la coupure en deux de l'Europe résultant de la guerre froide. L'unité européenne est liée aussi à une forme d'organisation des pouvoirs publics européens, la fédération, puisque la déclaration Schuman annonce bien une haute autorité supranationale. Du moins est-ce la feuille de route au départ.

L'attribution du prix Nobel de la Paix à l'Union a suscité des critiques qu'il ne convient pas de développer ici, faute de temps mais qu'il est indispensable de garder à l'esprit en regard du beau concept de la Paix par l'unité. En effet la réalité des relations intereuropéennes sur l'ensemble du $\mathrm{XX}^{\mathrm{e}}$ siècle, y compris après la déclaration Schuman et la CECA est là pour rappeler l'omniprésence de la violence et de la guerre. C'est pourquoi les historiens voudront déstructurer l'équation 
unité européenne $=$ Paix, pour en analyser les termes et contribuer ainsi à asseoir ou à réduire sa pertinence au nom de la vérité historique, qui n'est pas la vérité politique, ni le fantasme de l'harmonie entre les peuples.

\section{Bilan historiographique et épistémologique de l'histoire de l'unité européenne}

L'historiographie de l'unité européenne', produite par la génération de l'après seconde guerre mondiale, a trouvé son autonomie relative par rapport à l'histoire des relations internationales et par rapport à la théorisation du présent et de l'histoire faites par les politologues. Les historiens de l'unité européenne n'ont plus seulement été des historiens de la conscience européenne, illustrés par Federico Chabod ${ }^{2}$ ou Bernard Voyenne ${ }^{3}$, mais aussi des historiens-politistes de l'action européenne des États ou des historiens-sociologues capables de comprendre les sentiments des citoyens européens sur l'unité, ou encore des historiens- économistes de l'unité économique et monétaire européenne ou des historiens -institutionnalistes du droit communautaire et des institutions communes.

Ils se sont intéressés à l'identité communautaire européenne, née des pratiques de l'Union et non plus seulement au vieux fonds culturel, commun aux élites européennes, scandé par l'héritage de la Grèce classique et de la Rome classique et chrétienne. Ils ont pris conscience des transformations de toutes sortes que l'unité européenne provoquait dans les sociétés européennes. Leur analyse allait au-delà d'une vision partisane des instances communautaires. Mais ils ont fait apparaitre que le monde des serviteurs de la cause commune, fonctionnaires européens, diplomates et parlementaires européens, créé à partir de cultures différentes étaient les prototypes d'une société européenne post-nationale. Cette génération d'historiens a fait la différence entre recherche historique et célébration de l'idée européenne par les militants de la cause fédéraliste. Ils ont dénoncé par leurs pratiques professionnelles et leurs écrits l'instrumentalisation de l'histoire souvent tordue pour démontrer que le fédéralisme était le destin naturel de la construction européenne ou que les constructions européennes tuaient l'identité nationale. L'enthousiasme des premiers jours de la construction européenne s'expliquait par son succès tellement inattendu qu'il en était presque miraculeux après les échecs si nombreux des décennies précédentes. L'Europe n'était plus seulement « le sédiment de ses conflits » (Simon Nora, 1966); elle mettait en œuvre, enfin, les principes les plus généreux de son génie philosophique, exprimés par Erasme ou Victor Hugo.

1 Bossuat Gérard, Bussière Eric, Frank Robert, Loth Wilfried, Varsori Antonio, L'expérience européenne, 50 ans de construction de l'Europe, 1957-2007, des historiens en dialogue, actes du colloque international de Rome, Bruylant, LGDJ; Nomos Verlag, 2010.

2 Histoire de l'idée d'Europe, republiée dans Yves Hersant et Fabienne Durand-Bogaert, Europes, de l'antiquité au XXe siècle, anthologie critique et commentées, Robert Laffont, 2000, pp. 209-212.

3 Histoire de l'idée européenne, Petite bibliothèque Payot, Payot, 1964, 249 pages. 


\section{Les failles ignorées de l'extraordinaire succès}

Mais ce succès comporte des failles ignorées. Après deux guerres mondiales et la grande crise de 1929, après la faillite éthique et philosophique de l'Europe, la société européenne cherchait expressément ou confusément à comprendre comment on pouvait stopper les conflits intereuropéens. Plus concrètement, était-il possible de faire cesser le cycle infernal des affrontements germano-français tout en réussissant le développement économique et social?

La réponse la plus efficace fut la Déclaration Schuman du 9 mai 1950 qui mit un terme à l'affrontement germano-français. Mais les historiens, tout en rendant compte du processus d'unité, de l'action personnelle d'Adenauer, Monnet et Schuman, s'interrogeaient sur sa durée, sa généralisation, sur sa capacité à devenir un modèle dans les relations internationales et à générer de la croissance et de la richesse. Jusqu'où l'unité régionale était-elle compatible avec la mondialisation ? La question de la fixation des frontières de l'Union européenne était posée. Les débordements enthousiastes de certaines élites pour l'unité ont pu émousser le sens critique des européistes et provoquer en retour une critique féroce contre la naïveté des fédéralistes ; l'euroscepticisme avait de beaux jours ; il n'a fait que s'amplifier au rythme des approfondissements de l'unité et a véritablement commencé avec le rejet du projet de Communauté européenne de défense.

En effet, le bilan de l'unité, s'il est heureux, comporte des failles qui ont été tues par peur de détruire l'image de l'extraordinaire succès. D'abord, le processus d'unité a imposé progressivement l'idée que l'organisation économique devait être libérale, érigeant en loi suprême le déclin de la puissance publique nationale et européenne et l'économie de marché sans régulation dans les années 90 . La domination de la droite libérale dans la gestion des institutions d'unité a donné le ton de la construction européenne ${ }^{4}$. L'Europe sociale n'a pas été convaincante pour les citoyens européens alors que Margaret Thatcher détruisait l'Etat-providence. Ensuite une autre faille consista à ignorer la partie orientale de l'Europe, certes pour des raisons évidentes de sécurité, mais néanmoins dommageables, car elle faisait partie de l'univers européen jusqu'en 1947-48 et on savait qu'elle serait amenée à partager, un jour, le projet d'unité. Il aura fallu, ironie de l'histoire, qu'un chef d'Etat soviétique, Mikhaïl Gorbatchev, rompe l'amnésie en rappelant la « maison commune européenne »! L'insistance accordée à la relation euro-américaine révélait une autre fracture; en raison de la guerre froide, les exigences de

4 Walter Hallstein était chrétien-démocrate, Jean Rey, un libéral, Franco-Maria Malfatti, un conservateur, Sicco Mansholt, socialiste, François -Xavier Ortoli, conservateur UDR, Roy Jenkins, travailliste, Gaston Thorn, libéral, Jacques Delors, socialiste, Jacques Santer, droite conservateur, Manuel Marin, PSE, Romano Prodi, gauche, José Manuel Barroso, conservateurs. Depuis 1958, la droite a tenu la présidence de la Commission pendant 33 ans, la gauche autour de 20 ans. 
sécurité des pays occidentaux disposèrent les élites de la petite Europe à valoriser la relation avec les Etats-Unis, même quand ceux-ci, au temps de Nixon et de Kissinger, entendaient faire des Européens de l'ouest des supplétifs de L'Empire américain.

Les historiens de l'unité européenne ont minoré, involontairement, les autres choix possibles (ceux de de Gaulle ou de Mendès France et même ceux des Britanniques). Qui s'est demandé quel était l'intérêt de l'Europe ? N'était-il pas de penser une Europe plus autonome pour l'avenir post-communiste du monde, capable d'assumer la sécurité du continent européen ? N'était-ce pas de réfléchir à l'identité européenne et d'agir en conséquence.

L'autonomie européenne ou même l'indépendance européenne c'est « préserver ou reconquérir les bases d'une capacité propre de détermination, se reconnaître ou se créer un projet civilisateur commun et spécifique ; c'est surtout s'accorder avec elle-même pour se proposer aux autres comme un interlocuteur indépendant apportant aux tensions mondiales des solutions neuves. Sa difficulté à être tient à ce que chacune de ces exigences l'oblige à se définir par rapport aux USA et que cette définition ne peut être une simple opposition si elle se veut commune à tous les pays qui la composent $»^{5}$. Un essai de définition de l'identité européenne, signée cette fois-ci par les Etats-membres à Copenhague en décembre 1973 a représenté aussi une étape dans la prise de conscience de la spécificité européenne. En même temps une autre Europe, unifiée par la force à l'Est, vivait une curieuse expérience d'unité. Cette expérience doit être évaluée en termes de paix et de guerre pour l'Europe ? Une quatrième faille réside dans la complexité de la pensée européenne à propos de la relation Nord-Sud. Les historiens ont travaillé sur les moyens de développer le Sud que l'Europe avait colonisé. La Communauté a organisé son association avec un groupe de pays en développement, les pays ACP. Elle se fondait sur l'intérêt des Etats membres et sur une doctrine souvent implicite, l'aide au Tiers-monde, mélange de bons sentiments et de mercantilisme intéressé6. Une dernière faille existe, celle qui consiste à dire que le processus de l'unité est seulement lié au sentiment fédéraliste au sein des opinions publiques et chez les acteurs politiques. Autrement dit, la persistance du sentiment national est-il réellement contraire à l'intérêt de l'Union européenne ? L'unité intergouvernementale est-elle impossible ? Ne peut-on réconcilier Nation, Etat-nation et construction de l'unité ? Il reste à écrire une histoire des idéologies qui animent les acteurs du processus d'unité. Il aura fallu un certain temps pour que l'Union se définisse par l'unité dans la diversité. Les historiens ont commencé à analyser le phénomène de l'euroscepticisme qui nous conduit à une autre question plus importante: quel sens

5 Nora Simon, Le choix d'une politique étrangère. Europe atlantique, Europe européenne: un faux dilemme, Club Jean Moulin, 1996. Voir FJME, AMKC 30/4/250, p. 10.

6 Bossuat Gérard (dir.) La France, l'Europe et l'aide au développement, des traités de Rome à nos jours, Paris Ministère des Finances, IGPDE, CHEFF, 2013. 
faut-il donner à l'unité européenne ? Les historiens ont-ils la mission de donner du sens à la construction européenne ? Probablement pas mais ils ont la mission d'expliquer le temps long du processus d'unité, et d'être, sinon les conseillers des princes,au moins ceux qui donnent de la profondeur aux prises de décision des princes et qui éclairent les voies que la société emprunte.

Que signifie maintenant pour les chercheurs de la seconde décennie du XXI ${ }^{\mathrm{e}}$ siècle cette assertion, «l'Europe et la paix»? Quel contenu donner lui aujourd'hui ?

\section{Des paix multiples}

On peut résumer ainsi les réponses :

1. L'Europe c'est la paix en raison de la reconstruction de la confiance franco-allemande par le moyen de la déclaration du 9 mai 1950. Cette paix est intimement liée à un conflit entre deux protagonistes qui dans l'histoire a provoqué de graves dégâts à l'Europe et au monde.

2. L'Europe c'est la paix parce que les organisations et institutions d'unité ou de coopération intereuropéenne ont réussi à diminuer les tensions dans les relations intereuropéennes. Un point essentiel pour notre temps est l'analyse du système communautaire européen, original assure-t-on. L'histoire de ce système reste à faire. Il est à l'origine de beaucoup d'espoirs déçus et pose deux questions: est-il efficace ? Est-il démocratique ? Mais ce système est-il, à proprement parler, européen ? L'après-seconde guerre a vu se développer en effet des organisations mondiales de coopération qui maillent désormais les relations internationales.

3. La construction de l'unité européenne a un objectif de développement économique et social fort et donc de paix sociale. L'équation entre unité européenne, libéralisme et production de richesses était devenue axiomatique, au moins au $\mathrm{XX}^{\mathrm{e}}$ siècle. Cette relation a fonctionné au temps de la grande croissance économique. Mais était-il besoin d'unité européenne pour bénéficier des trente glorieuses ? La Grande-Bretagne ou les pays scandinaves l'ont connue sans être membres des Six. L'articulation entre unité européenne et développement économique est douteuse dans les théories de la mondialisation. Dans cette perspective l'unité européenne serait même un obstacle à la pacification des relations économiques internationales puisque l'unité européenne contribue à isoler le marché commun du reste du monde. Le débat sur les solutions à la crise économique et bancaire de 2008 semble n'aboutir qu'à deux solutions: l'austérité ou un ministre fédéral des Finances. Tensions et troubles se manifestent dans les opinions publiques, à l'opposé du projet de pacification du marché du travail, ou d'éradication du chômage. Quelles politiques font l'unité du plus grand nombre d'Européens qui redonneraient à l'Union sa faculté de produire de la richesse ? La paix européenne passe par l'invention d'un nouveau modèle économique capable de donner de la richesse 
et du travail aux Européens ; il est clair que ce modèle ne peut restaurer l'ancien, gaspilleur d'énergie et de ressources naturelles.

4. L'Union européenne a une dimension internationale qui en fait un acteur des relations internationales mais suscite des interrogations. Le régionalisme européen est-il nécessaire ? Les organisations européennes de coopération et d'unité ont-elles un projet pour les relations internationales ? L'intervention de l'Union a été cantonnée à des missions dites de Petersberg, plus humanitaires que militaires, des missions de gestion de crise. L'Union s'est engagée aussi dans la lutte contre le terrorisme international après les attaques contre le World Trade Center de New-York, le 11 septembre 2001. De plus, autre volet de son action internationale, l'Union a des pratiques de co-développement et des politiques de stabilisation économique et politique. Mais de bons esprits affirment que le commerce doit remplacer l'aide. Le succès de l'Union européenne est manifeste dans les relations monétaires internationales depuis la création du système monétaire européen en 1979 et de la monnaie unique, en 1992. Les politiques de normalisation commerciale européennes sont à la fois facteurs de tension et de régulation. La normalisation européenne pacifie-t-elle les relations commerciales internationales ? On doit en discuter et la mettre en relation avec d'une part la recherche de modes de production et d'échange originaux et, d'autre part, avec les risques d'affrontement avec des espaces économiques rebelles tels que les États-Unis et la Chine. Les interventions de l'Union européenne et de ses États dans les questions de protection environnementale et de la lutte contre le réchauffement climatique, ou du passage d'une économie prédatrice à une économie adaptée aux ressources réelles de la Terre peuvent contribuer à la paix entre les nations. Enfin l'Union européenne et le Conseil de l'Europe ont imposé l'exigence du respect des droits de l'Homme qui est un acte de paix interne et internationale.

\section{L'Europe et l'intérêt général européen}

Les historiens doivent prendre part à l'évaluation de l'équation, " l'Europe c'est la paix » et ne pas laisser des parties intéressées, respectables au demeurant, se l'approprier seules à des fins de célébrations ou d'indignation. Déconstruire l'équation ne signifie pas en refuser les termes a priori, mais conduit à faire apparaître sa complexité, ses succès et ses limites, conformément aux méthodes des sciences humaines.

Qu'est-ce que la paix par l'Europe ? L'absence de guerre sans doute bien qu'elle ne soit pas totalement absente des pratiques de l'Union sous le terme de « gestion de crise ». Mais il faut redire que depuis 1945, il n'y a plus eu de conflits intereuropéens. L'unité européenne facilite tous les jours le dialogue entre les Etats membres grâce aux institutions communautaires et aux traités constitutifs et permet de trouver des compromis difficiles sur certains sujets au risque de laisser des 
situations se dégrader gravement. L'unité européenne est un élément qui assure la paix en Europe, à côté des agences de l'ONU, de l'OMC des réunions régulières des grands Etats du monde, G8 et G20, de l'OTAN, du Conseil de l'Europe, de l'OSCE et de diverses enceintes intergouvernementales. L'Union européenne n'a donc pas le monopole de la paix en Europe.

La paix par l'Union suppose que l'organisation européenne se donne une philosophie de l'action qui tranche avec les pratiques politiques séculaires des Étatsnations, souverains protecteurs de leur intérêt national. La seule possible est de satisfaire l'intérêt général européen. Evidemment il faut travailler à définir ce terme, mais c'est en référence à cette utopie-réalité que les Nobel ont décerné le prix de la Paix à l'Union européenne.

\section{Bibliographie}

Hersant Yves et Durand-Bogaert Fabienne, Europes, de l'antiquité au XXe siècle, anthologie critique et commentées, Robert Laffont, 2000.

Bossuat Gérard, Bussière Eric, Frank Robert, Loth Wilfried, Varsori Antonio, L'expérience européenne, 50 ans de construction de l'Europe, 1957-2007, des historiens en dialogue, actes du colloque international de Rome, Bruylant, LGDJ; Nomos Verlag, 2010.

Bossuat Gérard, Histoire de l'Union européenne, fondations, élargissements, avenir, Paris, Belin, 2009. 


\title{
Régionalisme agraire et crédit agricole en Europe Centrale autour de l'année 1930
}

\author{
Sylvain SCHIRMANN
}

\begin{abstract}
As the Great Depression invaded Europe, East-Central countries experienced particular difficulties, owing to their reliance on agriculture. Hence, a series of conferences amongst the latter debated, in 1930, common challenges and potential bases for what we may boldly refer to as a common regional agricultural policy. A broad range of sensitive aspects were brought into discussion, such as overproduction, import rights and free trade, to the mistrust of developed western countries. Albeit the bone of contention may also be found around the institutional dimension of projects centred on agricultural credit, for instance, the aforementioned endeavours were interesting laboratories meant to bring the "two Europes" closer and experiment with ideas of cooperation that manifested themselves under the auspices of Europeanism.
\end{abstract}

Après avoir bénéficié de l'aide américaine à travers le plan Dawes et les investissements qui lui furent consécutifs, l'Europe put envisager la fin de sa reconstruction économique et financière. Les principales monnaies furent progressivement stabilisées et la SDN réfléchit aux principes d'un ordre économique international. La conférence économique de Genève de mai 1927 est, de ce point de vue, essentielle. Elle cherche à imposer deux principes : le démantèlement douanier et la cartellisation, comme moyen de régulation du marché. Si l'on enregistre quelques progrès dans cette direction entre 1927 et 1929 (par exemple le traité de commerce franco-allemand d'août 1927), la question reste posée de sa pertinence pour l'Europe centrale et orientale et plus particulièrement pour les économies pour lesquelles l'agriculture constitue encore un secteur fondamental.

Au moment du plan Briand, ces problèmes restent d'actualité. La crise est déjà présente dans la partie orientale du continent et les difficultés atteignent progressivement l'ouest. La proposition française comporte également une dimension économique forte, et par conséquent il est important d'analyser la position et l'action des pays d'Europe centrale et orientale dans ce contexte. L'importance du secteur agricole dans ces Etats explique pourquoi la question de l'organisation à la fois de la production et du crédit agricole y revêt une importance capitale. Y envisage-t-on une forme de régionalisme, compte tenu de la proximité des problèmes et des situations? Sous quelles formes et avec quels projets ? Quels en sont les résultats?

Une série de conférences agraires entre les pays d'Europe centrale et orientale cherchent à donner forme à ces projets dès 1930. Force est cependant de constater que progressivement ces perspectives restent illusoires. Elles méritent cependant une réflexion sur les causes de leur échec. 


\section{I- Les conférences agraires ${ }^{I}$}

La conférence agraire qui s'ouvre à Varsovie le 28 août 1930 réunit pratiquement la totalité des pays d'Europe centrale et orientale ${ }^{2}$. Y sont présents les Etats suivants : Pologne, Yougoslavie, Roumanie, Bulgarie, Hongrie, Estonie, Lettonie, Tchécoslovaquie et un observateur finnois. La réunion poursuit plusieurs objectifs. Il s'agit non seulement de constituer un front dans la perspective des conférences d'action économique concertée qui se réunissent à Genève à l'automne 1930, mais également de réfléchir à une meilleure organisation de la production et ainsi penser un espace agricole. Les travaux sont loin d'être vains, car les Etats évoquent une cartellisation de l'agriculture, c'est-à-dire une organisation de la production agricole, sa rationalisation, une réflexion sur une politique des transports, et une ouverture réciproque des marchés. Cela passe par l'octroi réciproque de la clause de la nation la plus favorisée pour le commerce des produits agricoles. Pour éviter une concurrence préjudiciable entre eux, les Etats présents à Varsovie s'engagent à des concertations régulières. Dans l'immédiat, ils instituent dans la capitale polonaise un organisme central commun : un Office d'information et d'harmonisation des questions agricoles. Enfin, ils affichent une forme d'unité politique qui doit déboucher sur une action commune à Genève, et ce en vue de l'obtention d'une convention pour la limitation des restrictions à l'exportation. Le 30 août lorsque la conférence se sépare règne un relatif climat d'optimisme. Selon un responsable polonais, on vient de franchir : « un premier pas vers le bloc agraire des pays de l'Est $»^{3}$.

Deux mois plus tard, le même groupe se retrouve à Bucarest du 18 au 20 octobre 1930. La conférence de Bucarest se situe dans la même veine que celle de Varsovie. A Bucarest, les Etats d'Europe centrale et orientale instaurent entre eux un Comité permanent d'études économiques, qui informe les Etats sur les réalités statistiques de l'agriculture. Ce Comité est invité à travailler avec l'Institut international agricole dont le siège est à Rome. Le travail de réflexion s'y poursuit : chaque pays est

1 On peut se reporter à :

Gilbert NOËL, « La société des Nations et les questions agricoles : géométrie variable et flexibilité », in Sylvain Schirmann (direct.), Organisations internationales et architectures européennes 1929-1939, Metz, Publications du Centre de recherche Histoire et Civilisation de l'université de Metz, 2003, pp. 345-367;

Sylvain Schirmann, Crise, coopération économique et financière entre Etats européens 1929 - 1933, Paris, Cheff, 2000, p. 108 et suiv.

2 Sur cette conférence et les suivantes, l'auteur a bénéficié du dossier "Internationale Konferenzen - April 1929 - Dezember 1930 », de la Reichsbank, Dossier R. 2501/5894, Bundesarchiv, Berlin.

3 D'après un article de la Germania, 31 août 1930, « Eine wirtschaftliche Entente Cordiale des Ostens?». 
déterminé à se lancer au lendemain de la réunion dans une étude sur le crédit agricole. Cette étude est appelée à servir de base à une réunion d'experts qui pourraient promouvoir une attitude commune sur la question. Deux autres points figurent encore à l'ordre du jour et sont largement discutés. Le premier concerne la création d'institutions qui coordonneraient les exportations des Etats d'Europe centrale et orientale ; le second invite les Etats à réfléchir ensemble à un système de traitement préférentiel. La cartellisation de l'agriculture semble ainsi en marche ${ }^{4}$.

La troisième réunion entre le même groupe d'Etats se déroule à Varsovie du 10 au 13 novembre 1930. Elle se penche sur la question du crédit agricole. Ses travaux débouchent sur un Mémorandum consacré au crédit agricole à moyen terme. Celui-ci est destiné à être transmis à la SDN et discuté lors de la conférence d'action économique concertée ${ }^{5}$. Les experts réunis en Pologne pensent que le prêt à moyen terme devrait essentiellement servir à des buts productifs : rationalisation de la production, diminution des coûts, organisation de l'écoulement, amélioration de la qualité. Le prêt serait soit dédié au fonds de roulement des exploitations, soit aux investissements. Les capitaux engagés seraient exigibles dans un délai de 2 à 5 ans et leur utilisation contrôlée par un institut local. Les garanties proviendraient d'hypothèques. Au volet économique de la réorganisation de l'agriculture s'ajoute alors le volet financier. Une impression se dégage progressivement : le front agraire des pays d'Europe centrale et orientale a trouvé en trois mois un terrain d'entente qui pourrait jeter les fondements d'une " politique agricole commune ».

A qui doit-on cette apparente réussite?

\section{II - Les raisons d'un succès}

La Pologne tout d'abord a mis la logistique et la puissance de son administration à la disposition de la conférence : documentation, fonctionnaires. Elle dote le comité d'études de statuts et l'héberge à Varsovie. Les experts polonais lancent les grandes études. Il est certain que sans cette disponibilité matérielle, les travaux n'auraient pas été aussi rapides. Mais il ne faut pas oublier le rôle pionnier d'un trio. La Yougoslavie, la Roumanie et la Hongrie se sont en effet retrouvées le 24 juillet 1930 à Bucarest pour tenter de répondre en commun au questionnaire élaboré par la SDN pour les conférences d'action économique concertée et envisager ensemble le principe du régime préférentiel pour leurs productions agricoles ${ }^{6}$. Cette réunion est suivie d'une autre début août 1930 à Sinaia entre Roumains et Yougoslaves, au cours de laquelle les deux Etats conviennent de la nécessité d'un modus vivendi

4 L'auteur a pu consulter les archives de la SDN à Genève à ce sujet. Sur cette conférence, Archives SDN, document $2^{\mathrm{e}}$ conf./AEC/9, Protocole de la conférence des experts agricoles du Centre et du Sud-Est de l'Europe qui s'est tenue à Bucarest du 18 au 20 octobre 1930.

5 Archives de la SDN, SDN, document $n^{\circ}$ C.149.M.48.1931, II. B., p. 256 et suiv.

6 Bundesarchiv, Berlin, Deutsche Reichsbank, R. 2501/5894. 
portant sur la concession d'avantages mutuels dans les échanges. Ils expriment leur volonté d'éviter une concurrence à l'exportation qui leur serait préjudiciable, et souhaitent réfléchir à une éventuelle création d'organes communs. Les deux décident également d'inviter la Tchécoslovaquie aux rencontres ultérieures et s'engagent à communiquer le résultat de leurs travaux et leur calendrier éventuel aux autres Etats d'Europe centrale. Ces différentes initiatives permettent sur les questions agricoles à un régionalisme infra européen de prendre corps ${ }^{7}$. Celui-ci répond de surcroît pleinement au contexte d'alors.

La crise vient d'abord à l'esprit. Les pays d'Europe centrale et orientale qui exportent essentiellement des produits agricoles se heurtent de plus en plus à la surproduction mondiale, à la baisse des prix et à la politique protectionniste des pays qui constituent leurs marchés habituels. S'y ajoutent souvent des problèmes de paiement, qui débouchent sur des situations sociales problématiques. Mais les Etats réagissent également à une initiative de Genève : l'action économique concertée. Ces réunions se comprennent en effet à la lumière de la politique menée par la SDN. Son comité économique souhaite mettre en route la trêve douanière décidée à la conférence économique internationale de 1927. A l'assemblée de septembre 1929, les Etats se rallient au principe d'une conférence d'action économique concertée qui a vocation à aller vers la baisse du protectionnisme et à organiser la production et les marchés, aussi bien industriels qu'agricoles ${ }^{8}$. En février - mars 1930, une réunion préliminaire de cette conférence se tient à Genève pour entendre les différentes positions des Etats. Les Etats d'Europe centrale et orientale sont prêts à accepter l'idée d'une trêve douanière si un certain nombre de dérogations ou de possibilités d'action leur sont données. Ils envisagent ainsi un abaissement du protectionnisme qui frappe les productions agricoles comme l'exprime par exemple De Nickl, le représentant hongrois à cette réunion : «La Hongrie exporte des produits agricoles et elle constate que nombre d'Etats qui devraient, par nécessité, importer de tels produits, pratiquent un protectionnisme exagéré, dont ils attendent le relèvement de leur agriculture, mais qui par ses répercussions mêmes ébranlent la vie économique de la Hongrie $»^{9}$.

D'autres encore envisagent purement et simplement des mesures de rétorsion. Le délégué yougoslave le laisse entendre clairement : il faut « inaugurer dans nos Etats un protectionnisme industriel $\gg^{10}$. Polonais et Roumains défendent quant à eux l'idée de contracter des ententes économiques régionales. Le ministre roumain

7 Bundesarchiv, Berlin, Deutsche Reichsbank, R.2501/5894, Abschluss der Konferenz von Sinaia.

8 Antoine Fleury, «Un sursaut anti-protectionniste dans le contexte de la crise de 1929 : le projet d'une trêve douanière multilatérale», Relations internationales, $n^{\circ} 39,1984$

9 SDN, document $n^{\circ}$ C. 222. M. 109. 1930, II, Intervention septième séance, 20 février 1930, p. 110.

10 SDN, document $n^{\circ}$ C. 222. M. 109. 1930. II, Intervention huitième séance, 20 février 1930, p. 115. 
Madgearu en fixe les contours. Il s'agit « d'accepter une dérogation à la clause de la nation la plus favorisée dans ce sens qu'un traitement préférentiel soit appliqué aux Etats qui seront partie à ces accords [régionaux]. » Ces regroupements locaux, élaborés en fonction de structures économiques comparables ou d'intérêts communs sont à ses yeux « une première étape dans la voie de l'établissement de l'unité économique européenne $\rangle^{11}$. Dans le débat sur l'organisation de l'Europe, si le projet Briand s'intéresse à une construction qui intègre l'ensemble de l'Europe, d'autres propositions s'appuient sur le régionalisme infra européen comme élément de la mise en place d'une unité européenne, notamment une unité économique. Il suffit de se reporter à la vision exprimée par le belge Paul Hymans, le 5 septembre 1929 ou par l'ouvrage de Delaisi sur les deux Europes, pour comprendre que la résolution de 1927 sur le libre-échange appliquée sans discernement pouvait conduire à la catastrophe. Pour ces personnalités, il s'agissait de donner corps à des marchés communs régionaux, seuls viables à leurs yeux. C'est à partir de ces unions douanières qu'il fallait penser progressivement l'union économique de l'Europe ${ }^{12}$.

Les résolutions de la conférence préliminaire consacrent, le 24 mars 1930, le principe de la trêve douanière jusqu'au $1^{\text {er }}$ avril 1931 et admettent des exceptions pour les produits agricoles. Une dernière disposition prévoit un programme de négociations ultérieures. Pour le lancer, la SDN envisage d'envoyer un questionnaire aux gouvernements ; celui-ci constituerait la base des discussions qu'il conviendrait de mener avant la fin de la trêve en avril 1931. Or, ce questionnaire comporte des interrogations quant à la limitation des excédents agricoles, à la réduction des droits sur les céréales, à l'élaboration de conventions plurilatérales, bref contient des chapitres qui intéressent les pays d'Europe centrale et orientale ${ }^{13}$. C'est pour préparer ces discussions prévues pour novembre 1930, que les pays d'Europe centrale et orientale imaginent le régionalisme présenté dans les lignes précédentes. La conférence d'action économique concertée se réunit en effet en 2 sessions : du 17 au 28 novembre 1930 (1 $1^{\text {ere }}$ session), du 16 au 18 mars 1931 pour la $2^{\text {ème }}$ session. Elle est saisie d'une demande déposée conjointement par la Yougoslavie, la Roumanie, la Hongrie, la Pologne et la Bulgarie. Leur texte insiste sur trois points:

- le traitement préférentiel, notamment pour les céréales;

- la consolidation de droits d'importation de produits agricoles à un niveau raisonnable;

11 SDN, document $n^{\circ}$ C. 222. M. 109. 1930, II, Intervention cinquième séance, 19 février 1930 , p. 92.

12 Sur le régionalisme, voir par exemple, Eric Bussiere, «L'Organisation économique de la SDN et la naissance du régionalisme économique en Europe ", in Relations internationales, $\mathrm{n}^{\circ} 75,1993$, pp. 301-313.

13 Voir Résumé des travaux mensuels de la Société des Nations, Volume X, n 3, mars 1930, pp. 89-93. 
- la liberté complète du commerce des produits en provenance de l'Europe de l'Est et du Centre.

L'Europe centrale conformément aux échanges des mois précédents relatés ci-dessus s'exprime ainsi en faveur d'une ouverture des frontières des Etats développés de l'Ouest européen. Cette ouverture devrait lui permettre d'affronter la crise dans de meilleures conditions. La contrepartie serait constituée par un effort commun de restructuration agricole destiné à moderniser le monde rural ${ }^{14}$. Cette «politique agricole commune » que mèneraient ces Etats serait ainsi un facteur de leur développement et sécuriserait cette partie de l'Europe. Objectifs économiques et politiques allaient de pair.

\section{III - L'échec du régionalisme agraire centre européen et la question du crédit agricole}

Lors des conférences d'action économique concertée l'Europe centrale et orientale se heurte néanmoins à la réticence des pays industriels de l'Ouest européen. L'attitude de ces derniers provoque l'irritation de leurs partenaires centreeuropéens. Manoilesco, le représentant roumain, l'exprime en ces termes : « $\mathrm{Si}$ l'Amérique du Nord avait conquis pour ses produits industriels l'Orient de l'Europe, comme l'Amérique du Sud a conquis l'Occident pour les produits agricoles, l'idée de préférence et de protectionnisme européen serait peut-être née, non pas dans l'Orient, mais dans l'Occident de l'Europe $»^{15}$. Les réticences occidentales ouvrent également la voie à l'Allemagne, prête à des négociations bilatérales.

D'autres questions sont abordées au cours de cette session : sur la méthode faut-il accorder des préférences douanières ou ne vaut-il pas mieux développer les capacités de concurrence des pays d'Europe centrale et orientale pour les amener à rivaliser efficacement avec les pays d'Outre-Mer? Polonais et tchèques souhaitent la mise en place d'une organisation technique et financière qui favorise la mutation agricole. En tout état de cause, pour les Etats d'Europe centrale et orientale, la priorité reste l'équilibre de cette partie du continent, avec un système de préférences sans contrepartie, car ce mode de fonctionnement est déjà un avantage pour l'ensemble du continent et tient lieu de réciprocité. Fierlinger, le représentant tchécoslovaque, le dit sans réserve : « insister sur un régime préférentiel bilatéral... signifierait que l'on envisage le problème dans un esprit mercantile et que l'on veut accentuer la règle du donnant-donnant, ce qui dans ce cas s'appliquerait à des situations tout à fait inégales ». La réciprocité figerait économiquement le continent et ne règlerait en rien la question agricole pour les Etats danubiens. Le

14 SDN, Document $2^{\mathrm{e}}$ conférence/AEC/ 10, Propositions soumises par Manoilesco au nom de la Pologne, de la Yougoslavie, de la Roumanie, de la Bulgarie et de la Hongrie, le 19 novembre 1930.

15 SDN, Document n C. 149. M. 48. 1931. II. B., 19 novembre 1930, p. 69 
système préférentiel est pour ces Etats l'amorce de la coopération sur le continent européen, économique d'abord, politique ensuite. Il faut donc - les experts polonais insistent là-dessus - une organisation de la production et du commerce des produits agricoles, à la fois à l'échelle infra régionale et à la fois à l'échelle continentale. Ils posent à nouveau la question du crédit agricole. Seul, ce dernier pointretient l'attention et donne lieu à décision. Pour le reste tout est en suspens. Comment empêcher alors certains Etats d'envisager les préférences dorénavant par la voie du bilatéralisme ? En mars 1931, selon les mots même de Colijn, le néerlandais qui préside la Conférence d'action économique concertée, « les efforts déployés en vue de mettre en application les recommandations de la conférence économique mondiale ont abouti à un échec complet ». Il signifie par la même occasion l'échec de l'action multilatérale en Europe ${ }^{16}$.

Reste finalement la question du crédit agricole qui pourrait constituer l'ultime bouée de secours pour la partie orientale du continent. Doter l'Europe centrale et orientale d'institutions modernes de crédit agricole comblerait indiscutablement une lacune. Le projet est ancien car la question d'un organisme international de crédit agricole est étudiée dès 1926 à l'Institut international d'Agriculture à Rome. La crise relance ce projet souhaité par les Etats d'Europe centrale et orientale à partir de 1930. Deux banques privées qui s'étaient préoccupées de ces questions, la Compagnie centrale de Prêts fonciers d'Amsterdam et le Crédit foncier international de Bâle n'ont pas les ressources suffisantes et ne peuvent donc courir de grands risques dans cette partie de l'Europe. C'est en janvier 1931, entre les deux sessions de la conférence d'action économique concertée que la Commission d'études pour l'Union européenne, créée dans la foulée du mémorandum Briand de 1930, adopte une résolution sur l'institution d'un Crédit agricole international financé par les Etats détenteurs de capitaux. Elle instaure un comité chargé de coopérer avec le Comité financier de la SDN et souhaite qu'un projet complet soit soumis au Conseil de la SDN pour sa session de mai $1931^{17}$.

C'est donc dans l'urgence entre février et avril 1931 qu'est imaginé un Institut international, une Société internationale de crédit hypothécaire agricole, dont les premiers statuts sont rédigés par Eugène Renard, sous-gouverneur du Crédit foncier de France. C'est un organisme d'utilité publique, mais de droit privé, contrôlé par la SDN, dont le siège devrait être fixé à Paris. Ses opérations permettraient de rembourser les prêts usuraires et modifieraient les cultures de prêt. Son capital (50 millions de dollars) serait souscrit par des personnes physiques ou morales privées.

16 Sur l'ensemble des Conférences d'action économique concertée, lire Sylvain Schirmann, Crise, coopération économique... op. cité, pp. 83-105.

17 Sur la question du crédit agricole, Schaeffer Patrick J., " Les illusions de la coopération financière européenne au début de la crise des années 1930 : l'exemple de la société internationale de crédit hypothécaire agricole » in Sylvain Schirmann (direct.), Organisations internationales et ... op. cité, pp. 367-386. 
Pour offrir des garanties solides, en bout de chaine le crédit serait garanti par des hypothèques. Celles-ci seront détenues par un institut national, seul organisme à qui l'on prêtera. A lui de voir par quel système local il passera pour acheminer l'argent vers le secteur agricole. Mais ce dossier est également éminemment politique. Paris et Londres approuvent cette perspective pour des raisons différentes. Le gouvernement britannique, conscient du fait que les capitaux seraient essentiellement français en espère un avantage pour la Livre, dans la mesure où la pression qui pèse sur elle se relâcherait. Mais l'opinion publique anglaise se désintéresse du projet. Paris soutient la perspective, dans la mesure où les actionnaires représenteront une partie du capital ce qui ne peut qu'avantager la France. Quant à l'Allemagne, en pleine crise de la tentative d'Anschluss économique (mars 1931), elle manifeste une méfiance envers la Société, qu'elle considère comme un moyen de pénétration économique française en Europe centrale et orientale. Les textes sont malgré tout adoptés à l'unanimité le 14 mai 1931 et Paris renonce au siège qui est fixé à Genève. Le Conseil de la SDN approuve la création et les statuts du nouvel organisme le 21 mai 1931. Le 5 juin, Eugène Regard est porté à la tête du nouvel organisme et le travail, en attendant la ratification, peut commencer. Au 30 septembre 1931, on a déjà réuni 31 millions de francs suisses!

Mais la Société ne voit pas le jour. Paris traîne et la ratification n'intervient pas. Les autorités françaises doivent faire face à l'opposition des chambres d'agriculture et du Quai d'Orsay. Pour les responsables de la diplomatie française, la place faite à la France, qui apporte l'essentiel des capitaux, est insuffisante. Elle doit en effet, à travers la SDN et les statuts de l'organisme, partager la gouvernance avec d'autres Etats, qui exercent ainsi à ses yeux un contrôle sur des fonds français. Le Royaume-Uni n'en fait pas non plus une priorité. Il a choisi d'autres préférences : elles sont impériales, et non centre européennes. L'Allemagne préfère la logique du bilatéralisme, tout comme l'Italie et, dès l'automne 1931, une série d'accords de ce type desserre quelque peu l'étau. Cela leur permet de faire rentrer petit à petit ces Etats de l'Europe centrale et orientale dans leur orbite. L'Allemagne, par exemple, signe en juin et juillet 1931 trois accords avec la Bulgarie, la Roumanie et la Hongrie. Elle leur accorde des réductions de droits sur les céréales. L'Italie réserve à ces Etats (Yougoslavie, Roumanie, Hongrie) des ristournes et des abaissements de taxes. La conférence du Bloc agraire réunie à Varsovie le 27 août 1932 réclame quant à elle l'entrée en fonction de la Société de crédit agricole, pratiquement un an après sa constitution. Sans succès. Il en est de même pour le fonds de revalorisation des céréales et le fonds de soutien monétaire imaginé depuis le début de l'année 1932. Ces projets ne sont d'ailleurs plus adaptés à l'Europe centrale et orientale, car c'est un plan d'une autre ampleur qu'il faut pour relancer l'économie dans cet espace.

Au total, le débat a été fécond. La crise a permis le rapprochement dans cette partie de l'Europe de pays révisionnistes et de pays satisfaits par l'ordre versaillais. 
Les solutions discutées laissaient entrevoir l'émergence d'une politique agricole régionale, qui avec l'aide des puissances de l'ouest européen, pouvait peut-être stabiliser le continent dans un contexte économique difficile, mais également dans un climat de débats prometteurs fruit des initiatives de la SDN depuis 1927 et du plan Briand. Force est de reconnaître que l'instrumentalisation de la crise par les puissances a eu raison de ces projets. Celles-ci préfèrent développer avec leurs voisins de l'Est des rapports fondés sur le clientélisme. Ces rapports favorisent l'entrée des Etats de l'Europe centrale et orientale dans l'orbite des puissances révisionnistes, qui ont bien davantage à leur offrir dans le cadre des accords bilatéraux, que la France et le Royaume-Uni, timides et recroquevillés sur leurs égoïsmes nationaux. Incapables de renoncer à des vues étroites, elles ne savent donner corps à des projets ambitieux auxquels les Etats d'Europe centrale ont commencé à réfléchir au tournant des années 1930. Si la responsabilité des puissances est largement engagée pour comprendre l'échec de ces tentatives, il ne faut pas oublier non plus de méditer sur la solidarité effective entre des pays qui n'hésitèrent pas dès 1931 à se lancer dans des accords bilatéraux qui font fi des réflexions entamées entre eux en 1930. De telles dispositions minent la confiance et rendent difficile la poursuite d'une politique agricole régionale. Faut-il cependant ne garder en mémoire que cet échec aux perspectives tragiques?

Les desseins esquissés par les pays d'Europe centrale sont à bien des égards prometteurs. L'européisme qui les caractérise fourmille de réflexions sur la nécessité de lier les deux Europes, interroge la méthodologie de la construction d'une Europe unie. Il vise à élaborer une politique agricole régionale, s'intéresse à la régulation du marché agricole et à l'organisation de la production de manière telle à garantir des ressources aux agriculteurs. Au-delà, c'est une ébauche d'un système de préférences que les desseins tentent d'élaborer, reposant également sur la solidarité entre l'Est et l'Ouest du continent. Cette solidarité comporte à travers les projets de crédit agricole un volet financier. A regarder cela, il nous faut constater que certaines de ces idées refont surface dans le cadre de la construction européenne qui part à l'Ouest dans les années 1950. Elles y ont été portées par des hommes mêlés aux discussions d'alors (Jules Gauthier, Andreas Hermes...), par des organisations (l'Institut international d'agriculture). Au-delà de l'échec dans le contexte des années 1930, ces projets restent un laboratoire d'idées en matière d'européisme! 


\title{
Le paradigme du développement économique en Europe Centrale et Orientale pendant l'entre-deux-guerres. Des contributions françaises en Roumanie
}

\author{
Nicolae P $\breve{A} U N$
}

\begin{abstract}
The end of the First World War opened up new ways towards the economic modernisation of East-Central European states, albeit the setbacks they experienced at the time proved to be major. The disparities between East and West were chiefly noticeable in Romania, whose figures regarding industrialisation exhibited a situation that was inferior even to that of certain countries in the region. The process of modernisation of the Romanian economy was decisively influenced by foreign capital, originating mostly from France, which gave rise to viable endeavours within the most prominent industrial branches.

Keywords: décalages, modernisation, capitaux étrangers, développement, industrie.
\end{abstract}

1. Le patrimoine de l'Europe centrale et orientale après 1918.

Stéréotypes identitaires et différences en matière de développement

Dès le début de leur affirmation en tant qu'États-nations, la viabilité des nouveaux pays centraux et est-européens a été questionnée en raison de leur sousdéveloppement socio-économique, de la crise économique générale d'après la première guerre mondiale, mais aussi à cause de la situation nationale pas encore résolue, d'où il est apparu le problème naturel de la stabilité et la durabilité des frontières formées après $1918 .{ }^{1}$

S'il faut discuter, toutefois, la problématique des décalages économiques, le niveau de synchronisation et d'européisation entre l'ouest et l'est de l'Europe, ceci doit être fait de manière méthodique et correcte. Ainsi, en premier lieu, une telle question doit être placée dans le contexte historique approprié, afin de permettre la mise en relief de l'impact que le moment historique respectif a eu sur le niveau du développement, mais aussi pour illustrer plus clairement la façon dont l'identité centrale-orientale a contribué elle-même au règlement des clivages dans l'entre-deux-guerres. ${ }^{2}$

Du point de vue économique, les États centraux-orientaux n'ont pas réussi à performer, au moins pendant la première moitié du $\mathrm{XX}^{\text {ème }}$ siècle, à un très haut niveau, car ils n'avaient pas de fondements solides (dans certains cas, ils manquaient totalement). Parmi les carences, on peut énumérer la précarité de l'urbanisation (ce

1 Judy Batt, Introduction: Regions, State and Identity in Central and Eastern Europe. In: Regional and Federal Studies, 2010, p. 5.

2 David F. Good, Economic Transformation in Central Europe: The View from History. In: Working paper 92-1, January 1992, p. 6. 
qui a rendu extrêmement rares les centres autonomes d'activité, soit économique, soit politique) et le fait que les élites culturelles, professionnelles et politiques de la région (ayant, dans plusieurs cas, une origine nobiliaire) ont promu des programmes de modernisation étatistes et bureaucratiques, négligeant les solutions entrepreneuriales privées, la politiques participative et le principe de la (ré)distribution générale du pouvoir. Ce désir de centralisation de l'État résulte de l'identité de peuple conquis, trouvé tout le temps en défensive, qui, une fois maître de son propre territoire, a pour principal but sa consolidation, aussi rapidement que possible.

Ce trauma despotique (si on peut le nommer de la sorte) a déterminé une autre grande insuffisance de la zone centrale-orientale : l'absence d'une classe moyenne stable. Les classes sociales étaient formées des très riches - la noblesse (latifundiaires, politiciens, clergé, bureaucrates) et des très pauvres, notamment des paysans. À cause du faible développement industriel et urbanistique, les associations d'artisans des villes réussissaient à peine à se constituer, pendant les premières années d'après la guerre. ${ }^{3}$

Une autre carence (qui résulte d'une certaine mesure de ce que nous avons présenté ci-dessus), qui a déterminé le développement lent de cette zone, est présentée logiquement par Schopfin. Selon celui-ci, l'apparition des nouveaux États en Europe orientale après la première guerre mondiale n'a pas été accompagnée aussi du développement significatif de la société civile autonome (surtout en raison de l'absence d'une classe moyenne), ce qui constitue une particularité définitoire du spécifique « tardif » du processus de modernisation de cette région. La raison pour l'impossibilité de former une société civile puissante a été déterminée par les répercussions de la domination étrangère prolongée, ce qui a mené à la construction de la société civile non pas comme une structure autonome par rapport aux facteurs du pouvoir (militant pour les droits des citoyens, comme à l'Occident), mais comme une structure quasi-dépendante des facteurs du pouvoir, militant pour des droits nationaux et pour la consolidation des États-nations solides. ${ }^{4}$

Il est à remarquer, cependant, le fait que pour la première fois dans l'histoire, les États centraux-orientaux, y compris la Roumanie, ont connu une période de liberté économique et la possibilité de se forger leur propre voie et leur propre vision. Les décalages par rapport aux grands pouvoirs sont restés quasi-intacts, voire ont augmenté çà et là, au moins pendant les premières années d'après la guerre. ${ }^{5}$ Par contre, en ce qui concerne strictement la zone centrale-orientale, les

3 Derek, H. Aldcroft, Europe's Thirld World: The European Periphery in the Interwar Years, Ashgate Publishing Company, Vermont, USA, 2006, p. 14.

4 Piotr. S Wandycz, Prețul libertății. O istorie a Europei central-răsăritene din Evul Mediu pînă în prezent, traduction: Mihaela Paraschivescuet Valentin Dragu-Banu, Éd. ALL, Bucarest, 1998, p. 8.

5 David F. Good, op. cit., p. 6. 
différences économiques entre les États qui la composent se sont uniformisées en grande mesure dans les années 1920, notamment en raison de l'homogénéité plus prononcée de la partie orientale, qui était en général moins développée. Celle-ci, sans devoir gérer des minorités qui s'élevaient même à $30 \%$ de la population dans certains cas (comme en Pologne et en Tchécoslovaquie), a eu une liberté plus prononcée d'accroître sa productivité et ses ressources économiques. ${ }^{6}$

L'État le plus influent et impliqué dans la région a été la France ${ }^{7}$, qui jouissait de relations étroites avec beaucoup d'États qui venaient d'être créés, mais qui était aussi directement intéressée par le renforcement de ces États, afin d'éviter une éventuelle expansion allemande, autrichienne ou même russe dans cette partie de l'Europe. D'autre part, la Grande Bretagne était presque indifférente à l'égard du sort de l'Europe centrale, étant beaucoup plus préoccupée par le maintien et l'exploitation de ses possessions coloniales, une direction dans laquelle elle a dirigé la plupart de son capital.

Pour ce qui est de l'Allemagne, quoiqu'elle se trouvât dans un déclin visible, en tant qu'état d'esprit et de perception de soi, le peuple allemand continuait à se regarder en termes de grand pouvoir. Par conséquent, ne pas ayant une monnaie forte, étant dénuée de fonds en monnaie étrangère et incapable de placer ses marchandises sur d'autres marchés, contrôlés par la concurrence, l'Allemagne pressait là où les facteurs le lui permettaient, donc vers l'est. ${ }^{8}$ Néanmoins, quant à cette zone, les nouveaux États qui la peuplaient étaient extrêmement réticents de collaborer avec l'Allemagne, étant épouvantés par ses prétentions révisionnistes. Pratiquement, les échanges commerciaux et économiques de l'entre-deux-guerres ont été en grande mesure déterminés par les intérêts politiques de l'époque et les relations formées entre de différentes catégories d'États, après la première guerre mondiale. Plus précisément, les territoires réunis et contents suite à la redéfinition des frontières européennes sont devenus extrêmement proches et, implicitement, ils ont entamé une collaboration étroite, sur tous les fronts. Les meilleurs exemples sont donnée pas la Yougoslavie, la Roumanie, la Tchécoslovaquie et la Pologne.

6 Jeffrey S Kopstein, Jason Wittenberg, Beyond Dictatorship and Democracy: Rethinking National Minority Inclusion and Regime Type in Interwar Eastern Europe, in Comparative Political Studies, 2010, p. 1093.

7 Voir, par exemple, la contribution financière et l'expertise technique que la France a accordées massivement aux États centraux et est-européens pendant la période de la Grande Dépression. Ceci a été décisif pour la Roumanie dans l'obtention des emprunts de stabilisation et de consolidation financière (1928-1934). Archives de la Banque Nationale de Roumanie, Service études 1933-1969, deuxième partie, Secrétariat. Conseillers étrangers : dos. 7/1929-1933 (s.n.).

8 Gheorghe Cazan, Nicolae Copoiu, Ion Cupşa, Leonida Loghin, N.Z Lupu, Alexandru Siperco, Dumitru Tuţu, Constantin Ucrain, Gheorghe Unc, Alexandru Vişanu, Gheorghe Zaharia, Marea Conflagrație a secolului XX: Al Doilea Război Mondial, Éd. Politica, Bucarest, 1974, p. 43. 
Tous ces États étaient proches de la France et soutenaient la cause de la Ligue des Nations, à laquelle ils ont adhéré sans hésitation, étant également adeptes du maintien du status-quo européen. Dans ce but, la Roumanie, la Yougoslavie et la Tchécoslovaquie formèrent l'alliance connue sous le nom La Petite Entente, la première alliance au caractère régional créée après la première guerre mondiale. ${ }^{9}$

\section{Les stratégies de développement et de modernisation de la Roumanie après 1918}

La Roumanie a pris le contact avec la civilisation occidentale et a commencé à adopter le modèle occidental seulement à partir du XIX ${ }^{\text {ème }}$ siècle. Ses décalages peuvent être mieux remarqués si l'on se réfère à la productivité agricole et au développement industriel de la Roumanie, par rapport à la situation en Europe occidentale. Nous devons noter tout d'abord le fait que l'Europe occidentale avait déjà parcouru les deux étapes de la révolution agricole : la première, commencée au XVIII ${ }^{\text {mè }}$ siècle, a été fondée sur le passage à une forme d'agriculture intensive, avec des cultures plus étendues, une amélioration des semences et la combinaison entre l'élevage des animaux et les cultures des plantes; la deuxième a commencé au XIX ${ }^{\text {ème }}$ siècle et a continué également au $X^{\text {ème }}$ siècle - elle consistait en un remplacement de la force de travail manuel par la mécanisation. Si on la compare à ces évolutions, « La Roumanie du XIX ${ }^{\text {ème }}$ siècle n'a parcouru que de façon partielle la première révolution agricole moderne et a commencé tardivement et à une échelle réduite le processus de mécanisation des travaux agricoles. ${ }^{10}$ 》 En dépit de cela, la productivité agricole de la Roumanie se situait au-dessous de la moyenne des pays développés, comme il est démontré par les données du tableau suivant :

Tableau 1. Indices de la productivité agricole (millions de calories/habitant de sexe masculin, actif sans le secteur agricole)

\begin{tabular}{|l|l|l|l|l|}
\hline & 1800 & 1860 & 1890 & 1910 \\
\hline Roumanie & 6,0 & 6,7 & 10,8 & 13,9 \\
\hline Moyenne européenne & 6,0 & 8,0 & 9,1 & 11,3 \\
\hline Moyenne européenne moins la Russie* & 6,2 & 9,1 & 11,3 & 14,9 \\
\hline Moyenne des pays occidentaux développés & 7,1 & 12,5 & 18,0 & 23,4 \\
\hline
\end{tabular}

* La moyenne européenne est réduite par la contribution consistante de la Russie, avec un faible développement agricole.

Source: Paul Bairoch, L'agriculture des pays développés, 1800 à nos jours : production, productivité, rendements, Éd. Economica, Paris, 1999, pp. 136-137.

9 Piotr. S Wandycz,France and Her Eastern Allies, 1919-1925: French-Czechoslovak-Polish Relations from the Paris Peace Conference to Locarno, University of Minnesota Press, 1962, p. 202.

10 Bogdan Murgescu, România şi Europa. Acumularea decalajelor economice (1500-2010), Ed. Polirom, Iaşi, 2010, p. 135. 
Ainsi, par l'analyse de ce tableau on peut observer le fait que la Roumanie n'était pas loin de la moyenne européenne en ce qui concerne la productivité agricole, mais la distance par rapport aux pays occidentaux s'est accentuée graduellement pendant les deux siècles. Ce qui est notable, c'est qu'en 1910, la Roumanie réussit même à dépasser la moyenne européenne, mais celle-ci inclut aussi les États de l'Europe centrale et de l'est, donc la comparaison est plus utile pour notre étude lorsqu'on observe les décalages entre la Roumanie, un État de l'Europe centrale, et les États occidentaux qui ont déjà parcouru les étapes de la révolution industrielle.

Les décalages les plus évidents peuvent être observés, cependant, au niveau du développement industriel, où la Roumanie se trouvait à proximité de la valeur zéro au début du XIX ${ }^{\text {ème }}$ siècle. En revanche, les États occidentaux avaient déjà une industrie en plein essor, étant donné que l'industrialisation y avait commencé au XVIII ${ }^{\text {ème }}$ siècle. L'une des explications de ce phénomène réside dans le fait qu'en Roumanie, l'industrialisation était plutôt liée à la Transylvanie, qui, jusqu'en 1918, avait appartenu à l'Empire Austro-hongrois.

L'Ancien Royaume ne disposait pas de ressources suffisantes pour démarrer un processus d'industrialisation à une grande échelle, celui-ci se résumant aux biens de consommation. Toutefois, on peut y enregistrer des évolutions, d'autant plus que nous parlons d'un très faible niveau d'industrialisation au début. Par conséquent, tout progrès peut être mis en évidence, comme on l'observe dans ce tableau visant la production industrielle européenne :

Tableau 2. Production industrielle per capita (indices rapportés au Royaume-Uni en 1900 $=100)$

\begin{tabular}{|l|l|l|l|l|l|l|}
\hline & 1800 & 1830 & 1860 & 1880 & 1900 & 1913 \\
\hline Moyenne européenne & 8 & 11 & 17 & 23 & 33 & 45 \\
\hline Austro-Hongrie & 7 & 8 & 11 & 15 & 23 & 32 \\
\hline Belgique & 10 & 14 & 28 & 43 & 56 & 88 \\
\hline Bulgarie & 5 & 5 & 5 & 6 & 8 & 10 \\
\hline Danemark & 8 & 8 & 10 & 12 & 20 & 33 \\
\hline Suisse & 10 & 16 & 26 & 39 & 67 & 87 \\
\hline France & 9 & 12 & 20 & 28 & 39 & 59 \\
\hline Allemagne & 8 & 9 & 15 & 25 & 52 & 85 \\
\hline Grèce & 5 & 5 & 6 & 7 & 9 & 10 \\
\hline Italie & 8 & 8 & 10 & 12 & 17 & 26 \\
\hline Norvège & 9 & 9 & 11 & 16 & 21 & 31 \\
\hline Pays-Bas & 9 & 9 & 11 & 14 & 22 & 28 \\
\hline Portugal & 7 & 7 & 8 & 10 & 12 & 14 \\
\hline Royaume-Uni (Grande Bretagne) & 16 & 25 & 64 & 87 & 100 & 115 \\
\hline Roumanie & 5 & 5 & 6 & 7 & 9 & 13 \\
\hline Russie & 6 & 7 & 8 & 10 & 15 & 20 \\
\hline Serbie & 5 & 5 & 6 & 7 & 9 & 12 \\
\hline
\end{tabular}




\begin{tabular}{|l|l|l|l|l|l|l|}
\hline Espagne & 7 & 8 & 11 & 14 & 19 & 22 \\
\hline Suède & 8 & 9 & 15 & 24 & 41 & 67 \\
\hline
\end{tabular}

Source: Paul Bairoch, Maurice Lévy-Leboyer (éds.), Disparities in Economic Development since the Industrial Revolution, Éd. Palgrave Macmillan, 1981, pp. 294, 330-331.

Nous pouvons déceler, grâce à ce tableau, le fait que la Roumanie se trouvait au-dessous de la moyenne européenne en ce qui concerne l'industrialisation ${ }^{11}$, mais le même va pour ses voisins : la Serbie, la Bulgarie et même la Grèce, située au sud-est de l'Europe. L'Europe centrale et de l'est se situaient, ainsi, au début de l'industrialisation, tandis que les États occidentaux avaient déjà enregistré de véritables progrès dans ce domaine. La Grande Bretagne (le lieu d'origine de la révolution industrielle), la France et la Belgique ont connu une augmentation spectaculaire des indices du développement industriel.

Un autre point où les décalages sont visibles se réfère à la proportion de la population active dans l'industrie. Selon Victor Axenciuc, « la population active dans l'industrie, en 1911, représentait, du total du pays, en France 36,1\%, en Grande Bretagne 51,7\%, et en Allemagne 40,9\% », tandis que « la Roumanie, avec seulement $6,1 \%$, se trouvait à une distance de plus de cinq fois de la France, huit fois de la Grande Bretagne et 6,4 fois par rapport à l'indice d'Allemagne; une distance d'au moins un siècle dans l'ère de l'industrialisation-même $»^{12}$. Ce décalage par rapport aux États occidentaux a été clairement saisi, vu que le nombre réduit du personnel employé dans l'industrie dénote un faible développement de l'industrialisation. Or, nous avons pu observer que la Roumanie se trouvait à une distance suffisamment grande de plusieurs États, comme la France, le Royaume-Uni et l'Allemagne, une distance que Victor Axenciuc estimait à approximativement un siècle.

La Roumanie n'était pas le seul pays européen qui ait enregistré un véritable recul dans le domaine de l'économie. L'espace de l'Europe centrale et du sud-est était, en effet, plein d'exemples pareils à celui de la Roumanie. La Hongrie avait un profil agraire-industriel, mais elle a commencé à récupérer (au moins dans le secteur agricole) par l'introduction de la mécanisation et par une concentration du capital dans l'industrie du profil. La Yougoslavie avait un caractère prépondérant agraire, car approximativement $80 \%$ de la population était employée dans ce secteur, tandis que du point de vue industriel, tout progrès y a été compromis à cause des dégâts provoqués par la guerre. La Bulgarie était également un État au caractère prépondérant agraire, au sein duquel l'industrie moderne était pratiquement absente (des progrès ont été enregistrés seulement dans l'industrie légère et dans l'extractive), et l'agriculture était marquée par de très faibles rendements. La

11 Nicolae Păun, Stat şi economie, Éd Interferențe, 1992, pp. 48-95.

12 Victor Axenciuc, Formarea sistemului industrial modern în România. Etapa 1859-1914: demarajul industrializării, Éd. de l'Académie Roumanie, Bucarest, 2008, p. 280. 
Grèce connaissait un niveau de développement plus élevé, autant dans le secteur agricole, que dans l'industriel, mais aucun secteur ne se faisait remarquer par un progrès spectaculaire.$^{13}$ En outre, ce qui est important à remarquer dans le cas des États centraux et sud-est européens, c'est le fait que le développement de leurs économies ou les progrès y enregistrés était plutôt fondés sur les capitaux étrangers. Ils ne possédaient pas assez de capital pour développer leurs secteurs agricoles et industriels, c'est pourquoi ils ont recouru à des emprunts externes.

En dépit de cela, il y a aussi un cas de succès en Europe centrale, la Tchécoslovaquie. C'était « l'un des mieux développés États de l'Europe centrale, surtout du point de vue industriel $»^{14}$, ce qui a encouragé également la pratique d'une agriculture intensive, due à la mécanisation.

Un autre indicateur important dans l'analyse de la question des décalages entre les deux Europes est le produit intérieur brut per capita des États européens. Il faut pourtant préciser que cet indicateur est apparu plus tard, et son équivalent dans l'entre-deux-guerres est représenté par le Revenu national. ${ }^{15}$ Cet indicateur est important parce qu'il relève le degré de développement de l'économie d'un État, puisque le Revenu national per capita nous montre le potentiel de production de l'économie d'un État, rapporté à sa population. En plus, il est important de préciser que dans la littérature de spécialité on trouve peu de données statistiques sur la période entière, tandis que celles qui existent sont questionnables ou incomplètes. Néanmoins, l'an 1938 est considéré le zénith des économies européennes, où l'on a atteint le point culminant du développement de l'entre-deux-guerres. Certes, lorsqu'on se réfère à cet an, il faut aussi saisir que c'est assez loin de la Grande dépression et à la distance de seulement une année de la seconde guerre mondiale, qui marque une nouvelle chute économique. Donc, il est utile de comparer le Revenu national per capita au niveau de plusieurs États européens.

Tableau 3. Revenu national per capita en Roumanie et dans d'autres pays européens 1938 (dollars américains)

\begin{tabular}{|l|l|}
\hline Grande Bretagne & 378 \\
\hline Allemagne & 338 \\
\hline Danemark & 318 \\
\hline Belgique et Luxembourg & 285 \\
\hline Irlande & 248 \\
\hline France & 237 \\
\hline Tchécoslovaquie & 174 \\
\hline
\end{tabular}

13 Andrei Josan, Evoluții economice pe plan mondial în perioada interbelică, Éd. ASE, Bucarest, 2004, pp. 96-97.

14 Maria Mureşan, Andrei Josan, Istoria economiei europene: de la revoluția industrială la Uniunea Europeană, Éd. ASE, Bucarest, 2005, p. 97.

15 Voir: Dragoş Păun, Romania’s road towards the Euro, Presa Universitară Clujeană, 2011. 


\begin{tabular}{|l|l|}
\hline Italie & 127 \\
\hline Hongrie & 111 \\
\hline Pologne & 104 \\
\hline Grèce & 80 \\
\hline Roumanie & 76 \\
\hline Bulgarie & 68 \\
\hline Yougoslavie & 68 \\
\hline Niveau moyen dans 20 pays européens & 222 \\
\hline
\end{tabular}

Source: Gheorghe Dobre, Economia României în context european - 1938, Éd. Fundației Ştiințifice „Memoria Oeconomica”, Bucarest, 1996, p. 138.

Grâce à ce tableau, nous pouvons affirmer le fait que la Roumanie se trouvait à un niveau inférieur par rapport aux États européens occidentaux, mais aussi à la Hongrie. Le niveau moyen européen était approximativement trois fois plus grand, par comparaison avec la Roumanie, mais aussi à la Yougoslavie et à la Bulgarie. On peut observer que les États centraux et sud-est européens se trouvaient au-dessous de la moyenne des États européens, et si on établit une comparaison avec les pays occidentaux, comme la Grande Bretagne, on se confronte à des rapports d'environ 1:2 (Tchécoslovaquie) et 1:5 (Bulgarie ou Yougoslavie).

Il y a des opinions qui placent pourtant la Roumanie sur une position beaucoup meilleure dans la hiérarchie des États de l'Europe orientale, et les progrès qu'elle a enregistrés étaient perçus comme beaucoup plus consistants. Par exemple, Gheorghe Iacob affirme que « si on établit une comparaison entre la Roumanie de 1914 et la Roumanie d'A.I. Cuza, entre la Roumanie de 1938 et celle de Carol I autour de la première guerre mondiale, nous constaterons l'achèvement d'un bond spectaculaire. Ce n'est pas par accident [...], que les observateurs étrangers surnommaient la Roumanie, au début du $\mathrm{XX}^{\mathrm{ème}}$ siècle, la Belgique de l'est ou le Japon européen, tandis qu'en 1938, la Roumanie se situait - du point de vue de plusieurs repères, à la tête des pays du sud-est de l'Europe $»^{16}$. Cependant, tenant compte du tableau ci-dessus, on peut observer que la Belgique se trouvait à une distance considérable par rapport à la Roumanie en ce qui concerne le revenu national per capita, qui reflète très clairement le développement et la performance économique. En outre, on observe que la Roumanie ne se trouvait pas à la tête des États sud-est européens, son revenu national per capita étant dépassé par la Grèce. Par ailleurs, la faible distance entre la Roumanie, d'une part, et la Bulgarie et la Yougoslavie, d'autre part, relève le fait que ces pays se trouvaient à un niveau similaire de développement. Pour conclure, il est évident que les pays agraires continuaient même vers la fin de l'entre-deux-guerres à être non-performants, ce

16 Gheorghe Iacob, Procesul modernizării/integrării în Europa. Etape şi trăsături. In: Ion Agrigoroaiei (coord.), România interbelică în paradigmă europeană, Éd. de l'Université «Alexandru Ioan Cuza », Iaşi, 2005, pp. 33-34. 
qui a augmenté davantage les différences entre les États occidentaux et orientaux. Il est vrai qu'on a enregistré aussi des progrès, mais cela est dû surtout au fait que les pays de l'est sont partis d'un niveau de développement très faible dans le secteur industriel (parfois même inexistant).

La seule solution pour réduire les décalages entre les deux Europes était, donc, l'industrialisation. Bien que cette solution ait été identifiée, dans beaucoup d'États centraux et sud-est européens, ce processus d'industrialisation a été très lent. Parmi les causes principales de ce phénomène, on retrouve : le manque des capitaux, l'absence d'une force de travail qualifiée, le manque de politiques cohérentes etc.

Une explication possible du niveau relativement faible du développement atteint par les États orientaux à la fin de 1938 se réfère à la politique que la majorité d'entre eux ont promue : la politique de brûlage des étapes. Ainsi, l'évolution économique et sociale ne peut être comprise que « dans le cadre du phénomène général qui a provoqué, dans tous les États retardés, la précipitation des étapes du développement historique et leur réduction à des intervalles de temps extrêmement courts ${ }^{17}$. $\gg$ Cela a mené cependant à une assimilation incomplète des aspects caractéristiques aux sociétés occidentales développées.

Il est intéressant de signaler dans notre analyse le fait qu'à partir du contexte central-européen mentionné ci-dessus, on a avancé dans la société roumaine des solutions pour la modernisation et le développement de la communauté. Les intellectuels humanistes, expérimentalistes, les économistes, les juristes etc. ont assumé des idées, des solutions, des théories, non seulement en tant que bénéficiaires, mais, maintes fois, en qualité de contributeurs appréciés au niveau européen. Eugen Lovinescu, Mihail Manoilescu, Dimitrie Drăghicescu, Virgil Madgearu, Victor Slăvescu, Mitiță Constantinescu etc. ont généré à l'intérieur de la société roumaine l'émulation et la soutenance nécessaires à l'encadrement du pays dans le modèle de développement occidental. Très souvent, les politiciens se sont impliqués eux-aussi dans le débat sur les idées modernes, intégratrices, qu'ils ont transposées dans des programmes ou de l'action politique. ${ }^{18}$

Les lignes d'évolution d'après 1918, au sein de la pensée et de la pratique économique-politique de notre pays, ont tenu compte autant des réalités auxquelles se confrontait le modèle occidental, que de la complexité du dossier économique à la résolution duquel elles étaient appelées à répondre.

Les institutions ont été les plus importantes surfaces de contact entre l'Autorité, la Société et l'Économie. Elles ont favorisé des connexions entre la théorie et la pratique économiques; par ce biais on a accompli la structuration de l'économie

17 Andrei Josan, op. cit., p. 139.

18 Voir: Nicolae Păun, "Il modello romeno nel periodo interbellico », dans le volume La tentazione autoritaria. Istituzioni, politica e società nell'Europa centro-orentale tra le due guerre mondiali (a cura di Pasquale Fornaro), Éd. Rubettino, 2004, pp. 163-189. 
nationale dans des couches horizontales et verticales. ${ }^{19}$ Ceci est dû aussi à l'impressionnant patrimoine, dont le noyau était constitué par les ressources du soussol. Conformément à l'article 19 de la Constitution promulguée en 1923, à l'exception des carrières de pierre, des roches communes et des minerais de tourbe, celles-ci ont été nationalisées et passées dans la propriété de l'État.

Par la Constitution de 1923, l'option pour le renouvellement, la synchronisation et la modernisation a constitué un élément de fermeté et de constance. D'ailleurs, la Constitution de 1923 est le document qui attestait la volonté des élites, mais aussi une option pour la convergence avec un certain modèle de développement - l'occidental, sous inspiration française. L'expérience roumaine n'a pas été une simple copie du modèle occidental, mais un appréciable raccordement à l'esprit européen, sous des conditions socio-économiques et géopolitiques spécifiques, relativement différentes de celles de l'Occident.

\section{Les contributions françaises à la modernisation de la Roumanie}

La conception de la modernisation au niveau européen, suite à la première guerre mondiale, visait des investissements en industrie, mais cela s'est avéré plus difficile à achever dans des États tels la Roumanie, qui se trouvaient à plusieurs pas derrière ceux de l'occident. Ces États orientaux percevaient la modernisation comme une nécessité d'avoir des investissements dans leurs économies nationales, en vue de la consolidation de leurs propres industries, tout en acceptant la collaboration avec le financement extérieur. Ainsi, on y a formulé des plans par lesquels on a établi le rôle de l'État au sein de l'économie nationale et l'attitude envers le capital étranger. ${ }^{20}$ Malheureusement, beaucoup de ces plans sont restés au niveau des idées, par manque de mesures pratiques qui étaient si nécessaires, ce qui a permis l'action du capital étranger, étant donné l'absence d'un système économique roumain cohérent. « Le capital étranger était présent dans l'économie roumaine depuis la seconde moitié du $\mathrm{XIX}^{\mathrm{ème}}$ siècle, notamment dans l'industrie pétrolifère, où à cause des risques à long terme, des technologies coûteuses importées, du manque du personnel qualifié etc., le capital autochtone modeste du point de vue financier, ne représentait que $6 \% \mathrm{du}$ capital investi dans cette branche jusqu'à la première guerre mondiale. $\nu^{21}$

La branche de l'industrie lourde détenait la plus grande partie du capital étranger total investi en Roumanie. « À partir de 1928, les capitaux se sont déplacés lentement depuis l'industrie minière vers les branches métallurgiques et électrotechniques, suivies par la sidérurgie, l'industrie alimentaire, chimique, des matériaux de construction,

19 Idem, Viața economică a României 1918-1948. Dezvoltare. Modernizare. Europenizare, Presa Universitară Clujeană, 2009, pp. 135-136.

20 Idem, The Impact of the Great Union on Romania's Interwar Economic Development, « Studia Universitatis Babeş-Bolyai, Historia », 1988, 2, Cluj-Napoca, pp. 38-39.

21 Idem, Societățile anonime din România în anii 1919-1924, « Anuarul Institutului de Istorie şi Arheologie Cluj-Napoca », no. XXVIII, Université de Cluj-Napoca, 1987-1988, p. 380. 
textile et du cuir. $1 »^{22}$ Le capital étranger s'est consolidé progressivement en Roumanie dans l'entre-deux-guerres, celui-ci visant surtout les secteurs économiques qui assuraient un profit immédiat, ou bien très élevé. ${ }^{23}$ En 1924, « La statistique minière de la Roumanie nominalisait 120 sociétés anonymes constituées dans le pays et considérées roumaines, 29 autres au capital étranger et roumain en lei, 26 fondées avec du capital en livres sterling, 12 en francs français ou belges, 4 aux capitaux en florins hollandais, soit 191 sociétés anonymes avec un capital initial de 7.249.040.629 lei". ${ }^{24}$ Le groupe financier français avait à sa tête « Banque de Paris et des Pays-Bas », "Banque Mirabaud et $\mathrm{C}$-ie » et « Omnium International des Pétroles ».

\section{L'industrie du pétrole}

Après la première guerre mondiale, conformément aux conditions générées par la paix de Versailles, qui stipulaient la nationalisation des capitaux ennemis, le capital allemand et, partiellement, l'austro-hongrois ${ }^{25}$, auraient dû devenir roumains, mais les choses ne se sont pas déroulées de la sorte, notamment en ce qui concerne l'industrie du pétrole. ${ }^{26}$ En réalité, la France et l'Angleterre ont partagé de manière paritaire le capital qui avait appartenu à l'Allemagne, tandis que la Roumanie arrivait à détenir 6,6\% du capital de la société Steaua Română (Étoile Roumaine) et $5 \%$ de celui des sociétés Vega, Concordia et Crédit Petrolifer (Crédit Pétrolifère).

«En 1923, le gouvernement français a décidé d'accorder aux sociétés au capital français de Roumanie certains paiements remboursables, sans intérêts, dans le compte des compensations qu'on avait établies pour celles-ci. ${ }^{27}$ On précisait que ces paiements ne préjudiciaient pas la résolution finale des compensations. $»^{28}$

22 Ioan Saizu, Politica economică a României între 1922 şi 1928, Éd. de l’Académie de la République Socialiste Roumanie, Bucarest, 1981, p. 107.

23 Voir l'activité de la Chambre du Commerce Franco-roumaine 1926-1932, dans les Archives de la Banque Nationale de Roumanie, Service études, 1913-1969, Deuxième partie. Secrétariat. Conseillers étrangers, dos. 6/1929-1931, f. 1-10.

24 Statistica Minieră a României pe anul 1924, Bucarest, 1925, p. V-VI, 3-17.

25 Sur les liquidateurs de la Banque Austro-hongroise, voir les Archives de la Banque Nationale de Roumanie. Service secrétariat, vol. I, dos. 1/1924-1925 (s.n.).

26 Archives Nationales Historiques Centrales, fond Maison Royale Ferdinand, dos. 5/1923, f. 4-5.

27 « Despăgubirile de război », « Moniteur du Pétrole Roumain », 1923, 23, vol. 22, pp. 15501551. Les sociétés suivantes ont reçu des avances: „Aquila Franco-Română”, 11504 407, „Petrofina” („Concordia”, „Vega”), 8000 000, „Colombia”, 7563 285, Raffineries „Predinger”, 1989 697, „Vulcăneşti”, 941 332, „Victoria”, 856 350, „Comp. Industrielle des Pétroles”, 480 510, „Apostolache”, 323 527, „Société de Pétrole de Buştenari”, 230 872, Exploatarea „Tacite Delort”, 228 307, „Société de Pétrole de Bordeni”, 179 280, Société „Romana”, 55912 francs français. Voir aussi: Gheorghe Calcan, Industria petrolieră din România în perioada interbelică, Éd. Tehnică, Bucarest, 1997, p. 193; Mihail Manoilescu, Politica statului şi chestiunea refacerii industriale, Bucarest, 1920, p. 15.

28 Gheorghe Calcan, op. cit., p. 159. 
La production de pétrole de la Roumanie, dans l'entre-deux-guerres, a eu une dynamique qui a culminé en 1936. «En général, la législation minière de la période 1924-1944 a reflété les intérêts réels de l'État, sans ignorer pourtant les intérêts d'affaires des entrepreneurs autochtones ou étrangers, avec des avantages de la part des uns ou des autres, mais aussi avec des changements fortuits dans une certaine conjoncture économique ou politique, comme il a été le cas en 1929 et 1940. $\gg{ }^{29}$ Les ressources importantes de pétrole de la Roumanie ont déterminé que celles-ci y deviennent la principale activité industrielle, étant aussi le domaine le plus sollicité par le capital étranger. ${ }^{30}$ En dépit de cela, dans l'entre-deux-guerres on peut observer, chaque année, une baisse du capital étranger et une augmentation de l'implication du capital autochtone. Ceci est dû à l'orientation du capital étranger vers d'autres branches industrielles, en plein essor, et qui n'étaient pas aussi sollicitées que le pétrole, à l'époque. « Du point de vue absolu, entre 1921 et 1938, le capital étranger du pétrole a augmenté, de 8,02 milliards lei à 10,35 milliards lei, soit de presque $30 \%$. Pourtant, entre temps, le capital roumain de cette branche a crû presque cinq fois, ce qui a déterminé la modification du rapport entre le capital étranger et l'autochtone, par la diminution du taux du capital étranger, du capital social total, de $91,19 \%$ en 1921 à $73,84 \%$ en 1938, et la croissance du capital roumain, de $8,81 \%$ en 1921 à $26,16 \%$ en 1938 . $»^{31}$

Le capital français a manifesté son intérêt d'investir dans le pétrole, la métallurgie, la sidérurgie etc ${ }^{32}$. Parmi les sociétés de l'industrie du pétrole, nous faisons mention seulement des suivantes :

La compagnie Concordia, avec un capital social de 150 millions lei, en 600000 actions ordinaires, au porteur, à 250 lei chacune, a appartenu avant la guerre presque totalement au capital allemand, autrement dit à la société Deutsche Erdöl AG. Elle a été « naturalisée » en 1920, par le groupe belgo-franco-roumain ayant des relations avec la société Petrofina - Compagnie Financière belge des Pétroles. ${ }^{33}$

Colombia est une société franco-roumaine du pétrole, créée en 1905, avec un capital de 380 millions lei. La société Colombia est née par la fusion de la

29 Gheorghe Ivănuş, Istoria petrolului în România, Éd. AGIR, Bucarest, 2004, p. 216.

30 Archives Nationales Historiques Centrales, fond Maison Royale Ferdinand, dos. 5/1923, passim.

31 Constanța Bogdan, Adrian Platon, Capitalul străin în societățile anonime din România în perioada interbelică Éd. de l'Académie de la République Socialiste Roumanie, Bucarest, 1981, p. 52.

32 Voir aussi l'activité des conseillers techniques français, respectivement Charles Rist et Aubain, délégués par la Banque de France à la Banque Nationale de Roumanie, pendant la Crise, bénéficiant l'appréciation du Gouvernement roumain et du Ministère des finances pour les deux ans passés en Roumanie : Archives de la Banque Nationale de Roumanie, Service études 1913-1969, Deuxième partie, Secrétariat. Conseillers étrangers, dos. 7/19291933 (s.n.).

33 «Moniteur du Pétrole Roumain », 1923, vol. 22, p. 159. 
Société Colombia - membre du groupe français d'intérêts Omnium International de Pétroles et les Sociétés Alpha et Aquila Franco-Roumaine (à partir de 1928). ${ }^{34}$ Colombia est contrôlée par un groupe franco-belge puissant, dirigé par Banque de Paris et des Pays-Bas, la Société Pétroles de Roumanie d'Anvers, à côté d'autres compagnies, représentées toutes par Omnium International des Pétroles, qui détenait environ 200000 actions de Colombia, des 276000 qui avaient été émises. ${ }^{35}$

Avec un capital social de 600 millions lei, dont 150 millions était détenu par la Société Industrielle de Pétroles, Industria română de petrol S.A.R. București (Industrie roumaine du pétrole S.A.R. Bucarest), fonctionnait toujours avec l'appui du capital français de Paris. ${ }^{36}$

Steaua Română S.A. București, ayant comme domaine d'activité, dans le cadre des deux raffineries, l'industrie pétrolifère, aussi bien que les opérations inhérentes à cette industrie, a été créée en 1895, ayant en 1922 un capital social de 310000000 lei, en 620000 actions ordinaires au porteur, à 500 lei chacune. Cette société, la plus grande de sa branche, dépendait avant la guerre d'un groupe d'institutions financières allemandes, à la tête duquel se trouvait Deutsche Bank, qui exerçait son contrôle en Roumanie par l'intermédiaire de Deutsche Petroleum AG. En 1920, Steaua Română est passée sous le contrôle d'un groupe financier roumain-français-anglais. Le groupe français avait à sa tête les trois banques mentionnées ci-dessus. ${ }^{37}$

D'autres exemples de compagnies du domaine du pétrole qui déroulaient leur activité grâce aux investissements du capital français étaient Petrolmina, Sondrum, Telega Moreni, Metal Petrol, Continentala Petroliferă, Rafinăria Moinești, Continentala Petroliferă et Petrofina Française.

1922 représente l'an où à Anvers il est arrivé le premier bateau-tank chargé de pétrole roumain. La marchandise avait été envoyée par la société Concordia à sa société-mère, Compagnie financière belge des pétroles, qui possédait des installations importantes d'emmagasinage dans ce port-là. L'année même, on a créé la Compagnie Commerciale de Pétrole, avec un capital de 1000000 lei, entièrement versé. Son dessein était notamment le commerce et le transport des produits pétrolifères. La fondatrice de la société a été la Compagnie Industrielle de Pétrole de Paris.

Le groupe français Consortium $d u$ Nord, l'un des plus importants groupes industriels français, a montré son intérêt pour l'industrie roumaine du pétrole. Il a acheté plusieurs terrains du Crédit Minier, aussi bien que d'autres organismes, et a décidé de créer une société roumaine avec un capital de 50 millions lei. En

34 Union des Chambres du Commerce et de l'Industrie, Darea de seamă a activității Uniunii Camerelor de Comerț și Industrie dela 15 iunie 1938 la 15 iunie 1939, « Moniteur Officiel et Imprimeries de l'État ». Imprimerie Nationale, Bucarest, 1939, p. 82.

35 «Moniteur du Pétrole Roumain », Bucarest, 1923, 23, vol. 22, p. 57.

36 Union des Chambres du Commerce et de l'Industrie, op. cit. p. 82.

37 Ibidem. 
octobre 1922, on a constitué la société Foraky Românească, une création de la société belge Foraky. La nouvelle société avait été créée avec un capital initial de 5000000 lei, dont on a versé $30 \%$ lors de sa fondation. ${ }^{38}$

À côté du rachat de certaines actives des sociétés roumaines par des compagnies au capital français, il y a eu des cas où le groupe français a perdu la domination. Un exemple à ce propos est l'entrée d'un groupe anglais dans la société Sospiro, au lieu du groupe français.

C'est toujours dans l'entre-deux-guerres qu'on a constitué, à Paris, la société Petrol-Block français, avec un capital de 2000000 francs français, comme mesure de consolidation du taux du capital français à l'intérieur d'autres États, qui était en fait une entreprise de l'étranger liée au pétrole roumain. Nous faisons mention aussi de la Compagnie Financière Belge de Pétroles, fondée en 1920 avec un capital étranger de 85000000 francs belges. Elle contrôlait les entreprises Concordia, Vega și Internaționala, détenant la majorité des actions de la première, qui détenait à son tour la totalité des actions des deux autres entreprises. ${ }^{39}$

\section{L'industrie extractive}

D'ailleurs, autant dans le domaine minier que dans le pétrolier, il y avait d'autres entreprises et exploitations qui ont fonctionné grâce au capital français ou francobelge. On fait mention des suivantes : Société Astra-Română, Aquila FrancoRomână - capital de 72000000 lei qui appartenait entièrement au groupe de raffineurs français Desmarais fréres-Fenaille \& Despeaux-Deutsch, en 1923. Société Petrolul, Société Internaționala, Société des Pétroles de Buștenari, Société Victoria, La Société roumaine-belge de pétrole, au capital francoroumain-belge, Compania Comercială de Petrol, avec un capital de 1000000 lei entièrement versé- le capital en était français, l'entreprise étant une création du groupe Compagnie Industrielle des Pétroles - la Société Gallia, avec un capital prédominant français - 1250000 francs français, fondée par la Société nouvelle de sondages Bonne Espérance; Minerva, Apollo - capital prédominant roumain et dans une faible mesure français; Sidus, Pétroles de Bordeni, Société Commerciale Danubienne des Pétroles, Société Continentale des Pétroles - société anonyme française; Vega etc. ${ }^{40}$

\section{L’industrie métallurgique}

En bref, nous aurions raison d'affirmer que l'industrie sidérurgique de Roumanie est née dans l'entre-deux-guerres. Cependant, en entrant dans plus de détails, nous

38 «Moniteur du Pétrole Roumain», op. cit, p. 134.

39 Ibidem, p. 167.

40 Archives Nationales Historiques Centrales, fond cit, passim. 
verrons qu'à l'époque, une industrie métallurgique se développait dans un rythme beaucoup plus accéléré et dans un cadre mieux défini que pendant la période avant la guerre. «Dans la métallurgie, comme dans d'autres branches de l'industrie, le capital étranger a connu, dans l'entre-deux-guerres, une tendance de croissance continue du volume. Ainsi, il a atteint en 1938 la valeur de 3916 millions lei, contre 350 millions lei en 1921, représentant 12,84\% du capital étranger total, contre seulement 3,76\% en 1921, par rapport au capital autochtone, dont le taux a baissé depuis presque $87 \%$ en 1921 , à $61,63 \%$ en $1938 . »^{41}$

Le capital étranger peut pénétrer dans l'économie d'un pays par le biais des investissements directs, une méthode préférée par le développement capitaliste. « Après avoir fait une visite à Bucarest, entre 27 et 29 juin 1938, Champlin, le président de la Société franco-roumaine de matériel pour les chemins de fer, est revenu à Paris, convaincu du fait que, du point de vue économique, il fallait faire au moins un geste en faveur de la Roumanie $»^{42}$, comme une mesure préventive contre un possible rapprochement de l'État roumain à l'Allemagne. « La France aurait eu la possibilité d'investir à long terme dans les industries locales de l'entière Péninsule Balkanique, ce qui équivalait à la manifestation d'un intérêt pour les marchés respectifs. ${ }^{43}$

« Le capital français avait un taux consistant de l'industrie métallurgique de Roumanie, occupant en effet la deuxième place, après le capital anglais. À part les entreprises plus anciennes qu'il contrôlait, le capital français fonde quelques entreprises métallurgiques importantes, parmi lesquelles on retrouve, en 1925, Industria Aeronautică Română (I.A.R.) (Industrie Aéronautique Roumaine), et en 1927 Fabrica românească de munițiuni (Fabrique roumaine de munitions). $»^{44}$ L'entreprise la plus importante de l'industrie métallurgique qui était financée avec du capital français dans l'entre-deux-guerres, c'était Lemaitre.

$$
* * *
$$

Nous avons présenté dans cette étude seulement quelques aspects qui visent l'industrie extractive, du pétrole et métallurgique, c'est-à-dire les branches qui ont incorporé le progrès technique, de forts capitaux et, surtout, qui ont exprimé la volonté des gouvernements de Roumanie d'avoir un certain type d'industrialisation. Celle-ci était fondée sur la valorisation des ressources, la couverture du

41 Constanța Bogdan, Adrian Platon, op. cit., p. 61.

42 Georgiana-Margareta Scurtu, Din istoria diplomației europene. Relațiile României cu Franța (1935 - 1938), Éd. Cartea Universitară, Bucarest, 2006, p. 219.

43 Documents Diplomatiques Français, deuxiéme série, tome X (10 juin - 2 septembre 1938), Paris, Imprimerie Nationale, 1976, document no. 187, Note du Directeur-adjoint des Affaires politiques. Voyage de M. Champin en Roumanie et en Yougoslavie, 11 juillet 1938, pp. 346347, apud Georgiana-Margareta Scurtu, op. cit., p. 219.

44 Nicolae Marcu, Istorie economică, Éd. Didactică și Pedagogică, Bucarest, 1979, p. 286. 
marché intérieur des biens de consommation et agricoles et, pas dernièrement, sur la création d'une industrie de la défense vouée à répondre aux tensions et aux provocations multiples de l'époque.

À l'intérieur de cette industrie lourde, par l'intermédiaire du capital de l'Entente - voir la législation libérale de la première décennie d'après l'Unification - on a déroulé un processus moins ample, mais très visible, au bout duquel, dans les années 1939-1940, nous pouvons parler de l'existence des compagnies autochtones, d'un capital roumain dans des proportions acceptables dans la vie économique, d'une gestion et d'un entrepreneuriat formés dans les écoles polytechniques roumaines, elles-aussi organisées selon le modèle occidental. Autrement dit, il s'agit d'un processus de modernisation et d'européisation, qui a réussi à disloquer une économie éminemment agraire et à la transformer en agraire-industrielle, bien qu'elle gardât dans beaucoup de ses articulations l'archaïsme et le sous-développement qui ont marqué l'Europe orientale, y compris la Roumanie.

Sans avoir la prétention d'avancer des conclusions qui se proposent d'argumenter et de configurer un certain paradigme du développement, il s'impose de faire plusieurs observations pertinentes à la fin de cette étude.

Ainsi, les pays de l'Europe centrale et orientale ont construit leurs stratégies de développement et d'européisation par l'imitation des modèles occidentaux. Ce processus n'a pas connu une évolution constante, mais il a été caractérisé par des ruptures, des réorientations et, souvent, des stagnations. Les sources de financement ont été également diverses, mais insuffisantes, pendant la période entière. Les changements provoqués par la grande guerre ont réorienté les sollicitations de capitaux, depuis les marchés de Budapest et Vienne, vers ceux de France et de Grande Bretagne. Ce changement de paradigme économique et la réaction positive des marchés démontrent aussi de l'intérêt pour la zone sur laquelle nous nous concentrons. Si au XIX ${ }^{\text {ème }}$ siècle, l'agriculture et les ressources forestières ont été décisives pour une certaine modernisation et intégration qui s'est proposé de réaliser de véritables marchés nationaux, plus tard, au XX ${ }^{\text {ème }}$ siècle, le paradigme de développement économique s'est construit à l'aide des matériaux minéraux, de la métallurgie et du pétrole.

C'est autant l'intérêt que le mérite des grandes finances franco-britanniques d'avoir mis en valeur ces ressources minérales, conçu des technologies, assuré la gestion des grandes compagnies et de les avoir fait assimiler le niveau européen, engendrant le début d'un projet industriel de développement.

Ces images, mises ensemble, bien que souvent isolées, donnent la mesure de plusieurs accomplissements positifs dans cette zone, dépendant des capitaux français, visant notamment la Pologne, la Tchécoslovaquie et la Roumanie. 


\section{Bibliographie :}

1. Archives de la Banque Nationale de Roumanie, Service études 1933-1969, deuxième partie, Secrétariat. Conseillers étrangers : dos. 6/1929-1931, 7/1929-1933.

2. Archives de la Banque Nationale de Roumanie. Service secrétariat, vol. I, dos. 1/1924-1925.

3. Archives Nationales Historiques Centrales, fond Maison Royale Ferdinand, dos. 5/1923.

4. Aldcroft, Derek, H., Europe's Thirld World: The European Periphery in the Interwar Years, Ashgate Publishing Company, Vermont, USA, 2006.

5. Axenciuc, Victor, Formarea sistemului industrial modern în România. Etapa 1859-1914: demarajul industrializării, Éd. de l'Académie Roumanie, Bucarest, 2008.

6. Bairoch, Paul, L'agriculture des pays développés, 1800 à nos jours : production, productivité, rendements, Éd. Economica, Paris, 1999.

7. Bairoch, Paul; Lévy-Leboyer, Maurice (éds.), Disparities in Economic Development since the Industrial Revolution, Éd. Palgrave Macmillan, 1981.

8. Batt, Judy, Introduction: Regions, State and Identity in Central and Eastern Europe, in Regional and Federal Studies, 2010.

9. Bogdan, Constanța; Platon, Adrian, Capitalul străin în societățile anonime din România în perioada interbelică, Éd. de l'Académie de la République Socialiste Roumanie, Bucarest, 1981.

10. Calcan, Gheorghe, Industria petrolieră din România în perioada interbelică, Éd. Tehnică, Bucarest, 1997.

11. Cazan, Gheorghe; Copoiu, Nicolae; Cupşa, Ion; Loghin, Leonida; Lupu, N.Z.; Siperco, Alexandru; Tuțu, Dumitru; Ucrain, Constantin; Unc, Gheorgher, Vişanu, Alexandru; Zaharia, Gheorghe, Marea Conflagrație a secolului XX: Al Doilea Război Mondial, Éd. Politica, Bucarest, 1974.

12. Dobre, Gheorghe, Economia României în context european - 1938, Éd. Fundației Ştiințifice „Memoria Oeconomica”, Bucarest, 1996.

13. Good, David F., Economic Transformation in Central Europe: The View from History, in Working paper 92-1, January 1992.

14. Iacob, Gheorghe, Procesul modernizării/integrării în Europa. Etape şi trăsături, in Ion Agrigoroaiei (coord.), România interbelică în paradigmă europeană, Éd. de l'Université «Alexandru Ioan Cuza », Iaşi, 2005.

15. Ivănuş, Gheorghe, Istoria petrolului în România, Éd. AGIR, Bucarest, 2004.

16. Josan, Andrei, Evoluții economice pe plan mondial în perioada interbelică, Éd. ASE, Bucarest, 2004.

17. Kopstein, Jeffrey S; Wittenberg, Jason, Beyond Dictatorship and Democracy: Rethinking National Minority Inclusion and Regime Type in Interwar Eastern Europe, in Comparative Political Studies, 2010.

18. Manoilescu, Mihail, Politica statului şi chestiunea refacerii industriale, Bucarest, 1920.

19. Marcu, Nicolae, Istorie economică, Éd. Didactică și Pedagogică, Bucarest, 1979.

20. Mureşan, Maria; Josan, Andrei, Istoria economiei europene: de la revoluția industrială la Uniunea Europeană, Éd. ASE, Bucarest, 2005.

21. Murgescu, Bogdan, România şi Europa. Acumularea decalajelor economice (1500-2010), Editura Polirom, Iaşi, 2010.

22. Păun, Dragoş, Romania's road towards the Euro, Presa Universitară Clujeană, 2011.

23. Păun, Nicolae, "Il modello romeno nel periodo interbellico », dans le volume La tentazione autoritaria. Istituzioni, politica e società nell'Europa centro-orentale tra le due guerre mondiali (a cura di Pasquale Fornaro), Éd. Rubettino, 2004. 
24. Păun, Nicolae, Societățile anonime din România în anii 1919-1924, " Anuarul Institutului de Istorie şi Arheologie Cluj-Napoca », no. XXVIII, Université de Cluj-Napoca, 1987-1988. 25. Păun, Nicolae, Stat și economie, Éd Interferențe, 1992.

26. Păun, Nicolae, The Impact of the Great Union on Romania 's Interwar Economic Development, «Studia Universitatis Babeş-Bolyai, Historia », 1988, 2, Cluj-Napoca.

27. Păun, Nicolae, Viața economică a României 1918-1948. Dezvoltare. Modernizare. Europenizare, Presa Universitară Clujeană, 2009.

28. Saizu, Ioan, Politica economică a României între 1922 şi 1928, Éd. de l'Académie de la République Socialiste Roumanie, Bucarest, 1981.

29. Sauvy, Alfred, Histoire économique de la France entre les deux guerres, vol. 1 et 2, Éd. Economica, 1979/1984.

30. Scurtu, Georgiana-Margareta, Din istoria diplomației europene. Relațiile României cu Franța (1935 - 1938), Éd. Cartea Universitară, Bucarest, 2006.

31. Wandycz, Piotr. S, France and Her Eastern Allies, 1919-1925: French-Czechoslovak-Polish Relations from the Paris Peace Conference to Locarno, University of Minnesota Press, 1962.

32. Wandycz, Piotr. S, Prețul libertății. O istorie a Europei central-răsăritene din Evul Mediu pînăinprezent, traduction: Mihaela Paraschivescu et Valentin Dragu-Banu, Éd. ALL, Bucarest, 1998.

33. Anuarul Institutului de Istorie şi Arheologie Cluj-Napoca, no. XXVIII, Université de ClujNapoca, 1987-1988.

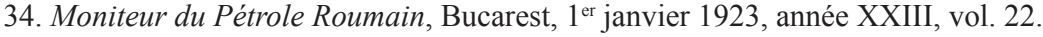

35. Statistica Minieră a României pe anul 1924, Bucarest, 1925, p. V-VI, 3-17 apud Anuarul Institutului de Istorie şi Arheologie Cluj-Napoca, no. XXVIII, Université de Cluj-Napoca, 1987-1988.

36. Union des Chambres du Commerce et de l'Industrie, Darea de seamă a activității Uniunii Camerelor de Comerț și Industrie dela 15 iunie 1938 la 15 iunie 1939, Moniteur Officiel et Imprimeries de l'État. Imprimerie Nationale, Bucarest, 1939. 


\title{
"New Central Europe" in Co-operating and United Europe. Czechoslovak Ideas in 1920s and 1930s and Attempts at Co-ordination with Austrian and Hungarian Ideas
}

\author{
Vladimír GONĚC
}

\begin{abstract}
Immediately after the end of the 50-year-long dissolution process of AustroHungary, the first progressive integration projects for Central Europe emerged. Further projects reacted to new circumstances in 1920s and 1930s. Some projects accentuated the need of security in the geopolitically sensitive area between Germany and Russia. Most projects focused on the search for new mechanisms that would replace the original more or less common economic area; often in the solution of , central Europe within Europe”. Some thinkers based their plans on the already present cultural community of Central Europe that should be able to transform itself first to economical, later to political union. Hodža's "Danubian Plan" was prepared very thoroughly. As soon as in 1918 it was stressed that Central European union is possible only among countries with democratic government.

Keywords: European integration, Central European integration, Czechoslovakia in interwar-period, Milan Hodža, Danubian Community
\end{abstract}

Political and economical disintegration of Central European area did not start in 1918 but as soon as in 1867, by Austrian-Hungarian Settlement. In 1870s, both parts went their separate political ways. In the west, modernized and developed political system evolved, based on emerging civic society. In the east, the political system rather declined than evolved (from the Viennese point of view, it was perceived as Oriental) and was based on estates, with civic society suppressed heavily.

Indeed, the economic area of Austro-Hungary was not united. On one side, there was liberal economical policy of Austrian government, on the other side, anti-liberal economical policy of Hungarian government. Two different and incompatible economical systems formed and soon voices were heard demanding functioning custom border between both systems. Such a border was almost established around 1900 , the process was stopped only by direct imperial order - a non-constitutional measure. By 1907 the demand for custom border between Austria and Hungary was back in the game.

$* * *$

Concerning the layout of programmes for Central European integration that formed during the inter-war-period it is necessary to mention the development of industrial centres in Austria-Hungary and on economic consequences of Dissolution of Austria-Hungary. The core of economic integration emerged in $19^{\text {th }}$ century, following the line Trieste-Ljubljana/Laibach-Graz-Vienna-Brno/ 
Brünn-Ostrava/Ostrau-Krakow/Krakau(-Lwow/Lemberg). This was the oldest and the most important railway line in Austria, well known by its names Südbahn and Kaiser-Ferdinand-Nordbahn. Four main industrial areas formed on this line: Trieste as main Austrian port, Wien, Brno and Austrian Silesia. On this line, two out of three economically most efficient regions of Austria-Hungary formed.

Vienna + Brno - region based on state-of-the-art machine industry and modernized textile industry, supporting other regions by its innovations originating from its technical universities (focused also on electric and chemical technologies) and technical schools.

Austrian Silesia (with adjacent areas of northeast Moravia) - region based on coal mining, iron and steel production, machine and textile industry.

Liberec/Reichenberg-Jablonec/Gablonz - region in northernmost Bohemia, the richest region in Bohemia, based on textile and glass industry, tightly connected to Germany (Dresden, Berlin).

In all these regions, the companies were focused on export and were of great importance for the whole Austria-Hungary. Along the main railway line, other smaller industrial areas evolved, supported by and supporting the railway. One of the most important economical areas in Europe was formed.

Economic integration of Austria-Hungary, Germany and Belgium was started in 1880s. Since 1900, the demand for full custom union grew, with suggestion for including also other countries (e.g. Switzerland, Netherlands). Analyses by Viennese professor Eugen Philippovich ${ }^{1}$ played major role in this process.

$$
* * *
$$

Czechoslovak plans from inter-war-period for united Central as well as whole Europe includes three main trends, with particular analytical methods, arguments and goals.

1. Pacifist plans with geopolitical elements: These plans follow the ideas of the pacifist generation that included two Nobel Prize winners - Bertha von Suttner (1843-1914; Nobel Prize 1905) and Alfred Fried (Nobel Prize 1911). A pupil of von Suttner, Thomas Masaryk (1850-1937) published his New Europe before the end of the war. ${ }^{2}$ In this area he included small nations between Germany and Russia that needed the union to survive. In 1918, he spoke about Central European union with US Americans of Central European origin and exiled Central Europeans. He saw clearly that any member state of such a union has to be democratic and guaranteeing civic rights; otherwise, the union will not be functioning. In general, these

1 For example: Eugen von Philippovich, Ein Wirtschafts- und Zollverband zwischen Deutschland und Österreich-Ungarn, Leipzig: Hirzel, 1915.

2 Thomas Garrigue Masaryk, The New Europe, London: [sine], 1918; Thomas Garrigue Masaryk, L'Europe nouvelle, Paris: Imprimerie Slave, 1918; Thomas Garrigue Masaryk, Das nеuе Europa, Berlin: Schwetschke, 1922; etc. 
plans focused on the ways to ensure peace for new small countries formed after the dissolution of Austria-Hungary.

1a. Before the war, and during the war, there were also pragmatist reformers, whose ideas survived the fall of the Austria-Hungary. What they wanted in the beginning was the reforms and federalization that could have stabilized and integrated Central Europe. They argued that the dualist system caused political and economical disintegration. There were more groups: the Belveder group headed by the successor archduke Franz Ferdinand which included many Czech and Slovaks, e.g. Milan Hodža with his political analysis.

The law system reformers, e.g. Kelsen and Weyr, focused on constitution laws. In Cisleithania, many elements of civic society and constitution system were implemented - the Supreme Administration Court that was reformed in 1912 could act as constitutional court. During the war, they worked on the reform of federalist system that stressed the protection of individual rights and minority rights. ${ }^{3}$ They analysed contemporary international law and suggested new principles that would have to be introduced after the war to renew its function.

2. Economical plans: These became the most significant and the most important. During the war, there were several attempts to plan the economic restoration after the war by re-starting liberal economy, overcoming direct consequences of the war, and using tools of Central European integration.

After the dissolution of Austria Hungary, Czechoslovakia had to answer two sets of questions:

Can the old industrial centres function? Do the economic relations exist still? Have they been lost?

How should Czechoslovakian foreign trade be organized? Where are hindrances and what losses can appear?

New countries in the area as well in whole Europe increased their custom rates stopping Czechoslovak export. Vast areas of common market disappeared behind the growing impenetrable custom forest.

The Vienna + Brno region became divided between two countries, enabling the continuation of scientific and technological co-operation and development but damming the flow of goods and investment. The region of Austrian Silesia lost its eastern part that became part of Poland. "Vítkovice", huge machinery and metallurgy enterprise lost its main financial partner - the Vienna Rothschild bank and in Czechoslovakia lacked bank able to cover the company's demands. The Liberec/Jablonec region lost its direct connection to Vienna as well as German market that collapsed. On the other side, most banks resided in Vienna and the absence of investment possibilities was dangerous.

Rudolf Hotowetz and Václav Schuster were involved in the attempts to use Saint Germain and Trianon Peace Treaties for economic purposes. Gradually, the

3 Among others the large discussion coordinated by H. Kelsen in Österreichische Zeitschrift für öffentliches Recht, Year 1917. 
idea of preferential trade zones in Central Europe was brought forward. In 1936, preferential custom rates between Czechoslovakia and Austria were introduced. However, Hitler forced Austria to abandon the plan the same year. The possibilities of coordinated Central European agricultural policy were also analyzed. After 1930, the economical crisis caused extensive drop of price in agricultural products and these theme gained on significance. Out of all plans, it was Hodža's plan that was received by most people concerned. ${ }^{4}$

3. Cultural plans: The Central Europe was seen as area with common cultural heritage. These concepts did not look in the past, they were not based on sentimental reminescence of fallen empire, nor romantic call for „lost values“. They were based on knowledge of cultural dynamics of large cities, connected with each other forming a belt from Trieste to Lwów, and able to change the cultural development in smaller towns (even though with some delay). Out of this cultural community, the new feeling of communion should grow that would be essential for functional economic and political union. The notion of identity should deepen the Central Europeanism feeling of the people, as well as their Europeanism, and stand against the growing nationalism.

These concepts warned that cultural and intellectual boundaries in Central Europe do not coincide with political borders. The existence of cultural and spiritual borders supports the tension between contra-traditionalists who prepare certain "cultural and spiritual Central European union" and traditionalists who fight for nationalism, political or religious control of culture. ${ }^{5}$ Moreover, there was another group of contra-traditionalists who built barriers by their unilateral, often passive, focus on English-speaking or French-speaking cultural area; or refused cultural relations between Czechoslovakia and Austria, or Czechoslovakia and Poland, ${ }^{6}$ etc. Such refusals ignored the facts, e.g. that the cultural triangle Vienna-BrnoBratislava is active in close relation with West European cultural centres.

$$
* \quad * *
$$

Creative Czechoslovak authors of particular concepts of Central European and European integration included politicians as ministers of Czechoslovak government Rudolf Hotowetz or Edvard Beneš, scholars as university professor František Weyr, and pragmatic businessmen who were able to prepare concepts in European context and base them on both theory and analyses. Some of them were both scientific analysts and political pragmatists, e.g. Milan Hodža. The other included:

Rudolf Hotowetz spoke about European economic union as soon as in 1907 when he took part in the discussion on changes in Austrian-Hungarian Settlement.

4 See below.

5 Including hidden antisemitism.

6 Czechoslovak-Polish cultural relations were extraordinarily intensive and open between the wars, mainly when compared to cold (bordering on hostile) mutual political relations. 
Immediately after the end of the war, he demanded close economical co-operation of successor countries. Later, he called for Central European custom union, existence of which was possible thanks to Article 222 of Saint Germain Peace Treaty and Article 205 of Trianon Peace Treaty. The politicians of all countries disagreed. In 1920s he suggested European economical union that could have been launched by the core Central European economical union. He saw European economical union as the sole chance to overcome the consequences of the war. He argued that Czechoslovak foreign trade can survive only with support of custom union or at least preferential custom rates. After 1925, he warned that both Czechoslovakia and many European countries got into economic isolation that "might have been very splendid but was highly harmful" resulting in absolute disorganisation of production and distribution in whole Europe. ${ }^{7}$ The crisis of 1930s forced him to call for quick march from preferential custom rates to full custom Central European union. Similar cores would form in other European regions and would grow and finally merge in single "economic Pan-Europe" that were historically inevitable. Hotowetz pointed out repeatedly, that the gradualism was essential and that any sudden change would be both harmful and impossible to be enforced political$1 y .{ }^{8}$ Václav Schuster was against any protectionist policy and demanded the fully free trade. He accentuated the key importance of economic co-operation between France and Germany. Joined French-German economics would be able to dominate Europe or even the world in many branches; in some of them it would be able to dominate global markets (e.g. chemical products). European Economic Community should be reached slowly, preferably by gradual removal of custom barriers within whole Europe and parallelly by forming regional custom associations and custom unions and joining them together later. He admitted that Europe can perform as economic union without political union. However, that would be less effective. On the other hand, he refused the US model as excessively centralized. He suggested starting with Central Europe united in Danubian Economic Community and shaping it into a political union in long term. ${ }^{9}$

7 Rudolf Hotowetz, Hospodářské sbliženi evropských států, Praha: Česká národohospodářská společnost, 1926; Rudolf Hotowetz, [sine], in: Rozprava o obsahu prednášky Dr. V. Schustera Hospodářská pospolitost Evropy z hlediska Československa, Praha: Česká národohospodářská společnost, 1927, pp. 7-11.

8 Rudolf Hotowetz, Změny v struktuře čsl. hospodárství a výhledy do budoucna, Praha: Řivnáč, 1933; Rudolf Hotowetz, Naše hospodářská situace ke sklonku světové krise, Praha: Česká národohospodářská společnost, 1934.

9 Václav Schuster, Z poválečného vývoje naši obchodni politiky, Praha: Česká národohospodářská společnost, 1923; Václav Schuster, Problém evropské hospodářské pospolitosti s hlediska československého, Praha: Česká národohospodářská společnost, 1927; Václav Schuster, Otázka hospodářské součinnosti a stěžejni ekonomické problémy v Evropě, Praha: Česká národohospodářská společnost, 1930; Václav Schuster, Obchodně politický problém středni Evropy, Praha: Česká národohospodářská společnost, 1931; 
On the contrary, Jaromír Nečas warned against one-sided economical integration, namely against "Europe as stock company". Europe cannot function without European effective tools of civic control, European social policy, peace programme, and minority protection system. ${ }^{10}$

Milan Hodža saw Central Europe as functional living cultural community with many pressures wanting economical community, as well. These pressures came from various sides and lacked order. He suggested gradual way from preferential custom rates within Central Europe to European Union. Hodža pointed out that the will to unite had to come from the new Central European countries themselves. Only thus, the truly consensual common interest could be found. Hodža argued that following the international consolidation of new Central European countries, it would be possible and "necessary to look for that mutual context of spiritual, economic and social nature" going on towards the will of convergence and union. Central Europe had to be stabilized economically to be able to become the part of larger projects for Europe. After 1925 Hodža as well as others used the terms co-operation and community in the same meaning and sense as it was perceived later in names like European Coal and Steel Community and European Economic Community. ${ }^{11}$

Hodža's lecture at the Central European Institute in ${ }^{12}$ Brno in March 1931 was noticed also abroad. Hodža emphasized the idea that it was Central Europe that was the long-term key to the solution of problems of whole Europe. Without consolidated Central Europe the stability of whole Europe and real European integration system were impossible. He warned against the people who promoted a defensive group against Germany as the goal and sense of Central European concentration and consolidation. At that time, these ideas had signification impact on French, Czechoslovak and Polish politicians. Should there be stability and peace in whole Europe, a cooperating group of powers France-Germany-Central Europe was necessary, Hodža emphasized. ${ }^{13}$

Hodža's "Danubian plan" was presented in inter-parliamentary economical conference in London in October $1935 .{ }^{14}$ It is a perfect example of sector integration.

Václav Schuster, Výhledy do př́štího obchodně-politického vývoje, Praha: Řivnáč, 1933; Václav Schuster, Nynějši stav hospodářského problému podunajského, Praha: Česká národohospodářská společnost, 1936.

10 Jaromír Nečas, Spojené státy evropské, Praha: Čin, 1926.

11 On the Hodža's European activities see: Vladimír Goněc: „Milan Hodža before „Milan Hodža““", in Vladimír Goněc (ed.), In between Enthusiasm and Pragmatism: How To Construct Europe?, Brno: Masaryk University Press, 2007, pp. 66-112.

12 See below.

13 Milan Hodža, „Československo a střední Evropa“. In: Milan Hodža, Články, reči, štúdie, vol. 4, Cesty stredoeurópskej agrárnej demokracie, 1921-1931, Praha: Novina, 1931, pp. 369-393.

14 Milan Hodža, Le problème agricole en Europe centrale [Vingt-et-unième conférence parlementaire internationale $d u$ commerce, Palais de Westminster, Londres], Prague: Imprimerie de l'Etat, 1935. 
The plan was based on agricultural community of Central Europe. These countries were dependent on the export of agricultural products. When part of European economic co-operation, these countries would be able to import more industrial products and to improve their own industry. Hodža demanded that particular "organ of cooperative action" should be established to reach significant and lasting positive results. This institution should be supra-national and permanent (perhaps a "Central agricultural administration" residing in Vienna). This office would not only record the statistics of surplus and shortage of key agricultural products but also manage the actual export of surplus production within compensation trade.

Nevertheless, the programme would not be purely agricultural as it was sometimes interpreted unilaterally. Hodža suggested gradual integration of "Danubian Community", starting with the agriculture and ending with economical community. He argued that only free economic competition would be able to increase the economical growth in Central European countries. He observed the exchange of industrial goods for raw materials that was growing already between the countries. Beside that, he emphasized the perspective of co-operation and division of workforce in industry. Eventually, the focus of economic cooperation of Danubian countries would shift towards the mutual exchange of industrial goods while these countries would go on with general industrial growth. Hodža refused then popular conception of stabilization of European economies by forming "Europe A" consisting of industrial countries and "Europe B" consisting of agricultural countries that should retain their economy dominated by agriculture. The stabilization could not have been reached by increased exchange of agricultural and industrial production between "Europe A" and "Europe B" any more.

Hodža described also the solution of particular financial and banking tools, foreign exchange policy, and technical measures for the facilitation and growth of mutual trade exchange of Central European countries. Last but not least, he suggested the legal and administrative mechanisms, including uniting of several regulations, to achieve legal security and balance of conditions for business in the whole integrated area.

Furthermore, Hodža planned the conditions for Central European federation in state law dimension. Such a federation would have to be formed by gradual steps within longer time. In 1942, this Hodža's activity peaked by presentation of his detailed plan. ${ }^{15}$

Edvard Beneš standing in the background of the Briand plan and the Tardieu plan, in 1929 he saw only two futures of Europe: co-operation and economic and political union of European countries consisting of democratic units, or never ending conflicts and crises. Since 1922, he planned the transformation of Central Europe through various degrees of union to full federation. Several smaller

15 Milan Hodža, Federation in Central Europe. Reflections and Reminiscences, London - New York: Jarrolds, 1942. 
federations throughout whole Europe could be then united in a large, stable, balanced European one. This concept was finished by Beneš in exile in USA and London at the turn of 1930 s and 1940 s. ${ }^{16}$

Victor Bauer (1874-1939) was cultural thinker, important sugar producer and supporter of art and science. (Architect Adolf Loos and painter Egon Schiele were his friends.) Supporting Viennese Institut für Kulturforschung, he was its active member and for 15 years he had been working on his book "Central Europe as a living organism". ${ }^{17}$

He saw Central Europe not as a piece of geography but as a cultural process on the border between the West and the East. This process was running mostly in large cities - Vienna, Gdaňsk, Łódź, Breslau/Wrocław, Ostrava, Brno, Graz, and Trieste. These are centres of both economical and cultural growth and innovation. They are the foundations for the common town culture in the whole area among Stettin, Venice, Kaliningrad/Königsberg, and Constantinople. Not only society (Gesellschaft), but real cultural community (Gemeinschaft) was formed. ${ }^{18}$ In large cities, the long-term inter-culturalism process is running, getting its inputs from mixed ethnical and cultural background. The western and eastern elements not only meet each other, both join and form new qualities, sending new impulses both to East and West. These cities boast large share of Oriental people. The Jews were fleeing Western Europe in the Middle Ages, and the Eastern Europe later, forming about $10 \%$ of population in these cities (in Łódź even $27 \%$ ). Furthermore, there were other oriental nations, e.g. Armenians (most numerous in Vienna and Lwów). These intercultural people should form Central European Economic Community and then enter the European Economic Community. Full integration of Central Europe would end by supranational federation and that process would need some effort.

This could not be reached by some theoretical formal legal constructions. The formation of cultural community have to be analyzed, the pressures for economical union have to be analyzed as well and based on that, necessary tools for economical union of Central Europe should be defined. Only in the end, it would be possible and essential to choose suitable political system, compatible with both cultural and economical union.

František Weyr was a law specialist who focused on quality theoretical law construction and smoothly functioning supranational community. At the end of the war he demanded that new law constructions had to be looked for, bringing

16 Edvard Beneš, Democracy Today and Tomorrow, London: Macmillan, 1939; Edvard Beneš, La démocratie aujourd'hui et demain, Neuchâtel: Baconnière 1944.

17 Victor von Bauer, Zentraleuropa, ein lebendiger Organismus, Brünn-Leipzig: F. Irrgang, 1936, 1937.

18 Similar these were developed by the Austrian sociologist Tönnies. See: Ferdinand Tönnies, Gemeinschaft und Gesellschaft. Grundbegriffe der reinen Soziologie, Leipzig: Buske, 1935 (8th enlarged edition). 
efficient and guaranteed peace. He thought that absolute state sovereignty was the main obstacle against peaceful order in Europe.

Only if the countries abandon their sovereignty, recognize their common interests and settle together on supranational state. If we want United States of Europe, we must accept these principles as starting point. There is no sense in planning an "ideal federation". In the community, the norms have to be written together and supranational court system is necessary. In 1918, independent of Masaryk, Weyr claimed that all member state of the community had to be democratic. At the same time, all "new international law" had to be supranational as well as based on guaranteed rights of any individual. ${ }^{19}$

Weyr's ideas were discussed repeatedly in various committees of the League of Nations, mainly in 1924-1928; nevertheless, they did not become obligatory documents.

In 1939, teams working with Weyr's and Kelsen's ideas suggested also the notion of independent supranational court that would be the core of all European community. ${ }^{20}$

The work of new generation of great industrialists in Brno is represented namely by Tugendhat and Jellinek. Hans Tugendhat wrote about the beginnings of large economic crisis as soon as in $1930 .{ }^{21} \mathrm{He}$ deduced that the economic integration should be begun by those countries, whose situation was the worst at that moment. This would be Germany, Czechoslovakia, Austria, Hungary, Yugoslavia and Romania. First, however, small Central European countries should group to become an equal partner of Germany. Germany would join the group only later. When these six countries consolidate enough, the rest of the countries would be allowed to join (Poland, Baltic, Balkan).

Germany and partially Czechoslovakia and Austria, too, would absorb the surplus of agriculture. On the other hand, the agricultural countries of Central Europe would have much more sources to buy consumer goods, invest, and modernize the agricultural and food branch of their economies. This conception was therefore more than the traditional ideas about complementarity of Central European countries. Tugendhat suggested starting gradually with the preferential system of trade between these countries. The custom union would be reached only later. ${ }^{22}$

Fritz Jellinek analysed the results of the great economic crisis and its specificity for Central Europe. He criticised economic policy of countries that increased protective measures and argued that mere decrease in custom rates would not

19 Weyr's work was written in summer 1918: František Weyr, Soudobý zápas o nové mezinárodni právo, Brno: Píša, 1919.

20 At the Institut universitaire de hautes études internationales in Geneve, parallelly the co-workers of W. Churchill, etc.

21 Based on economic data from Dresdner Bank.

22 Hans Tugendhat, Ein handelspolitischer Konsolidierungsplan, Brünn: Mitteleuropa Institut zur Förderung der wirtschaftlichen und kulturellen Annäherungen, 1930. 
be sufficient for solving the economic crisis. He called for complex transformation of economic relations between Central European countries, free movement of capital and workforce. Only then free movement of goods would be possible. He suggested the establishment of Central European bank that would provide Czechoslovakia, Austria, Hungary, Romania, and Yugoslavia with such services as European investment bank does now. He also claimed that Central European parliament was necessary for organizing economic integration. ${ }^{23}$

* * *

Beside individuals, organizations were important as well, promoting these programmes, spreading them in the public and uniting professionals and ordinary citizens for co-operation. We should mention at least Paneuropean Union and the Central European Institute at Brno.

Until 1939, Richard Nikolaus Coudenhove-Kalergi was not only Czechoslovak citizen but also a holder of Czechoslovak diplomatic passport. The organization Pan-Europe Union was accepted widely by Czechoslovak top politicians, industrialists and intellectuals. Directly supported by TG Masaryk and his daughter Alice, Czechoslovak branch of Pan-Europe Union was one of four the most numerous branches. It was headed by Edvard Beneš (Czechoslovak minister of foreign affairs until 1935, since 1935 president of Czechoslovakia) and led by executive vicepresident Václav Schuster (economic diplomat who prepared most Czechoslovak international trade treaties). Pan-European Economic Committee group was influenced by Ladislav Karel Feierabend, later Czechoslovak minister and after 1948 (in exile) the most close Czechoslovak co-worker of R. N. Coudenhove-Kalergi. Other members of the Pan-European Economic Committee included František Hodáč, director of Czechoslovak industrial council, Adolf Sonnenschein, director of Vítkovice Company, and Václav Schuster.

The first Czech edition of Coudenhove-Kalergi's Pan-Europe was published in 1926 and supported by Beneš, who also wrote the foreword. ${ }^{24}$ (He also supported the first Czech edition of "Europe of the future"/ L'Europe de demain, by E. Herriot in 1931. ${ }^{25}$ )

Mitteleuropa-Institut für Förderung der wirtschaftlichen und kulturellen Annäherungen was established in Vienna in March 1929, followed by co-operating institutes in Brno, Budapest etc. All institutes worked as a network and through personal connection. The Brno branch was leaded by František Weyr, with Karel Tomeš (mayor of Brno) and Elemér Hantos ${ }^{26}$ as vicechairmen. The Brno insti-

23 The chapter „Das Problem Mitteleuropa“, in: Fritz Jellinek, Die Krise des Bürgers, Zürich: Europa Vlg., 1935.

24 Richard Nikolaus Coudenhove-Kalergi, Pan-Evropa, Praha: Aventinum, 1926.

25 Edouard Herriot, Evropa budoucnosti, Praha: Orbis, 1931.

26 E. Hantos was the head of Vienna Institute. 
tute was supported by local industrial and trade chamber, exporting companies, lawyers, economists, innovators, and Brno branch of Pan Europe Union. The institute focused on the possibilities of economical co-operation in Central Europe, namely on tools for export growth and improvement of transport systems. Its lectures, aimed at businessmen and bankers, promoted Central European economic co-operation. Furthermore, it focused on the development of cultural relations in Central Europe and Central European culture.

In Brno institute, Austrian and Hungarian pro-European activists were active significantly as well, for example, Heinrich Mataja - former minister of Austrian government, Siegfried Strakosch - sugar producer and economic analyst, ${ }^{27}$ Elemér Hantos - Hungarian financial specialist, ${ }^{28}$ and Pál Auer - head of Hungarian national organisation of Pan-Europe Union.

It was the discussions within this institute that gave rise to Hodža's Danube Plan. Besides Weyr and Hodža, the industrialist Fritz Jellinek played major role in the institute, dealing with forming and promotion of new ideas.

$$
* * *
$$

It is essential to discuss the question "With or against Germany". The ideas in many countries were based on open or hidden goal to build a barrier against Germany and its economy; this was incited by both general fear and nationalist plans.

Czechoslovak programmes by Hodža, Beneš, or Hotowetz can be characterised by another goal - stabilisation of Central European economy that would be an equal partner of Germany - its partner and neighbour. The policy of open and correct economic and political relations with Germany was functional between Germany and Czechoslovakia in 1920s and in early 1930s, until the end of Weimar republic.

Good relations were not possible under the Nazi-regime and became completely unreal when Germany occupied demilitarized Rhineland in March 1936. From then on, the only goal was to protect the peace in Europe. The question if France would protect the interests of its allies when it did not protect its own interests was

27 See for example: Siegfried Strakosch, Europa als Teuerungsgrund. Studie über die eigentlichen Ursachen der Teuerung, Wien: Holder - Pichler - Tempsky, 1926; Siegfried Strakosch, Das Agrarproblem im neuen Europa. Berlin: Parey, 1930.

28 See for example: Elemer Hantos, Die Handelspolitik in Mitteleuropa. Jena: Fischer, 1925; Elemer Hantos, Das Kulturproblem in Mitteleuropa. Stuttgart: Enke, 1926; Elemer Hantos, Europäischer Zollverein und Mitteleuropäische Wirtschaftsgemeinschaft, Berlin/Organisation Vlgges., 1928; Elemer Hantos, L'Europe Centrale. Une nouvelle organisation économique. Paris: Alcan, 1932; Elemer Hantos, Der Weg zum neuen Mitteleuropa. Die wirtschaftliche Neugestaltung, Berlin: Mitteleuropa Vlg., 1933; Elemer Hantos, Institut pour l'Europe centrale, Vienne. Memorandum sur la crise économique des pays Danubiens <Autriche, Hongrie, Tchecoslovaquie, Roumanie, Yougoslavie et Bulgarie $>$. Présenté à la Conférence monétaire et économique Londres 1933. Wien: St. Norbertus, 1933; Elemer Hantos, Die Neuordnung des Donauraumes. Berlin - Wien: Heymann - Oesterr. Wirtschaftsverlag, 1935. 
also important. On the other hand, Czechoslovak thinkers counted on democratic Germany devoid of Nazism as a member and partner in united Europe. ${ }^{29}$

Since 1939, the theme of Central Europe was often present in programme and conceptual activities by Czechoslovak and Polish exile. It is easy to understand that the particular question of Central Europe security within the new post-war organisation of Europe was the most important. As soon as in 1939 it was suggested, not only by Polish thinkers, that the main enemy of Central European security is the Soviet Union. This was based on careful analyses, not emotions.

This was the last theme that became the intensive focus of Milan Hodža, described in detail in new chapters he prepared for the re-edition of his Federation in Central Europe. ${ }^{30}$ Czechoslovak thinkers of the next generation shared his ideas. ${ }^{31}$ Much effort was put in the ideas on economical co-operation or economical union of Central Europe. This should be a part of restored European economy. Czechoslovak thinkers Josef Macek, before the WWII professor of Economic University in Prague, and Antonín Basch, professor of Charles University, took part in these plans. ${ }^{32}$

The new generation of thinkers included the fresh exiled thinkers after 1947/1948. Czechoslovak and Polish exiled politicians and analysts were joined by their Hungarian and Romanian colleagues, later as well as Yugoslavian, Lithuanian, Latvian and Estonian thinkers. These activities peaked in the plan for the Central European Coal and Steel Community by team lead by Jan Wszelaki and plan for the Central European Federation by Hubert Ripka. ${ }^{33}$ Further exile waves ${ }^{34}$ moved

29 For example: Hubert Ripka, Munich: Before and After, London: Gollancz, 1939, pp. 467, 476, 477.

30 These manuscripts went to press only in 1950s.: Milan Hodža, „On the Regional Federalism“, in: International Peasant Union Bulletin, 1953, Dec., pp. 22-26; Milan Hodža, „Europe at the Crossroads“, in: International Peasant Union Bulletin, 1954, Jan.-Febr., 14-18; Milan Hodža, „No Changes in Russia“, in: International Peasant Union Bulletin, 1954, March, 17-20; Milan Hodža, „Germany's Push to the East“, in: International Peasant Union Bulletin, 1954, April, pp. 22-26. One of them was published in Slovak much later. Milan Hodža, „Medzi Nemeckom a Ruskom“, in: Milan Hodža, Federácia v strednej Európe a iné štúdie, Bratislava: Kalligram, 1997, pp. 330-341.

31 See for example: Vladimír Goněc, „Hubert Ripka en exil à Londres: Projets pour l'Europe unie d'après guerre", in: Gérard Bossuat (ed.). Inventer l'Europe.Histoire nouvelle des groupes d'influence et des acteurs de l'unité européenne, Bruxelles: P.I.E. - Peter Lang, 2003, pp. 157-178.

32 See for example: Antonín Basch, A Price for Peace. The New European and World Markets, New York: Columbia University Press, 1945; Vladimír Goněc, „Antonín Basch a jeho prŕnos světovému ekonomickému myšlení“, in: Milý Bore... [Hommage Ctibor Nečas], Brno: Historický ústav AV ČR, 2003, pp. 73-81.

33 Vladimír Goněc, An Eastern Schuman Plan? Project of Central and East European Coal and Steel Community (1953), Brno: Masaryk University Press, 2009; Vladimír Goněc, „Le programme «La fédération de 1'Europe centrale » de février 1953“, in: Vladimír Goněc, Hubert Ripka: un européen; Brno: Masaryk University Press, 2006, pp. 140-192.

34 Namely 1956 from Hungary and 1968 from Czechoslovakia. 
the co-operation to new generations and the activites were moved from New York, Paris, and London to Stockholm, Hamburg, Munich, Zürich, Vienna, Rome; these towns were much nearer to the communist countries. ${ }^{35}$ Another important project was the plan to neutralise Central Europe, co-ordinated by Paul Auer, Hungarian exiled diplomat and political thinker; ${ }^{36}$ further analyses were based on changing situation in 1980s and influenced by Polish struggle against the communist government.

$* * *$

At the end of 30's, the Central European and European integration had to be moved away, to wait for better times. These came more than 50 years later. What was the fate of Central Europe after 1990 is the matter for another study.

\section{Bibliography}

Basch, Antonín (1945), A Price for Peace. The New European and World Markets, New York: Columbia University Press.

Bauer, Victor von (1937), Zentraleuropa, ein lebendiger Organismus, Brünn-Leipzig: F. Irrgang. Beneš, Edvard (1939), Democracy Today and Tomorrow. London: Macmillan.

Beneš, Edvard (1944), La démocratie aujourd'hui et demain, Neuchâtel: Baconnière.

Coudenhove-Kalergi, Richard Nikolaus (1926), Pan-Evropa, Praha: Aventinum.

Goněc, Vladimír (2003), „Hubert Ripka en exil à Londres: Projets pour l'Europe unie d'après guerre". In: Bossuat, Gérard (ed.). Inventer l'Europe.Histoire nouvelle des groupes d'influence et des acteurs de l'unité européenne, Bruxelles: P.I.E. - Peter Lang, 157-178.

35 On those Central European and European activities of exilés see too: Vladimír Goněc, Hubert Ripka: un européen, Brno: Masaryk University Press, 2006; Vladimír Goněc, „First Programmes of the Council of Free Czechoslovakia for European Politics (1951-1953)“, in: Vladimír Goněc (ed.), In Between Enthusiasm and Pragmatism: How to Construct Europe? Brno: Masaryk University Press, 2008, pp. 121-134; Vladimír Goněc, An Eastern Schuman Plan? Project of Central and East European Coal and Steel Community (1953), Brno: Masaryk University Press, 2009; Vladimír Goněc, „Ripkovy analýzy pro Radu svobodného Československa na přelomu 1956-1957“, in: Edita Ivaničková (ed.), Z dejín demokratických a totalitných režimov na Slovensku a v Československu v 20. storočí, Bratislava: Historický ústav SAV, 2008, pp. 284-298; Vladimír Goněc, „Československý exil ve vztahu k mad'arskému exilu a mad'arské revoluci 1956“, in: Vladimír Goněc, Radomír Vlček (eds.), Z dějin visegrádského prostoru. Richardu Pražákovi k pětasedmdesátinám, Brno: Masaryk University Press, 2006, pp. 249-266; Vladimír Goněc, „Pál Auer jako následník Huberta Ripky?“", in: Slavica Litteraria, 14, 2011, No 1, pp. 111-120; Vladimír Goněc, „Exily ze střední Evropy v koordinaci aktivit“, in: Česko-slovenská historická ročenka 2010, Brno: Academicus 2010, pp. 81-93; Vladimír Goněc, Jak se vymanit z komunismu a co po komunismu. Iniciativy pod koordinaci Huberta Ripky v padesátých letech, Brno: Academicus, 2010.

36 Studies for a New Central Europe, 31 pp., Archives of Institute of Political Science of Slovak Academy of Sciences, Fonds: Martin Kvetko, cart. Manuscripts (in the state of edition). 
Goněc, Vladimír (2003), „Antonín Basch a jeho přínos světovému ekonomickému myšlení”. In: Milý Bore... [Hommage Ctibor Nečas]. Brno: Historický ústav AV ČR, 73-81.

Goněc. Vladimír (2006), Hubert Ripka: un européen. Brno: Masaryk University Press.

Goněc, Vladimír (2006), „Československý exil ve vztahu k mad'arskému exilu a mad'arské revoluci 1956”. In: Goněc, Vladimír - Vlček, Radomír (eds.), Z dějin visegrádského prostoru. Richardu Pražákovi k pětasedmdesátinám. Brno: Masaryk University Press, 249-266.

Goněc, Vladimír (2008), „Milan Hodža before „Milan Hodža“. In: Goněc, Vladimír (ed.), In between Enthusiasm and Pragmatism: How To Construct Europe? Brno: Masaryk University Press, 66-112.

Goněc, Vladimír (2008), „First Programmes of the Council of Free Czechoslovakia for European Politics (1951-1953)". In: Goněc, Vladimír (ed.). In Between Enthusiasm and Pragmatism: How to Construct Europe? Brno: Masaryk University Press, 121-134.

Goněc, Vladimír (2008), „Ripkovy analýzy pro Radu svobodného Československa na přelomu 1956-1957”. In: Ivaničková, Edita (ed.), Z dejín demokratických a totalitných režimov na Slovensku a v Československu v 20. storoči. Bratislava: Historický ústav SAV, 284-298.

Goněc, Vladimír (2009), An Eastern Schuman Plan? Project of Central and East European Coal and Steel Community (1953), Brno: Masaryk University Press.

Goněc, Vladimír (2010), „Exily ze střední Evropy v koordinaci aktivit”. In: Česko-slovenská historická ročenka 2010. Brno: Academicus, 81-93.

Goněc, Vladimír (2010). Jak se vymanit z komunismu a co po komunismu. Iniciativy pod koordinaci Huberta Ripky v padesátých letech. Brno: Academicus.

Goněc, Vladimír (2011), „Pál Auer jako následník Huberta Ripky?” In: Slavica Litteraria, 14, 2011, No 1, 111-120.

Hantos, Elemer (1925), Die Handelspolitik in Mitteleuropa. Jena: Fischer.

Hantos, Elemer (1926), Das Kulturproblem in Mitteleuropa. Stuttgart: Enke.

Hantos, Elemer(1928), Europäischer Zollverein und Mitteleuropäische Wirtschaftsgemeinschaft, Berlin: Organisation Vlgges.

Hantos, Elemer (1932), L'Europe Centrale. Une nouvelle organisation économique. Paris: Alcan.

Hantos, Elemer (1933), Der Weg zum neuen Mitteleuropa. Die wirtschaftiche Neugestaltung, Berlin: Mitteleuropa Vlg.

Hantos, Elemer (1933), Institut pour l'Europe centrale, Vienne. Memorandum sur la crise économique des pays Danubiens < Autriche, Hongrie, Tchecoslovaquie, Roumanie, Yougoslavie et Bulgarie>. Présenté à la Conférence monétaire et économique Londres 1933. Wien: St. Norbertus.

Hantos, Elemer (1935), Die Neuordnung des Donauraumes. Berlin - Wien: Heymann - Oesterr. Wirtschaftsverlag.

Herriot, Edouard (1931), Evropa budoucnosti, Praha: Orbis.

Hodža, Milan (1931), „Československo a střední Evropa“. In: Hodža, Milan, Články, reči, štúdie, vol. 4, Cesty stredoeurópskej agrárnej demokracie, 1921-1931, Praha: Novina, 369-393.

Hodža, Milan (1935), Le problème agricole en Europe centrale [Vingt-et-unième conférence parlementaire internationale du commerce, Palais de Westminster, Londres]. Prague: Imprimerie de l'Etat.

Hodža, Milan (1942), Federation in Central Europe. Reflections and Reminiscences, LondonNew York: Jarrolds.

Hodža, Milan (1953), „On the Regional Federalism“, In: International Peasant Union Bulletin, 1953, Dec., 22-26; 
Hodža, Milan (1954), „Europe at the Crossroads“, In: International Peasant Union Bulletin, 1954, Jan.-Febr., 14-18.

Hodža, Milan (1954), „No Changes in Russia“, In: International Peasant Union Bulletin, 1954, March, 17-20.

Hodža, Milan (1954), „Germany's Push to the East“, In: International Peasant Union Bulletin, 1954, April, 22-26.

Hodža, Milan (1997) „Medzi Nemeckom a Ruskom“, In: Hodža. Milan, Federácia v strednej Európe a iné štúdie. Bratislava: Kalligram, 330-341.

Hotowetz, Rudolf (1926), Hospodářské sbliženi evropských států, Praha: Česká národohospodářská společnost.

Hotowetz, Rudolf (1927), „[sine]“. in: Rozprava o obsahu přednášky Dr. V. Schustera Hospodářská pospolitost Evropy z hlediska Československa, Praha: Česká národohospodářská společnost, 7-11.

Hotowetz, Rudolf (1933), Změny v struktuře čsl. hospodářství a výhledy do budoucna, Praha: Řivnáč.

Hotowetz, Rudolf (1934), Naše hospodářská situace ke sklonku světové krise, Praha: Česká národohospodářská společnost.

Jellinek, Fritz (1935), Die Krise des Bürgers, Zürich: Europa Vlg.

Masaryk, Thomas Garrigue, (1918), The New Europe, London: [sine].

Masaryk, Thomas Garrigue, (1918), L'Europe nouvelle, Paris: Imprimerie Slave.

Masaryk, Thomas Garrigue, (1922), Das neue Europa, Berlin: Schwetschke.

Nečas, Jaromír (1926), Spojené státy evropské, Praha: Čin.

Philippovich, Eugen von (1915), Ein Wirtschafts- und Zollverband zwischen Deutschland und Österreich-Ungarn, Leipzig: Hirzel.

Ripka, Hubert (1939), Munich: Before and After. London: Gollancz.

Schuster, Václav (1923), Z poválečného vývoje naši obchodni politiky, Praha: Česká národohospodářská společnost.

Schuster, Václav (1927), Problém evropské hospodářské pospolitosti s hlediska československého, Praha: Česká národohospodářská společnost.

Schuster, Václav (1930), Otázka hospodářské součinnosti a stěžejni ekonomické problémy v Evropě, Praha: Česká národohospodářská společnost.

Schuster, Václav (1931), Obchodně politický problém středni Evropy, Praha: Česká národohospodářská společnost.

Schuster, Václav (1933), Výhledy do príštího obchodně-politického vývoje, Praha: Řivnáč.

Schuster, Václav (1936), Nynější stav hospodářského problému podunajského, Praha: Česká národohospodářská společnost.

Strakosch, Siegfried (1926), Europa als Teuerungsgrund. Studie über die eigentlichen Ursachen der Teuerung, Wien: Holder - Pichler - Tempsky.

Strakosch, Siegfried (1930), Das Agrarproblem im neuen Europa. Berlin: Parey.

Tönnies, Ferdinand (1935), Gemeinschaft und Gesellschaft. Grundbegriffe der reinen Soziologie, Leipzig: Buske.

Tugendhat, Hans (1930), Ein handelspolitischer Konsolidierungsplan, Brünn: Mitteleuropa Institut zur Förderung der wirtschaftlichen und kulturellen Annäherungen.

Weyr, František (1919), Soudobý zápas o nové mezinárodní právo, Brno: Píša. 


\title{
Uniting the Balkans: Common Desires and First Initiatives in the Interwar Period
}

\author{
Roumiana PRESHLENOVA
}

\begin{abstract}
The political and intellectual atmosphere in Europe after World War I, on the one hand, and the impact of the Great Depression on the agrarian states in the Balkans, on the other, fuelled the desire to search for solutions to common problems. The concern to unify winners and defeated in the war and to offer better prospects for economic development of the region led to the Balkan Conferences (1930-1933) and the Balkan Entente (1934) as their aftermath. Inner regional and European motives, promoters and mechanisms of the rapprochement between the Balkan peoples and its limits are outlined, along with the ineffectiveness of the integration plans and their institutionalization.

Keywords: Balkans, integration, Balkan Conferences, Balkan Entente, interwar period
\end{abstract}

Ideas about integration in the Balkans have a fairly rich tradition. The era of nationalism in the long $19^{\text {th }}$ century bore numerous plans of establishing a federation to succeed the Ottoman and the Habsburg Empires. These projects were elaborated mainly by intellectuals involved in revolutionary movements such as the Greek pioneer Rigas Fereos Velestinlis in the 1790s, and since the 1860s, the Bulgarians Georgi Rakovski, Liuben Karavelov, Hristo Botev; Svetozar Marković in Serbia; Ion Ghika, Ion Brătianu and Nicolae Bălcescu in Romania. Partisans of a Balkan Federation were also the revolutionary leaders Lajos Kossuth, Giuseppe Garibaldi and Giuseppe Mazzini. Unification should not only promote the entire development of the region but also fulfil the motto "The Balkans to the Balkan peoples", a common desire of almost all political leaders in the region. Later on, prominent "external" politicians interested in Balkan affairs like Bernhard von Bülow, Agenor Gołuchowski, Tommaso Tittoni and Alexander Iswolski regarded it as a means to surmount rivalry between the nascent Balkan nations.

In the $20^{\text {th }}$ century, one can retrace a dozen well documented negotiations on projects for Balkan integration beyond bilateral agreements. ${ }^{1}$ Surprisingly, Romania participated in most of them, although the attribute "Balkan" is neither relevant from the point of view of some present day Western historians nor acceptable for

1 The most important attempts at and agreements on Balkan integration in the 20th century are summarized in Roumiana Preshlenova, "Der Balkan: Bilanz misslungener Annäherungsversuche", in Michael Daxner, Peter Jordan, Paul Leifer, Klaus Roth und Elisabeth Vyslonzil (Eds.), Bilanz Balkan, Wien: Verlag für Geschichte und Politik, Wien, München: Oldenbourg Wissenschaftsverlag, 2005, pp. 24-46. For an overview up to World War II see also Loukianos Hassiotis, "The Ideal of Balkan Unity from a European Perspective (1789-1945)”, Balcanica, 41, 2010, pp. 209-229. 
this country according to many Romanian scholars. Parallel to the attempts of agrarians, socialists and communists to include the federation movement in their programs for social reforms, the new trend took shape also among neoliberals in Europe. The latter regarded the federation as a desirable alternative for socialist international planning. ${ }^{2}$

In the Balkans as well, liberal politicians and intellectuals sought to induce the Balkan governments to overcome their controversies, to establish closer cultural, economic and political relations, and eventually to unite within a federal framework. An early manifestation of this strive, for example, was the daily journal entitled Balkanski Zgovor [Balkan Entente], whose first issue appeared in Sofia on July 28, 1915. The aim of its editor, Dimităr Mishev³, was to promote rapprochement among the Balkan states, and political leaders contributed with various articles in support of this goal. At this time, a similar idea was also launched by Winston Churchill. In the autumn of 1914, after the outbreak of the First World War, he sent the Roden Buxton brothers, Noel and Charles, activists of the Balkan Committee in London ${ }^{4}$, on a semi-official mission to Bulgaria with very indicative instructions: "The creation of a Balkan Confederation comprising Bulgaria, Serbia, Romania, Montenegro and Greece, strong enough to play an effective part in the destinies of Europe, must be the common dream of all their peoples.... I want you to make your friends in Greece and Bulgaria realize the brilliant but fleeting opportunity which now presents itself, and to assure them that England's might and perseverance will not be withheld from any righteous effort to secure the strength and union of the Balkan peoples". ${ }^{5}$ The choice the different Balkan states made to fight on different sides of the front line prevented the fulfilment of this idea.

The war divided the Balkans and Europe as a whole into winners and defeated who had to live together and trade with one another again. The concern of how to overcome the division reflected a common desire for a better future. A newspaper

2 On the neoliberal concepts of integration after the First World War, see Milène Wegmann, „Neoliberale Europa-Föderations konzepte 1918-1945“, in Journal of European Integration History, Number 1, Volume 8, 2002, pp. 11-35.

3 Later on, he published a survey on this issue, D[imităr] Mishev, Boris P. Petkov, La fédération balkanique, origine, développement et perspectives actuelles, Sofia: [s. n.], 1930.

4 On their mission, see Noel \& Charles Buxton, Missiyana Balkanite, Ivan Ilchev (ed.), Sofia: Universitetsko Izdatelstvo Kliment Ohridski, 1987. As a result of it, a book was published according to which the Balkan rapprochement was to be imposed from outside, by the Triple Entente. See Noel Buxton and Charles Roden Buxton, The War and the Balkans, London: George Allen \& Unwin Ltd., 1915. On the Balkan Committee in London (1903-1946) see Leften S. Stavrianos, “The Balkan Committee”, in Queen's Quarterly, XLVIII (Autumn) 1941, pp. 258-267.

5 Noel Buxton, C. Leonard Leese, Balkan Problems and European Peace, London: George Allen \& Unwin Ltd., 1919, pp. 71-72. 
campaign in favour of a Balkan customs union began in 1926 by C. Georgević. In 1928, he even organized the "Inter-Balkan Association for Peace and Prosperity". In June 1929, this group sent to the principal journals and statesmen of the Balkan and Western European countries a statement urging the creation of a Balkan customs union which would lead to political rapprochement and would be economically advantageous for the Balkans and the rest of Europe. Neither the governments nor the general public showed any appreciable interest in the plan. As a result of the influence of the leaders of the agrarian parties Stjepan Radic and Alexandar Stamboliyski, a number of societies for the furtherance of Yugoslav unity were organized in Belgrade, Prague, Vienna, Berlin, Munich, Paris, Geneva, Toulouse, Leipzig and other centres. In January 1930, these various groups combined to form the "League for the Rapprochement of the Serbs and Bulgarians and for the Union of all the South Slavs". ${ }^{6}$ The intellectual desire to unify the Balkan states developed parallel to the recovering of the official political relations between them. In 1929-1930, this was achieved on a bilateral base between Yugoslavia and Greece, Yugoslavia and Bulgaria, Greece and Turkey. On this occasion, Leften S. Stavrianos stated that "the Balkan situation was more settled at the end of 1929 than at any other time in the post-war period". ' In addition, most of the Balkan states concluded bilateral commercial treaties among them in 1926-1930. ${ }^{8}$

This retrieval of bilateral relations in the region was combined with the impact of the Great Depression. Comprised of predominantly agrarian states, the Balkans experienced a decrease in the prize of their main exports on international markets. The price of cereals dropped by about 50\% (which hit Yugoslavia, Romania and Bulgaria), of Mediterranean products (olives, olive oil, raisins, dried figs) by nearly $20 \%$ and of tobacco by $15 \%$. An agrarian block of eight East European states, including Yugoslavia, Romania and Bulgaria, assumed amid its two conferences in August and October 1930 in Warsaw and Bucharest, respectively, that the efforts of individual nations are no longer adequate for coping with such a situation and that common action was necessary. ${ }^{9}$

A third trend that gave impetus to positive developments in the Balkans was the idea of European unification which got stronger during and after World War I. It started in this period from Friedrich Naumann, with his Mitteleuropa (1915), continued with Tomas Masaryk, with his New Europe, and the establishment of the League of Nations as a supranational organization to protect the liberty of all

6 Leften S. Stavrianos, Balkan Federation. A History of the Movement toward Balkan Unity in modern times, Smith College Studies in History, vol. XXVII, Northampton, Mass., 1944, pp. 224-225.

7 Ibidem, pp. 224-229.

8 Robert J. Kerner, Harry N. Howard, The Balkan Conferences and the Balkan Entente 19301935, Westport, Connecticut: Greenwood Press Publishers, 1970, p. 22.

9 Leften S. Stavrianos, Balkan Federation, pp. 229-230. 
nations and secure world peace on the initiative of Woodrow Wilson at the Paris Peace Conference in 1919. Unification plans were further launched by Richard Nikolaus von Coudenhove-Kalergi, with his Paneuropean Union (1923), and culminated in Aristide Briand's proposal for the United States of Europe in 1929. ${ }^{10}$ They were all based on the French-German political understanding and economic co-operation with Aristide Briand and Gustav Stresemann as their personification, who received the Nobel Peace Prize for this initiative in 1926. In 1919-1939, no fewer than 600 books and articles in journals on the idea of European unification were published, most of them in French and German, not including texts in the daily press. ${ }^{11}$ Briand's initiative found supporters among politicians and intellectuals in all Balkan countries, and Coudenhove-Kalergi gave a public lecture at the Bulgarian Academy of Sciences in Sofia on March $25^{\text {th }} 1926 .{ }^{12}$ All these ideas were reflected in the press or in particular books in the Balkans. Thus, the strive for Balkan integration emerged concurrently with similar initiatives for economic and political unions at a European level and was maybe inspired by them.

Former Greek prime-minister Alexander Papanastassiou used the 1929 meeting of the XXVII Universal Congress of Peace in Athens to gain support for the establishment of an institution for Balkan rapprochement in economic, social, intellectual and political terms, in the hope of achieving a Balkan union. He believed that, despite the different languages, Balkan peoples had common economic interests and shared history, culture and traditions, and that the republican reforms in Turkey since the 1920s would make Balkan unification possible. In the resolution of the congress on this issue it was stated that: "The Conference considers that a union among the Balkan peoples is most opportune, and for this purpose special Balkan Conferences should be organized annually". ${ }^{13}$

The International Bureau of Peace in Geneva invited the six foreign ministers of the Balkan states - Albania, Bulgaria, Greece, Romania, Turkey and Yugoslavia, in May 1930, to a Balkan Conference to be held in Athens. All governments had expressed their willingness to send delegates. In the preparatory work, 23 memoranda altogether from Greek, Yugoslav, Romanian, and Bulgarian scholars, politicians, and experts were submitted. They considered all major aspects of economy, culture and social life. It was felt that the process of fusion would be longer,

10 Peter Bugge, "The nation supreme. The idea of Europe 1914-1945", in Kevin Wilson, Janvander Dussen (eds.), The History o fthe Idea of Europe, London and New York: Routledge, 1995, pp. 83-106.

11 Wolfgang Schmale, Geschichte Europas, Wien-Köln-Weimar: Böhlau Verlag, 2000.

12 Konstantin Manchev, "Ideyata za Panevropa", in Otets Paisiy, X, 4, 1937, p. 124. See also Konstantin Manchev, Panevropa i balkanskata federatsiya (idei i realizatsiya), Lom 1932; Constantin Svolopoulos, L'attitude de la Grèce vis-à-vis du project Briand “D’Union fédérale de 1'Europe“, in Balkan Studies, Vol. 29, Nr. 1, 1988, pp. 29-38.

13 Robert J. Kerner, Harry N. Howard, op. cit., p. 173. 
starting with preliminary technical and economic agreements, followed by the formation of a customs agreement, and finally the creation of the federation of Balkan states. ${ }^{14}$

The best description of the Balkan Conference is that by Al. Papanastassiou: "Though based on the national groups, composed of politicians, representatives of peace organizations, universities, and professional organizations, and though its decisions do not obligate the governments, this organization has nevertheless an official character, not only because the governments of the six countries support the activities of the national groups, but also because the delegations of each country to the Conferences are chosen after consultation with the government, and these governments are represented at each Conference by their diplomatic officials (who follow the deliberations in the capacity of observers) in the country in which the Conference meets". ${ }^{15}$

The first Balkan Conference took place in Athens on $5^{\text {th }}-12^{\text {th }}$ October 1930 , as a semi-official gathering of about 150 delegates, experts, and observers. Prominent politicians attended the event: the president of the Romanian Chamber of Deputies, the vice-president of the Turkish National Assembly, senators, deputies, the diplomatic corps in Athens, representatives of the League of Nations Secretariat, the International Labour Office, the International Peace Bureau, the Inter-parliamentary Union, the Carnegie Endowment for International Peace and other international organizations. The opening was organized as a great festivity. A Balkan flag with six golden stars and six stripes of white, blue, green, yellow, red, and white symbolized the future union, and a band played the "Balkan Hymn of Peace", composed specifically for the auspicious event. The Balkan Olympic Games brought the youth of the peninsula together. It seemed that a new epoch in Balkan history was about to begin. In his welcoming address, Papanastassiou expressed the common inspiration: "The achievement of our ideal will mark a new era of prosperity and progress... Today, by our attitude in the Conference and by its continuation, we prove that we, the Balkan peoples, are to become the masters of our destinies and are to develop again in this corner of Europe a new and glorious civilization which will illuminate the world". ${ }^{16}$ Later on, Mustafa Kemal Attaturk expressed similar optimism and enthusiasm when addressing the works of the conference in Turkey. ${ }^{17}$ The proceedings and/or many of the official documents were published in Première Conférénce balkanique. Documents

14 Ibidem, pp. 26-29. The concept of Rainer Santi about the First Balkan Conference in Athens in 1930 is that it was „Defusing the European powder-keg” (,die Entschärfung des europäischen Pulverfasses"). Rainer Santi, 100 Jahre Friedensarbeit. http://www.santibox. $\mathrm{ch} /$ Peace/Friedensarbeit.html\#Entschärfung. Accessed May $10^{\text {th }} 2013$.

15 Cited after Leften S. Stavrianos, Balkan Federation, p. 231.

16 Cited after Robert J. Kerner, Harry N. Howard, op. cit., p. 31.

17 Les Balkans, 1931, No. 13-14, p. 1. 
officiels (Athens 1931), II ${ }^{\mathrm{e}}$ Conférénce balkanique. Documents officiels (Istanbul 1932), III Conférénce balkanique. Documents officiels (Bucharest 1932), IV Conférénce balkanique.Documents officiels (Athens 1934) and in the journal Les Balkans, founded in 1930 by A. Papanastassiou jointly with M. X. Lefcoparidis and financed mainly by the Carnegie Endowment for International Peace. ${ }^{18}$

Four annual conferences were held altogether, as follows: the first in Athens, October $5^{\text {th }}-12^{\text {th }}, 1930$; the second in Istanbul and Ankara, October $19^{\text {th }}-26^{\text {th }}, 1931$; the third in Bucharest, October 22 $2^{\text {nd }}-27^{\text {th }}$, 1932; the fourth in Salonica, November $5^{\text {th }}-11^{\text {th }}, 1933 .{ }^{19}$ It is impossible to present their work within a limited publication. ${ }^{20}$ An overview could just summarize their results, rather than present a detailed factual account.

Six particular commissions had been appointed to study the various aspects of regional unification. They were chaired by representatives of each Balkan country. The Commission on Organization prepared the statutes and the rules of the Balkan Conference.

The Commission on Economic Affairs studied in detail the economic position of every Balkan country and of the peninsula as a whole. It proposed measures for their improvement and for Balkan co-operation. The general aim was to protect agriculture and industry in the Balkans, as well as to adopt a concerted commercial policy, to promote collaboration between banks, and to investigate the possibility of a monetary union. Some specific projects were also discussed, for example the establishment of the Balkan Chamber of Commerce and Industry patterned after the International Chamber of Commerce. It was officially opened in Istanbul, in May 1932.

The weak basis for economic co-operation of the Balkan states, however, is evident even from the data reflecting their mutual trade. While trade with the neighbours accounted for about half of the overall commodity turnover in Central and Western Europe, in the Balkans it remained insignificant for all countries.

18 For a full account of all memoranda submitted by members of the particular national delegations, see Robert J. Kerner, Harry N. Howard, op. cit., pp. 245-257.

19 The dates of the conferences vary in the different sources. Here they are as given in Alexanderos Papanastassiou, Vers l'union balkanique: les conférences balkaniques: Athènes: 5-12 Oct. 1930: Istanbul et Ankara: 19-26 Oct. 1931: Bucarest: 22-27 Oct. 1932: Salonique: 5-11 Nov. 1933. Paris: Conciliation Internationale, [1934].

20 The work of the Balkan Conferences is retraced in detail in Theodore Ivanoff Geshkoff, Balkan union: a road to peace in Southeastern Europe, New York: Columbia University Press, 1940; Robert J. Kerner, Harry N. Howard, op. cit.; Norman J. Padelford, Peace in the Balkans. The Movement Towards International Organization in the Balkans, New York: Oxford University Press, 1935. A first German reaction see in Hermann Gross, Grundlagen und Ziele der Balkankonferenz, Leipzig: C. Heymann, 1932. 
Balkan Trade as Share of the Overall Foreign Trade of the Various Balkan States ${ }^{21}$

\begin{tabular}{|c|c|c|c|c|}
\hline & \multicolumn{2}{|c|}{ 1926-1929 } & \multicolumn{2}{|c|}{$1931-1938$} \\
\hline & Imports & Exports & Imports & Exports \\
\hline Albania & 14 & 26 & - & - \\
\hline Bulgaria & 11 & 16 & 6 & 2 \\
\hline Greece & 19 & 3 & 14 & 5 \\
\hline Romania & 2 & 9 & 3 & 6 \\
\hline Turkey & 5 & 8 & 2 & 5 \\
\hline Yugoslavia & 5 & 10 & 4 & 5 \\
\hline
\end{tabular}

The Commission on Communications accounted that direct connections between the Balkan states were still undeveloped and not a single bridge spanned the Danube. The first conference adopted resolutions for the construction of direct rail, air, road, and telegraphic lines between all the capitals and of two main trunk lines (rail and road) from the Black Sea to the Adriatic and from the Danube to the Aegean. It approved a convention for a Balkan Postal Union to reduce postal rates between the Balkan countries and to improve postal service in the region. This convention was partially applied.

The Commission on Intellectual Cooperation adopted a program, calling for exchange of university students, professors, and intellectual associations; instruction in a Balkan language other than that of the national state in all universities; teaching history as an aid to union; translation of Balkan folklore into the various Balkan languages; and the celebration of a Balkan Week in each country at a fixed date. A Balkan Institute for Intellectual Cooperation with a women's section was approved. A Permanent Commission of Balkan Jurists was established to harmonize the law of the particular states.

The Commission on Social Policy urged that serious attention be given to the precarious plight of the agricultural and industrial workers, pointing out that their support was a prerequisite for success. Resolutions were adopted in favour of the improvement and collaboration of sanitary services, abolition of child labour and prostitution, equal treatment of foreign workers, and ratification of the conventions and recommendations adopted by the International Labour Office.

From this overview it is evident that, in the fields of intellectual cooperation, social policies, communications and economic relations, a number of constructive projects were adopted, and a few of them were put into operation. In political questions, however, the situation was quite different.

The Commission on Political Relations faced the task of reconciling conflicting interests. The Bulgarian delegation insisted on including the problem of minorities

21 Estimated from data in Vera Katsarkova, Ikonomicheskite otnosheniya na Bălgariya $s$ balkanskite dărzhavi mezhdu dvete svetovni voyni (1919-1941), Sofia: Bălgarska akademiya na naukite, 1989, pp. 181, 231, 241-2. 
in the agenda of the conference. After World War I, the country had to yield territories to all neighbours - altogether $11,000 \mathrm{~km}^{2}$ populated by Bulgarians. ${ }^{22}$ About 600,000 of them left these territories and fled to Bulgaria. Next to reparations and contributions, this refugee influx created a serious economic and social problem for the government. Many ethnic Bulgarians remained in the lost territories, becoming a minority. Papanastassiou conceded that the minority issue might be regarded "in principle". A general discussion on minorities took place, but since the fundamental questions at hand had already been ruled out, the debate was limited and inconclusive. On the other hand, the Yugoslav representatives at the second Balkan Conference in Istanbul underlined as an obstacle for political understanding the involvement in other states' affairs (Bulgarian support for the irredentist Internal Macedonian Revolutionary Organization, IMRO, in the Yugoslav part of Macedonia was inferred) and the alliance of Balkan states with external powers (in this case Albania's treaties providing for friendship and alliance with Italy were envisaged). Nevertheless, the commission adopted a resolution recommending that the Balkan foreign ministers meet annually to discuss outstanding questions; that the council appoint a committee to undertake the study of a Balkan pact involving outlawry of war, amicable settlement of all disputes, and mutual assistance. The proposed pact was modelled after the Little Entente's General Act of Conciliation, Arbitration and Judicial Settlement. The conference further recommended that, pending the elaboration of the pact, an attempt should be made to dispose of the contentious minorities question by direct, bilateral negotiations between the national groups. Consequently, the Bulgarian delegation at the third conference in Bucharest proposed the adjournment of the debate on a Balkan Pact until the next conference, in order to arrange bilateral negotiations on the minorities' question. With the rejection of this proposal the Bulgarian delegates left the conference. ${ }^{23}$

In their absence, the delegates of the other five countries approved The Draft Balkan Pact of the Balkan Conference. It envisaged non-aggression, friendship, peaceful settlement of conflicts and mutual assistance. In addition, this draft included proposals for dealing with the minorities problem, which provided that each contracting party should establish an Office of Minorities to collect

22 It is impossible within the limits of this publication even to cite the huge amount of publications on the minorities issue in the Balkans. A recent publication on this matter is Dušan T. Bataković (ed.), Minorities in the Balkans: state policy and interethnic relations: (1804-2004), Belgrade: Balkanološki institut SANU, Special editions 111, 2011.

23 On the Bulgarian position see Georgi P. Genov, La Bulgarie et les conférences balkaniques, Sofia, Impr. "La Bulgarie", 1931. D. Mishev had emphasized earlier that a Balkan Federation which would leave millions of people as minorities without national and human rights would be a parody of the great idea, that those who would be against the prior application of the treaties concerning the minorities would be against peace and the Balkan federation. D[imitar] Mishev, Boris P. Petkov, op. cit., p. 35. 
petitions on the application of the treaties concerning minorities, and that a Balkan Commission of Minorities representing the six Balkan countries should meet once a year in turn, to examine complaints from minorities. Any question on which the members of the Commission failed to agree would be referred to the League of Nations. This pact represents the most important achievement of the conferences in the political field. The fourth conference at Salonica expressed the hope that the governments would adopt the draft Balkan Pact and arrange for annual meetings between their foreign ministers to smooth out disagreements. In reply, the Bulgarian delegation issued a declaration accepting the pact on condition that the equal status of Bulgaria would be recognized and the provisions regarding minorities would be loyally enforced.

Nevertheless, different diplomatic activities undermined the understanding achieved. Turkey, Yugoslavia and Romania signed non-aggression pacts with the Soviet Union in summer 1933. In the same year, a rapprochement between Bulgaria and Yugoslavia was reached (a protocol for measures against bands was signed and the royal families exchanged visits), Turkey and Greece concluded a treaty for mutual warranty of their common frontiers, for friendship, understanding and collaboration in protection of their common interests. Thus, the idea of Balkan integration was parcelled and replaced by a series of bilateral agreements.

At a meeting in Ankara, the foreign ministers of Romania, Yugoslavia, Greece and Turkey agreed on a Balkan Pact. The respective treaty was signed on February $9^{\text {th }} 1934$ in Athens, again with great festivities. It was patterned after the Little Entente of February 1933, which united Czechoslovakia, Romania and Yugoslavia, aiming to contain Hungarian revisionism. Some observers regarded the Balkan Entente as an extension of the Little Entente or as its parallel organization. ${ }^{24}$ The treaty provided mutual warranty for the existing frontiers in the Balkans. In addition, the particular members of the pact explicitly declared that its application would not involve any of them into hostilities with a Great Power. ${ }^{25}$ Thus, the pact was reduced to a pure anti-Bulgarian instrument. Not coincidentally, one spoke in Bulgaria about it as an "encircling". It was criticized by the Greek opposition headed by Eleftherios Venizelos as worthless, given the absence of Bulgaria. And the British ambassador to Athens stated in, a press communication on the very day of the conclusion of the pact, that every rapprochement and co-operation between the Balkan states would be welcome if it is not directed against any state in the region and if the accession of Bulgaria is guaranteed. ${ }^{26}$ Only in France, which

24 Hans Hartl, Der "einige” und "unabhängige” Balkan, München: R. OldenbourgVerlag, 1977, pp. 26, 37.

25 Four-Power Balkan Pact, of The Statute of Organization of the Balkan Entente and of The Statute of the Advisory Economic Council of the Balkan Entente are published in Robert J. Kerner, Harry N. Howard, op. cit., pp. 232-237.

26 Hans Hartl, op. cit., pp. 37-38. 
remained the patron and defender of the status quo in Southeastern Europe, was the treaty admired despite the fact that it divided the Balkan countries again in winners and losers. The conclusion of the Balkan Pact was the main reason to adjourn sine die the fifth Balkan Conference scheduled for early October 1934 in Istanbul. In fact, the delegations never met again.

The general political conjuncture at this time predetermined the further development of the Balkan rapprochement once again. The rise of Hitler to power and his bellicose statements regarding the Treaty of Versailles stimulated the revisionist movement throughout Europe. On the other hand, trade dependence of all Balkan states upon Nazi-Germany grew since mid 1930s: about $35 \%$ of their imports came from Germany and $27-50 \%$ of their exports went there. Furthermore, Germany, which had a trade deficit with them, did not liquidate its debt, except by exports. Admittedly, this economic hegemony combined with direct or indirect political repercussions additionally undermined Balkan understanding.

The Balkan Conferences were a promising but fragile beginning of a rapprochement between the Balkan states. In contrast to all previous plans for regional integration that were directed against a common enemy and thus were "anti" in their character $^{27}$, they were pro-Balkan and pro-European. They brought together a part of the Balkan elites and demonstrated that they were capable of mutual understanding. They are telling evidence that the idea of a Balkan federation was not limited only to left and leftist parties which issued in Vienna, Austria, and then in Frankfurt, Germany, their newspaper La Fédération balkanique from 1924 to 1932. ${ }^{28}$ The Balkan Conferences stimulated co-operation between non-governmental organizations in the region. Most successful and long-lasting were the established relations among the national medical associations, the unions of mathematicians and sportsmen. ${ }^{29}$

During the years of the Balkan Conferences, a number of newspapers and journals were printed in Bulgaria under the name Balkan [Balkan], Balkanski pregled [Balkan Review], Balkanski săyuz [Balkan Union], Balkansko sdruzhenie [Balkan Unification] etc. Besides, the Paris based edition Revue des Balkans was supplied. Many of them disseminated hope and great expectations, but sober evaluations were present, too. Repeatedly, the motive of turning the Balkans into a Great Power through their integration was stressed. The journal Balkani $[$ Balkans] for instance wrote that the Balkan peoples had started understanding that their unification as a

27 See for example Henrik Batowski, "Le mouvement pan balkanique et les différents aspects des relations interbalkaniques dans le passé (Indications de méthode et aperçu des faits), in Revue internationale des Études balkaniques, vol. 6, 1938, pp. 320-343.

28 Vladimir Claude Fišera, "Communisme et intégration supranationale: la Revue „La Fédération balkanique" (1924-1932)", in Revue d'histoire moderne et contemporaine, T. 34e, No. 3, 1987, pp. 497-508.

29 Apostolos Hristakudis, Mnogostrannoto sătrudnichestvo $v$ Yugoiztochna Evropa $i$ evropeyskata integratsiya. Istoriya i săvremennost, Sofia: Heron pres, 2002, pp. 22-26. 
federation with an area of 1,250.000 square miles or twice as much as France, and a population of 50 million, had to become the third most important [European] state after Russia and Germany. ${ }^{30}$

The Balkan Conferences outlined some important principles, first of all a General Resolution on the Balkan Union. Further, a number of practical goals were achieved: a Balkan Postal Convention; a Balkan Chamber of Commerce and Industry; a Balkan Press Association; a Balkan Tourist Federation; a Draft Balkan Pact; a Convention on the status of Balkan citizens; a draft of a Regional Economic Understanding; a Draft Statutes of the Balkan Parliamentary and Social Union. The Balkan Conferences did not bring progress and prosperity to the predominantly agrarian and underdeveloped region, nor did they launch a new civilization, as Papanastassiou pretended, but there were no military conflicts on the peninsula until the Second World War. In other words, the territorial status quo was being preserved until again external powers - Italy and Nazi-Germany - forced changes of borders and human distress in the region.

\section{Bibliography}

Bataković, Dušan T. (ed.), (2011), Minorities in the Balkans: state policy and interethnic relations (1804-2004), Beograd: Balkanološki institut SANU, Special editions 111.

Batowski, Henrik, (1938), "Le mouvement panbalkanique et les différents aspects des relations interbalkaniques dans le passé (Indications de méthode et aperçu des faits) ", in Revue internationale des Études balkaniques, vol. 6, 320-343.

Bugge, Peter, (1995), “The nation supreme. The idea of Europe 1914-1945”, in Wilson, Kevin and Dussen, Jan van der (ed.), The History of the Idea of Europe, London and New York: Routledge, 83-146.

Buxton, Noel and Charles Roden, (1915), The War and the Balkans, London: George Allen \& Unwin Ltd.

Buxton, Noel and C. Leonard Leese, (1919), Balkan Problems and European Peace, London: George Allen \& Unwin Ltd.

Buxton, Noel i Charles, (1987), Missiya na Balkanite, Ivan Ilchev (ed.), Sofia: Universitetsko Izdatelstvo Kliment Ohridski.

Fišera, Vladimir Claude, (1987), “Communisme et intégration supranationale: la Revue „La Fédération balkanique" (1924-1932) ", in Revue d'histoire moderne et contemporaine, T. 34e, No. 3, 497-508.

Genov, Georgi P. (1931), La Bulgarie et les conférences balkaniques, Sofia: Impr. La Bulgarie.

Geshkoff, Theodore Ivanoff, (1940), Balkan union: a road to peace in Southeastern Europe, New York: Columbia University Press.

30 Cited after Milcho Lalkov, Ot nadezhda kăm razocharovanie. Ideyata za federatsiyata $v$ Balkanskiya Yugoiztok (1944-1948), Sofia: IK „Vek 22“, 1994, p. 63. The Turkish newspaper Stambul (03.10.1931) estimated the population of a Balkan union even higher, at 57,450.000. See Hans Hartl, op. cit., p. 28. Other estimations fix the area at 600,000 square miles and the population at some 60,000.000, which exceeds that of France, Italy or Great Britain. See Robert J. Kerner, Harry N. Howard, op. cit., p. 23. 
Gross, Hermann, (1932), Grundlagen und Ziele der Balkankonferenz, Leipzig: C. Heymann. Hartl, Hans, (1977), Der "einige” und "unabhängige” Balkan, München: R. Oldenbourg Verlag. Hristakudis, Apostolos, (2002), Mnogostrannoto sătrudnichestvo v Yugoiztochna Evropa i evropeyskata integratsiya. Istoriya i săvremennost, Sofia: Heron pres.

Katsarkova, Vera, (1989), Ikonomicheskite otnosheniya na Bălgariya s balkanskite dărzhavi mezhdu dvete svetovni voyni (1919-1941), Sofia: Bălgarska akademiya na naukite.

Kerner, Robert J., Howard, Harry N., (1970), The Balkan Conferences and the Balkan Entente 1930-1935, Westport, Connecticut: Greenwood Press Publishers.

Lalkov, Milcho, (1994), Ot nadezhda kăm razocharovanie. Ideyata za federatsiyata $v$ Balkanskiya Yugoiztok (1944-1948), Sofia: IK „Vek 22“.

Hassiotis, Loukianos, (2010), “The Ideal of Balkan Unity from a European Perspective (17891945)", Balcanica, 41, 209-229.

Manchev, Konstantin, (1932), Panevropa i balkanskata federatsiya (idei i realizatsiya), Lom.

Manchev, Konstantin, (1937), "Ideyata za Panevropa", in Otets Paisiy, X, 4, 121-125.

Mishev, D[imitar], Boris P. Petkov, (1930), La fédération balkanique, origine, développement et perspectives actuelles, Sofia: [s. n.].

Padelford, Norman J., (1935), Peace in the Balkans. The Movement towards International Organization in the Balkans, New York: Oxford University Press.

Papanastassiou, Alexanderos, [1934], Vers l'union balkanique: les conférences balkaniques: Athènes: 5-12 Oct. 1930: Istanbul et Ankara: 19-26 Oct. 1931: Bucarest: 22-27 Oct. 1932. Salonique: 5-11 Nov. 1933, Paris: Conciliation Internationale.

Preshlenova, Roumiana, (2005), „Der Balkan: Bilanz misslungener Annäherungsversuche“, in Michael Daxner, Peter Jordan, Paul Leifer, Klaus Roth und Elisabeth Vyslonzil (Hrsg.): Bilanz Balkan, Wien: Verlag für Geschichte und Politik, München: Oldenbourg Wissenschaftsverlag, 24-46.

Santi, Rainer, 100 Jahre Friedensarbeit. http://www.santibox.ch/Peace/Friedensarbeit.ht$\mathrm{ml}$ \#Entschärfung. Accessed May $10^{\text {th }} 2013$.

Schmale, Wolfgang, (2000), Geschichte Europas, Wien-Köln-Weimar: Böhlau Verlag.

Stavrianos, Leften Stavros, (1941), "The Balkan Committee”, in Queen's Quarterly, XLVIII (Autumn), 258-267.

Stavrianos, Leften Stavros, (1944), Balkan Federation. A History of the Movement toward Balkan Unity in Modern Times, Smith College Studies in History, vol. XXVII, Northampton, Massachusetts.

Svolopoulos, Constantin, (1988), L'attitude de la Grèce vis-à-vis du project Briand 'D'Union fédérale de l'Europe“, in Balkan Studies, Vol. 29, Nr. 1, 29-38.

Wegmann, Milène, (2002), „Neoliberale Europa-Föderationskonzepte 1918-1945“, in Journal of European Integration History, Number 1, Volume 8, 11-35. 


\title{
The End of the Nazi "Empire" in East- Central Europe and the Creation of a New "Empire" in the East (1945-1989)
}

\section{La Conférence du Mouvement Européen sur l'Europe Centrale et Orientale en janvier 1952}

\author{
Gergely FEJÉRDY
}

\begin{abstract}
En 1949 la Commission de l'Europe centrale et orientale (CECO) fut établie. Dans ce groupe de travail se retrouvaient des Occidentaux intéressés par le sort des peuples du bloc de l'Est ainsi que les représentants émigrés des pays concernés. Les objectifs et les outils de la CECO n'ont été précisés qu'au fur et à mesure, mais l'essentiel de son message essentiel est resté le même : "l'Europe doit être unie et ne peut pas rester continuellement divisée ou démantelée. "La première conférence de cette commission du Mouvement Européen eut lieu entre les 21 et 24 janvier 1952 à Londres. La présentation s'attarde sur des questions telles que la préparation de cette rencontre, les participants incontournables, les résolutions et les conséquences de cet événement.

Keywords: Mouvement Européen, Réfugiés politiques de l'Europe Centrale et Orientale, Commission de l'Europe Centrale et Orientale, Construction européenne, National Committee for Free Europe
\end{abstract}

Lundi 21 janvier 1952, à 11 heures, la conférence du Mouvement Européen sur l'Europe centrale et orientale s'ouvrit à Londres, au Church House dans le quartier de Westminster, sous la présidence de Léopolde Stennet Amery ${ }^{1}$, homme politique

1 Léopolde Stennett Amery (1873-1955), journaliste, homme politique européiste de grande influence, membre du parti conservateur britannique jusqu'en 1945. Il fut secrétaire d'Etat des colonies (1922-1929) et durant la Seconde Guerre mondiale il occupa le poste de secrétaire d'État des Indes. Européiste de longue date, il fut membre fondateur de l' « United European Movement ». Sa mère étant originaire d'une famille juive hongroise de Pest, il parlait couramment hongrois. S'il n'avait plus de contact avec sa mère après le divorce de ses parents en 1885, il s'intéressait à la région de l'Europe centrale et orientale. C'est ainsi notamment qu'il fit des études dans l'Empire Austro-hongrois en 1912. Son choix comme président de la conférence de Londres en janvier 1952 était d'autant plus compréhensible qu'il parlait au total quatorze langues dont beaucoup d'européennes. Son fils Julien Améry fut l'un des vice-présidents de la Commission de l'Europe Centrale et Orientale, et par ailleurs le gendre de Harold Macmillan. Concernant la biographie de L. S. Amery voir : Oxford Dictionary of National Biography, [http://www.oxforddnb.com/view/article/30401], (02.05.2013). 
britannique de 79 ans. L'idée de cette réunion remonte en 1950, mais sa réalisation fut plutôt compliquée. Al'origine, ce furent les mois de septembre, puis de décembre 1951 qui avaient été retenus pour la tenue de la conférence, mais finalement celle-ci dut être ajournée. Le premier orateur, Harold Macmillan, souligna ainsi dans son discours : " Je crois qu'en certains moments plusieurs d'entre nous, devant tant de complications et de difficultés doutèrent de l'aboutissement de la conférence. Enfin ces doutes sont dissipés, puisque nous voilà réunis. $»^{2}$

\section{Des origines de la conférence}

Harold Macmillan fut particulièrement satisfait que la conférence ait pu se réunir à Londres. ${ }^{3}$ Il avait en effet beaucoup œuvré pour que cette conférence puisse avoir lieu. Dès la fin de la Seconde Guerre mondiale, il fut parmi les hommes politiques britanniques favorables au renforcement de l'unité du Vieux continent, sans exclure les pays sous obédience soviétique. Il fut notamment membre de l' « United European Movement », lancé par Winston Churchill en janvier 1947. ${ }^{4}$ C'est ainsi qu'il participa au "Congrès de l'Europe » réuni à la Haye en mai 1948. Suite à cet événement où les nations vivant derrière le rideau de fer furent représentées par les émigrés politiques, le député conservateur britannique s'intéressa à la problématique des pays européens se trouvant sous occupation soviétique. Il accepta ainsi de présider la Commission d'Europe centrale et orientale du Mouvement Européen (CECO) en 1949. La naissance de ce groupe était le résultat du lobbying des émigrés proeuropéens de grande influence, tel que Joseph Retinger $^{5}$, et de quelques personnalités des pays occidentaux, essentiellement britanniques, comme Harold Macmillan, ou Edward Beddington-Behrens etc.

Suite au congrès de la Haye la décision fut en effet prise de promouvoir la formation de groupes nationaux pro-européens regroupant les différentes tendances politiques. L'objectif en était notamment de choisir des délégués représentatifs pour constituer une assemblée qui élaborerait une constitution européenne. Lors du meeting de Bruxelles le 25 octobre 1948, le Comité international de coordination

2 Léopolde S. Amery (préface) : Conférence de l'Europe centrale et orientale organisée par la Commission de l'Europe centrale et orientale du Mouvement Européen, Rapport complet, „Le Monde”, Paris, 1952, p. 1.

3 Cf. : Harold Macmillan: Tides of Fortune 1945-1955, London, Macmillan Publisher, 1969.

4 Cette initiative prévoyait une confédération européenne assez souple sur le modèle du Commonwealth britannique. cf. : Jean-Michel Guieu : « Le Congrès de La Haye (7-10 mai 1948), « porte-parole de l'Europe » ? in Jean-Michel Guieu et Christophe Le Dréau (dir.) : Le "Congrès de l'Europe » à la Haye (1948-2008), Bruxelles, P.I.E. Peter Lang, 2009. pp. 18-19.

5 Jozef Laptos : « Jozef Retinger, le père d'ombre de l'Europe. Le rôle de Jozef Retinger et de ses réseaux personnels dans les débuts de la construction européenne » in Gérard Bossuat, (dir.), Inventer l'Europe. Histoire nouvelle des groupes d'influence et des acteurs de l'unité européenne, Bruxelles, P.I.E. Peter Lang, 2003, pp. 179-196. 
des mouvements pour l'unité européenne qui avait organisé le « Congrès de l'Europe »fut transformé en Mouvement Européen, dont le conseil exécutif était présidé par Duncan Sandys, et le secrétaire général était Josef Retinger, un homme politique influent d'origine polonaise. Ce dernier était particulièrement favorable à la présence des émigrés venant des États sous le joug soviétique dans les actions du Mouvement Européen. ${ }^{6}$ C'est à son initiative qu'en automne 1948 l'idée de la création d'un « Secrétariat Provisoire de la Commission des Pays de l'Est » vit le jour. ${ }^{7}$ La réalisation de cette idée se révéla toutefois très difficile. La formation des comités nationaux était très lente, et la mise en place d'un secrétariat provisoire commun piétinait. ${ }^{8}$

Lors de la réunion du comité exécutif international du Mouvement Européen à Paris les 5 et 6 février 1949, où les pays de l'Est étaient représentés par l'ancien ministre des affaires étrangères roumain, Grégoire Gafencu, en tant que membre coopté, il fut décidé de mettre en place un " Conseil Provisoire » avec les représentants des nations se trouvant derrière le rideau de fer et l'Espagne. ${ }^{9}$ Cette idée fut finalement abandonnée, et une structure purement centrée sur les questions des États du bloc soviétique fut créée. Lors de la réunion du comité exécutif international du Mouvement Européen des 6 et 8 mai 1949, tenue à Paris un jour après l'institution du Conseil de l'Europe, la mise en place d'un "Sous-Comité Est Européen » fut décidée. ${ }^{10}$ Trois mois plus tard, son nom avait déjà été modifié et sa présidence confiée à Harold Macmillan. Le 17 août 1949, lors de la première session de 1'Assemblée consultative du Conseil de l'Europe à laquelle les émigrés politiques pouvaient être présents en tant qu'observateurs, une Commission de l'Europe Centrale et Orientale du Mouvement Européen (CECO) vit le jour. ${ }^{11}$

6 Cf. : John Pomian (éd.) : Joseph Retinger, Memoirs of an Eminence Grise, London, Sussex University Press, 1972, pp. 238-241.

7 Archives historiques de l'Union européenne, Florence, (AHUEF), Villa Il Poggiolo. Dépôts, DEP, Mouvement européen, ME 851, lettre de Rebattet datée : Paris, le 12 novembre 1948, $\mathrm{CR} / \mathrm{MP} / \mathrm{n}^{\circ} 1813$.

8 Ce sont les Hongrois qui ont créé le premier Comité National du Mouvement Européen formé par les exilés. Cf.: Fejérdy Gergely : "Les Hongrois ayant rejoint le Mouvement européen en 1948 » in Öt Kontinens, Az Új-és Jelenkori Egyetemes Történeti Tanszék közleményei, Numéro spécial de la collaboration entre ELTE et l'Université Bordeaux3, 2011. 2, Budapest, Robinco, 2012, pp. 129-140. En 1949, seuls les Roumains et les Bulgares ont suivi l'exemple des Hongrois.

9 Archives du Centre d'Étude d'Histoire de l'Europe Contemporaine à l'Université Catholique de Louvain (ACEHEC), Série B, Mouvement européen (1947-1959), Dossier 1, Procèsverbal du les réunions du Comité executif du Mouvement Européen, Paris, les 5 et 6 février 1949. EX/M/8, f. 4.

10 Ibid., Procès-verbal des réunions du Comité exécutif du Mouvement Européen, Paris, les 6 et 8 mai 1949, EX/M/ 12, f.8, § 76. A cette réunion, Erwin Mueller et Paul Auer étaient membres cooptés à titre personnel.

11 Jozef Laptos: «L'élargissement avant la lettre. La place de l'Europe Centrale et orientale dans l'activité du Mouvement Européen (1949-1952)» in Catherine Horel et al. (dir.), Nations 
Elle était présidée par Harold Macmillan, son rapporteur général en était le Major Edward Beddington-Behrens, et parmi ses vice-présidents on trouvait notamment Joseph Retinger, et le sénateur français Ernest Pezet. Elle était donc composée d'Occidentaux intéressés par les pays derrière le rideau de fer, mais aussi d'exilés provenant des pays d'obédience communiste. ${ }^{12}$

Durant l'année 1950 la CECO devint de plus en plus active, motivée tant par le plan Schuman que par les tensions internationales de plus en plus tangibles suite au début de la guerre de Corée. Dans ce contexte, en accord avec la plupart des hommes politiques occidentaux, Harold Macmillan développa d'ailleurs un programme prévoyant qu'en cas de chute des régimes communistes du bloc de l'Est, les exilés réfugiés en Europe occidentale en lien avec le Mouvement Européen pourraient les remplacer et assurer la stabilité dans la région.

En mai une petite brochure vit le jour, qui concrétisait les objectifs de la CECO, et était intitulée «Éléments pour une politique est-européenne »" Au même moment pour la première fois le poste de vice-président fut confié à un émigré. Il s'agissait de l'ancien chef de la légation de Hongrie à Paris, influent juriste international, Paul Auer. ${ }^{14}$ A partir du mois d'août 1950, la Commission de l'Europe centrale et orientale s'efforça d'amener les représentants des exilés à contribuer aux travaux en faveur de l'unité du Vieux Contient, par le biais d'une étroite collaboration avec le Comité spécial chargé de veiller aux intérêts des nations européennes non représentées au Conseil de l'Europe. ${ }^{15}$ L'idée émergea par ailleurs d'organiser une grande conférence au sujet de l'Europe centrale et orientale. A la tête du comité chargé de préparer cet événement, la Commission désigna le

cultures et sociétés d'Europe centrale aux XIX $X^{e}$ et XX Michel, Paris, Publication de la Sorbonne, 2006, pp.126-127. Voir également: Ricardo M. Martin de la Guardia et Guillermo Á. Pérez Sánchez : «El Movimiento Europeo y los paises del Este Ante el Inicio de la Guerra Fría » in Carlos Flores Juberías (éd.), Estudios sobre la Europa Oriental, Universitat de Valencia, 2002, pp. 273-274. Voir par ailleurs : Macher Anikó : «Une institution pour promouvoir l'idée de l'unité européenne. La Commission de l'Europe centrale et orientale du Mouvement Européen (1948-1953) » in Jean-Michel Guieu et Christophe Le Dréau (dir.) : Le "Congrès de l'Europe » à la Haye (1948-2008), Bruxelles, P.I.E. Peter Lang, 200, p. 349.

12 Les Comités nationaux du Mouvement Européen (Bulgarie, Hongrie, Roumanie) désignent leurs représentants. Lorsqu'il n'existe pas de Comité national, le président procède aux invitations nécessaires (Pologne, Tchécoslovaquie, Yougoslavie).

13 Macher A. : op. cit., p. 350.

14 Paul (Pál) Auer (1885-1978), juriste international, européiste hongrois, président de la commission des affaires étrangères du Parlement de Budapest entre 1945-1946, puis chef de la légation hongroise à Paris jusqu'en juin 1947. Entre les deux guerres, il est engagé dans le mouvement Pan Europe, puis après 1948 dans le Mouvement Européen.

15 Conseil de l'Europe, Assemblée parlementaire, Résolution 127 ( $2^{\mathrm{e}}$ Session 1950), Strasbourg, le 28 août 1950, cf.: [http://www.assembly.coe.int/ASP/XRef/X2H-DW-XSL. asp?fileid=180\&lang=FR] (05. 05. 2013). Voir par ailleurs, Macher A. : op. cit., p. 351. 
vice-président Paul Auer. Le Ministère des affaires étrangères britannique donna son accord au mois de septembre. ${ }^{16}$ Mais finalement, lors de la réunion d'octobre de la CECO, consacrée essentiellement aux questions de la future conférence à Londres, sous la pression polonaise, le comité de préparation de cet événement fut confié à une présidence tournante. ${ }^{17}$

La date de cette grande rencontre autour de la question de l'Europe centrale et orientale dans la capitale britannique était prévue pour la fin du mois de septembre $1951 .{ }^{18}$ Cette date fut modifiée le 29 juin 1951 par le bureau de la CECO. La Conférence de Londres fut ainsi reportée aux 10-12 décembre $1951 .{ }^{19}$ Le 15 juillet 1951, lors de la réunion de la CECO, cette décision fut confirmée et une modification fut apportée à la structure de l'organisation. La réunion adopta en effet l'augmentation du nombre des vice-présidents. Quatorze nouvelles personnalités furent désignées à ces postes plutôt honorifiques. On trouve parmi eux le sénateur belge Etienne de la Vallée-Poussin, les anciens présidents du conseil français Paul Ramadier et Paul Reynaud, les hommes politiques britanniques Arthur Greenwood et Clement Davies, le slovaque Stefan Osusky, ancien ambassadeur de Tchécoslovaquie en France, le roumain Virgile Veniamin, ancien député et professeur droit, etc. Lors de cette réunion la question du soutien de l'activité culturelle et scientifique des réfugiés était à l'ordre de jour. Deux mois plus tard la date de la conférence prévue à Londres fut une nouvelle fois modifiée, et ajournée aux 21-24 janvier 1952, la date de la réunion de l'Assemblée consultative du Conseil de l'Europe ayant été elle-même modifiée et placée juste à la date initialement prévue pour la conférence. ${ }^{20}$ Suite à cette modification, les questions pratiques purent être examinées.

\section{L'influence américaine dans la question des participants}

Plusieurs questions concernant l'organisation concrète de la conférence de Londres furent évoquées lors de la réunion du Bureau de la CECO du 25 septembre 1951. Un projet concernant le nombre de participants fut adopté : au total, 157, se

16 Magyar Országos Levéltár (MOL), (Archives Nationales de Hongrie), P 2066, Fond. György Bakach-Bessenyey, microfilm n 3 , Correspondance avec Dénes Nemestóthy, Paris, le 27 septembre 1950, f. 2287.

17 Ibid., Paris, le 27 octobre 1950, f. 2276.

18 Cf. : Ibid., microfilm, n¹, Correspondance avec Pál Auer, Paris, le 27 février 1951. Paul Auer attache à sa lettre une proposition datée du 23 février 1951, concernant le programme de la Conférence de Londres.

19 ACEHEC, Série A, Papier de Etienne de la Vallée-Poussin, carton 25, dossier 217, Procèsverbal de la réunion de la Commission d'Europe Centrale et Orientale, Paris, le 15 juillet 1951. f. 2.

20 Ibid., Procès-verbal de la réunion de Bureau de la CECO, Paris, le 25 septembre 1951, §13, f. 3 . 
répartissant entre 108 personnalités originaires d'Europe Centrale et Orientale et 48 Occidentaux.

Le rapporteur général, le Major Beddington-Behrens, informa par ailleurs les membres du bureau de la CECO de ses pourparlers avec le président du Comité pour l'Europe Libre, Charles Douglas Jackson, ancien membre de l'OSS (Office of Strategic Service), et désigné par le président Eisenhower comme personne de liaison entre le CIA et le Pentagone. La CECO souhaitait en effet avoir des soutiens financiers pour faire venir ses membres habitant aux Etats-Unis, et prévoyait une coopération étroite avec le Comité pour l'Europe libre dans le domaine de la radiodiffusion des émissions adressées aux nations derrière le rideau de fer. Jackson promit de payer le voyage de 11 personnalités exilées, et le projet de diffuser à la « Radio Free Europe » des programmes pour promouvoir l'unité européenne fut également approuvé. ${ }^{21}$ Cette coopération neutre en apparence permit en réalité aux services américains de mieux contrôler les activités des exilés est-européens. Les liens entre le Mouvement Européen et les organisations dépendantes de la CIA comme l'Américain Committee on United Europe (ACUE) et le National Committee for a Free Europe (NCFE) étaient presque permanents. ${ }^{22}$ Mettant en avant sa politique anticommuniste, Washington soutenait par des circuits financiers complexes les groupements proeuropéens généralement en grand besoin. C'est ainsi par exemple que le trésorier du Mouvement Européen, le Major BeddingtonBehrens, était particulièrement en lien avec les Américains. On peut supposer que sa présence d'abord comme rapporteur général, puis comme président à la CECO à partir du mois de novembre 1951, était un choix orienté par la CIA. ${ }^{23}$ Washington comptait en effet sur les exilés du bloc de l'est, et souhaitait donc surveiller leurs organisations. Ces réfugiés politiques touchaient d'ailleurs des subventions souvent mensuelles provenant de fonds en lien avec l'ACUE ou le NCFE. Ces aides permettaient en effet d'obtenir des informations et d'exercer une grande influence. En offrant de payer des frais de voyage des membres de la CECO habitant aux États-Unis, la CIA pouvait ainsi par exemple filtrer les participants.

21 Ibidem. f. 2.

22 Richard J. Aldrich: « OSS, CIA and European unity: The American committee for United Europe, 1948-1960 » in Diplomacy and Statecraft, 1997, 8/1, p. 184-227. Voir par ailleurs: Frances Stonor Saunders : Qui mène la danse? La CIA et la Guerre Froide culturelle, Paris, Denoël, 2003. Voir également: Jusine Faure : «Visions américaines d'une Europe réunifiée : les institutions européennes et les exilés est européens à Strasbourg » in Antoine Fleury et al. (dir.), Une Europe malgré tout, 1945-1990, contacts et réseaux culturels, intellectuels et scientifiques entre Européens dans la guerre froide, Bruxelles, P.I.E. Peter Lang, 2009, pp. 23-30.

23 Harold Macmillan rejoignit le gouvernement de Churchill en novembre 1951, c'est la raison pour laquelle il a fallu trouver un nouveau président à la CECO. Le Major BeddingtonBehrens resta à ce poste jusqu'en septembre 1952, lorsque Richard Law fut lui-même élu à la tête de cet organisme. Le successeur de ce dernier sera le sénateur belge Etienne de la Vallée-Poussin, en décembre 1953. 
Dans le cas de la délégation hongroise on peut notamment constater que la liste définitive des participants ne fut pas entièrement établie par les Hongrois, mais vraisemblablement avec l'intervention des Américains. D'après la correspondance entre Paul Auer et György Bakach-Bessenyey ${ }^{24}$, on peut voir par exemple comme représentants magyars à la conférence les noms de l'ancien premier ministre hongrois Ferenc Nagy, ou de l'ancien président des sociaux-démocrates hongrois Károly Peyer, ainsi que celui de Tibor Eckhardt. ${ }^{25} \mathrm{Ce}$ dernier était un homme politique, ancien député, représentant de la Hongrie à la SDN, connu comme anti-nazi et anticommuniste, installé aux États-Unis en 1941 à la demande de Budapest. Sa mission était de préparer le terrain pour un éventuel gouvernement en exil, projet qui ne fut finalement jamais réalisé. Après la Seconde Guerre mondiale il fut l'un des membres fondateurs du Comité National Hongrois (Magyar Nemzeti Bizottmány), organisme mis en place et financé par le NCFE, dans l'objectif de regrouper les exilés magyars. Eckhardt fut membre du comité exécutif et président du sous-comité militaire de cet organisme. En 1950, il prit la décision de rejoindre l'Association des Anciens Combattants Hongrois (Magyar Harocosok Bajtársi Közössége $M H B K$ ), groupe formé officiellement en 1949, essentiellement de militaires, d'anciens officiers anticommunistes, en lien jusqu'au début des années 1950 avec les services secrets militaires américains et français. Les Etats-Unis ne comptaient pas vraiment sur cet organisme hongrois, même si leur utilisation éventuelle dans le cadre de l'OTAN n'était pas exclue. ${ }^{26}$ Eckhardt fut vivement attaqué par divers groupes d'exilés hongrois pour sa décision de rejoindre le $M H B K$, généralement considéré par la propagande communiste comme fasciste. Sa position au Comité National Hongrois en fut affaiblie. ${ }^{27}$ Dans ces circonstances, Eckhardt n'était vraisemblablement pas pour le CIA le participant idéal à la conférence de la CECO à Londres.

Washingon souhaitait en effet sensibiliser les Occidentaux à la problématique des nations européennes derrière le rideau de fer. Au tout début des années 1950, sous la couverture d'une politique de containment les Etats-Unis ont lancé

24 György Bakach-Bessenyey (1892-1959) diplomate hongrois. Il fut notamment entre 19431944 le chef de la légation de la Hongrie à Berne où sur la demande du gouvernement de Budapest, il tenta par ses contacts anglo-saxons de faire sortir la Hongrie de la guerre. Il fut parmi les fondateurs du Comité National Hongrois à New York en 1948. Il en assura la direction des affaires étrangères jusqu'en 1956. Il fut également vice-président de la CECO à partir de l'automne 1951 .

25 MOL, P 2066, Fonds György Bakach-Bessenyey, microfilm n 1, Correspondance avec Paul Auer, Paris, le $1^{\text {er }}$ décembre 1951. f. 196.

26 Ministère des Affaires étrangères, Archives Diplomatiques (Paris), (MAE AD), Europe Généralités, vol. 51, note, A/s.: enrôlement des émigrés de l'Est dans les rangs Atlantiques, f. 74-84.

27 Kádár Lynn Katalin : Eckhardt Tibor amerikai évei 1941-1972, Budapest, L'Harmattan, 2006. pp. 148-149. 
une série d'opérations destinées à libérer les pays sous emprise communiste. Les Américains souhaitaient préparer l'intégration de l'Europe de l'Est dans une Europe solidement ancrée aux Etats-Unis. Avec le soutien du Mouvement Européen, et notamment de la CECO, l'administration Truman souhaitait faciliter le processus de la réunification, espérée dans un proche avenir. C'est la raison pour laquelle Washington voyait dans son soutien à la conférence de Londres un moyen de choisir, préparer et former les futures élites de l'Europe centrale et orientale. ${ }^{28}$ Il était donc important de trouver des hommes politiques en exil à la fois dévoués à la politique américaine et appréciés par la grande majorité de leurs compatriotes émigrés.

Dans ces circonstances, à la place de Tibor Eckhardt, Ferenc Nagy, ou Károly Peyer, les Américains favorisait le président du Comité National Hongrois plutôt respecté par tous les exilés magyars, Mgr. Béla Varga, prêtre catholique, ancien député, et président de l'assemblée nationale hongroise en 1946-1947. Finalement, le NCFE ne financèrent donc que le voyage de Béla Varga et de György BakachBessenyey, lui-même responsable des affaires étrangères du Comité National Hongrois à New York. ${ }^{29}$

La préparation des listes des délégations n'était pas aisée. Les noms présentés par les exilés ne furent pas toujours retenus à la suite du contrôle des organisateurs et de celui, indirect, de la CIA. A quelques exceptions près, les réfugiés politiques d'Europe de l'Est avaient généralement des problèmes financiers, et ne pouvaient donc se rendre à Londres sans soutien matériel..$^{30}$ Les organisateurs avaient donc un outil très efficace pour faire venir essentiellement des personnalités qui étaient membres du Mouvement Européen. La CECO refusa d'ailleurs d'accueillir les émigrés de Biélorussie et d'Ukraine qui souhaitaient se joindre à la conférence. ${ }^{31} \mathrm{Au}$ final, 12 nations vivant derrière le rideau de fer furent représentées à la conférence, par plus de 100 personnes, généralement anciens députés ou diplomates. ${ }^{32}$

28 Cf. : J. Faure, op. cit., pp. 24-25.

29 MOL, P 2066, Fonds György Bakach-Bessenyey, microfilm n 1, Correspondance avec Paul Auer, New York, le 27 décembre 1951. f. 192.

30 Le prix de l'hôtel était déjà élevé :1,1 livres au minimum par nuit. ACEHEC, Série A, Papier de Etienne de la Vallée-Poussin, carton 25, dossier 220, Lettre adressée par le secrétariat, London, 11 janvier 1952. Les participants pouvaient choisir des chambres d'hôtel de différents conforts, par exemple avec ou sans salle de bains etc.

31 Ibid., dossier, 218, lettre adressée par les membres du mouvement fédéral biélorusse à Léo Amery, Louvain, 16 janvier 1952.

32 En comptant les jeunes, les représentants hors Mouvement Européen et les observateurs. Voir la liste exhaustive: L. Améry (préface) : Conférence de l'Europe centrale et orientale organisée par la Commission de l'Europe centrale et orientale du Mouvement Européen, Rapport complet, op. cit., pp. 141-146. 


\section{Les participants à la conférence de Londres}

A la conférence de Londres, la plus grande délégation était la polonaise. Les Polonais représentaient plus de $30 \%$ des participants. Parmi eux se trouvaient des diplomates, anciens ministres, anciens députés, syndicalistes, et un grand nombre de personnalités qui avaient des réseaux importants en Occident, en particulier en Angleterre. Sans les énumérer, on peut souligner les noms du comte Raczinski ${ }^{33}$, de Kajetan Morawski ${ }^{34}$, de Jerzy Zdziechowski ${ }^{35}$ qui jouaient un rôle considérable dans la préparation de la conférence. Avec 18 personnes, la deuxième plus grande délégation était celle des Roumains. Parmi eux se trouvaient notamment deux ex-ministres des affaires étrangères de grande réputation, Grigore Gafencu $^{36}$ et Constantin Visoianu ${ }^{37}$. Du point de vue de son nombre, la troisième plus grande délégation était la hongroise, avec 17 personnes, essentiellement anciens diplomates. Les pays baltes, notamment l'Estonie, étaient également bien représentés, et leur activités dans la péréparation fut particulièrement remarquable. ${ }^{38}$ Parallèlement, une dizaine de représentants de Tchécoslovaquie, dont Stefan Osusky ${ }^{39}$ et Hubert $\mathrm{Ripka}^{40}$, était également à Londres en janvier 1952. La délégation yougoslave était composée par trois groupes bien distincts (Serbes, Croates, Slovènes) selon les principales ethnies qui composaient ce pays. Même l'Albanie put être représentée

33 Le Comte Edward Raczinski (1891-1993) fut le quatrième président des Polonais en exil, ancien ministre des affaires étrangères, diplomate, ambassadeur, écrivain. Après 1945, il œuvra à l'insertion dans la société britannique de ses concitoyens - nombreux, en particulier les militaires, à choisir de rester au Royaume-Uni - en travaillant pour l' " Interim Treasury Committee for Polish questions » et, dans les années 1947-1952, comme conseiller auprès du Ministère britannique du Travail et de la Protection sociale. Membre éminent de la CECO.

34 Kajetan Morawski (1892-1973) écrivain, diplomate, fut ministre des affaires étrangères par intérim en mai 1926. Il représenta la Pologne libre à Paris. Il fut reconnu à titre personnel comme ambassadeur en France.

35 Jerzy Zdziechowski (1880-1975), ancien ministre des finances, économiste. Après 1945, membre du Comité exécutif du Conseil Politique Polonais à Londres.

36 Grigore Gafencu (1892-1957), homme politique, journaliste. Il fut ministre des affaires étrangères de Roumanie entre 1938 et 1940.

37 Constantin Visoianu (1897-1994) juriste, diplomate, diplomate. Il fut ministre des affaires étrangères de Roumanie entre 1944-1945.

38 Pauli Heikkilä : «Uniting the Devided Continent, The Estonian National Committee of the European Movement" in NORDEUROPA forum, 20, 2010, 1-2, p. 135-161. Le nombre de la délégation estonienne mentionné dans cet article paraît surévalué (p. 146). D'après les compte-rendus publiés sur l'événement, le chifre exact n'est pas 16, mais 8 .

39 Stefan Osusky (1889-1973), homme politique slovaque. Il fut ambassadeur à Paris dans les années 1920. Après la guerre il devint enseignant à l'Université d'Oxford puis à l'Université Colgate à New York.

40 Hubert Ripka (1895-1958), journaliste, homme politique tchèque. Il fut ministre du commerce extérieur entre 1945-1948. 
par deux délégués. Parmi les participants d'Europe de l'Est on trouve un grand nombre de jeunes exilés. Leur invitation s'explique par le fait qu'on comptait sur eux notamment dans les luttes intellectuelles contre le communisme, et que l'on souhaitait préparer la nouvelle génération à l'union future du Vieux Continent.

Du côté des Occidentaux, les Britanniques étaient les plus nombreux, essentiellement des députés. Parmi eux se trouvaient notamment l'économiste lord Walter Thomas Layton, vice président de l'Assemblée Parlementaire du Conseil de l'Europe, ou Clement Edouard Davies, un homme politique gallois, leader du Parti libéral, Lady Violet Bonham-Carter proche de Winston Churchill ainsi qu'Alexandre Loveday, ancien directeur de la section économique de la SDN. Parallèlement, une dizaine de participants français étaient également présents à Londres : il s'agissait notamment du socialiste André Philip, de l'ancien ministre Henri Frénay, militaire et résistant, du vice président de l'Assemblée parlementaire du Conseil de l'Europe Robert Bichet, de l'ancien commandant en chef de la zone française en Autriche le Général Antoine Béthouart, du juriste réputé René Courtain, et du sénateur Ernest Pezet. ${ }^{41}$ Il faut encore mentionner la présence d'une petite délégation belge et hollandaise, ainsi que d'un groupe de députés allemands. En tant que membres de l'exécutif du Mouvement Européen, le député suédois Karl Wistrand et le directeur de la Commission culturelle de la même organisation, l'espagnol Salvador de Madariaga participaient également à cette rencontre. Par ailleurs, quatre observateurs américains étaient également présents. La NCFE avait délégué trois personnalités, dont William E. Griffith conseiller politique de la Radio Free Europe, ainsi que John Foster Leich, responsable de la coopération avec les comités nationaux formés par les exilés. L'ACUE avait de son côté envoyé Fugitt Waren à la conférence. La présence de ces Américains montre bien les liens, même indirects, entre la CECO et la CIA.

Deux présidents du conseil, le belge Paul-Henri Spaak et le français Paul Reynaud, furent également invités au grand rassemblement final à l'Albert Hall, mais finalement ni l'un ni l'autre ne purent venir - l'un à cause des devoirs familiaux, l'autre ayant été retenu par ses problèmes de santé. Le discours de Paul Reynaud fut toutefois lu à la fin de la conférence de Londres. Sur les listes des délégués ne figure pas le nom de fils de Winston Churchill, pourtant il fit une intervention à l'Albert Hall le 24 janvier 1952. Randolph Churchill tint un discours plutôt pathétique, mettant en avant l'Unité du Vieux continent. Il déclara notamment : « Tandis que l'Europe Occidentale réédifie sa prospérité et sa civilisation et unifie journellement son pouvoir pour la défense de la liberté et de la paix, une sombre nuit Arctique d'esclavage Asiatique, de torture et de mort est descendue sur huit

41 D'après la liste communiquée par l'ambassadeur de France à Londres on peut constater que plusieurs personnalités françaises renoncèrent au dernier moment à se rendre à la conférence. MAE AD, Europe, Généralités, vol. 51, télégramme n²9-34, Londres, le 2 janvier 1952 , f. 145. 
nations qui historiquement et géographiquement font partie de l'Europe [...] C'est pourquoi dans cette magnifique salle célèbre [...] nous nous engageons en tant que bons Européens, à poursuivre sans varier notre idéal, qui le seul vrai gage de paix, une Europe heureuse, prospère, unie et libre. $\gg{ }^{42} \mathrm{Ce}$ discours, comme tous ceux prononcés à l'Albert Hall, allaient dans le sens des objectifs formulés en 1951, dans la lettre adressée aux intervenants. La CECO souhaitait en effet atteindre trois buts avec la conférence : garder vivante en Occident l'idée de ne jamais accepter l'asservissement actuel des pays derrière le rideau de fer ; préparer des idées constructives dans les domaines politique et économique pour ces pays dans le cadre d'une union européenne plus étendue ; enfin, démontrer aux nations derrière le rideau de fer que leurs chefs exilés travaillaient ensemble avec leurs amis de l'Ouest sur des projets pour l'unité future de l'Europe orientale et occidentale. ${ }^{43}$

\section{Le déroulement de la Conférence de Londres et ses résolutions}

Pour que ses objectifs puissent être atteints, la CECO mit en place six commissions de travail. Celles-ci traitaient respectivement des questions économiques, sociales, culturelles, agricole et de la jeunesse, la sixième commission étant quant à elle chargée de finaliser la résolution de la conférence. Pour chaque sujet une proposition fut préparée par écrit. Durant la Conférence à Londres, qui se tint finalement entre le 21 et le 24 janvier 1952, les délégués pouvaient apporter leur contribution aux documents proposés. Les 22 et 23 janvier, les participants se retrouvèrent ainsi en commissions pour élaborer les textes définitifs. Le premier et le dernier jour, les sessions plénières tenues à la "Church House » permirent de débattre sur les principales questions. Le seul moment plutôt détendu fut le dîner offert par le Major Beddington Behrens à l'hôtel Park Lane, le 21 janvier, où cent invités supplémentaires furent conviés. La cérémonie finale fut organisée à l'Albert Hall où plus de 7000 personnes étaient présentes. A la fin de la conférence des résolutions furent approuvées sur les sujets des problèmes économiques, agraires, sociaux, des réfugiés, culturels, et de la jeunesse.

Le préambule de ce document récapitule bien l'esprit et le principal message de cette rencontre importante organisée par le Mouvement Européen : «La coupure actuelle de l'Europe est inadmissible sur le plan moral comme sur le plan politique et économique. La Conférence est convaincue que cette situation ne doit pas et ne peut pas se maintenir. L'Europe est appelée à trouver son unité dans le respect de la dignité humaine, dans la liberté des peuples, et dans la paix. Un immense

42 L. Améry (préface) : Conférence de l'Europe centrale et orientale organisée par la Commission de l'Europe centrale et orientale du Mouvement Européen, Rapport complet, op. cit., p. 115.

43 ACEHEC, Série A, Papier de Etienne de la Vallée-Poussin, carton 25, dossier 218, projet de lettre adressée à Paul-Henri Spaak, Londres, le 25 septembre 1951. 
effort d'imagination et de volonté créatrice sera nécessaire alors pour surmonter la misère et le chaos qu'aura laissé la domination soviétique dans l'Est de l'Europe. Il appartiendra aux gouvernements librement élus des pays libérés de prendre alors les mesures que la situation demandera du point de vue national. La Conférence désire, dès maintenant, étudier à l'avance les grandes lignes des questions qui se poseront alors dans le cadre national ainsi que dans le cadre européen. »

Par les textes approuvés, les congressistes souhaitaient donner des repères pour la période suivant la chute du communisme. Sans faire une analyse détaillée des différentes dispositions de la conférence, on peut souligner qu'elles supposaient une intégration immédiate des pays libérés aux organisations communautaires existantes au moment de la chute des régimes communistes.

Les idées formulées notamment dans la résolution économique sont particulièrement intéressantes. Au $\S 6$ nous pouvons lire notamment : " La création immédiate d'une monnaie commune à l'ensemble de l'Europe libérée de la domination communiste constituerait, à cet égard, un instrument particulièrement puissant de prospérité et d'unification. $\gg^{44}$ Pour la mise en œuvre de toute une série de mesures économiques, la résolution suppose que les Etats libérés du communisme seraient aidés de manière conséquente par les pays occidentaux. Elle déclare notamment à ce sujet : "Cet acte de solidarité européenne pourra être financé à la fois par un accroissement de la productivité dans les pays de l'Ouest et par l'économie sur les dépenses d'armement. »

Un grand enthousiasme d'agir ensemble est également présent dans les résolutions. Il fut décidé notamment qu'un Comité d'action culturelle des exilés au sein de la CECO serait créé, ainsi qu'un Institut de Recherche et d'Information. Pour préparer la population vivant derrière le rideau de fer au temps qui suivrait la chute du communisme, la conclusion de la commission culturelle insiste sur l'importance que "l'Esprit d'unité européenne » soit présent dans les émissions radiophoniques adressées aux pays de l'Europe de l'Est.

La Conférence fut un événement de poids parce qu'elle permit notamment aux exilés politiques de sortir du « salon des refusés » et qu'elle leur reconnut le droit de discuter les problèmes de leurs pays avec les représentants occidentaux. ${ }^{45} \mathrm{Ce}$ fut la première fois que l'émigration politique put présenter une alternative aux gouvernements communistes en proposant une série de réformes à réaliser. Par ailleurs, le succès de la Conférence fut notamment que les hommes politiques au pouvoir et les parlementaires occidentaux, pour la première fois, osaient parler ouvertement du fait inacceptable de la situation derrière le rideau de fer.

44 L. Améry (préfacé) : Conférence de l'Europe centrale et orientale organisée par la Commission de l'Europe centrale et orientale du Mouvement Européen, Rapport complet, op. cit., p. 133.

45 J. Laptos : L'élargissement avant la lettre... op. cit., p. 133. 


\section{Les principales réactions et conclusion}

Si la réussite de cette rencontre à Londres paraît indiscutable, elle suscite une image plutôt mitigée. Les gouvernements des pays du bloc de l'Est protestèrent tous vivement contre cette initiative. Les autorités communistes furent mises au courant notamment par le fait que les résolutions furent communiquées par la voix de la Radio Free Europe. Les ministères des affaires étrangères hongrois, tchécoslovaque, roumain, s'élevèrent immédiatement contre la conférence de la CECO par une note diplomatique. ${ }^{46}$ Le gouvernement de Bucarest déclara notamment : "Ces réfugiés sont des fascistes notoires et des diffamateurs professionnels à la solde du gouvernement américain et des autres gouvernements de NATO (sic). Parmi eux figurent un certain nombre d'individus condamnés pour crimes dans la République populaire roumaine. Sous l'étiquette Conférence de la Commission de l'Europe centrale et orientale du Mouvement Européen, ces instruments de l'impérialisme américain se sont livrés, avec l'appui du gouvernement britannique, à de criminelles provocations à la guerre contre l'Union soviétique et les démocraties populaires. ${ }^{47}$ Cet événement fut commenté avec outrance par la presse dans les pays du bloc de l'Est.

Si la conférence fit beaucoup de bruit dans les Etats communistes, en Occident elle n'eut en revanche pas le retentissement souhaité. Les journaux la passèrent généralement sous silence, les gouvernements tentèrent de l'ignorer. Le cabinet de Churchill qui avait eu le courage d'accueillir la conférence à Londres, ne montra aucun enthousiasme. Si Harold Macmillan salua le rassemblement de la part du gouvernement britannique, officiellement son intervention ne fut pas appréciée par Downing street. Churchill s'opposa à ce que l'ancien président de la CECO soit présent au dîner du 21 janvier, mais celui-ci y alla toutefois à titre personnel. Les autres pays de l'Europe occidentale se montrèrent également très réservés. ${ }^{48}$ Seules la Belgique et la Grèce eurent le courage d'être représentées par leurs ambassadeurs à Londres à certains moments de la conférence. ${ }^{49}$ Leur collègue français René Massigli, commentant cet événement, écrit à Robert Schuman, à l'époque ministre des affaires étrangères de la France : "Outre qu'elle est par-

46 Budapest fut le premier à déposer une note de protestation à la légation du Royaume Uni à Budapest le 31 janvier 1952. cf. : MAE AD, Europe, Généralités, vol. 51. rapport n³4, Budapest, le 2 février 1952. f. 210.

47 Archives du Centre d'Histoire des Sciences Politiques (ACHSP), fond Ernest Pezet, PE 7, Rapport sur la Conférence de la CECO du Mouvement Européen, tenue à Londres du 21 au 24 janvier 1952, présenté par M. Pezet à la Commission Spéciale Chargée de Veiller aux Intérêts des Nations Européennes non Représentés au Conseil de l'Europe, $4^{\mathrm{e}}$ session, annexe au AS/SNR (3) 18, Strasbourg, le 12 mars 1952, f. 6.

48 Macher A. : op. cit., pp. 355-356.

49 J. Laptos : L'élargissement avant la lettre....op. cit., p. 132. M. Laptos a fait allusion à la présence du ministre des affaires étrangères belge, Paul van Zeeland, mais nous n'avons trouvé aucun document qui confirme cette affirmation. 
faitement vaine, une manifestation de ce genre me semble fort inopportune, en tant qu'éminemment propre à donner à penser à Moscou sinon que les Puissances occidentales nourrissent des intentions agressives, du moins que ces Puissances sont décidées à s'engager, à l'égard de l'URSS, dans la politique de 'compression'. Elle n'est pas de nature, au surplus, à dissiper la défiance qu'inspire aux Soviets l'idée européenne [...] Dans ces conditions, ma place ne me semble pas être à une manifestation qui va si directement à l'encontre de la politique de détente que nous poursuivons. $\|^{50}$ Massigli insiste d'ailleurs dans son rapport détaillé sur les désaccords qui purent être détectés entre les différents participants de la conférence. ${ }^{51}$ Si du côté des exilés on peut observer un enthousiasme compréhensible, ils durent très vite se rendre compte que leur optimisme se heurtait à la réalité de la Guerre Froide. Dans les années qui suivirent la conférence on revint de temps en temps aux conclusions de Londres, mais en perdant de plus en plus l'espoir d'une chute imminente du communisme derrière le rideau de fer. La CECO, qui traversait des difficultés dues à certaines décisions personnelles, ne profita pas comme elle aurait pu du capital de confiance dont elle disposait en 1952. Le visage du Mouvement Européen changea progressivement lui aussi. ${ }^{52}$ Les Britanniques s'intéressaient ainsi de moins en moins aux problématiques de l'unité européenne, et au rôle de l'Europe de l'est. Le changement à la tête de la CECO en décembre 1953, avec l'arrivée à la présidence du belge Etienne de la Vallée-Poussin en est très symbolique. La mort de Staline et la politique de coexistence pacifique réduisirent rapidement les marges de manœuvre déjà très restreintes des exilés. La conférence de Londres fut donc peu à peu oubliée, de telle sorte que jusqu'aux années 2000 ce sujet tomba quasiment dans l'oubli, même pour les historiens.

Plus de vingt ans après la chute du communisme, et peu avant le dixième anniversaire de l'adhésion à l'Union Européenne d'une grande partie des pays concernés par cette manifestation en 1952, il est particulièrement intéressant de revoir l'histoire de cet événement qui imagina un scénario pour rétablir l'unité du Vieux Continent brisé par les conséquences de la Seconde Guerre Mondiale.

50 Raphaële Ulrich-Pier : René Massigli (1888-1988), Une vie de diplomate, tome 2, Bruxelles, P.I.E. Peter Lang, 2006. p. 1157.

51 MAE AD, Europe, Généralités, vol. 51. rapport n¹56, Londres, le 29 janvier 1952, f. 189-196.

52 Cf. : Cristina Blanco Sio-López: « Memories and horizons: The Legacy of the Central and Eastern European intellectuals in exile and the „reunification” of Europe " in Pliegos de Yuste, ${ }^{\circ} 11-12,2010$, pp. 34-35. 


\section{Bibliographie}

Aldrich, J. Richard (1997), « OSS, CIA and European unity: The American committee for United Europe, 1948-1960 » in Diplomacy and Statecraft, 1997, 8/1, 184-227.

Améry, Léopolde (préface), (1952), Conférence de l'Europe centrale et orientale organisée par la Commission de l'Europe centrale et orientale du Mouvement Européen, Rapport complet, (1952), Paris, „Le Monde”.

Blanco Sio-López, Cristina (2010), Memories and horizons: The Legacy of the Central and Eastern European intellectuals in exil and the ,reunification” of Europe, in Pliegos de Yuste, $n^{\circ} 11-12,32-40$.

Faure, Jusine (2009), «Visions américaines d'une Europe réunifiée : les institutions européennes et les exilés est européens à Strasbourg » in Fleury, Antoine et al. (dir.), Une Europe malgré tout, 1945-1990, contacts et réseaux culturels, intellectuels et scientifiques entre Européens dans la guerre froide, Bruxelles, P.I.E. Peter Lang, 23-30.

Fejérdy Gergely, (2012), «Les Hongrois ayant rejoint le Mouvement européen en 1948 » in Öt Kontinens, Az Új- és Jelenkori Egyetemes Történeti Tanszék közleményei, Numéro spécial de la collaboration entre ELTE et l'Université Bordeaux 3, 2011. 2, Budapest, Robinco, 129-140.

Guieu, Jean-Michel, (2009), « Le Congrès de La Haye (7-10 mai 1948), «porte-parole de l'Europe » ?, in Guieu, Jean-Michel et Le Dréau, Christophe (dir.), Le "Congrès de l'Europe » à la Haye (1948-2008), Bruxelles, P.I.E. Peter Lang, 15-42.

Heikkilä, Pauli (2010), «Uniting the Devided Continent, The Estonian National Committee of the European Movement" in NORDEUROPAforum, 20, 1-2, 135-161.

Kádár Lynn Katalin, (2006), Eckhardt Tibor amerikai évei 1941-1972, Budapest, L'Harmattan.

Laptos, Jozef, (2003), « Jozef Retinger, le père d'ombre de l'Europe. Le rôle de Jozef Retinger et de ses réseaux personnels dans le débuts de la construction européenne » in Bossuat, Gérard (dir.), Inventer l'Europe. Histoire nouvelle des groupes d'influence et des acteurs de l'unité européenne, Bruxelles, P.I.E. Peter Lang, 179-196.

Laptos, Jozef (2006), « L'élargissement avant la lettre. La place de l'Europe Centrale et orientale dans l'activité du Mouvement Européen (1949-1952)» in Horel, Catherine et al. (dir.), Nations cultures et sociétés d'Europe centrale aux XIXe et XX siècles, Mélange offerts à Bernard Michel, Publication de la Sorbonne, Paris, 123-135.

Macher Anikó (2009), « Une institution pour promouvoir l'idée de l'unité européenne. La Commission de l'Europe centrale et orientale du Mouvement Européen (1948-1953) » in Guieu, Jean-Michel et Le Dréau, Christophe (dir.) : Le "Congrès de l'Europe » à la Haye (1948-2008), Bruxelles, P.I.E. Peter Lang, Bruxelles, 347-369.

Macmillan, Harold, (1969), Tides of Fortune 1945-1955, London, Macmillan Publisher.

Martin de la Guardia, M. Ricardo et Pérez Sánchez, Á. Guillermo, (2002), «El Movimiento Europeo y los paises del Este Ante el Inicio de la Guerra Fría » in Juberías, Carlos Flores (éd.), Estudios sobre la Europa Oriental, Universitat de Valencia, 273-274.

Oxford Dictionary of National Biography [http://www.oxforddnb.com/view/article/30401], (02.05.2013)

Pomian, John (éd.), (1972), Joseph Retinger, Memoirs of an Eminence Grise, London, Sussex University Press.

Saunders, S. Frances (2003), Qui mène la danse? La CIA et la Guerre Froide culturelle, Paris, Denoël.

Ulrich-Pier, Raphaële, (2006), René Massigli (1888-1988), Une vie de diplomate, tome 2, Bruxelles, P.I.E. Peter Lang. 


\section{Sources d'archives}

Archives historiques de l'Union européenne, Florence, (AHUEF), Villa Il Poggiolo. Dépôts, DEP, Mouvement européen, ME 851.

Archives du Centre d'Étude d'Histoire de l'Europe Contemporaine à l'Université Catholique de Louvain (ACEHEC), Série B, Mouvement européen (1947-1959), Dossier 1.

Archives du Centre d'Étude d'Histoire de l'Europe Contemporaine à l'Université Catholique de Louvain (ACEHEC), Série A, Papier de Etienne de la Vallée-Poussin, carton 25.

Archives du Centre d'Histoire des Sciences Politiques (ACHSP), (Paris), fond Ernest Pezet, dossier PE 7.

Magyar Országos Levéltár (MOL), Budapest, (Archives Nationales de Hongrie), P 2066, Fond. György Bakach-Bessenyey, microfilm n³, Correspondences avec Dénes Nemestóthy.

Magyar Országos Levéltár (MOL), Budapest, (Archives Nationales de Hongrie), P 2066, Fond. György Bakach-Bessenyey, microfilm, n¹, Correspondences avec Pál Auer.

Ministères des Affaires étrangères, Archives Diplomatiques (Paris), (MAE AD), Europe Généralités, vol. 51.

Conseil de l'Europe, Assemblée parlementaire, Résolution 127 (2 $2^{\mathrm{e}}$ Session 1950), Strasbourg, le 28 août 1950, cf.: [http://www.assembly.coe.int/ASP/XRef/X2H-DW-XSL.asp?filei$\mathrm{d}=180 \&$ lang $=\mathrm{FR}](05.05 .2013)$. 


\title{
Un continent, deux blocs, trois idees. Le COMECON, la CEE et le processus d'Helsinki
}

\author{
Nicolas BADALASSI
}

\begin{abstract}
Au tournant des années 1960 et 1970, l'URSS entend se servir de la Conférence sur la Sécurité et la Coopération en Europe pour accrô̂tre ses relations économiques et commerciales avec les pays de la CEE tout en luttant contre la construction européenne à l'Ouest. Elle promeut l'idée d'intégration est-européenne pour parvenir à terme à l'unification économique paneuropéenne. Elle tente ainsi de faire reconnaître le Comecon comme étant l'équivalent socialiste du Marché commun, d'obtenir l'octroi de la clause de la nation la plus favorisée et de mettre sur pied un organisme de sécurité paneuropéen. Mais, à chaque fois, elle doit faire face à l'opposition des pays de la CEE.

Keywords: COMECON, CEE, CSCE, paneuropéanisme, guerre froide
\end{abstract}

Le processus d'Helsinki est aujourd'hui considéré par les historiens des relations internationales comme l'un des facteurs ayant conduit à la fin de la guerre froide. Les dispositions de la Conférence sur la Sécurité et la Coopération en Europe en matière d'échanges culturels et de contacts humains ont en effet permis aux dissidents du bloc de l'Est, dès la deuxième moitié des années 1970, de disposer d'un document multilatéral sur lequel s'appuyer pour faire entendre leurs revendications. Pourtant, à l'origine, le projet soviétique de conférence avait un tout autre but, que les Occidentaux ont réussi à retourner en leur faveur.

Au milieu des années 1960, alors que la détente s'installe progressivement dans les relations Est-Ouest, l'URSS de Brejnev confère à sa politique européenne un objectif central : il s'agit de faire reconnaître aux Occidentaux la mainmise soviétique sur l'Europe orientale et, plus généralement, le statu quo politique et territorial européen. Moscou veut ainsi geler la division Est-Ouest afin de pouvoir faire face à la menace grandissante de la Chine qui ose remettre en question la suprématie soviétique au sein du mouvement communiste international.

Pour parvenir à ses fins, le Kremlin promeut, auprès des pays d'Europe occidentale, l'idée de réunir une conférence paneuropéenne de sécurité qui, rassemblant l'ensemble des Etats du continent, pourrait consacrer l'existence des deux blocs. L'emploi du qualificatif « paneuropéen » montre néanmoins que Brejnev est disposé à aller plus loin que le simple statu quo : une telle conférence pourrait aussi contribuer à émousser la solidarité occidentale. En effet, lorsque les Soviétiques émettent leur proposition, en 1965, les rapports entre pays de l'Ouest n'ont jamais été aussi tendus depuis le début de la guerre froide, ce pour plusieurs raisons : la guerre que mènent les Etats-Unis au Vietnam est très impopulaire en Europe occidentale et nuit aux relations transatlantiques, la " crise de la chaise vide " 
due à l'intransigeance du général de Gaulle freine la construction européenne, la politique pro-américaine du chancelier ouest-allemand Ludwig Erhard a mis entre parenthèses le partenariat franco-allemand voulu par le président français. Dans ce contexte, l'idée de conférence paneuropéenne apparaît comme un moyen, pour les Soviétiques, de tirer profit des tensions intra-occidentales. Ils développent ainsi un véritable projet de sécurité collective : la détente rendant caducs l'OTAN et le pacte de Varsovie, on pourrait remplacer ces deux alliances militaires par un organisme paneuropéen de sécurité qui couvrirait tout l'espace s'étendant de l'Atlantique à l'Oural. Lorsqu'en 1969-1970, les dirigeants occidentaux finissent par donner leur accord à l'organisation d'une Conférence sur la Sécurité et la Coopération en Europe en échange de l'insertion dans son ordre du jour des thèmes des droits de l'homme et de la circulation des hommes, des idées et des informations, aux objectifs initiaux de l'URSS s'est ajouté un nouvel impératif, de taille : il est indispensable d'accroître les relations économiques et commerciales avec l'Occident, le PIB des pays du bloc socialiste étant en perpétuelle diminution à partir du milieu des années 1960. La nécessité de se rapprocher du Marché commun pour accroître les échanges économiques avec l'Ouest, conjuguée aux objectifs structurels que Moscou confère à la CSCE, conduit les Soviétiques à élaborer une stratégie visant à répondre à ces impératifs mais sans les opposer les uns aux autres. Le Kremlin cherche, via la conférence, à réaliser un double processus d'intégration : est-européen d'abord, paneuropéen ensuite. Il s'agit de créer un partenariat privilégié entre la CEE et le Comecon en faisant reconnaître aux Occidentaux que le second est l'équivalent socialiste de la première. Moscou entend pour ce faire renforcer l'intégration au sein du Comecon pour obtenir, à terme, la désintégration de la CEE et l'instauration d'un cadre paneuropéen de coopération s'étendant de l'Atlantique à l'Oural. A la CSCE, le désir de parvenir à la réalisation de ce double objectif se manifeste lors des débats dévolus aux suites de la conférence et au moment des discussions relatives à la « deuxième corbeille d'Helsinki »" sur la coopération économique et commerciale Est-Ouest. Celle-ci est l'objet, à Genève, d'âpres négociations qui opposent les pays du pacte de Varsovie à ceux de la Communauté européenne.

Cette contribution propose d'analyser les arguments avancés par les pays socialistes pour justifier leurs projets d'intégration est-européenne et paneuropéenne. Il s'agit également de voir comment ces plans sont systématiquement contrecarrés par les Etats de la Communauté européenne.

1 Les thèmes discutés à la CSCE sont répartis en trois « corbeilles ». La première traite des questions de sécurité européenne proprement dite ; la deuxième regroupe les questions économiques, scientifiques et techniques ; la troisième a trait à la circulation des hommes, des idées et des informations. Deux autres thèmes figurent à l'ordre du jour de la CSCE mais demeurent hors corbeilles : la sécurité et la coopération en Méditerranée et les suites à donner au processus d'Helsinki. 
$\mathrm{Si}$, malgré tous leurs efforts, les Soviétiques échouent à établir un partenariat entre le Comecon et la CEE (I), ils tentent de compenser cet échec en obtenant des pays du Marché commun qu'ils accordent à tous les Etats de la CSCE la clause de la nation la plus favorisée (II) et en insistant pour mettre sur pied un organisme paneuropéen permanent destiné à leur conférer un droit de regard sur les affaires ouest-européennes (III).

\section{CEE et Comecon, l'impossible partenariat}

Dans le discours qu'il prononce lors de la première phase de la CSCE en juillet $1973^{2}$, le ministre soviétique des Affaires étrangères Andreï Gromyko préconise l'organisation en Europe d'une coopération économique à long terme, tant multilatérale que bilatérale : cette affirmation laisse penser aux pays de l'OTAN que l'un des buts essentiels de l'URSS à la CSCE est d'obtenir un plus large accès aux ressources financières, à la science et à la technologie de l'Occident, accès qu'elle n'a pu s'assurer bilatéralement ou par des négociations avec la $\mathrm{CEE}^{3}$.

En outre, le Kremlin cherche de nouveaux moyens pour remédier à la diminution continue du taux de croissance économique de l'URSS. De fait, Brejnev et Gromyko savent qu'il est temps pour eux d'admettre la viabilité de la CEE pour en tirer profit ${ }^{4}$. Jusqu'alors, celle-ci était perçue comme un bloc commercial fermé et discriminatoire, une simple émanation ouest-européenne de l'OTAN accusée de maintenir la division économique du continent.

L'URSS infléchit sa position en janvier 1972 et semble la modifier en mars lorsque Brejnev évoque devant le Congrès soviétique des unions du commerce les possibilités de coopération entre le Marché commun et les pays socialistes, reconnaissant de fait que la CEE est une réalité. L'initiative est suivie, en décembre 1972, par une proposition du Secrétaire général du PCUS d'ouvrir des négociations sur un accord commercial entre la CEE et le Comecon ${ }^{5}$. A l'Ouest, on perçoit

2 Tandis que les pourparlers préparatoires multilatéraux (PMP) de la CSCE durent de novembre 1972 à juin 1973, la conférence proprement dite est constituée de trois phases : la première, du 3 au 7 juillet 1973, permet aux trente-cinq ministres des Affaires étrangères rassemblés à Helsinki de valider l'ordre du jour fixé durant les PMP ; la deuxième, qui se déroule à Genève, correspond à la phase de négociation du contenu de l'Acte final et s'étale entre septembre 1973 et juillet 1975 ; la troisième réunit à Helsinki du 30 juillet au $1^{\text {er }}$ août 1975 les chefs d'Etat et de gouvernement des trente-cinq pays représentés en vue de la signature de l'Acte final.

3 Document OTAN, C-M (73) 75, 17 septembre 1973. Archives du Quai d'Orsay (AMAE), CSCE, vol. 29.

4 Marie-Pierre Rey, "L'URSS et l'Europe communautaire, représentations et pratiques, 19571991", in Anne Deighton, Gérard Bossuat (eds.), L'Union européenne, acteur de la sécurité mondiale, Paris : Soleb, 2007, p. 61.

5 Télégramme n8690/99, de Seydoux, 22 décembre 1972. AMAE, Europe 1971-76, Organismes internationaux et grandes questions internationales, vol. 2925. 
comme une manifestation de bonne volonté la réévaluation de l'attitude soviétique à l'égard de la construction européenne ; mais on comprend également qu'elle a pour but de faire un geste en direction de l'opposition conservatrice ouest-allemande afin que le Bundestag ratifie au plus vite le traité de Moscou du 12 août 1970.

Pour ne pas perdre la face, le Kremlin justifie l'évolution de sa position en s'appuyant sur une argumentation selon laquelle l'avenir économique de l'Europe ne peut se concevoir sans la participation de l'URSS qui, seule, dispose de ressources naturelles abondantes ${ }^{6}$. Il lie cependant la pleine reconnaissance de la CEE par l'URSS à la reconnaissance du statu quo territorial européen par les Occidentaux.

En parallèle, la diplomatie soviétique s'efforce de rehausser le prestige du Comecon et de le faire admettre par la communauté internationale comme l'homologue de la CEE. C'est dans le cadre de cette nouvelle tactique qu'il faut placer la proposition soviétique d'instaurer des rapports entre les deux instances. Moscou veut éviter que ses satellites noue des relations bilatérales avec la CEE, d'où l'utilisation du Comecon qui en deviendrait l'interlocuteur obligé7.

En effet, les autres pays de l'Est adoptent une attitude plus réaliste et, dans certains cas, reconnaissent de facto la Communauté européenne : la Pologne établit des contacts visant à un accord sur les textiles; la Bulgarie, la Hongrie, la Pologne et la Roumanie passent des accords techniques avec la CEE sur le commerce des produits agricoles ; la Roumanie se rapproche du Marché commun pour obtenir un statut de privilégié auprès de la Communauté ${ }^{8}$. Ces pays satellites, dont la majeure partie des produits d'importation provient des Etats ouest-européens, poussent Moscou à trouver rapidement un moyen d'institutionnaliser les relations avec la CEE sans porter atteinte à l'organisation économique du pacte de Varsovie, d'autant que la plupart de leurs accords temporaires passés avec les Neuf arrivent à expiration en 1974.

Malgré cela, l'attitude soviétique à l'égard du Marché commun demeure très méfiante et, encore en 1974, les organes du PCUS parlent de la CEE avec dédain?. Celle-ci est toujours perçue comme un ensemble économique fermé et l'embryon d'un nouveau bloc politique, voire militaire ${ }^{10}$.

6 Note de la sous-direction d'Europe orientale, 23 janvier 1974. AMAE, Europe 1971-76, Organismes internationaux..., vol. 2927.

7 Ibidem.

8 Angela Romano, "Western Europe's self assertion towards the superpowers : the CSCE chance and its aftermath", in Anne Deighton, Gérard Bossuat (eds.), L'Union européenne, acteur de la sécurité mondiale, op. cit., p. 158.

9 Note de l'ambassade de France en URSS, 28 janvier 1974. AMAE, Europe 1971-76, URSS, vol. 3721 .

10 Note de la sous-direction d'Europe orientale, 5 mars 1975. AMAE, Europe 1971-76, URSS, vol. 3727. 
La question de la participation du Comecon à la CSCE est clairement soulevée à l'été 1973. Elle intervient en réaction au débat des Neuf sur les moyens d'intégrer la Commission européenne aux négociations de la conférence. En effet, lors de la première phase de la CSCE, le ministre des Affaires étrangères du Danemark, qui préside la Communauté européenne, annonce l'implication de la Commission dans les futurs travaux de la conférence, dans la mesure où la deuxième corbeille inclut des sujets qui sont de la compétence de la $\mathrm{CE}^{11}$. François-Xavier Ortoli, alors président de la Commission, propose même qu'un représentant de cette dernière soit présent lors des négociations à trente-cinq consacrées à l'exécution du mandat sur les échanges commerciaux et industriels, et qu'il prenne la parole au nom de la Communauté ${ }^{12}$. Tandis que la RFA se montre favorable à ce projet, la France et l'Italie s'y opposent ${ }^{13}$, jugeant que la coordination entre les Neuf pour ce qui est de la CSCE s'effectue dans le cadre de la seule coopération politique et que la conférence ne doit rassembler que des Etats ${ }^{14}$.

Malgré les oppositions, les neuf ministres des Affaires étrangères acceptent, en septembre 1973, de permettre à la Commission d'être représentée au sein de la délégation du pays qui exerce la présidence de la Communauté ${ }^{15}$. Pourtant, à Genève, la France poursuit son action contre une institution qu'elle accuse de conférer trop d'importance à la deuxième corbeille par rapport aux deux autres ${ }^{16}$.

Ainsi, lorsque, constatant l'inclusion progressive de la coopération industrielle dans les compétences de la Commission, le vice-ministre tchécoslovaque des Affaires étrangères insiste auprès du directeur de la section Europe du Quai d'Orsay, Claude Arnaud, sur l'intérêt d'une prise de contact rapprochée entre la CEE et le Comecon, le diplomate français affirme que son pays entend préserver le caractère bilatéral de sa coopération industrielle avec les Etats d'Europe orientale ${ }^{17}$. Il y va de l'image de la France, qui ne souhaite pas que les bénéfices issus de ses rapports anciens et privilégiés avec Moscou lui échappent et profitent à la Commission. Arnaud précise en outre ne pas voir sur quelle base deux organismes

11 Déclaration de la présidence de la Communauté européenne à la première phase de la CSCE, 3 juillet 1973, Helsinki. AMAE, CSCE, vol. 20.

12 Télégramme au départ, 13 août 1973. Archives nationales de France (AN), 5 AG 21041. CSCE. 1969-1974.

13 Note CSCE n³46, 9 octobre 1973. AMAE, Europe 1971-76, RFA, vol. 2982.

14 Télégramme au départ, 13 août 1973. AN, 5 AG 2 1041. CSCE. 1969-1974.

15 Ainsi, ces représentants siègent tour à tour au sein des délégations danoise, allemande, française, irlandaise et italienne. Surtout, il revient à Aldo Moro de parapher l'Acte final d'Helsinki en tant que président du Conseil italien et " en sa capacité de président en exercice du Conseil des Communautés européennes »

16 Document français de 1975, sans date précise. AMAE, CSCE, vol. 20.

17 Entretiens Arnaud/Ruzek, 25 et 26 octobre 1973, Prague. Circulaire nº70, 2 novembre 1973. AMAE, CSCE, vol. 33. 
à vocations très différentes pourraient coopérer, évoquant indirectement l'un des problèmes majeurs que pose la deuxième corbeille.

Alors qu'on aurait pu s'attendre à une attitude positive des Français sur la possibilité de développer les relations entre les deux organes, leurs réticences peuvent sembler déroutantes. Elles n'ont pourtant rien d'étonnant : on est conscient à Paris qu'un rapprochement entre la CEE et le Comecon suppose une reconnaissance de la première par les pays qui composent le second. Or, aux yeux du président Georges Pompidou, une telle reconnaissance ne constitue pas un objectif en soi $^{18}$, d'autant plus que Brejnev lie cette dernière à la confirmation, via la CSCE, du statu quo politique et territorial en Europe. La France considère la CSCE comme un moyen de rapprocher les deux moitiés du continent et non comme un instrument destiné à en renforcer la division. L'essentiel, pour le président français, est que les pays de l'Est consentent à s'engager dans le processus d'échanges économiques engagé en Occident depuis le Plan Marshall.

L'autre raison qui explique la réticence de Paris à un rapprochement entre la $\mathrm{CEE}$ et le Comecon repose sur leur volonté de ne pas cautionner une nouvelle relation de bloc à bloc qui pourrait gêner certains pays socialistes. Car, outre celle de la France, les voix qui s'élèvent de la manière la plus virulente à l'encontre d'une participation de représentants de la Commission aux travaux de Genève proviennent de l'Est. La Roumanie accuse les Neuf d'introduire la notion de blocs dans une conférence qui vise à surmonter les divisions en Europe ${ }^{19}$. Elle craint surtout, et elle est suivie en cela par la Yougoslavie, que cela donne le droit au Comecon d'en faire de même ${ }^{20}$, ce qui reviendrait - c'est en l'occurrence ce qui arrive par la suite - à faire des négociations de la deuxième corbeille un face-àface entre Moscou et les Neuf. Ce n'est qu'au début du mois de novembre 1973 que les pays socialistes acceptent de voir les représentants de la Commission siéger dans la délégation de la présidence danoise et intervenir dans les domaines qui relèvent des compétences communautaires ${ }^{21}$.

Un tel changement d'attitude n'est pas dû au hasard : la plupart des traités commerciaux Est-Ouest expirent en 1973 et les pays du Comecon, à commencer par l'URSS, prennent conscience qu'avec la caducité, au $1^{\text {er }}$ janvier 1975, des derniers accords bilatéraux qui ont été signés entre eux et les Etats de la CEE, ils vont devoir négocier directement avec la Communauté : le Marché commun constitue un débouché non négligeable pour beaucoup de produits, notamment agricoles, d'Europe de l'Est. Désormais, les pays importateurs de ces produits

18 Entretien Pompidou/Brandt, 11 février 1972, Paris. AN, 5 AG 2 106. RFA. 1972-73.

19 Télégramme $n^{\circ} 1539 / 41$, de Fernand-Laurent, 4 octobre 1973. AMAE, Europe 1971-76, Roumanie, vol. 3537.

20 Note CSCE n³55, 11 octobre 1973. AMAE, Europe 1971-76, Roumanie, vol. 3537.

21 Note pour le président de la République, 8 novembre 1973. AN, 5 AG 2 1015. GrandeBretagne. 1973. 
seront soumis aux quotas imposés par Bruxelles. Il s'agit par conséquent pour les Etats du Comecon de combattre ces pratiques commerciales restrictives en réclamant l'octroi de la clause de la nation la plus favorisée. Or, pour cela, il faut accepter la présence de représentants de la Commission à la CSCE. De fait, grâce à la conférence, les pays du bloc de l'Est se retrouvent pour la première fois impliqués dans des négociations économiques et commerciales directes avec la CEE.

Cependant, les négociations de la deuxième corbeille ne débouchent pas sur une coopération fructueuse entre la Communauté et le Comecon. Les discussions de Genève ne sont d'ailleurs pas celles d'une conférence économique à proprement parler. Contrairement à ce qui se passe dans d'autres instances, on ne négocie pas à la CSCE des mesures précises et détaillées basées sur des tableaux statistiques. On ne cherche pas non plus à atteindre des objectifs chiffrés en termes de volume d'échanges ou de production. La marge de manœuvre des négociateurs est en effet très limitée : la diversité des régimes économiques représentés à Genève et la nature très différente de la CEE et du Comecon font qu'il est impossible pour les pays de la CSCE de pouvoir engager des discussions concrètes. Le Comecon n'a rien d'un marché commun et constitue essentiellement une instance chargée de coordonner les plans de production nationaux. Les échanges commerciaux et la coopération technique et scientifique en son sein ne s'accomplissent que sur la base d'accords bilatéraux entre les différents pays membres. L'organisation n'émet que des recommandations que ses membres ne sont pas forcés de suivre. Il n'y a donc aucune politique d'échanges extérieurs commune comme dans la $\mathrm{CEE}^{22}$. De fait, l'objectif soviétique visant à l'amélioration des relations entre la Communauté et le Comecon via la CSCE n'est pas atteint.

Constatant son échec, Moscou s'appuie, à la CSCE, sur une autre de ses revendications pour tirer profit du dynamisme économique des pays de l'Ouest.

\section{Le débat sur la clause de la nation la plus favorisée}

Dès la première phase de la CSCE en juillet 1973, la Hongrie et la RDA déposent un projet de déclaration sur le " développement de la coopération économique, commerciale, scientifique et technique, ainsi que dans le domaine de l'environnement $»^{23}$. Ce document met l'accent sur l'élimination des obstacles au développement du commerce. A ce titre, l'objectif majeur de l'URSS, dicté par son besoin de réaliser les premiers plans privilégiant les industries légères et la production de biens de consommation, est d'obtenir l'octroi de la clause de la

22 Note de la sous-direction d'Europe orientale, 14 février 1972. AMAE, Europe 1971-76, RFA, vol. 3017.

23 Note CSCE n²17, 10 juillet 1973. AMAE, Europe 1971-76, Hongrie, vol. 3337. 
nation la plus favorisée. Pour Moscou, la satisfaction de cette requête marquerait la fin de la guerre froide économique et permettrait de contourner les quotas du Marché commun ${ }^{24}$.

L'un des Etats occidentaux les moins gênés par cette demande soviétique est la France, dans la mesure où la clause de la nation la plus favorisée existe déjà dans les accords qu'elle a passés avec les pays de l'Est et que la CEE en applique le régime de jure ou de facto, sans y déceler de danger particulier ${ }^{25}$. Cette application ne touche cependant que le domaine tarifaire et exclut celui des contingents ${ }^{26}$. Or les Soviétiques cherchent justement à obtenir l'extension maximale de la clause, qui engloberait ainsi les contingents et les autres restrictions quantitatives à l'importation ${ }^{27}$.

Quoi qu'il en soit, afin que l'amélioration des échanges commerciaux ne soit pas à sens unique, les Neuf réclament le principe de la réciprocité des échanges ${ }^{28}$, même s'ils sont conscients que seuls des pays, ou dans le cas de la CEE des groupements de pays, à économie de marché peuvent accorder la clause de la nation la plus favorisée. Ainsi, les Occidentaux ne voient pas comment ils peuvent être traités favorablement " par une économie d'Etat qui n'a pas de tarifs et effectue toutes ses importations au moyen de décisions administratives $»^{29}$. Toujours est-il que les Soviétiques demeurent campés sur leur position et refusent toute réciprocité, préférant parler d' " égalité » des droits ${ }^{30}$. Mais les Neuf insistent pour préserver le terme de "réciprocité », qui doit figurer dans le préambule de la deuxième corbeille et être clairement défini comme impliquant que les avantages et obligations pour les parties doivent être d'égale portée ${ }^{31}$. La notion d' ' égalité des droits » est inacceptable pour la Commission européenne en ce qu'elle implique la non-discrimination et la libéralisation totale des rapports commerciaux entre les pays socialistes et la Communauté.

Seule la France, parmi les Neuf, se prononce en faveur d'une mention, dans le texte de l'Acte final, de l'égalité des droits demandée par l'Est. Aux yeux des

24 Document du sous-comité CSCE, projet de rapport, 15 mai 1975. AMAE, CSCE, vol. 20.

25 Dépêche $\mathrm{n}^{\circ} 12$ de la direction des Affaires économiques et financières du Quai d'Orsay, 18 juillet 1973. AMAE, CSCE, vol. 26.

26 Les contingents tarifaires subordonnent à une limite fixe la quantité de marchandises pouvant être importée au bénéfice d'une suspension de droits.

27 Dépêche $\mathrm{n}^{\circ} 1355$, de Vimont, 2 juillet 1973. AMAE, CSCE, vol. 26.

28 Note CSCE n¹96, 6 novembre 1974. AN, 5 AG 3 1089. URSS. 1974.

29 Simone Courteix, "La coopération dans les domaines de l'économie, de la science, de la technique et de l'environnement", Annuaire de l'URSS et des Pays socialistes européens 1975, Paris : Librairie Istra, 1977, p. 644.

30 Télégramme n²80/92, de Vimont, 17 janvier 1975. AMAE, Europe 1971-76, URSS, vol. 3689.

31 CPE RM(75)7P, Rapport du président du sous-comité CSCE, 23 mai 1975. AMAE, CSCE, vol. 18. 
Français, parler de l'égalité des partenaires préserverait les chances d'une éventuelle négociation entre la CEE et les pays socialistes ${ }^{32}$. De fait, la délégation française à Genève élabore en février 1975 un texte de compromis, que l'URSS accepte, dans lequel elle reprend à la fois toutes les notions souhaitées par les Neuf et la mention de l'" égalité des droits $»^{33}$.

Pour ce qui est du traitement de la nation la plus favorisée, les Neuf veillent à ce que la formule qui sera retenue ne risque pas d'être interprétée comme constituant en elle-même l'octroi du traitement ou bien comme impliquant que le champ d'application du traitement puisse s'étendre au-delà du domaine tarifaire, à savoir dans le domaine des contingents ${ }^{34}$.

Ce n'est que le 17 juillet 1975 que les experts de la deuxième corbeille parviennent à adopter un projet final englobant les questions essentielles de la clause de la nation la plus favorisée et de la réciprocité des avantages économiques. La formule adoptée évite toute obligation réelle d'accorder la fameuse clause et parvient à compenser l'impossibilité pour une économie socialiste de l'octroyer ${ }^{35}$. Dans le bilan qu'ils font des discussions de la deuxième corbeille, les Neuf considèrent comme " un important progrès pour les relations futures » la reconnaissance de la notion de réciprocité effective dans les échanges commerciaux ${ }^{36}$.

Il ressort des négociations de la deuxième corbeille que les efforts déployés par les diplomates soviétiques dans le but d'utiliser la CSCE pour à la fois développer les rapports commerciaux avec l'Ouest et renforcer l'intégration économique de l'Est ne sont guère fructueux. Au contraire, cette partie de la négociation révèle la cohésion des pays de la Communauté et les faiblesses des échanges EstOuest. L'autre projet soviétique d'intégration, qui a, lui, un caractère paneuropéen, conféré au processus d'Helsinki, n'a pas plus de succès.

\section{Le paneuropéanisme en question : le débat sur l'institutionnalisation de la CSCE}

Depuis 1970, Moscou souhaite la création par la CSCE d'un organe permanent paneuropéen dont la fonction principale serait de prolonger le processus d'Helsinki

32 Document français de 1975, sans date précise. AMAE, CSCE, vol. 20.

33 Télégramme n615/20, de la part de Gérard André, 24 février 1975. AMAE, Europe 197176, URSS, vol. 3689.

34 Document CPE RM(75)2P, 10 février 1975. AMAE, CSCE, vol. 19.

35 Les Etats participants reconnaissent « qu'une telle coopération, en tenant compte des différents niveaux de développement économique, peut-être développée, sur la base d'égalité et de satisfaction mutuelle des partenaires, et de réciprocité, permettant, dans l'ensemble, une répartition équitable des avantages et des obligations d'ampleur comparable, dans le respect des accords bilatéraux et multilatéraux ».

36 Document CPE, CP (75) 23 P, Rapport du Comité politique, 8 juillet 1975. AMAE, Europe 1971-76, CEE, vol. 3820. 
et d'y aborder la question du désarmement. Les Polonais vont plus loin en présentant cet organe comme la pièce maîtresse de la CSCE, chargée d'appliquer les décisions de la première conférence et d'en préparer une seconde ${ }^{37}$.

L'ambassadeur de France en URSS, Roger Seydoux, est l'un des premiers à en appeler à la méfiance. Selon lui, avec la création d'un organe permanent paneuropéen dans lequel ne siégeraient pas les Etats-Unis, «l'influence prépondérante de l'URSS en Europe serait en quelque sorte officiellement reconnue, et le désengagement américain confirmé $»^{38}$. Un tel système permettrait à Moscou d'affirmer, à terme, son droit à une présence active en Europe occidentale. En régionalisant l'Europe, il empêcherait le développement de la Communauté européenne, tarirait les possibilités d'élargir les relations avec l'Est et réduirait l'Europe à un rôle marginal puisqu'elle ne pourrait s'appuyer que sur la garantie des superpuissances dont l'une seulement, l'URSS, serait directement insérée dans ledit système en raison de la contiguïté géographique ${ }^{39}$.

Très vite, les neuf membres de la Communauté se montrent unanimes. Un élément essentiel vient cependant les gêner, les Français surtout : au cours de l'année 1972, la Roumanie prend la tête des pays désireux de créer un organe au sein duquel tous les Etats européens siégeraient sur un pied d'égalité, en dehors des blocs, et qui veillerait au respect des principes d'Helsinki, en particulier celui de l'indépendance des Etats ${ }^{40}$. Comment la France, dont la politique européenne demeure largement fondée sur les idées gaulliennes de souveraineté, d'égalité et d'indépendance des Etats, peut-elle repousser un pareil projet sans perdre sa crédibilité dans les pays d'Europe de l'Est soumis au joug soviétique ? Cette question prend un caractère central au sein de l'appareil diplomatique français au cours des mois de préparation de la CSCE. On peut y voir un joli coup tactique de la part du Kremlin : bien que développant une politique destinée à démontrer qu'elle dispose d'une relative marge de manœuvre par rapport à l'URSS, la Roumanie est toujours, en 1972, un satellite de Moscou. Encerclée par des pays communistes, loin de l'Allemagne et du rideau de fer, disposant de l'un des régimes les plus durs du pacte de Varsovie, la Roumanie ne constitue pas vraiment un danger aux yeux des Soviétiques. Au contraire, ces derniers profitent des velléités roumaines pour laisser paraitre au reste du monde que leur mainmise sur l'Europe orientale n'est pas aussi redoutable qu'on veut bien le croire.

37 Circulaire $n^{\circ} 349$, de Beaumarchais, 4 octobre 1971. AMAE, Europe 1971-76, Pologne, vol. 3476 .

38 Télégramme n7592/7600, de Seydoux, 3 novembre 1972. AMAE, Europe 1971-76, Organismes..., vol. 2925.

39 Dépêche non signée et non datée précisément, 1972. AMAE, CSCE, vol. 1.

40 Note de la sous-direction d'Europe orientale, 14 avril 1972. AMAE, Europe 1971-76, Roumanie, vol. 3537. 
Toujours est-il que les Français comprennent que des pays comme la Roumanie, la Yougoslavie, voire l'Autriche ou la Finlande souhaitent disposer, après la CSCE, d'une instance de recours pour les cas où ils se sentiraient menacés ${ }^{41}$. On considère donc que l'unique condition pouvant permettre la mise sur pied d'un tel organe est que la CSCE produise des résultats positifs dans l'ensemble des domaines qu'elle aborde ; il s'agit de ne pas donner l'impression que la conférence a déjà réussi à transformer les relations entre Etats ${ }^{42}$. La France conçoit une institutionnalisation de la CSCE seulement si l'URSS et ses alliés se décident à davantage de concessions sur le changement pacifique des frontières, les droits de l'homme et la coopération culturelle et s'ils appliquent par la suite les dispositions de l'Acte final.

C'est finalement une proposition émanant du Danemark qui l'emporte : elle prévoit une période intérimaire de quelques années durant lesquelles les Etats participants s'attacheraient à mettre leurs engagements en œuvre, suivie d'une réunion de représentants officiels en 1977. L'institutionnalisation des suites ne serait possible qu'à l'issue de la période probatoire, selon le degré de respect des dispositions de l'Acte final. L'idée danoise permet ainsi aux Neuf de garder un maximum de contrôle sur l'évolution ultérieure du processus multilatéra ${ }^{43}$. Elle leur permet également de combattre l'idée soviétique selon laquelle la CSCE représente un aboutissement, la consécration définitive du statu quo politique et territorial en Europe.

La tendance des Neuf, appuyés par les Neutres ${ }^{44}$, consistant à lier la question des suites aux résultats de la CSCE produit peu à peu ses effets : après une dernière déclaration sur le sujet le 19 avril 1974, les Soviétiques et leurs alliés se montrent soudainement moins intéressés par ce problème. Ils prennent conscience du danger que pourrait créer la filiation entre suites institutionnelles et application des dispositions de la conférence, particulièrement en matière d'échanges culturels et de contacts humains.

Le recul de l'URSS et la prudence des Neuf rendent finalement unanime la décision d'adopter la proposition danoise sur les suites. En accord avec le document ouest-européen, on assigne à la réunion de hauts fonctionnaires prévue en 1977, précédée d'une réunion préparatoire, la tâche d'évaluer la mise en œuvre des décisions de la CSCE et l'état des relations entre les Etats participants ainsi que de présenter des propositions concernant des mesures propres à permettre d'atteindre

41 Entretien Pompidou/Brandt, 22 janvier 1973, Paris. AN, 5 AG 2 106. RFA. 1972-73.

42 Note CSCE, 5 janvier 1974. AMAE, Europe 1971-76, URSS, vol. 3689.

43 Document CPE, rapport du président du sous-comité CSCE, 23 mai 1975. AMAE, CSCE, vol. 18.

44 Chez les Neutres et Non-alignés, seules la Yougoslavie et l'Espagne se prononcent clairement en faveur d'un organisme permanent. Les Espagnols exercent une pression sur les Français pour les faire changer d'avis, tentant, de la sorte, de compenser leur déception d'être tenus à l'écart de la CEE et de l'Alliance atlantique. Entretien de Courcel/Gehlhoff, 21 juillet 1975, Bonn. AMAE, Europe 1971-76, RFA, vol. 2999. 
les objectifs de la conférence ${ }^{45}$. En juillet 1975, seule la Roumanie, par la voix de Ceausescu lui-même, en appelle encore, en vain, à la création d'un organisme permanent ${ }^{46}$. En fin de compte, quand intervient la signature de l'Acte final d'Helsinki le $1^{\text {er }}$ août 1975 , l'URSS n'est parvenue à mener à son terme aucun des deux objectifs qu'elle s'était fixés en matière d'intégration européenne : elle n'a pas réussi à renforcer suffisamment la cohésion du Comecon pour en faire l'équivalent de la CEE ; elle n'a pu convertir les Occidentaux au paneuropéanisme. Ni son projet d'intégration est-européenne ni son dessein d'intégration paneuropéenne n'ont été réalisés lors de la CSCE. Sur l'un comme sur l'autre, la conférence a abouti au résultat inverse : elle a renforcé la propension des pays du bloc communiste à négocier bilatéralement avec la $\mathrm{CE}$ et la Commission européenne, discréditant un peu plus le Comecon; elle a renforcé la méfiance des pays de l'Ouest à l'égard de tout ce qui relève de la sécurité collective et a mis en exergue le rôle dynamique des Neuf.

La deuxième corbeille a également le mérite d'essayer de poser les bases multilatérales de la détente économique et, par certains aspects - comme le développement des échanges commerciaux ou l'étude et la réalisation de projets industriels et de transports importants - peut aider les pays du Comecon à accéder à la technologie occidentale tout en permettant aux Etats capitalistes de conclure des contrats à long terme avec l'Est. Pour les Neuf, qui se félicitent que le rôle des entreprises et, le cas échéant, celui des individus soient reconnus, les textes de la deuxième corbeille constituent « une contribution positive au développement de la coopération $»^{47}$. Si la CSCE ne renforce ni l'intégration est-européenne ni l'intégration paneuropéenne, au moins est-elle le fruit d'un vrai compromis entre les deux visions de l'économie qui prévalent de part et d'autre du rideau de fer.

\section{Bibliographié}

Courteix, Simone, (1977), "La coopération dans les domaines de l'économie, de la science, de la technique et de l'environnement", Annuaire de l'URSS et des Pays socialistes européens 1975, Paris: Librairie Istra.

Du Réau, Elisabeth et Frank, Robert (eds.), (2002), Dynamiques européennes : nouvel espace, nouveaux acteurs, 1969-1981, Paris: Publications de la Sorbonne.

Ludlow, N. Piers (ed.), (2007), European integration and the Cold War: Ostpolitik-Westpolitik, 1965-1973, London: Routledge.

45 Projet de rapport du sous-comité CSCE, 15 mai 1975. AMAE, CSCE, vol.20.

46 Début juillet 1975, Ceausescu demande, en vain, à Sauvagnargues de le soutenir dans sa demande. Il réitère son désir d'un organe permanent dans son discours à Helsinki. Télégramme au départ n562/65, de Laboulaye, 9 juillet 1975. AMAE, Europe 1971-76, Roumanie, vol. 3537.

47 Document CPE, CP (75) 23 P, Rapport du Comité politique, 8 juillet 1975. AMAE, Europe 1971-76, CEE, vol. 3820. 
Möckli, Daniel, (2008), European Foreign Policy during the Cold War: Heath, Brandt, Pompidou and the Dream of Political Unity, 1969-1974, Londres: I.B Tauris.

Rey, Marie-Pierre, (2007), “L'URSS et l'Europe communautaire, représentations et pratiques, 1957-1991”, in Deighton, Anne et Bossuat, Gérard (eds.), L'Union européenne, acteur de la sécurité mondiale, Paris : Soleb, pp. 48-67.

Rey, Marie-Pierre, (2005), "Le retour à l'Europe? Les décideurs soviétiques face à l'intégration ouest-européenne, 1957 - 1991", in Journal of European Integration 1, 11, pp. 7-27.

Romano, Angela, (2009), From Détente in Europe to European Détente. How the West shaped the Helsinki CSCE, Bruxelles: PIE-Peter Lang.

Romano, Angela, (2007), "Western Europe's self assertion towards the superpowers : the CSCE chance and its aftermath", in Deighton, Anne et Bossuat, Gérard (eds.), L'Union européenne, acteur de la sécurité mondiale, Paris : Soleb, pp. 148-165.

Takeshi, Yamamoto, (2007), "Détente or Integration? EC Response to Soviet Policy Change towards the Common Market, 1070-75”, in Cold War History, Vol. 7, N¹, pp. 75-94.

Wenger, Andreas, Mastny, Vojtech et Nuenlist, Christian (eds.), (2008), Origins of the European Security System: the Helsinki Process revisited. 1965-1975, London: Routledge. 


\title{
Autarkic tendencies in the Council for Mutual Economic Assistance
}

\author{
Jerzy $€ A Z O R$ \\ Wojciech MORAWSKI
}

\begin{abstract}
Autarky was an important part of the Soviet economic model which emerged in the early 1930s. After this model had been forced onto other Eastern European countries during the Szklarska Poręba Conference in 1947, the economy of the entire Eastern Bloc started showing strong autarkic tendencies. Surprisingly, they did not imply autarky within the Bloc as a whole, but within each communist country on its own. From a geopolitical point of view this was an irrational move. USSR would have profited more from satellite countries with economies complementary to its own, rather than just copies of its regime. Autarkic tendencies proved to be a constant feature of the Eastern Bloc, despite attempts at reforms. The pursuit of self-sufficiency in each country soon moved down all the way to the microeconomic level. While rational there, it proved disastrous macroeconomically and paved the way for the system's subsequent demise.
\end{abstract}

Keywords: shortage, autarky, Soviet, communism, economy

Many public issues in the Eastern bloc became the subject of jokes. The so called 'socialist integration' was no exception. In one memorable example, the inefficiency of the Council of Mutual Economic Assistance (CMEA) was ironically explained with 'Russian honesty, Polish sobriety, the power of Cuban industry, German sense of humour and the use of Hungarian as the official language'. ${ }^{1}$

The joke, however stereotypical, tries to identify some reasons behind the Soviet bloc's meagre economic integration. Our goal in this paper is broadly similar. Since our interests lay in the foundation of the system, rather than in its later evolution, we will restrict ourselves to the time before the fall of Krushchev. We aim to show that the communist system in Central and Eastern Europe was governed by emergent economic and social mechanisms, which promoted autarky on progressively lower levels. In particular, we believe that autarky first emergedin the bloc when stalinism was forced onto Soviet satellites in the lat 1940s, the second time was the result of economic and political reforms of the 1950s, and the third (perhaps not chronologically) was caused by the growing impact of shortage on communist economies.

Two elements of Stalin's post-NEP system had far-reaching consequences for our interpretation of the emergent mechanism in the Eastern Bloc: the idea of 'socialism in one country', and terror.

1 The authors would like to thank dr. Andrzej Zawistowski for sharing his immense knowledge of communist-era jokes. 
Whereas in other totalitarian regimes autarky could be considered a goal motivated mostly by military doctrine, in the case of the USSR it was an integral part of the economy. It was argued, that the only socialist country should not be dependent on capitalist states. Self-sufficiency was combined with over-investment in heavy industry, underdevelopment of light industry, collectivisation of land, and central planning, to transform the economy into 'one big factory', independent from the rest of the world and its crises, and theoretically free from the cost of competition.

The economic use of terror can be understood in a number of ways. The brutal transformation of Soviet society wouldn't have been possible without the fear terror produced. Moreover, Stalinism abolished market elements, which had played such an important role in the NEP. In theory, the market uses egoism of individual homini oeconomici, which through the invisible hand of the market, transcends individual needs. The Soviet system lacked this mechanism, and needed different stimuli to achieve results. The economy can be understood to have operated on a top-down (rather than bottom-up) basis, in which 'altruism' was promoted by ideology and terror. The latter was considered crucial - at least officially - because the system was being built by a society rooted in the previous system. When the society moved to communism, terror would have no longer been necessary.

The fundamental element of (both pre- and post-war) communist terror was its irrationality. Irrationality differentiates terror from oppressiveness. The former keeps the population in fear, by convincing citizens that anyone can be accused of anything. The latter loses much of its effectiveness, as rational strategies can be devised to avoid it. Under Stalin's rule no such strategies could be devised: neither staying out of politics nor engaging in the party's activities worked. Ideological heresy was easy to prove even to the most loyal communists. Stalin likened the party to a living organism, needing to replace its cells before they died off by themselves. ${ }^{2}$ The purge became a crucial socio-political institution. As the majority of the population lived in abject poverty and belonging to the ruling class was the only way to achieve a higher level of living, a place in the party apparatus was both desirable and dangerous. Thus terror slowed the process of petrification of the ruling class, but did not prevent its appearance. ${ }^{3}$

Despite Stalin's (arguably overquoted) declaration to Djilas, ('whoever occupies a territory also imposes his own social system. Everyone imposes his own system as far as his army can reach. It cannot be otherwise ${ }^{4}$ '), the first years after the

2 Jerzy Holzer, Europa zimnej wojny, Warszawa: Znak, 2012, p. 144.

3 Moreover, according to some historians, purges allowed Stalin to promote 'young, more vigorous and educated staff [which] could give a new impulse to the economic development', Khlevnyuk Oleg, "Economic Officials in the Great Terror, 1936-1938”, in Melianie Ilič (ed.), Stalin's terror revisited, Houndmills-New York: Palgrave Macmillan, 2006, pp. 39-41, 63.

4 Milovan Djilas, Conversations with Stalin, trans. Michal B. Petrovich, New York: Harcourt Brace \& World, 1962, p. 114. 
second world war were a period of transition, when a number of scenarios seemed plausible. On the one hand, the future of communism in France and Italy looked promising, on the other, local communist party leaders in Central and Eastern Europe considered variations on the stalinist theme adapted to local situations, communist in their ideas, but built in a somewhat different manner - the so called national roads to socialism ${ }^{5}$.

This period, which did not serve the coherence of Stalin's new 'external empire' in Europe, came to a close soon after the Marshall Plan had been proposed. Using John Gaddis' term, Stalin needed to improve his methods of imperial management $^{6}$. This was done through ideological integration of communist parties, started with the conference in Szklarska Poręba in September 1947, which saw the creation of the Information Bureau of Communist Parties (Cominform). During his conference speech, chief Soviet ideologue Andriej Zhdanov: 'main mouthpiece of the new world view'7, painted of a vision of the world devided into two opposing blocs. ${ }^{8}$ This marked the beginning of a bloc-wide stalinisation, which could be seen particularly strongly in 1948. With stalinism considered immutable, local communists were no longer free to rearrange its components. As a result, the political system in satellite states was cloned from the USSR, rather than adapted. It was - as Adam Zwass put it - a perverse implementation of the early modern cuius regio, eius religio. Forced stalinisation extended to all aspects of life - politics, literature, music and architecture were to look the same in Berlin, Warsaw, Budapest, Moscow or Magnitogorsk. Terror spread west ${ }^{9}$, and with it

5 John Lewis Gaddis, We Now Know. Rethinking Cold War History, Oxford: Claredon Press, 1997, pp. 14, 203; Adam Zwass, The Council for Mutual Economic Assistance. The Thorny Path from Political to Economic Integration, Armonk-London: M.E. Sharpe, 1989, pp. 12-13, Andrzej Skrzypek, Mechanizmy uzależnienia. Stosunki polsko-radzieckie 19441957, Pułtusk: Wyższa Szkoła Humanistyczna, 2002, pp. 182-187; Tadeusz Kowalik, Spory o ustrój spoleczno-gospodarczy w Polsce. Lata 1944-1948, Warszawa: Wydawnictwo Key Text \& Instytut Nauk Ekonomicznych PAN, 2006, p. 116.

6 Gaddis, We Now Know, p. 46; Henryk Bartoszewicz, Polityka Zwiazku Sowieckiego wobec państw Europy Środkowo-Wschodniej w latach 1944-1948, Warszawa: Książka i Wiedza, 1999, p. 7.

7 Vladislav Zubok and Constantine Pleshakov, Inside the Kremlin's Cold War: from Stalin to Khrushchev, Cambridge-London: Harvard University Press, 1996, p. 111; Vojtech Mastny, Stalin i zimna wojna. Sowieckie poczucie bezpieczeństwa, trans. Małgorza Werner, Warszawa: Trio, 2006, pp. 61-64.

8 Werner G. Hahn, Postwar Soviet Politics. The Fall of Zhdanov and the Defeat of Moderation, 1946-1953, Ithaca-London: Cornell University Press, 1982, p. 98; Baroszewicz, Polityka, pp. 322-332.

9 'If the Nazi caught you as a political dissident, they usually wanted to know what you did, who your friends were, what were your plans etc. The Communists did not go for that. They already knew, when they arrested you, what kind of confession you were going to sign', Jacques Rupnik, The Other Europe. The Rise and Fall of Communism in East-Central 
- purges, waves of which occurred to different degrees in all countries of the bloc. Economic elements of the new system included over-investment in heavy industry, forced collectivisation of land and, crucially, central planning. ${ }^{10}$

One element of forced stalinisation was particularly interesting: a deeply ingrained seeking of self-sufficiency on a country level. Moreover, each state was to follow the same basic development path. ${ }^{11}$ This was a paradox: at the same time it strengthened ideological coherence and loosened potential economic ties. If the USSR wanted to exploit its 'external empire' more efficienctly, it would have made more sense to make the satellites specialise in products the Soviets particularly needed. ${ }^{12}$

This effect was strengthened by the evolution of intra-bloc trade. While there were huge differences between such countries as Czechoslovakia and Romania, in general they had substitute rather than complementary economies. This is confirmed by a low level of trade between them before the second world war (excluding the USSR, no more than $10 \%$ of their total trade ${ }^{13}$ ). The forceful adoption of very similar development paths after 1947 only strengthened their substitute character. ${ }^{14}$ The USSR forced new trade relations, which followed a hub-and-spoke model, with the Soviets acting as the hub, and trade between satellite countries remaning relatively small (which was also the model for political relations in the bloc). Exchange was mostly based on middle-term bilateral agreements, which tied new communist countries to the USSR. ${ }^{15}$ As Ivan T. Berend put it (writing about a sli-

Europe, New York: Pantheon Books, 1989, p. 113; George Hodos, Show Trials: Stalinist Purges in Eastern Europe 1948-1954, New York: Praeger, 1982.

10 Zwass, The Council, p. 4; Skrzypek, Mechanizmy uzależnienia, pp. 227-222, 234-239; János Kornai, The Socialist System. The Political Economy of Communism, Princeton: Princeton University Press, 1992, pp. 111-130; Ben Fowkes, The Rise and Fall of Communism in Eastern Europe, 2nd ed., Houndmills-London: Macmillan Press, 1995, pp. 52-65; Jacek Luszniewicz, "Wzorzec radziecki a system Polski w latach 1944-1956. Odwzorowanie, modyfikacja czy rewizja”, Konrad Rokicki, Sławomir Stępień (eds), W objęciach wielkiego brata. Sowieci w Polsce 1944-1993, Warszawa: Instytut Pamięci Narodowej, 2009, pp. 95-122.

11 Zwass, The Council, p. 8.

12 That is not to say that severe exploitation did not take place, Bartoszewicz, Polityka, pp. 227-269.

13 Cecylia Leszczyńska, "Socjalistyczny neomerkantylizm. System rozliczeń obrotów płatniczych między państwami socjalistycznymi w latach 1945-1970”, in: Jachowicz Piotr (ed.), W poszukiwaniu modelu gospodarki centralnie kierowanej, Warszawa: Oficyna Wydawnicza Szkoły Głównej Handlowej w Warszawie, 2013, p. 110; Zwass, The Council, p. 6; Ivan T. Berend, Decades of Crisis. Central \& Eastern Europe Before World War II, Berkeley-Los Angeles-London: University of California Press, 1998, pp. 271-272.

14 Antoni Marszałek, Planowanie $i$ rynek $w$ RWPG. Geneza niepowodzenia, Łódź: Wydawnictwo Uniwersytetu Łódzkiego, 1993, p. 22.

15 Skrzypek, Mechanizmy uzależnienia, p. 200; Gaddis, Now We Know, p. 204; Holzer, Europa, p. 340; Valerie Bunce, Subversive Institutions. The Design and the Destruction of Socialism and the State, Cambridge-New York: Cambridge University Press, 1999, pp. 39-40. 
ghtly later period): 'the most negative effect of this isolationist „Socialist-Worldmarket" was its contribution to the realization of the autarkic orientation, which would not have been possible in international frameworks'. ${ }^{16}$

In communist states, there were no market mechanisms to stimulate producers. As a result, international trade additionally sanitised by an inconvertible currencies, did not help the economy, as it promoted neither specialisation nor innovation. ${ }^{17}$ The value of goods exchanged, usually via barter, was entirely detached from cost. Satellite states could consider exports to the USSR as an abstract tax put on the economy. If temples of a strange cult had suddenly been erected in Prague, Warsaw, and Berlin, with their priests demanding coal and machines in exchange for oil, the economic effect would not have been much different. Especially since the quality of these machine didn't matter as much as on a real market. In such a system exports can at most be considered a way to finance imports of needed materials, and self-sufficiency is sought whenever possible. This was exacerbated by the fact that without a convertible currency, communist countries pursued not only general bilateral balance of payments with each state, but also aimed to achieve it within individual product groups being traded with this state. Thus exports of raw materials had to be met by other prioritised items, such as machines ${ }^{18}$, and no advanced export policy could be implemented.

The founding of the Council for Mutual Economic Assistance (CMEA, Comecon) in 1949 changed very little. It can be argued that the organisation was created for purely political reasons ${ }^{19}$, as a formal alternative to the Marshall plan, and a means of 'freeing' the socialist countries from 'Western economic discrimination'20. During Aleksey Lavryshchev's brief time as CMEA's secretary, it showed some action, but under Mikoyan it was little more than a name. ${ }^{21}$ No new meetings were called until 1954, and as Jens Hacker put it, most of what the organisation did before Stalin's death, was to fervently boycott Tito's Yugoslavia. ${ }^{22}$

16 Ivan T. Berend, Central and Eastern Europe 1944-1993. Detour from the periphery to the periphery, Cambridge-New York: Cambridge University Press, 1996, p. 82.

17 Leszczyńska, "Socjalistyczny neomerkantylizm”, p. 115.

18 Henryk Różański, Spojrzenie na RWPG. Wspomnienia-dokumenty-refleksje 1949-1988, Warszawa: Wydawnictwo Naukowe PWN, 1990, pp. 60-61; Kazimiera Wilk, Integracja wschodnio-europejska. Powstanie, funkcjonowanie i upadek, Wrocław 1994, p. 111; Berend, Central and Eastern, pp. 77-78.

19 The first Secretary of the CMEA did not receive documents concerting its founding, as in the USSR they had been classified as secret and obtaining them would have required a complicated procedure. Instead, he unofficially copied them from his Polish and Hungarian colleagues, Różański, Spojrzenie, p. 20.

20 And it's official goals were fairly modest: 'exchanging economic experience and providing mutual technical assistance as well as assistance in raw materials, foods, machinery and equipment', Zwass, The Council,pp. 9-15; Skrzypek, Mechanizmy uzależnienia, pp. 232-233

21 Dissenting views: Różański, Spojrzenie, pp. 37-38, 43; Fowkes, The Rise and Fall, pp. 61-62.

22 Quoted in Holzer, Europa, p. 336. 
Interestingly, as Stalin controlled the states of the blocs through other means, CMEA was officially founded on the principles of sovereign equality of all members and required unanimous decisions on all matters. This played a role in future discussions within the Council. ${ }^{23}$

Stalin's death had important consequences for autarkic tendencies, particularly through the abolishment of terror and economic decentralisation.

During his famous secret speech during the 20th Congress of the Soviet Communist Party in 1956, Khrushchev condemned some 'abuses' of the previous system: in particular its use of terror against communists. His critique ushered in a new approach. From now on a communist leader could retire and die in his bed, rather than at the hands of his successor. While Beria had been executed in 1953, Khrushchev let Malenkov live not only after his deposition from the post of prime minister in 1955, but also after the party opposition's revolt in 1957. This policy became an integral part of the system, as Krushchev himself was not killed in 1964. With some minor exceptions (such as Hungary after 1956), this spread to other countries of the bloc. The purge as an institution was abolished. 'Obscurity rather than death awaited the losers' ${ }^{24}$

Terror was also rescinded on a more general scale. The system was no longer random: it was now possible to develop strategies to keep out of harm's way. Instead of terrorising the population, it now served as a (very oppressive) deterrent. The system certainly certainly remained a totalitarian regime, but its character noticeably changed. ${ }^{25}$

This had a tremendous effect. By giving party members personal safety, it allowed the nomenklatura to calcify to a much greater degree than under Stalin ${ }^{26}$. With decalcifying mechanisms gone, but party privileges intact, this accelerated the creation of a safe, egoistic bureaucratic class. To use a metaphor from a different era, it was not unlike the creation of a feudal class, now given a personal privilege of safety - like a medieval neminem captivabimus of sorts. It introduced a certain amount of independence - a greater possibility for pursuing self-sufficiency should it be to one's advantage. Perhaps most tellingly, terror was not abolished, as the utopian vision predicted, with the establishment of 'real communism', but rather as a part of a process of feudalisation of the Soviet society. This effect could be seen on a local, state and international level.

The abolishment of terror on a country level coincided with changes to the economy. Malenkov, who played a leading role in 1953-1955, questioned the dominance of heavy industry. Krushchev's vision followed a somewhat different path.

23 Różański, Spojrzenie, p. 16.

24 Charles Gati, The Bloc that Failed. Soviet-East European Relations in Transition, Bloomington-Indianapolis: Indiana University Press, 1990, p. 30.

25 Holzer, Europa, p. 458.

26 Fowkes, The Rise, pp. 64-65. 
His reforms had a certain incoherence, somewhat parallel with the development of socialist economic theory at the time (works by Oscar Lange, Michał Kalecki and Aleksy Wakar, to look just at Polish examples ${ }^{27}$ ). While too great centralisation had come under attack, this did not extend to even a slight rehabilitation of market forces (like within the New Economic Policy). Both the central planner or workers' committees were assumed to be altruistic. Central planning, rather than abolished, was to be perfected by allowing lower-level cadres to participate in the process.

Reforms followed, to a certain degree, this point of view. Basic ideas behind the system were not challenged: the economy would still be owned by the state, and governed by central planning. The questioned element was the 'one big factory' paradigm. In general, too great a degree of centralisation was now considered a hurdle for effectiveness, in particular with the difficulty of high-level bureaucracy to take decisions and the ineffectiveness of the all-powerful ministries.

Tito's policy had, of course, been an early example of this trend, with self-management of state-owned companies playing an important role, but Yugoslavia remained outside of the CMEA. A swiftly aborted experiment on the Yugoslavian theme could be seen in post-October Poland, but the defining experience of communist decentralisation came with Soviet reforms.

Soviet central ministries, as Philip Hanson writes, 'had been guilty of "departamentalism" (vedomstvennost): a narrow preoccupation with the concerns of one's economic branch... it meant a tendency for the objectives of the individual ministry's empire to prevail over those of the national economy as a whole' ${ }^{28}$ Vedomstvennost can be considered a form of economic disintegration, caused by central planning. The decentralisation reform meant to address this problem, by relegating a degree of decision-making to the level of regions. Accordingly, starting in 1957, 105 Regional Economic Councils (sovnarkhozy) were created, closely matching the divisions of local party administration. This did not imply giving any power to managers of enterprises: all decisions were taken on the region level, with local party leaders 'playing a stop-gap role, chasing up inputs for local producers' ${ }^{29}$ As Adam Zwass put it, 'the local patriotism generated by the regional administrations did more damage to the economy than did the self-centred tendencies of the economic ministries' ${ }^{30}$ Together with political changes, it gave birth

27 Oscar Lange, O socjalizmie $i$ gospodarce socjalistycznej, Warszawa: Wydawnictwo Naukowe PWN, 1966; Michał Kalecki, Zarys teorii wzrostu gospodarki socjalistycznej, Warszawa: Wydawnictwo Naukowe PWN, 1963; Aleksy Wakar, Morfologia bodźców ekonomicznych, Warszawa: Wydawnictwo Naukowe PWN, 1963.

28 Philip Hanson, The Rise and Fall of the Soviet Economy: An Economic History of the USSR From 1945, Harlow: Pearson Education, 2003.

29 Peter Rutland, The Politics of Economic Stagnation in the Soviet Union: The Role of Local Party Organs in Economic Management, New York: Cambridge University Press, 1992, p. 75 .

30 Zwass, The Council, p. 30. 
to the first emergent mechanism. Without the use of terror it became increasingly difficult to force the local cadres into obedience, as they followed their own goals. Again using a feudal analogy, this can be compared to the bureaucracy gaining a form of economic privilege, not unlike feudal lords acquiring greater control of their fiefdoms at the cost of the ruler.

This situation was soon contested by the state, and already in 1962 the number of sovnarkhozy was lowered to 47 , which aimed to reduce the power of regional party officials. From and economic and administrative perspectives, much more interesting conflicts occurred not between communist parties and society at large, but rather within the power structures themselves ${ }^{31}$, with a particular tension between the centre and lower cadres. The former aimed to protect its position and power, why the latter fought for para-feudal privileges. This conflict was one of the reasons behind the system's inherent resistance to reforms. This inertia also owed much to the overgrowth of the heavy industries sector, which was able to put immense pressure on the system.

Regionalisation resulted in chaos and additional supply problems. Its failure found the most dramatic expression in the Novocherkassk massacre in June 1962, when a revolt was drowned in blood by the military. ${ }^{32}$ When Krushchov fell two years later, central ministries were immediately brought back. On a larger time scale, the economy went into a cycle of reforms and counter-reforms ${ }^{33}$, but the development of autarky was difficult if not impossible to tackle without the help of market mechanism - and those did not come before Ghorbachev.

Policy changes against terror and centralisation reacted with another inherent element of communist economy: as Kornai so eloquently showed, planning resulted in an economic system consistently plagued by shortage. ${ }^{34}$ At the same time, decentralisation reforms introduced more egoistic behaviours. It can be (and has been) argued that market behaviours arose even with what little leeway people in the communist countries were given. It was something we'd like to call the mutilated market - that is a market in which shortage was ever present and market behaviours were counter-system.

Shortage in such a situation has a peculiar property - it leads to autarky. Its most obvious symptom is the unreliability of markets. A buyer is never guaranteed to receive what he seeks. In the case of consumers (if one might use this term in reference to citizens of socialist countries) and products with low price

31 Bunce, Subversive, p. 36 shows that the Soviet institutions inherently generated these conflicts.

32 Zubok and Pleshakov, Inside the Kremlin, pp. 263-264.

33 Zbigniew Landau, "Etapy rozwoju Polski Ludowej”, Przegląd Historyczny 78 (1987), 2, pp. 211-250.

34 János Kornai, Economics of Shortage, Amsterdam-New York: North Holland, 1980; idem, The Socialist System. 
elasticity of demand, in the short term it might mean turning to the black market. Non-crucial products might simply be foregone. In a longer scope of time various para-market behaviours might be sought, be it barter or bribes. The very same mechanism applied to economic regions or production plans of single enterprises. If the well-being of their management depended on meeting a centrally predetermined set of parameters, managers would turn to unofficial channels to procure the needed resources. This was evident in the fact that newly built factories found it more difficult to operate: they lacked, as Peter Rutland puts it, an established network of contacts. ${ }^{35}$ This process was of course visible under Stalin, as the threat of death forced managers to seek alternative ways of reaching plans, but the process took on a new rapidity as local activists gained greater independence and structures began to settle. In the long term, ministries and individual enterprises sought samosnabzhenie ('self-supply'), to mitigate these shortage-induced problems. In other words, the seeking of autarky spread ever lower, from country to region, from region to company and ultimately down to the level of individual households. Quoting I. Berend: 'Central planning and the lack of market incentives actually pushed each country and each firm toward self-sufficiency, in order not to be "dependent" on other non-interested countries that might and did cause permanent troubles by nont fulfilling or delaying deliveries, thus endangering the plan fulfilliment'. ${ }^{36}$

This was famously shown by Stanisław Lem in short story about the adventures of Ijon Tichy. ${ }^{37}$ The hero finds himself in an African country in which shortage is king. A rational solution to its woes is to have as many children as possible and either educate them, or marry off to people working in key industries - from healthcare through plumping through food production to - ultimately - funerary services. Each extended family becomes self-sufficient, but at the cost of paralysing high-level functions of the economy.

Shortage made this process rational on a microeconomic level, but drove the Soviet economy into stagnation. We believe that the acceleration of this process was another emergent mechanism, with roots in Soviet economic an social reforms. This development makes one question the validity of calling the communist economy 'planned'. With successive changes, the centre had an ever limited array of methods of influencing sufficiency-seeking lower levels, which operated within the reality of a mutilated market, governed by shortage. Some parts of the economy (particularly the military-industrial complex) continued to grow in force and gained a form of immunity. Moreover, the centre found it progressively

35 Rutland, The Politics, p. 76. Those contacts often included the planning apparatus, Berend, Central and Eastern, pp. 75-76.

36 Berend, Eastern and Central, p. 192.

37 Stanisław Lem, "Profesor A. Dońda (Ze wspomnień Ijona Tichego)", in: idem, Dzienniki gwiazdowe: Wydanie rozszerzone, Kraków: Wydawnictwo Literackie, 1982, pp. 487-521. 
difficult to understand what was happening, as it operated in an abstract paradigm of political economy, useless in describing the real processes ${ }^{38}$ Paradoxically, without the reintroduction of market mechanics, any reform aimed at democratising or decentralising the system would only serve to further the progress of autarky.

The problem of self-sufficiency was also easily visible on the international scale, and solutions were sought after Stalin's death. It was Krushchev who could be called the real father of the CMEA. During his years in the Kremlin, the organisation was brought back to life. Already the first meeting after Stalin's death in March 1954 provided it a broad set of long-term goals, while the summit in May 1958 introduced formal statutes and a more robust institutional structure. ${ }^{39}$

As mentioned above, a model of 'socialist co-operation' where all the countries follow the same development pattern and produce broadly the same set of products wasn't optimal, and resulted in a propensity for autarky in the economy. Without Stalin's steel grip, even political paths of individual countries began to diverge ever so slightly. Krushchev saw economic integration as one way of keeping the bloc closely knit.

An alternative to Stalin's vision of the bloc would include specialisation between CMEA member countries, or, as it was called, 'socialist division of labour'. This was not easy to introduce - the idea of specialisation was at odds with the basic precepts of stalinism, and local communist leaders found to difficult to let go of certain key policies. In particular, it would force still predominantly rural countries like Romania to remain but foodstuff producers, serving more advanced states such as Czechoslovakia or the GDR. From USSR's point of view, this was a rational choice - it would have meant a fuller utilisation of its political power on the economic level. For poorer countries it would have been a disaster: a petrification of their economic structures. ${ }^{40}$

Until Krushchev's fall, there were two approaches to this type of greater specialisation. The first was based on plan co-ordination, in which countries would use the CMEA as a forum for aligning their plans. Indeed already the summit in 1954 criticised what it dubbed 'unjustified parallelism' of communist economies. This voice was heard throughout the 1950s. However, member countries were loathe to agree to a co-ordination of investment plans ${ }^{41}$, especially since it took a fairly

38 Kazimierz Kloc, "Narodziny ekonomii politycznej socjalizmu - perspektywa wewnątrzsystemowa", in: Jachowicz Piotr (ed.), W poszukiwaniu modelu gospodarki centralnie kierowanej, Warszawa: Oficyna Wydawnicza Szkoły Głównej Handlowej w Warszawie, 2013, pp. 42-48.

39 Zwass, The Council, pp. 17, 24-26, 34.

40 Skrzypek, Mechanizmy uzależnienia, p. 374; Zwass, The Council, p. 5.

41 Różański, Spojrzenie, p. 54; Skrzypek, Mechanizmy uzależnienia, p. 334; Andrzej Skrzypek, Mechanizmy autonomii. Stosunki polsko-radzieckie 1956-1965, Pułtusk: Wyższa Szkoła Humanistyczna, 2005, p. 41. 
crude form. Polish economist Henryk Różański recalled how it was enforced in the machine sector. Council clerks prepared a large table, in which each of around 600 columns represented different machines types, while the rows signified member states. The placements of crosses in cells determined the future of industries (some of them already existing) and was thus met with long and hard negotiations. Many elements of plan co-ordination were contested, but, when it seemed that it would go forward, in December 1958 Krushchev decided to let it go, surprising everyone during CMEA's $10^{\text {th }}$ meeting in Prague. His decision was motivated by the start of the decentralisation reform, which required recasting of all plans.

The second approach to forced integration was more severe. It originated with Gomułka's proposals ${ }^{42}$, and evolved from a co-ordination of plans, to a single unified plan, by relegating all planning within the CMEA to Soviet's Gosplan. Such a move - from an economic perspective - would turn member states into entities on the level of Soviet republics, following their centrally-determined 'selective development plan'. It should be noted, however, that particularly after the 20th congress, party leaders within the CMEA saw greater opportunity for negotiating their own positions..$^{43}$ Romania was the country which voiced its disagreement so effectively, that the reform was cancelled, and the CMEA temporarily lost much of its meaning, particularly after Krushchev's deposition. Adam Zwass argues that even had there been no disagreement, the organisation lacked mechanisms needed to introduce such a plan. On the international level, the initial drive for self-sufficiency was hard to overcome, despite subsequent tries. As countries had different levels of development, their economic integration goals were also differed. Only a centralised planning system could have forged them into a coherent unit, but that had only been possible during Stalin's times. ${ }^{44}$

To sum up, we believe that the propensity for autarky was an inherent attribute of the economic and social system introduced in European communist countries after the second world war. Reforms which came in the late 1950s only amplified this tendency. This outcome had not been planned by the people in power, but can be considered an emergent behaviour of actions aiming to ameliorate the system. In a way, the communist economy turned out to be, starting from the 1950 s, less centrally planned, and less dependant on top-level political decisions than it seemed.

42 Różański, Spojrzenie, pp. 135-159; Skrzypek, Mechanizmy autonomii, pp. 253-256; Wojciech Morawski, "Poglądy gospodarcze Władysława Gomułki”, in: Elżbieta Kościk, Tomasz Głowiński (eds), Gospodarka i społeczeństwo w czasach PRL-u (1944-1989), Wrocław: Gajt, 2007, pp. 326-332; Zwass, The Council, p. 40.

43 As Henryk Różańki put it, "Doubtlessly, when Stalin was alive many would not have had the courage to disagree", Różański, Spojrzenie, pp. 62, 81-88, 93; Skrzypek, Mechanizmy autonomii, p. 164; Skrzypek, Mechanizmy uzależnienia, p. 375; Gaddis, Now We Know, p. 208.

44 Ibidem, p. 10-11, 186; Różański, Spojrzenie, pp. 165-185; Skrzypek, Mechanizmy autonomii, p. 261. 


\section{Bibliography}

Bartoszewicz, Henryk (1999), Polityka Zwiazku Sowieckiego wobec państw Europy ŚrodkowoWshodniej w latach 1944-1948, Warszawa: Książka i Wiedza.

Berend, Ivan T. (1996), Central and Eastern Europe 1944-1993. Detour from the periphery to the periphery, Cambridge-New York: Cambridge University Press.

Berend, Ivan T. (1998), Decades of Crisis. Central \& Eastern Europe Before World War II, Berkeley-Los Angeles-London: University of California Press, 1998.

Bunce, Valerie (1999), Subversive Institutions. The Design and the Destruction of Socialism and the State, Cambridge-New York: Cambridge University Press.

Brzeziński, Zbigniew (1990), The Grand Failure. The Birth and Death of Communism in the Twentieth Century, London-Sydney: Macdonald.

Cambell, John C. (1984), „Soviet Policy in Eastern Europe: an Overview”, in: Sarah Meiklejohn Terry (ed), Soviet policy in Eastern Europe, New Haven-London: Yale University Press.

Davis, Robert W. (2006), „The Soviet Econonomy and the Launching of the Great Terror”, in: Stalin's Terror Revisited, ed. Melianie Ilič, Houndmills-New York: Palgrave Macmillan, 11-37.

Fowkes, Ben (1995), The Rise and Fall of Communism in Eastern Europe, $2^{\text {nd }}$ ed., HoundmillsLondon: Macmillan Press.

Gaddis, John Lewis (1997), We Now Know. Rethinking Cold War History, Oxford: Claredon Press.

Gati, Charles (1990), The Bloc that Failed. Soviet-East European Relations in Transition, Bloomington-Indianapolis: Indiana University Press.

Hahn, Werner G. (1982), Postwar Soviet Politics. The Fall of Zhdanov and the Defeat of Moderation, 1946-1953, Ithaca-London: Cornell University Press.

Hanson, Philip (2003), The Rise and Fall of the Soviet Economy: An Economic History of the USSR From 1945, Harlow: Pearson Education.

Hodos, George (1982), Show Trials: Stalinist Purges in Eastern Europe 1948-1954, New York: Praeger.

Holzer, Jerzy (2012), Europa zimnej wojny, Warszawa: Znak.

Landau, Zbigniew (1987), "Etapy rozwoju Polski Ludowej”, Przegląd Historyczny 78, 2, 211-250.

Lange, Oscar (1966), O socjalizmie i gospodarce socjalistycznej, Warszawa: Wydawnictwo Naukowe PWN.

Lem, Stanisław (1982), "Profesor A. Dońda (Ze wspomnień Ijona Tichego)”, in: idem, Dzienniki gwiazdowe: Wydanie rozszerzone, Kraków: Wydawnictwo Literackie, 487-521.

Leszczyńska, Cecylia, (2013), "Socjalistyczny neomerkantylizm. System rozliczeń obrotów płatniczych między państwami socjalistycznymi w latach 1945-1970”, in: Jachowicz Piotr (ed.), W poszukiwaniu modelu gospodarki centralnie kierowanej, Warszawa: Oficyna Wydawnicza Szkoły Głównej Handlowej w Warszawie, 107-124.

Luszniewicz, Jacek (2009), "Wzorzec radziecki a system Polski w latach 1944-1956. Odwzorowanie, modyfikacja czy rewizja”, Konrad Rokicki, Sławomir Stępień (eds), W objęciach wielkiego brata. Sowieci w Polsce 1944-1993, Warszawa: Instytut Pamięci Narodowej, 95-122. 
Jarosz, Dariusz (2013), „Mały indywidualizm”[!!!], in: Jachowicz Piotr (ed.), W poszukiwaniu modelu gospodarki centralnie kierowanej, Warszawa: Oficyna Wydawnicza Szkoły Głównej Handlowej w Warszawie.

Kalecki, Michał (1963), Zarys teorii wzrostu gospodarki socjalistycznej, Warszawa: Wydawnictwo Naukowe PWN.

Khlevnyuk, Oleg (2006), „Economic Officials in the Great Terror, 1936-1938”, in: Stalin's Terror Revisited, ed. Melianie Ilič, Houndmills-New York: Palgrave Macmillan, 38-67.

Kloc, Kazimierz (2013), "Narodziny ekonomii politycznej socjalizmu - perspektywa wewnątrzsystemowa", in: Jachowicz Piotr (ed.), W poszukiwaniu modelu gospodarki centralnie kierowanej, Warszawa: Oficyna Wydawnicza Szkoły Głównej Handlowej w Warszawie, 29-50.

Kornai, János (1980), Economics of Shortage, Amsterdam-New York: North Holland.

Kornai, János (1992), The Socialist System. The Political Economy of Communism, Princeton: Princeton University Press.

Kowalik, Tadeusz (2006), Spory o ustrój społeczno-gospodarczy w Polsce. Lata 1944-1948, Warszawa: Wydawnictwo Key Text \& Instytut Nauk Ekonomicznych PAN, 2006.

Marszałek, Antoni (1993), Planowanie i rynek w RWPG. Geneza niepowodzenia, Łódź: Wydawnictwo Uniwersytetu Łódzkiego.

Morawski, Wojciech (2007), „Poglądy gospodarcze Władysława Gomułki”, in: Elżbieta Kościk, Tomasz Głowiński (eds), Gospodarka i społeczeństwo w czasach PRL-u (1944-1989), Wrocław: Gajt, 326-332.

Mastny, Vojtech (2006), Stalin i zimna wojna. Sowieckie poczucie bezpieczeństwa, trans. Małgorza Werner, Warszawa: Trio.

Różański, Henryk (1990), Spojrzenie na RWPG. Wspomnienia-dokumenty-refleksje 1949-1988, Warszawa: Wydawnictwo Naukowe PWN.

Rupnik, Jacques (1989), The Other Europe. The Rise and Fall of Communism in East-Central Europe, New York: Pantheon Books.

Rutland, Peter (1992), The Politics of Economic Stagnation in the Soviet Union: The Role of Local Party Organs in Economic Management, New York: Cambridge University Press.

Skrzypek, Andrzej (2002), Mechanizmy uzależnienia. Stosunki polsko-radzieckie 1944-1957, Pułtusk: Wyższa Szkoła Humanistyczna.

Skrzypek, Andrzej (2005), Mechanizmy autonomii. Stosunki polsko-radzieckie 1956-1965, Pułtusk: Wyższa Szkoła Humanistyczna.

Wakar Aleksy, (1963), Morfologia bodźców ekonomicznych, Warszawa, Wydawnictwo Naukowe PWN.

Wilk Kazimiera, (1994), Integracja wschodnioeuropejska. Powstanie, funkcjonowanie i upadek, Wrocław: Wydawnictwo Akademii Ekonomicznej.

Zubok, Vladislav and Pleshakov, Constantine (1996), Inside the Kremlin's Cold War: from Stalin to Khrushchev, Cambridge-London: Harvard University Press.

Zwass, Adam (1989), The Council for Mutual Economic Assistance. The Thorny Path from Political to Economic Integration, Armonk-London: M.E. Sharpe. 


\title{
Muddling Through the European Bloc System: The Evolution of Italian-Polish Relations over the 1970's and 1980's
}

\author{
Sara TAVANI
}

\begin{abstract}
This article discusses the role Italian Ostpolitik played in normalising Warsaw's postwar relations with Western Europe, as well as in encouraging a greater Polish confidence in the EC/EU security prospects. All of which anticipated Poland's democratic transition and eventual access to the European Union. The intensifying Italian-Polish dialogue and economic cooperation over the 1970's and 1980's, both encouraged Poland's reform process and assuaged its wariness regarding changes in the continental status-quo. These bilateral dynamics are investigated against the backdrop of an awakening vision of the European Union, envisioned to become independent from the bloc system and based upon mutual interdependence.

Keywords: Italian Ostpolitik, Polish Westpolitik, European Détente, European security, Interdependence
\end{abstract}

\section{Introduction}

This paper will discuss the role played by Italian Ostpolitik in normalising Poland's post-war relations with Western Europe, as well as in encouraging a greater Polish confidence in the EC/EU security prospects, all of which anticipated Poland's democratic transition and eventual access to the European Union. During the 1970's and 1980's, Poland faced continuous and significant changes on both its domestic as well as international stages. In fact, Polish economic and social reforms, launched under Edward Gierek at the beginning of the 1970's, became more articulated over the following years and went hand in hand with the transformation of EastWest relations in Europe. ${ }^{1}$ This meant an evolutionary and varied perception of the European building process on the part of Poland, since both the subject and the object of this perception were changing. Poland was, indeed, experiencing the economic and social consequences of its domestic reforms, as well as its overtures towards the West, especially towards Western Europe. At the same time, the nature itself of political cooperation in Europe was starting to develop, both between Eastern and Western countries and among the EC members themselves, with the introduction

1 Works on this subject include Wilfried Loth, George H. Soutou (eds.), The Making of Détente: Eastern and Western Europe in the Cold War, 1965-75, London-New York: Routledge, 2008; Piers N. Ludlow (ed.), European Integration and the Cold War: OstpolitikWestpolitik, 1965-1973, London: Routledge, 2007; John Van Oudenaren, Détente in Europe. The Soviet Union and the West since 1953, Duhram: Duke University Press, 1991. 
of the EPC (European Political Cooperation) and the emergence of the European Union project. ${ }^{2}$

Italian diplomatic records from the Giulio Andreotti Archive $^{3}$ shed light on the evolution of the Italian-Polish relations over these years and provide insight on how Poland weighed the transformations that were sweeping across the continent as well as the role that the country could play in this changing Europe. The resulting image is of a lingering wavering between attraction and mistrust towards the European Community as well as the European Union project. On one hand, the Polish government, and the Polish society as well, took great interest in a unified and independent Europe that was gaining popularity in the early 1970's. In fact, this ideal Europe envisioned becoming a geo-strategic pole independent from the superpowers, rescued from the bloc system of balance, and prosperous, thanks to expanded social and economic ties. In this new Europe, Poland would have been able to rediscover its historical roots without security concerns that included territorial revisionism, as well as its political and economic subordination. On the other hand, the Polish government often exhibited wariness towards this ambitious plan, which the West European countries were carrying out between ups and downs. The attraction was therefore hampered by a lack of confidence in the European ability to scrap national interests and discords in order to build a reliable security framework. The rapprochement to Western Europe also jeopardized Polish relations with its Eastern allies, especially the Soviet Union and the German Democratic Republic. This was to be avoided, since the security ties with the Warsaw Pact remained irreplaceable as long as the security of the continent lied upon the military blocs.

Italian-Polish relations during the 1970's and 1980 have clearly mirrored Poland's hesitations, especially after the crisis of détente had plunged confidence levels between the East and West. In fact, Poland's dual perception of the European Community corresponded to the Italian diplomatic efforts that included encouraging Polish European vocation while, at the same time, assuaging its security and economic concerns, by way of reasserting European Union credibility. This was especially true in early 1980's, when Polish uncertainties became greater and thereby badly soured the sensitive course of German-Polish relations, following the INF (Intermediate Nuclear Forces) deployment on German soil and the election of the CDU-FDP coalition. Italian diplomatic initiatives,

2 Cf. among others Angela Romano, "The main task of European Political Cooperation: fostering détente in Europe", in Poul Villaume, Odd A. Westad (eds.), Perforating the Iron Curtain: European Détente, Transatlantic Relations, and the Cold War, 1965-1985, Copenhagen: Museum Tusculanum Press, 2010, pp. 123-142; Daniel Möckli, European Foreign Policy during the Cold War, London: I. B. Tauris, 2009, pp. 95-139.

3 Giulio Andreotti Archive (GA) is currently part of the Historical Archive of the Luigi Sturzo Institute (ASILS), Rome. 
such as the 1984 visit to Warsaw by Foreign Minister Giulio Andreotti, filled the vacuum deriving from Chancellor Kohl's diplomatic troubles in Central Europe as well as President Mitterrand's difficulties in conciliating French Ostpolitik with his human rights policy. At the same time, Italian diplomatic activity was also directed towards its European allies with the aim of re-launching political as well as military integration, so to make the European project more attractive; the 1983 Stuttgard Resolution, based upon the Colombo-Genscher Plan, and the 1984 WEO (Western European Organization) update were intended to inspire greater credibility. ${ }^{4}$

These diplomatic initiatives succeeded in reintegrating Poland into a normalized circuit of East-West relations as well as fostering a more active role, on the part of Warsaw, in the European pursuit of concrete confidence-building and disarmament measures at the Stockholm Conference. These efforts ultimately persuaded the Polish government to accelerate its reform process and accept the dismantlement of the bloc system. Gorbačev's reforms and the NATO Eastern enlargement, which implied a stretching of the US strategic guarantee to Poland, certainly had a fundamental role in this process. Nonetheless, this bipolar evolution could not be more than a strategic frame of both a peaceful inter-European coexistence and a final settlement of the post-war inheritance.

\section{The intensifying Italian-Polish cooperation following the normalisation of Polish-West German relations}

Poland's attraction to Western Europe was greatly boosted by the 1972 ratification of the Treaty between Warsaw and Bonn. In fact, the treaty formally provided for Bonn's acknowledgement of the Oder-Neisse post-war border ${ }^{5}$ and it represented the first breach in the Iron Triangle policy, which had traditionally committed Poland, East Germany and Czechoslovakia to a firm policy of closure towards the West. ${ }^{6}$

4 Recent works on the Italian role in the EC/EU integration process include Antonio Varsori, L'Italia e la fine della guerra fredda: La politica estera dei governi Andreotti (1989-1992), Bologna: Il Mulino, 2013, and La Cenerentola d'Europa. L'Italia e l'integrazione europea dal 1947 ad oggi, Soveria Mannelli: Rubbettino, 2010; Piero Craveri, Antonio Varsori (eds.), L'Italia nella costruzione europea. Un bilancio storico (1957-2007), Milano: Franco Angeli, 2009; Luciano Tosi (ed.), L'Italia e la dimensione sociale nell'integrazione europea, Padova: Cedam, 2008.

5 See Wanda Jarząbek, "Polish reactions to the West German Ostpolitik and East-West détente, 1966-1978", in Perforating the Iron Curtain,cited above, pp. 35-56, and Krzysztof Ruchniewicz, "Ostpolitik and Poland", in Carole Fink, Bernd Schaefer (eds.), Ostpolitik, 1969-1974: European and Global Responses, Cambridge: Cambridge University Press, 2009, pp. 39-57.

6 Cf. Pierre-Frédéric Weber, Le Triangle RFA-RDA-Pologne (1961-1975). Guerre froide et normalisation des rapports germano-polonais, Paris: L'Harmattan, 2007, pp. 51-168. See 
Willy Brandt's Ostpolitik was not able to alleviate all of the Polish concerns regarding the Oder-Neisse border, especially due to the perception that it was not fully accepted by several German political and public circles, such as the Exiles' Association. ${ }^{7}$ Despite this, as the US State Department had predicted ${ }^{8}$, the Warsaw treaty brought about a general improvement in German-Polish as well as European East-West relations by curbing the satellites' political reliance on Moscow, consequently increasing Soviet bloc fragility along with East German isolation. Moreover, the treaty went hand in hand with a collective call for pan-European negotiations aimed at reshaping the continental security system and reinforcing East-West cooperation. ${ }^{9}$ These calls partially derived from and fulfilled the Polish quest for a commonagreement on Central Europe which the Warsaw government had started to envisage in 1957 with the so-called Rapacki or Gomutka Plan. ${ }^{10} \mathrm{In}$ this new climate of confidence-building, Poland began to develop its Westpolitik, by establishing a wider range of closer diplomatic, commercial and cultural relations with Western Europe. Gierek actively promoted several political improvements in Polish Western relations, which included greater freedom of movement and a more flexible policy on family reunions. ${ }^{11}$ This rapprochement fostered Polish commercial relations with the EC members and with the EC itself by driving Western investments and credits in Poland, thus giving rise to the prosperous, but short-lived, Polish Market Socialism. ${ }^{12}$

also Willy Brandt, Memorie [Erinnerungen], Milano: Garzanti, 1991, pp. 196-238.

7 See Jurij V. Posadnev, Problema zapadnoj granicy PNR v Bundestage FRG v 1969-1972 g, Moskva: Ministerstvo Prosveščenija RSFSR, 1983.

8 "Possible FRG Non-Aggression Pact with Poland", US Department of State background paper, 12.15.1965, Thomson Gale Collection (DDRS), n. 3526, v. 1992.

9 This process was defined by Oliver Bange as "the multilateralisation of Ostpolitik" in "An Intricate Web: Ostpolitik, the European Security System and German Unification", in Oliver Bange, Gottfried Niedhart (eds.), Helsinki 1975 and the Transformation of Europe, Oxford-New York: Berghahn Books, 2008, p. 24. See also Andrej V. Zagorskij, Chel'sinkskij process, Moskva: Prava Čeloveka, 2005.

10 Zoltán Marusza, Denuclearization in Central Europe? The Rapacki Plan during the Cold War, 2008 [coldwar.hu/html/en/publications/Online\%20PublicationMar.pdf], last consulted on 07.10.2013.

11 See Julia von Dannenberg, The Foundations of Ostpolitik: The Making of the Moscow Treaty between West Germany and the USSR, London-New York: Oxford University Press, 2008; Arne Hofmann, The Emergence of Détente in Europe. Brandt, Kennedy and the Formation of Ostpolitik, London-New York: Routledge, 2007; Helga Haftendorn, Coming of Age: German Foreign Policy since 1945, Lanham: Rowman \& Littlefield, 2006.

12 Trade with the West reached $50 \%$ of Polish foreign trade and the productivity rate rose from $4.9 \%$ in 1971 to $8.4 \%$ in 1973. George Andersen, Combat, 16.04.1974. See also COMECON DATA 1979, London: Vienna Institute for Comparative Economic Studies, 1980; Eurostat data reported by Peter Van Ham, The EC, Eastern Europe and European Unity. Discord, Collaboration and Integration since 1947, London-New York: Pinter, 1995. 
Polish Westpolitik, in 1974, led to the Ten-year Agreement between Rome and Warsaw for the development of economic, industrial and technological cooperation. This agreement was required to regulate the growing bilateral commercial and financial exchanges. It also provided for comprehensive cooperation in the economic field, by establishing a Joint Commission of Polish and Italian economic experts in order to translate general provisions into concrete measures. In 1975, the economic Long-term Plan and the Five-year Agreement on economic cooperation completed the terms of the Ten-Year Agreement.

The mid 1970's was therefore the golden period of bilateral cooperation, being that the Italian trade balance was still positive and Polish productivity was still robust. ${ }^{13}$ Exports of Italian goods and machineries, mainly granted by Italian credits, were offset by Polish exports in the energy field, especially coal. This economic synergy was further reinvigorated in October 1977, with Gierek's visit to Rome to sign Italian-Polish protocols on bilateral cooperation. This included the so-called Gierek economic package which provided for new institutional as well as industrial arrangements. According to these agreements, bilateral cooperation had to be enhanced through more intense SME (Small Medium Enterprises) activity, as well as greater exchange diversification.

The protocols also established new bilateral bodies, including a permanent economic committee and working groups within the Joint Commission. Albeit, the Rome Summit in 1977 was also characterized by a dash of pessimism. In fact, Gierek expressed initial concerns regarding Poland's growing dependence on Western credits as well as perplexities regarding outstanding debts and stagnant exports. In response to this, the Polish delegation called for the institution of joint ventures, which aimed to share market risks and improve Polish marketing and export activities. ${ }^{14}$

During his talks in Rome, Gierek also let it be known that Poland feared an escalation in military confrontation within Central Europe, for the most part due to the NATO plans to supply the Federal Republic with neutron bombs, and it was interested in searching for a common ground on security matters. Indeed, Gierek argued that weaknesses in military détente were obstructing political détente and, thus, he held that the SALT agreement between Washington and Moscow was essential to safeguard it. Moreover, prior to arriving in Rome, Gierek had met with Chancellor Schmidt and both leaders had accepted that progress on bipolar disarmament necessitated a more active role on behalf of the medium powers.

13 Cf. Domenico M. Nuti, "The Polish crisis: economic factors and constraints", in Socialist Register, vol. 18, 1981 [socialistregister.com/index.php/srv/article/view/5463], last consulted on 07.10.2013.

14 "Cooperazione economica e industriale italo-polacca", Italian Ministry of Foreign Affairs (IMFA) preparatory study in view of Edward Gierek's visit to Rome, 17-19.10.1977. GA, ASILS, Polonia, Personalità A-K, Gierek, f. 572. 
Therefore, this opened the way for Poland, West Germany and Italy to play direct roles in promoting general disarmament. ${ }^{15}$

In 1977, Gierek was therefore showing signs of uncertainty regarding the solidity of his economic policy as well as fret regarding the Atlantic military plans. Yet, in spite of the emerging concerns, Poland's approach to its Western neighbours was still collaborative and greatly differed from the Soviet approach which was becoming more wary and defensive. ${ }^{16}$ Therefore, the Western countries, including Italy, were strongly keen on maintaining this state of affairs, even if this meant to invest huge amounts in the ever more tottering Polish economy.

Several Italian industries, including FIAT, FINSIDER, the ENI Group, Montedison as well as numerous SME, were involved in Italian-Polish trade, with the car industry having the leading role. This bilateral cooperation was financed by 1975 credits from Mediobanca, for about $\$ 300$ million, and from IMI, for about $\$ 200$ million. ${ }^{17}$ Moreover, Warsaw obtained further large financial concessions in 1977. The Italian Minister of Foreign Trade Rinaldo Ossola visited Poland in June offering new credits for the enlargement of the FIAT-POLMOT joint ventures as well as the FINSIDER project for realizing a coal pipeline between Katowice and Trieste $^{18}$. In October, Gierek bargained in Rome for new credit lines, including \$ 300 million for the steel industry, \$100 million for the textile and chemical sectors, and $\$ 75$ million for the engineering industry. ${ }^{19}$

The Italian government also invested greatly in cultural and social exchanges, which included joint cultural events, fellowships, and visiting professorships. To this regard, in 1977, Italian diplomats registered with satisfaction that bilateral cooperation in these fields was "very good" and this led the Italian Ministry to record that "Poland looks on Italy as one of its strong links with the European world and culture". ${ }^{20}$

An even greater impetus was observed in scientific and technological cooperation, which gave evidence of Poland's desire to overcome its technological gap. Moreover, Italian-Polish relations also benefited from the ongoing normalisation

\section{Ibid.}

16 Cf. Georges Sokoloff, The economy of Détente. The Soviet Union and Western Capital, Hamburg-New York: Berg-Leamington Spa, 1987, pp. 177-179.

17 "Interscambio commerciale italo-polacco", Italian Ministry of Foreign Affairs (IMFA) preparatory study in view of Edward Gierek's visit to Rome, 17-19.10.1977, GA, ASILS, Polonia, Personalità A-K, Gierek, f. 572.

18 Minister of Foreign Trade Rinaldo Ossola to Prime Minister Giulio Andreotti, Rome, 8.6.1977, GA, ASILS, Polonia, Personalità A-K, Gierek, f. 572.; “Cooperazione economica e industriale italo-polacca", Italian Ministry of Foreign Affairs (IMFA) preparatory study in view of Edward Gierek's visit to Rome, 17-19.10.1977, cited above.

19 Ibid.

20 "Cooperazione culturale italo-polacca", IMFA/ Directorate General for Cultural Cooperation preparatory study in view of Edward Gierek's visit to Rome, 17-19.10.1977. GA, ASILS, Polonia, Personalità A-K, Gierek, f. 572. 
between the Polish State and the Polish Catholic Church. Gierek allowed Catholics a more active role in public life and he settled old controversies, including Church claims regarding confiscated property. ${ }^{21}$ The Italian government reacted very positively to these concessions. Indeed, Rome retained that the Catholic Church's greater public role would have weakened Poland's ties with Moscow, due to the "national" and "identity value" of the Polish Kościól and its traditional role in impeding foreign assimilation policies. ${ }^{22}$

\section{Polish need for the Soviet guarantee}

Poland's growing attraction towards West Europe and the EC during the 1970's did not eradicate the Polish need for the Soviet security guarantee. Following WW II, the Polish regime considered the establishment of close relations with Moscow and, later, its entry into the Warsaw Pact, as not only due to a strained Sovietisation of the Eastern Europe but, above all, to an assessment of its practical needs. Concerning this, Wojciech Jaruzelski commented: "Considering its territory and its geo-political situation, Poland cannot be a free electron. When, following WW II, we found ourselves in a different and divided world, our place naturally was in the Warsaw Pact. I don't say now that it was for the good or for the bad, I just say it was natural". ${ }^{23}$

In Jaruzelski's reflection, it was thereby the nature itself of the European relations at the end of the war, above all the Oder-Neisse vulnerability, together with the progressive shaping of the post-war balance of power on the continent that induced the country to take its position within the Eastern bloc. Some Polish intellectuals, such as Stefan Kisielewski, shared this opinion..$^{24}$ Diplomatic records indicate that Italian diplomats were well aware of the set of "historical, geographical and political factors" that were conditioning Polish foreign policy. ${ }^{25}$ The Polish border provisions in the Warsaw Treaty substantially improved the Polish perception of West Germany and, therefore, of the West European integration process, but they did not replace an international settlement or avoid the need for a Soviet guarantee.

21 "Programmi polacchi riguardo alla normalizzazione delle relazioni con la Chiesa", telegram from the Italian Ambassador to Warsaw Manlio Castronuovo, 25.11.1971. GA, ASILS, Polonia, Personalità, Wyszinksi, f. 567.

22 "Relazioni Stato-Chiesa", IMFA preparatory study in view of Edward Gierek's visit to Rome, 17-19.10.1977. GA, ASILS, Polonia, Personalità A-K, Gierek, f. 572.

23 Wojciech Jaruzelski, Interv'ju -Radiostancija Echo Moskvy, 09.5.2005 [echo.msk.ru/ guests/2606], last consulted on 07.10.2013.

24 Stefan Kisielewski, “Komu potrzebna jest Polska?”, in Tygodnik powszechny, n. 9, 1990, pp. 1-5.

25 "Politica estera polacca", IMFA preparatory study in view of Edward Gierek's visit to Rome, 17-19.10.1977. GA, ASILS, Polonia, Personalità A-K, Gierek, f. 572. 
Moreover, the Polish rush towards the West started to slow down in the late 1970 's, due to the crumbling of Poland's economy and strains within the society. Poland's foreign debts continued to rise with the deterioration of its trade balance. Being so, the Warsaw government was forced to curb its imports, therein, the EC countries suffered for the consequential fall in bilateral exchange. ${ }^{26}$ From 1976 onwards, Polish domestic production decreased and an inflationary spiral drastically slashed Poles' spending power and living standards. Moreover, Gierek's economic reform had produced a hybrid system, where elements of market and planned economy found it difficult to cohabitate, while the international monetary crisis severely reverberated within the Polish economy which was now exposed to international monetary volatility. Worker and intellectual protests then started to add social instability to this gloomy economic picture. The social effects of the economic crisis and the expectations brought about by the CSCE negotiations spawned forms of organized opposition, such as the KOR (Komitet Obrony Robotnikow). ${ }^{27}$

This domestic unraveling had a direct impact on the wavering Polish foreign policy since it harshly reminded Gierek of the limits in his international options. Indeed, in late 1977, the Farnesina noted that Polish-Soviet relations had returned to a state of "complete alignment" and this was attributed to both the economic crisis and the changing political climate within the socialist bloc following the European Communist Party Conference in East Berlin in June 1976, where the CPSU started to re-impose its authority.

According to Rome, Poland's realignment with Moscow was encouraged by the Soviet initiatives to restore socialist integration "through ideological, political and military commitments" ${ }^{28}$ In fact, around the mid 1970's the Soviet Union introduced unpopular conservative reforms into its bloc. COMECON reforms sought to tighten integration among the allied economies. In 1975, the Concerted Plan of Multilateral Integration Measures endorsed a better sharing of bloc resources as well as improved exchanges. ${ }^{29}$ The Soviet command within the Warsaw Pact was further consolidated through modifications in the Political Advisory Committee. ${ }^{30}$ Concurrently, Moscow promoted bilateral agreements as well as constitutional reforms in the East European countries that sought to reinforce inter-allied political alignment. According to the Italian diplomatic corps, these integration efforts were being bolstered by mutual

26 "Commercio italo-polacco", IMFA preparatory study in view of Edward Gierek's visit to Rome, 17-19.10.1977. GA, ASILS, Polonia, Personalità A-K, Gierek, f. 572.

27 "Polica interna polacca", IMFA preparatory study in view of Edward Gierek's visit to Rome, 17-19.10.1977. GA, ASILS, Polonia, Personalità A-K, Gierek, f. 572.

28 "Politica estera polacca", cited above.

29 Cf. William V. Wallace, Roger A. Clarke, Comecon Trade and the West, London: Frances Pinter, 1986, pp. 5-11; Joseph Pelzman, "Soviet-Comecon trade: the Question of IntraIndustry Specialization", in Review of World Economics, n. 2, vol. 114, 1978, pp. 297-304.

30 See Anatoly I.Gribkov, Sud'ba Varšavskogo Dogovora. Vospominanija, dokumenty, fakty, Moskva: Russkaja Kniga, 1998, pp. 23-36. 
visits and agreements among East European countries, including the renewal of the Polish-East German Treaty of Friendship, Cooperation and Mutual Assistance. ${ }^{31}$ A first consequence of this in Poland was the 1975 constitutional reform, which granted constitutional value to the socialist character of the state and its "indissoluble" alliance with Moscow. A second consequence was the signing of the November 1976 joint declaration where Polish alignment with Moscow was formally cited, together with a clear reference to the Brežnev Doctrine. ${ }^{32}$

Polish leadership and the society were distressed for the return to a policy of bowing to the Soviet positions, confirmed by Gierek's visit to Moscow in November 1976. The principle of bloc resource sharing was not enthusiastically accepted within the COMECON community and thereby it failed to produce economic solidarity. The 1975-1976 political reforms immediately provoked protests among intellectual and Catholic circles, which coupled with riots in Ursus and Radom instigated by rising staple prices. ${ }^{33}$

In face of this, the Warsaw government tried to make up for the tightening of its Eastern ties by maintaining diplomatic contacts with West European countries. In fact, the normalisation of Polish relations with West Germany was not interrupted, but it was further enhanced by Gierek's visit to Bonn, in July 1976, and Chancellor Schmidt's visit to Warsaw, in December 1977. The same can be said for Polish relations with other West European countries, such as the 1977 visits by Gierek to Paris and Rome. ${ }^{34}$

Even if the Polish international stance during the 1970's remained strongly anchored to the Soviet concept of European security, according to the Italian analysis the Polish government appeared to be open to different alternatives. Unlike the Russian perspective, "the Polish vision" was considered "non-static". ${ }^{35}$ The Warsaw government was persuaded that the Helsinki Final Act was the grounds for "a peaceful evolution of European cooperation over the next decades". ${ }^{36}$ and it demonstrated this conviction by exercising a more flexible stance at the 1977 Belgrade Conference, where the Polish delegation adopted a proactive approach, far less polemic than the Soviets' and other satellites'. ${ }^{37}$ According to Rome, this

31 Other examples include Ceaușescu's 1977 visit to Warsaw and his signing of the PolishRomanian joint declaration, Gierek's 1977 visits to Prague and Budapest, and Prime Minister Jaroszewicz's visit to Sofia in October 1977.

32 "Politica estera polacca", cited above.

33 "Politica interna polacca", cited above.

34 "Politica estera polacca", cited above.

35 "CSCE: posizione polacca", IMFA preparatory study in view of Edward Gierek's visit to Rome, 17-19.10.1977. GA, ASILS, Polonia, Personalità A-K, Gierek, f. 572.

36 Cf. Wanda Jarząbek, "Preserving the status quo or promoting change: the role of the CSCE in the perception of Polish authorities", in Helsinki 1975 and the Transformation of Europe, cited above, pp. 144-159.

37 "CSCE: posizione polacca", cited above. 
suggested that there was a constant quest for a reliable European security system behind the Polish wavering.

\section{East or West: a challenging choice for Poland}

From the end of the 1970's, the failure of Polish Market Socialism became undeniable and brought about a full rejection of Gierek's half-reformed system. This fueled both the ongoing domestic confrontation between the state and the society as well as the Soviet pressures for a quick repression of mounting political opposition. Solidarity leaders demanded radical reforms which, according to the Italian Ambassador to Warsaw Marco Favale, would have not been tolerated by the Soviet Union due to its fear of a Polish "Westernisation" process, even in the form of a "third way". ${ }^{38}$ Acceleration in domestic liberalisation would have therefore pushed Warsaw to a breaking point with Moscow. Therefore, the introduction of Martial Law halted a domestic evolution that the Polish government feared it could not control.

To this regard, in 1982, Ambassador Favale reminded Rome of the natural limits of Polish autonomy from Moscow. In fact, both Warsaw and Moscow still shared the persuasion that the Helsinki principle of boundary inviolability, the Ostverträge and the Quad's agreements represented a whole: according to the old Latin dictum "simul stabent, simul cadent", they all would have been respected or none of them would have been. ${ }^{39}$ This meant that Warsaw was as persuaded as Moscow that East-West coexistence and cooperation in Europe had to be based upon the West's acceptance of Eastern regimes and, especially, the East German regime.

In the early 1980's Poland was still caught between change and restoration which led to a choppy Polish foreign policy during the 1980-81 crisis. The country strove to restore political and economic support from the Soviet Union and the other socialist countries without permanently jeopardizing its Western relations. In fact, the Polish government was avoiding making a radical choice regarding the orientation of its foreign relations. The resulting behaviour was a Polish wavering between a policy of reassurance towards its Eastern allies, regarding its unbroken loyalty towards both the Warsaw Pact and socialist ideals, and a quest to justify to West European governments the hard choices it had been forced to take by introducing Martial Law.

According to the Italian government, what the Poles were truly seeking was a "historical normalisation" of their foreign relations, not only an "economic and "psychological" one, with a central focus on the traditional claim regarding the

38 Note from the Italian Ambassador to Warsaw Marco Favale (without date, attributable to 1982). GA, ASILS, Polonia, Viaggi 1981 and 1984, f. 569.

39 Note from the Italian Ambassador to Warsaw Marco Favale (without date, about May 1982).

GA, ASILS, Polonia, Ambasciata, f. 567. 
international acknowledgement of the Oder-Neisse border. ${ }^{40}$ The Polish leadership was therefore described as "chased by the ghosts of its history and torn between the Western and the Eastern calls". ${ }^{41}$

The normalization of Polish Eastern relations remained a top priority for the country until the mid 1980's since the Soviet bloc still was its first security reference. Jaruzelski's visits to allied countries between 1982 and 1984 helped to restore a positive inter-allied climate, with the only exception of EastGermany. Above all, Polish-Soviet relations were developing in a very satisfactory manner, following Brežnev's initial suspicions concerning the ambiguities of Jaruzelski's Martial Law. ${ }^{42}$ The improvement in bilateral relations brought about a renewed political endorsement, as well as substantial financial aid from Moscow, both of which favoured a certain expansion of Polish trade in the COMECON area. ${ }^{43}$

Regarding the West, the normalisation of Polish relations with Western Europe remained an urgent issue. Uncertainties regarding the continuity of Western credit flows and the US economic sanctions, triggered by the Solidarity crisis, led to a sudden and severe economic downturn in Poland, due to the highly developed interdependence among the European economies. Nonetheless, this did not mean that the Polish dependence on West European credits could have induced the country to shirk on its Eastern commitments. Indeed, the need for Western support was counterbalanced by military concerns following the deployment of the intermediate nuclear missiles in West Germany and the reopening of a thorny debate on the future of the German military status.

Whenever there were no desirable options, the Polish government simply refrained from choosing. In mid 1980's, Jaruzelski strongly reasserted Poland's commitment to the European project, while at the same time advocating a true "Europeanisation" of the continent. This would have required not just a West European willingness to cooperate with the socialist countries, but also the political acceptance of the socialist governments. ${ }^{44}$ One can also add that this Europeanised Europe, and the acceptance of the existence of a Socialist Germany which it entailed, would have satisfactorily met the Polish security demands. Nonetheless, the sacrifice of the German aspiration to live in a reunified nation was too high a price to ask to bring back Poland into Europe. Therefore, the key to the problem

40 "Politica estera polacca", cited above.

41 Ibid.

42 Brežnev's reacted with initial distrust to Jaruzelski's decision to introduce Martial Law as demonstrated in the CPSU bulletin "Ob oficial'nom vizite partijno-gosudarstvennoj delegacii PNR vo glave s V. Jaruzel'skim v Moskvu 1-2 marta 1982”, 07.03.82, Sovetskij Archiv [bukovsky-archives.net/pdfs/poland/pol-gdr82.pdf],last consulted on 07.10.2013.

43 "Politica estera polacca", cited above.

44 Ibid. 
had to be found in a strengthened European interdependence and in a renewed security system. ${ }^{45}$

\section{The crisis of détente and the 1984 Andreotti visit to Poland}

During the Détente Crisis, Polish domestic tensions were amplified by international concerns generated by the 1979 NATO double-track decision. The looming theatre nuclear missile deployment in West Germany re-instilled old angst in Poland. Moreover, this military development was coupled with an ongoing political upheaval in Bonn, following the 1982 election of Helmut Kohl's centre-right government. The incoming Federal Chancellor reassured Poland that German Ostpolitik would not change under the new government. Nevertheless, the Poles remained suspicious, as demonstrated by the cancelation of the 1984 visit by Foreign Minister Hans-Dietrich Genscher to Warsaw.

Hans-Jochen Voegel, the SPD opposition leader, told Luigi Vittorio Ferraris, the Italian Ambassador to Bonn, that the deterioration of Polish-West German relations was due to both bilateral and wider international circumstances. On one hand, the new CDU leadership had gained its electoral consent on the promises of both renewed West-German-American cooperation, which included the INF deployment, and greater attention to German revisionist circles. On the other hand, Voegel was persuaded that the hurdles that the CDU was encountering could also be seen as a consequence of the lingering strains in bipolar relations as well as a growing instability within the Eastern bloc. ${ }^{46}$

Polish relations with the West, and especially with Washington, temporarily experienced a setback due to Martial Law and the Polish security dilemma. Thereby, a reorientation of Polish political and economic ties towards the Soviet Union became greatly feared, especially by the West German and Italian governments who agreed upon conciliatory gestures having the aim of resuming a confidence-building process. Bonn's diplomatic difficulties, emotionally amplified on the eve of the $40^{\text {th }}$ anniversary of the end of WW II, could have been eased by mediating initiatives on the part of Italy and Western allies. The ongoing renewal of diplomatic contacts between Rome and Warsaw, therefore, along with the planned visit by Honecker to Rome, could have supported the Eastern leaders, including Jaruzelski, in those critical circumstances, by widening their

45 On the concept of "interdependence" cf. Federico Romero, Antonio Varsori (eds.), Nazione, interdipendenza, integrazione. Le relazioni internazionali dell'Italia, 1917-1989, Roma: Carocci, 2006; Ennio Di Nolfo, "La politica estera italiana tra interdipendenza e integrazione", in Agostino Giovagnoli, Silvio Pons, Tra guerra fredda e distensione, Soveria Mannelli: Rubbettino, 2003, pp. 17-28.

46 "Relazioni con la Polonia e la RDT: conversazioni con il presidente del gruppo parlamentare SPD Voegel", telegram by the Italian Ambassador to Bonn Luigi Vittorio Ferraris, 12.12.1984. GA, ASILS, Polonia, Viaggi, f. 571. 
manoeuvring room vis à vis the Soviet Union as well as encouraging a more flexible approachto security issues. ${ }^{47}$

Following the Solidarity crisis, Italian-Polish relations were described by the Farnesina's General Secretariat as "an exception", compared with FrenchPolish and West German-Polish relations, since they were characterised by lack of controversies and greater confidence. ${ }^{48}$ Indeed, Italy was perceived as a less menacing partner than Bonn and the Euromissiles deployed on Italian soil did not arouse the same Polish concerns as those deployed on German soil. Also, Italy's foreign policy was considered by the Poles to be more reassuring than those of other EC countries. Specifically, unlike Mitterrand's and Kohl's electoral successes, the 1983 election of the socialist government led by Bettino Craxi gave the idea of continuity with the Christian Democrat Ostpolitik, especially due to the appointment of Andreotti as Foreign Minister. ${ }^{49}$ Moreover, diplomatic contacts with Rome would have led to better contacts with the Vatican, whose international stances had become extremely influential in Polish domestic affairs.

From January 1982, the Polish government sought to open a diplomatic channel through its embassy in Rome, by inviting Andreotti to Poland in that March, together with three other Christian Democrat deputies. ${ }^{50}$ To this, Andreotti responded "we will see", demonstrating both his openness and his prudence to the offer. ${ }^{51}$ In fact, it was not until December 1984 that Foreign Minister Andreotti made this visit, following the enactment of the first Polish amnesty. Before the visit, Italian diplomats had highlighted domestic and international reasons why the time had come for an official visit: the ongoing relaxation of Polish state-society relations and the Western concerns regarding a possible radicalisation of the Polish policy of reorientation towards the East. ${ }^{52}$

\section{Ibid.}

48 "Polonia", IMFA/Secretariat General report, June 1985. GA ASILS, Europa, Consiglio Europeo di Milano, June 28-29, 1985, f. 377. Due to French public sentiment, at the beginning of the 1980's Mitterrand decided to keep his relations with the Warsaw government at a low profile. Proof of this was the late and low key visit by General Jaruzelski to Paris on 4th December 1985, which was the first bilateral summit following the introduction of martial law.

49 See Ennio Di Nolfo (ed.), La Politica estera italiana negli anni '80, Venezia: Marsilio, 2007, and specifically par. "L'Italia e la Ostpolitik", with contributions by Giorgio Petracchi, Luigi V. Ferraris, Roman Gutkowski, pp. 271-324.

50 Memorandum to Giulio Andreotti, January 1982. GA, ASILS, Polonia, Viaggi 1981 and 1984, f. 569.

51 President of the Parliamentary Commission for Foreign Affairs Giulio Andreotti to the Italian Ambassador to Warsaw Marco Favale, Rome, 18.5.1982. GA, ASILS, Polonia, Viaggi 1981 and 1984, f. 569.

52 "Polonia-situazione interna", IMFA preparatory study in view of Giulio Andreotti visit to Warsaw, 20-22.12.1984. GA, ASILS, Polonia, Viaggi, f. 571. 
This visit had the aim of persuading the Poles that both the evolution of the European strategic scenario would have been risk-free and the European Union would have held great prospects for European security and cooperation. At the summit, Jaruzelski opened the talks reiterating that Poland's close rapprochement to the Soviets was a "historical and contemporary free choice" while refusing the idea that it was a subordinate relationship. ${ }^{53}$ At the say time, anyway, he expressed his will to preserve, as much as possible, the Polish "specificity" and, specifically, Polish economic reforms. However, he also confessed that maintaining such a system had become very onerous. ${ }^{54}$ The Western countries, especially the US sanctions, were jeopardizing the fruits of a decade of economic cooperation, thus forcing Poland to renounce half of its imports which led to serious economic damages. Being so, Jaruzelski concluded that the economic reorientation towards the Soviet Union was not an ideological or emotional choice, but would have been dictated by national interests:"In our opinion, the line to follow is dictated by what the country needs [...]. The iron curtain is historically outdated. Nonetheless, I believe that the reasons for which we need to be cautious in rebuilding our relations with the West are understandable". ${ }^{55}$

These "understandable" reasons obviously includedPoland's "known" security concerns, as the Polish Foreign Minister Stefan Olszowski missed no opportunity to reassert during the meeting. Olszowski said that the Poles were interested in avoiding any new military threat that could arise from Germany and were afraid of the revisionist and revanchist manifestations, specifically of "some declarations which leave open the German problem and question the intangibility of the European boundaries". Moreover, he added that this Polish fear was sharpened by the aggressive behaviour on the part of the US. ${ }^{56}$

Andreotti sought to dissipate these security fears by persuading the Polish Minister that the continental strategic situation would have soon evolved into a new military balance and the Stockholm Conference on Disarmament in Europe (CDE) would have successfully elaborated a concrete platform on arms reduction. He was also confident that the Geneva negotiations between the superpowers would have resumed in 1985, on the wave of intensified contacts between NATO and the Warsaw Pact. Andreotti believed that by visiting Warsaw, he was further encouraging the resumption of the East-West dialogue.

But, as important as the bipolar agreements might have been, according to Andreotti, the task of reforming the inter-European relations lay properly on the

53 Telegram from the General Director of Foreign Affairs, Bruno Bottai, 22.12.1984. GA, ASILS, Polonia, Viaggi 1981 and 1984, f. 569.

54 Ibid.

55 Minutes of talks between Giulio Andreotti and Wojciek Jaruzelski, 22.12.1984, part I. GA, ASILS, Polonia, Viaggi 1981 and 1984, f. 569.

56 Minutes of talks between Giulio Andreotti and Stefan Olszowski, 20.12.1984, GA, ASILS, Polonia, Viaggi 1981 and 1984, f. 569. 
shoulders of European countries: "We are responsible, also bilaterally, for building a new type of relations, where there is total respect for the independence and intangibility of the boundaries of each and every nation, parallel to a shared quest for an active collaboration and forms of economic solidarity". ${ }^{57}$

Andreotti shared the Polish aspirations of garnering the West European solidarity, as well as having safe borders, but he did not recognise the socialist regimes as being unchangeable and unreformable entities. The Helsinki process was turning out to be a path for the rebuilding of the inter-European relations, in which all countries had a role to play while respecting their alliances, but with the ultimate goal of reaching similar stances. The EC facilitated this process through three main goals: 1) engage European countries in the peaceful destruction of the continental armaments; 2) avoid that any new conflict could arise between France and Germany; 3) combine the economies of the European countries in order to strengthen their collective stance.

Olszowski completely agreed with Andreotti that the superpowers needed to be the frame of the picture but it had to be the medium-sized countries within Europe who realised it. Albeit, Olszowski remained skeptical regarding Andreotti's confidence in what he believed would have been a quick improvement in bipolar negotiations. Also, the Polish Minister exhibited certain helplessness when he remarked: "What can we do in Warsaw? We do not have many original ideas. We run in circles around a certain reality deriving from international relations", ${ }^{58}$

Here, once again, Andreotti reassured Olszowski on what he believed were the positive prospects emerging at the Stockholm Conference: the joint declaration on non-use of force, that the Soviet Union and the Eastern countries demanded, should be the framework for practical and well-defined Confidence Building Measures. The Soviets had already facilitated this process by accepting to divide nuclear and conventional problems, that is, separately negotiating to renounce the first use of nuclear arms and renounce the use of force.

\section{Towards a new concept of inter-European relations}

The productive climate of Andreotti's talks in Warsaw was revived by the visit that Prime Minister Craxi made to Warsaw in May 1985. These summits aimed to restore the East-West European dialogue on security and cooperation which, according to the Italian government, had become urgent in the mid 1980's due to the swift resumption of bipolar dialogue. Following the worst years of the Détente crisis, President Reagan softened his Soviet policy, which included both pursuing more pragmatic bipolar relations and achieving concrete agreements. The Soviet Union, on the other hand, following Brežnev's passing, showed growing interest

57 Ibid.

58 Ibid. 
in these US steps which led to Andropov's gambit regarding the INF issue. This more flexible stance was attributed to Soviet collegial and less united direction, as well as bloc instability and technological and economic gaps.

At the end of 1984, the Italian government noted that both the superpowers seemed to be more inclined to reach an agreement on their European differences, by circumscribing the free initiatives of their minor allies. For this, the Italian government was concerned about a "return to a bipolar scheme" of negotiations which would have limited the European role in the security and disarmament talks. To avoid this, as in Helsinki in 1972, Eastern and Western European countries needed to be collectively engaged in order to exert a greater leverage on the superpowers and obtain an active role in the disarmament process. Some Eastern leaders had already independently revitalized their Westpolitik hoping to renew the panEuropean dialogue on security matters. Specifically, the 1984 visits of Kádár to Paris and Ceaușescu to Bonn openly challenged the Soviet opposition. Moreover, in early 1984, the socialist countries had endorsed new joint political documents, such as the April Budapest declaration and the June declaration of the COMECON Political Committee, demanding the renewal of a "policy of dialogue and negotiation with the West based upon realism and concrete collaboration". ${ }^{59}$ These joint initiatives encouraged a more flexible Soviet approach to security and strategic issues and promoted a greater commitment on the part of Moscow to achieve shared goals at the Stockholm CDE Conference. ${ }^{60}$

The efforts of the European countries were rewarded in December 1984, when the CDE negotiations were able to begin, following an agreement on the procedural mechanisms which had, for long time, stalled the opening of the conference. Nonetheless, the positions of participating countries remained far apart: Western countries demanded the introduction of affective CBMs; neutrals requested a drastic reduction in military activity; whereas, Warsaw Pact sought a collective declaration on the non-use of force. The Italian government foresaw a final compromise based on a convergence of these stances. ${ }^{61}$ Through the CDE talks, the European countries would have introduced innovative East-West CBMs, including on-site inspections on demand, as well as pursued an effective reduction of conventional arms. ${ }^{62}$ The Stockholm confidence-building process, therefore, had

59 "Relazioni Est-Ovest", IMFA preparatory study in view of Giulio Andreotti visit to Warsaw, 20-22.12.1984. GA, ASILS, Polonia, Viaggi, f. 571.

60 On the concept of cooperative security cf. James Goodby,Europe undivided, Washington: USIP, 1998, and The Stockholm conference: negotiating a cooperative security system for Europe, Washington: Foreign Service Institute, Occasional Paper n. 6, 1987.

61 "CDE: stato dei negoziati alla Conferenza di Stoccolma dopo la 4a sessione, 14.12.1984", IMFA preparatory study in view of Giulio Andreotti visit to Warsaw, 20-22.12.1984. GA, ASILS, Polonia, Viaggi, f. 571.

62 On this subject cf. John Freeman, Security and CSCE process: the Stockholm Conference and beyond, London: Pelgrave McMillan, 1991; Carl C. Krehbiel, Confidence- and Security 
to provide practical responses to the unresolved post-war differences in Europe, including Polish security concerns. Thus, the Italian government considered the restoration of Poland's active role in this process more important than ever: "It is therefore an evident Western interest to promote as well as respond to these pushes toward East-West dialogue. The gradual reinsertion of Poland into a normalized circuit of political contacts and cooperation with the West European countries continued to respond to this interest, in spite of the difficulties in this process made evident by the recent postponement of Genscher's visit to Warsaw". ${ }^{63}$

Andreotti also insisted that the Poles be more confident in the European Union project, which he considered the only possible solution to the German problem: "if the European Union is realized, the historical danger of an expansionist Germany will be removed" ${ }^{64}$ In fact, the EU envisioned strong links of economic interdependence and military confidence among the European countries, thereby avoiding national conflicts and peacefully including a reunified Germany. Jaruzelski responded to Andreotti's pro-European pronouncements with some overtures. Indeed, he assured the Italian Foreign Minister that Poland would have played a very active role in Stockholm. Moreover, Jaruzelski believed that the appointment of Marshal Sergej Sokolov as Defense Minister would have further softened the Soviet strategic stance. ${ }^{65}$

The Italian-Polish summits were followed by a substantial improvement in Poland's political relations with the EC countries, also due to the parallel resumption of economic relations among them. In 1983, the Italian-Polish trade exchange recorded a significant increase, with a $40 \%$ growth in Italian imports. However, financial support from West Europe did not pick up as fast, given the huge Polish arrears in debt payments. In fact, Warsaw was not able to honour its European debts between 1982 and 1984, with the debt towards Italy reaching $\$ 1.185$ billion, of which $\$ 600$ million was overdue. Being so, the Italian government was very hesitant to grant ulterior credits to Poland, therein, the initial resumption of bilateral exchanges was sustained by Italian industries that resorted to international credit at their risk. ${ }^{66}$

This recovery in bilateral trade initially developed out of the institutional framework and soon regained the support of the Italian-Polish Joint Commission, which

building measures in Europe: the Stockholm Conference, New York: Praeger 1989; John Borawski, From the Atlantic to the Urals: negotiating arms control at the Stockholm Conference, London: McMillan, 1987.

63 "Relazioni Est-Ovest", cited above.

64 Minutes of talks between Giulio Andreotti and Wojciek Jaruzelski, 22.12.1984, part II. GA, ASILS, Polonia, Viaggi 1981 and 1984, f. 569.

65 Ibid.

66 "Relazioni economiche italo-polacche, 12.12.1984", IMFA/ Directorate General for Economic Affairs preparatory study in view of Giulio Andreotti visit to Warsaw, 20-22.12.1984. GA, ASILS, Polonia, Viaggi, f. 571. 
resumed talks in Rome at the beginning of October 1984. To this regard, during Andreotti's visit to Warsaw, a new agreement on economic cooperation was signed which updated the 1975 arrangements. The Italian Foreign Minister also exerted strong pressure on the Italian Minister of Treasury GiovanniGoria to overcome the obstacles in providing new credits. ${ }^{67}$ In 1986, a bilateral agreement on the rescheduling of the outstanding debts was reached and the SACE agency decided to insure the transactions with payment delays for up to 12 months. ${ }^{68}$ This reawakening in Italian-Polish economic relations also took place between Poland and other EC countries, thanks to the Paris Club agreement on the Polish debt rescheduling which led to a noteworthy recovery in bilateral exchanges over the 1984-1985 period, following the bottoming out in 1981-1982. ${ }^{69}$ Therein, Poland was once again strongly attracted to the EC market.

\section{Conclusions}

In the second half of the 1980's the Polish reorientation towards the Soviet bloc was averted. Brežnev's plans to restore a firm Soviet control on a strongly integrated alliance had failed and this fostered new currents of thought among Soviet foreign policy makers, allowing Gorbačev and his new thinking to prevail.

Muddling through the bloc system, Europe was gradually moving away from the post-war order. Nonetheless, Polish uncertainties remained deeply rooted. ${ }^{70}$ From the mid 1980's, Gorbačev had promoted inter-allied reforms granting more political freedom to the socialist countries, thus loosening the intra-bloc relations and weakening the military guarantee of the Warsaw Pact. ${ }^{71}$ These reforms also led to a weaker backing of the East German regime, with unpredictable consequences in inner-German relations. Meanwhile, Gorbačev's proposal to build a Common European Home, with German-Soviet relations as the corner-stone, aroused in Poland old fears of a new Rapallo agreement.

Ambassador Ferraris communicated to Rome in late 1985 that the Bonn government was aware that any further rapprochement to Pankow or Moscow would have been unwelcomed in Warsaw. Albeit, Bonn could not realistically renounce

67 Foreign Minister Giulio Andreotti to the Minister of Treasury Giovanni Goria, Rome, 18.12.1984. GA, ASILS, Polonia, Viaggi, f. 571.

68 "Relazioni economiche bilaterali", FMA preparatory study in view of General Jaruzelski's visit to Rome, 7.11.1987, Rome. GA, ASILS, Polonia, Personalità A-K, Jaruzelski, f. 572.

69 Ibid.

70 See Robert Cooper "Integration and Disintegration", in Journal of Democracy, n. 1, vol. 10, 1999 , pp. 8-21.

71 Cf. The Diary of Anatoly Chernyaev, entries for January 4 and March 30, 1985 (ed. by Svetlana Savranskaja), [www2.gwu.edu/ nsarchiv/NSAEBB/NSAEBB192/Chernyaev Diary_translation_1985.pdf], last consulted on 07.10.2013, and Anatolij S. Černjaev, My Six Years with Gorbachev, University Park: Pennsylvania State University Press, 2000, p. 12. 
its inner-German relations along with its renewed relations with the Soviet Union. ${ }^{72}$ In March 1985, Genscher dropped in on Warsaw and in September 1985 a meeting took place between Jaruzelski and Genscher alongside a UN Assembly reunion. Ambassador Ferraris held that the meetings had not produced any serious rapprochement on strategic issues, due to the recurrent Polish proposal to create a nuclear as well as chemical arm free zone in Central Europe. According to Ambassador Ferraris, the Poles still feared that a reunified Germany would not have recognized the commitments on the Oder-Neisse taken by the West German government.

Nonetheless, Poland was gradually starting to make overtures, including the approval of an official visit by Genscher to Warsaw. ${ }^{73}$ The Italian government considered both Olszowski's withdrawal from the PUWP electoral list as a signal of change and the Brussels Declaration, endorsed by the Atlantic Alliance in December 1986, as the Western response to the 1984 Budapest Declaration. In fact, the Brussels declaration proposed opening immediate talks, aside and distinct from the MBFR, in order to reach a conventional arms balance at the lowest possible level from the Atlantic to the Urals. During Jaruzelski's visit to Rome, in January 1987, the Italian government repeatedly stressed the significance of such negotiations which had the aim of promoting "a major conventional stability through a balance of power with reduced offensive capacity". ${ }^{74}$ In the Italian opinion, this conventional disarmament was to be pursued before nuclear disarmament, given that, during this process, the bipolar nuclear armaments would have remained an indispensable 'umbrella' for Europe. Indeed, a conventional balance would have curbed the European reliance on nuclear armaments and strengthened both the inter-European confidence and security ties.

The decline of Gorbačev's Common European Home at the beginning of the 1990's quelled the remaining Polish fears of a dominant German-Russian axis. A further assurance came in the form of Poland's entry into NATO. Concurrently, Poland's attraction towards the EC and the promising Single Market continued to grow and Polish economic recovery relied ever more unilaterally on the West. Exploratory talks between the EC and Warsaw initiated in July 1986, with the aim of establishing a trade agreement as well as diplomatic relations between the two. West Germany remained the biggest trade partner for Poland, bringing about an even greater interdependence. ${ }^{75}$ The 1986 Vienna agreement, which outlined

72 Telegram by the Italian Ambassador to Bonn Luigi Vittorio Ferraris, 3.10.1985. GA, ASILS, Polonia, Rapporti con la Germania, f. 574.

73 Ibid.

74 "Visita ufficiale in Italia del Presidente del Consiglio di Stato e Primo Segretario del POUP, Generale Wojciech Jaruzelski (12-14.12.1987). Problemi del disarmo convenzionale", IMFA preparatory study in view of General Jaruzelski's visit to Rome, 7.11.1987. GA, ASILS, Polonia, Personalità A-K, Jaruzelski, f. 572.

75 "EC-Polonia", IMFA preparatory study in view of General Jaruzelski's visit to Rome, 7.11.1987. GA, ASILS, Polonia, Personalità A-K, Jaruzelski, f. 572. 
an ulterior rescheduling of the Polish debt, as well as Poland's accession to the IMF, in May 1986, both greatly contributed to the Polish rapprochement with West European countries. ${ }^{76}$

The renewal of Polish trust in Europe, coupled with the successful conclusion of the Round Table process, represented fundamental advances for building the European Union and promoting its Eastern enlargement. As Andreotti had predicted in Warsaw, the interdependence among the European economies was becoming the new guarantee of cooperation and peaceful coexistence among the European countries.

\section{Bibliography}

Bange, Oliver, Niedhart, Gottfried (eds.), (2008), Helsinki 1975 and the transformation of Europe, Oxford-New York: Berghahn Books.

Bange, Oliver, (2008), "An intricate web: Ostpolitik, the European security system and German Unification", in Bange, Oliver, Niedhart, Gottfried (eds.), Helsinki 1975 and the transformation of Europe, Oxford-New York: Berghahn Books, 43-64.

Borawski, John, (1987), From the Atlantic to the Urals: negotiating arms control at the Stockholm Conference, London: McMillan.

Brandt, Willy, (1991), Memorie [Erinnerungen], Milano: Garzanti.

(von) Dannenberg, Julia, (2008), The Foundations of Ostpolitik: The Making of the Moscow Treaty Between West Germany and the USSR, London-New York: Oxford University Press.

Černjaev, Anatolij S., (2000), My Six Years with Gorbachev, University Park: Pennsylvania State University Press.

COMECON DATA 1979, (1980), London: Vienna Institute for Comparative Economic Studies. Cooper, Robert, (1999), "Integration and Disintegration", inJournal of Democracy, n. 1, vol. 10, 8-21.

Craveri, Piero, Varsori, Antonio (eds.), (2009), L'Italia nella costruzione europea. Un bilancio storico (1957-2007), Milano: Franco Angeli.

Di Nolfo, Ennio (ed.), (2007), La Politica estera italiana negli anni '80, Venezia: Marsilio.

Di Nolfo, Ennio, (2003), "La politica estera italiana tra interdipendenza e integrazione", in Giovagnoli, Agostino, Pons, Silvio, Tra guerra fredda e distensione, Soveria Mannelli: Rubbettino, 17-28.

Fink, Carole, Schaefer, Bernd (eds.), (2009), Ostpolitik, 1969-1974: European and global responses, Cambridge: Cambridge University Press.

Freeman, John, (1991), Security and CSCE process: the Stockholm Conference and beyond, London: Pelgrave McMillan.

Giovagnoli, Agostino, Pons, Silvio, (2003), Tra guerra fredda e distensione, Soveria Mannelli: Rubbettino.

Goodby, James, (1998), Europe Undivided, Washington: United States Institute of Peace Press.

Goodby, James, (1987), The Stockholm Conference: negotiating a cooperative security system for Europe, Washington: Foreign Service Institute, Center for Study of Foreign Affairs, Occasional Paper n. 6.

76 "Debito estero polacco", IMFA preparatory study in view of General Jaruzelski's visit to Rome, 7.11.1987. GA, ASILS, Polonia, Personalità A-K, Jaruzelski, f. 572. 
Gribkov, Anatoly I., (1998), Sud’ba Varšavskogo Dogovora. Vospominanija, dokumenty, fakty, Moskva: Russkaja Kniga.

Haftendorn, Helga, (2006), Coming of Age: German Foreign Policy since 1945, Lanham: Rowman \& Littlefield.

Hofmann, Arne, (2007), The Emergence of Détente in Europe. Brandt, Kennedy and the Formation of Ostpolitik, London-New York: Routledge.

Jaruzelski, Wojciech, (09.5.2005), Interv'ju - Radiostancija “Echo Moskvy” [echo.msk.ru/ guests/2606], last consulted on 07.10.2013.

Jarząbek, Wanda, (2010), "Polish reactions to the West German Ostpolitik and East-West détente, 1966-1978", in Villaume, Poul, Westad, Odd A. (eds.), Perforating the iron curtain: European détente, transatlantic relations, and the Cold War, 1965-1985, Copenhagen: Museum Tusculanum Press, 35-56.

Jarzabek, Wanda, (2008), "Preserving the status quo or promoting change: the role of the CSCE in the perception of Polish authorities", in Bange, Oliver, Niedhart, Gottfried (eds.), Helsinki 1975 and the transformation of Europe, Oxford-New York: Berghahn Books, 144-159.

Kisielewski, Stefan, (1990), “Komu potrzebna jest Polska?”, in Tygodnik powszechny, n. 9, 1-5.

Krehbiel, Carl C., (1989), Confidence- and Security building measures in Europe: the Stockholm Conference, New York: Praeger.

Loth, Wilfried, Soutou, George-H. (eds.), (2008), The Making of Détente: Eastern and Western Europe in the Cold War, 1965-75, London-New York: Routledge.

Ludlow, Piers N. (ed.), (2007), European Integration and the Cold War: Ostpolitik-Westpolitik, 1965-1973, London: Routledge.

Möckli, Daniel, (2009), European Foreign Policy during the Cold War, London: I. B. Tauris.

Nuti, Domenico M., (1981), "The Polish crisis: economic factors and constraints", in Socialist Register, vol. 18 [socialistregister.com/index.php/srv/article/view/5463], last consulted on 07.10.2013.

Pelzman, Joseph, (1978), "Soviet-Comecon trade: the Question of Intra-industry Specialization", in Review of World Economics, n. 2, vol. 114, 297-304.

Posadnev, Jurij V., (1983), Problema zapadnoj granicy PNR v Bundestage FRG v 1969-1972 g, Moskva: Ministerstvo Prosveščenija RSFSR.

Romano, Angela, (2010), "The main task of European Political Cooperation: fostering détente in Europe", in Villaume, Poul, Westad, Odd A. (eds.), Perforating the iron curtain: European détente, transatlantic relations, and the Cold War, 1965-1985, Copenhagen: Museum Tusculanum Press, pp 123-142.

Romero, Federico, Varsori, Antonio (eds.), (2006), Nazione, interdipendenza, integrazione. Le relazioni internazionali dell'Italia, 1917-1989, vol. 1 and 2, Roma: Carocci.

Ruchniewicz, Krzysztof, (2009), "Ostpolitik and Poland", in Fink, Carole, Schaefer, Bernd (eds.), Ostpolitik, 1969-1974: European and global responses, Cambridge: Cambridge University Press, 39-57.

Savranskaja, Svetlana (ed.), The Diary of Anatoly Chernyaev: 1985 [www2.gwu.edu/ nsarchiv/ NSAEBB/NSAEBB192/Chernyaev_Diary_translation_1985.pdf], last consulted on 07.10.2013.

Sokoloff, Georges, (1987), The economy of Détente. The Soviet Union and Western Capital, Hamburg, New York, Berg Publisher-Leamington Spa.

Tosi, Luciano (ed.), (2008), L'Italia e la dimensione sociale nell'integrazione europea, Padova: Cedam.

Van Ham, Peter, (1995), The EC, Eastern Europe and European Unity. Discord, Collaboration and Integration Since 1947, London-New York: Pinter. 
Van Oudenaren, John, (1991), Détente in Europe. The Soviet Union and the West since 1953, Duhram: Duke University Press.

Varsori, Antonio, (2013), L'Italia e la fine della guerra fredda: La politica estera dei governi Andreotti (1989-1992), Bologna: Il Mulino.

Varsori, Antonio, (2010), La Cenerentola d'Europa. L'Italia e l'integrazione europea dal 1947 ad oggi, Soveria Mannelli: Rubbettino.

Villaume, Poul, Westad, Odd A. (eds.), (2010), Perforating the iron curtain: European détente, transatlantic relations, and the Cold War, 1965-1985, Copenhagen: Museum Tusculanum Press.

Wallace, William V., Clarke, Roger A., (1986), Comecon Trade and the West, London: Frances Pinter.

Weber, Pierre-Frédéric, (2007), Le Triangle RFA-RDA-Pologne (1961-1975). Guerre froide et normalisation des rapports germano-polonais, Paris: L'Harmattan.

Zagorskij, Andrej V., (2005), Chel'sinkskij process, Moskva: Prava Čeloveka.

Zoltán, Marusza, (2008), "Denuclearization in Central Europe? The Rapacki Plan during the Cold War" [coldwar.hu/html/en/publications/Online\%20PublicationMar.pdf], last consulted on 07.10.2013.

Archival sources:

Giulio Andreotti Archive (GA), Historical Archive of the Luigi Sturzo Institute (ASILS), Rome.

- Polonia: Ambasciata (567); Viaggi 1981 e 1984 (569); Viaggi (571); Personalità A-K (572); Personalità K-Z (573); Rapporti con la Germania (574).

- Europa: Consiglio Europeo di Milano (377).

Sovetskij Archiv (collected by Vladimir Bukovskij) [bukovsky-archives.net], last consulted on 17.10.2013. Poland.

Declassified Documents Reference System (DDRS). Primary Source Media, Thomson Gale. The Declassified Documents. Vol. 1992. 


\title{
The Transferable Rouble and 'Socialist \\ Integration' - What Kind of Relationship?
}

\author{
Janusz KALIŃSKI \\ Łukasz DWILEWICZ
}

\begin{abstract}
The paper analyses the influence of the introduction of the transferable rouble in 1963 on the integration processes inside CMEA. It places it as a stage in the series of attempts of creating an effective exchange rate mechanism for centrally planned economies. The supposed new international money was still accompanied by general separation of foreign trade from internal markets in the centrally planned economies. Thus it did not perform most of the functions of money and was still merely a unit of account for clearing settlements, not an efficient tool for further integration of Soviet bloc. Quite contrarily, it contributed significantly to its final disintegration, being a part of incoherent institutional status quo.

Keywords: Comecon, CMEA, transferable rouble, international financial integration, Cold War
\end{abstract}

\section{The Council for Mutual Economic Assistance}

Bipolar division of the world after World War II expanded the area under the system of central planning, which was before 1945 reserved only for the territory of the Soviet Union. It was then imposed on the Central European states and became also rooted in the Far East. The beginnings of the Cold War systematically deepened the separation processes in the East-West relations and favoured shaping of distinct economic institutions.

A fundamental organization on the Soviet Bloc's side was the Council for Mutual Economic Assistance (CMEA, Comecon), established by the representatives of the six states (Soviet Union, Poland, Czechoslovakia, Hungary, Bulgaria and Romania) on the meeting in Moscow on January 1949. Initially its tasks were limited to the exchange of experiences, mutual granting of technical assistance, as also cooperation in the spheres of raw materials, food, machines and industrial equipment. ${ }^{1}$ The founding members were successively joined by Albania (1949) and German Democratic Republic (1950), Mongolia (1962), Cuba (1972) and Vietnam (1978). An institutionalized cooperation with the CMEA was later undertaken by Yugoslavia, Finland, Iraq, Mexico, Ethiopia, Yemen, Angola and Afghanistan. A joint declaration about the establishment of official relations between the CMEA and the European Economic Community was signed in 1988.

1 Press release of the Polish Press Agency announcing the establishment of CMEA, $25^{\text {th }}$ Jan. 1949 in: Dokumenty i materiaty do historii stosunków polsko- radzieckich, vol. 9, Warszawa: Książka i Wiedza, 1974, p. 441. 
The activity of Comecon in 1949-1953 was very limited mostly because of the Joseph Stalin's attitude. He exercised the control of the Eastern Bloc countries by the individual bilateral meetings with their leaders, as also by sending them numerous military and economic advisors. The functioning of the Council was based on the organization of the multilateral sessions, pronouncing the need of the development of bilateral relations, especially with the Soviet Union. ${ }^{2}$ From 1954 onwards, the attempts of coordination of economic plans of the member countries were occurring. A few branch commissions, as also lists of products which manufacturing was allocated to specified countries, were created to serve that purpose. ${ }^{3}$

The charter of the organization was enacted as late as in 1959 , on the $12^{\text {th }}$ Session of the CMEA in Sofia.

At the beginning of 1960's, the works over creation of "international socialist division of labour" were started. They focused on exchanging of competition between different member countries by the complementary economic structures, allowing for savings on investment processes. Coordination of economic planning (especially of 5-year plans and long-term prospective plans) was supposed to be the main instrument of ensuring the division of labour. It was not enacted without disagreements. Romania was the main source of resistance to the attempts of creating single planning agency for all member states, as also was obstructing the establishment of a few common economic organizations. Ideological concerns were the reason behind resigning from the participation in the Comecon activities by Albania in 1961.

Main forms of collaboration in the Comecon were the permanent council committees for cooperation in planning and scientific and technical cooperation, as also agreements concerning mutual supplies of goods. However, institutions reflecting break of the national barriers appeared. They included Central Dispatch Administration for the Combined Power Systems (sometimes translated as Central Dispatching Board), allowing for cross-border transmission of energy between USSR, Poland, GDR, Czechoslovakia, Hungary, Bulgaria and Romania. The other institutions of that type in industry included among others: the Organization for Co-operation in Ferrous Metallurgy 'Intermetall' (1964), the Organization for Co-operation in the Bearing Industry (1964), International Branch Organization for Cooperation in Small-Tonnage Chemical Products "Interkhim" (1969), International Organization for Economic and Scientific-Technical Cooperation in the Electrical Engineering Industry, "Interelektro". The leading examples of such cooperation in the transport sector were Common Freight Cars Pool (1963)

2 Andrzej Korbonski, “Comecon”, International Conciliation, 549/1964, p. 7.

3 A significant role was played by the commission for military industry. See: I.V. Bystrova, "VPK SSSR i sozdanye sistemy voenno-ekonomicheskoi integracii stran Vostochnoi Evropy" in: E. Sheinin (ed.), K 60-letiu Soveta Ekonomicheskoi Vzaimopomoshchi, Moskva: Rossijska Akademia Nauk, 2009, p. 101. 
focusing of more efficient use of railroad cars, and Council on the Joint Use of Containers in International Communication. Since the end of 1960's, the term "international socialist division of labour" was exchanged by "socialist integration". The new catchy phrase was understood as coordination of planning and forecasting of economic development, with the main focus on gradual convergence of development levels of national economies of the member countries. The beginning of the 1970's was marked with the preparation of "The Comprehensive Program for the Further Extension and Improvement of Cooperation and the Further Development of Socialist Economic Integration by Comecon Member Countries". It included basic goals, principles and methods, as also specified undertakings, of economic as well as scientific and technological cooperation for time horizon of 15-20 years. Its main fault was multiplicity of goals and lack of clear vision, masked by bureaucratic jargon, striking even in the title of the whole document.

According to "Comprehensive Program", complemented by "The Agreed Plan of Multilateral Integration Measures", multilateral cooperation was developed in primary commodities. Hence decision about the common construction of cellulose, asbestos and iron ore enrichment plants in the USSR. Member countries were also engaged in many projects in energy sector - construction of Khmelnitsky nuclear power plant in Ukraine, construction of power trunk lines to Poland and Hungary, exploitation of Soviet gas deposits, combined with the construction of necessary pipelines.

The crisis of 1980's was accompanied by return to bilateral relations. Member countries were fighting thus numerous shortages and imbalances. It was also reaction to the growing problems with cooperation with the Western countries, resulting from the intensification of the Cold War. ${ }^{4}$

Gorbachev's perestroika brought the last attempts to revive CMEA. The cooperation between enterprises was included in the CMEA activities in 1988, mostly due to arising economic crisis. Document called "Collective Concept of International Socialist Division of Labour" was accepted in 1988. In response to worldwide trends it assumed deep structural changes in order to narrow the technological gap between Comecon members and the developed countries, especially in terms of energy efficiency of manufacturing. ${ }^{5}$

The breakdown of communist system in the European satellite countries and political changes in the Soviet Union caused fall of the Comecon. Official

4 Andrzej Skrzypek, „Etapy rozwoju Rady Wzajemnej Pomocy Gospodarczej” in: Romuald Chwieduk, Andrzej Krawczewski (eds.), 40 lat RWPG. Ewolucja instytucji i struktur socjalistycznej integracji gospodarczej, Warszawa: Polska Akademia Nauk 1988, p. 18 and further.

5 Henryk Różański, Spojrzenie na RWPG. Wspomnienia-dokumenty-refleksje 1949-1988, Warszawa: Państwowe Wydawnictwo Naukowe, 1990, p. 276. 
disbandment of the organization, despite the attempts of its reconstruction, was enacted in Budapest in June 1991.

\section{Systems of trade settlements between the members of Comecon}

The restoration of foreign trade by Central and Eastern European countries in 1944-1945 was based on the pre-war principles. They included exchange, export and import controls, system of settlements and bilateral clearing agreements, special exchange rate mechanism. Commonly used compensation agreements were strictly defining class and quantity of goods subject to exchange on both sides. It was leading to the adjustment of trade volume to the potential of the weaker partner in order to meet the demands of payments equilibrium. Multilateral agreements, softening the requirements of bilateralism, were rarely used. ${ }^{6}$

The beginning of 1950's, together with the deepening isolation of the Soviet bloc, brought abandonment of direct ties between the structures of domestic and world prices based on the exchange rate mechanism. The system of inconvertible and internally circulating currency was created, allowing for autonomous price system on the domestic market. Foreign trade settlements between bank and special foreign trade enterprise were made on the basis of fixed exchange rates of foreign currency for the trade using foreign prices. Settlements between foreign trade enterprise and its domestic customer or recipient of goods were based on domestic prices. ${ }^{7}$ In fact, the exchange rates affected neither the activities of suppliers of exportable goods nor the recipients of imports. Hence the exchange volume was influenced neither by structural and cyclical changes of world prices, nor by changes of domestic prices. ${ }^{8}$

Because of introduction of new monetary and financial systems (with artificial gold parities of the currencies used for calculation of exchange rates) in countries of the Soviet bloc, the basis for international settlements in the countries of Central and Eastern Europe became the clearing rouble, with the overvalued exchange rate of 4 clearing roubles per dollar. Overvaluation was also a feature of the exchange rates of currencies of Comecon countries against currencies of Western countries. ${ }^{9}$

The whole system had to constantly deal with the recurring issue of the level and structure of prices in the trade between the Comecon member countries.

6 A. Korbonski, „Comecon”, p. 37; Stanisław Rączkowski, Międzynarodowe stosunki finansowe, Warszawa: Państwowe Wydawnictwo Ekonomiczne, 1984, p. 373.

7 „Uchwała Rady Ministrów z dnia 17 kwietnia 1950 r. w sprawie zasad organizacji finansowej i systemu finansowego przedsiębiorstw państwowych, objętych budżetem centralnym”, Monitor Polski, 55/1950, pos. 630.

8 Jerzy Wesołowski, Bilans płatniczy $w$ gospodarce Polski, Warszawa: Państwowe Wydawnictwo Ekonomiczne, 1984, p. 119.

9 Jan Głuchowski, Prawnomiędzynarodowe stosunki finansowe państw socjalistycznych, Warszawa, Poznań, Toruń: Państwowe Wydawnictwo Naukowe, 1984, p. 28. 
Initially, the principle, used in the trade relations inside the Soviet Bloc since the end of World War II, was maintained. It included fixing contract prices on the basis of market prices from leading world exchanges from the period of a few months preceding the contract. The price of the good was increased by the half of transport costs which would be paid in the case of its import from a capitalist country. Together with the centralization of command of the economy and turn towards multiannual agreements in the foreign trade, as also in order to become independent from the cyclicality of the world economy, the so-called fixed contract prices ("stop prices") were accepted as a basis. The prices fixed on the base of 1949-1950 period, were binding for first half of 1950's. However, they protected the economies of the Soviet bloc from the effects of fast price growth during the Korean War, but they lead also to big differences between prices of world markets and those of Comecon economies. As a result, every year brought corrections to the prices of exported and imported goods, which meant annual stability of prices in mutual trade flows.

The $9^{\text {th }}$ Session of the Comecon, held in June 1958 in Bucharest, brought the application of the average world prices from a few years preceding conclusion of long-term trading agreements. ${ }^{10}$ New principles eliminated short-term fluctuations of world prices and simultaneously were allowed for following main trends.

Until 1963, settlements between the members of the Soviet bloc (also between Comecon members) were using bilateral clearing, with the clearing rouble as unit of account. It led to balancing of bilateral flows in the yearly periods. Potential positive balances in bilateral settlements could not be used for payments to the third parties. The whole framework enabled trading without gold and convertible currencies, which was with no doubt favourable to weak economies of the socialist countries, reconstructing from the wartime havoc. That state of affairs had some important flaws, above all the necessity of adjusting the volume of trade to the potential of the weaker partner. ${ }^{11}$

The principal breakthrough in the settlements system was supposed to happen in the form of multilateral clearing, a system which was already abandoned five years before by Western European countries in favour of full convertibility. It is worth noticing that Poland reacted to rising obsolescence of bilateral clearing with the proposals of at least partial convertibility of national currencies, allowing for the use of surpluses from the intra-Comecon trade for payments to third parties from

10 Paweł Bożyk, Bronisław Wojciechowski, Handel zagraniczny Polski 1945-1969, Warszawa: Państwowe Wydawnictwo Ekonomiczne, 1971, pp. 195, 203.

11 Eugeniusz Drabowski, System rubla transferowego (Problem zwiazków rubla transferowego ze złotem), Warszawa: Instytut Finansów, 1972, p. 39 and further; Friedrich Levcik, Transferable Rouble and Convertibility, Wien: Wiener Institut für Internationale Wirtschaftsverglieiche, 1978, p. 65; I. Rzendowski, „Wprowadzenie rozliczeń wielostronnych między państwami RWPG”, Życie Gospodarcze, 9/1964, p. 11. 
outside the organization. The initial concepts of Polish side included also far reaching reorganization of the Comecon, increasing the role of smaller states, as also the competences of the whole organization. Multilateralization of settlements was thus from the very beginning a conservative compromise, not a radical reform. ${ }^{12}$

Mid-July 1963 witnessed the acceptance of agreements about the switch to multilateral settlements in the trade among the Comecon countries and creation of the common bank. It was the result of the Moscow meeting of the representatives of leaderships of communist parties and governments of 8 member countries (Bulgaria, Czechoslovakia, GDR, Hungary, Mongolia, Poland, Romania and USSR). "Agreement Concerning Multilateral Settlements in Transferable Roubles and the Establishment of an International Bank for Economic Co-operation" was signed during the $9^{\text {th }}$ Session of the Executive Committee of the Comecon on $22^{\text {nd }}$ October 1963.

The agreement stated, concerning the common bank: "The functions of the Bank shall be:(a) To effect multilateral settlements in transferable roubles; $(b)$ To provide credit for foreign trade and other operations between the Contracting Parties; (c) To encourage the deposit of free funds in transferable roubles and to act as depositary of such funds; (d) To encourage countries members of the Bank and other countries to place gold and freely convertible and other currencies into accounts and deposits with the Bank and to conduct operations with such funds up to the limit of the sums in question (...); (e) To conduct other banking operations in keeping with the aims and functions of the Bank under its Charter". ${ }^{13}$

Capital of the bank, which was joined also later by Cuba (1974) and Vietnam (1977), was set at the level of 300 million roubles and shares of every member depended from the scale of exports in the mutual contacts. Hence Polish share was calculated at $9 \%$ of the whole capital. Creation of the capital was gradual, beginning from $20 \%$ in the first year, and the payments could be made also in gold or convertible currencies. ${ }^{14}$ In 1964 capital amounted to 60 million transferable roubles (including 30 million in convertible currencies), in 1978 to 121.5 million. ${ }^{15}$

The IBEC had the function of a clearing house, and the settlements were made via the accounts opened in the Bank and the accounts of authorized banks from the member

12 Cecylia Leszczyńska, „Socjalistyczny neomerkantylizm. System rozliczeń obrotów płatniczych między krajami socjalistycznymi w latach 1945-1970" in: Piotr Jachowicz (ed.) W poszukiwaniu modelu gospodarki centralnie kierowanej, Warszawa, Oficyna Wydawnicza SGH, 2013, p. 119; Andrzej Skrzypek, Mechanizmy autonomii. Stosunki polsko-radzieckie w latach 1956-1965, Pułtusk, Warszawa: Wyższa Szkoła Humanistyczna w Pułtusku, 2005, p. 253.

13 "Agreement Concerning Multilateral Settlements in Transferable Roubles and the Establishment of an International Bank for Economic Co-operation. Signed at Moscow, on 22 October 1963" ,United Nations Treaty Series, vol. 506, 1964, http://treaties.un.org/doc/ publication/unts/volume\%20506/volume-506-i-7388-english.pdf, p. 218.

14 Ibidem, pp. 218, 220.

15 Zbigniew M. Klepacki, Organizacje międzynarodowe państw socjalistycznych, Warszawa, Państwowe Wydawnictwo Naukowe: 1981, p. 199. 
countries. Documents were addressed to the authorized banks, which were informing the IBEC on the daily basis about the sums of receivables and payments. Basic form of settlements was collection with subsequent acceptance (immediate payment). ${ }^{16}$

Bilateral balance did not have to amount to zero but the general balance was to be achieved between separate states and the rest of the countries participating in the system. Financing of deficits was enabled by the use of IBEC credits. Until 1970 they were of short-term (annual) character, and their interest was between $1.5-2.5 \%$ per annum. The following years brought extension of credit durations and rate increases, reaching $5 \%$ p.a. for 3 -year credit. The system was supposed to foster efficiency and discipline of settlements and maintain the equilibria. In the second half of the 1970's the IBEC was conducting settlements of $60 \%$ of volume of intra-Comecon trade. In 1977 settlements in the transferable roubles amounted to 142 billion transferable roubles, settlements in convertible currencies amounted 79 billion transferable roubles. The surplus of granted credits exceeded 1 billion transferable roubles. ${ }^{17}$ The IBEC participated also in the settlements with the third parties, conducted in gold and convertible currencies.

\section{The transferable rouble - rules and practice}

„Agreement Concerning Multilateral Settlements in Transferable Roubles and the Establishment of an International Bank for Economic Co-operation" stated:

"Article I

Settlements under bilateral and multilateral agreements, or special contracts, for reciprocal deliveries of goods, and under agreements concerning other payments between the Contracting Parties shall, as from 1 January 1964, be effected in transferable roubles.

The gold content of the transferable rouble shall be 0.987412 gramme of fine gold.

Any Contracting Party having funds in transferable-rouble accounts may freely draw on such funds in effecting settlements with other Contracting Parties.

When concluding trade agreements, each Contracting Party shall make provision for the setting off within the calendar year of its total receipts from, and total payments to, all the other Contracting Parties in transferable roubles (...)". ${ }^{18}$

16 Romuald Chwieduk, H. Syroczyńska, „Rozwój struktur organizacyjnych RWPG w świetle dokumentów” in: R. Chwieduk, A. Krawczewski (eds.), 40 lat..., p. 167 and further.; E. Drabowski, System ..., p. 45.

17 Z.M. Klepacki, Organizacje..., p. 200.

18 “Agreement Concerning Multilateral...”, pp. 216, 218. The higher gold parity of the transferable rouble compared to the clearing rouble of 1950's was result of the monetary reform in Soviet Union from April 1961. The internal prices were recounted in the relation 1 new rouble for 10 old roubles. The clearing rouble prices were then recounted in the relation 1:4.44, which implied temporary reduction of the overvaluation against convertible currencies. The transferable rouble acquired its parity just from the new clearing rouble of 1961. Wojciech Morawski, Zarys powszechnej historii pieniqdza i bankowości, Warszawa: Trio, 2002, pp. 193, 356. 
The transferable rouble was created as a unit of account and bank money in the international trade of countries associated in the Comecon, without a link to their national currency system. It was an international currency, created by an international banking institution. The adjective "transferable" indicated distinct character from the rouble, Soviet national currency. But above all, it underlined the possibility of paying for goods and services not only in the country where the receivable was coming from, but also in the other member countries. It was used for clearing settlements, supposedly multilateral, as also for creation of the reserves and accounting the claims. Transferable roubles were achievable either via positive balance of trade with the Comecon countries or via credit from the IBEC or International Investment Bank, which was established in 1970 in order to finance infrastructural and industrial investments of the member countries. There was no possibility of exchanging defined amount of national currency for international currency.

Transferable rouble did not possess main features of international money, because it did not perform the functions of unit of value, means of payment and accumulation. Lack of unit-of-value function was a result of lack of link between the prices of intra-Comecon trade and internal prices in the member countries, as also prices in the world markets. Transferable rouble was only performing the function of conversion rate for world prices denominated in convertible currencies. The means-of-payment function was paralyzed by the limits for purchasing the goods with transferable rouble, resulting from quotas (expressed in terms of quantity or value) included in the long-term trade agreements. Therefore the transferable rouble was not commonly accepted and not exchangeable into goods without limits. Due to quotas, Comecon money could not be a currency reserve, because it did not create the possibility of unplanned purchases. Also the requirement of settling the transactions within a year was preventing the development of the accumulation function of money. ${ }^{19}$

The gold parity was equal to the parity of the clearing rouble and the Soviet rouble, after 1961 monetary reform. It remained stable without any relation to the currency situation of the Comecon countries, inflation level and the business cycle in the capitalist countries. Maintaining the parity was enabled by systemic guarantees to foreign trade and currency monopolies of the state, as also by basing the trade on long-term, planned agreements focusing on compensating the surpluses. The stability of the exchange rate however did not reflect real relations to other currencies. ${ }^{20}$ Józef Rutkowski was more radical, assessing that official rate based on unchanged gold parity was a fiction. ${ }^{21}$

19 Jerzy Wesołowski, System walutowy krajów RWPG, Warszawa: Państwowe Wydawnictwo Ekonomiczne, 1977, p. 103 and further.

20 Ibidem, p. 112

21 Irena Rutkowska, Józef Rutkowski, Problemy wspótczesnej gospodarki światowej, Warszawa: Książka i Wiedza, 1983, p. 370. 
The practice of fixing the rate on the basis of the structure of settlements of Comecon countries with the West, which was started by the IBEC in 1974, also did not help much in that matter. Exchange rate was fixed on the beginning of each month, the basket included 12 currencies (initially 6), which had the share in total settlements exceeding $1 \%$. It was dominated by the American dollar (40\%) and the Deutschmark (13\%). ${ }^{22}$ According to Wesołowski, the conditions of applying in the Comecon trade average world prices from the long term should have been accompanied by similar solutions concerning the exchange rate. Lack of such mechanism prevented from rational setting of the transferable rouble exchange rate against the world currencies. Similar phenomenon occurred also in relation to the national currencies of Comecon member countries. ${ }^{23}$

Before $20^{\text {th }}$ December 1971 the exchange rate against dollar resulting from the relation of gold parities was equal to 1.11 dollar per rouble. Due to devaluation of American currency it appreciated then to 1.20 USD and further to 1.32 USD in February 1973. In 1988 average exchange rate was 1.58 USD; in 1988 it was 1.52 USD. According to calculations of Dariusz Rosati the real exchange rate should be 2.5-3.0 transferable rouble per dollar (0.33-0.40 USD per rouble), which reflected the scale of deviation. ${ }^{24}$ Due to arbitrarily defined exchange rate, Poland was obtaining $25 \%$ of the value of its exports to the USSR. Undervalued exchange rate meant substantial losses of Polish enterprises in the case of exporting items containing components previously imported from the capitalist countries. This phenomenon occurred especially intensively in the case of exporting ships and construction equipment with significant so-called "convertible currency input". In the case of imports from the USSR, such exchange rate was very favourable to the partners of the Soviet side. Poland and other Comecon countries for many years were buying oil and petrochemical products much cheaper than would be in the case of using world prices. The situation changed as late as in $1986 . .^{25}$

The transferable rouble was used in the international trade transactions of the Comecon countries, in which the domestic prices were exchanged by the mentioned "contract prices", which were derived from the world prices. In 1965 the

22 Eugeniusz Drabowski, Pieniqdz międzynarodowy, Warszawa: Państwowe Wydawnictwo Ekonomiczne, 1988, p. 160; Imre Vincze, Międzynarodowy system waluty RWPG, Warszawa: Państwowe Wydawnictwo Ekonomiczne, 1981, p. 308; W. Morawski, Zarys..., p. 193.

23 J. Wesołowski, System..., pp. 114-115.

24 Dariusz Rosati, Poland. Impact of the replacing CMEA trade regime by a market trade, Warszawa, Instytut Koniunktur i Cen Handlu Zagranicznego, 1990, p. 9; Józef Rutkowski, „Koncepcja unii walutowej krajów socjalistycznych”, Sprawy Międzynarodowe, 12/ 1973, pp. 103-115.

25 D. Rosati, Poland..., pp. 9, 45; Leszek. J. Jasiński, Polskie kontakty gospodarcze z zagranica w XX wieku, Warszawa: Warszawska Wyższa Szkoła Ekonomiczna-Polska Akademia Nauk, 2003, p. 193. 
contract prices were based on world prices from 1960-1964, while in 1971-1975 the "stop prices" were based on world prices from the period of the previous 5 -year plan. ${ }^{26}$ Initially, because of the high growth of world prices resulting from the First Oil Shock in 1973, the system of contract prices was favourable for the member countries, importing primary commodities from the USSR. The situation changed in 1975, when, because of inflationary tendencies in the world economy, the principle of yearly corrections of prices in the intra-Comecon trade. The basis of contract prices for every year became the average world prices from 5-year period directly preceeding the given year (so called Bucharest formula or moving price basis). It caused strong price growth on the Comecon market, especially in the case of oil and gas imported from the USSR, which prices remained high due to the formula also in the period of price falls on world markets. ${ }^{27}$

Contract prices were set during bilateral negotiations, focused on finding adequate relations of national currency to the transferable rouble. Different adaptations and subjective multipliers were used in the search of profitability. Thus contract prices of the same goods could be different in separate international transactions. As a result, purchasing power of the transferable rouble against given good was varying and the deviations approached $20 \% .^{28}$

Differentiated purchasing power of accounts denominated in transferable roubles did not stimulate accumulation of reserves in international money. Quite opposite, it created incentives for taking credits from the International Investment Bank (IIB), which was set up in 1970. Initial capital amounted to 1 billion transferable roubles, and consisted of transferable roubles ( $70 \%$ of the total) and convertible currencies (30\%). Polish share was assessed for 13\% (130 million transferable roubles). The bank preferred the especially important investments in primary commodities sector, characterized by high level of technical advancement and efficiency. Long-term credit were being granted for 15 years, mid-term ones for 5 years, with the interest varying between $3 \%$ and 5\% p.a. ${ }^{29}$ Until 1981 IIB granted credits of total value 3.5 billion transferable roubles, initially mostly for the development of machine industry and railway transport. From 1970 to 1980 IIB participated in 65 large investment projects. The biggest investment financed by IIB was construction (with the participation of 7 member states) of Orenburg gas pipeline to the western border of the USSR..$^{30}$

26 E. Drabowski, Rubel..., p. 54 and further.; P. Bożyk, B. Wojciechowski, Handel ..., p. 213.

27 Jan Ptaszek, Polska - Zwiazek Radziecki: wspótpraca-integracja, Warszawa: Państwowe Wydawnictwo Ekonomiczne, 1979, p. 53.

28 E. Drabowski, Rubel..., p. 65.

29 Paweł Bożyk (ed.), Integracja gospodarcza krajów socjalistycznych, Warszawa: Szkoła Główna Planowania i Statystyki, 1979, pp. 169-170.

30 E. Drabowski, Rubel..., pp. 100-101; S. Rączkowski, Międzynarodowe..., p. 426; Rocznik Polityczny i Gospodarczy 1980, Warszawa: Państwowe Wydawnictwo Ekonomiczne, 1981, pp. 530-531. 
The transferable rouble with the end of 1990 and disbandment of Comecon was exchanged by convertible currencies as the means of settlement of international transactions. ${ }^{31}$

\section{Lack of reforms and its sources}

The introduction of the transferable rouble brought serious disappointment among the economists and politicians, associated with the failed attempt of switch from bilateral to multilateral settlements. The latter included only $1.5 \%$ of payments settled via the IBEC..$^{32}$ Main cause of failure was seen in the lack of convertibility of the common currency. Polish side from the very beginning of the transferable rouble's existence demanded partial exchange of surpluses and deficits denominated in transferable roubles into gold or convertible currencies. The Polish proposals from 1966 assumed the initial ratio of convertibility of transferable rouble assets on the level of $10-15 \%$ of country's account balance at the IBEC..$^{33}$ Polish demands were not positively welcomed in the USSR, as also in the other Comecon members. ${ }^{34}$

The furthest-reaching reform demands were presented to the Soviet highest authorities at the meeting between Polish (first secretary of the Central Committee of Polish United Workers Party Władysław Gomułka, chairman of the Council of State Edward Ochab, prime minister Józef Cyrankiewicz and member of the Political Bureau of PUWP Zenon Kliszko) and Soviet leaders (general secretary of the Central Committee of CPSU Leonid Brezhnev, prime minister Alexei Kosygin, chairman of the Presidium of the Supreme Soviet of the USSR Nikolai Podgorny) in Polish government holiday resort in Łańsk on 14.01.1968. Polish motions, although not much detailed, were underlining need of mutual convertibility of national currencies and introduction of credit and financial relations instead of clearing and administrative management of foreign trade. It implied the change of system of determining the domestic as well as foreign-trade prices and associating them with the level of world-prices. The whole reform was to be introduced with the beginning of new 5-year plan in 1.01.1971. According to Gomułka, the

31 Kazimiera Wilk, Integracja wschodnioeuropejska, powstanie, funkcjonowanie i upadek, Wrocław: Akademia Ekonomiczna, 1994, p. 101.

32 E. Drabowski, Rubel..., p. 26.

33 Piotr Jaroszewicz, „Pięciolecie doskonalenia struktury obrotów handlowych i rozwoju współpracy gospodarczej z zagranicą”, Nowe Drogi, 10/1966, p. 27; Robert Skobelski, Polityka PRL wobec państw socjalistycznych w latach 1956-1970. Wspótpraca-napięciakonflikty., Poznań: Wydawnictwo Poznańskie, 2010, pp. 208-209.

34 Problem stosunków walutowo-finansowych krajów RWPG i możliwości wykorzystania tych stosunków dla dalszego rozwoju wspótpracy gospodarcze, [Problem of currency and financial relations of the Comecon countries and possibilities of using these relations for further development of economic cooperation], quoted from: H. Różański, Spojrzenie..., p. 253. 
need of comparing prices with the Western counterparts, together with the lack of adequate point of reference in Soviet prices, was integrating the socialist countries with the West. The Soviet response expressed general cautiousness and was concerned mostly with the social effects of the domestic price adjustments, without significant references to the efficiency of the socialist integration. Also the Soviet assessments of the state of economic affairs seemed to be more positive than opinions of Gomułka, underlining the threats resulting from fast progress of Western European integration. General lack of interest in Polish proposals was also a result of technical difficulties of such operation, as also small chances for reaching final agreement with all member countries. Czechoslovakia and GDR were representing in that matter the same conservative stance as the USSR. ${ }^{35}$

The agreed attempts of making the transferable rouble an international currency appeared in the mentioned "Comprehensive Programme" of 1971. They were, however much less radical than Polish proposals from Łańsk, as also much more postponed in time. The Section 7 of the Programme was dedicated to the improvement of the financial relations. It contained the promises of future convertibility (de facto after 1980) of transferable rouble into national currencies of the member states, as also the mutual convertibility of the national currencies and creation of single exchange rates of national currencies. ${ }^{36}$

The expert circles of the Comecon were aware that making the transferable rouble a real settlement currency was associated with the necessity of previous introduction of a few reforms. The most important included partial convergence of domestic price structure of the member countries, adjusting the exchange rates to the purchasing power and liberalization of trade flows. It meant principal reforms of centrally planned economy, which were meeting strong resistance in separate member countries. As a result, the passages of the "Comprehensive Program", concerning the convertibility of the transferable rouble for other currencies were not reflected in reality until the end of the Comecon, even in the case of convertibility for the currencies of the member states. ${ }^{37}$ The potential internal troubles due to necessary domestic price increases were not the only barrier. There were fears that introduction of convertibility of the socialist countries into the currencies of the capitalist countries would put in motion the mechanism of disintegration of the Comecon due to integration with Western Europe and capitalist economy. ${ }^{38}$ Keeping the status quo was thus a result of barriers for further integration

35 Tajne dokumenty Biura Politycznego PRL - ZSRR 1956-1970, London: Aneks, 1998, pp. 519-522; R. Skobelski, Polityka ..., pp. 209-210, 219-222.

36 William Elliot Butler (ed.), A Source Book on Socialist International Organizations, Alphen aan den Rijn: Sijthoff and Nordhoff, 1978, pp. 70-72.

37 H. Różański, Spojrzenie ..., p. 296.

38 Antoni Marszałek, Planowanie $i$ rynek w RWPG. Geneza niepowodzenia., Łódź: Wydawnictwo Uniwersytetu Łódzkiego, 1993, p.102 
as also dangers of disintegration. Paradoxically, the barrier to further integration in the form of currency inconvertibility turned out to be a barrier to potential disintegration.

It must be also added that the persistence of the status quo was accompanied by the specific shape of the discourse over the financial relations inside Comecon. The critical opinions were allowed, especially in the countries with the loosest censorship regimes, such as Poland and Hungary. The apologetic attitude to the situation was the most present in the works of Soviet researchers, being de facto detailed explanation of the current position of the Soviet authorities and having thus the strongest influence. The examples from the literature circulating on Polish market in 1970's and 1980's include books by Polish economists Stanisław Rączkowski ("The transferable rouble does not meet the basic criterion of correct functioning of the international currency because it does not represent an universal purchasing power, possible to use in every time and every country") ${ }^{39}$ and Eugeniusz Drabowski ${ }^{40}$, as also Hungarian researcher, Imre Vincze ("actual measurement of the value was taking and takes place outside the Comecon community, on the world market"). ${ }^{41}$

Quite oppositely, the volume of important Soviet articles about the transferable rouble, included following statements: "The authors (...) being directed by the Marxist-Leninist science about world money and using primary sources - analyzing the nature and economic character of the transferable rouble, its functions, unveil the undisputed superiority of that currency in relation to capitalist currencies used in the international settlements"; "...collective currency is able to perform and practically performs all the functions of international socialist currency: unit of value, means of payment and means of accumulation". ${ }^{42}$ So the voices of dissent were on the fringes, the mainstream discourse was extremely ideological and not confronting the reality - here is another explanation of the lack of reform, besides internal and international policy problems created by potential changes.

\section{Conclusions}

The transferable rouble was a unit of account of completely different character than currencies of the capitalist countries. It was lacking basic functions of money: unit of value, means of payment and means of accumulation. It was convertible neither

39 Stanisław Rączkowski, „Pieniądz międzynarodowy krajów socjalistycznych - zasady funkcjonowania”, [in:] Paweł Bożyk (ed.) Integracja ekonomiczna krajów socjalistycznych, Warszawa: Książka i Wiedza, 1970, p. 297.

40 E. Drabowski, Rubel..., p. 91.

41 Imre Vincze, Międzynarodowy system waluty RWPG, Warszawa: Państwowe Wydawnictwo Ekonomiczne, 1981, pp. 71-73.

42 Międzynarodowa waluta socjalistycznych krajów RWPG, Warszawa: Państwowe Wydawnictwo Ekonomiczne, 1974, p. 54. 
into gold nor into world currencies and had no reasonably established exchange rate. It was strictly associated with the planned trade agreements, which were basis for all the trade among the Comecon members. Its creation was connected to the register confirming the export of goods or services. It depended not from the bank (in that case the IBEC), but from the parties participating in the exchange. It performed the functions of formal tool of registering and controlling the financial settlements between the Comecon countries. The possession of transferable roubles on an account in the IBEC did not mean the possibility of buying a desired good on the Comecon market because the good had to be previously included in the trade agreements. In the systemic aspect, the transferable rouble did not differ from the domestically circulating currency of centrally planned economies. The latter, besides the market of consumer goods and services, was performing only accounting and aggregating functions.

The switch to multilateral clearing in the Comecon, associated with the introduction of the transferable rouble, ended with failure. It was mostly an effect of maintaining bilateral clearing in trade settlements. Multilateralization would have to be preceded by unification of price structures and adjustments of exchange rates, as also by wider liberalization of foreign trade. Simultaneously, there was a lack of political will to conduct necessary economic reforms and the trade outside the limits of previously negotiated quotas was simply marginal to the whole volume.

The transferable rouble, however, had real impact on the trade relations between the states of the Soviet bloc. Its character led to different pathologies in the mutual exchange, made the integration processes more difficult and contributed to increasing internal and external imbalances of the economies of member countries. It was a part of the system responsible for permanent shortages in the economy, finally leading to structural crisis and collapse of the centrally planned economy in Central and Eastern Europe.

The automatic mechanisms of credit relations and balance-of-payments adjustments could not go in pair with the system based on central planning. Difficulties with management of foreign trade could not lead to the abandonment of planning in that area of economic activity in favour of ensuring some flexibility. The dogma of planning superiority resulted in treating automatic mechanisms as "chaotic" and bringing the danger of creating the bridgehead for capitalism, allowing for the influence of business conditions of world market on the socialist economies. Lack of significant systemic reforms of the Comecon and choosing instead the concept of integration based on the closer cooperation on the enterprise level and construction of common infrastructural projects, was contrasting with the experiences of the EEC, gradually ensuring clear rules for the integration process and creation of the common market. Imperfectness of the settlement system, lack of normal exchange rates and separation of internal markets of Comecon member states were making the type of integration chosen in 1970's extremely complicated in terms 
of bureaucratic efforts necessary for negotiating all the contract conditions and terms of payment. The result of these efforts was also unsatisfactory - the mutual liabilities resulting from the export of construction services, mineral resources or exploitation of common infrastructure were more and more difficult to assess. Tt is not strange that, for example, the post-Comecon disputes about the state of mutual debts between Poland and Russia were solved with zero-option due to mutual inability of making proper balance.

The deviated, overvalued exchange rate led to the unwillingness of the participants to export to other member countries. It was associated with the incentives towards maximizing cheap imports. It meant permanent shortages also on the level of international exchange of goods, as well as the fact that all the members were subsidizing trading partners via export channel. Possessing comparative advantage in one field thus did not lead to adequate gains. Besides the pursuit for self-sufficiency typical for Soviet-style central planning, it additionally explains the persistence of autarkic economic structures in the member countries and low advancement of industrial specialization inside the organization.

Summing up, it can be stated that the transferable rouble, mostly due to its limitations in performing basic functions of money, was not an efficient tool for further integration of Soviet bloc. Quite contrarily, it contributed significantly to disintegration of the Comecon.

\section{Bibliography}

Bloed, Arie, (1988), The External Relations of the Council for Mutual Economic Assistance, Dordrecht: Martinus Nijhoff Publishers.

Bożyk, Paweł, (1970), Integracja gospodarcza krajów socjalistycznych, Warszawa: Ksiązka i Wiedza.

Bożyk, Paweł, (1979), Integracja gospodarcza krajów socjalistycznych, Warszawa: Szkoła Główna Planowania i Statystyki.

Bożyk, Paweł, Wojciechowski Bronisław, (1971), Handel zagraniczny Polski 1945-1969, Warszawa: Państwowe Wydawnictwo Ekonomiczne.

Butler, William Elliott (ed.), (1978), A Source Book on Socialist International Organizations, Alphen aan den Rijn: Sijthoff and Nordhoff.

Chwieduk, Romuald, Krawczewski Andrzesj (ed.), (1988), 40 lat RWPG. Ewolucja instytucji i struktur socjalistycznej integracji gospodarczej, Warszawa: Polska Akademia Nauk.

Drabowski, Eugeniusz, (1972) System rubla transferowego (Problem zwiqzków rubla transferowego ze złotem), Warszawa: Instytut Finansów.

Drabowski, Eugeniusz, (1974), Rubel transferowy - międzynarodowa waluta krajów RWPG, Warszawa: Państwowe Wydawnictwo Naukowe.

Drabowski, Eugeniusz, (1988), Pieniqdz międzynarodowy, Warszawa: Państwowe Wydawnictwo Ekonomiczne.

Fedorowicz, Zdzisław, (1989), Kursy walutowe jako normy sterujace, Warszawa: Szkoła Główna Planowania i Statystyki. 
Głuchowski, Jan, (1984), Prawnomiędzynarodowe stosunki finansowe państw socjalistycznych, Warszawa, Poznań, Toruń: Państwowe Wydawnictwo Naukowe.

Jachowicz, Piotr (ed.), (2013), W poszukiwaniu modelu gospodarki centralnie kierowanej, Warszawa: Oficyna Wydawnicza SGH.

Jaroszewicz, Piotr, (1966), „Pięciolecie doskonalenia struktury obrotów handlowych i rozwoju współpracy gospodarczej z zagranicą", Nowe Drogi, 10/1966.

Jasiński, Leszek Jerzy, (1990), „Kurs złotego a poziom cen krajowych i ich relacje do cen za granicą", Studia i Materiaty IKiCHZ, 18/1990.

Jasiński, Leszek Jerzy, (2003), Polskie kontakty gospodarcze z zagranica w XX wieku, Warszawa: Warszawska Wyższa Szkoła Ekonomiczna, Polska Akademia Nauk.

Karpiński, Zygmunt, (1968), Ustroje pieniężne w Polsce od roku 1917, Warszawa: Państwowe Wydawnictwo Naukowe.

Klepacki, Zbigniew M., (1981), Organizacje międzynarodowe państw socjalistycznych, Warszawa: Państwowe Wydawnictwo Naukowe.

Kochański, Aleksander, et al. (ed.), (2000), Polska w dokumentach archiwów rosyjskich 19491953, Warszawa: Polska Akademia Nauk.

Korbonski, Andrzej, (1964), “Comecon”, International Conciliation, 549/1964.

Levcik, Friedrich, (1978), Transferable Roubel and Convertibility, Wien: Wiener Institut für Internationale Wirtschaftsverglieiche.

Marszałek, Antoni, (1993), Planowanie i rynek w RWPG. Geneza niepowodzenia, Łódź: Wydawnictwo Uniwersytetu Lódzkiego.

Międzynarodowa waluta socjalistycznych krajów RWPG, (1974), Warszawa: Państwowe Wydawnictwo Ekonomiczne.

Morawski, Wojciech, (2002), Zarys powszechnej historii pieniadza i bankowości, Warszawa: Trio.

Orłowski, Mirosław, (1972), Kursy walutowe - pieniqdz - kapital, Warszawa: Państwowe Wydawnictwo Ekonomiczne.

Problemy walutowe wspótpracy krajów RWPG, (1980), Warszawa: Instytut Finansów.

Ptaszek, Jan, (1979), Polska - Zwiqzek Radziecki: wspólpraca-integracja, Warszawa: Państwowe Wydawnictwo Ekonomiczne.

Rączkowski, Stanisław, (1984), Międzynarodowe stosunki finansowe, Warszawa: Państwowe Wydawnictwo Ekonomiczne.

Rocznik Polityczny i Gospodarczy 1980, (1981), Warszawa: Państwowe Wydawnictwo Ekonomiczne.

Rosati, Dariusz, (1990), Poland. Impact of Replacing CMEA Trade Regime by a Market Trade, Warszawa: Instytut Koniunktur i Cen Handlu Zagranicznego.

Różański Henryk, (1990), Spojrzenie na RWPG. Wspomnienia-dokumenty-refleksje 1949-1988, Warszawa: Państwowe Wydawnictwo Naukowe.

Rutkowska, Irena, Rutkowski, Józef, (1983), Problemy współczesnej gospodarki światowej, Warszawa: Książka i Wiedza.

Rutkowski, Józef, (1973), „Koncepcja unii walutowej krajów socjalistycznych”, Sprawy Międzynarodowe, 12/1973.

Rzendowski, I., (1964), „Wprowadzenie rozliczeń wielostronnych między państwami RWPG”, Życie Gospodarcze, 9/1964.

Sheinin, E. (ed.), (2009), K 60-letyu Soveta Ekonomicheskoy Vzaimopomoshchi, Moskva: Rossijska Akademia Nauk.

Skobelski Robert, (2010), Polityka PRL wobec państw socjalistycznych w latach 1956-1970. Współpraca-napięcia - konflikty., Poznań: Wydawnictwo Poznańskie. 
Skrzypek, Andrzej, (2005), Mechanizmy autonomii. Stosunki polsko-radzieckie w latach 19561965, Pułtusk, Warszawa: Wyższa Szkoła Humanistyczna w Pułtusku.

Tajne dokumenty Biura Politycznego PRL - ZSRR 1956-1970, (1988), London: Aneks.

Vincze, Imre, (1981), Międzynarodowy system waluty RWPG, Warszawa: Państwowe Wydawnictwo Ekonomiczne.

Wesołowski, Jerzy, (1975), Kurs walutowy w gospodarce socjalistycznej, Warszawa: Państwowe Wydawnictwo Ekonomiczne.

Wesołowski, Jerzy, (1977), System walutowy krajów RWPG, Warszawa: Państwowe Wydawnictwo Ekonomiczne.

Wesołowski Jerzy, (1984), Bilans płatniczy w gospodarce Polski, Warszawa: Państwowe Wydawnictwo Ekonomiczne.

Wilk Kazimiera, (1994), Integracja wschodnioeuropejska, powstanie, funkcjonowanie i upadek, Wrocław: Akademia Ekonomiczna. 


\title{
1989: the end of Europe's division. A new Europe through integration
}

\section{Austria. The Revolutions in Central and South Eastern Europe. Austrian Perceptions and International Reactions 1989-90}

\author{
Michael GEHLER
}

\begin{abstract}
The historical significance of the year 1989 was global; it was a year in which the entire world changed dramatically. ${ }^{1}$ This article deals with Austrian perceptions and international reactions to the revolutionary changes that occurred in Central and South Eastern Europe in 1989-90. This will first be examined in relation to the events in Poland (I.) and to the dramatic events at the Hungarian border, especially the Austrian reaction to the resulting wave of East German refugees (II.). Next will be analyzed the Austrian reaction to the revolutionary events in Czechoslovakia (III.) and, briefly, to the events in Romania, Bulgaria and Yugoslavia (IV.). The last section will describe how the role of the Warsaw Pact (V.) was evaluated.
\end{abstract}

\section{Austria's Foreign Policy and Poland 1989}

On 17 January 1989, Austria's Foreign Minister Alois Mock mentioned, in passing at the final Vienna Conference on Security and Cooperation of Europe (CSCE) meeting, that Austro-Polish relations were "very good". On the same occasion, Polish foreign minister Andrzej Olechowski acclaimed the conclusion of the CSCE follow-up meeting as a historic event, and stated that Austria had played a significant role in its positive outcome. For Warsaw, the CSCE process was one of its "most important foreign policy issues". Poland was "very interested" in having a good relationship with Austria "at all levels". ${ }^{2}$

The extent of the Polish debt constituted the country's largest economic and political problem. In order to have time for internal consolidation, several years of

1 Pierre Grosser, 1989. L'année où le monde a basculé, Paris: Perrin, 2009.

2 Amtsvermerk "Beziehungen Österreich-Polen; Gespräch HVK-AM Olechowski am Rande des Wiener KSZE-Abschlusstreffens, 17 January 1989", 23 January 1989, in Bundesministerium für europäische und internationale Angelegenheiten (BMEIA), GZ1. 750.04/46-II.3/89. After applying for special permission, I was allowed early access to diplomatic records at the Austrian Ministry of Foreign Affairs regarding the events in Central and Eastern Europe 1985-91. An edition project and a separate book documenting these records is forthcoming. I would like to thank Ambassadors Fritz Bauer and Franz Wunderbaldinger, as well as Ministerialrat Gottfried Loibl for their support in this project. 
leniency were requested. Agreements for long-term debt repayment were seen as a viable option. Poland sought a bilateral connection to the EC, as had Hungary. From the Polish perspective, the "friendly voice of Austria" could "help a lot". Olechowski assured Mock that the leader of the military government of Poland, General Wojciech Jaruzelski was undertaking the "greatest possible efforts" to "integrate, in the internal transformations", not only the important Catholic Church, but also the trade union movement Solidarity and its leader Lech Wałęsa. Poland was searching for a pluralistic means of operation for both the unions and public life. After Poland, Hungary and the USSR, it was only a matter of time for transformations to take place in the other socialist countries in Europe, Olechowski argued. Mock considered the political transformations in Eastern Europe "very significant". He recommended "striking the right balance", and referred to the negotiations that had begun concerning the reduction of conventional armed forces in Europe (CFE). He also asked the Polish authorities to speed up renovations on the Austrian Cultural Institute in Warsaw. ${ }^{3}$

\section{Hungary and its border with Austria}

The Austrian Chancellor Franz Vranitzky met the new Hungarian Prime Minister Miklós Németh for the first time on 13 February 1989. As part of delegation meetings, the two men met privately at the Hungarian Nagyoenk Palace as well as in the town of Rust on Austrian territory to discuss their bilateral relations and respective economic and political positions. Németh spoke of a "reform era" in Hungary, a process that had begun in 1986 when it was recognized that economic reforms were no longer feasible within the old political structures. ${ }^{4}$

For this reason, since May 1988 the aim had been to accelerate the separation of party and state, to establish democracy and the rule of law, to form an "entirely new political system", and to rapidly create the conditions for a market economy to develop by means of laws regarding banking, tax reforms and corporate bodies. According to Németh, both the population and the party had become divided into two camps due to the question of which direction to move: toward establishing a multiparty system or pluralism in the context of a single-party system. As part of the Central Committee meeting of 10-11 February 1989, the party had taken the initiative to create a multi-party system within the socialist context, so that various parties could compete with different agendas. The needs for new parties existed, and it was expected that some would actually be established in the coming year. With regard to the issue of how the events of 1956 should be defined, the Central Committee had reached a compromise. While the events had had the character of a popular uprising, towards the end, they were declared to be similar

$\begin{array}{ll}3 & \text { Ibid. } \\ 4 & \text { Ibid. }\end{array}$ 
to a counter-revolution. According to Németh, this "verdict decision" had been taken to prevent the party from being torn apart and to avoid the need for punishing particular individuals. It was hoped that the party and the people would see the events in the same way. Németh gave Vranitzky the impression that Hungary was "aware" of its great responsibility as the pioneer of political reform in the socialist world. Indeed, a new political competitive situation was emerging in Hungary, one for which no one was prepared. Thus the Central Committee was planning for the needed transition period. It was likely that a coalition government would form in Hungary. Németh raised the issue of work permits for Hungarian workers in Austria, and Vranitzky replied by assuring him that solutions would be found.

Despite critical voices, Németh said that his government supported holding a joint world exhibition together with Austria. Combined planning and implementation of joint ventures regarding the auto and rail industry, as well as joint efforts in securing (external) funding were considered essential. In private conversations, in some cases also in the presence of Johann Sipötz, the governor of Austria's easternmost province Burgenland, and his deputy, Franz Sauerzopf, it was agreed to construct new border and railway crossings at Pamhagen and Fertörakos/Mörbisch. It was also decided that the possibility of creating a duty-free zone in Sopron should be examined, a proposal that was to be made more concrete at the next meeting. Vranitzky declared his firm intention of maintaining Austria's neutrality if it were to become a member of the European Communities (EC). Notwithstanding Austria's efforts in this direction, its "excellent relations with Hungary would not be neglected". Németh announced that the physical barriers at the border would be completely dismantled by 1991 . The increasing organizational and technical cooperation between the two countries would also involve new obligations. ${ }^{5}$ In March Hungary joined the Geneva Refugee's Convention, entering into force on 12 June. The dismantling of the Hungarian border barricades had already begun on 2 May $1989 .^{6}$

The cutting of the Iron Curtain by Alois Mock and Hungary's Foreign Minister Gyula Horn on 27 June actually only involved last remnants of the barbed wire fences, as most of them had already been removed. The whole action was more

5 Resuméprotokoll, Sucharipa m. p., “Österreich-Ungarn; Grenztreffen HBK-MP Nemeth (13 February 1989)", 14 February 1989, in BMEIA, GZ. 222.18.22/12-II.3/89; see also Maximilian Graf, "Die Welt blickt auf das Burgenland 1989 - Die Grenze wird zum Abbild der Veränderung”, in Maximilian Graf/Alexander Lass and Karlo Ruzicic-Kessler (eds.), Das Burgenland als internationale Grenzregion im 20. und 21. Jahrhundert, Vienna: NeueWeltVerlag 2012, pp. 135-179.

6 Andreas Oplatka, Der erste Riss in der Mauer. September 1989 - Ungarn öffnet die Grenze, Vienna: Paul Zsolnay, 2009, pp. 87-104; 154-99; John Lewis Gaddis, Der Kalte Krieg. Eine neue Geschichte, Munich: Siedler, 2007, pp. 302-303; Bernd Stöver, Der Kalte Krieg. Geschichte eines radikalen Zeitalters 1947-1991, Munich: Beck, 2007, p. 443; Ilko-Sascha Kowalczuk, Endspiel. Die Revolution von 1989 in der DDR, Munich: Beck, 2009, p. 346. 
staged for the media. The images of the events that were provided by the television cameras stimulated the largest exodus of GDR citizens since the construction of the Berlin Wall in 1961. At a breakfast meeting the previous day, the two foreign ministers had discussed European integration and Hungary's participation. Horn thought that integration had come about for "objective reasons".

He was worried about the possibility of being isolated from the EC. Hungary sought an agreement on preferential tariffs with the EC like the one held by Yugoslavia and hoped, in due course, to have a "true free trade agreement". Before this could happen, the Hungarian economic system had to be liberalized, and the forint had to be made convertible. At the same time, Hungary desired an intensification of its cooperation with EFTA, whereby it imagined a joint declaration like the one that had been concluded by the EFTA with Yugoslavia. Horn suggested to Mock that a special EFTA fund for Hungary be created to the order of 80 to 100 million dollars. While this would not repair the Hungarian economy, it would give many companies new momentum. With regard to the Council of Europe, Hungary indicated that it was satisfied with having come closer and was "not impatient" for full membership. Mock agreed to support Hungary's rapprochement with the European Free Trade Association (EFTA) politically. He raised the question of whether a large fund for all reform-minded Eastern European states could be created. Horn stressed that in principle Hungary saw Austria's anticipated membership in the EC in a positive light. Hungary's concern lay with preserving the special quality of its bilateral relations with Austria. Mock pointed out that Austria's European policy rested on two pillars: its participation in West European integration (EU, EFTA, and the Council of Europe) and its neighborhood policy. With regard to the current state of the $\mathrm{EC}$ and its foreseeable development, he saw no reason for Hungarian concern. Horn made it clear that prospects for an agreement being passed on the disarmament issue had never been more positive, "but the devil is in the detail". As an example, he mentioned problems about the air forces ("not everything can be solved in one go"). In any event, a new political impetus was needed. This could be accomplished by a joint declaration being made at the higher levels of government, best that autumn. Mock agreed and repeated Shevardnadze's proposal for holding a meeting of heads of state. He explained the useful role of the "neutral and nonaligned $(\mathrm{N}+\mathrm{N})$ states", which were currently practicing restraint. Despite difficulties of internal consensus, they were always available as mediators in crisis situations. Horn did not wish to dramatize the fact that there had been a lack of agreement concerning a final document at the CSCE Paris meeting. The principle of consensus should not be abandoned, despite the fact that it also had disadvantages, such as allowing one or two countries to prevent decisions from being made (a reference to Romania made by the Hungarian

7 Resuméprotokoll, Sucharipa m. p., "Österreich-Ungarn; Grenztreffen HBK-MP Nemeth (13 February 1989)”, 14 February 1989, in BMEIA, GZ. 222.18.22/12-II.3/89 
Foreign Minister). Horn pointed to the major importance of the 13 June 1989 joint statement of the Federal Republic of Germany and the USSR, in which the need for changes in the internal political situation had been established (it included also the right of self-determination for the German people). ${ }^{8}$

Mock underlined the "leap forward" that had been accomplished by the Vienna CSCE Final Document. This meant that it had been predictable that little more than the "human dimension" could have been achieved at the Paris meeting. It was probable that in Copenhagen there would also be no major progress, this being reserved by the Soviet Union for the Moscow meeting in 1991. Horn described the Warsaw Pact as being in a process of defining itself. It was not collapsing, despite tendencies to that effect. The reform-minded members were dependent on one another, and had to strengthen their cooperation. The political objectives of the Pact had to be identified. Hungary was seeking modernization, not disintegration. In the future, the pact would have to coordinate its defense policy, whereby an extensive restructuring would also have to include a change in the balance between cooperative and national military forces, to define a basic approach toward international issues, and should also safeguard the sovereignty of member states in domestic affairs, bilateral issues, as well as national interests with regard to third countries and matters of integration. It was planned to discuss these issues at the Warsaw Pact meeting to be held in Bucharest in early July. While the pact had never been a monolithic alliance, now any impressions of the like were also disappearing: The internal situation of individual countries (for example, Romania) was inconsistent with the general easing of pressure. The restructuring efforts at the national level were leading to tensions with those countries that did not accept pluralism. The problem was that "conservatives" were questioning the legitimacy of the new structures, as was happening between Czechoslovakia and Hungary. ${ }^{9}$

Mock outlined some basic Austrian positions concerning the reform efforts:

1. The respective states were to make sovereign decisions;

8 Information Sucharipa "BRD-Sowjetunion; Gemeinsame Erklärung vom 13.6.1989", 15 June 1989, in BMEIA, GZ. 225.01.01/17-II.3/89; see also the point "Achtung des Selbstbestimmungsrechts der Völker", in Bulletin [der deutschen Bundesregierung], 15 June 1989, No. 61, pp. 542-544, here p. 542, see also Document 2 "Gespräch des Bundeskanzlers Kohl mit Generalsekretär Gorbatschow Bonn, 12. Juni 1989", Document 3 "Gespräch des Bundeskanzlers Kohl mit Generalsekretär Gorbatschow Bonn, 13. Juni 1989" and Document 4 "Delegationsgespräch des Bundeskanzlers Kohl mit Generalsekretär Gorbatschow Bonn, 13. Juni 1989”, in Hanns Jürgen Küsters/Daniel Hofmann, Dokumente zur Deutschlandpolitik. Deutsche Einheit. Sonderedition aus den Akten des Bundeskanzleramtes 1989/90, Munich: Oldenbourg, 1998, pp. 276-299; additionally see also Andreas Hilger (Ed.), Diplomatie für die deutsche Einheit. Dokumente des Auswärtigen Amts zu den deutsch-sowjetischen Beziehungen 1989/90 (Schriftenreihe der Vierteljahrshefte für Zeitgeschichte 103), Munich: Oldenbourg, 2011.

9 Amtsvermerk Schmid m. p., "Off. Besuch von AM Horn; Gespräche mit HBM, 26 June 1989; Internationale Themen”, 28 June 1989, in BMEIA, GZ. 222.18.23/25-II.SL/89. 
2. Austria was reacting in a differentiated manner: as far as possible, it was supporting the reforms in Poland, Hungary and the USSR; but where necessary, it was showing clear restraint, as for example with Bulgaria, Czechoslovakia, East Germany and Romania;

3. Austrian support should not cause any inconvenience, whereby Mock stated that he would be grateful for any suggestions;

4. The opening of Eastern Europe would not be lessening the role of Austria, but widening its possibilities;

5. The budding developments would diminish the differences between the systems, reducing tensions and bringing peace and stability to Europe. Austria's neutrality enabled it to make a competent contribution to the current events.

Due to the developments, it would become possible to leave the phase of "peaceful coexistence", which might be followed by a period of "wider cooperation". In the long term, this might lead to a third phase, that of a "Common European Home". ${ }^{10}$

Here, Mock was referring to the slogans of Nikita S. Khrushchev and Mikhail S. Gorbachev, seeing it as a possibility for dynamic development.

The reactions of the Warsaw Pact countries to the crackdown on the democracy movement in China on 4 June 1989 and the reburial of Imre Nagy in Budapest were watched closely by the Austrians and aptly interpreted. There was "a striking disagreement among the statements", ${ }^{11}$ which on one hand documented the crumbling of the monolithic character of the Warsaw Pact, and on the other, the emergence of two camps.

Poland and Hungary expressed dismay at the events in China. The Foreign Policy Committee of the Hungarian Parliament expressed its deep alarm. ${ }^{12}$ The Council of Ministers spoke of international responsibility in terms of human rights. The Polish dissident Adam Michnik argued that the events in Poland and China were an expression of the decline of political power. The Polish media considered Nagy's interment to be the end of Stalinism in Hungary. The GDR, Romania and Czechoslovakia disapproved of the Nagy interment. No representative of the Romanian government took part in the funeral rites; the Hungarian ambassador in Bucharest was summoned before the Romanian Ministry of Foreign Affairs and handed a memorandum of protest. The general secretary of the Czechoslovak Central Committee Jan Fojtik criticized certain circles in the West, which saw the Nagy interment as the symbolic burial of socialism in Hungary. The official

10 Ibid.

11 Sucharipa m. p., "Reaktionen der kommunistischen Staaten Europas auf das NagyBegräbnis", 21 June 1989, in BMEIA, GZ. 222.03.00/36-II.3/89.

12 "Reaktionen der WP-Staaten auf die Ereignisse in China und das Nagy-Begräbnis als Gradmesser für den Stand der eingetretenen Diversifizierung”, Vienna, 14 July 1989, ibid., GZl. 33.03.00/172-II.3/89. 
East German news agency ADN opined that the celebration expressed the enmity between the Hungarian Communist Party and that of the Soviet Union. Led by the GDR, the response of these three states (GDR, ČSSR, Romania) and Bulgaria to the events in China was also unanimous, although the reaction of the ČSSR was less severe.

The army's intervention was declared having been necessary in order to eliminate "errors" and "to fight a counter-revolutionary rebellion". In the GDR, the Church criticized the official position of the party and state with regard to the "Chinese solution". In Bulgaria, despite restraint with regard to Nagy's interment, the demonstrations in China were appraised as a "counter-revolutionary rebellion". The Soviet Union took a middle position in both cases; both liberal and orthodox opinions were expressed, whereby in the case of the Nagy interment, a remarkable effort at objectivity could be detected. The Congress of People's Deputies adopted a balanced resolution regarding the events in China, mentioning the use of troops and casualties, but also presenting the view that it was an internal matter and that no rash or hasty conclusions should be drawn. Other than a commentary in Pravda, which drew a comparison between the military deployment on Tiananmen Square and the fighting in Tbilisi and Fergana, what was published was only the official Chinese version, reproduced without comment. Gorbachev emphasized the need to find appropriate political solutions. ${ }^{13}$

The Pan-European Picnic, which was held on 19 August in the border region on Hungarian soil under the patronage of Otto von Habsburg together with Hungarian reform communists such as Imre Pozsgay, had the character of being a signal or a test, especially with regard to Gorbachev's reaction. But the picnic was not the decisive factor in Hungary's willingness to officially open the border. Another event was much more critical: In the night of 21 to 22 August, the East German citizen Kurt-Werner Schulz was shot dead during a scuffle with a Hungarian border guard. A bullet is said to have been released from the officer's submachine gun. The incident took place on Austrian territory in the Lutzmannsburg district. After the Hungarian authorities notified Austria, a border commission was immediately convened to clarify the case. Mock expressed his regrets about the incident. ${ }^{14}$

A few days later there was another fatality. After a successful escape to the West, a forty-year-old East German died of a heart attack. The transfer of the body was undertaken by the German Red Cross. The autopsy revealed that the man had been healthy, but had died of exhaustion. He had endured five days without food in a Budapest church so that he could meet his West German fiancée. ${ }^{15}$

A few years ago, Németh acknowledged in a television interview that these fatal incidents, especially the death of the GDR citizen Schulz, were the crucial events

13 Ibid.

14 APA Report 02635 AI, 22 August 1989.

15 APA Report 01175 AI, 28 August 1989. 
that triggered Hungary's explicit willingness to open the border. Németh's closest advisors had brought it to his attention that because of the "aggressive" behavior of the East German refugees, he would have to bear the responsibility for more incidents and fatalities. ${ }^{16}$ But while an internal decision had been made, it had, of course, not been settled at the highest levels between Budapest, Bonn and Vienna.

The East German refugees crept through corn fields, waded through swamps, swam across Lake Neusiedl, crawled over fields and used any hiding place they could find at the Hungarian-Austrian border. They left their cars "Trabis" and even more valuable "Wartburgs" back in Hungary. According to the West German ambassador in Vienna, Count Dietrich Brühl, "the hour of Burgenland", Austria's easternmost province, had struck. Without the Burgenlanders' "inestimable help for the Germans from the GDR", the exodus would never have grown to the extent it did before the border was opened. This help ranged from assistance during the escape and first aid in the homes along the border, to providing information about where buses to the embassy stood, or families letting exhausted refugees stay with them for longer periods of time. Mayors of the smallest villages at the Hungarian border opened aid facilities in gymnasiums and similar buildings. ${ }^{17}$

Medical care and ointments were needed for sunburns and babies suffering from countless mosquito bites. Donations were ready: from toys, diapers, clothes, food and medicine, to body care products, including shower gel, unknown in the GDR. The rooms of the German embassy were crowded with people. There were not enough rooms in simple hotels. The mayor of Vienna, Helmut Zilk, provided rooms in hostels. The Austrian Red Cross, the Maltese Order relief agency, and several parishes in Vienna took in refugees and helped. ${ }^{18}$

By allowing the departure of refugees who had sought refuge in the West German embassy in Budapest, the Hungarian government infringed on the rules of the Warsaw Pact. For the first time, East German citizens were allowed to leave Hungary to West Germany without permission of the GDR government. Until then, they had always been forced to return to their hometowns in the GDR,

16 ORF ZIB 2 Report, 19 August 2009.

17 Report by former ambassador Dietrich Graf von Brühl, "Flucht in die Freiheit. Die Flüchtlingsbewegung aus Ungarn im Jahre 1989", 3 with an accompanying letter to the author dated 20 November 2005. I would like to express my sincere thanks to Ambassador von Brühl (†) for the permission to use this report, as well as for the many conversations we had. See also Dietrich Graf von Brühl, "Deutsche Erfahrungen mit Österreich", in Michael Gehler and Ingrid Böhler, eds., Verschiedene europäische Wege im Vergleich: Österreich und die Bundesrepublik Deutschland 1945/49 bis zur Gegenwart. Festschrift für Rolf Steininger zum 65. Geburtstag, Innsbruck: Studienverlag, 2007, pp. 579-84; Jens Schöne, The Peaceful Revolution. Berlin 1989/90 - The Path to German Unity, Berlin (Berlin Story Verlag) 2009, pp. 53-69, here pp. 54-61; Interview with Countess Maria Octavia von Brühl, 26 February 2013 in Vienna as well as Graf/Lass/Ruzicic-Kessler, Das Burgenland.

18 Brühl, "Flucht in die Freiheit", p. 4. 
where at best they were released to the Federal Republic in the West after paying a large bribe to the government. The unimpeded group exodus of refugees from the embassy was new. ${ }^{19}$

A comprehensive solution for the refugees living in camps, however, required high-level talks. On Friday, 25 August, one day after the arrival of the refugees from the Budapest embassy in Austria, Németh and Horn met at Gymnich Castle near Bonn for secret talks with Chancellor Helmut Kohl and Foreign Minister Hans-Dietrich Genscher. ${ }^{20}$ When discussing the East German citizens in Hungary seeking to escape to the West, Németh stated that deportation of the refugees back to East Germany was out of the question, and added: "We are opening the border. If there is no military or political power from outside that forces us to act differently, we will keep the border open for East Germans". The departure of the refugees was to take place until mid-September $1989 .{ }^{21}$

On 21 August, Genscher had already declared in an interview that no one in the GDR was being encouraged to leave the home. But anyone who did come had to be helped. In the same breath, he confided that he had turned to his "best people" to ensure that there would be help. He mentioned the former government spokesperson and foreign secretary Jürgen Sudhoff, his highest officials, and his former chief of cabinet Michael Jansen. To organize help, Sudhoff went to Budapest several times, and Jansen to Budapest and Vienna. Jansen was the main person responsible for organizing aid in Austria. He saw to it that Ambassador Brühl, who as a precaution had left "on vacation" to Tyrol, was brought back to duty. Brühl returned to Vienna the same day. On 25 August, Jansen was in Vienna to get a transit "green light" from Mock. Austrian approval was granted immediately. Between 28 August and 10 September, important details were clarified with the head of the foreign ministry's consular section, Ambassador Erik Nettel, and his deputy, Erich Kussbach, and an agreement was reached. Brühl recalls: "It was a

19 Ibid., p. 7.

20 On this conversation, see Genscher's memorandum, 25 August 1989, in Küsters and Hofmann, eds., Dokumente zur Deutschlandpolitik, pp. 377-80. The memorandum, however, contains no mention of the opening of the Hungarian border to East German refugees, but only recounts the difficult economic situation in Hungary, as had been reported by Prime Minister Németh; without mentioning Austria's and Mock's role when opening the Austro-Hungarian boarder see Andreas Rödder, Deutschland einig Vaterland. Die Geschichte der Wiedervereinigung, Munich: Beck 2009, pp. 72-75; Hans-Peter Schwarz, Helmut Kohl. Eine politische Biographie, Munich: Deutsche Verlags-Anstalt 2012, 526. In contrast to Rödder and Schwarz see Grosser, 1989. L'année où le monde a basculé, pp. 44-45; Kowalczuk, Endspiel, pp. 350-351, 377.

$21 \mathrm{Ibid}$. At the end of the statement was a hidden message to the refugees. See also, Helmut Kohl, Erinnerungen 1982-1990, Munich: Droemer, 2005, pp. 921-23; concerning Bonn's instrumentalization of the GDR's refugee problem and the intensified reform process in Central Europe see Janusz Sawczuk, Turbulentes 1989. Genese der deutschen Einheit (Nationalisms across the Globe 6), Oxford - Bern - Berlin - Bruxelles - Frankfurt am Main - New York - Wien: Peter Lang, 2011, pp. 174-206. 
pleasant conversation. The goal was clear. The road had to be paved. But it was not as easy as it sounds today. For example, a treaty with the German Democratic Republic obligated Austria to allow entry to persons arriving from East Germany only if they had a visa".22

The main problem was how to organize the transit journey. The Austrian government maintained the decision it had already made with regard to the embassy refugees from Budapest: The Austrian Red Cross was commissioned with the task to make it clear that the activities were providing humanitarian aid. Using private buses and not the state railways from the Österreichische Bundesbahn (ÖBB) was practical for preserving neutrality. A combination of train-bus or even only trains was ruled out, because the big camps in Hungary were not near railway stations. In addition, the number of refugees was too large. Reloading so many refugees twice was not feasible. The bulk of the refugees were therefore to be transported by bus to the German border via three major routes, along which the Red Cross had set up aid and support stations. The border crossings to Germany were Passau and Freilassing. ${ }^{23}$

Each Trabi driver who could identify him- or herself as a citizen of the GDR at the Austro-Hungarian border was given 700 Austrian shillings by Red Cross workers at the aid stations, enough to buy the gasoline needed to reach the German border. The Red Cross also prepared maps that showed the routes through Austria. The problem of the Austria-GDR visa agreement was regulated with a flexible "Austrian solution" by the government in Vienna: a loose piece of paper with a visa stamp was inserted into the identification papers of each East German refugee. Only the refugee's name was recorded, whereupon entry was authorized. The insert was then removed at the German border. This satisfied the visa agreement. Bonn had relayed the message to the West German embassy in Vienna that "money does not matter". The expenses incurred by the Red Cross were refunded. ${ }^{24}$

On September 10-11, the border was opened for free crossing. Germany's Chancellor Helmut Kohl was aware of the date by September 4 as a result of an agreement by his advisor Horst Teltschik with Hungarian Prime Minister Miklós Németh. Foreign Minister Hans-Dietrich Genscher was in the loop at the latest as of September 7 after Horn had informed employees of the German Federal Foreign Office in Budapest. Bonn had provided substantial financial assurances and thus had also made Hungary more inclined to follow through. On September 12, the paralyzed SED Politburo belatedly discussed countermeasures in East Berlin that

22 Brühl, "Flucht in die Freiheit", p. 7.

23 Ibid, 8; Michael Jansen, "Vielleicht sah Genscher mit der Deutschen Einheit seine Mission nach achtzehn Jahren als Außenminister als erfüllt an", in Michael Gehler and Hinnerk Meyer (eds.), Deutschland, der Westen und der europäische Parlamentarismus. Hildesheimer Europagespräche I (Historische Europa-Studien 5), Hildesheim - Zürich New York: Olms, 2012, pp. 148-172, here pp. 169-170.

24 Brühl, "Flucht in die Freiheit", p. 9. 
had been hectically developed by the Stasi, but it had neither political arguments nor concrete means of exerting pressure with respect to Budapest. Considerations about recalling the ambassador were dropped. At first, there was not even a decision about heightened controls on GDR tourists going to Hungary. In a protest note, East Berlin demanded that Budapest immediately reverse the opening of the border, which was promptly rejected. Hungary referred to Article 62 of the Vienna Convention on the Law of Treaties: the clausula rebus sic stantibus (the Fundamental change of circumstances) ${ }^{25}$

During these days and weeks the USSR remained neutral in the bilateral conflict between East Berlin and Budapest, while the triangle of Bonn-Vienna-Budapest coordinated with each other and organized the transfer of ten thousand East Germans to the West, thus driving another wedge into the uncertain states of the "Eastern Bloc". Standing opposed to the reform-oriented Poles and Hungarians was the communist-orthodox triangle of East Berlin-Prague-Bucharest.

In the period from 10 July to 13 November, the German embassy in Vienna directly furnished about 15,000 refugees with money, tickets and identity cards. In addition, from 11 September, at least 5,000 people were provided 700 Austrian schillings for gasoline by the Red Cross. More than 20,000 refugees crossed Austria to Germany in Red Cross buses or drove from Hungary, so that the wave of refugees who were counted numbered some 40,000 people. This does not include the many who were brought by West German tourists from Hungary, or were picked up directly at the Austro-Hungarian border by West German relatives. Thus, a total of up to 50,000 refugees chose to travel to West Germany through Austria in the summer and fall of 1989. The costs to the German embassy in the fiscal year 1989, including daily allowances, in some cases hotel rooms, tickets, the expenses for buses and general care, were around 3.8 million DM. The Red Cross was refunded around 1.5 million DM, and thus the total was about 5.2 million DM. ${ }^{26}$

The German-Austrian-Hungarian cooperation, which, whether unwittingly or consciously, further aggravated the erosion of the SED regime, was thus not particularly expensive.

25 See the backgrounds and developmens presented very detailed in different chapters by Oplatka, Der erste Riss in der Mauer, pp. 170-184, 184-199, 199-216, 216-230; neither document nor mentioning these forms of German-Austrian-Hungarian cooperation during the summer of 1989 Ines Lehmann, Die Außenpolitik der DDR 1989/90. Eine dokumentierte Rekonstruktion, Baden-Baden: Nomos 2011, to the Foreign and Europe policy of Kohl see Günter Buchstab/Hans-Otto Kleinmann (Bearb.), Helmut Kohl. Berichte zur Lage 19891998. Der Kanzler und Parteivorsitzende im Bundesvorstand der CDU Deutschlands (Forschungen und Quellen zur Zeitgeschichte 64), Düsseldorf: Droste, 2012, introduction: XXXII-XXXVI, XL-XLIII, 12-14, 38-39 as well as the documents: 9. 10. 1989, pp. 11-17; 6. 11. 1989, p. 36; 15. 11. 1989, pp. 37-39, 43-48, 27. 11. 1989, pp. 52-59; 15. 1. 1990, pp. 71-75; 11. 6. 1990, pp. 145-150.

26 Brühl, "Flucht in die Freiheit", pp. 10-11. 
For both sides, policy concerning the media was a balancing act from the beginning. On one hand, as Brühl has emphasized: "Without the photo of the two foreign ministers cutting the barbed wire, which went around the world, and the reaction of the East Germans who were willing to flee, the rapid collapse of socialism in its communist form [would have been] unthinkable". The media's "daily drumming", its reports on the growing numbers of people eager to flee, fed the public pressure on politicians to help. Without the influence of the media, the events of the summer of 1989 would have been unimaginable. But information about the refugees still had to be muted. If a refugee appeared in front of a television camera, this could trigger retaliations against relatives who still lived in the GDR. For Brühl it is clear: "If the information about the death strip being eradicated had not spread so quickly, especially the extremely popular image of the two foreign ministers cutting the barbed wire fence on 27 June 1989 , the movement of refugees probably would not have been so rapid". ${ }^{27}$

Bonn praised Vienna, and Austria's policy received gratitude and approval. Kohl personally thanked the citizens of Burgenland. The Austrian Federal Chancellery on Ballhausplatz registered the West German reaction: it was "admonishing stubborn patience", it continued to talk about the integration of the West and its active participation in the European unification process, and it held "relieved gratitude" for confidence statements from its allies such as US president Bush. ${ }^{28}$

The position of the USA from the view of the diplomatic reports and evaluations of the political situation by the Austrian Foreign Ministry (BMfaA) shows that what was involved was essentially the continuation and safeguarding of the Western security policy, the guarantee of the peaceful reform process in Central and Eastern Europe, and the support of the policies of Mikhail Gorbachev. In spite of different positions (Henry Kissinger doubted the continuous logical development of the line pushed by Gorbachev from Wladimir I. Lenin's Decree on Peace to the idea of a "common house" in Europe), one thing was totally clear for Washington: the CSCE process was to be strengthened and the human rights situation in Central and Eastern Europe was to improve. The Intermediate-Range Nuclear Forces (INF) Treaty of 1987 was adopted as a foreign policy success of US president Ronald Reagan. Austria's geopolitical situation was taken into account by American military and security strategists in their considerations and evaluated negatively, that is, it was viewed as a weak point (literally a "nightmare") for the defense of Western Europe. ${ }^{29}$

27 Ibid., pp. 11-12, quote here p. 12; see also Horst Teltschik, 329 Tage. Innenansichten der Einigung, Berlin (Siedler) 1991, p. 39.

28 Report "BRD; Regierungserklärung des Bundeskanzlers zur Lage der Nation im geteilten Deutschland (8.11.1989)", Loibl, Austrian embassy Bonn, to Austrian BMfaA, 10 November 1989, in Archive of the Austrian embassy Bonn, Nr?. Z1. 21.56.02/2-A/89.

29 Report "Einige Aspekte der Sicherheitspolitik des Westens (Lage zu Jahresbeginn 1988)", Plattner, 2 February 1988, in BMEIA GZ. 703/1-II.1/88. 
Nevertheless, US-Deputy Secretary of State Lawrence Eagleburger assessed Austria's knowledge of and experience with Central and Eastern Europe for the State Department as "valuable". On the other hand, he evaluated the proposal for a neutralization of Germany (such as by the Modrow Plan of 1990) as "very dangerous". 30

Austria itself welcomed the rapprochement between the superpowers (with regard to the disarmament of conventional weapons systems and the elimination of nuclear weapons) and also wished to see these measures extended to cultural and economic areas. Against the background of the new reduction of tensions, Vienna wanted to newly present its function as a bridge between East and West through its neutrality, which for the most part still remained untouched.

\section{The changes in the Czechoslovak Republic}

The first official visit since 1981 of a Czechoslovak head of government to Austria took place on 24-25 October 1989. For Prime Minister Ladislav Adamec, this was also his first visit to the West. The long delay for this official visit to Austria made it evident that from the Austrian viewpoint, bilateral relations with Czechoslovakia were not as deep-rooted or close as those with Hungary. Adamec's visit left the impression in Vienna that the government in Prague had decided on a policy of cautiously becoming more open and of pursuing matters that Austria considered important. A sign of this had already been seen by a number of humanitarian cases being resolved before the visit. This indicated Prague's willingness to introduce a series of other measures that would make it easier for the citizens of both countries to cross the border. But one key Austrian request, a reduction in visa fees, did not appear on the list of measures proposed by Adamec. It seemed that the ČSSR either could not or did not want to relinquish this source of foreign currency earnings, especially when tourism was increasing. When questioned later, the former Czechoslovak ambassador to Vienna Marek Venuta agreed that this had been the case. Environmental issues were presented as one of the Czechoslovak government's biggest concerns. Vienna was expecting Czechoslovakia to build more nuclear power plants. Adamec repeated that it was very interested in intensifying its economic relations with Austria. There were opportunities for this particularly in the area of environmental technology. According to Vienna's appraisal of the situation, Prague was aware of its need for socio-political change, particularly in light of the incipient reform developments in the GDR and the

30 Quotation from Information "Österreichisch-amerikanische KSZE-Konsultationen (Washington, 2.2.1990", Vukovich, 7 February 1990, in BMEIA GZ. 807.30/39-II.7/90; also in that respect: Aktenvermerk "Besuch des stv. amerikanischen AM Eagleburger in Wien (23. bis 25.2.) Besuch bei HBM, Round Table-Gespräch; AV”, Prohaska, 5 March 1990, in BMEIA GZ. 224.18.13./2-II.9/90. 
possibility of an impending isolation, which sparked serious concern. But any attempts at other political forces gaining political participation were still rigidly tied to the communist party's grasp on its governing role, and thus from the outset were severely limited. This was unequivocally expressed by Adamec during his Vienna visit: There would be "dialogue with 'independent groups' only if they do not place the existing system in question". ${ }^{31}$

In October 1989, the course had been set in Prague for a careful and yet perceptible intensification of Austro-Czechoslovak relations. But the CSCE human rights stipulations continued to be a limiting factor from Vienna's point of view, while in Prague they were perceived by many communists as annoying. ${ }^{32}$

A few weeks later, Mock concluded in retrospect that the developments in Czechoslovakia had been "less dramatic" than those in the GDR. Because of the sudden feeling of political isolation, the local leadership yielded "relatively rapidly to the pressure of the powerful demonstrations, especially after 17 November". ${ }^{33}$

The rigid functionaries heading the communist party were soon replaced by leaders ready for power-sharing. With the election of former dissident Václav Havel as president, "an unambiguous signal [was] set in the direction of democratization". During Mock's visits to Prague and Bratislava in March 1990, he was able to "perceive this change clearly". Just as Mock had initiated the first stage of the CSCE human rights control mechanism when Havel had been arrested the previous year, Mock intervened on 25 October 1989 for the release of Jan Čarnogurský, who was imprisoned in Bratislava. A few weeks later Čarnogurský had become part of the government as the first deputy to the prime minister. Mock made it clear "that today at the top of the Czechoslovak state are people with whom we are closely connected because of our natural solidarity in difficult times". ${ }^{34}$

\section{The changes in Romania, Bulgaria and Yugoslavia}

Especially dramatic were the developments in Romania, which coincided with the Christmas holidays. Hundreds of people died in chaotic conditions during the struggle for freedom. ${ }^{35}$ Vienna was informed about the continuing miserable supply situation and the violation of human rights. The government's position could only be sustained by the security forces. Although a few individuals could be

31 Record entry, Sucharipa m. p., "CSSR; offizieller Besuch Ministerpräsident Adamec; Gesamteindruck”, 30 October 1989, in BMEIA, GZ. 35.18.09/36-II.3/89.

32 Ibid.

33 Report Valentin Inzko “'Der Wandel in Europa als Herausforderung für Österreich,' Rede des Herrn Bundesministers im Nationalrat; Verteilung [15.3.1990]" 16 March 1990, in BMEIA, Zl. 700.17.15/149-I.3/90.

34 Ibid.

35 Anneli Ute Gabanyi, Die unvollendete Revolution: Rumänien zwischen Diktatur und Demokratie, 2nd ed., Munich: Piper, 1990, pp. 82-131. 
registered as being part of an opposition, their efforts were ineffective. The federal government in Vienna had applied the CSCE human dimension mechanism (levels 1 and 3 ) according to the Vienna follow-up meeting. ${ }^{36}$

As stressed by Mock, Austria could also be proud "that it had the courage to call on the United Nations Security Council to deal with the situation in Romania". ${ }^{37}$

However, due to the nature of the Security Council decision-making process, with permanent members having veto power, the Council was blocked (by Moscow and Beijing). As soon as the tide had turned in Romania after the bloody overthrow of Nicolae Ceaușescu, Austria and its population distinguished themselves, as Mock notes, "through a huge wave of aid and solidarity that was internationally recognized". 38

The reform efforts in Bulgaria were judged in Vienna as being "art for art's sake". At the first signs of pluralistic impulses, repressive forms could immediately be seen. Austria served as a transit country for Turkish-Islamic minorities. ${ }^{39}$

While the developments in Bulgaria were still largely dominated by the communist party, although excesses toward the country's Islamic ethnic minority had subsided (Sofia initiated a brutal bulgarization $=$ assimilation policy against the Turkish population which led to mass flights). Additional to these facts Mock let it be known that the developments in Yugoslavia gave "cause to a certain degree of concern". Old nationalistic and ethnic divisions that were thought to have been overcome threatened to erupt again. The foreign minister, however, was swayed by the idea "that Yugoslavia is strong enough to cope with these problems politically, and to solve them step by step in the course of the democratization process". ${ }^{40}$

$\mathrm{He}$ was mistaken. Hungary's foreign minister Horn had informed the Ballhausplatz about "Hungary's great concern" already in March 1989: "Milošević is pursuing a neo-Stalinist model that is even more dangerous when seen in a nationalist-Serbian framework. This can lead to unforeseeable consequences". ${ }^{41}$

In the 1990s, Europe was to experience three new wars in the so-called Balkan (from 1991, Slovenia-Croatia against "Rump Yugoslavia", the latter one against the part-republics of Slovenia and Croatia that had declared themselves independent; from 1992 to 1995, a civil war in Bosnia-Herzegovina; and in 1999, NATO against "rest Yugoslavia" as a result of the Kosovo crisis). There had already been four Balkan wars until 1945 (in 1912, 1913, 1914-1918, and 1941-1945), and

36 Information, Sucharipa m. p., "Osteuropa; aktuelle Lagebeurteilung", 8 June 1989, in BMEIA, GZ. 713/6-II.3/89.

37 Speech Mock, “Der Wandel in Europa als Herausforderung für Österreich”, 15 March 1990.

38 Ibid.

39 Information, Sucharipa m. p., "Osteuropa; aktuelle Lagebeurteilung", 8 June 1989, in BMEIA, GZ. 713/6-II.3/89.

40 Speech Mock, "Der Wandel in Europa als Herausforderung für Österreich", 15 March 1990.

41 Record entry, Sucharipa m. p., "Entwicklungen in Osteuropa; Gespräch des HGS mit Staatssekretär Horn”, 20 March 1989, in BMEIA, GZ. 502.16.03/19-II.3/89. 
thus today one can count a total of seven Balkan wars in the twentieth century. The year 1989 and the liberation movements in Central and Eastern Europe were not to change that.

\section{The Warsaw Pact in Transition and other trends in Central and Eastern Europe}

In Austria's assessment (based on Yugoslav and Hungarian sources), the meeting of the Warsaw Pact countries in Bucharest on 7 and 8 July $1989^{42}$ was marked by a "new atmosphere" that allowed "genuine consultations" of the type held between equals. The Pact was in the process of evolving into something similar to a political alliance. The Hungarian foreign minister considered three aspects worth mentioning: There was no resistance to Gorbachev's disarmament proposals, or even misgivings. Perestroika was deliberate, and the Brezhnev Doctrine had been "suspended". And a clear division had emerged between the socialist states with regard to their willingness to reform: On one side were the "hardliners", to which Horn counted not only the GDR and Romania, but also Bulgaria, to the surprise of Vienna. The progressive states were considered the USSR, Hungary and Poland. The ČSSR's low-key stance did not allow an opinion to be formed. According to information provided by Yugoslavia, bilateral issues were discussed in Bucharest, but not within the framework of the Pact's conference, but at a concomitant meeting of the party leaders. Ceausescu made serious reproaches against Hungary, but was "held back" by other party leaders. Todor Zhivkov requested support in Bulgaria's conflict with Turkey, but it was pointed out to him that he could hardly expect support from the partners now, after having neither informed nor consulted them with regard to his unilateral handling the dispute with Ankara (because of the heavy pressures against the Turkish minority in his own country). ${ }^{43}$

In December 1989, Vienna considered the general trends in Central and Eastern Europe to be the following: Most of the Warsaw Pact countries were pursuing a course of reform, from which "positive regeneration effects" would develop. Pragmatically, shifts were occurring in Moscow's limits regarding what it considered tolerable in the satellite states' transformation processes. Membership in the Pact was "still a conditio sine qua non". The northern states in the Pact's territory (Poland and the GDR) had a different strategic importance than the southern area (Bulgaria and Hungary). Stronger aspirations for neutrality were seen in Hungary. It had also been noted that there were separatist tendencies in the Baltic Soviet republics, which would dangerously boost the opposition to Gorbachev in

42 Document No. 146: Records of the Political Consultative Commitee Meeting in Bucharest, July 7-8, 1989, in Vojtech Mastny/Malcolm Byrne, A Cardboard Castle? An Inside History of the Warsaw Pact 1955-1991, Budapest - New York: CEU Press, 2005, pp. 644-654.

43 Report, Austrian embassy Belgrad, "Zum Warschauer Pakt-Gipfel in Bukarest (7-8 July 1989)”, Zl. 395-RES/89, 2 August 1989, in BMEIA, Zl. 701.03/14 and 16-II.3/89. 
the bureaucratic and military apparatus. Vienna considered it best if the West practiced restraint. The transformation of the Warsaw Pact into a (defensive) military alliance that no longer had the authority to intervene in internal affairs was seen by the majority of the member states as the goal. ${ }^{44}$

The foreign ministers' meeting in Warsaw 26-27 October, the first Warsaw Pact meeting without a communist chair, went well. With the increasing equality of the member states' rights on foreign policy issues, the need was seen for improved coordination through the establishment of a permanent (political) Warsaw Pact secretariat. Vienna recommended that the West should encourage these developments, also during the Vienna CSCE negotiations. Moreover, the Austrian chancellery was watching the desperate Soviet attempts to create a more efficient basis for CMEA cooperation. Vienna thought it very unlikely that this would happen, due to the attractiveness of the European Community as well as the EFTA. Austrian foreign policymakers were aware that the West had the great task of economically assisting the East European states and cautiously binding them institutionally (Council of Europe, EFTA, EC).

The EFTA could not take on the function of a waiting room, and therefore the EC and EFTA had to act in tandem. Western economic support had to be reformoriented ("structural reform consistency"). At the Ballhausplatz it was accurately recognized that economic structural reforms represented "a bigger problem" than had been previously thought. The process would be happening for the first time in history under the worst possible conditions: debt burden, poor infrastructure, obsolete institutions. Then again, the generally high educational level of the Eastern population was noted. If the economic reforms failed in the mediumterm, it was feared that the political reforms would be threatened. The possibility of these countries tipping toward nationalist right-wing governments or military regimes could not be ruled out. A return to the old communist rule in the Warsaw Pact countries was considered possible only if a concurrent revolution occurred in Moscow. At the Ballhausplatz, the central issue was therefore considered the continued existence of the Soviet course of reforms. Despite Gorbachev's apparently strong political position, increasing signs were already noted in December 1989 that the gap between the accelerated political change and the slow economic reforms would become dangerous. Washington also thought this to be the case. With the rapid changes in East Germany and the reaction of West Germany, panEuropean issues were being faced. From the Austrian viewpoint, these were to be addressed "calmly". With regard to the question of (re-)unification, the right to self-determination was emphasized, which Austria supported unconditionally.

According to the Ballhausplatz, it was "self-evident that this also applied to the people of both German states". Nonetheless, any reorganization of the

44 Report Zl. 350-RES/89, “Osteuropa. Generelle Tendenzen”, Abteilung II.3, 13 December 1989, in BMEIA, Zahl?.Zl. 713/78-II.3/89 (6421i) 
German-German relationship should be done in a manner that neither endangered the process of détente and peace in Europe, nor created questions regarding the inviolability of the postwar borders for the neighboring countries. ${ }^{45}$

\section{Conclusion}

Austria responded early and positively to the reform efforts in the states of Central and Eastern Europe. Its strongest sympathies were for the changes in Hungary, as well as for those in Poland, albeit to a lesser degree. The reaction to the developments in Czechoslovakia, Romania and Bulgaria ranged from skeptical to disapproving. The end of the GDR had an entirely different impact and was to change the situation dramatically. The collapse of the communist dictatorship was received in Vienna with mixed feelings. While Vranitzky's attitude toward the reform mindedGDR was open, well-disposed and even friendly, Mock clearly sided with Kohl's policy. Dissent within the coalition was unmistakable. The differing attitudes of the Austrian government leaders toward the German developments were also due to their different lines regarding the EC. Mock's course was focusing on accession to the EC, whereby he was relying on West German support, just as he had also expressed his early support for Kohl's Germany policy. Vranitzky moved thoughtfully and carefully with regard to Austria's application for EC membership, at all times emphasizing and upholding the government's policy of neutrality. This resulted in his more economic-pragmatic approach to the reform movements in Central and Eastern Europe, while Mock's position was more strongly based on anti-communist - that is, ideological - as well humanitarian and cultural-political motives. In the second half of the 1980s, the ÖVP, with Busek and Mock, was more focused on Central and Eastern Europe than the SPÖ under Vranitzky. With the exception of the rapid onset of the German unification movement, which surprised all who were involved, it is amazing how accurately the changes in the other states were assessed.

To conclude, five aspects should be established:

1. Vienna was accurate in its assessment of the actual interdependence and mutual interaction between glasnost and perestroika in the Soviet Union and the changes in Central and Eastern Europe.

2. Gorbachev's key role in the reform processes and the further opening of Central and Eastern Europe was recognized by Vienna early: Whether the developments stood or fell was dependent on him. This is why the stability of the Gorbachev regime was accorded a top priority. In this regard, Austria's foreign policy moved completely in line with that of the West.

3. The reform movements in Central and Eastern Europe were judged realistically with regard to their significance and stage of development. The difference

45 Ibid. 
between the pioneering role of Poland and Hungary and the slower headway in Bulgaria, East Germany, Czechoslovakia and Romania was evaluated reliably and with fine distinctions.

4. The fact that the German question might result in a significant shift of power in Central Europe was perfectly clear in Vienna. The diplomats at the Ballhausplatz did not follow the changes in East Germany only by waiting and sitting still, but with a sense of urgency and concern. The fall of the GDR was different than the changes occurring in Hungary and Poland. While Vranitzky tried to moderate and Mock acted in a pronounced pro-German especially pro-unification manner, Busek remained silent.

5. The CSCE offered an important stabilizing and conciliatory framework into which the dramatic upheavals could be placed. This was also the consensus among all twelve EU member states. Austria's mediation services within the CSCEfollow up-process and Vienna as a meeting place had a positive impact on the further developments.

The only decisive way for Austria to intervene politically in the course of the events just before the fall of the Berlin Wall was through the symbolic cutting of the Iron Curtain and the assistance and support it gave to fleeing East German citizens. The Austro-Hungarian prologue in the summer of 1989 was decisive for the extreme speed of the developments in the autumn in Germany. The decision to unify Germany and to free the Central and Eastern part of the continent from communist dictatorship as well as from soviet oppression and involve it in the medium and long-term European integration project was the result of a "glorious moment of diplomacy". ${ }^{46}$ The decisions were not only made in Vienna, but in Moscow, Washington, Bonn, and later in Brussels within the framework of NATO and the EU.

46 Philip Zelikow and Condoleezza Rice, Sternstunde der Diplomatie. Die deutsche Einheit und das Ende der Spaltung Europas, 2nd ed., Munich: Propyläen, 2001, pp. 483-491. 


\title{
Ever Closer or Diverging: The Relationship between $\mathrm{EC}$ and the Latecomers (Bulgaria and Romania) Seen Through the Prism of CVM
}

\author{
Georgi DIMITROV
}

\begin{abstract}
Upon the formal accession of the last two member-states to the EU in 2005 it was evident that the Balkan countries had socio-political and institutional peculiarities and faced challenges which made it necessary to launch the unprecedented Cooperation and Verification Mechanism (CVM). In the beginning it was clear that the Bulgarian case was the worse one since the Bulgarian authorities had to fight the large scale organized crime as well. Yet it was even clearer that the gravest deficit in both countries was the lack of systematic policies of anticorruption fight.

Five years later it is quite interesting:

1. To what extent the objectives of CVM have been achieved in bringing local citizens to the standards of EU citizenship or the problems - and the threats to the basic EU principles and values - persist?

2. Are the two countries increasing their dissimilarities? Or do they keep moving in a common track (or even become more and more alike)?

3. Are there proofs that EC is really a partner (which would mean that it was capable of adequately addressing the specificity of the South-East European societies and had taken shared responsibility for the policy outcome) or the potential of the very CVM is limited by some initial paradigmal handicaps and it has actually aggravated the situation in contrast to its good intentions?

These are the major questions that have been answered by the comparative empirical study of the EC's regular reports under the CVM for the last 6 years. The paper presents the key findings of this study in brief.
\end{abstract}

I. Why should the level of commensurability (or similarity) between Bulgaria and Romania be studied? Because the two countries regularly appear as identical. But this is an appearance only

The level of similarity seems spectacular, indeed. For example, the findings of the so called "Catch-up index" are quite symptomatic. ${ }^{1}$ Having compared 35 European countries in terms of economy, democracy, governance, and quality of life in general the study summarizes the results about the Balkan countries under the paragraph title "A bunch of identical twins" p. 53 (only Croatia being somewhat different positively and Bosnia and Herzegovina - negatively). If one looks more carefully at the comparison between Romania and Bulgaria the conclusion is

1 M. Lessenski, Aftershocks: What Did the Crisis Do to Europe? OSI-Sofia, January 2013, http://www.thecatchupindex.eu/TheCatchUpIndex/, accessed 20.02.2013. 
inevitable - these two are twins, indeed. ${ }^{2}$ The diamond of the integrated indices for the two countries is not only overtly smaller than the one for all EU-27, i.e. the four crucial dimensions of public life are far less developed than the EU-27 average. The two diamonds actually coincide as if it is a single national case "Bul-manian" or "Ro-garian".

If we switch our attention to the results of the National Integrity System project the findings would not be that much different. Yet, with the exception of press freedom where Bulgaria lags far behind Romania, the two countries seem similar/ commensurable in overall account.

\begin{tabular}{|l|l|l|l|l|}
\hline & \multicolumn{2}{|l|}{ Rank } & Score \\
\hline & Bulgaria & Romania & Bulgaria & Romania \\
\hline Corruption perception index & $75 / 176$ & $66 / 176$ & 41 & 44 \\
\hline control of corruption & $52 \%$ & $54 \%$ & 0.183081909 & 0.158045272 \\
\hline global competitiveness & $62 / 142$ & $78 / 142$ & 4.27 & 4.07 \\
\hline judicial independence & $104 / 142$ & $94 / 142$ & 2.9 & 3.1 \\
\hline rule of law & $53 \%-0.080129673$ & $56 \%$ & 0.080129673 & 0.049652261 \\
\hline press freedom & $80 / 179$ & $47 / 179$ & 29 & 14 \\
\hline voice and accountability & $63 \%$ & $61 \%$ & 0.485637139 & 0.44657546 \\
\hline human development & $55 / 187$ & $50 / 187$ & 0.771 & 0.781 \\
\hline
\end{tabular}

Source: European National Integrity System Project, 2012. http://www.transparency.org/country, accessed on 20.02.2013

Obviously, both the field of measurement and the measurement technique provide for some important nuances of variance. But broadly speaking the sociostructural pattern behind the empirical pictures is very much the same.

This is why we should not be surprised neither by the fact that the EC packed Bulgaria and Romania tightly together in the accession process and in a common conditionality framework of their actual EU membership nor by the fact that the Bulgarian case used to be worse of the two. Consequently, Romania has been monitored under the $\mathrm{CVM}^{3}$ upon 4 benchmarks ${ }^{4}$ while Bulgaria had to report on 6 bench-

2 See app. 1. Both in Romania and Bulgaria, being inseparable, the economy is better developed than the overall quality of life and democracy scores higher than... governance.

3 The [local]"authorities and the other Member States recognised that far reaching judicial reform was necessary if [their citizens] were to be able to exercise their rights as EU citizens and benefit from all the opportunities, including financial support, that EU membership would bring. More broadly, they recognised that principles which are at the heart of the EU respect for the rule of law, mutual recognition and cooperating on the basis of a fundamental bargain of trust - could only be put into practice if these problems were tackled at source". Brussels, 27.6.2007 COM(2007)377 final http://ec.europa.eu/cvm/progress_reports_en.htm

4 "The Commission sees all the benchmarks as closely interlinked. In its dialogue with Romania ample evidence has been given that progress under one benchmark contributes to 
marks despite of the fact that in both cases the problem was one and the same insufficiency of the Rule of law principle which, according to the EC's phrase, is at the heart of EU. Not surprisingly, the bulk of the official reports issued by the EC for the last 6 years from 2007 to 2012 seem as speaking of one situation only in terms of policy and politics. Of course, they can be read as political evaluations derivative of the findings and conclusions from the specific national cases but the sheer amount of identical paragraphs - literary word by word, proves that it is not the particular empirical state of affairs in the country under scrutiny that is crucial for the final evaluation but much more important is the general scheme of interpretation of those findings. This is why a more careful study of the very CVM is urgently necessary. Bulgaria and Romania may seem identical just because they are observed from afar and the socio-cultural distance nullifies the important substantive differences.

\section{The empirical study of CVM reports}

\subsection{The method of research}

We have to admit that the shift of the focus of our attention from the performances in the respective policy spheres monitored under the CVM to the mechanism itself came out of necessity. Initially, our research intention was simply to trace the developments under the 6 benchmark areas in Bulgaria ${ }^{5}$ and 4 benchmark areas in Romania ${ }^{6}$. The point was exactly to identify and to measure as strictly

progress under another benchmark. The rationale for the CVM is not to establish a check-list, but to develop an independent, stable judiciary which is able to detect and sanction conflicts of interests, and combat corruption effectively. Therefore the Commission does not envisage removing the benchmarks one by one but rather working with Romania to the point where the CVM in its entirety is ended". REPORT FROM THE COMMISSION TO THE EUROPEAN PARLIAMENT AND THE COUNCIL On Progress in Romania under the Co-operation and Verification Mechanism, Brussels, 22.7.2009 COM(2009) 401 final http://ec.europa.eu/cvm/ progress_reports_en.htm, accessed 20.02.2013 The very same is the report for Bulgaria.

5 "Six benchmarks were established, covering the independence and accountability of the judicial system, its transparency and efficiency; the pursuit of high-level corruption, as well as corruption throughout the public sector; and the fight against organised crime". REPORT FROM THE COMMISSION TO THE EUROPEAN PARLIAMENT AND THE COUNCIL On Progress in Bulgaria under the Cooperation and Verification Mechanism, Brussels, 18.7.2012 COM(2012) 411 final, http://ec.europa.eu/cvm/progress_reports_en.htm, accessed 20.02.2013. "Benchmarks were established in four areas: Judicial reform, integrity, the fight against high-level corruption, and the prevention and fight against corruption in the public sector". REPORT FROM THE COMMISSION TO THE EUROPEAN PARLIAMENT AND THE COUNCIL On Progress in Romania under the Cooperation and Verification Mechanism, Brussels, 18.7.2012, COM(2012) 410 final, http://ec.europa.eu/cvm/progress_reports en.htm, accessed 20.02.2013.

6 "Benchmarks were established in four areas: Judicial reform, integrity, the fight against high-level corruption, and the prevention and fight against corruption in the public sector". 
as possible the levels of commonality and difference between the Bulgarian and the Romanian cases. In order to carry out this research task we composed a very complex research instruments comprised of about 130 indices concerning the complexity of the phenomenon of judiciary system reform and the anticorruption policies, for example - identified deficiencies, kinds of resources used, temporality and scope of the problems, levels of subject involved, kinds of interest abused, types of EC's assessment, emotional affectivity of the evaluations, etc. The idea was to trace the trends over the 6 year period and to analyze to areas of similarities or dissimilarities of the tracks between the two national cases. All national reports for Bulgaria and Romania have been studies both technical (issued usually in February each year) and political (issued in July).

\subsection{The empirical facts - divergence and similarities}

The empirical picture turned out to be very close to what one could expect - on closer inspection the two national cases performed processes simultaneously of homogenization, divergence and even incommensurability. Let me give just an illustration of the typical cases: a case of synchronized developments in both countries and a case opposite directions of the monitored processes. ${ }^{7}$

Keeping in mind the fact that we used 130 indices and through that research device observed only a tiny segment of the reform processes the empirical picture certainly could be classified as discouraging and predominantly chaotic. Not surprisingly the EC has been at pains to come up with systematic, logically consistent and concise interpretation of the on-going events. Again for the sake of an eventual clarity we calculated correlation coefficients for all the cases observed were there were more than 15 entries for a particular index per country for the entire period of 6 years. This is what has been found.

\subsection{Correlation of (dis)similarities}

\begin{tabular}{|l|l|l|}
\hline Correlation coefficient: & Number of cases/indices & per cent \\
\hline From $-1,00$ to $-0,68$ & 2 & 3,0 \\
\hline From $-0,67$ to $-0,34$ & 6 & 9,1 \\
\hline From $-0,33$ to $-0,01$ & 8 & 12,1 \\
\hline From 0,00 to 0,33 & 18 & 27,3 \\
\hline From 0,34 to 0,67 & 17 & 25,8 \\
\hline
\end{tabular}

REPORT FROM THE COMMISSION TO THE EUROPEAN PARLIAMENT AND THE COUNCIL On Progress in Romania under the Cooperation and Verification Mechanism, Brussels, 18.7.2012, COM(2012) 410 final, http://ec.europa.eu/cvm/progress_reports_ en.htm, accessed 20.02.2013.

7 See app. 2. These are just two illustrations of the correlations registered. 


\begin{tabular}{|l|l|l|}
\hline From 0,68 to 1,00 & 15 & 22,7 \\
\hline Total & 66 & 100,0 \\
\hline
\end{tabular}

As it becomes clear from the data in the table above, nearly three fourths of these 66 cases where intensive developments have been monitored in both countries prove a positive correlation and nearly half of the cases prove strong positive correlation. Yet in about 12 per cent of the cases there has been found a strong negative correlation. The analysis is far from being finalized because in the course of the study the research team was surprised by an unexpected fact emerging from the documents - the specificity of the CVM itself whose weird character happened to be documented in the annual monitoring and evaluation reports.

\section{The astonishing first findings}

\subsection{EC's wrong doings}

Within the limits of the current paper we can not provide the full-length proof of the conclusions we have made in the process of our work. They are summarized in a report of 75 pages. ${ }^{8}$ Here are some major observations:

- The CVM is designed to instruct national authorities who would be willing to undertake fundamental and far-reaching reforms but just lack know-how, avoiding to address theinevitable and comprehensive opposition to the reforms as a major institutional and political framework of the problem tackled;

- It is too narrowly focused on the procedures of the report preparation and the monitoring, while underestimating the methodology of practical cooperation between the EU institutions and the national governments;

- Although it is called a cooperation mechanism, it does not provide in practice for real policy partnership, (exemplified by the attribution of the advancements to the account of the EC's pressure mainly and all failures to the account of the two national governments only ${ }^{9}$ );

- Hence, there are many deficits, such as undefined scope and structures of the functional relations in the monitored areas; frequent blending of facts, emotional and ethic evaluations, normative statements and optimistic expectations within a single sentence or paragraph. Many substantial drawbacks derive from the plentiful recommendations possessing hidden crucial prerequisites, which - if present - would make the recommendations themselves superfluous.

8 Dimitrov, Haralampiev, Stoychev, Toneva-Metodieva - "The Cooperation and Verification Mechanism: A Shared Political Irresponsibility between European Commission and the Bulgarian Governments" (research findings from the project "The Role of Fight against Corruption in the Relations between the European Commission and the Bulgarian Governments 2007-2012"), (2013 in press).

9 See the two national reports from July 2012 for more details. 
3.2. It is a matter of approach ... and partnership (ownership and involvement)

The CVM has been designed to monitor and evaluate the progress in "putting in place" the rule of law in Bulgaria and Romania through a long-lasting and comprehensive reform in all authority systems. It is intended to instruct the national Governments how to perform the reform policies in fight against corruption. ${ }^{10}$ But it has been caught by surprise by the fact that no such policies are really envisioned by the successive national governments and that systematic corruption resists successfully any real reform attempts. Within the framework of this farreaching, omnipowerful opposition to reforms some key shortcomings of the CVM became obvious: its goals could be achieved only through systematic public international pressure towards authentic political responsibility but the mechanism at present does not provide legal grounds, legitimacy and even instruments for such an accomplishment. The CVM is operational as a means of monitoring; it is somewhat dubious as a means of evaluation and certainly a flawed instrument for cooperation if the latter implies solidarity: a shared responsibility for the interests of the citizens of the EU and for the validity of the rule of law. If we take the EC's statement that "Today's European Union is highly interdependent"11 seriously this means that the rule of law in the two South-Eastern countries concerns the welfare of all EU citizens and the functioning of the EU itself.

\section{Conclusion: the necessity of tuning up the CVM}

The initial aim of our research has to be postponed for a while. In the course of our study we found that the "optics" through which the Bulgarian and the Romanian societies are seen and politically monitored provides an aberration: the prevailing similarities of the two countries are due to this aberration and to the aloofness of

10 The problem of policy efficiency in fight against crime is not new and it is a matter of approach indeed: "Transitions from corrupt regimes to regimes where ethical universalism is the norm are political and not technical-legal processes.

...All good governance programs should be designed to promote this political approach: audits, controls and reviews should be entrusted to 'losers' and draw on natural competition to fight favouritism and privilege granting. No country can change without domestic collective action which is both representative and sustainable over time. The media, political oppositions and civil society should not be seen as non-permanent guests taking part in consultations on legal drafts but as main permanent actors in the process of anti-corruption and holding decisive seats in all institutions promoting ethical universalism.

...The failure of the anti-corruption conditionality is partly grounded in the lack of understanding of particularism as a regime of governance and in consequently selecting various implausible principals as main actors to change the regime". (Contextual Choices in Fighting Corruption: Lessons Learned, p. 7)

11 See the reports for Bulgaria and Romania from July 2012. 
the standpoint of the observer. They look as if similar a) to the extent they both (but not jointly) diverge from the basic EU principles and values and b) through the prism of their "common" failure to make qualitative progress. Yet the policy recommendations derivative from such a standpoint would never be productive. The CVM is designed as an instrument of the EC for providing support to the Bulgarian and Romanian Governments in order to overcome the fundamental political and institutional deficits, which would enable the rule of law. The latter is a necessary premise for guaranteeing the dignity and the interests, including quality of life, not only of the citizens in the two Balkan countries, but of all EU citizens. Given that the member-states of today's EU are unprecedentedly interconnected, as the EC itself underlines, there would be no market economy, real representative democracy and civil rights at all, if "black zones" exist where other rules are in place, corruption is a cultural norm and political responsibility has no real sense.

Has, however, the six-year long application of this instrument achieved its goals? The usage of the CVM up to present shows a 'mixed picture', to use the Commission's parlance. Undoubtedly there is a good will, devotedness and efforts invested by the Commission, not to forget the direct money investments in reforms, as well. Yet, what has been achieved is quite afar from the initially set goals. The mechanism is only partially successful - to the extent that it has not failed entirely. However, it does not meet the expectations because:

- It simply registers meticulously the transformations in the resistance against the reforms and against its goals which are different, in technical terms only, in Bulgaria and Romania (as is different their pace) while the common socio-structural pattern persists;

- It legitimizes the imitation of reforms in anticorruption policies through adoption of successive measures, varying in time but leading to no result in general.

The preservation of the CVM in its present form would lead to nothing more but escalating disappointment. Even further, the monitoring reports of the EC are turning into a source of political problems, since the mechanism itself possesses key drawbacks. Continuing the CVM would be meaningful only if its effectiveness drastically improves. ${ }^{12}$ For that reason it should be substantially transformed into an institutional mechanism for joint political liability to the results of its application. Its new pattern of operation should necessarily emerge as a result of a broad public European debate on the reason, the aims, the powers and the instruments. It should lead to stronger institutionalization of the pressure towards clear results in anticorruption policies for the protection of the interests of the European citizens and for fostering the integration processes in the EU.

12 It is hardly a coincident that the findings of the International Advisory Board instituted by the Bulgarian Prime minister in 2009 to assess the severe problems of Bulgaria's EU membership have been summarized in a report under the title Bulgaria in the EU: Building a New Partnership... 


\section{References}

Bulgaria in the EU: Building a New Partnership, International Advisory Board Report, 2009.

Dimitrov, Haralampiev, Stoychev, Toneva-Metodieva - The Cooperation and Verification Mechanism: A Shared Political Irresponsibility between European Commission and the Bulgarian Governments, (research findings from the project "The Role of Fight against Corruption in the Relations between the European Commission and the Bulgarian Governments 2007-2012), (2013 forthcoming).

Lessenski, M. - Aftershocks: What Did the Crisis Do to Europe?, Findings of the New European Catch-Up Index, Open Society Institute, Sofia, 2013

Mungiu-Pippidi, Al. et al. - Contextual Choices in Fighting Corruption: Lessons Learned, Norad, the Hertie School of Governance in Berlin, Evaluation studies 4/2011.

Appendix 1.

Graphical presentation of the finding of the Catch-up Index survey for Bulgaria and Romania in comparison with EU-27 http:/www.thecatchupindex.eu/TheCatchUpIndex/

\begin{tabular}{|l|l|l|}
\hline Detailed statistics by indicator & Bulgaria & Romania \\
\hline Economy & & \\
\hline GDP per capita in PPS with EU27 average $=100$ as a basis & 44.00 & 46.00 \\
\hline General government debt (\% of GDP) & 16.30 & 33.30 \\
\hline Sovereigns credit ratings (10 is best and 0 is worst) & 6.90 & 6.57 \\
\hline Employment rate \% & 58.50 & 58.50 \\
\hline Patents granted by USPTO per captita & 0.57 & 0.32 \\
\hline High-tech exports as \% of manifactured exports & 7.91 & 10.95 \\
\hline Information and Communication Technology (10 is best and 1 worst) & 5.19 & 5.20 \\
\hline $\begin{array}{l}\text { Energy intensity of the economy (e.g. over 900 is a bad coefficient, } \\
\text { below 100 is a very good one) }\end{array}$ & 853.77 & 588.93 \\
\hline Motorways per area 1000 km2 & 3.94 & 1.39 \\
\hline Motorways per 100000 inhabitants & 5.82 & 3.12 \\
\hline Other roads per 1000 km2 & 171.53 & 344.20 \\
\hline Other roads per 100000 inhabitants & 253.42 & 771.40 \\
\hline Doing Business rank (e.g. 1 is best and below 180 worst) & 59.00 & 72.00 \\
\hline Economic Freedom score (100 is maximum and 0 minimal freedom) & 64.70 & 64.40 \\
\hline Democracy & & \\
\hline Satisfaction with democracy \% (100 is best and 0 worst) & 27.00 & 22.00 \\
\hline Trust in people (10 is best and 0 is worst) & 4.10 & 5.50 \\
\hline Freedom House democracy score (1 is best and 7 is worst) & 2.00 & 2.00 \\
\hline $\begin{array}{l}\text { Economist Intelligence Unit Democracy Index (10 is best and 0 is } \\
\text { worst) }\end{array}$ & 6.78 & 6.54 \\
\hline $\begin{array}{l}\text { Freedom of the Press score by Freedom House (0 is best and 100 is } \\
\text { worst) }\end{array}$ & 36.00 & 41.00 \\
\hline $\begin{array}{l}\text { Press Freedom Index by Reporters without Borders (e.g. 0 is best and } \\
\text { 105 worst) }\end{array}$ & 74.34 & 84.21 \\
\hline Voice and Accountability - WGI (100 is best and 0 is worst) & 62.56 & 61.14 \\
\hline
\end{tabular}




\begin{tabular}{|c|c|c|}
\hline $\begin{array}{l}\text { Disrespect for human rights by Global Peace Index ( } 1 \text { is low disre- } \\
\text { spect and } 5 \text { high disrespect) }\end{array}$ & 2.00 & 2.50 \\
\hline E-participation index ( 1 is best and 5 worst) & 0.03 & 0.08 \\
\hline \multicolumn{3}{|l|}{ Quality of Life } \\
\hline Actual individual consumption with EU27 average $=100$ as a basis & 42.00 & 45.00 \\
\hline $\begin{array}{l}\text { Gini coefficient (e.g. over } 35 \text { is high inequality and below } 25 \\
\text { is low inequality) }\end{array}$ & 33.20 & 33.30 \\
\hline Relative median at-risk-of-poverty gap (\%) & 29.60 & 22.20 \\
\hline Long term unemployment rate & 6.30 & 3.10 \\
\hline Share (\%) of early school leavers & 13.90 & 18.40 \\
\hline Share of population (\%) with university degree & 19.40 & 11.90 \\
\hline $\begin{array}{l}\text { PISA score in reading literacy (e.g. over } 500 \text { is very good and below } \\
300 \text { is a very poor result) }\end{array}$ & 429.00 & 424.00 \\
\hline $\begin{array}{l}\text { PISA score mathematical literacy (e.g. over } 500 \text { is very good and } \\
\text { below } 300 \text { is very poor result) }\end{array}$ & 428.00 & 427.00 \\
\hline $\begin{array}{l}\text { PISA score in scientific literacy (e.g. over } 500 \text { is very good and be- } \\
\text { low } 300 \text { is very poor result) }\end{array}$ & 439.00 & 428.00 \\
\hline $\begin{array}{l}\text { Healthy life expectancy at birth in years (e.g. about } 74 \text { is very good } \\
\text { and about } 63 \text { is bad) }\end{array}$ & 66.00 & 65.00 \\
\hline $\begin{array}{l}\text { Life expectancy in years (e.g. about } 82 \text { is very good and about } 71 \text { is } \\
\text { bad) }\end{array}$ & 74.00 & 73.00 \\
\hline $\begin{array}{l}\text { Infant mortality by age of } 5 \text { (e.g. } 3 \text { is very good and below } 10 \text { is a } \\
\text { very poor result) }\end{array}$ & 11.00 & 13.00 \\
\hline $\begin{array}{l}\text { EuroHealth Consumer Index (e.g. over } 850 \text { is very good and below } \\
450 \text { is very poor) }\end{array}$ & 456.00 & 489.00 \\
\hline Human Development Index ( 1 is best and 0 is worst) & 0.77 & 0.78 \\
\hline \multicolumn{3}{|l|}{ Governance } \\
\hline Corruption Perception Index - 10 (very clean) to 0 (highly corrupt) & 3.30 & 3.60 \\
\hline Control of Corruption - WGI (100 is best and 0 is worst) & 52.15 & 53.59 \\
\hline $\begin{array}{l}\text { Political instability by Economist Intelligence Unit (1 most stable - } \\
10 \text { most unstable) }\end{array}$ & 6.00 & 6.40 \\
\hline $\begin{array}{l}\text { Political Stability and Absence of Violence - WGI ( } 100 \text { is best and } 0 \\
\text { is worst) }\end{array}$ & 57.55 & 54.72 \\
\hline $\begin{array}{l}\text { Conflicts and tensions in the country } 1 \text { - most peaceful; } \\
3 \text { - least peaceful(selected Global Peace Index indicators) }\end{array}$ & 1.67 & 1.83 \\
\hline Homicide rates per 100,000 population & 1.90 & 1.90 \\
\hline Governement Effectiveness - WGI (100 is best and 0 is worst) & 56.46 & 50.24 \\
\hline Regulatory Quality - WGI (100 is best and 0 is worst) & 71.77 & 74.16 \\
\hline Rule of Law - WGI (100 is best and 0 is worst) & 53.08 & 56.40 \\
\hline E-government development index ( 1 is best and 0 is worst) & 0.66 & 0.61 \\
\hline
\end{tabular}


chart by amCharts.com

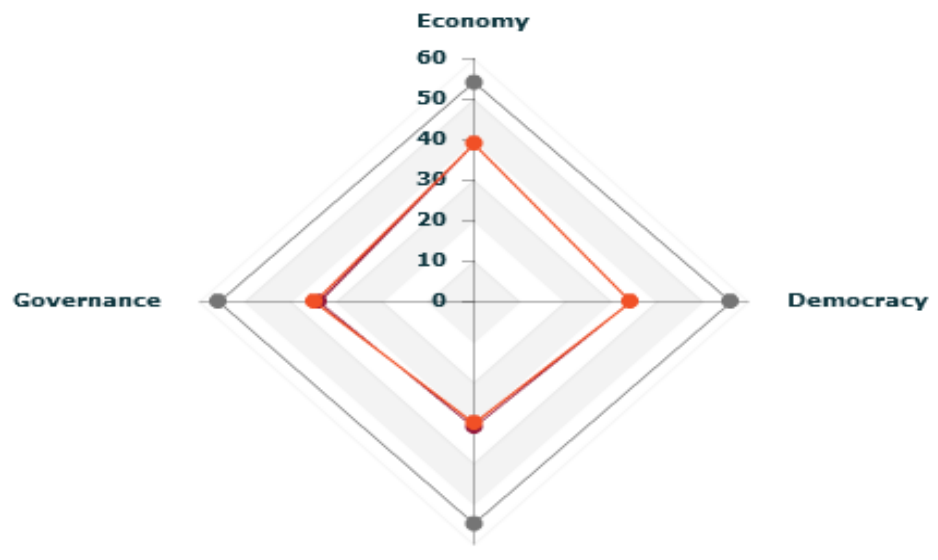

Quality of Life

Bulgaria

Romania

EU27

Appendix 2.

An example of a strong negative correlation between Romania and Bulgaria - levels of adopted anticorruption legislation by year.

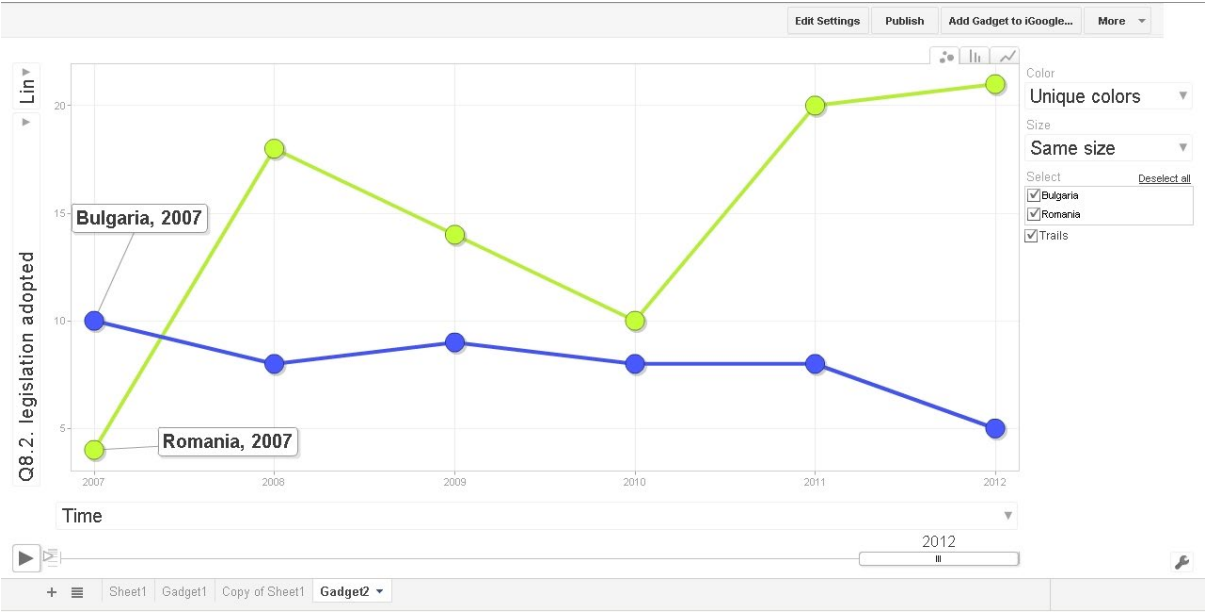


An example of a strong positive correlation - institutional deficit: independent judiciary by year.

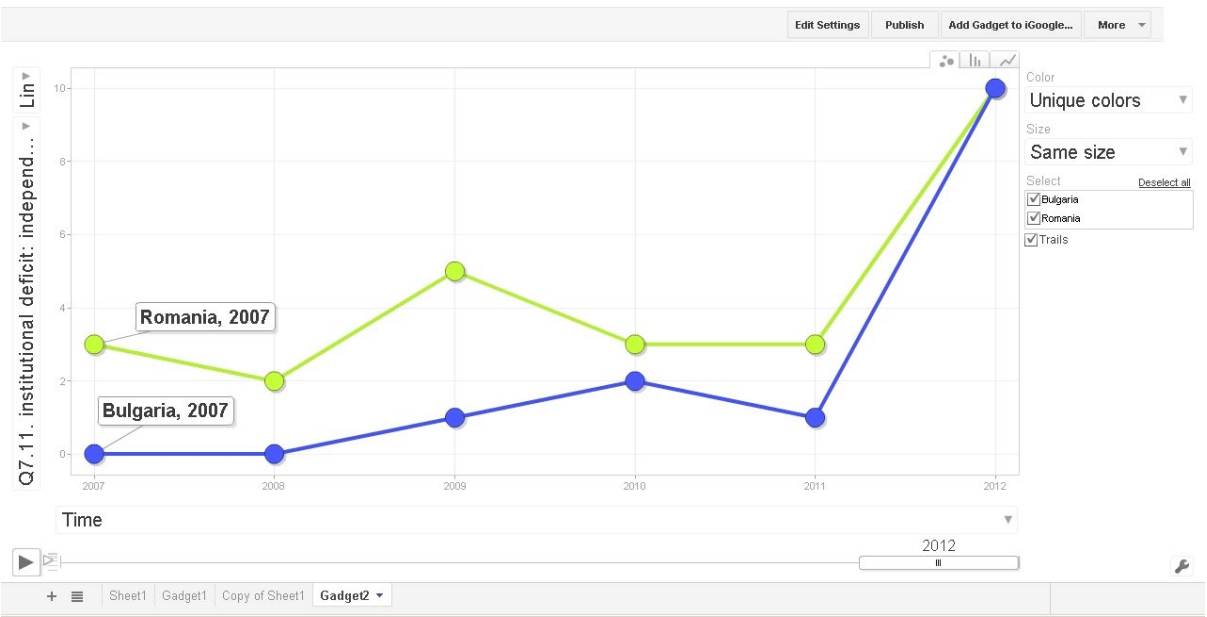

The statistical analysis and the visualization are carried out by Prof. K. Haralampiev. 


\title{
Coopération dans le cadre du Groupe de Visegrad à l'épreuve de l'integration européenne. Point de vue polonais
}

\author{
Ewa SZCZEPANKIEWICZ-RUDZKA
}

\begin{abstract}
Le Groupe de Višegrád fondé en 1991 représente la première " alliance " entre des pays démocratiques d'Europe Centrale et Orientale après 1989. Son objectif premier se focalisait sur la transition politique et économique ainsi que sur l'intégration avec les structures de l'Union Européenne et le développement de la coopération transatlantique. Ayant atteint ces priorités stratégiques, à savoir l'adhésion à l'OTAN et l'UE, le Groupe ne perd pas de son importance. Au contraire, il gagne une nouvelle dimension et devient un instrument géopolitique ainsi qu'un groupe de pression au sein de la CE. Cet article présente brièvement l'histoire ainsi que la problématique actuelle du fonctionnement de cette organisation régionale.
\end{abstract}

Keywords: Visegrad Group, V4, regional organisations

\section{Premières initiatives de la coopération dans l'Europe Centrale et Orientale}

Le printemps des peuples de l'année 1989 qui a touché tous les pays de la région a finalement abouti à la chute du bloc soviétique et à l'établissement d'une nouvelle donne des relations internationales en Europe. Le démantèlement de l'URSS, le démontage du Pacte de Varsovie et du Conseil d'Aide Economique Mutuelle (CAEM), ont d'une part débarrassé les pays de l'Europe Centrale et Orientale du diktat de Moscou mais d'autre part, ils ont fait disparaître les structures militaires et économiques jusque-là existantes. Les pays appartenant à la zone d'influence soviétique ont retrouvé leur indépendance mais dans le même temps ils se sont retrouvés dans une zone de plus grande incertitude, ce qu'on a appelé "la zone grise de sécurité" dont l'aménagement était dans l'intérêt des tous les pays de cette région géopolitique. L'un des enjeux principaux de ces pays, à part les tentatives de se lier de façon durable à l'Europe Occidentale, était en outre une politique active en Europe Centrale et Orientale, bilatérale et multilatérale. Dans cette nouvelle approche, appelée souvent « le nouveau régionalisme », il était facile de retrouver des références à des conceptions de coopération internationale plus anciennes, basées sur l'identité européenne commune.

Dans les années 80, en Tchécoslovaquie, en Hongrie et en Pologne des conceptions d'une coopération interétatique ont vu le jour. Les sociétés des pays en question souhaitaient en finir avec la domination soviétique ce qui a donné jour à une véritable communauté de résistance intellectuelle et morale. De cette communauté est née une identité centrale européenne. Ce phénomène était incontournable dans la mesure où c'est dans ce milieu dissident qu'est apparue une coopération transnationale. Milan Kundera, Václav Havel, György Konrád, József Antall, Leszek 
Kołakowski, Jean-Paul II parlaient d'une Europe dont les frontières n'étaient pas établies par des critères géographiques mais par des valeurs morales. ${ }^{1}$ Le contexte de bouleversements des années 80 et 90 a fait que les politiciens en sont venus à reprendre et repenser ces concepts.

Déjà en 1988, le professeur Zbigniew Brzeziński, conseilleur de Jimmy Carter, président des Etats Unis, en a parlé lors de son discours à l'Université Catholique de Lublin. Il a déclaré que dans " l'intérêt de la Pologne il fallait éviter un vide politique et économique en Europe Centrale... $»^{2}$. Il a également déclaré «... que la Pologne devrait relancer les négociations sur l'élargissement de l'Union Européenne incluant les nations de toute l'Europe Centrale et Orientale $»{ }^{3}$ De manière officielle l'idée d'une coopération transrégionale a été énoncée par Vaclav Havel lors de son exposé à l'Assemblée Nationale Polonaise en janvier 1990.

Les concepts de coopération se sont trouvés également dans les directions de la stratégie de la politique étrangère et de sécurité. En Pologne pour la première fois la proposition de coopération transrégionale a été lancée par Krzysztof Skubiszewski, ministre des affaires étrangères. Elle s'est trouvée à la troisième place des priorités de la politique étrangère polonaise. K. Skubiszewski estimait que la politique subrégionale constituait un élément incontournable au dualisme de l'Europe Centrale et Orientale et des puissances occidentales, politique dans laquelle une place importante serait réservée à l'établissement d'un triangle Tchécoslovaquie-Hongrie-Pologne. ${ }^{4}$

Pour remédier à une zone grise de la sécurité, Lech Wałęsa a proposé de créer un OTAN-bis, concept présenté pendant sa visite en Allemagne en 1992. Cette conception se basait sur un accord militaire et politique multilatéral des pays anciens membres du Pacte de Varsovie avec la participation de l'Ukraine, la Biélorussie et des pays baltes. Dans la mesure où cette proposition n'a pas été consultée avec qui que ce soit, elle a provoqué un étonnement général. Certains y ont vu un moyen de pression pour forcer l'OTAN à prendre position sur un élargissement futur. ${ }^{5}$

Dans le programme politique du Parti de la Confédération de la Pologne Indépendante on pouvait également trouver le concept d' " Entre-mer » incluant des pays baltes, l’Ukraine, la Biélorussie, la Hongrie, la Tchécoslovaquie, la

1 Sur cette question, voir Timothy Garton Ash, The Uses of Adversity. Essays on the Fate of Central Europe, New York 1989, pp. 179-213, Bogdan Góralczyk, "Współpraca Wyszehradzka. Geneza, doświadczenia, perspektywy”, Studia i Materiały, Vol. 20, 1999, p. 4.

2 Andrzej Grajewski, „Udział Polski w ugrupowaniach regionalnych w Europie Środkowej. Trójkąt Wyszehradzki”, Rocznik Polskiej Polityki Zagranicznej, Warszawa, 1991, p. 100.

3 Ibid.

4 Exposé à l'Assemblée Nationale Polonaise de K. Skubiszewski, ministre des affaires étrangères, „Zbiór Dokumentow”, Warszawa : PISM, 1992.

5 Andrzej Grajewski, ”Udział Polski w ugrupowaniach regionalnych w Europie Środkowej. Trójkąt Wyszehradzki”, Rocznik Polskiej Polityki Zagranicznej, Warszawa, 1991. p. 103. 
Pologne et des pays des Balkans. Les auteurs de ce concept ont visé un rétablissement du marché commun de l'entre-mer ainsi que la création d'une coopération militaire et politique. Cette structure devait construire un contrepoids à la Russie et aux Communautés Européennes. ${ }^{6}$

Les idées de la coopération subrégionale sont apparues aussi à l'étranger. Nous pouvons citer ici l'exemple d'une idée présentée par le ministre des affaires étrangères roumain, Adrian Nastase. Lors de sa visite officielle à Varsovie, en mars 1991 il a proposé de créer l'Union de l'Europe Centrale et Orientale à laquelle appartiendraient les pays de l'ancien bloc soviétique. Cette Union serait destinée à être un forum des consultations subrégionales en vue de l'établissement des conférences et d'une transparence des politiques militaires.

Au début des années 90 nous avons également pu observer une espèce de pression de la part des pays occidentaux pour créer des structures de coopération dans les pays de l'Est. La vieille Europe, attachée aux idées intégrationnistes, a considéré cet espace comme un vestibule à l'adhésion des PECO à l'Union Européenne. Les pays occidentaux partaient du principe que dans cette partie de l'Europe, surtout en ce qui concerne les Etats souhaitant adhérer à la $\mathrm{CE}$, devaient collaborer au préalable entre eux pour s'habituer aux mécanismes d'intégration. Cette exigence de l'Europe Occidentale était à l'origine des directions que les PECO ont prises en matière de la coopération. Le point commun entre ces pays était la volonté de s'intégrer rapidement avec l'Europe Occidentale. Par ailleurs, le potentiel économique, l'état du processus de transformation, la proximité géographique, un niveau comparable du développement, ont prédestiné ces pays à la coopération.

\section{La création du Groupe de Višegradet son développement dans les années 1993-2004}

Dès ses origines la coopération régionale en Europe Centrale et Orientale a rencontré de nombreuses difficultés. Les différences résidaient dans des intérêts nationaux respectifs.

Le premier sommet des présidents, des chefs des gouvernements et des ministres des affaires étrangères à Bratislava, le 9 avril 1990 était un échec pour plusieurs raisons. Sa faiblesse résultait d'une mauvaise préparation. Il convient également d'ajouter que les délégations des pays concernés semblaient être illégitimes étant donné que Wojciech Jaruzelski se trouvait à la tête de la délégation polonaise, élu un an plutôt par la diète contractuelle. Quant à la délégation hongroise, elle était dirigée par le président Matas Szürös, issu de l'ancien état communiste. D'ailleurs ce même président a perdu le pouvoir à la suite d'élections libres et démocratiques. ${ }^{7}$

$6 \quad$ Ibid. p. 103.

7 Andrzej Grajewski, „Kwadratura Trójkąta Wyszehradzkiego”, Polska w Europie, 1992, Vol. 3, p. 6. 
La rencontre qui a eu lieu à Bratislava, le 9 avril 1990 n'a eu pour résultat qu'une déclaration de coopération commune. Malgré ce départ raté des négociations, l'initiative de coopération a été bien accueillie dans les trois pays. La rencontre suivante, qui a eu lieu le 15 février 1991 était aussi importante que symbolique. Elle s'est déroulée à Višegrad, une ville marquée déjà comme lieu de rencontre des quatre parties ${ }^{8}$. Les signataires ont rédigé une déclaration commune annonçant la création du Triangle de Višegrad ainsi que les objectifs de la prochaine coopération : rétablissement de souveraineté pour chacun des pays, implantation de la démocratie, destruction des barrières économiques, politiques et comportementales du système totalitaire, établissement d'une économie moderne de marché et une pleine intégration avec le système politique et économique européen. ${ }^{9}$

D'autres éléments étaient prioritaires lors du troisième sommet à Cracovie, le 6 octobre 1991 dont le déroulement a été bouleversé par deux événements: un putsch raté en Russie soviétique ainsi que le déclenchement de la première guerre des Balkans. ${ }^{10}$

Par contre, la quatrième partie des négociations, à Prague, le 6 mai 1992 s'est déroulée sous le signe de la révolution de velours en Tchécoslovaquie. Malgré les tentatives du président de l'Etat hôte, Václav Havel, qui a appelé à mettre en commun les efforts " pour que nos postulats soient mieux entendus », ce sommet n'a pas jouit de succès. ${ }^{11}$

Suite à ces bouleversements il n'y a pas eu de nouveau sommet, même si la structure de ce triangle s'était officiellement transformée en carré - V4 ou Groupe de Višegrad. Les efforts de la diplomatie polonaise qui était à l'époque la plus active pour sauvegarder cette entité régionale, n'ont pas abouti à la relance de cette initiative. Elle a opté même pour son institutionnalisation. Toutefois les ressentiments historiques ont ressurgi à la surface dans les relations magyaro-slovaque et tchéco-slovaque. Le premier ministre József Antall restait farouchement opposé à cette coopération, ce qui s'explique par une mauvaise expérience vécue sous l'ancien régime (bloc soviétique) quand tous les Etats étaient régis par le diktat du Conseil d'Aide Economique Mutuelle (CAEM). ${ }^{12}$

Du point de vue de la coopération du Groupe de Višegrad la position la moins productive était celle du premier ministre tchèque Václav Klaus qui, après la

8 Il s'agit d'une rencontre entre les rois des trois pays, la Bohême, la Pologne et la Hongrie à Višegrad en 1335, qui a abouti à la résolution d'un conflit territorial entre le Casimir le Grand, roi de Pologne et Jean de Luxembourg (Roi tchèque) concernant de la couronne polonaise. Ils ont établi aussi une espèce d'alliance entre les trois royaumes. Sur cette question voir: Site officiel du Group du V4 : [http://www.visegradgroup.eu/historia-v4] (20.02.2013).

9 Rafał Wiśniewski, „Po Wyszehradzie- środkowoeuropejskie perspektywy”, Polska w Europie, Vol 1, 1991, p. 1.

10 Ibid. p. 2.

11 Ibid.

12 Rudolf Chmel, Nagykövet voltam Magyrországon, Bratislava, 1997, pp. 129-130. 
déclaration de l'indépendance de la République Tchèque n'était pas partisan de cette coopération en l'Etat. Lors d'une interview pour le Figaro, le 7 janvier 1993, V. Klaus a déclaré que la coopération de V4 n'était qu'entité artificielle créée à la demande des pays de l'Europe Occidentale. ${ }^{13}$

L'affaiblissement de cette coopération ne peut s'expliquer seulement par la seule dissolution de la Tchécoslovaquie. Il est important de rappeler que c'est la chute de l'URSS qui a eu le plus grand impact sur le bon fonctionnement du groupe Višegrad. Quelques mois auparavant le Pacte de Varsovie ainsi que le CAEM ont été dissous. De cette manière ont disparu les éléments clés qui ont permis la coopération de Višegrad. Cette coopération paraît dès lors comme un pacte inutile dans la mesure où la menace commune n'était plus. Même si la coopération avait pour but de s'approcher des structures euro-atlantiques, elle était également destinée à mettre un terme à la dépendance de l'Europe Centrale et Orientale vis-à-vis de la Russie soviétique ${ }^{14}$.

Certes, les anciennes menaces ont disparu mais elles ont laissé place à d'autres dangers tels que: le crime organisé, le trafic d'armes, etc. Toutefois les pays du V4 n'étaient pas à ce moment-là prêts à mettre en place une réelle collaboration politique. Le seul domaine où cette coopération s'est avérée efficace était la coopération économique. Les pays voulaient à tout prix garder cette coopération et ont accepté la conception de Klaus d'en limiter la compétence au domaine économique. Son premier acte a été la signature de l'Accord de Libre Echange. Les parties de cet accord ont visé l'élimination de toutes les barrières commerciales et un libre échange, d'ici huit années. Des clauses extraordinaires ont été créées pour les marchandises agricoles et celles de l'industrie agroalimentaire ainsi que pour l'industrie de textile. ${ }^{15}$

Les années 1993-1998 constituent une période d'affaiblissement de cette coopération, certaines publications parlaient même d'une $\operatorname{crise}^{16}$. Cet affaiblissement peut s'expliquer par le fait que chacun des pays membres cherchaient sa propre voie en Europe. Par ailleurs, l'arrivée au pouvoir en Slovaquie de Vladimír Mečiar, un politicien sceptique vis-à-vis des projets intégrationnistes, a affaibli encore d'avantage cette coopération. Sa politique a eu pour conséquence une mise à l'écart de la Slovaquie par l'UE et l'OTAN. Selon les décisions prises au sommet de l'OTAN à Madrid en 1997 et au sommet de l'UE la même année, la Slovaquie ne faisait pas partie du premier groupe des candidats invités à ces organisations. La politique du premier ministre V. Mečiar s'est avérée une vision à court terme. La société slovaque a clai-

13 Jiri Musil, The end of Czechoslovakia, Budapest, London, New York, 1995, p. 274.

14 Bogdan Góralczyk, "Współpraca Wyszehradzka. Geneza, doświadczenia, perspektywy", Studia i Materiaty, Vol 20, 1999, p. 8.

15 Accord de libre Echange de l'Europe Centrale et orientale (CEFTA, Central European Free Trade Agreement) a été signé le 21 décembre 1992 à Cracovie. Entre 1995 et 1998, les trois autres pays ont adhéré à CEFTA : La Slovénie, la Roumanie et la Bulgarie.

16 Bogdan, Góralczyk, "Współpraca Wyszehradzka. Geneza, doświadczenia, perspektywy", Studia i Materiały, Vol 20, 1999, p. 13. 
rement rejeté « ce renfermement sur soi » lors de l'élection de $1998 .{ }^{17}$ Le pouvoir a été repris par une toute nouvelle coalition. Le nouveau cabinet de Mikuláš Dzurinda, dès son entrée en fonction a décidé de renforcer la coopération centrale-européenne. L'adhésion à l'OTAN et à l'UE constituaient ses objectifs principaux. ${ }^{18}$

Les changements survenus sur la scène politique slovaque ont permis la revitalisation et le développement de la coopération au sein du V4. Le début de cette nouvelle ère était le sommet des chefs des Etats et des gouvernements prévu pour mai 1999 en Hongrie. Lors de ce sommet a été prise la décision d'un système de rotation de la présidence du groupe. Selon cet accord chaque présidence annuelle est clôturée par le sommet des premiers ministres. De plus, ce sommet prévoyait un bilan des activités du groupe et la mise en place des objectifs pour l'année suivante. Là, le rôle clé fut joué par les ministres des affaires étrangères qui coordonnaient les activités entreprises dans le cadre de la coopération. De plus, dans chacun des ministères des Etats membres, a été mise en place la fonction de coordinateur du V4. Avec cette nouvelle méthode de fonctionnement la coopération dans la région est devenue plus intense et plus systématique. Jusqu'alors les rencontres aux sommets n'étaient pas régulières.

Dans les années qui suivirent, le V4 a acquis une seule forme institutionnalisée (ayant une personnalité juridique). En juin de l'an 2000 le Fond International de Višegrad a été créé, doté d'un budget de 7 millions d'euros. Son rôle est de promouvoir et de soutenir financièrement une coopération entre les Etats membres ainsi qu'une stratégie de rapprochement avec des pays tiers, surtout dans les Balkans de l'Ouest et les pays de Communauté des États Indépendants.

Durant la période 2000-2010 a commencé à s'instaurer une coopération dans le cadre du format élargi - V4+ (par exemple la rencontre des premiers ministres du G4 avec le chancelier allemand Gerhard Schröder - à Berlin, le 10 novembre 1999, ou le sommet du V4 avec les pays de Benelux - en décembre 2001). Durant cette période s'est également constituée la coopération interparlementaire. Les rencontres annuelles des présidents des parlements nationaux sont devenues coutume. ${ }^{19}$

\section{L'activité de V4 dans le cadre de l'intégration européenne}

L'adhésion des quatre pays de l'Europe Centrale et Orientale à l'Union Européenne en 2004 constitue une nouvelle étape dans l'évolution du Groupe de Višegrad. Dans une déclaration signée à Kroměříž en République Tchèque, le 12 mai 2004, les

17 Bogdan, Góralczyk, "Współpraca Wyszehradzka. Geneza, doświadczenia, perspektywy", Studia i Materiały, Vol 20, 1999, p. 11.

18 L'Interview dans le „Gazeta wyborcza” avec M. Dzurinda: Nie pokazywać rogów, „Gazeta Wyborcza”, 16 novembre 1998.

19 Accord des présidents des parlements des pays du V4 en vue de l'institutionnalisation de la coopération interparlementaire:[http:/oide.sejm.gov.pl/oide/images/files/international/ porozumienie_wyszehrad_pl.pdf] (20.02.2013). 
premiers ministres des quatre pays en question ont exprimé leur pleine satisfaction car l'objectif principal de la coopération a été atteint. En même temps ils ont déclaré « leur détermination à continuer la coopération régionale en tant que pays membres de l'UE et de l'OTAN ». Dans la déclaration susmentionnée les chefs de gouvernements ont dessiné les nouveaux enjeux du V4, tels que: le renforcement de l'identité régionale de l'Europe Centrale et Orientale; la coordination des intérêts nationaux au sein des institutions européennes; l'assistance aux autres pays de la région, souhaitant se joindre à l'UE. ${ }^{20}$

A ces objectifs très vaguement définis, il faut ajouter ceux qui ont été élaborés lors de la rencontre des ministres chargés du développement régional et du transport, en mars 2005. Dans une déclaration commune ils ont décidé d'entreprendre des actions communes en vue de la revitalisation des villes, de la coopération territoriale, ainsi que du développement des corridors infrastructurels de transport. ${ }^{21}$

Parmi les documents qui contiennent le programme des travaux au sein du V4, il convient d'indiquer encore une déclaration, signée en octobre 2006, lors d'une rencontre à Višegrad, organisée à l'occasion de son quinzième anniversaire. De nouveaux champs de coopération y ont été évoqués, tels que la coopération en matière de la politique énergétique, étrangère et de défense de l'Union Européenne. ${ }^{22}$

L'analyse du fonctionnement des pays du Groupe de Višegrad dans une organisation plus grande permet de constater qu'elle sert de plate-forme de formulation des besoins communs et de négociations visant les solutions les plus adéquates pour les pays du groupe lors de la création de la politique européenne. Sur le forum des institutions européennes ces pays ont la même catégorie des besoins qui ne sont pas toujours pris en considération par les procédures et les programmes européens. Nous pouvons constater une tentative de position commune des Etats de l'Europe Centrale et Orientale sur les questions européennes et de l'OTAN. La formule des rencontres précédant chaque sommet de Conseil Européen en vue de bâtir une position commune est devenu coutume. D'ailleurs, nous avons pu observer lors de la présidence des PECO au conseil de l'UE qu'on avait consulté l'agenda politique de présidences respectives avec d'autres partenaires centre-européens pour la Hongrie et la République Tchèque en année 2009 et pour la Pologne en 2011.23

20 Declaration of Prime Ministers of the Czech Republic, the Republic of Hungary, the Republic of Poland and the Slovak Republic on cooperation of the Visegrad Group countries after their accession to the European Union, 12 May 2004 (The Kroměřǐž Declaration): [http://. visegradgroup.eu/2004/declaration-of-prime] (20.02.2013).

21 Declaration of the Meeting of Ministers of infrastructure and transport in Sztraszyn, Poland (16-18 March 2005): [http://www.visegradgroup.eu/2005/declaration-of-the] (20.02.2013).

22 Declaration of the Prime Ministers of the Visegrad Countries Visegrad, Hungary, 10 October 2006: [http://www.visegradgroup.eu/official-statements/documents/declaration-of-the] (20.02.2013).

23 Sylwia Serwońska, „Współpraca regionalna Polski w ramach członkostwa w Unii Europejskiej”, in: Renata Podgórzańska (ed.), Polityka zagraniczna Polski w warunkach członkostwa w UE, Toruń: Wydawnictwo Adam Marszałek, 2009, pp. 128-129. 
La mise en place des alliances au sein au groupe a lieu dans le cas où il s'agit de défendre des intérêts nationaux.

L'exemple d'une position commune des pays du V4 furent les négociations du Paquet Climat-énergie, acquis lors du sommet européen en décembre 2008. Les objectifs très ambitieux de l'UE dans le cadre de la lutte contre le réchauffement climatique, adoptés par le Conseil le 8 et 9 mars 2007, prévoyaient la réalisation « du pacage $3 \times 20$ », dont l'élément principal était la réduction de gaz à effet de serre de $20 \%$ d'ici à $2020 .{ }^{24}$

Son pilier principal consistait à éliminer la distribution gratuite du droit d'émission dans le secteur énergétique, ce qui n'était pas accepté par les membres du V4 et des pays baltes, chez lesquels l'énergie est produite au charbon, donc l'émission de $\mathrm{CO}^{2}$ y est élevée. ${ }^{25}$

Il est important de constater que la priorité de la sécurité énergétique était désormais constamment présente dans les documents et travaux du V4. L'impératif stratégique ainsi que la volonté de devenir moins dépendant de la Russie en approvisionnement en gaz, a contribué le 31 octobre 2012 à Varsovie à la conclusion d'un accord, sur l'intégration de ses systèmes de gaz,grâce à la construction d'inter-connecteurs en Europe Centrale et Orientale, à savoir le corridor de transfert Nord-Sud. ${ }^{26}$

24 Pour en savoir plus : Débat sur le paquet climat/énergie: Négociations «dans la dernière ligne droite», Parlement Européen : [http://www.europarl.europa.eu/news/expert/infopress page/064-43670-336-12-49-911-20081203IPR43669-01-12-2008-2008-false/default_ pl.htm] (17.02.2013).

25 Dans la position établie à Varsovie en 2008 avec la participation des premiers ministres du V4 ainsi que ceux de pays baltes, on a proposé la mise en place d'une "fourchette de prix", c'est-à-dire, la limitation de variation des prix d'autorisation des émissions CO2 qui ne peuvent pas dépasser un certain seuil.

26 Le moment culminant dans la position en matière de la sécurité énergétique était la "guerre du gaz" entre l'Ukraine et la Russie en 2009 qui a provoqué des bouleversements en approvisionnement en gaz pour les pays de l'UE, notamment de la Slovaquie. Grâce à la solidarité de la République Tchèque et de la Pologne un approvisionnement d'urgence fut organisé en direction de l'Ouest. Cette crise a mobilisé les partenaires du V4 pour intensifier la coopération en matière d'énergie. Pendant le sommet de Cracovie en 2009 un groupe de Višegrad de haut niveau fut créé pour la sécurité énergétique (3 juin 2009). Avec l'appui de l'Union Européenne les travaux de construction des inter-connecteurs Nord-Sud ont démarré. Le connecteur polono-tchèque en Silésie a été inauguré en 2011. La connexion austro-hongroise est en cours de construction. De plus, on est en train de négocier le corridor de réseaux de transfert en Pologne et en Slovaquie. Ils peuvent assurer les connexions avec le gazoduc nord-sud tel qu'Adria, corridor croate. Il est notamment très intéressant, du point de vue de l'intérêt stratégique polonais, de développer l'infrastructure du gazoduc Nabucco qui pourrait transporter le gaz provenant d'Iran, d'Azerbaïdjan, de Russie et de Turquie orientale jusqu'à l'Autriche, en passant par la Bulgarie, la Roumanie, la Hongrie, la Slovaquie et la Pologne. Ce projet fait partie d'un projet Trans-Européen Energy Network, financé en grande partie par l’Union Européenne : Piotr A. Maciążek, „Energetyka: zakwas 
En ce qui concerne l'énergie nucléaire, les partenaires de Višegrád ont la même position. Ils ont commencé la coopération en la matière. Vu que la construction d'un réacteur nucléaire à Mochovce en Slovaquie et Timeline en République Tchèque est en phase de construction, les pays du groupe de Višegrad ne sont pas d'accord pour négliger et déprécier cette source d'énergie dans l'Union Européenne. En sachant par ailleurs que les PECO possèdent de ressources de gaz de schiste et qu'ils peuvent en tirer profit, ils ont formé un bloc régional commun pour intensifier les travaux en vue de son exploitation. ${ }^{27}$

Un autre exemple de coopération au niveau européen a été observé lors des négociations des cadres financiers pluriannuelles (Multiannual Financial Framework) pour les périodes consécutives: 2007-2013 et 2014-2020. La République Tchèque, la Hongrie, la Slovaquie et la Pologne sont devenues membres du groupe dit: Amis de la politique de cohésion, mis en place il y a sept ans. Il est composé par 15 Etats membres et la Croatie. Les activités du groupe visent à amplifier la cohésion en Europe aux régions les moins avancées. L'accord budgétaire d'un montant de plus de 325 milliard d'euro pour la politique de Cohésion, lors du dernier sommet européen du 7 février 2013 est un succès incontestable des bénéficiaires nets du budget et surtout de la Slovaquie et de la Pologne dont le budget pour la cohésion est en hausse par rapport au budget précédent (voir les tableaux ci-dessous).

Tableau 1: Comparaison des budgets pour la politique de la cohésion pour des années 2007-2013 et 2014-2020

\section{Budget pour la cohésion 2007- 2013 (Total $=354,8$ mld d'euros)}

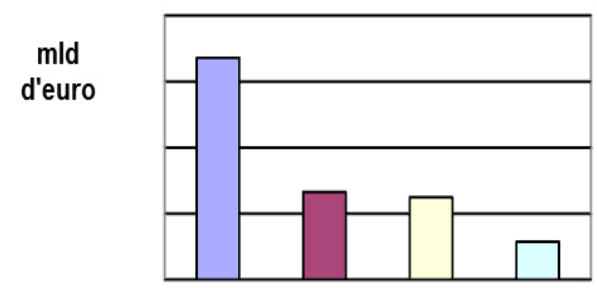

Budget pour la cohésion 20142020 (Total $=325,149 \mathrm{mld}$ d'euros)

Source: Site internet du premier ministre polonais : Kancelaria premiera Rady Ministrów 2013

Il est important de souligner que la politique de cohésion était un domaine de coopération au format $\mathrm{V} 4+$. En cette matière, la Pologne a lancé l'incitative d'une coopération plus profonde et renforcée avec la Roumanie, la Bulgarie et la Slovénie. ${ }^{28}$

Wyszehradu+", Polityka Wschodnia, [http://politykawschodnia.pl/index.php/2013/02/07/ energetyka-zakwas-wyszehradu/] (20.02.2013).

27 Ibid.

28 Sur ce sujet: Radek Pietruszka, PAP: Przyjaciele Spójności: żadnych cięć w funduszach spójności:[http://www.pap.pl/palio/html.run?_Instance=cms_www.pap.pl\&_PageID=1\&s= 
L'objectif du développement de l'identité et de la défense des PECO dans le cadre de l'UE, mentionné en 2006, est réalisé par l'initiative de mise en place d'un groupe de réaction rapide. Les détails de son fonctionnement ont été établis à Litoměřice, en mai 2012, lors de la rencontre des ministres de la défense nationale des pays du groupe de Višegrad. Un groupe, au nombre de 1300 soldats, devrait être opérationnel en $2016 .^{29}$

A part la réalisation de leurs propres intérêts nationaux, les pays du groupe de Višegrád tentent de modérer et d'influencer la politique étrangère de l'Union Européenne. Les PECO soutiennent à l'unanimité l'élargissement progressif de l'UE, surtout par rapport aux pays des Balkans Orientaux. D'ailleurs, c'est le projet de Partenariat de l'Est qui constitue l'élément le plus actif de leurs actions extérieures.

La coopération avec leurs voisins de l'Est est un élément clé de leur politique de voisinage. Cette politique publique de l'UE était un des impératifs les plus évoqués lors des présidences de la République Tchèque et de la Pologne au sein du Conseil de l'UE, en 2009 et 2011. Le Partenariat de l'Est a été un projet suédo-polonais à l'origine, concrétisé lors de la présidence tchèque au Conseil de L'UE. Une des priorités de celle-ci, appelée « l'Europe dans le Monde », s'est focalisée sur la mise en place de ce partenariat, à savoir des relations approfondies avec l'Arménie, l'Azerbaïdjan, la Biélorussie, la Moldavie, la Géorgie et l'Ukraine. Le premier sommet inaugurant le Partenariat de l'Est, avec la participation de tous les bénéficiaires, a eu lieu le 7 mai 2009 à Prague. ${ }^{30}$

Le deuxième sommet du Partenariat de l'Est a eu lieu lors de la présidence polonaise au Conseil, au deuxième semestre de 2011. L'un des éléments clé de cette présidence était la continuation de la promotion des relations privilégiées avec les voisins de l'UE à l'Est. Parmi les progrès en matière de coopération dans cette zone nous pouvons citer entre autre : la signature de la déclaration lors de ce sommet, mentionnée ci-dessus, précisant les enjeux et les outils de ce concept de partenariat. ${ }^{31}$ En décembre 2011 les pays membres de l'Union Européenne ont adopté une déclaration politique qui a fait naître le Fond Européen Pour la Démocratie.

infopakiet $\& \mathrm{dz}=$ gospodarka\&idNewsComp $=\&$ filename $=\&$ idnews $=76679 \&$ data $=$ infopakiet \&_ CheckSum=1139423844] (17.02.2013), Katarzyna Zachariasz, „Wielki szczyt budżetowy Unii Europejskiej. Dlaczego jest tak ważny?”, Gazeta Wyborcza, 6 février 2013: [http://wyborcza. biz/biznes/1,100896,13359972,Wielki_szczyt_budzetowy_Unii_ Europejskiej_Dlaczego. html\#ixzz2KEmoLpA7] (20.02.2013).

29 Joint Communiqué of the Ministers of Defence of the Visegrad Group, Litoměřice, $4^{\text {th }}$ May 2012: [http://www.mon.gov.pl/pliki/File/dok1.pdf] (17.02.2013).

30 Aleksander Fuksiewicz, Agnieszka Lada, Czeska prezydencja w Radzie Unii Europejskiej. Spojrzenie z Polski, Instytut Spraw Publicznych: [http://www.isp.org.pl/files/150498395102 24281001249991477.pdf] (20.02.2013).

31 Ces accords vont faire partie des accords d'associations, dont les négociations ont été mises en place en 2010 pour les deux pays dans le cadre de la Politique Européenne de Voisinage. 
D'ailleurs, ils ont tenté de signer des accords d'associations et de libre-échange avec l'Ukraine et la Moldavie. Ceux-ci n'ont pas été finalisés en raison de la crise dans ces pays (l'affaire de Julia Timoshenko). En plus, dans le cadre de la priorité « l'Europe profitant de son ouverture » ont été finalisés les travaux préparatoires en vue de négociations en 2012 d'un accord de libre-échange avec la Géorgie et la Moldavie. ${ }^{32}$

Finalement, lors de la présidence polonaise, les pays membres de l'UE sont arrivés à la conclusion du traité d'adhésion de la Croatie à l'UE. Son adhésion réelle à l'UE est prévue pour juillet de l'année en cours. ${ }^{33}$

\section{Menaces et perspectives du fonctionnement $d u V 4$}

En 20 ans de son fonctionnement le V4 a vécu des moments de gloire et d'échec. Parfois sa fin fut prédite. Le groupe devait affronter plusieurs crises. La plus grave étant l'affaire des décrets de Beneš, remis à l'ordre du jour par le premier ministre hongrois Victor Orban..$^{34}$ Une autre affaire a eu lieu en 2002, lors de la conclusion des négociations d'adhésion à l'UE avec les 10 pays candidats à l'UE, dont quatre pays du V4. Ce sommet, appelé parfois « la course des négociateurs », démontra bien que chacun des pays avait représenté ses propres intérêts, en niant la solidarité de Višegrad. Afin de faire une évaluation, il est indispensable de faire une approche réaliste et non pas maximaliste. Les difficultés de s'exprimer à unanimité au sein de l'Union ne constituent pas la plus grande menace pour son fonctionnement. Son problème réside plutôt dans la conjoncture politique variable des pays membres. Les facteurs qui peuvent affaiblir la coopération sont liés aux problèmes historiques du passé, comme par exemple les différends territoriaux. L'affaire des décrets de Beneš, mentionnée ci-dessus, en constitue un exemple.

La vulnérabilité suivante que nous pouvons indiquer c'est une faible structure institutionnelle (le V4 est doté d'une seule institution avec des fonctions administratives). Elle rend cette identité régionale moins cohérente et peu décisive. Les sommets des chefs des gouvernements où les politiques communes sont élaborées, constituent la forme principale du mécanisme décisionnel. La complémentarité des structures intergouvernementales venant s'ajouter aux structures extra-gouvernementales pourrait être profitable.

D'ailleurs, le fonctionnement et l'efficacité du V4 dépendent de la conjoncture politique variable des pays membres et des différents enjeux, relatifs à leur politique étrangère. Nous avons pu observer l'hostilité de l'équipe du président

32 Tomasz Kubin, „Europa korzystająca na otwartości- priorytet prezydencji Polski w Radzie UE”, in: Adam Kirpsza, Grzegorz Stachowiak (ed.), Podsumowanie polskiej prezydencji w Radzie UE, Kraków: Kontekst, 2012, pp. 79-80.

33 Ibid.

34 Les décrets Beneš concernaient l'expropriation et l'expulsion des Allemands des Sudètes et d'une partie des Hongrois de Slovaquie à la fin de la Seconde Guerre mondiale. 
tchèque précédent Václav Klaus qui représentait une position souverainiste et anti-intégrationniste. En Pologne sous le gouvernement du parti Droit et Justice - PIS (2005-2007) c'est l'axe nord-sud dans la politique étrangère qui était en première position. Après la prise du pouvoir par la coalition de la Plateforme Civique (PO) et du Parti Paysan Polonais (PSL) la Pologne a plutôt visé une coopération avec les pays majeurs de l'Europe, tels que la France où l'Allemagne.

Un autre phénomène auquel le V4 doit faire face est une Europe à plusieurs vitesses. Selon ce concept certains pays peuvent progresser plus vite ou s'engager plus profondément dans l'intégration européenne, en adhérant où pas à certaines politiques communautaires. Cette situation apparaît au sein du groupe de Višegrad, où seule la Slovaquie est membre de la zone euro. La Pologne avance dans ses préparatifs pour y adhérer, tout en sachant que la date finale n'est pas encore fixée. En ce qui concerne la République Tchèque et la Hongrie, ces pays ont ajourné leur perspective d'une monnaie unique. ${ }^{35}$

Ceux qui contestent la raison d'être de ce Groupe, soulignent que le V4 est une entité de partenaires inégaux du point de vue de la taille et du Produit National Brut. ${ }^{36}$ On entend dire parfois que la Pologne est le leader du groupe, par rapport aux facteurs mentionnés, qu'elle instrumentalise le V4 au profit de ses propres intérêts, qu'elle crée des alliances de géométrie variable au sein de l'organisation européenne, en entrant en coopération soit avec ses partenaires du Groupe de Višegrad soit avec des pays majeurs, tels que l'Allemagne. D'un autre coté, il faut noter une espèce de réticence de la part des pays mineurs qui ne veulent pas se soumettre à ce leadership polonais. Le fait que les pays constituant ce groupe sont inégaux, d'une certaine façon peut affecter son opérationnalité. Du point de vue polonais nous pouvons nous interroger sur la « valeur ajoutée » d'une coopération avec des pays mineurs. Tous les gouvernements polonais successifs ont vu la coopération dans le cadre régional comme un moyen de renforcer la position de la Pologne au sein de l'Union Européenne. L'efficacité des coalitions entre PECO, dont la Pologne est souvent à l'origine, a démontré plusieurs fois que le leadership d'un partenaire majeur dans le V4 peut être utile pour promouvoir des intérêts nationaux des pays mineurs. D'un autre côté, il est important de souligner que la coopération du V4 ne nuit pas aux contacts/coalitions de la Pologne avec ses partenaires majeurs.

Il existe des sujets qui opposent les pays membres du V4, mais les 20 ans de collaboration dans le cadre de cette organisation subrégionale ont démontré qu'il

35 Radovan Kavickỷ, "Is the V4 cooperation a Safe Haven In Turbulent Times?", in: Towards a $V 4$ position on the Future of Europe, The Polish Institute of International Affairs, Warszawa, December 2012, p. 11.

36 PNB polonais en 2010: 470 mld USD, République Tchèque: 198 mld USD, Hongrie: 129 USD, Slovaquie: 87 mld USD: Edward Lucas, "Po co nam Grupa Wyszehradzka", Gazeta Wyborcza, 15 decembre 2012. 
existe des domaines où des compromis peuvent, voire doivent être recherchés. Même si les partenaires développent des stratégies de coopération orientées vers d'autres directions en Europe, il est important de constater que la coopération au sein du groupe de Višegrad est décrite dans tous les documents du programme des gouvernements de Peter Necas, Viktor Orban, Robert Fico ou de Donald Tusk en tant que la meilleure initiative où les intérêts communs peuvent être réalisés et en tant que facteur important de construction d'une identité internationale commune.

Comme l'a déclaré Radoslaw Sikorski, ministre des affaires étrangères polonais lors de la rencontre à Budapest en juillet 2012 : «... le V4 est une image de marque forte, dans laquelle il faut investir d'avantage, puisqu'elle rassemble sous son égide 64 millions de citoyens et se trouve parmi les vingt meilleurs économies du monde. Le pouvoir d'achat en son sein lui donne la quinzième position. La preuve de son fort potentiel est faite puisqu'au Conseil de l'UE elle possède autant de voix que la France et l'Allemagne réunies... $\gg{ }^{37}$ Ce potentiel des pays de l'Europe Centrale et Orientale qui cherchent toujours leur rôle au sein de l'Union Européenne ne devrait pas être négligé.

\section{Bibliographie}

Accord des présidents des parlements des pays du V4 en vue de l'institutionnalisation dela coopération interparlementaire: [http://oide.sejm.gov.pl/oide/images/files/international/porozumienie_wyszehrad_pl.pdf] (20.02.2013).

Ash, Timothy Garton, 1989, The Uses of Adversity. Essays on the Fate of Central Europe, New York.

Chmel, Rudolf, 1997, Nagykövet voltam Magyrországon, Bratislava.

Exposé à l'Assemblée Nationale Polonaise de K. Skubiszewski, le ministre des affaires Etrangères, 1992, „Zbiór Dokumentow”, Warszawa, PISM.

Fuksiewicz, Aleksander, Lada, Agnieszka, 2013, Czeska prezydencja $w$ Radzie Unii Europejskiej. Spojrzenie z Polski, Instytut Spraw Publicznych: [http://www.isp.org.pl/files/15049839510224281001249991477.pdf] (20.02.2013).

Gniazdowski, Mateusz, 2011, Polityka polski w Grupie Wyszehradzkiej, Warszawa, PISM.

Góralczyk, Bogdan, 1999, „Współpraca Wyszehradzka. Geneza, doświadczenia, perspektywy”, Warszawa, Studia i Materiaty, Vol. 20, 1-24.

Grajewski, Andrzej, 1992, „Udział Polski w ugrupowaniach regionalnych w Europie Środkowej. Trójkąt Wyszehradzki”, Rocznik Polskiej Polityki Zagranicznej, Warszawa, PISM, p. 91-106. Grajewski, Andrzej, 1992, „Kwadratura Trójkąta Wyszehradzkiego”, Polska w Europie, Warszawa, pp. 4-17.

Groupe de Višegrad (site officiel) : [http://www.visegradgroup.eu/historia-v4] (20.02.2013).

Joint Communiqué of the Ministers of Defence of the Visegrad Group, Litoměrice, $4^{\text {th }}$ May 2012: [http://www.mon.gov.pl/pliki/File/dok1.pdf] (17.02.2013).

37 Mateusz Gniazdowski, Polityka polski w Grupie Wyszehradzkiej, Warszawa, PISM, 2011, p. 155 . 
Kavickỷ, Radovan, 2012, "Is the V4 cooperation a Safe Haven In Turbulent Times?", in: Gostyńska. Agata, Parkes, Roderick (ed.), Towards a V4 position on the Future of Europe, Warszawa, PISM, pp. 11-16.

Kubin, Tomasz, 2012, „Europa korzystająca na otwartości- priorytet prezydencji Polski w Radzie UE",in: Kirpsza, Adam, Stachowiak, Grzegorz (ed.), Podsumowanie polskiej prezydencji w Radzie UE, Kraków: Kontekst, pp. 75-88.

Lucas, Edward, 2012, „Po co nam Grupa Wyszehradzka”, Gazeta Wyborcza, suplement, 15th of December).

Maciążek, Piotr A., 2012, „Energetyka: zakwas Wyszehradu+”, Polityka Wschodnia, [http://politykawschodnia.pl/index.php/2013/02/07/energetyka-zakwas-wyszehradu/] (20.02.2013).

Musil, Jiri, 1995, The end of Czechoslovakia, Budapest, London, New York.

Pietruszka, Radek, PAP: Przyjaciele Spójności: żadnych cięć w funduszach spójności: [http:// www.pap.pl/palio/html.run?_Instance $=$ cms_www.pap.pl\&_PageID $=1 \& \mathrm{~s}=$ infopakiet $\& \mathrm{dz}=$ gospodarka\&idNewsComp $=\&$ filename $=\&$ idnews $=76679 \&$ data $=$ infopakiet\& CheckSum=1139423844] (17.02.2013).

Serwońska, Sylwia, 2009, „Współpraca regionalna Polski w ramach członkostwa w Unii Europejskiej”, in: Podgórzańska, Renata (ed.), Polityka zagraniczna Polski w warunkach członkostwa w UE, Toruń, Wydawnictwo Adam Marszałek, pp. 222-241.

Wiśniewski, Rafał, 1991, „Po Wyszehradzie- środkowoeuropejskie perspektywy”, Polska w Europie, Warszawa, pp. 1-22.

Zachariasz, Katarzyna, 2013, „Wielki szczyt budżetowy Unii Europejskiej. Dlaczego jest tak ważny?, Gazeta Wyborcza: [http://wyborcza.biz/biznes/1,100896,13359972,Wielki_szczyt_ budzetowy_Unii_Europejskiej_Dlaczego.html\#ixzz2KEmoLpA7] (20.02.2013). 


\title{
Rethinking Cultural Relations between the European Union and United States in Age of the Transatlantic Rift
}

\author{
Marius JUCAN
}

\begin{abstract}
In the present article I intend to raise the issue of the relevance of religion and religiosity in the light of the transatlantic drift and of the cultural integration in the UE. The reawakening of religiousness, either Christian or Islamic demonstrates the appearance of a new cultural map of Western world, due to the consequences of globalization, cultural relativism, present-day economic crisis, military or terrorist threats. Underlining the politicization of religion and its different traits in the US and the UE, not forgetting about Romanian postcommunist religiosity, the article attempts to define the degree according to which religion in the twenty-first century might affect and possibly change Western modernity.

Keywords: religion, religiosity, America, Europe, modernity
\end{abstract}

The question whether religion will enhance European integration or hinder it, or if, on larger plane, religion will act as a major factor in EU-US relations determining the rapprochement between the two former components of the Western world, or aggravate the crisis between them, is held in the views of many present-day authors as a major cultural preoccupation. Growing aware of the radical transformations in religiosity in both US and UE, as well as in Eastern European countries, scholars and analysts consider that religion has started to play a sensitive role in public matters. True enough, the legacy of the relations between religion and society in America, on one hand, and between the State and Church in Europe especially, is definitely rich and complex. The secularization process, which was confounded for long with the so-called "death of religion", contained the seeds, so to say, of discontent with modernity and sooner than it was expected, religiosity began to manifest itself as a powerful contender of ideology in the postwar world. Religion has never ceased to be an important vector of social cohesion in the United States, so that the popularity of the religious discourse in the Cold War period did not come unexpectedly, out of the blue sky. Religious attitudes in Europe at the end to the last century may have been determined by a series of causes, globalization, consumerism, cultural relativism, though it is not obvious whether one of these phenomena or their juxtaposition with internal elements created favorable conditions for the renaissance of religion, especially in Eastern Europe. The constant slackening of public authority and the undermining of trust in state institutions accentuated the existential anxiety of postmodern citizens, making their identities shallow and vulnerable. The political overtones of ethnically focused attitudes manifested by younger generations of either Christian or Islamic faiths could not be overlooked any longer after September 2001. 
The economic worsening conditions of the recent past years have determined people on both shores of the Atlantic and inside the enlarged EU to be more perceptive of the redeeming content of the religious discourse. The intensity of religious sensibilities, sparking civilizational fears, was caused by massive waves of immigration in the EU, proving the existence of deep seated connections between religion and culture. In Western Europe, immigrants were exposed to a gamut of inhospitable attitudes ranging from xenophobia to outspokenly racist attitudes. Religiosity in Eastern European countries may have thwarted the course of cultural integration, reklinding the flame of nationalism, delaying the process of achieving a necessarily cohesive European identity. "Rethinking" cultural relations under the circumstances, implies a necessary reevaluation of the national and international frame in which religion and cultural relations are defined, before Euro-skepticism hardens into institutional forms. American exceptionalism and European patriotism seen as the two opposing factors fuelling the disunion in the Western hemisphere appear particularly prone to be influenced by renascent religiosity. American exceptionalism and European patriotism, though not comparable in their historical development, have struck deep roots not only in the diverging political attitudes of the past, but also in the general understanding of the role of religion in modernity.

The passing from the post-Cold War American leadership to a yet uncharted global role of Europe raises many unyielding issues. Will religion reemerge in the 21th century as an appeasing factor of the political and economic crisis? How will the language of this moderation sound like in current politics? Will religion in the frame of culture supply the necessary concrete steps for stopping the ongoing drift between the US and the EU, or will it accelerate it? Might the analysis of the new role of religion dissipate the ambiguity of the future of the transatlantic world? Such questions remain open. In the frame of this article, I consider that the "rethinking" of the role of religion in connection to culture depends on a deper and more coherent interpretation of modernity, culture and also of the concept of the paradigm. The latter has proved crucial in understanding the specificity of the Western world, in demarcating the particular conditions of European enlargement and integration, as well as in describing intellectuals and/or experts as primary sources of mirroring reality reflexively. In the following, I shall briefly point to some of the many definitions given to modernity, culture and of the notion of the paradigm, which may circumscribe more comprehensively the content of what is meant by "rethinking".

The distinct cultural consequences of the Enlightenment, or rather the cultural differences between Enlightenment and counter-Enlightenment in Europe and America gave birth to contradictory versions of modernity. According to S.N. Eisenstadt's theory of "multiple modernities", the history of modernity is a "multiplicity of cultural programs" which determined various social movements and as 
well as of different views leading to the weakening of the state-nation, simultaneously to the the appearance of new autonomous cultural, political and administrative spaces. A special attention is given by Eisenstad in this context to "modern Jacobinism", a notion combining strong anti-modern and anti-Enlightenment elements. Modern Jacobinism, considers Eisenstadt, paved the way towards neototalitarianism, by relying on cultural and political impetuous drives of transforming society in a "new order". ${ }^{1}$ It is worth reminding in this sense, that in the first part of the last century, in the United States, the so-called "Christian Atlanticism" was very influential, showing that Atlanticism as a doctrine and as a state of mind was not born at the end of WW II. In the vision of Christian Atlanticism, American and Europe had been locked in a strong entity forming the shield of Western civilization. America and Europe had been perceived as the heirs of the same religious community, defending it from the perils of expanding totalitarianism and nationalism. The concept of the "free world" was thus coined in accordance with the vision of the Western world acting against the "pagan" dangers emerging from Europe. In this sense, America was regarded during the whole period of the $20^{\text {th }}$ century as a conservative force, the only able to continue the Christian heritage and to demarcate it from the antimodern ideologies of fascism, nazism and communism. ${ }^{2}$

A second necessary step regards the choice of the most adequate definition given to culture as to fit the complex situation of the transatlantic disrupture and especially regarding the antithetical relationship between anti-Americanism and European patriotism. I chose to refer in this context to German historian Reinhart Koselleck's definition which claims that culture cannot be imagined as a pre-established form which must be carried out into practice, but it should be figured out as the state of a continous process due to its reflexivity. ${ }^{3}$ Culture should not take a political uniform, upheld Koselleck, reminding what had occurred in the totalitarian period. Therefore, one should expect that decisionist policies imposed without considering the cultural and religious context might trigger overwhelming reactions from different sectors of European or American societies. Thirdly, regarding the notion of the paradigm, I think that Giorgio Agamben's definition may suit better than other definitions the complexity of the cultural transatlantic relations in a critical moment, beyond the cultural fractures separating the Eastern and the Western part of the continent.

"A paradigm is a form of knowledge that is neither inductive nor deductive but analogical. It moves from singularity tosingularity. 2. By neutralizing the

1 S. N. Eisenstadt, "Multiple Modernities" Daedalus, Winter 2000, 129, pp. 16-19.

2 Emiliano Alessandri, "The Atlantic Community as Christendom. Some Reflections on Christian Atlanticism in America, circa 1900-1950" in Mariano Marco, (ed.) Defining the Atlantic Community. Culture, Intellectuals, and Policies in the Mid-Twentieth Century, London: Routledge, 2010, pp. 47-48.

3 Reinhart Koselleck, Conceptele și istoriile lor. Semnatica si pragmatica limbajului socialpolitic. București: Art, 2009, p. 98. 
dichotomy between the general and the particular, it replaces a dichotomous logic with a bipolar analogical model. 3. The paradigmatic case becomes such by suspending and, at the same time, exposing its belonging to the group, so that it is never possible to separate its exemplarity from its singularity. 4 . The paradigmatic group is never presupposed by the paradigms; rather, it is immanent in them. 5 . In the paradigm, there is no origin or archei every phenomenonis the origin, every image archaic. 6 . The historicity of the paradigm lies neither in diachrony nor in synchrony but in a crossing of the two". ${ }^{4}$

Seeking for more interpretations in the present-day content of modernity, culture and of the notion of the paradigm, one may explain the interconditioning relation existing between the construction of anti-Americanism and of European patriotism. Whether in the past, between intellectuals' perceptions and the common people's opinions there was space of neutrality, after the Iraq war, anti-Americanism has augmented in popularity and European patriotism has strengthened as a cultural and political response to American power. European patriotism has turned to be a relatively recent asset pointing to the the success of the European construction and to its consequential awareness that cultural and political views as being opposed to the ones expressed by Americans in the same period. European patriotism should not be confused with the revival of Eurocentrism, as it should not be viewed as an emotional lever in the hands of a circle of bureaucrats and European party leaders. European patriotism succeeded in drawing a clear limit separating itself from the totalitarian period of Europe, or from the specter of European exceptionalism triggered by the supremacy of certain state nations in the history of Europe. European patriotism has been fostered by the blooming awareness of the value of Europeaness after the collapse of communism. On the other hand, European patriotism could not have emerged without the permanent competition and, let's face it, comparison with American exceptionalism. European patriotism stands out nowadays as one of the challenging values of European cultural integration.

Not being an ideology, or a simple perception of the US foreign policy, antiAmericanism was called by Tony Judd as "the major narrative" of our century ${ }^{5}$, a definition with complies both with the postmodern content of the term narrative and the changing conditions of the cultural paradigm. Actually, in the case of Europe's recent anti-Americanism, Europeans displayed a larger amount of opposing attitudes to the US than in the whole past of the European-American relations. Anti-Americanism is undoubtedly a strong element deepening the course of the transatlantic estrangement. In the already classic example of France, altera-

4 Giorgio Agamben, The Signature of All Things, New York: Zone Books, 2009, p. 15.

5 Tony Judt, "A New Master Narrative? Reflections on Contemporary Anti-Americanism" in Tony Judt and Denis Lacorne, (eds.), With Us or Against US. Studies in Global AntiAmericanism, London: Palgrave, Macmillan, 2005, pp. 11-12 
tions of perceptions upon America occurred in a course of two centuries from Tocqueville to Baudrillard, from Crevecoeur to Georges Duhamel or from Paul Valery to Emanuel Todd. The fluctuation of America's perceptions may be well under the spell of the media, of resentments against American cultural imperialism, but besides fear, rejection or sheer anger, the solid cement of the deficient and disturbing experiences with America has hardened even more, not only in France. Yet, Eastern Europeans, as known, still look up to an America shrouded in the ideals of virtuous democracy, an imperial America though, dividing the world into allies and enemies.

If one seeks for a trenchant representation of the antithetical relations between the US and the EU, there is probably no better illustration than Robert Kagan's essay Of Paradise and Power. The vehemence of Kagan's anti-European arguments shows the political decisionist inclination of American conservatism underpinned the call for religious morality, which at its turn expressed the anxiety of losing political supremacy. ${ }^{6}$ Linking "strategic culture" and political action, Robert Kagan coated in the neoconservative vocabulary the cultural dissensions existing in the Western world, without solving them. The appearance of anti-Europeanism in the United States, which is far from breathing the same enthusiasm as of antiAmericanism in Europe, may however show a change in the mindset of Americans who have always admired Europe as the paragon of culture and sophistication. But in spite of this uneven balance, thinks Timothy Garton Ash, the series of loud or hushed reciprocal incriminations point to two cultural modes not only divergent, but also definitely opposed. ${ }^{7}$

But however ominous the actual portraying of the Western world may appear, the reality of the transatlantic crisis is enframed into two types of discourses. The first type focuses on the final split between the two entitites of the Western world. The second attenuates the discrepancies to the level of a struggle for representation waged by the members of the same family, thus minimizing the possible future damages. For Aldo Morelli and Peter Baldwin the two poles of the West are relying on each other more than anyone could deem, according to their profound similarities founded of the legacy of religion, democracy, state of law. Without losing from sight that America has been under the criticism of Europeans since its beginnings $^{8}$, it is understandable why Europeans do not think that their future hinges on the American version of modernity, even if they realize their autonomy without military might is utopian. Geir Lundestad considered that though the current trans-

6 Robert Kagan, Of Paradise and Power. America and Europe in the New World Order, New York: Random House, 2004, pp. 3-12.

7 Timothy Garton Ash, Lumea libera. America, Europa si viitorul surprinzator al Occidentului. Bucuresti:Incitatus, 2005, pp. 126-133.

8 Peter Baldwin, The Narcissism of Minor Differences. How America and Europe Are Alike, London: Oxford University Press, 2009, p. 7. 
atlantic crisis is but one of the many, the drifting powers, US and EU show nowadays a more determined attitude to carry out their divergences onto the way of no return. ${ }^{9}$ The cultural climate between the US and countries in the EU changed considerably after 2000 according to Lunestad, who thought that Europeans had adopted more critical views on American culture. Cultural differences between the US and the EU have witnessed the growing of the distance between the two components of the once apparently united West. ${ }^{10}$ Rob Kroes, a reputed Americanist, considered that in the first decade of a new millennium, Europeans and Americans are certainly more divided than bonded by culture, though the answer is not a simple one, due to cultural hibridity and globalization. Nevertheless, it is evident, that religion and religiosity in America and Europe may create contradictory and even opposed interpretations to the concept of "culture" in its current perceptions. ${ }^{11}$

Whereas American exceptionalism has been inspired by a pugnacious religious spirit, European patriotism appears to dwell on an intellectual contruction, namely on an ethic cosmopolitanism, aiming at a peaceful, rational course of negociating conflicts. It is clear from this perspective that Americans will entertain a nostalgic superiority, counting on their formidable military force, while Europeans will continue to negociate to acquire the status of equal partners. The ongoing process of perfecting the enlargement of EU favors the rise of Europe as a more and more independent pole of the West, challenging the $20^{\text {th }}$ century aura of the US. Yet, the main hindrance standing against of this historical achievement which is still not finished, lies not so much outside Europe, but inside the continent in the current difficulties met with in the enlargement process in Eastern and Southern Eastern Europe. If everyone agrees on the existence of Europe's immense cultural heterogeneity, only a few authors dare looking into the problematic aspects of this legacy, foreseeing how European political and cultural traditions will peacefully harmonize themselves beyond the frame of national(ist) experiences. ${ }^{12}$ The cultural diversity of Europeans to which one should add the migrationist waves appears as an ever changing horizon hiding areas of ethnic and religious conflicts. It is true that the motto of the EU since 2000 has been "unity in diversity", but European diversity was not understood and stated until recently as a diversity of equal members. In the past the diversity of Europeans was achieved by exclusion

9 Geir, Lundestad, The United States and Western Europe Since 1945, London: Oxford University Press, 2003, pp. 284-291.

10 Geir Lundestad, "Conclusion: the United States and Europe: Just Another Crisis?" in Geir Lundestad (ed.), Just Another Major Crisis? The United States and Europe Since 2000, London: Oxford University Press, 2008, p. 304.

11 Rob Kroes, "Worlds Apart? The United States, Europe, and the Cultural Ties that Bind Them", in Geir Lundestad, (ed.), Just Another Major Crisis? The United States and Europe Since 2000, London: Oxford University Press, 2008, pp. 226-227.

12 Stanley Hoffmann, Sisiful european. Studii despre Europa, 1964-1994, București, Curtea Veche, 2003, pp. 50-60. 
and / or subjection, depending on the rules of Machtpolitik. Compared with the 1960s situation, when religion was deemed as having ended its mission, nowadays the new waves of religiosity may determine the color of politics in adverse and probably rival nuances. Standing against ideologization, consumerism and consequences of the technocratic revolution, the religious revival stems in the conflicting area between political strategies of governance and man's seeking for authenticity.

Under the pen of Tocqueville, religion in America was deemed to pave the road to political freedom, moderating and counterpoising the acquisitive and depersonalizing features of capitalism. Tocqueville thought that religion would eventually compensate the uniformization produced by equality of individuals in "democratic times" and ward off the abuses of liberalism and rugged individualism. Naturally, Tocqueville's $19^{\text {th }}$ century civilizational theory regarding the role of religion in democracy calls for a whole critical reconsideration. Yet, the absence of the moral cement in building an equal civil society has been remarked upon by almost all cultural critics in the last century. It was not surprising that in the name of a grandiose reformist project of Western Europe after WWII, religion was again pivotal in the construction of political project, which envisaged the new blossoming of European civilization. The $20^{\text {th }}$ century history of European Catholicism was essential for the beginnings of the European unification, though later, in the course of the European enlargement process the Catholic factor was forgotten, because of new pressing political and economic issues. At the same time, Protestantism appeared for some authors as being one of the causes for the spreading of Euro-skepticism. In this respect, one can affirm that nowadays, Europe and the United States are less bonded by their common religion, than in the past. ${ }^{13}$ Though, the two great entities of the Western world differ in many respects concerning their Church-state relations, religiosity and the number of religious denomination, the existing differences should not however be overestimated. ${ }^{14}$ Nevertheless, there is no denial that the terrorist attacks of $9 / 11$ have had as major consequence the politicization of religion not only in the US but also in Western European countries. Scholars agree that religion is far more dynamic in the United States than in Europe, according to the competing religious denominations and to the absence of a national authority or monopoly over the public expression of religious faith. On the contrary, the existence of a strong religious institutional hierarchy in Europe, seen either in its being separated from the state or in its being intricately interwoven with the state as in Eastern Europe, contributed to a more passive religious behavior. In many cases in Europe, religious affiliation concides with public required civic virtues, which triggers unwanted consequences on level of the public discourse and also on

13 Mathias Bös and Kai Hebel, "Religion" in Alberto Martinelli, (ed.), The Transatlantic Divide. Comparing American and European Society, London: Routledge, 2007, p. 198.

14 Ibid. p. 208. 
how the religious minorities are treated. ${ }^{15}$ In the United States, Christian religion knew cycles of awakenings, as in the case of evangelicalism, but it also witnessed commercial or cultic experiments as in the case of the Church of Scientology. It is noteworthy mentioning that in the religious awakening elites influence masses in the first phase, but afterwards masses influence elites, which may restructure religious elites, and further on to prevent or accelerate political changes. ${ }^{16}$ Another consequential phenomenon is the widespread interest for "spirituality" which speaks for the Europeans' and Americans' tendency to embrace religious synchretism and disengage from traditional religious life. ${ }^{17}$ In spite of the counter effect religious synchretism especially in higher educated strata of society, religion may instrumentalize important political attitudes in Europe and the United States, reasserting its role as political and civilizational factor. ${ }^{18}$

In the case of Romania, which is definitely not an exception to the wave of changes brought by de-secularization, relations between religion and politics are quite transparent, showing the characteristics of Eastern Christianity and of the tradition of the Byzantine concept of the sinfonia, underscoring the overt alliance between the state and the church. The case of Greek-Catholic Church forbidden by law and condemned to oblivion during the communist regime, reborn after 1990, stands for an enlightening example of the lack of freedom of religious faith in totalitarianism and of the bitter struggle inside the institution of Romanian national Church. The religious Orthodox tradition may be described as conservative and there is no wonder why it has hindered modernization in Romania, under the pretext of losing national identity. Both Romanian traditional Churches, the Orthodox and the Greek-Catholic ones, contributed to the actual making of the national identity, yet the Orthodox Church distinguished itself by a more rigid, anti-modern attitude, often expressing loudly resistance to Western values. The myth of Romanian "exceptionalism" was particularly supported by the Orthodox Church, which saw its mission of defending Romanians from alienating influences coming especially from the West rather than from the East. Such an attitude was clearly voiced in the years of the communist regime, when the high clergy of Romanian Orthodox Church did not officially oppose the abusages of the communist regime as in comparison with the Greek Catholic high hierarchy. The narrative of Romanian

15 Steven Pfaff, 2008, "The Religious Divide: Why Religion Seems to Be Thriving in the United States and Waning in Europe" in Jeffrey Kopstein and Sven Steinmo (eds.), Growing Apart? America and Europe in the Twenty-First Century, Cambridge, New York: Cambridge University Press, pp. 24-28.

16 Amanda Porterfield, The Transformation of American Religion: The Story of a LateTwentieth-century Awakening, London: Oxford University Press, 2001, pp. 228-229.

17 Ibid., pp. 6-12.

18 Jeffrey Haynes, "Religion and Politics in Europe, the Middle East and North Africa" in Jeffrey Haynes, (ed.), Religion and Politics in Europe, the Middle East and North Africa, London: Routledge, 2010, pp. 2-7. 
exceptionalism was especially valued by the communist dictatorial regime, which found in it a resourceful framework to sustain the figure of the national communist unique leader.

From this perspective, the merging of the political discourse and the religious one was highly consequential for Romanian nationalism. After the fall of the communist regime, religious effervescence inspirited Romanian clergy and the laymen alike, echoing the wide, popular trust of citizens in the national Church. The daily public presence of the Church in the media, especially of the Orthodox one, proved that in various cases the church as an institution became the legitimator of political decisions and sometimes also of party initiatives. According to polls, Romanians appeared to trust more the Church than any other institution, which speaks for the political manipulation of the religious belief and of the strength of populism. At the same time, such opinions spoke eloquently about the quality of democracy and the missing traditions of civil society. In many regards the Orthodox Church was considered as the most powerful opponent of European integration. ${ }^{19}$ The Romanian society has undergone the impact of a double process of secularization during the last century, the one imposed by communist ideology to which there had been added other secular influences emerging from different international factors. Immediately, after the fall of communism, in a period described as insecure from an existential point of view, Romanians relied increasingly on the promises of the religious discourse. ${ }^{20}$ But after 2000, a decrease in religiosity was remarked upon, due to the relatively higher standards of living. Again, the situation changed in 2008, with the shock of the economic crisis in Romania. Such oscillations prove the Romanian deficit of modernization and that secularization was premature in Romania. ${ }^{21}$

Instead of a conclusion, I think that religion will continue its ascending course in public matters, asserting more clearly its role of a society mediator and probably of a competitor for a better representation of its institutional interests but also for the people's discontentment with the decisions of European integration. Culture wars in America as well as European economic integration might cause social confrontations fuelled by populism, nationalism, ethnic issues and migrationist fears. Regionalization in Eastern Europe could resuscitate old religious fears and feuds and the vortex of glocalization may provide churches, mosqs and temples new chances to make people bow in respect for an ancient and yet new, revered authority.

19 Lavinia Stan, Lucian Turcescu, Religion and Politics in Post-Communist Romania, London: Oxford University Press, 2007, pp. 199-207.

20 Mălina Voicu and Andreea Constantin, "Religious Revival in Romania: Between Cohort Replacement and Contextual Changes" in Gert Pickel, Kornelia Sammet (eds.), Transformations of Religiosity. Religion and Religiosity in Eastern Europe. 1989-2010. Springer, VS, Wiesbaden, 2012, pp. 157-159.

21 Ibid., p. 169. 


\section{Bibliography}

Agamben, Giorgio, 2009, The Signature of All Things, New York: Zone Books.

Allessandri, Emiliano, "The Atlantic Community in Christendom. Some Reflections on Christian Atlanticism in America, circa 1900-1950" in Marco, Mariano, 2010, (ed.) Defining the Atlantic Community. Culture, Intellectuals, and Policies in the Mid- Twentieth Century, London: Routledge, 47-71.

Baldwin, Peter, 2009, The Narcissism of Minor Differences. How America and Europe Are Alike, London: Oxford University Press.

Bös, Mathias and Hebel, Kai, 2007, "Religion" in Martinelli, Alberto, (ed.), The Transatlantic Divide. Comparing American and European Society, London: Routledge, 211-231.

Eisenstadt, N.S., 2000, "Multiple Modernities", Daedelus, 2000, Winter, 129, 1-29.

Garton Ash, Timothy. Lumea liberă. America, Europa și viitorul surprinzător al Occidentului. București: Incitatus, 2005

Haynes, Jeffrey, 2010, "Religion and Politics in Europe, the Middle East and North Africa" in Haynes, Jeffrey, (ed.), Religion and Politics in Europe, the Middle East and North Africa, London: Routledge, 1-21.

Hoffmann, Stanley, 2003, Sisiful european. Studii despre Europa, 1964-1994. București: Curtea Veche.

Kagan, Robert, 2004, Of Paradise and Power. America and Europe in the New World Order, New York: Random House.

Koselleck, Reinhart, 2009, Conceptele și istoriile lor. Semnatica și pragmatica limbajului social-politic. Bucuresti: Art.

Kroes, Rob, 2008, "Worlds Apart? The United States, Europe and the Cultural Ties that Bind Them" in Lundestad, Geir, Just Another Major Crisis? The United States and Europe Since 2000, London: Oxford University Press, 210-230.

Judt, Tony, "A New Master Narrative? Reflections on Contemporary Anti-Americanism" in Judt, Tony and Lacorne, Denis (eds.), With Us or Against US. Studies in Global Anti-Americanism, London: Palgrave, Macmillan, 2005, 11-35.

Lundestad, Geir, 2003, The United States and Western Europe since 1945, London: Oxford.

Lundestad, Geir, 2008, "Conclusion: the United States and Europe: Just Another Crisis?" in Lundestad, Geir, Just Another Major Crisis? The United States and Europe Since 2000, London: Oxford University Press, 298-304.

Porterfield, Amanda, 2001, The Transformation of American Religion: The Story of a LateTwentieth-century Awakening, London: Oxford University Press.

Pfaff, Steven, 2008, "The Religious Divide: Why Religion Seems to Be Thriving in the United States and Waning in Europe" in Kopstein, Jeffrey and Steinmo Sven, (eds.), Growing Apart? America and Europe in the Twenty-First Century, Cambridge, New York: Cambridge University Press, 24-52.

Stan, Lavinia, Turcescu, Lucian, 2007, Religion and Politics in Post-Communist Romania, London: Oxford University Press.

Voicu, Mălina, Constantin Andreea, 2012, "Religious Revival in Romania: Between Cohort Replacement and Contextual Changes" in Pickel, Gert, Sammet, Kornelia, (eds.), Transformations of Religiosity. Religion and Religiosity in Eastern Europe. 1989-2010, Wiesbaden: Springer VS, 155-174. 


\title{
Atlanticism and the Changing Dynamics of European Security in the 'New Global Order'
}

\author{
Michael O’NEILL
}

\begin{abstract}
The Atlantic Alliance was the bedrock of western security throughout the postwar decades. Theend of the Cold war and the subsequent changes this historic outcome has wrought in the international order has brought altogether new challenges to the Atlantic Community, requiring both the American and European partners old and new, to rethink their security and foreign policy priorities. The paper reviews this process of international change and the challenges this has brought to the idea of Atlanticism.
\end{abstract}

Keywords: Atlanticism; Europe; America; security; Cold War; foreign policy

\section{Debating Atlanticism: NATO quo vadis?}

The first NATO Secretary General Hastings Ismay defined the organisation's raison d'être as follows: "To keep the Americans in (Europe) the Russians out and the Germans down". Today, both the USA and the Europeans see NATO's central purpose in broadly similar terms, as insurance against a reviving Russia, and even (though let it not be said too loudly!) as a collective guarantee vis-a-vis a reunified and revived Germany. However this broad strategic objective occurs nowadays within a much-changed security environment. The critical issue now is how the Atlantic community should operate in an altogether different global order from that which brought it into being.

Trying to reconcile the two historic 'halves' of Europe, to re-integrate east and west in the enlargement negotiations for both NATO and the EU has been a far from straightforward process.Following the initial euphoria that mostly greeted the fall of the Berlin wall the ensuing process has been fraught with misconceptions, misplaced expectations, and no less by false hopes and disappointments on all sides. The circumstances of enlargement revealed much about the dynamics of European integration, both its limits and its prospects. The focus of the discussion here is the impact of these historic developments on regional security, the consequences for Atlanticism in the post-Cold War age, and indeed whether a panEuropean security policy within NATO or without is a realistic option.

Three critical issues are suggested by this particular inquiry. In the first instance the significance of enlargement for the security debate in both the EU and the USA, and no less for relations between them. A related question is the impact on policy of this narrative about regional and Western security, and likewise its consequences for Atlantic relations and for the very idea of 'Atlanticism' per se. What is the impact of the EU and NATO enlargements for Western security?And 
in what way should we measure success here, 'successful' for whom: for the USA by extending the reach of its own its security strategy in 'the new world order, for the EU's role in stabilising a potentially turbulent neighbourhood, or indeed successful for both sides because of the positive impact of enlargement on Atlantic relations?

The second principal question is what these enlargements have meant for the new applicants, the post-1989 demandeurs? Whether and how far the process has contributed to the 'successful' domestic stabilisation of the accession states and to their security in what is a problematic neighbourhood? A final consideration for this brief review of options and consequences for regional security is the question of 'futures'. How should we assess the impact of enlargement for regional and western security over the longer term?

\section{The Cold War's strategic aftermath}

The end of the Cold War began a debate about European security that is far from being resolved. On the one side there are bold predictions about the 'end of an era', the prospect of a wholly new security agenda for what used to be called 'the West'. And on the other side the claim that the Atlantic Alliance will, indeed must survive albeit reformed. ${ }^{1}$ In fact, the actual situation is altogether more nuanced, neither an end-game nor easy continuity, but instead a process of mutual adaptation to fastchanging circumstances and to novel security and political challenges. Atlanticism was never an easy relationship; it was problematic for some Western Europeans and Americans alike from the outset. So recent frictions are nothing new and they do not necessarily signify a parting of the ways. Fall-outs between Europe and Washington have arisen periodically over everything from the war in Vietnam, Washington's singular approach to détente, the emplacement of American weaponry on European soil, Washington's response to the 1974 oil crisis, and on to all manner of trade disputes from bananas to agricultural subsidies, and much more.

The end of the Cold War saw significant change in NATO's strategic direction, and not least reinforced American reticence about relations with Europe both 'old' and 'new'. ${ }^{2}$ Washington's immediate concern was security for the former Soviet satellite states, although unsure about how the former Warsaw pact countries could usefully contribute to this objective, and not least what the negative externalities of such an enlargement would have on a Russia struggling to come to terms with its sudden loss of international heft. Even as this delayed NATO enlargement

1 J. Howorth, "France, Britain and the Euro-Atlantic crisis", in Survival 45, no. 4, 2003-4, pp. 173-92.

2 F. Heisbourg, "The Future of the Atlantic alliance: Whither NATO, Whether NATO?", The Washington Quarterly 15, no. 2, 1992, pp. 127-39. 
Washington continued to promote EU enlargement, preferring Brussels to take the lead role in stabilising its own region as America shifted its security priorities away from Europe and embraced a wider global outlook.

Washington's objections here were a mix of ideology and self-interest. On the one hand, to underpin democratic values, commitment to a market economy and furtherance of human rights seen as the surest foundation for securitising the region against latent threat. And on the other hand to use the reforms and the prosperity that would follow from EU membership to thwart residual Russian ambitions in what Moscow still saw as its own geo-political hinterland. Accordingly, Washington saw both enlargements as mutually supportive, as a cultural and a strategic commitment by Western democracies, each one underpinning the other. For the most part the CEECs shared this outlook, seeing NATO as both the most reliable source of political stability for their fragile democracies and their principal security guarantee against residual Russian interests in the region. But even the best laid plans sometimes go awry, and 'events' in Europe obliged Washington to revise its plans with the outbreak of civil war in the Balkans. ${ }^{3}$

In the immediate aftermath of the Cold War the 'West' did embark on a twintrack enlargement, extending membership of both NATO and the EU to those former Communist states that sought membership. Good intentions however were soon confronted by complex realities brought all manner of difficulties such that Washington and the EU15 states alike became concerned about the impact of sudden 'big bang' enlargements. The enlargements stalled, becoming a protracted and for some EU15 member states even a reluctant process.

Events in Bosnia confirmed Washington's security dilemma and underlined its own freedom of action, not least the EU's tardy response there that required Washington to take the lead in using military force to bring Serbia to the negotiating table at Dayton and later over the Kososvo imbroglio. The USA could not easily relinquish its role in European security. But over the longer term Washington remained convinced that the Cold War was indeed a turning point for Atlanticism, for its own security policy, with resources and strategic priorities concentrated more exclusively on homeland security by operating on global level rather than giving primacy to the European theatre. America now looks beyond Europe for the main source of threats and focuses now on preventing the spread of WMDs and nuclear proliferation, and on countering the threat of 'new' terrorism and what are seen as 'failed' states. ${ }^{4}$

The fall-out from the break-up of the Yugoslavian federation also confirmed America's long-held view that Europe must take greater responsibility for its own security. This priority shift was reflected in James Baker's observation that

3 R. Holbrooke, "America: A European Power", in Foreign Affairs 83, no. 4, 1995, pp. 2-7.

4 B. Buzan, People, States and Fears: An Agenda for International Security Studies in the Post-Cold War Era, Harvester Press, Hemel Hemstead, 1991. 
Washington has 'no dog in that (Balkans) fight', a shift confirmed by the Clinton administration's embrace of an 'Asia first policy'. ${ }^{5}$ Washington's immediate priority after 1989 was the stability of the former Communist states now seeking membership of both the EU and NATO. As Washington saw it the enlargement of these formerly Western institutions would ensure regional peace and bring stability through prosperity, a neat conclusion to the Cold War.

\section{Trans-Atlantic relations post-Iraq}

The onset of the war in Iraq war in 2003 only confirmed Washington's determination to realign its security policy away from the Atlantic region, in the process downgrading what for a clear half century had been its principal security commitment. The fall-out with some leading EU states over Iraq justified Washington's reduced commitment to Atlanticism, its preference for a more utilitarian and no less a more unilateral approach to relations with erstwhile allies.

In so far as Atlanticism remains important in Washington, the Alliance is now denominated more in bilateral terms than as collective security, ad hoc relations and 'coalitions of the willing' for whatever actions Washington chooses to define as threats to 'global' security. American disengagement from the Balkans, devolving responsibility for peacekeeping there to the EU, resistance to involvement in NATO peacekeeping in Macedonia and Bosnia were all clear signals of strategic revision. If this does not quite amount to wholesale abdication of concern for regional security, it is now 'concern' at a distance, rather more indirect than 'hands on', and without any abiding sense of obligation underpinned by military involvement.

\section{Burden sharing: a new security balance?}

By the mid-2000s then it was becoming clear that NATO was undergoing significant strategic transformation. Whilst the organisation's security guarantee to the CEECs did remain central to NATO's mission, the European and American sides of the 'partnership' had different if not quite divergent security priorities. The European states are as reticent as they have always been for the most part about undertaking 'out of area' engagements. Whereas the USA is reluctant to contribute to peacekeeping and soft security tasks in the wider European neighbourhood, preferring instead to lead 'coalitions of the willing' in undertaking selective military operations as and when Washington determined. ${ }^{6}$

5 M. Cox, US ForeignPolicy after the Cold War: Superpower without a Mission?, Pinter London, 1995.

6 A. Cottey, "Globalisation or Redundancy?" in Contemporary Security Policy,volume 25, no. 3, 2004, pp.1-30. 
Above all Washington is more exercised now by 'burden sharing', expecting the Europeans to shoulder greater responsibility not only for regional security but also 'out of area'. The outcome is an uneasy compromise for both sides: NATO took over responsibility (2003) for the command and control of international peacekeeping operations in Afghanistan, its first mission outside Europe and subsequently and significantly extended its force levels there, and likewise played the lead role in training Iraq's new security forces. Whereas the so-called 'Berlin-plus' arrangements permit the Europeans to use NATO military assets (military planning / command and control facilities) for operations in which US and other NATO members may choose not to participate, with Washington agreeing to the formation (again in 2003) of a NATO Response Force for regional crisis deployment. ${ }^{7}$

\section{Rethinking Atlanticism: George 'Dubyah's'new security agenda}

This shift in the strategic balance of the Alliance is plain to see from the early 1990s but it was 9/11 that was the real 'game changer', accelerating shifts already underway, altering mindsets on both sides of the Atlantic. ${ }^{8}$ The Bush 'revolution' while hardly a new foreign policy departure certainly raised the stakes, embedding a mindset whereby paranoia as much as strategic logic propelled foreign policy, with its emphasis, indeed obsession, with the so-called 'axis of evil'. The intensification of militarised foreign policy gave priority to a doctrine of preventive war, with firststrike hard power and missile defence against perceived 'threat' as the leitmotif of security policy at the expense of classic diplomacy or active peacekeeping, and in the process widened the breach with Europe. ${ }^{9}$

This breach was emblematically underlined by Donald Rumsfeld's deliberately provocative distinction between 'old' and 'new' Europe, a phrase that signaled both a discernible weakening of the very idea of commonality of interest, and no less of those shared values that had been the ballast of Atlanticism for a generation and more. ${ }^{10}$ What up until then had been gradual American disengagement from, periodic irritation with Europe became a serious fall-out, and one with adverse consequences for Atlanticism. Europe was no longer Washington's principal security commitment as priorities shifted to elsewhere. The Alliance was downgraded, replaced by ad hoc 'coalitions' of those states prepared issue on issue to

7 NATO (2006), Missile Defence at http://www.nato.int/issues/missile_defence/index.html.

8 J. Peterson, "Europe, America, Iraq: Worst Ever, Ever Worsening?", in Journal of Common Market Studies 42, 2004.

9 I. Daalder and J. Lindsay, America Unbound: The Bush Revolution in Foreign Policy, Washington: Brookings Institution, 2003.

10 Rumsfeld, D., Secretary Rumsfeld Speaks on $21^{\text {st }}$ Century Transformation of US Armed Forces, National Defense University, Fort McNair, Washington DC, January $31^{\text {st }} 2002$, at http://www.defense.gov/Speeches/Speech.aspx?SpeechID=183 
unconditionally endorse US policy. Europe meanwhile became increasingly critical of what it saw as confrontational unilateralism, an atmosphere that prompted America's Ambassador to NATO to describe these events as a "near death experience" for that organisation. ${ }^{11}$

\section{How Washington sees European security}

American and European perspectives on the meaning and no less on the value of Atlanticism have undoubtedly eroded trust, weakening consensus about how best to respond to the challenges of the new international order. Critical here is the problem of how to ensure a credible EU security role. For even where there is transatlantic agreement on global security tasks, NATO is now only one of several institutional frameworks available for addressing such challenges and it is not necessarily the first preference for either the EU or America. Europe has as much responsibility for this state of affairs as Washington. NATO will struggle to bridge the growing Atlantic divide unless the Europeans show greater willingness to burden share, to develop a more credible capability than is currently available in the fledgling ESDP with its limited 'battle groups' and less than convincing 'rapid reaction' force capability. Whether the Alliance has a credible future will depend as much on European as on American commitment.

Yet all is by no means lost for Atlanticism, the idea still has some emotional purchase, and no less strategic relevance for Washington. The Atlantic region may not be the keystone of US security policy it once was but it is still seen as an important aspect of Washington's global security strategy. This continuing commitment is a mix of both strategic self-interest and cultural ballast. Current threat perceptions, much as they were during Cold War, are principally about raw politics but not entirely so. From the very beginnings of the Republic foreign policy has been driven as much by values as by interests, and it remains to this day a matter of furthering cherished ideals: democracy, free markets, freedom and so forth, those very principles that one notable commentator who should have known better once foolishly described as now finally assured, the ultimate victory and no less 'the end of history'.

Of course, 'history' as defined in these boastful terms did not end in 1989, and nor will it 'end' any time soon. Washington is now quite aware of that unpalatable truth, realises that it still needs like-minded allies who share these same values, and that very fact indicates a continuing basis for Atlanticism. But things are not quite what they once were even between close allies. The ballast of shared values that underpinned the Alliance from the outset is threatened nowadays by

11 Guardian (London), December $5^{\text {th }} 2003$. 
accelerating cultural and social change, and the idea of partnership continues to experience tensions.

\section{And the Europeans...}

Europe too is facing hard strategic choices as it responds to current security challenges. The shifts in the Atlantic order discussed above have encouraged Europeans, long since ambivalent about over-dependence on Washington, to review the Continent's strategic options. This is less about abandoning Atlanticism altogether and than it is about finding a credible role for Europe within the Atlantic system. ${ }^{12}$ There is still much to play for and though 'Atlanticism' is under strain it is by no means a lost cause. But neither is the Alliance the entrenched community of mutual values and shared interests it once was.

The debate in Europe about security has centred on how far Europe should accommodate Washington's growing unilateralism and the strategic and security policy preferences that follow from this. Whether on the one hand to work principally through NATO, make strategic accommodations with Washington, maximising consensus and cooperation, agreeing a division of labour acceptable to both sides. Or instead, to strike out in a new direction, to develop a more autonomous role for Europe as a counterweight to American power, as France has always preferred to do. ${ }^{13}$ The EU remains divided over this strategic dilemma: Euro-Atlanticists are wary of offending (and indeed alienating) their principal ally, whereas panEuropeanists are more concerned to develop a credible European security policy, more autonomous yet complementary to NATO.$^{14}$

There are those too, often described as Euro-Gaullists, who want Europe to break with Atlanticism, preferring instead a wholly independent security policy. In a riposte to the policy of both recent centre right and centre left governments in France to re-join NATO's integrated command structure, Regis Debray amongst others makes the case for European autonomy as follows: "NATO is useless because it is anachronistic. At a time when every major nation is playing its own hand... when religious pride or cultural identities are being asserted or reinforced, signing up to NATO is not building for the future. What matters now is ad hoc coalitions, bilateral cooperation and practical

12 See the debates in J. Howorth and J. Keeler (eds), Defending Europe: NATO and the Quest for European Autonomy, Basingstoke 2003.

13 H. Grabbe, The EU's Transformative Power: Europeanisation through Conditionality in Central and Eastern Europe, Basingstoke 2006.

14 P. Cornish and G. Edwards, "The Strategic Culture of the EU: A Progress Report", in International Affairs 84, no. 4, 2005, pp. 801-820. 
arrangements, not a simplistically dualistic worldview. NATO is a survivor from a bye-gone age". ${ }^{15}$

\section{The state of Atlanticism: rift or drift?}

Few close observers of the current state of Atlantic relations would deny that these difficult choices are at very core of the rising debate about security options. This is now an altogether looser security community with even the broad ballast of common 'values' that underpinned it from the outset now diminished. Nevertheless NATO remains operational, a viable alliance though changed and changing for sure, no longer the steady-state security blanket against 'clear and present' ideological threat that it was in earlier decades. Nevertheless a residual consensus remains about broad objectives albeit with much less agreement now about operational 'means'. ${ }^{16}$

Re-appraisal and re-evaluation are apparent on both sides but whether present flux is merely temporary or implies an ineluctable rift remains to be seen. America too is actively reviewing how far, or indeed whether Europeans are still 'valued partners'. Much is made there of perceived European 'free-riding', what seems to be habitual reticence to undertake (and pay for) burden sharing, widespread censure of a supposed absence of political will to divert public monies from 'expensive' welfare programmes and other public goods to ensure a fairer Atlantic division of labour. ${ }^{17}$ There is growing impatience amongst American commentators for instance with Europe's reliance on soft power rather than doing more of the 'heavy lifting', notwithstanding recent praise from Secretary of State Hilary Clinton for Europe's contribution here. ${ }^{18}$

\section{Explaining'Atlanticist security logics: some theoretic narratives}

How might we explain these differences in security priorities between formerly close allies? International relations theory offers some insights into the motives of key policy actors, explains how and why particular outcomes occur, though of course competing theoretical narratives yield quite different explanations of outcomes. The realist narrative dominant in the American academy sees the

15 Regis Debray, "Why France should leave NATO, a response to the report by foreign minister Hubert Vedrine endorsing the Sarkozy governments re-embrace of NATO strategy", in Le Monde Diplomatique (English edition) April 2013, pp. 12-13.

16 J. Nye, “The US and Europe: Continental Drift?”, in International Studies 76, no. 1, 2000, pp. 51-60.

17 D. Gompert and R. Kugler, "Free-Rider Redux: NATO needs to Project Power (And Europe Can't Help)", in Foreign Affairs 74, no. 1, 1995, pp. 3-12.

18 C. Kupchan, "The Atlantic order in transition: The nature of change in US-Europe relations", in J. Anderson, J. Ikenberry, and T. Risse (eds), The End of the West? Crisis and Change in the Atlantic Order, Ithaca, 2008. 
'rational pursuit' by states of what they define as strategic interests as the main driver of policy motives, the principal reason why states with a capacity for exercising power are more disposed to use it to achieve their policy objectives, and especially 'hard' power. ${ }^{19}$ As Robert Kagan has famously made the case, the difference between American and European strategic cultures, and especially their differential will to use hard power as a first reflex of foreign and security policy is itself a reflection of quite different capacities for exerting international and especially military power. ${ }^{20}$

For Kagan this merely confirms wholly different cultural instincts, antithetical indeed divergent outlooks 'across the pond' on the logics of the 'new world order'. The USA 'sees' the world from the perspective of a global superpower, indeed a hyper-power. Europeans on the other hand tend to 'see' the world from the quite different perspective of what are at best 'middling' powers with only a modest strategic capacity and much-reduced global clout. More conscious of the limits of their residual power, European statesmen prefer to use multilateral agency as the less risky strategic option for maximising influence, indeed they make a positive virtue of it. For realists such as Kagan these quite different strategic mindsets are pulling apart the two sides of the Atlantic Community.

Liberal commentators on the other hand are rather more sanguine about the prospects for Atlanticism. As they see it values shape strategic choices as much as they are shaped by them. In this Weberian view of the modus vivendi for political action shared values and common institutions sustain mutual policy objectives on those things that really matter in the Atlantic Community regardless of differential power. Commonality of values figures too in the modish social constructivist narrative, and in this theoretic outlook both reinforces shared historic memory, underpins shared institutions and cements a common outlook on security even across a widening Atlantic. ${ }^{21}$ There is then continuing transatlantic consensus on the dangers of nuclear proliferation, shared antipathy to terrorism, wariness of failed states and broad agreement too about the security challenges to 'free' states, all of which amounts to some continuing consensus on the real challenges facing 'the West' in the new and highly mutable 'world order'. ${ }^{22}$

The assumption here of a simplistic causal link between 'values' and political action, the very idea that merely by participating in shared international institutions

19 See for instance J. Mearsheimer, "Back to the Future: Instability in Europe After the Cold War", International Studies 15, no. 1, 1999, pp. 5-56; and K. Waltz, "The Emerging Structure of International Politics", International Security 18, no. 2, 1993.

20 R. Kagan, "Power and Weakness", Policy Review vol. 113, 2002.

21 H. Sijursen, "On the Identity of NATO", in International Affairs 80, no. 4, 2004, pp. 687703; T. Risse-Kappen, "Identity in a Democratic Security Community: The Case of NATO", in P. Katzenstein (ed), Promoting National Interest, New York, 1996, pp. 359-99.

22 J. Nye, "Conflicts after the Cold War", in The Washington Quarterly 19, no. 1, 1996, pp. 5-24. 
invariably promotes understanding and common purpose is as crudely deterministic in its own way as the realist narrative it seeks to challenge. Simplistic emphasis on values as the critical independent variable is as questionable as the realist assumption of path-dependent power as the driving force behind foreign policy preferences. What each of these contested theoretic narratives does do however is to suggest some explanations, deepening our understanding of causality over 'merely' contingent description, indeed yields insights that are essential for the primary task of the social and behavioural sciences to explain rather than merely to assume a priori the reasons for collective political action, in this as in any policy domain.

That values may be shared between actors who might otherwise have quite different strategic preferences and interests is too complex an issue to be resolved in this short essay. However, the question of why things happen in politics is an important one and merits deeper consideration in as much as much as Atlanticism has long been premised on the very idea of shared cultural affinities. One might reasonably question whether, or how far 'common values' are indeed sufficient cultural cement for binding a community facing altogether new challenges in a fast-changing world.

Does Atlanticism imply and will its continuity depend on enduring 'common values'? Debate about transatlantic 'commonality' or American 'exceptionalism' has been the stuff of a fascinating cultural anthropology from De Tocqueville and Charles Dickens to the present day. ${ }^{23}$ Do shared values necessarily mean common interests, do they imply shared threat assessment, let alone a commitment to respond to perceived threat in any particular way? Might we not reverse the causal link here and argue just as plausibly that shared values notwithstanding, different perceptions of interests and no less of threat may mean diverse, indeed divergent expectations that over time might alter value preferences, thereby weakening the glue of alliance and even sunder longstanding relations?

More is required then for sustaining alliance, underwriting a common security endeavour than merely reliance on values per se. Shared cultural preferences are certainly a necessary prop for bolstering common political purpose but they are hardly sufficient to cement alliance. Indeed there are many on both sides of this debate who question nowadays whether there is any longer an abiding commonality of values or interests across the Atlantic. Frequent and often bitter disputes are explained away by some commentators as merely 'the narcissism of small differences' ${ }^{24}$ But others are much less convinced, seeing instead a growing cultural lacuna and even irreconcilable ideological differences across the wide ocean,

23 S. M. Lipset, Continental Divide: The Values and Institutions of the United States and Canada, London, 1990.

24 P. Baldwin, The Narcissism of Minor Differences: How America and Europe are Alike, New York, 2011. 
for instance the cultural impact, the mainstreaming of neo-liberal and no less of neo-conservative ideas on American values, amounting to a culture shift that now extends way beyond the Grand Old Party and even its Tea Party insurgents.

Cultural shifts between Europe and America may well be exaggerated but they do exist and they compound other differences rooted in differential power, and just as significant a differential propensity to use it. The cumulate impact of demographic shifts such as growing Hispanicisation, the geographical shift in America's political axis from the Atlantic seaboard to the new South and the West, resistance to gun law reform, continued use of the death penalty and popular as much as political resistance to socialised medicine and quite different views on the role of the state in economic and public policy, are all trends that confirm an ideological lacuna and maybe even an unbridgeable cultural rift between Europeans and Americans. And the cumulative impact of these different value preferences does impact on the security debate, altering strategic expectations and prompting serious re-evaluation of strategic goals and security priorities on both sides.

\section{Of 'Mars' and 'Venus' and the future of Atlantic relations}

This narrative on the extent of transatlantic similarity and difference has its advocates on both sides, and nowhere more so than in the writings of Robert Kagan. For Kagan quite different geo-strategic positions / power capabilities as between the US and Europe reflect fundamentally different assessments, indeed competing priorities about current and impending security challenges. And though the US and Europe do still share some important interests this writer sees quite distinct strategic cultures, deep differences of outlook on both the source and the use of power. ${ }^{25}$

The USA as Kagan sees it is the world's hyper-power it has global interests and responsibilities that incline it to employ hard power as a first reflex of security policy because it can, with the capacity and no less the will to act unilaterally. In this narrative the America 'Mars' both resents and resists what it sees as the (superficial) ethical constraints prescribed by weaker European states who, 'Venus-like', object to first use of hard power and seek to constrain its use even by close allies in pursuit of supposedly shared strategic objectives. Europe's reticence here is deemed to be less about the role of ethics in foreign policy and more the logical consequence of that Continent's own brutal experience of power politics. Two immensely destructive 'civil' wars both reduced Europe's international status and no less diminished its moral authority, disinclining its states thereafter from using force as the first reflex of politics, preferring instead to pursue multi-lateral and negotiated solutions to international problems.

25 R. Kagan, Paradise and Power: America and Europe in the New World Order, London, 2002. 
The overly simplistic juxtaposition in this account between ethics and realpolitik as the elemental drivers of security and foreign policy has not gone unchallenged. Robert Cooper's spirited rebuttal of Kagan's brutal realism for example attributes European reticence about first-use of hard power, aversion to militarised foreign policy, the Continent's altogether readier embrace of civilian or soft power not merely to the differential emphasis Europeans place on ethics per se. And not even to a vague moral predilection amongst Europeans to cooperate rather than talk up conflict as the first instinct of managing security policy. Instead Cooper sees this more benign strategic culture as a direct consequence not of self-indulgent idealism but rather the outcome of brutal experience. For Europeans the experience of twentieth century wars has not meant abjuring the use of power but instead a concerted endeavour to tame it, to channel it into more positive, even progressive ends. To find instituionalised ways of resolving conflicted interests, an experience of a new approach to old problems that translated into the positive legacy of sixty years of mostly successful community-building, regional cooperation and multilateral integration, and even wholly novel supranational governance. ${ }^{26}$

In truth no singular narrative can satisfactorily explain the marked disparity between the strategic cultures of Europe and America: strategic self-interest does play its part in shaping what are quite different, even divergent outlooks on mutual problems. And whereas a residuum of shared values does constrain unalloyed selfinterest, is a brake on the disintegration of a longstanding international alliance, the likely future of this 'special relationship' in a mutable world, and how far is it still 'special' remains problematical for all concerned. This question is less about how deep the differences are between the two sides of the Atlantic Community and rather more about how they might continue to work together on the things that they do still share in common.

\section{Conclusions: a future for Atlanticism?}

Novel security challenges do sustain an abiding sense of common interests across the Atlantic, though rather less so now in the multipolar post- Cold War world. Of course tensions, even fall-outs are hardly a new experience for transatlantic relations. After all this has always been an ambivalent relationship for both sides. But there is no ineluctable sense yet that the Alliance faces its Rubicon, a final parting of the ways, for even the American hyper-power needs allies, reliable partners and the Europeans fit the bill here rather better than most. ${ }^{27}$ Europeans too for their part are far from convinced that a more independent approach to regional

26 R. Cooper, The Breaking of Nations: Order and Chaos in the Twenty-first Century, London 2007.

27 J. Nye, The Paradox of American Power: Why the World's only Superpower Can't Go it Alone, Oxford, 2002. 
security means giving up on Atlanticism, though there are clear differences with Washington nowadays over both interests and strategy.

Something remains then of a sense of common endeavor that sustained the Alliance over the duration. Europe may no longer be the exclusive let alone the primary theatre for US security but it remains important for Washington, an outreach or in the language of siege warfare a counterscarp of its forward security. Yet there is a discernible shift in how Washington policy wonks see Atlanticism. The emerging global order has altered perceptions on all sides, both about economic and security interests, and though the European theatre remains important for Washington it is much discounted nowadays in the broader scheme of things.

The Obama Administration may have softened the tone of its security policy, forbearing in the gratuitous use of confrontational language preferred by its Republican predecessor, but the shift in Atlantic relations is nevertheless plain to see. Washington continues to reconfigure its security policy, and Europeans too are reviewing where they stand on many of the critical issues that define the new international order. Clearly the Alliance is not what it once was and is aptly described by one close observer of events as much less the unconditional alliance of old and rather more as a conditional and 'elective partnership', an arrangement where both 'sides' opt in and out of close relations as circumstances and events dictate. ${ }^{28}$

What we do glimpse then 'through the glass darkly' from this brief overview of the shifting state of Atlanticism is altogether more problematic relations than in times past. This is now an Alliance where the once firm cement of shared interest and common values is increasingly challenged by the vagaries of a wholly new, a mutable and far from predictable global order. It is too soon to pronounce the end of Atlanticism but we should expect altogether more change than continuity in the direction of relations here in the years and decades ahead.

\section{Bibliography}

Anderson, J., J. Ikenberry, and T. Risse (eds), (2008), The End of the West? Crisis and Change in the Atlantic Order, Ithaca: Cornell University Press.

Baldwin, P., (2011), The Narcissism of Minor Differences: How America and Europe are Alike, New York: OUP.

Buzan, B., (1991), People, States and Fears: An Agenda for International Security Studies in the Post-Cold War Era, Hemel Hemstead: Harvester Press.

Cooper, R., (2007), The Breaking of Nations: Order and Chaos in the Twenty-first Century, London: Atlantic Books.

Cornish, P. and G. Edwards, (2005), "The Strategic Culture of the EU: A Progress Report", in International Affairs 84, no. 4.

28 J. Steinberg, “An Elective Partnership: Salvaging Transatlantic Relations", in Survival 45, no. 2, 2002, pp. 113-46. 
Cottey, A., (2004), "Globalisation or Redundancy?" in Contemporary Security Policy, volume 25 , no. 3 .

Cox, M., (1995), US Foreign Policy after the Cold War: Superpower without a Mission?, London: Pinter.

Daalder, I., and J. Lindsay, (2003), America Unbound: The Bush Revolution in Foreign Policy, Washington: Brookings Institution.

Rumsfeld, D., (2002), Secretary Rumsfeld Speaks on $21^{\text {st }}$ Century Transformation of US Armed Forces, National Defense University, Fort McNair, Washington DC, January $31^{\text {st }} 2002$, at http://www.defense.gov/Speeches/Speech.aspx?SpeechID=183

Gompert, D., and R. Kugler, Free-Rider Redux (1995), "NATO needs to Project Power (And Europe Can't Help)", in Foreign Affairs 74, no. 1.

Grabbe, H., (2006), The EU's Transformative Power: Europeanisation through Conditionality in Central and Eastern Europe, Basingstoke: Palgrave.

Heisbourg, F., (1992), “The Future of the Atlantic alliance: Whither NATO, Whether NATO?", in The Washington Quarterly 15, no. 2.

Holbrooke, R., (1995), “America: A European Power” in Foreign Affairs 83, no. 4.

Howorth, J., (2003), "France, Britain and the Euro-Atlantic crisis", in Survival 45, 2003-4, no. 4.

Mearsheimer, J., (1999), "Back to the Future: Instability in Europe after the Cold War", in International Studies 15, no. 1, pp. 5-56.

Howorth, J., and J. Keeler (eds), (2003), Defending Europe: NATO and the Quest for European Autonomy, Basingstoke: Palgrave.

Kagan, R., (2002), "Power and Weakness" in Policy Review, vol. 113.

Kagan, R., (2002), Paradise and Power: America and Europe in the New World Order, London: Atlantic Books.

Kupchan, C. (1990), "The Atlantic order in transition: The nature of change in US-Europe relations", in Lipset, S.M. (ed.), Continental Divide: The Values and Institutions of the United States and Canada, London: Routledge.

NATO, Missile Defence at http://www.nato.int/issues/missile_defence/index.html

Nye, J., (1996), "Conflicts after the Cold War", in The Washington Quarterly 19, no. 1, pp. 5-24.

Nye, J., (2000) “The US and Europe: Continental Drift?", in International Studies 76, no. 1, pp. 51-59.

Nye, J., (2002), The Paradox of American Power: Why the World's only Superpower Can't Go it Alone, Oxford: OUP.

Peterson, J., (2004), "Europe, America, Iraq: Worst Ever, Ever Worsening?", in Journal of Common Market Studies 42.

Risse-Kappen, T., (1996), "Identity in a Democratic Security Community: The Case of NATO", in Katzenstein, P. (ed), Promoting National Interest, New York: Columbia University Press, pp. 359-99.

Sijursen, H., (2004), “On the Identity of NATO”, in International Affairs 80, no. 4, pp. 687-703

Steinberg, J., (2002), “An Elective Partnership: Salvaging Transatlantic Relations”, in Survival 45, no. 2, pp. 113-46.

Waltz, K., (1993), “The Emerging Structure of International Politics”, in International Security 18, no. 2 . 


\title{
Between the Economic Agenda and the Need of Strategic Security: East-Central Europe in the Context of the Transatlantic Relation's Disruption
}

\author{
Valentin NAUMESCU
}

\begin{abstract}
The end of the Cold War had opened for the first time after 1945 a window of opportunity for the East-Central European nations to express and fulfill their will of joining the Western system. The paradigm of integration was therefore the success story of the last two decades. Both NATO and EU enlargements to the East (1999-2007) are historic achievements that have been engineered and eventually decided in Washington, London, Berlin or Paris but (unlike the bitter experiences of the $20^{\text {th }}$ century) the direction was in keeping with what people in the region really wanted to happen. This time, strategic decisions on East-Central Europe trigged positive developments in the whole region and got the support of an overwhelming majority. That make seven harder now for East-Central Europeans to understand and agree with the transatlantic divide.
\end{abstract}

Keywords: East-Central Europe, United States, West, transatlantic, crisis

Over the past decade, the vast majority of the analyses, theories and academic reflections with respect to the decline of the Western order ${ }^{l}$ were based on the common idea that we are witnessing a rift of the post-1945 transatlantic relationand also the rise of Asia-Pacific region to the level of global pre-eminence. There are facts, evidences, surveys ${ }^{2}$, political statements as well as policy papers ${ }^{3}$ which prove that America is turning its head towards China, India and all the emerging economies of the Pacific and Indian Ocean area while, for instance, Europe was not even a topic in the recent presidential campaign.

After years of setback, the beginning of Obama's second term at White House is finally bringing a bud of hope and good news as the EU-US High Level Working Group is to announce a draft of an "Atlantic Internal Market". The political message for investors as well as for strategists is however significant: the German

1 See Jeffrey Anderson, G. John Ikenberry, and Thomas Risse (editors), The End of the West? Crisis and Change in the Atlantic Order, Ithaca and London: Cornell University Press, 2008.

2 In 2011, being asked about the priority of the bilateral relation for the U.S. interests, Americans placed Asia on top (51\%) followed by Europe (38\%), while in 2004 the answer to the same question was Europe (54\%) then Asia (29\%).

3 In Strategic Defense Review we learn that "U.S. economic and security interests are inextricably linked to developments in the area extending from the Western Pacific and East Asia into the Indian ocean region and South Asia, creating a mix of evolving challenges and opportunities. Accordingly, while the U.S. military will continue to contribute to security globally, we will of necessity rebalance to the Asia-Pacific region".(Department of Defense, Washington D.C., January $3^{\text {rd }}$, 2012). 
Foreign Minister Guido Westerwelle believes that "a transatlantic agreement holds potential that goes far beyond the strictly economic. This would send a strong political signal about the West's ability to shape our world" ${ }^{4}$ In his January $31^{\text {st }}$ 2013 statement, Westerwelle also thinks that "our coordination and cooperation have grown even closer. Nonetheless, in the face of a pressing need for reform, both Europe and the US have become more inward-looking in their economic and financial policy than is good for us in a rapidly changing world". 5

The past decade was one of a shrinking partnership between America and Europe especially if we look to the Western continental countries. From Paris to Berlin and from Brussels to Rome, an attitude of Anti-Americanism has been insidiously looming, at least at the level of "Europe's political and intellectual elites". ${ }^{6}$ In his provocative book "Uncouth Nation: Why Europe Dislikes America", Andrei Markovits sees a connection between anti-Americanism and growing anti-Semitism in Europe ${ }^{7}$ and consider both of them ideological products of the leftist elites, even more visible recently in Western Europe than in East-Central Europe. In the historical shift of world's "gravity centre" from Atlantic to Pacific ${ }^{8}$, Europe doesn't seem to be prepared for a major role. Somewhat paradoxically, even it is almost absent as a unitary political system in international relations or it only has a weak, hesitating voice in the global decision-making process, any malfunction of the European Union as a whole can seriously damage the world economy.

East-Central European countries take part in this global restructuring process in triple capacity: as a component of the European Union (using the narrow definition of the region, with ten post-communist member states), as allies of the United States within NATO (the group of ten EU member states plus Croatia and Albania) but also with respect to their own national economic interests (in fact, there are 20 countries in total, based on the largest, geographical perspective ${ }^{9}$ of the region) all of them with the concerns and troubles that any independent state has nowadays: dealing with the global recession, looking to emerging markets and searching for

4 Guido Westerwelle, The Time has Come for an Atlantic Internal Market, Atlantic Community, Berlin, January 31, 2013, http://www.atlantic-community.org/-/the-time-has-come-for-anatlantic-internal-market, consulted on February 16, 2013.

5 Ibid.

6 Jeffrey Kopstein, "Anti-Americanism and the Transatlantic Relationship" in Perspectives on Politics, vol. 7, no. 2, 2009, p. 368.

7 Andrei S. Markovits, Uncouth Nation: Why Europe Dislikes America, Princeton: Princeton University Press, 2007, p. 45.

8 See Valentin Naumescu, "From the Atlantic Order to the Pacific Pre-Eminence: A Historical Shift?" in Studia Universitatis Babeş-Bolyai/Studia Europaea, no. 2/2012, Cluj-Napoca: Cluj University Press, 2012, p. 67-82.

9 The geographical "list" does not include the Russian Federation and Turkey (because of their large non-European territories and significantly different profiles) but it counts all states resulted from Yugoslavia's disintegration and three of the former Soviet republics: Belarus, Ukraine and the Republic of Moldova. 
new resources and business opportunities. In the post-1989 process of (re)defining and setting the boundaries of this part of the continent, there were political leaders, theories and authors who suggested that a "resurrection" of the old German concept of Mitteleuropa could be a good approximation of the region with a real potential to be integrated in the West. That was obviously a more cultural and historic approach considering only the territories of Central Europe sharing the common heritage of the Habsburg Empire in the Dualist Era ${ }^{10}$. The debate with regard to other countries was proposed to take place "outside the accepted boundaries of Central Europe: in the Balkans or in the Far Eastern Europe (Belarus, Ukraine, and Moldova)". ${ }^{11}$ The Visegrad Group was thus in the early 1990s a political attempt of recreating cleavages in the region, based on historic and identity reasons. For the present paper, in order to avoid any theoretical confusion, the ECE region will be considered as including the ten former communist countries which already joined the European Union.

The foundation of the Western system (which shaped, regulated and led the world as we know $\mathrm{it}^{12}$ ) has begun recently to weaken, due to economic recession, political disagreements, and also structural deficits affecting the competitiveness of the highly developed countries: ageing of population, public pensions' crisis, more money needed to sustain expensive health-care systems, increasing rates of unemployment, high costs on the labour market, incredible levels of public debts, frustration within the middle class which can eventually ruin the social order that has been in place since World War II, as George Friedman believes. Being a fragile and sophisticated political structure of 27 countries, the European Union seems more exposed to risks of dissolution than the U.S. Comparing America with Europe in terms of possible effects to long economic slowdown, George Friedman believes that "the United States does not face political disintegration from unemployment, whatever the number is. Europe might". ${ }^{13}$

Prestigious scholars from both sides of the Atlantic have focused in the past decade on the issue of the "transatlantic divide" and its multiple consequences: John Ikenberry, Jeffrey Anderson, Thomas Risse, Robert Kagan, Richard Kupchan, Jeffrey Kopstein and Svein Steinmo are just a few authors among those whose works had emphasized a variety of reasons and "nuances" for this split. ${ }^{14}$ From divergent economic visions in relation to markets and limits of government inter-

10 Guido Franzinetti, "Mitteleuropa in East-Central Europe: from Helsinki to EU Accession (1975-2004)" in European Journal of Social Theory, Sage Publications, 2008, p. 229.

11 Ibid., p. 226.

12 Naumescu, op. cit., p. 67.

13 George Friedman, The Crisis of the Middle Class and American Power, Stratfor, January 8, 2013, http:/www.stratfor.com/weekly/crisis-middle-class-and-american-power consulted on January 9, 2013.

14 Jeffrey Kopstein and Sven Steinmo (editors), Growing Apart? America and Europe in the $21^{\text {st }}$ Century, Cambridge and New York: Cambridge University Press, 2008. 
vention to cultural, religious or immigration different approaches, from military power and "think big" perspective to small, local and temporary adaptations or regional approaches, America and Europe had (re)discovered after the end of the Cold War the taste of being different. There are ten years now since Robert Kagan said that Americans are from Mars and Europeans from Venus. In his short but famous book "Of Paradise and Power", he added: "When it comes to setting national priorities, determining threats, defining challenges, and fashioning and implementing foreign and defense policies, the United States and Europe have parted ways". ${ }^{15}$ In simple words, Kagan wanted to point out that America is strong and Europe is weak which is to a certain extent true. But because the year was 2003, the month when the book was published was March (the beginning of the U.S. campaign in Iraq) and the author is a well-known conservative pundit we can easily understand that it was all about the American frustration caused by FrancoGerman reluctance to join the military invasion project. As we know, some of the East-Central European new allies supported the Bush-Blair costly adventure to Bagdad, searching in vain for Saddam's weapons of mass-destruction.

We might disagree with the severity of the diagnosis with regard to Europe's global influence in the coming years but some analytical demarches are to be done in order to understand the directions of a changing world. Having in mind the global or regional transformations following Western political, diplomatic and military crisis of 2003 as well as the international implications of the financial crisis of 2008, we have to admit the end of the American unipolarity ${ }^{16}$ with reference to almost twenty years of U.S. hegemony after the demise of the Soviet Union as well as a certain fading of the European-American strategic alliance. The crisis of the Atlantic system was further deepened in 2009-2010 by divergent ideological visions regarding solutions to economic crisis: European austerity (basically inspired by Germany and France) vs. American bailout, meaning conservative vs. liberal programs.

Since 2003, East-Central Europe has faced the provocation of managing a strategic partnership with the United States in the context of fulfilling the EU economic agenda. While the national economic programmes follow European benchmarks and aim to work properly with the common legislation, the need of strategic security makes the alliance with the United States a political priority. If the above mentioned cleavage between the old Western partners is still valid today, when the Iraqi issue is over (though it has somewhat receded, got a chronic form and switched to a risky lack of interest for the transatlantic alliance), we can only imagine the diplomatic pressures and challenges in 2003, when most of the ECE countries were still candidates, both to NATO and EU, except Poland, the Czech

15 Robert Kagan, Of Paradise and Power: America and Europe in the New World Order, New York: Alfred Knopf, 2003, p. 102.

16 Fareed Zakaria, Post-American World, New York: W. W. Norton \& Company, 2008. 
Republic and Hungary, already in NATO since 1999. To give just an example, Donald Rumsfeld's "division" between Old and New Europe ${ }^{17}$ had prompted a wave of indignation in Germany and France and satisfaction to Warsaw, Prague or Bucharest. "You're thinking of Europe as Germany and France...I don't. That's old Europe. Look at the vast majority of countries in Europe. They are not with France and Germany. They are with the U.S...If you look to the entire NATO Europe today, the gravity centre is shifting to the East" 18 tried to explain his approach the unpopular Secretary of Defense, followed by reactions like these: "Rumsfeld is not exactly a diplomat and it is not very wise to say something like that..." (Volker Ruhe, former German Minister of Defence) or "If you knew what I felt telling Mr. Rumsfeld..." (Roselyn Bachelot, French Minister of Environment). French criticism continued at the highest level with then-President Chirac telling that Romania lost a good opportunity to "shut up" in that affair, while President Băsescu responded in 2005 that Chirac's comment on Romania was an offense to the dignity of the country and Romania will continue to work with Washington and London in main security issues. We also find French Foreign Minister Michel Barnier declaring that President Băsescu did not have a "European reflex". ${ }^{19}$ In Poland, probably the flagship of the "new Europe" and also a devoted Atlanticist ECE country (especially in the 90s and early 2000s) the mainstream politicians, both conservatives and liberals, fully enjoyed Rumsfeld's appraisal of the Polish strategic affiliation to the U.S. foreign and security policy. Pretty similar reactions animated political leaders in Hungary and the Czech Republic, although public rates of approval for Iraqi invasion were quite low in all these countries.

As a symbolic political move, the "Letter of Eight" was signed by Poland, the Czech Republic and Hungary together with UK, Spain, Italy, Denmark and Portugal to ask for European unity in supporting the enforcement of the UN Security Council Resolution $1441 .^{20}$ That was a new step in dividing Europe along the "fault line" created by the issue of military intervention in Iraq, though we can understand from this alignment that new and old Europe were not actually

17 In January 2003, Secretary of Defense Donald Rumsfeld had introduced the political term "new Europe" related to the allies in East Central Europe, as a transparent message of the U.S. frustration caused by German and French lack of support in Iraq. The term stirred a huge controversy in politics and media and eventually was considered as a gaffe of the American high ranking dignitary.

18 BBC News, Outrage at 'Old Europe' Remarks, 23 January, 2003, http://news.bbc.co.uk/2/ hi/europe/2687403.stm, consulted on January 15, 2013.

19 George Parker, Romania hits back at French 'lecturing' (We love America!), in Financial Times, April 19, 2005, http://www.ft.com/intl/cms/s/0/d6a84882-b02f-11d9-ab9800000e2511c8.html\#axzz2LuIwviEk consulted on February 1, 2013.

20 Bezen Balamir Coskun, "Old Europe, New Europe and the European Union's Middle East Policy between Old and New Europe", in Reflecting on Wider Europe and Beyond, Tartu: Central and East European Studies Association, 2006, p. 6. 
working as East-Central vs. Western Europe but rather as Atlanticist European countries vs. France and Germany, while Berlusconi's government was quite hesitating and oscillating between "yes" and "no". Needless to say that former President of France, Jacques Chirac, threatened in 2003 the ECE candidates to EU accession in an "old European" manner: "...this is not a responsible attitude...they have not well brought up...Beyond the fact of being infantile, this attitude is also dangerous. One must not forget that...enlargement will not work if one member state blocks it. These countries were both not well brought up and ignorant of the dangers of aligning themselves too closely to the American position". ${ }^{21}$

The underground legacy of the neo-conservative Bush-Cheney-Rice-Rumsfeld doctrine still erupts in East-Central Europe. Years after the most tensioned period of the so-called "war on terror", a huge scandal with regard to secret CIA prisons in Europe had shaken the political establishment in Poland and Romania, two of the mentioned countries. Unveiled firstly by Washington Post, later developed by Human Rights Watch, Amnesty International and especially the Council of Europe, the sensitive issue was obviously put to rest by national authorities. Nevertheless, the existence of secret American detention centres in Poland between December 2002 and September 2003 (hosting torture procedures against at least 11 prisoners flown by CIA in disguised aircrafts ${ }^{22}$ ) erupted in open and virulent critics against then-Prime Minister Leszek Miller and former President Kwasniewski. Miller later named the journalists who investigated the issue "two useful idiots who invited Al-Qaeda to Poland".

The most recent chapter of the East-Central Europe's strategic alliance with the United States is the project of the American anti-missile shield. Components of this defence system (including sea and land-based batteries of SM-3 interceptors) will be deployed in Poland, Romania and Turkey and will be "operational by 2015, plan known as Phase Adaptive Approach...will defend forward-deployed US troops and allies in the region from Iranian missiles". ${ }^{23}$ The Czech Republic withdrew from the initial project while Polish President Komorowski decided to work on a European Missile Defence system, integrated in the one operated by NATO, after President Obama had announced in 2009 that the U.S. interceptors' deployment in Poland will be "delayed a few years", a stance interpreted in Warsaw as an effect of the Washington-Moscow "reset". Needless to say that Russia is still opposing the project after a few years of sensitive talks, arguing with

21 Coskun, op. cit., p. 7.

22 Stare Kiejkuty, Poland's secret CIA prisons, in The Economist, August 28, 2012, http:// www.economist.com/blogs/easternapproaches/2012/08/poland-and-america, consulted on February 4, 2013.

23 John Reed, Nations Scramble to Erect Missile Shields in Defense News, Springfield (USA): March 22, 2010, http://www.defensenews.com/print/article/20100322/ DEFFEAT06/3220312/Nations-Scramble-Erect-Missile-Shields, consulted on February 2, 2013. 
a decrease of its potential of ballistic deterrence and threatening with political and military counter-measures, "including possible deployment of Iskander missiles in the neighbouring Kaliningrad region" ${ }^{24}$, according to Voice of Russia.

From political to economic dimension and from strategic to military issues, the "post-American world" 25 which Fareed Zakaria had described so accurately in 2008 is moving to a multipolar architecture with several centres of growth and influence that are competing for resources and pre-eminence. Accordingly, global economy and international politics are rebalancing from Atlantic to Pacific, from West to Asia. According to Fareed Zakaria, "by most estimates, China's economy will become the world's largest between 2016 and 2018... Beijing's defense spending is likely to surpass America's by $2025 " .{ }^{26}$ For one reason or another, several American authors like Thomas P. M. Barnett ${ }^{27}$ or Thomas Friedman ${ }^{28}$ deny the possibility of a definitive loss of America's supremacy and also the fact that Asia's ascension will continue with the same spectacular speed in the next one or two decades. Despite the optimistic theories, none of the European governments can ignore the actual trends of the Western economy. In August 2012, for instance, chancellor Merkel and half of the German government had paid an important two-day visit to Beijing, amid the crisis of the sovereign debts in Europe. International media saw in that move a clear sign of looking for economic solutions in China rather than in the West, even with the price of tempering criticism in relation to Beijing's lack of consideration for human rights. ${ }^{29}$ We see therefore a nascent political and economic approach on our continent, still Brussels-oriented but way more open and flexible in drafting scenarios, enlarging in fact the perspective of all member states beyond the frontiers of the European Union. Five or ten years ago, that was almost impossible to imagine, especially for the new EU member states or candidates, whose political dialogue and trade relations were almost in integrum connected with the Euro-Atlantic community.

24 Dmitry Babich, Poland's own ABM System: A fruit of victimization complex, The Voice of Russia, August 6, 2012, http://english.ruvr.ru/2012_08_06/Poland-s-own-ABM-system-afruit-of-victimization-complex/ consulted on February 3, 2013.

25 Zakaria, op. cit., p. 1.

26 Idem, The world has changed, Mr. Romney, The Washington Post, February 01, 2012, http:// articles.washingtonpost.com/2012-02-01/opinions consulted on January 3, 2013.

27 See Thomas P. M. Barnett, Great Powers: America and the World After Bush, New York: G. P. Putnam's Sons, 2009.

28 See Thomas Friedman, That Used to Be Us: How America Fell Behind in the World It Invented and How We Can Come Back, New York: Picador, 2012.

29 Wieland Wagner, The Domesticated Chancellor: Merkel Shies Away from Direct Criticism in China, Spiegel Online International, August 31, 2012, http://www.spiegel.de/international/ world/german-chancellor-merkel-avoids-criticism-during-visit-to-china-a-853185.html consulted on January 17, 2013. 
What is essential to notice within this historic game of global influences and continuous power rebalancing is the fact that East-Central Europe has never been a major actor or at least the maker of its own destiny, but only part of a larger, changing drama. Starting with the Great War, continuing with World War II and the Cold War, later the transatlantic divide over Iraq invasion, the global crisis of 2008 or the shift of the gravity centre to Asia-Pacific, the ECE region was caught in contemporary history in various conflicts, tensions, sometimes hidden agreements or simply in the dynamics of the political and economic relations between Western European powers, the Soviet Union (Russia respectively, after 1991), the United States and nowadays the emerging economies from Asia. All ideological frenzies that Europe faced in the $20^{\text {th }}$ century, from Nazi and fascist regimes to the Bolshevik Revolution and its consequences were actually major events and international movements which flooded in East-Central Europe, from one side or another, not local innovations. Those disastrous political ideas that served as foundations of the authoritarian regimes just came and spread in the region, finding supporters, militants and opportunists. In very simple words, we only had here some busy apprentices, while the masters were in Berlin and Moscow. The political decisions regarding state frontiers, world wars, division of the continent and rival blocs were always adopted out of the region, most frequently without the consultation of the involved East-Central European countries. Between Germany and Russia, basically the entire history of the region until the successful EuroAtlantic integration consisted in a series of "traumas" as well as a polygon of invasions, fragmentation, and conflicting interests. Although Germany had successfully implemented an intensive policy of reconciliation with ECE nations, the German reunification in the early 1990s still left a number of unsolved issues and unhappy memories in the region. "Poland's animosity toward Germany was matched by its hatred of Russia". ${ }^{30}$ The Poles know probably the best of all what East-Central Europe used to be and many of us living today in territories "loaded" with the burden of past tragedies fully understand why Poland and other countries in the region chose to be firm Atlanticists after the fall of the Iron Curtain.

The end of the Cold War had opened for the first time after 1945 a window of opportunity for East-Central European nations to express and fulfill their will of joining the Western system. The paradigm of integration was therefore the success story of the last two decades. Both NATO and EU enlargements to the East (19992007) are historic achievements that have been engineered and eventually decided in Washington, London, Berlin or Paris but (unlike the bitter experiences of the $20^{\text {th }}$ century) the direction was in keeping with what people in the region really wanted to happen. This time, strategic decisions on East-Central Europe trigged

30 Ann L. Phillips, "The politics of reconciliation revisited: Germany and East-Central Europe" in World Affairs, Volume 163, Issue 4, Spring 2001, Washington: Heldref Publications, p. 173. 
positive developments in the whole region and got the support of an overwhelming majority. That make seven harder now for East-Central Europeans to understand and agree with the transatlantic divide.

\section{Bibliography}

Barnett, Thomas P. M., (2009), Great Powers: America and the World After Bush, New York: G. P. Putnam's Sons.

Coskun, Bezen Balamir, (2006), “Old Europe, New Europe and the European Union's Middle East Policy between Old and New Europe”, in Reflecting on Wider Europe and Beyond, Tartu: Central and East European Studies Association.

Department of Defense, (2012), Strategic Defense Review, Washington D.C.

Franzinetti, Guido, (2008), "Mitteleuropa in East-Central Europe: from Helsinki to EU Accession (1975-2004)" in European Journal of Social Theory, New York and London: Sage Publications.

Friedman, Thomas, (2012), That Used to Be Us: How America Fell Behind in the World It Invented and How We Can Come Back, New York: Picador.

Kagan, Robert, (2003), Of Paradise and Power: America and Europe in the New World Order, New York: Alfred Knopf.

Kopstein, Jeffrey, (2009), "Anti-Americanism and the Transatlantic Relationship" in Perspectives on Politics, Cambridge University Press .

Kopstein, Jeffrey, and Steinmo, Sven, (editors), (2008), Growing Apart? America and Europe in the $21^{\text {st }}$ century, Cambridge and New York: Cambridge University Press.

Markovits, Andrei, (2007), Uncouth Nation: Why Europe dislikes America, Princeton: Princeton University Press.

Naumescu, Valentin, (2012), "From the Atlantic Order to the Pacific Pre-Eminence: A Historical Shift?" in Studia Universitatis Babeş-Bolyai/Studia Europaea, Cluj-Napoca: Cluj University Press.

Phillips, Ann L., (2001), “The politics of reconciliation revisited: Germany and East-Central Europe" in World Affairs, Volume 163, Issue 4, Washington: Heldref Publications.

Zakaria, Fareed, (2008), Post-American World, New York: W. W. Norton \& Company.

Web sources:

Babich, Dmitry, (2012), Poland's own ABM System: A fruit of victimization complex, The Voice of Russia, http://english.ruvr.ru/2012_08_06/Poland-s-own-ABM-system-a-fruit-ofvictimization-complex/ consulted on February 3, 2013.

BBC News, (2003), Outrage at 'Old Europe' Remarks,http://news.bbc.co.uk/2/hi/europe/2687403.stm, consulted on January 15, 2013.

Friedman, George, (2013), The Crisis of the Middle Class and American Power, Stratfor, http:// www.stratfor.com/weekly/crisis-middle-class-and-american-power consulted on January 9, 2013.

Kiejkuty, Stare, (2012), Poland's secret CIA prisons, in The Economist, http://www.economist. com/blogs/easternapproaches/2012/08/poland-and-america, consulted on February 4, 2013.

Parker, George, (2005), Romania hits back at French 'lecturing' (We love America!), in Financial Times, http:/www.ft.com/intl/cms/s/0/d6a84882-b02f-11d9-ab98-00000e2511c8. html\#axzz2LuIwviEk consulted on February 1, 2013. 
Reed, John, (2010), Nations Scramble to Erect Missile Shields in Defense News, http://www. defensenews.com/print/article/20100322/DEFFEAT06/3220312/Nations-Scramble-ErectMissile-Shields, consulted on February 2, 2013.

Wagner, Wieland, (2012), The Domesticated Chancellor: Merkel Shies Away from Direct Criticism in China, Spiegel Online International,http:/www.spiegel.de/international/world/ german-chancellor-merkel-avoids-criticism-during-visit-to-china-a-853185.html consulted on January 17, 2013.

Westerwelle, Guido, (2013), The Time has Come for an Atlantic Internal Market, Atlantic Community, http://www.atlantic-community.org/-/the-time-has-come-for-an-atlantic-internal-market, consulted on February 16,2013.

Zakaria, Fareed, The world has changed, Mr. Romney, in The Washington Post, http://articles. washingtonpost.com/2012-02-01/opinions consulted on January 3, 2013. 


\title{
The European Community and Yugoslavia in the Late Cold War Years, 1976-1989
}

\author{
Benedetto ZACCARIA
}

\begin{abstract}
Most existing studies on EC/EU policy towards Yugoslavia only focus on the period after the outbreak of the Yugoslav wars in the 1990s. This essay sheds new light on the relations between the European Community (EC) and Yugoslavia in the preceding fifteen years, which coincided with the renewal of Cold War tensions and the eventual demise of the Communist regimes in East-Central Europe. Drawing on newly declassified sources from several Community and national archives, it shows that, from 1976 to 1989, the EC established firmly based political relations with Yugoslavia, which were primarily determined, and constrained, by the need to prevent the expansion of Soviet influence in the Balkans and to foster détente in Europe.
\end{abstract}

Keywords: European Community, Yugoslavia, Non-alignment, Mediterranean, détente.

\section{Introduction}

As noted in 2004 by the German scholar Rafael Biermann, the large number of studies on EC/EU policy towards Yugoslavia after the outbreak of the 1990s wars contrasts with the silence of the scholarly front on relations between the EC and Yugoslavia before the demise of the latter. ${ }^{1}$ The EC's Yugoslav policy before 1991 has commonly been described as a "policy of neglect", which may be summarised as follows: a) ill-advised support to the Yugoslav federal government, to the detriment of the single federal republics $s^{3} ; b$ ) diplomatic ignorance and unawareness about Yugoslavia's fragile internal situation ${ }^{4}$; c) idea of Yugoslavia as a simple trading partner and labour exporter. ${ }^{5}$ However, analysis of newly declassified

1 Rafael Biermann, "Back to the roots. The European Community and the Dissolution of Yugoslavia - Policies under the Impact of Global Sea-Change" in Journal of European Integration History, No. 1, Vol. 10, 2004, 29. On the scholarly debate on Yugoslavia's collapse, see: Sabrina P. Ramet, Thinking about Yugoslavia. Scholarly Debates about the Yugoslav Breakup and the Wars in Bosnia and Kosovo, New York: Cambridge University Press, 2005.

2 Biermann, "Back to the roots", op. cit., p. 49.

3 Stevan K. Pavlowitch, "Yugoslavia: Why did It Collapse?", in Vassilis K. Fouskas (ed.), The Politics of Conflict, London: Routledge, 2007, pp. 147-154; Jože Pirjevec, Le guerre jugoslave 1991-1999, Torino: Einaudi, 2001, 49; Sonia Lucarelli, Europe and the Breakup of Yugoslavia. A Political Failure in Search of Scholarly Explanation, The Hague: Kluwer Law International, 2000, pp. 15-18.

4 Viktor Meier, Yugoslavia: A History of its demise, London/New York: Routledge, 1999; James Gow, Triumph of the Lack of Will: International Diplomacy and the Yugoslav War, London: C. Hurst \& Co., 2003.

5 Branislav Radeljić, Europe and the Collapse of Yugoslavia. The role of Non-State Actors and European Diplomacy, London/New York: I. B. Tauris, 2012, p. 2. 
sources from several Community and national archives offers new interpretations which challenge the above-mentioned views. ${ }^{6}$ This essay argues that, since 1976, the EC established with Yugoslavia ongoing relations, which were based on sound political rationale. Indeed, the EC's policy towards Yugoslavia was primarily motivated by the need to prevent the expansion of Soviet influence in the Balkans and the Mediterranean. As it will be demonstrated in the following sections, the Cold War framework deeply affected EC's policy towards Yugoslavia until the very end of the bloc-to-bloc confrontation in Europe.

\section{The origins of EC-Yugoslav relations (1968-1975)}

The Cold War framework had shaped relations between the Western bloc and Yugoslavia since the 1948 Tito-Stalin split. Since then, the US, UK and France kept Tito "afloat" by economic and military means to contain Soviet influence in the Balkans, which would have seriously altered the post-World War II balance of power in Europe. ${ }^{8}$ As far as the EC was concerned, the first coordinated policy towards Yugoslavia goes back to 1968. The EC Commission entered into trade negotiations with Belgrade after the Warsaw Pact intervention in Czechoslovakia, which was regarded by EC member states (i.e. the Six) as a potential threat to other Socialist countries, including Yugoslavia. ${ }^{9}$ Negotiations were influenced by the Six's will to demonstrate their support to the latter's economic stability. ${ }^{10}$ The first trade agreement, signed in March 1970, was non-preferential in nature, which suited Yugoslavia's non-aligned status and aimed to fix the imbalance of EC-Yugoslav trade. ${ }^{11}$ The EC took advantage of the new relationship with

6 This chapter draws primarily on archival sources from the following archives: Historical Archives of the European Union (Florence); Historical Archives of the European Commission (Brussels); Archives of the Council of the European Union (Brussels); UK National Archives (Kew); Archives du Ministère des Affaires Étrangères (La Courneuve, Paris). For comments and suggestions on earlier drafts of this essay I am grateful to Angela Romano, Maria Elena Cavallaro and Antonio Varsori.

7 Lorraine M. Lees, Keeping Tito Afloat: The United States, Yugoslavia and the Cold War, University Park, PA: Penn State University Press, 1997.

8 Beatrice Heuser, Western "Containment" Policies in the Cold War. The Yugoslav Case, 1948-1953, London/New York: Routledge, 1989.

9 Historical Archives of the European Union, Florence (HAEU), EM (Edoardo Martino's papers), Box No. 65, Direction Général du Commerce Extérieur, Note à l'attention de M. Le President Rey, Bruxelles, 12 September 1968.

10 French Foreign Ministry Collections, Entretiens et messages, Vol. 5, Compte Rendu des Entretiens de M. Gaja et de M. Puaux, Rome 1er Octobre 1968; HAEU, EM, 65, Négociations entre la CEE et la Yougoslavie - Communication de la Commission, Bruxelles, 31 October 1968.

11 Historical Archives of the European Commission (HAEC), BAC 31978 871, Conseil des Communautés Européennes, Communication à la Presse, 19 March 1970. See also: Panos Tsakaloyannis, "The Politics and Economics of EEC-Yugoslav Relations", in Journal of 
Yugoslavia to relaunch its image within the non-aligned movement (NAM) as an international actor with a well-defined identity. This emerged when the President of the EC Commission, Franco Maria Malfatti, visited Tito in June 1971. During the meeting with the Yugoslav leader, Malfatti stressed the new course of the EC as an "open Community (...) with a deep concern for the problems of her partners" by highlighting the value of the EC's Generalised System of Preferences (GSP) to all developing countries. ${ }^{12}$ Malfatti emphasised the Community's views on the process of détente, which suited Yugoslavia's non-aligned stance well: "We do not want to be a bloc but, although faithful to our friends, we want to overcome the strict and sterile logic of the blocs. (...) The vitality of the Community is fed by the new international environment in which new and flexible structures are replacing the virulence and the total character of the Cold War". ${ }^{13}$ The common goal of a genuinely European détente was emphasised by the cooperation between the EC Nine and the Neutral and non-aligned countries during the Conference on Security and Cooperation in Europe (1972-1975). ${ }^{14}$

However, in the early 1970s, EC-Yugoslav relations were affected by the stagnation of bilateral trade. Yugoslavia's trade deficit deteriorated as an effect of the Community's protectionist measures, urged by several member states to face the economic consequences of the 1973 Oil Shock. Therefore, Yugoslavia was forced to improve its trade with the Soviet bloc countries. Yet, the shift of trade flows from the EC to the Comecon area was viewed with deep concern in Belgrade. On 10 June 1975, the Yugoslav government sent the EC an official Memorandum, in which the Community was urged to facilitate the access of Yugoslav exports, to prevent Belgrade's dependency on the Comecon market. ${ }^{15}$

European Integration, Vol. 5, No.1, 1981, pp. 29-52; Stephen Holt and Ken Stapleton, "Yugoslavia and The European Community 1958-1970", in Journal of Common Market Studies, No. 1, Vol. 10, 1971, pp. 47-57; Patrick F. R. Artisien and Stephen Holt, "Yugoslavia and the EEC in the 1970s", in Journal of Common Market Studies, No. 4, Vol. 18, 1980, pp. 355-369.

12 HAEU, EN (Emile Noel's papers), 1250, Note a l'attention de Monsieur Sigrist, Voyage officiel en Yougoslavie, 30 June 1971; HAEC, BAC 971986 15, Note de dossier, La Yougoslavie, principale bénéficiaire des préférences généralisées de la Communauté, Bruxelles, le 22 janvier 1975.

13 HAEU, EN 1518, Progetto di brindisi del Presidente Malfatti al Pranzo ufficiale offerto dal Ministro Granfil, Belgrado, 25 June 1971.

14 Archives du Ministère des Affaires Étrangères (AMAE), Direction Europe 1971-1976 (DE 71-76), Carton 3759, Note, La Yougoslavie et la CSCE, Paris, le 5 décembre 1974; See Angela Romano, From Détente in Europe to European Détente: How the West Shaped the Helsinki CSCE, Bruxelles: Peter Lang, 2009, pp. 128-131; Jože Pirjevec, "Yugoslavia and the Helsinki Process", in Carla Meneguzzi Rostagni (ed.), The Helsinki Process. A Historical Reappraisal, Padova: CEDAM, 2004, pp. 87-95.

15 HAEC, BAC 481984 662, Note à l'attention de Monsieur E. Noel, Secrétaire Général, Bruxelles, le 16 VI 1975. 


\section{The fall of détente and the relaunch of EC-Yugoslav relations (1976)}

The EC Nine's initial reluctance to meet Yugoslavia's requests was overcome due to the decline of the process of the superpower détente, which had dominated international relations during the first half of the 1970s. ${ }^{16}$ The fall of détente implied the resurgence of Western fears of a Soviet "grand design" on the global stage. ${ }^{17}$ The installation of SS-20 missiles in Warsaw pact territories raised confrontation also in the European continent. ${ }^{18}$ Yugoslavia was in the midst of these tensions. In fact, since the late 1960s, NATO military experts had been discussing potential Soviet plans to regain positions in the Balkans and the Mediterranean basin. ${ }^{19} \mathrm{In}$ the aftermath of the 1973 Arab-Israeli war and the end of Soviet-Egyptian military cooperation, Belgrade was seen as a potential victim of Soviet pressures, because of the strategic position of the Adriatic ports in Croatia and Montenegro. ${ }^{20}$ Yugoslavia's international weakness was also revealed by two other elements. The first was the mounting crisis of Yugoslavia's leadership within the NAM which, since the early 1960s, had represented one of the starkest symbols of Belgrade's international autonomy. In particular, the EC Nine were worried about the emergence within the Movement of a pro-Soviet faction headed by Cuba. ${ }^{21}$ The second element concerned alarming perspectives for the post-Tito era. Most analysis elaborated by Western embassies in Belgrade about the question: "After Tito, what?" depicted disquieting scenarios for Yugoslavia's future..$^{22}$ Although the direct intervention of the USSR in

16 Raymond L. Garthoff, Détente and Confrontation: American-Soviet Relations from Nixon to Reagan, Washington D.C.: Brookings Institutions, 1985, pp. 849-886; Odd Arne Westad (ed.), The Fall of Détente: Soviet-American Relations during the Carter Years, Oslo: Scandinavian University Press, 1997; Leopoldo Nuti (ed.), "The Crisis of Détente in Europe. From Helsinki to Gorbachev, London/New York: Routledge, 2009.

17 Olav Njølstad, "The collapse of superpower détente, 1975-1980", in Melvyn P. Leffler and Odd Arne Westad (eds.), The Cambridge History of the Cold War, Vol. III, Cambridge: Cambridge University Press, 2010, p. 142.

18 Federico Romero, Storia della guerra fredda. L'ultimo conflitto per l'Europa, Torino: Einaudi, 2009, p. 270.

19 The National Archives (TNA), FCO 28/2962, Yugoslav/Soviet Relations, British Embassy Belgrade, 8 September 1976, Confidential; Akten zur Auswärtigen Politik der Bundesrepublik Deutschland 1976, doc. 207 and 221. See also Effie G. H. Pedaliu, “'A Sea of Confusion': The Mediterranean and Détente, 1969-1974”, in Diplomatic History, No. 4, Vol. 33, 2009, pp. $735-750$.

20 TNA, FCO 28/2119, Parliamentary Under-Secretary of State for Defence for the Royal Air Force, 16 August 1972, Confidential.

21 AMAE, DE 76-80, 4845, Note, Réunion ministérielle du Bureau de coordination des pays non-alignés, Paris, le 7 Juin 1978; Note de Synthèse, Visite du Président de la République en Yougoslavie (6-7 Décembre 1976), Paris, le 24 Novembre 1976.

22 TNA, FCO 28/2119, Bilateral discussions with the Italians, 5 October 1972; The outlook for Yugoslavia, 26 October 1972; HAEC, BAC 971986 19, Notes de Synthèse sur le problème 
Yugoslav affairs was considered to be unlikely, Moscow was considered interested in favouring the emergence of pro-Soviet forces in Yugoslavia, able to exploit interrepublican rivalries and weaken the Balkan state's unity and stability. ${ }^{23}$

In the mid-1970s, the EC Nine and their NATO allies were therefore confronted with the following question: how to manage the rise of Soviet pressure towards Yugoslavia? The issue had been initially discussed within the NATO framework, in which national representatives agreed that no discussions on Yugoslavia's situation should be publicly undertaken within the Alliance and that no official statements on that topic should be released to the Western media. ${ }^{24}$ This would indeed lead to confrontation with Moscow and give the USSR a pretext for intervening in turn in Yugoslavia's internal affairs. ${ }^{25}$ As declared by a French diplomat to his EC colleagues in November 1976, the West should respect Yugoslavia's non-aligned position and peculiar social system: "Une attitude contraire aurait des conséquences désastreuses, car elle ferait tomber les barrières qui existent actuellement contre une éventuelle intervention russe, mais ce qui est plus grave, raidirait également l'attitude yougoslave elle-même, en détruisant ce qui constitue leur ciment national et donc en les incitant à basculer dans l'autre camp (...) En outre, une attitude trop 'impérialiste' de la part des pays occidentaux, non seulement ferait peser sur la Yougoslavie le risque de l'intervention russe, mais aussi nous ferait perdre sur le front des pays du tiers-monde un interlocuteur essentiel en tant que tête de pont" ${ }^{26}$ Hence, there was the need to find new ways of strengthening Western links with Belgrade by more discreet and subtle means which should formally respect Yugoslavia's autonomy. One of these was the development of relations between the EC and Yugoslavia. ${ }^{27}$ Thanks to its newly acquired competence in the commercial sphere, the EC Commission could indeed act as a porte-parole of the Nine and establish useful contacts with Belgrade in a "low profile" way. ${ }^{28}$

Yougoslave, Novembre 1976; AMAE, DE 71-76, 3761, Note, La Yougoslavie et l'Union Soviétique, Paris, le 29 mars 1971; AMAE, DE 71-76, 3759, De la politique de l'Europe des Neuf et de la France envers la Yougoslavie, Belgrade, le 12 Décembre 1974; TNA, FCO 28/2967, NATO Political Consultations-Yugoslavia, 10 November 1976.

23 TNA, FCO 28/2967, Yugoslavia: Discussion among permanent representatives to NATO, 19 October 1976.

24 AMAE, DE 71-76, 3760, Commentaires sur la position de l'OTAN vis-à-vis de la Grèce et de la Yougoslavie, Bruxelles, le 2 Octobre 1974; TNA, FCO 28/2965, Call by Yugoslav Ambassador, 20 October 1976; FCO 28/2962, United Kingdom delegation to NATO, Soviet interest in Yugoslav port facilities, 27 August 1976; TNA, FCO 28/2813, Changes in the threat to NATO and options for UK Reactions arising from Warsaw Pact pressures on Yugoslavia, 3 June 1975.

25 TNA, FCO 28/2412, Yugoslavia: Possible future instability, 8 November 1973.

26 HAEC, BAC 971986 19, Notes de Synthèse sur le problème Yougoslave, Novembre 1976.

27 Akten zur Auswärtigen Politik der Bundesrepublik Deutschland 1976, doc. 322.

28 TNA, FCO 28/3166, EEC/Yugoslavia, Note by the Foreign and Commonwealth Office, 26 July 1976; Prime Minister, Yugoslavia and the EEC, 10 June 1976. For the contemporary 
This is why after 1975 the Yugoslav issue was discussed with new impetus within Community Brussels. From May to October 1976, several meetings between EC and Yugoslav officials took place in Brussels to relaunch bilateral relations. ${ }^{29}$ On 12 October 1976, Pierre Duchateau, director of the Directorate General for External Relations (DG I) of the EC Commission, met the Yugoslav ambassador to the EC. Discussion focused on relations between Yugoslavia and the USSR in the perspective of the post-Tito era. According to Duchateau: "Le raisonnement yougoslave est que les Russes n'interviendront [in Yugoslavia] que s'ils sont sûrs de réussir. C'est pourquoi tout le calcul yougoslave est de prendre les assurances à l'Ouest par n'importe quel moyen de façon à dissuader les Russes dans leur souci d'intervenir". ${ }^{30}$ At the end of October 1976, Roland de Kergorlay, deputy director of DG I, went to Belgrade, where he met the Yugoslav representatives in charge of relations with the Community. Once back from his mission, he urged the Nine to give Yugoslavia a formal assurance about EC interest in developing bilateral relations. ${ }^{31}$ De Kergorlay's views were supported by the British Secretary of State, Anthony Crosland, who, after visiting Yugoslavia in early November 1976, emphasised to his EC colleagues the need for the Community to improve relations with Belgrade in order to sustain Yugoslavia's unity, independence, and stability. ${ }^{32}$

A few weeks later, on 15 and 16 November 1976, USSR leader Leonid Brezhnev visited Belgrade. ${ }^{33}$ The visit aroused Western distress, for two main reasons. The first was Moscow's interest in obtaining access to Yugoslavia's Adriatic port facilities. The second concerned Brezhnev's alleged plans to establish closer economic relations with Belgrade in the perspective of the post-Tito era. ${ }^{34}$ In the eyes of French diplomats, for example, these were clear signs of Soviet leaders' long term objective of bringing Yugoslavia back into the bloc. The French highlighted that: "L'avantage que représenterait le contrôle d'un pays dont la position géographique au milieu du rivage septentrional de la Méditerranée est stratégiquement importante, est évident. Les perspectives qu'ouvrirait un tel contrôle pour le renforcement

action of the EC in other Mediterranean scenarios, see the monothematic issue of the Journal of European Integration History, No. 1, Vol. 15, 2009.

29 TNA, FCO 28/3166, Record of meeting between the Minister of State for foreign and Commonwealth Affairs and the Yugoslav Federal Secretary for Foreign Affairs, 5 October 1977.

30 HAEC, BAC 971986 19, Note à l'attention de Monsieur de Kergorlay, Compte rendu d'un déjeuner avec M. Tomasevic le 12 Octobre, 13 Octobre 1976.

31 TNA, FCO 28/2971, Council of Ministers (Foreign Affairs), 18/19 October, Luxembourg, EEC/Yugoslavia; HAEC, BAC 2501980 501, Note de Dossier, Compte rendu des entretiens exploratoires de M. de Kergorlay à Belgrade, Bruxelles, 28 October 1976, Secret.

32 AMAE, DE 76-80, 4835, Note, Politique extérieure de la Yougoslavie, Paris, le 4 octobre 1977.

33 TNA, FCO 28/2962, British Embassy, Belgrade, 29 November 1976.

34 TNA, FCO 28/2962, Brezhnev's Visit to Yugoslavia, 22 November 1976. 
de l'influence soviétique en Europe du Sud-Est et dans le Bassin Méditerranéen ont incité les dirigeants de Moscou à manifester aux Yougoslaves un intérêt plus que 'fraternel' et à leur ouvrir systématiquement de larges possibilités de coopération, en particulier dans le domaine économique". ${ }^{35}$ These concerns, largely shared by the Nine and the US Administration, confirmed the need for the EC to counter Soviet pressures by enlarging the fields of cooperation with Yugoslavia in the years to come. ${ }^{36}$ It was no coincidence that, during the very days of Brezhnev's visit to Belgrade, the EC Council confirmed that the President-in-Office of the EC Council and a European Commissioner would visit Belgrade on 1 and 2 December "to manifest, by their presence, EC's will to reinforce its relations with Yugoslavia". ${ }^{37}$ The EC mission resulted in the signing of a Joint Statement by the Yugoslav Prime Minister, Džemal Bijedic, and the Community representatives. The statement, which defined Yugoslavia as a non-aligned, European and Mediterranean country, referred in warm but general terms to a number of ways in which economic cooperation between Yugoslavia and the EC might be strengthened. ${ }^{38}$

\section{From the Joint Declaration to the Co-operation Agreement (1976-1980)}

After the signing of the 1976 declaration, the question arouse as to how practical follow-up could be given to this general statement of interest. In 1977, the EC Commission embarked on an intensive and accelerated program of work with the Yugoslavs, involving several meetings of three EC-Yugoslav joint committees on agricultural, industrial and economic cooperation..$^{39}$ Their task was to identify the nature and content of a new bilateral agreement. ${ }^{40}$ However, the first round of negotiations (February-April 1978) was not successful. ${ }^{41}$ The political necessity to respect Yugoslavia's non-aligned status forced the two parties to negotiate a non-preferential agreement, since a preferential treatment would have cut across the Yugoslav policy of strict non-alignment. ${ }^{42}$ As declared on 28 March 1977 by a

35 AMAE, DE 76-80, 4835, Note, La politique extérieure yougoslave et les Grands, Paris, le 20 novembre 1976.

36 AMAE, DE 76-80, 4840, Yougoslavie-URSS, Belgrade le 12 Janvier 1977; HAEC, BAC 971986 19, Office of Mr. Soames, Note to Mr. Gundelach, Relations with Yugoslavia, Bruxelles, 17 December 1976; TNA, FCO 28/3166, EEC/Yugoslavia, 8 September 1977.

37 Archives of the Council of the European Union (ACEU), Extrait du: "Communiqué à la Presse" de la 418ème Session du Conseil tenue à Bruxelles, le 16/11/76. Doc. 1261/76 (Presse 141).

38 TNA, FCO 98/118, Council of Ministers (Foreign Affairs), Brussels, 13/14 December 1976.

39 TNA, FCO 28/3166, EEC/Yugoslavia, 8 September 1977.

40 HAEC, BAC 971986 19, Yougoslavie, Note de synthèse pour le Vice-président Haferkamp, Bruxelles, le 28 juin 1977.

41 HAEC, BAC 971986 22, Projet d'exposé de M. le Vice Président Haferkamp au Conseil des Ministres du 25 juillet 1978, Bruxelles, le 24 Juillet 1978.

42 HAEC, BAC 97 1986, Note à l'attention de Monsieur Duchateau, renouvellement de l'Accord de coopération CEE-Yougoslavie. Commentaires sur les propositions yougoslaves, Bruxelles, 
Member of the Yugoslav Federal Executive Council to the newly elected president of the EC Commission, Roy Jenkins: "A preferential agreement would not be acceptable, neither politically nor economically". ${ }^{43}$ However, the non-preferential approach had great limitations, since all non-preferential trade concessions given to Yugoslavia could be automatically extended, according to the GATT rules, to all EC trade partners. This was clearly against the Nine's economic interests.

The impasse was overcome in June 1978, when EC Commissioner for External Relations, Wilhelm Haferkamp, proposed that his Yugoslav counterparts should negotiate a co-operation agreement envisaging a preferential trade system within the framework of EC's "Global Mediterranean Policy" ${ }^{44}$ This proposal would benefit EC-Yugoslav relations for several reasons. First, it would offer a legal background for the reduction of EC barriers to Yugoslavia's exports on the basis of agreements already concluded by the EC with other Mediterranean countries. ${ }^{45}$ Second, it would pave the way for bilateral cooperation in several economic fields. Third, it would represent a step forward towards the policy of EC rapprochement to Yugoslavia in the perspective of the post-Tito era. ${ }^{46}$ Faced with the need to solve the deficit of its trade balance, Belgrade accepted the EC's preferential approach, on condition that it would be publicly presented as sui generis. ${ }^{47}$ The EC Commission was indeed aware of the importance of formally preserving Yugoslavia's nonaligned stance. ${ }^{48}$ As noted by Haferkamp: "Cette politique constitue en effet le pilier de la position extérieure yougoslave. La Communauté doit la respecter". ${ }^{49}$

le 24 IV 1978; TNA 73/239, Yugoslavia and the EEC, 10 June 1976; AMAE, DE 76-80, 4845, Compte rendu de la visite du Secrétaire d'Etat en Yougoslavie, Paris, le 15 Juin 1978.

43 HAEC, BAC 971986 19, Note for the Record, Visit of Mr. Smole, Member of the Yugoslavian Federal Executive Council, on 28 March 1977, 30/3/1977.

44 HAEC, BAC 971986 22, Note de Dossier, Voyage de M. Haferkamp à Belgrade les 22 et 23 juin 1978, Bruxelles, le 26 juin 1978; BAC 97 198624, Note à l'attention de MM. les Membres de la Commission, Bruxelles, le 15 décembre 1978; On EC's Global Mediterranean Policy, see: Elena Calandri, "L'eterna incompiuta: la politica mediterranea tra sviluppo e sicurezza", in Elena Calandri (ed.), Il primato sfuggente. L'Europa e l'intervento per lo sviluppo (19572007), Milano: Franco Angeli, 2009, pp. 53-88, and Guia Migani, "La politique globale méditerranéenne de la CEE, 1970-1972" in Antonio Varsori and Guia Migani (eds.), Europe in the international arena during the 1970s: entering a different world, Bruxelles: Peter Lang, 2011, pp. 193-210.

45 See Guia Migani, "Re-Discovering the Mediterranean. First Tests of Coordination among the Nine", in Elena Calandri, Daniele Caviglia and Antonio Varsori (eds.), Politics and Diplomacy in the Mediterranean and the Middle East, London/New York: I. B. Tauris, 2012, pp. 49-60.

46 TNA, FCO 98/369, Council of Ministers (Foreign Affairs), Luxembourg, 16-17 October 1978.

47 HAEC, BAC 971986 22, Voyage de M. Haferkamp à Belgrade les 22 et 23 juin 1978, Bruxelles, le 26 juin 1978.

48 HAEC, BAC 971986 22, Projet de Speaking Note, Bruxelles, le 7 juillet 1978.

49 HAEC, BAC 971986 22, Projet de communication de la Commission au Conseil, Bruxelles, le 10 juillet 1978 . 
On 17 October 1978, the EC Council discussed Haferkamp's proposal. In the opening session of the meeting, the EC commissioner stated: "Tout le monde sait bien que derrière ce problème économique se profile une évolution politique de notre partenaire yougoslave que la Communauté doit soutenir". ${ }^{50}$

Haferkamp's proposal was endorsed unanimously by the Nine. ${ }^{51}$ The Council approved the new Commission's mandate on 6 February 1979. Negotiations with Yugoslavia officially opened on 2 July $1979 .{ }^{52}$

Several international issues affected EC-Yugoslav negotiations throughout the rest of the year ${ }^{53}$. From the EC's viewpoint, the main issue regarded the Nine's reluctance to grant several Yugoslav products access to the EC market. Belgrade instead was mainly concerned with the evolution of the USSR's negative attitudes towards Yugoslavia, which had emerged during Tito's visit to Moscow in August $1979^{54}$. In particular, Belgrade feared the radicalisation of an ideological confrontation with Moscow and the rise of Kominformist forces within the country, which would be able to exploit inter-republican contrasts and weaken the federation. ${ }^{55}$ The Yugoslavian government was also concerned about the Balkans' geopolitical stability, due to Greece's imminent accession to the EC and growing tensions between Belgrade and Sofia about the Macedonian issue. ${ }^{56}$ Last but not least, Belgrade was worried about the future of the NAM. ${ }^{57}$ Indeed, Vietnam's invasion of Cambodia in January 1979 was portrayed by Belgrade as patent aggression against a non-aligned country, whereas Moscow's close relations with countries like Cuba, Ethiopia, Mozambique and South Yemen were considered as a catastrophe for the autonomy of the Movement. ${ }^{58}$ Yugoslavia's efforts to strengthen its

50 HAEC, BAC 971986 23, Speaking Note à l'attention de Monsieur Haferkamp, Yougoslavie - Conseil des Affaires Etrangères du 17 octobre, Bruxelles, le 13 octobre 1973.

51 TNA, FCO 98/369, Council of Foreign Affairs 17 October: Luxembourg, EEC/Yugoslavia.

52 HAEC, BAC 971986 22, Note de Dossier, Yougoslavie-Mission de M. Duchateau à Belgrade du 14 au 17 juillet 1979, Bruxelles, le 12 juillet 1979.

53 HAEU, EN, 2781, Note de Dossier, Yougoslavie-CEE, Bruxelles, le 14 Mai 1979.

54 TNA, FCO 28/3157, Canadian Delegation to NATO, Tito's visit to the USSR, August 25, 1977; FCO 28/3916, Info Belgrade-Visit to USSR by President Tito, 22 May 1979.

55 TNA, FCO 28/3157, Tito's visit to Moscow, 2 September 1977; Soviet Interest in Yugoslav Republics, 14 July 1977.

56 TNA, FCO 28/3924, Visit by the Minister of State to Belgrade, 9 January 1979; FCO 28/3916, British Embassy, Belgrade, Yugoslav-Soviet Relations, 28 February 1979; FCO 28/3916, British Embassy Belgrade, Yugoslav-Soviet Relations, 24 January 1979.

57 TNA, FCO 28/3924, Record of Talks between the Yugoslav Minister for Foreign Affairs and the Minister of State for Foreign and Commonwealth Affairs at 12.30 pm on 4 January 1979 in Belgrade, undated.

58 TNA, FCO 28/3921, British Embassy Belgrade, China/Vietnam, 28 February 1979; FCO 28/3917, Record of a call by the Yugoslav Ambassador on Mr Bullard in the FCO on Friday 20 April 1979 at 11.30 am; FCO 28/3916, Inappropriate analogies of TASS (Borba, Thursday, November, 1979, p. 7, c. 6). 
role among non-aligned and developing countries (G77) affected negotiations with the Community. ${ }^{59}$ This emerged during the visit to Belgrade on 15 March 1979 by the Director of the DG I, Roy Denman, who noted evident divisions among the Yugoslavs vis-à-vis the ongoing negotiations with the EC: "La nouvelle approche de la Communauté, principalement dans le domaine commercial, ne reçoit pas une adhésion complète du côté yougoslave. L'école non préférentielle et tiers-mondiste qui est celle du Ministère du commerce extérieur semble regagner du terrain (...)". Nevertheless, according to Denman, the EC was obliged to insist on its preferential approach which was the only way to strengthen bilateral relations with Belgrade in a future perspective. ${ }^{60}$

The turning point in EC-Yugoslav negotiations was the Soviet invasion of Afghanistan in December 1979. This event nourished Western suspicious of some "grandiose Soviet scheme" behind Moscow's policy which might include Yugoslavia. ${ }^{61}$ Uncertainty about Soviet plans was flanked by growing divisions within the NAM in condemning Soviet intervention in Afghanistan and by the deterioration of Tito's health in January 1980. Faced with these challenges, the Yugoslav ambassador in Brussels told Jenkins that he hoped to devise a straight procedure of negotiation between the Community and his government at political level..$^{62}$ The request was welcomed by the Nine, who, on 15 January, agreed on the need to sustain Belgrade in this delicate political conjuncture. ${ }^{63}$ The final round of negotiations took place in Belgrade in February 1980. Closer relationship with the Community was weaved with extreme discretion in order to avoid any danger of any USSR countermove. As stressed by the Yugoslav representative to Jenkins, "safeguarding Yugoslav independence without provoking the Soviet Union to precipitate action must now be one of the key issues to be examined by the West". Therefore, as in 1976, EC-Yugoslav relations should not appear as a Western plan to include Yugoslavia in the Western sphere of influence. On 28-29 February 1980, Jenkins went to Belgrade to set the seal on the negotiation for a sui generis Co-operation agreement, which was eventually

59 TNA, FCO 28/3924, Secretary of State, Visits to Yugoslavia and the Lebanon, 12 January 1979.

60 HAEC, BAC 971986 27, Note à l'attention de Monsieur Haferkamp, Bruxelles, le 5 juillet 1979.

61 Tvrtko Jakovina, "Sovjetska intervencija u Afganistanu 1979. i Titova smrt", Historijski zbornik, No. 60, 2007, pp. 295-320; Anatoly Dobrynin, In confidence: Moscow's ambassador to America's six Cold War presidents (1962-1986), New York: Times Books, Random House, 1995, p. 446; Odd Arne Westad, The Global Cold War. Third World Interventions and the Making of Our Times, Cambridge: Cambridge University Press, 2007, pp. 321-26.

62 HAEU, EN, 2782, Note for the Record, The Ambassador of Yugoslavia, Mr. Jevtic, 10 January 1980.

63 Ante Batović and Branko Kasalo, "Britanski i američki izvori o smrti Josipa Broza Tita" in $\check{C} S P$, No. 1, 2012, p. 13. 
signed on 2 April $1980 .{ }^{64}$ Before Jenkins' visit, upon explicit Yugoslav request, the EC Commission urged the President of the European Parliament (EP), Emilio Colombo, to limit parliamentary debates on Yugoslavia ${ }^{65}$ : "Il est clair qu'une négociation si délicate ne doit pas être mise sur la place publique. Différentes interventions de parlementaires européens qui ont par example mentionné comme solution pour la Yougoslavie de s'associer à la Communauté sont particulièrement préoccupantes. Il est clair que si les Yougoslaves apprennent par la presse qu'un tel courant se dégage, ceci risquerai de remettre en cause les efforts qu'ils font actuellement pour conclure. Dans ces conditions je crois que nous avons tout intérêt à éviter un débat en séance plénière à la prochaine session du Parlement européen" ${ }^{66}$ The EC-Yugoslavia Co-operation agreement had indefinite duration and aimed at balancing bilateral trade through a preferential and non-reciprocal system envisaging substantial reductions of custom duties for a number of agricultural and industrial products. It also set up new mechanisms of cooperation in several economic fields, including finance.$^{67} \mathrm{In}$ addition, the two parties established a Co-operation Council which was to become the main forum for bilateral economic negotiations throughout the 1980s ${ }^{68}$ Both the EC and Yugoslavia depicted the Agreement as a milestone for future relations. The Yugoslav representatives stressed the importance of having achieved a "contractual" link with the Community which formally respected Belgrade's autonomy and offered guarantees for Yugoslavia's economic stability.

For the Nine, the agreement symbolised EC's support to Yugoslavia's stability in the perspective of the post-Tito era and, at the same time, preserved its non-aligned stance. ${ }^{69}$ Furthermore, as declared by US President Jimmy Carter to Jenkins in January 1980, the EC's Yugoslav policy enjoyed Washington's full support. Since Haferkamp's initiative in 1978, US traditional criticism to EC's network of preferential agreements in the Mediterranean region had indeed not

64 HAEU, EN, 2782, President, Your Visit to Yugoslavia, 5 March 1980; HAEC, BAC 971986 30, Vice President Haferkamp, President Jenkins' visit to Yugoslavia, 27-29 February 1980, Brussels, 6 March 1980.

65 HAEC, BAC 971986 30, President, Yugoslavia, 4 February 1980.

66 HAEC, BAC 971986 30, Note à l'attention de Monsieur Denman, Résultat des travaux de la Commission des Relations extérieures et de la Commission politique du Parlement européen sur le projet d'accord entre la Yougoslavie et la Communauté, Bruxelles, 31 Janvier 1980.

67 HAEU, EN, 2782, Europe Information, Relations extérieures, Edition provisoire 30/80, La Communauté Européenne et la Yougoslavie. Cooperation included the following fields: finance, industry, energy, scientific and technological research, agriculture, transport, tourism, environment, fisheries, labour.

68 Ibid.

69 HAEC, BAC 971986 28, Éléments de l'intervention de Monsieur Haferkamp, Yougoslavie - Conseil du 18 Mars 1980, Bruxelles, le 14 mars 1980; HAEU, EN, 2783, Note à l'attention du Président, visite du Ministre Andov, 12 Février 1981; Akten zur Auswärtigen Politik der Bundesrepublik Deutschland 1980, doc. 76. 
concerned Yugoslavia, whose economic link to the Community was deemed by Carter to be a Western priority. ${ }^{70}$

\section{The EC and Yugoslavia after Tito's death (1980-1985)}

After Tito's death, on 4 May 1980, the EC continued its traditional "low profile" policy towards Yugoslavia ${ }^{71}$. The Community's support for Belgrade took place in an atmosphere of growing confrontation among the superpowers. ${ }^{72}$ In 1980, Western media and diplomacies frequently discussed the problem of Soviet hostile plans in the Balkans. In keeping with Ronald Reagan's anti-Soviet rhetoric ${ }^{73}$, the New York Times observed that, faced with Soviet expansionism in Afghanistan, Tito "had chosen the worst moment to die", while the Christian Monitor Observer caricaturised Yugoslavia as a helpless widow who received the visit of a sinister Russian whispering: "I'm your long-lost uncle. I'm here to take care of you". ${ }^{74}$ These views, however extreme, corresponded to those of several Western European diplomatic reports, emphasising Moscow's strategic interests in taking advantage of Tito's death to regain control over Yugoslavia. ${ }^{75}$ Accordingly, as stressed on 30 June 1980 by the FRG delegation to NATO: "The West should show its interest in an independent, stable, economically strong Yugoslavia, but should avoid creating the impression that we want to urge Yugoslavia towards a one-sided western orientation or to the abandonment of its social order" $"$.

Therefore, in the early 1980s, the Nine and their NATO allies still regarded Yugoslavia as an hotbed of bipolar confrontation ${ }^{77}$, one of the major Western anxieties being the emergence of a weak Yugoslav leadership unable to cope with

70 HAEC, BAC 971986 30, Note de dossier, Visite du Président Jenkins à Washington Yougoslavie, Bruxelles, le 16 janvier 1980.

71 AMAE, DE 81-85, 5724, Conseil du 14 Septembre Relations avec la Yougoslavie, le 15 Septembre 1981.

72 AMAE, DE 76-80, 4840, Relations soviéto-yougoslaves, Moscou, le 3 Juin 1980; Visite à Belgrade de M. Kouznetsov, 11 Juillet 1980; Controverse avec 1'Union Soviétique, le 17 mars 1980.

73 Beth A. Fischer, "US foreign policy under Reagan and Bush", in Melvyn P. Leffler and Odd Arne Westad (eds.), The Cambridge History of the Cold War, Vol. III, Cambridge: Cambridge University Press, 2010, pp. 269-272.

74 AMAE, DE 76-80, 4841, Ambassade de France aux Etats Unis, Décès du Maréchal Tito, Réactions et commentaires de la presse américaine, Washington, le 8 mai 1980.

75 TNA, FCO 28/4235, UKDEL NATO, Meeting of Permreps on Yugoslavia, 18 January 1980; FCO 28/4240, Yugoslavia: Valedictory despatch, Diplomatic report No. 125/80, 8 April, 1980; FCO 28/3687, NATO experts working groups on Soviet Union and Eastern Europe, 1979.

76 TNA, FCO 28/4240, Dolanc, British Embassy, Belgrade, 15 October 1980.

77 TNA, FCO 46/2322, Record of Anglo/Italian Politico/Military talks held at the Italian Ministry of Foreign Affairs on 28 November 1980, 22 December 1980. 
traditional Soviet pressures. ${ }^{78}$ Concerns about Moscow's plans in the Balkans combined with those regarding Yugoslavia's economic fragility and growing tension between the federal government and the single republics. According to the Nine's economic counsellors in Belgrade, Tito's death had occurred at a moment when it had become increasingly evident that Yugoslavia would suffer the effects of several external and internal factors which, together, would seriously jeopardise the country's economic health: the rising cost of energy at international level, the low productivity of labour, high deficit of the balance of payments, high rate of foreign indebtedness, and inflation. ${ }^{79}$ According to the economic counsellors, the right answer to growing economic disequilibrium was to strengthen the role of the central government and establish a system of uniform economic regulations at federal level. ${ }^{80}$ However, they also noted that: "Avec l'absence de Tito de la scène politique, le dirigeants politiques yougoslaves auront beaucoup plus de difficultés à procéder dans cette voie compte tenu de l'opposition des autorités républicaines. Si la situation actuelle yougoslave apparaît complexe et les perspectives futures du pays assez incertaines, cela est dû en grande partie à l'absence d'une autorité centrale qui ait le pouvoir de coordonner efficacement l'économie (...)" ${ }^{81}$ From their viewpoint, the West should welcome Belgrade's efforts to foster economic centralisation at federal level, even though this would imply the infringement of the single republics' constitutional prerogatives: "Dans le jugement que les diplomaties occidentales donnent sur le processus de démocratisation ultérieure en Yougoslavie, elles ne peuvent pas ne pas tenir compte des risques politiques que la faiblesse d'une autorité économique fédérale (Etat ou parti) entraîne pour un pays comme la Yougoslavie, où se manifestent des tendances structurelles au déséquilibre économique et à la fragmentation du marché". ${ }^{82}$ The imperative of sustaining Yugoslavia's stability, strongly advocated by the Italian Government, drove the EC to strengthen relations with Belgrade within the Co-operation agreement ${ }^{83}$ and conclude a new trade protocol on 15 January 1982 to regulate trade relations between Yugoslavia and Greece, after the latter's accession to the EC in $1981 .{ }^{84}$

78 AMAE, DE 76-80, 4840, Ambassade de France en Yougoslavie, Délégations économiques soviétique, américaine et chinoise à Belgrade, Belgrade, le 9 juin 1980.

79 ACEU, Rapport des Conseillers Commerciaux des Pays de la Communauté Economique Européenne en Yougoslavie (22 ${ }^{\text {ème }}$ rapport), Bruxelles, le 9 avril 1981.

80 ACEU, Rapport des Conseillers Commerciaux des Pays de la Communauté Economique Européenne en Yougoslavie (20 ème rapport), Bruxelles, le 26 février 1979.

81 Ibid.

82 ACEU, Rapport des Conseillers Commerciaux des Pays de la Communauté Economique Européenne en Yougoslavie (21 ${ }^{\text {ème }}$ rapport), Bruxelles, le 25 juillet 1980.

83 ACEU, EN, 2783, Note à l'attention du President, Visite du Ministre ANDOV, Bruxelles, le 12 février 1981.

84 On the policy carried out by the Italian Government to sustain Yugoslavia's stability during the late 1980s, see Antonio Varsori, L'Italia e la fine della guerra fredda. La politica estera 
The political importance of EC-Yugoslav relations was confirmed in April 1983, when the Yugoslav Prime Minister, Milka Planinc, stressed to the president of the EC Commission, Gaston Thorn, Yugoslavia's will to strengthen relations with the Community. ${ }^{85}$

From 1980 to 1985, Belgrade's struggle against anti-unitary political forces in Yugoslavia did not affect bilateral dialogue within the Co-operation Council. Similarly, the Nine and the EC Commission did not release any overtly critical statement on this issue. The EC's policy of non-interference was dictated by the need to avoid any sign of Western interference which could hinder the political status quo in the Balkans. ${ }^{86}$ This emerged in a 1984 note by Albert Maes, a Community representative in Yugoslavia, which regarded Belgrade's protest against the Western media's and EP members' reports on the respect of political freedom in Yugoslavia ${ }^{87}$ : “(...) étant donné d'une part la situation économique et social très difficile que travers le pays et d'autre part le nombre et la nature relativement limités des entorses, une position très en flèche des Dix et notamment une démarche officielle ne pourrait qu'exacerber les autorités yougoslaves et provoquer une remise en cause par certains dirigeants de la politique de rapprochement avec l'Occident qui a été poursuivie au cours des dernières années dans le cadre du maintien d'une neutralité et d'un non alignement formel". ${ }^{88}$ In the early 1980 s, this Community attitude was encouraged by the seemingly good results of economic cooperation with Yugoslavia. In this regard, the Nine's economic counsellors in Belgrade reported that positive results had been obtained in 1984 in some priority economic sectors, which indicated that the Federal authorities had managed to implement a stabilisation policy leading to a surplus of the balance of payments, reduction of the trade deficit and increase of industrial and agricultural production. ${ }^{89}$

dei governi Andreotti (1989-1992), Bologna: Il Mulino, 2013, pp. 121-157; ACEU, Relex III, Aide Mémoire, Relations avec la Yougoslavie, Bruxelles, le 27 mars 1987.

85 ACEU, EN, 2784, Note à l'attention de Monsieur Fielding, Visite de Mme Planinc, Premier Ministre de Yougoslavie-28 Avril, Bruxelles, le 10 mars 1983; HACEU, Co-operation between the European Economic Community and Yugoslavia, Minutes of the first meeting of the EEC-Yugoslavia Co-operation Council (Brussels, Tuesday 24 May 1983), Luxembourg, 18 June 1984.

86 AMAE, DE 81-85, 5724, La Yougoslavie et les Groupements économiques régionaux, le 20 septembre 1985.

87 AMAE, DE 81-85, 5724, Présidence Française - Visite à Strasbourg d'une délégation Parlementaire Yougoslave le 18 janvier 1984, le 15 décembre 1983.

88 HAEU, EN, 2784, Note à l'attention de Monsieur L. Fielding, Directeur Général, Belgrade, le 3 septembre 1984.

89 ACEU, Rapport des Conseillers Commerciaux des Pays de la Communauté Economique Européenne en Yougoslavie (25ème rapport), Bruxelles, le 18 juillet 1985; HACEU, Relex III, Aide Mémoire, Relations avec la Yougoslavie, Bruxelles, le 27 mars 1987. 
The EC's traditional views on Moscow's geopolitical interests in the Balkans were still present within Community Brussels even after Mikhail Gorbachev's election to the head of the CPSU in 1985. The joint reports of the Nine's economic counsellors in Belgrade on Yugoslavia show that, from the Community's viewpoint, no major political changes were taking place within the Soviet bloc as a result of Gorbachev's "new thinking" ${ }^{90}$ Despite the encouraging resumption of the superpowers' dialogue after Reagan's re-election to the US Presidency in $1984^{91}$, the seemingly stable Cold War framework in Europe persuaded the EC and Yugoslavia not to change the pattern of their traditional relationship. ${ }^{92}$ Between 1985 and 1988, trade and financial agreements were signed to balance trade in the aftermath of the EC enlargement to Spain and Portugal, and to develop projects concerning infrastructures of common interest, in particular the trans-Yugoslavia motorway. ${ }^{93}$ The visit made by the President of the EC Commission, Jacques Delors, to Yugoslavia in July 1987 and the subsequent Co-operation Council's decision of 3 November 1987 to enlarge the provisions of the 1980 Agreement confirmed the EC's interest in developing relations with Belgrade. ${ }^{94}$ It was in fact the opinion of the General Secretariat of the EC Council that economic cooperation in trade and finance with Belgrade could become part of a long-term pattern. ${ }^{95}$ Bilateral relations, however, were perforce limited to a number of specifically economic areas, namely trade, finance, and technical, scientific and agricultural cooperation. ${ }^{96}$ Enhanced forms of cooperation between the two parties, such as an Association

90 See Archie Brown "The Gorbachev revolution and the end of the Cold War", in Melvyn P. Leffler and Odd Arne Westad (eds.), The Cambridge History of the Cold War, Vol. III, Cambridge: Cambridge University Press, 2010, p. 253.

91 David Reynolds, Summits: Six Meetings That Shaped The Twentieth Century, New York: Basic Books, 2007, pp. 343-400.

92 On EC's perception of Soviet bloc's apparent stability during the first years of Gorbachev's leadership see: Jacques Delors, L'Unité d'un homme: entretiens avec Dominique Wolton, Paris: Editions Odile Jacob, 1994, p. 255. On Gorbachev's "new thinking” towards EastCentral Europe, see Jonathan Haslam, "1989: history is rewritten", in Silvio Pons and Federico Romero (eds.), Reinterpreting the End of the Cold War. Issues, interpretations, periodisation, London/New York: Frank Cass, 2005, p. 175.

93 ACEU, General Secretariat of the Council, Note for Members of the Working Party on the Mediterranean (Yugoslavia), Subject: Annotated draft agenda for the sixth meeting of the EEC-Yugoslavia Co-operation Committee, Bruxelles, 30 October 1987.

94 ACEU, COM(87) 508 final, Recommandation de Décision du Conseil relative à la conclusion d'un Protocole additionnel à l'Accord de Coopération entre la Communauté économique européenne et la République Socialiste Fédérative de Yougoslavie établissant un nouveau régime commercial, Bruxelles, le 16 octobre 1987.

95 ACEU, General Secretariat of the Council, Note for Members of the Working Party on the Mediterranean (Yugoslavia), doc. cit., 30 October 1987.

96 Ibid. 
agreement (envisaging political links and common institutions) were never openly discussed. This was due to the rigid bipolar order which still conditioned bilateral relations: as reiterated by Community and Yugoslav representatives during all the meetings of the Co-operation Council from 1980 to 1988, Yugoslavia's internal autonomy and non-aligned stance were the major preconditions for geopolitical stability and international détente in Europe, the Balkans and the Mediterranean basin..$^{97}$ During the late 1980s, faced with growing centripetal trends in the country, the EC's imperative of sustaining Yugoslavia's international position was consequently translated into open support to the Yugoslav federal government's efforts to preserve the country's unity and stability. In addition, the simultaneous growth of nationalist rhetoric in Yugoslavia was not considered unusual in Communist states in those years. As noted by the historian Tony Judt: "In the era of Gorbachev, with the ideological legitimacy of Communism and its ruling party waning fast, patriotism offered an alternative way of securing a hold on power" ${ }^{98}$

EC-Yugoslav relations drastically changed only in the aftermath of the geopolitical earthquake which caused the rapid collapse of all East-Central European communist regimes from mid-November 1989 to the end of that year. ${ }^{99}$ Archival documents on EC-Yugoslav meetings in 1989 show that the European turmoil that took place in autumn 1989 was in fact an "unexpected revolution" coming as a "breathtaking surprise" to both Community and Yugoslav representatives. ${ }^{100}$ Indeed, until early November 1989, relations between the two parties had followed the traditional path described above. Even Italian attempts to strengthen relations with Belgrade within the broader framework of the "Iniziativa Adriatica" were mainly based on an economically oriented cooperation. ${ }^{101}$ This traditional

97 ACEU, Co-operation between the European Economic Community and Yugoslavia, Projet de Procès-verbal de la sixième session du Conseil de Coopération CEE-Yougoslavie Niveau ministériel (Bruxelles, le 14 décembre 1987), Bruxelles, le 17 octobre 1988.

98 Tony Judt, Postwar. A History of Europe Since 1945, New York: Penguin, 2005, p. 671.

99 See Francesco Privitera, "The Relationship Between the Dismemberment of Yugoslavia and European Integration”, in Jeffrey S. Morton, R. Craig Nation, Paul Forage and Stefano Bianchini (eds.), Reflections on the Balkan Wars. Ten Years after the Break Up of Yugoslavia, New York: Palgrave Macmillan, 2004, pp. 35-54.

100ACEU, General Secretariat of the Council, Note for Members of the Mediterranean Working Party (Yugoslavia), Annotated draft agenda for the eight meeting of the EECYugoslavia Co-operation Committee, MED 40/89 YU, Brussels, 8 November 1989; ACEU, Co-operation between the European Economic Community and Yugoslavia, Draft Minutes of the eight meeting of the EEC-Yugoslavia Co-operation Council at ministerial level (27 November 1989), Brussels, 26 April 1990. On the 1989 events defined as a "unexpected revolution", see John W. Young, "Western Europe and the end of the Cold War, 1979-1989", in Melvyn P. Leffler and Odd Arne Westad (eds.), The Cambridge History of the Cold War, Vol. III, Cambridge: Cambridge University Press, 2010, p. 306.

101 See Antonio Varsori, "Italy and the end of communism in Albania, 1989-1991", in Cold War History, No. 4, Vol. 12, 2012, p. 621. 
approach was radically shaken by the first anti-Communist revolutions in Poland, Hungary and the German Democratic Republic and, above all, by Gorbachev's refusal to use forces to maintain Communist regimes in East-Central Europe. ${ }^{102}$ The impending fall of the Soviet bloc made it clear that the Cold War framework which had constrained EC-Yugoslav relations so greatly since the mid-1970s was on the verge of collapse. This meant that a different road was open to Yugoslavia, i.e. the possibility of innovative political relations with the EC and, at the same time, the formal abandonment of its traditional non-aligned stance. This emerged clearly during the Co-operation Council's meeting of 27 November 1989 when, in sharp contrast with the past, neither Yugoslav nor EC representatives mentioned Yugoslavia's non-aligned stance as a factor of stability and détente in Europe and the Mediterranean. Conversely, faced with the crisis of legitimacy affecting all East-Central European Communist regimes, the Yugoslav Federal Secretary for Foreign Affairs, Budimir Loncar, declared to his Community counterparts that Yugoslavia was "more than ever in need of understanding and support from Europe and of new forms of co-operation with it". ${ }^{103}$ The Yugoslav representative noted that, when the first co-operation agreement had been signed in 1980, it had not been possible for either party to institutionalise relations to a greater degree. However, the "exceptional events taking place in Europe which might well herald the most important chapter in the history of Europe"104, urged both parties to place the question of future EC-Yugoslav relations on the agenda. Accordingly, the Yugoslav representative openly asked his Community counterparts, Presidentin-Office of the EC Council Roland Dumas and Commissioner Albert Matutes, to "improve the institutional framework of the relations between the two parties with the aim to place them at the level of Association with the European Community (...)" ${ }^{105}$ Yugoslavia's open request for future association with the EC in November 1989 clearly indicated that the end of the Cold War had definitively closed an era in EC-Yugoslav relations and opened the way to brand-new cooperation instruments to cope with the problem of Yugoslavia's stability. When in January 1990 inter-republican struggles had already reached a critical level, relations between the EC and Yugoslavia had to be re-thought from scratch by both parties.

102 Vojtech Mastny, "Did Gorbachev Liberate Eastern Europe?”, in Olav Njølstad (ed.), The last decade of the Cold War. From Conflict Escalation to Conflict Transformation, London/ New York: Frank Cass, 2005, pp. 336-354; Vladislav M. Zubok, A failed Empire. The Soviet Union in the Cold War from Stalin to Gorbachev, Chapel Hill: The University of North Carolina Press, 2007, pp. 321-335.

103 ACEU, Co-operation between the European Economic Community and Yugoslavia, Draft Minutes of the eight meeting of the EEC-Yugoslavia Co-operation Council at ministerial level (27 November 1989), Brussels, 26 April 1990.

104 Ibid.

105 Ibid. 


\section{Conclusions}

Analysis of EC-Yugoslav relations from 1976 to 1989 shows that the view according to which the EC carried out a "policy of neglect" towards Yugoslavia should be reconsidered. First, low-profile and unconditioned support to the Yugoslav federal government was, from the EC's viewpoint, the only viable road to preserve Yugoslavia's stability and independence, which had become a Community priority in the aftermath of the fall of détente in the mid-1970s. Second, Community and national archival sources show that the EC and its member states had clear knowledge of the political and economic issues affecting the Yugoslav federation since the early 1970s. It was the very awareness of Yugoslavia's internal fragility which forced the EC to develop intense relations with Belgrade during the late Cold War years. Third, Yugoslavia was more than a mere trading partner and labour exporter for the Community. Conversely, meaningful political rationales drove relations between the EC and Yugoslavia, which both shared the goal of maintaining stability and détente in Europe, the Balkans and the Mediterranean.

\section{Bibliography}

Books

Delors, Jacques, (1994), L'Unité d'un homme: entretiens avec Dominique Wolton, Paris: Editions Odile Jacob.

Dobrynin, Anatoly, (1995), In confidence: Moscow's ambassador to America's six Cold War presidents (1962-1986), New York: Times Books, Random House.

Garthoff, Raymond L., (1985), Détente and Confrontation: American-Soviet Relations from Nixon to Reagan, Washington D.C.: Brookings Institutions.

Gow, James, (2003), Triumph of the Lack of Will: International Diplomacy and the Yugoslav War, London: C. Hurst \& Co.

Heuser, Beatrice, (1989), Western “Containment” Policies in the Cold War. The Yugoslav Case, 1948-1953, London/New York: Routledge.

Judt, Tony, (2005), Postwar. A History of Europe Since 1945, New York: Penguin.

Lees, Lorraine M., (1997), Keeping Tito Afloat: The United States, Yugoslavia and the Cold War, University Park, PA: Penn State University Press.

Lucarelli, Sonia, (2000), Europe and the Breakup of Yugoslavia. A Political Failure in Search of Scholarly Explanation, The Hague: Kluwer Law International.

Meier, Viktor, (1999), Yugoslavia: A History of its demise, London and New York: Routledge.

Nuti, Leopoldo (ed.), (2009), The Crisis of Détente in Europe. From Helsinki to Gorbachev, London/New York: Routledge.

Pirjevec, Jože, (2001), Le guerre jugoslave 1991-1999, Torino: Einaudi.

Radeljić, Branislav, (2012), Europe and the Collapse of Yugoslavia. The role of Non-State Actors and European Diplomacy, London-New York: I. B. Tauris.

Ramet, Sabrina P., (2005), Thinking about Yugoslavia. Scholarly Debates about the Yugoslav Breakup and the Wars in Bosnia and Kosovo, New York: Cambridge University Press.

Reynolds, David, (2007), Summits: Six Meetings That Shaped The Twentieth Century, New York: Basic Books. 
Romano, Angela, (2009), From Détente in Europe to European Détente: How the West Shaped the Helsinki CSCE, Bruxelles: Peter Lang.

Romero, Federico, (2009), Storia della guerra fredda. L'ultimo conflitto per l'Europa, Torino: Einaudi.

Westad, Odd Arne (ed.), (1997), The Fall of Détente: Soviet-American Relations during the Carter Years, Oslo: Scandinavian University Press.

Varsori, Antonio, (2013), L'Italia e la fine della guerra fredda. La politica estera dei governi Andreotti (1989-1992), Bologna: Il Mulino.

Westad, Odd Arne, (2007), The Global Cold War. Third World Interventions and the Making of Our Times, Cambridge: Cambridge University Press.

Zubok, Vladislav M., (2007), A failed Empire. The Soviet Union in the Cold War from Stalin to Gorbachev, Chapel Hill: The University of North Carolina Press.

\section{Studies within a volume}

Brown, Archie, (2010), "The Gorbachev revolution and the end of the Cold War", in Leffler, Melvyn P. and Westad, Odd Arne (eds.), The Cambridge History of the Cold War, Vol. III, Cambridge: Cambridge University Press, 244-266.

Calandri, Elena, (2009), "L'eterna incompiuta: la politica mediterranea tra sviluppo e sicurezza", in Calandri, Elena (ed.), Il primato sfuggente. L'Europa e l'intervento per lo sviluppo (19572007), Milano: Franco Angeli, 53-88.

Fischer, Beth A., (2010), "US foreign policy under Reagan and Bush", in Leffler, Melvyn P. and Westad, Odd Arne (eds.), The Cambridge History of the Cold War, Vol. III, Cambridge: Cambridge University Press, 267-288.

Haslam, Jonathan, (2005), "1989: history is rewritten”, in Pons, Silvio and Romero, Federico (eds.), Reinterpreting the End of the Cold War. Issues, interpretations, periodisation, London/ New York: Frank Cass, 165-178.

Mastny, Vojtech, (2005), "Did Gorbachev Liberate Eastern Europe?", in Njølstad, Olav (ed.), The last decade of the Cold War. From Conflict Escalation to Conflict Transformation, London/New York: Frank Cass, 336-354.

Migani, Guia, (2011), "La politique globale méditerranéenne de la CEE, 1970-1972” in Varsori, Antonio and Migani, Guia (eds.), Europe in the international arena during the 1970s: entering a different world, Bruxelles: Peter Lang, 193-210.

Migani, Guia, (2012), "Re-Discovering the Mediterranean. First Tests of Coordination among the Nine", in Calandri, Elena, Caviglia, Daniele and Varsori, Antonio (eds.), Politics and Diplomacy in the Mediterranean and the Middle East, London/New York: I. B. Tauris, 49-60.

Pavlowitch, Stevan K., (2007), "Yugoslavia: Why did It Collapse?", in Fouskas, Vassilis K. (ed.), The Politics of Conflict, London: Routledge, 147-154.

Pirjevec, Jože, (2004), "Yugoslavia and the Helsinki Process", in Meneguzzi Rostagni, Carla (ed.), The Helsinki Process. A Historical Reappraisal, Padova: CEDAM, 87-95.

Privitera, Francesco, (2004), "The Relationship Between the Dismemberment of Yugoslavia and European Integration", in Morton, Jeffrey S., Nation, R. Craig, Forage, Paul and Bianchini, Stefano (eds.), Reflections on the Balkan Wars. Ten Years after the Break Up of Yugoslavia, New York: Palgrave Macmillan, 35-54.

Njølstad, Olav, (2010), "The collapse of superpower détente, 1975-1980”, in Leffler, Melvyn P. and Westad, Odd Arne (eds.), The Cambridge History of the Cold War, Vol. III, Cambridge: Cambridge University Press, 135-155. 
Young, John W., (2010), "Western Europe and the end of the Cold War, 1979-1989", in Leffler, Melvyn P. and Westad, Odd Arne (eds.), The Cambridge History of the Cold War, Vol. III, Cambridge: Cambridge University Press, 289-310.

Studies in periodicals

Artisien, Patrick F. R. and Holt, Stephen, (1980), "Yugoslavia and the EEC in the 1970s", in Journal of Common Market Studies, N. 4, Vol. 18, 355-369.

Batović, Ante and Kasalo, Branko, (2012), "Britanski i američki izvori o smrti Josipa Broza Tita" in ČSP, N. 1, 7-22.

Biermann, Rafael, (2004), "Back to the roots. The European Community and the Dissolution of Yugoslavia - Policies under the Impact of Global Sea-Change" in Journal of European Integration History, No. 1, Vol. 10, 29.

Holt, Stephen and Stapleton, Ken, (1971), "Yugoslavia and The European Community 19581970", in Journal of Common Market Studies, No. 1, 47-57.

Jakovina, Tvrtko, (2007), "Sovjetska intervencija u Afganistanu 1979. i Titova smrt", Historijski zbornik, No. 60, 295-320.

Pedaliu, Effie G. H., (2009), “'A Sea of Confusion': The Mediterranean and Détente, 19691974”, Diplomatic History, No. 4, Vol. 33, 735-750.

Tsakaloyannis, Panos, (1981), "The Politics and Economics of EEC-Yugoslav Relations", in Journal of European Integration, No.1, Vol. 5, 29-52.

Varsori, Antonio, (2012), "Italy and the end of Communism in Albania", in Cold War History, No.4, Vol. 12, 615-635. 


\title{
Serbia's EU Future: Concerns and Perspectives
}

\author{
Branislav RADELJIĆ
}

\begin{abstract}
Since the early 1990s European involvement in the former-Yugoslav space has shifted from protecting and separating other republics and peoples from Serbia and the Serbs to supporting the new post-Milošević Serbian elites with the processes of democratization and Europeanization. This paper examines a number of challenges surrounding Serbia's European Union future. Accordingly, while noting that the Brussels administration has continuously confirmed its readiness to provide advice and assistance, the discussion suggests that both the stagnation and progress are likely to rest exclusively with the Serbs themselves. Keywords: European Union, Serbia, Kosovo, Russia.
\end{abstract}

The first major European intervention in Yugoslavia resulted in the collapse of the Yugoslav federation. The decision to recognize Slovenia and, more importantly, Croatia, meant that the war was then transferred to Bosnia and Herzegovina. Once the Milošević regime had realized that its intention of a Serbia-dominated Yugoslavia, serving the interests of the Serbs living outside the republic of Serbia, was not going to materialize, it pursued the policy of ethnic cleansing that resulted in the Srebrenica Genocide in July 1995. Still, the growing international criticism and isolation did not prevent the Serbian authorities from testing their power elsewhere: deeper ethnic antagonisms led to the outbreak of conflict in Kosovo in 1998, culminating in January 1999 when Serbian military forces committed a crime against humanity killing forty-five civilians in Račak. According to Joschka Fischer, the then German Foreign Minister, acting politely with Belgrade officials would lead only to more mass graves, so he stated that the use of force should be taken into consideration: "I am not a friend of using force, but sometimes it is a necessary means of last resort. So I am ready to use it if there is no other way. If people are being massacred, you cannot mutter about having no mandate. You must act". ${ }^{1}$ Following the termination of the NATO-led bombing campaign against Serbia in June 1999 (or the second major European intervention in the post-Yugoslav region), the West looked forward to the removal of Slobodan Milošević. In this paper, I examine a number of challenges capable of affecting Serbia's European Union (EU) future. Accordingly, while noting that the Brussels administration has continuously confirmed its readiness to provide advice and assistance, the discussion suggests that both the stagnation and progress are likely to rest exclusively with the Serbs themselves.

1 Fisher cited in Ivo H. Daalder and Michael E. O'Hanlon, Winning Ugly: NATO's War To Save Kosovo, Washington, DC: The Brookings Institution, 2000, p. 75. 


\section{Post-Milošević Dynamics}

The overthrow of Milošević in October 2000 provided the Serbs with an opportunity to change their well-established image abroad as a vampire nation to that of one portraying them as regular human beings. Shortly after, the European Union decided to reward the newly elected anti-Milošević Democratic Opposition of Serbia by lifting its economic sanctions, securing reconstruction assistance, providing aid packages and signing trade agreements. The new Prime Minister Zoran Djindjić (whose main success was, in fact, the arrest and transmittal of Milošević to the International Criminal Tribunal for the former Yugoslavia (ICTY) in The Hague) kept saying that there was no time to waste. In his view, Kosovo was de facto independent and Serbia had to move on with the processes of democratization and Europeanization. However, on the other hand, the new President Vojislav Koštunica, who was also welcomed by the European officials as a symbol of new democratic orientation, did not fully agree with Djindjić's approach. For example, he rejected the urgency of the Kosovo status claiming that it was better to "wait for another five years, because the later this issue is addressed the better it will be for [the Serbs]". ${ }^{2}$ In addition, the delayed cooperation with the Hague tribunal was a confirmation of Koštunica's reluctance to break up with the Milošević era: on various occasions, he was accusing the tribunal of its undue interference and assault on the dignity of his state. ${ }^{3}$ As one survey covering the period 2001-2005 showed, Koštunica's rhetoric managed to influence the Serbian public to the extent that two thirds of the general public opposed any cooperation with the Hague tribunal. ${ }^{4}$

The assassination of Prime Minister Djindjić in 2003 represented an enormous loss for Serbia: the processes of democratization and Europeanization were immediately interrupted. Soon after the assassination and the replacement government headed by Zoran Živković, Koštunica became the new Prime Minister. As summarized elsewhere, "[t]he assassination stopped Serbian reforms in their tracks. It compromised further cooperation with the ICTY as the only element in the Serbian government inclined to cooperate was removed, and Koštunica went back to his entrenched position of noncompliance". ${ }^{5}$ The European officials were naïve enough to believe that he was ready to make a big step towards European integration, shifting from introverted post-communist conservatism to a modern,

2 UNMIK, "Djindjić Wants Status Resolved Now, Koštunica in Five Years", 2003 [http://www.unmikonline.org/press/2003/mon/jan/lmm200103.htm\#4], 12 October 2011.

3 Jacques Rupnik, "The Demise of Balkan Nationalisms? A Skeptical View”, in Judy Batt (ed.), The Western Balkans: Moving on, Paris: Institute for Security Studies, 2004, p. 105.

4 Beogradski centar za ljudska prava, "Javno mnenje u Srbiji: Stavovi prema pravosudju za ratne zločine i Haškom tribunalu”, Beograd: Beogradski centar za ljudska prava, 2005.

5 Jelena Subotić, "Explaining Difficult States: The Problems of Europeanization in Serbia" in East European Politics and Societies, Vol. 24, No. 4, 2010, pp. 595-616: 601. 
democratic, and open society. Indeed, they continued to express their support for Serbia leading to the opening of negotiations for the Stabilization and Association Agreement with the EU in October 2005. However, given an obvious lack of cooperation with the Hague tribunal, the negotiations were suspended in May 2006 and reassumed only after the victory of the President Boris Tadić's Democratic Party, in the 2007 Serbian parliamentary elections.

The talks about the Kosovo status and various speculations about the regional implications of Kosovo's policy of independence accentuated the differences between the dominant political parties in Serbia. For example, Prime Minister Koštunica and his Democratic Party of Serbia insisted that "the existence of Kosovo and Metohija as part of Serbia and the existence of the Serbian people in Kosovo [were] the key objectives of Serbia's involvement in the political talks for the future status of that region" and any decision on Kosovo "should be made within Serbia, in the framework of the large autonomy of Kosovo and Metohija within Serbia". ${ }^{6}$ As one author observed, Koštunica was an ardent nationalist with a deep-seated suspicion of the West and a habit of postponing difficult decisions: he preferred being remembered as the patriot who succeeded Milošević than the president who gave away Kosovo. ${ }^{7}$

At the same time, President Boris Tadić and his Democratic Party reaffirmed that he would not sign any document on Kosovo's independence. The 2006 Serbian constitution presented the province of Kosovo as a constituent part of Serbia and he accordingly continued to insist on new rounds of negotiations, thinking that they could change the West's already established position. What such an approach has done so far is to manipulate both the Serbs living in Kosovo and the Serbs living elsewhere to believe that Kosovo will continue to belong to Serbia. The main difference between the former Prime Minister Djindjić and his successors has been that while Djindjić was capable of reading the EU's messages betweenthe-lines and thus understanding that the preservation of Kosovo within Serbian borders and Serbia's EU future could never go hand in hand, his successors have tried to convince the public that such an arrangement is actually possible. The majority of successors, often too much concerned with preserving their own political careers, tend to ignore the fact that it is not the European Union that needs Serbia, but rather the other way around. Accordingly, the compliance with the EU's policy of conditionality has often been assessed as insufficient. However, based on the number of official statements, it is not the Europeans who lack a clearer vision with regard to the future of Serbia, but the Serbs themselves. This is primarily due to the diametrically opposing views among domestic political

6 Regnum, "Vienna Talks: Albanians Don't Hurry to Recognize the Rights of Serbs in Kosovo", 2006 [http://www.regnum.ru/ English/623129.html], 15 October 2011.

7 Tom Hundley, "Wary Serbs Watch Deadlocked Talks on Kosovo's Independence”, Chicago Tribune, 10 June 2006, p. 1. 
elites. For example, Vojislav Šešelj's neo-fascist Serbian Radical Party and, to a lesser extent, Vojislav Koštunica's Democratic Party of Serbia and numerous former members of Milošević's Socialist Party of Serbia have often encouraged antiEuropean feelings. In their view, the process or Europeanization and eventual EU membership is not something Serbia should pursue. In order to justify such a standpoint, their statements are often inspired by European (and American, of course) involvement in the Yugoslav state crisis of the early 1990s and, more importantly, in the 1999 NATO bombing of Serbia. On the other hand, Tadić's Democratic Party and Tomislav Nikolić's Serbian Progressive Party have generally been proEuropean, although some of their members' statements and actions have occasionally undermined their apparent commitment to the process of Europeanization. Finally, the Liberal Democratic Party, led by Čedomir Jovanović, Prime Minister Djindjić'smain advisor, has continued to promote some of Djindjić's ideas and thus the necessary integration in the EU, but given its small size (like many other political parties in Serbia), it tends to remain rather marginal. Given that the elites do not share the same or rather similar standpoint with regard to the Serbia's European perspective, the process of Europeanization is further complicated. One study, while pointing out that in transitional systems "consensus about basic social, political, and economic priorities and values is often absent", sees public opinion surveys as a useful way to discover what society really thinks and what its main concerns are. ${ }^{8}$ For example, back in 2004, the Serbian Government Office for European Union Integration conducted a study in order to show how the Serbian public approached Europe and accordingly, the respondents were divided in four categories. These categories comprise of the Euro-enthusiasts, who say that Serbia must make every effort in order to join the EU, Euro-realists, who perceive the integration in the EU as a necessity, Euro-skeptics, who question the intentions of Europe and the West in general, and the Euro-phobes, who fear the dominance of Western Europe and thus strongly oppose integration. ${ }^{9}$ Based on the results, Eurorealists were the dominant category ( $35 \%$ of respondents) while Euro-phobes were the least popular (12\% of respondents). Later on, following the Kosovo's declaration of independence in 2008, there were many opinions saying that European policy towards the region is a double standard policy and "[i]f there had been a credible alternative to the EU, the majority of Serbian voters would have probably opposed Serbian EU accession". ${ }^{10}$ In fact, some more recent studies show

8 Richard P. Farkas, Democratization in the Balkans: Prescription for a Badly Scarred Body Politic, Boston, MA: Northeastern University Press, 2007, p. 40.

9 Serbian Government Office for EU Integration, "Evropska orijentacija gradjana Srbije", 2004 [http://seio.sr.gov.yu], 5 January 2013.

10 Marko Stojić, "The Changing Nature of Serbian Political Parties' Attitudes towards Serbian EU Membership”, SEI Working Paper 122, Brighton: Sussex European Institute, 2011, pp. 1-53: 20 . 
that support to join the EU has continually decreased: for example, in December $2010,57 \%$ of respondents were in favor of Serbia's EU membership, whereas in December 2011, this number dropped to $51 \%{ }^{11}$

\section{From the Politics of Alternatives to the Politics of Opportunities}

According to one 2008 study correctly assessed, since the breakup of the Yugoslav federation, "Serbia has been invariably late: late in recognizing the spirit of change in 1989, late in reacting to Milošević's devastating policies, late in seeing the reality in Kosovo, late in accepting the cooperation with The Hague as a conditional sine qua non, late in defining the EU integration as the highest priority and hence late in conducting absolutely necessary reforms". ${ }^{12}$ Indeed, various indexes and indicators, such as the 2010 Democracy Index, the Global Competitiveness Index and the Worldwide Governance Indicators have demonstrated that Serbia has been late. The only significant progress can be associated with the electoral democracy and elections. Still, elections cannot consolidate democracy; they only serve to confirm democratic legitimacy. What is needed is a strong link between democracy (free and fair elections) and constitutional liberalism (rule of law and limited power) that would lead to the establishment of permanent institutions characterized by depoliticized public sector and independent courts. ${ }^{13}$ Here, although European Union involvement can provide assistance and apply its policy of conditionality, it is the Serbian leadership that decides on the level and speed of cooperation with both the EU and the Hague tribunal and, accordingly, the more they are ready to cooperate, the bigger the awards will be. While cooperation with the Hague tribunal has progressed satisfactorily, ${ }^{14}$ resulting in Serbia's EU candidacy in 2012, there are various issues that still require great attention. However, by this point, the dominant political parties had not synchronized their standpoints with regard to Serbia's key priorities and thus continued with the already wellembedded discourse of potential alternatives. The reputation of the Democratic Party seriously deteriorated and the fact that some of its officials seemed to have established their individual agendas, not fully reflecting the party's general aims - an aspect which further underlines the relevance of an earlier notion about strategic and ideological motives behind any party behaviour - questioned the unity and survival of the party. For example, in December 2011, Serbia's president

11 Serbian Government Office for EU Integration, "Serbia's EU Integration Supported by 51\% of Citizens", 2012 [http://www.seio.gov.rs/news.101.html?newsid=1121], 5 January 2013.

12 Irena Ristić, "Serbia's EU Integration Process: The Momentum of 2008", Panoeconomicus, Issue 1, 2009, pp. 111-125: 122.

13 Ilija Vujačić, "Deset godina političke tranzicije u Srbiji”, Analiza politike, Summer 2011, pp. 18-23: 22.

14 Here I primarily refer to the arrest and extradition of Radovan Karadžić in 2008, and Ratko Mladić and Goran Hadžić, in 2011. 
and leader of the Democratic Party Boris Tadic tried to reassure the public by saying that "the speculations are completely unrealistic and untrue, because there are no divisions in the party, and added there are different stances within the party, the same as in all other institutions, since it is constituted of different people". ${ }^{15}$ However, soon after the 2012 presidential elections in Serbia it became clear that the defeated Democratic Party was facing some serious internal challenges and that lack of immediate strategy as how to proceed could eventually result in a split of the party.

What seems to be even more relevant for the outcome of 2012 elections was that the voters were extremely disappointed with Serbia's economic performance, level of corruption across all sectors, poverty and unemployment rates etc. ${ }^{16}$ Taking all these issues into consideration, it is reasonable to argue that Tadić and his people simply failed to convince the public that they deserved to stay where they were. As one scholar summarized the trend: "The average voter did not perceive the politics of the Democratic Party as clearly pro-European and reformist, but only as one of several politics, which do not differ much in their fundamental premises. The politics of [the Democratic Party] is not defined as a clear alternative to the politics of Tomislav Nikolić, or even, until recently, Koštunica, but only as a variation of the same or similar politics ... The voters did not have the impression that by choosing Nikolić, they were choosing a truly different politics, but more of an alternative to the existing one. A part of the 'liberal intelligence' and certain public figures joined this political confusion about the true consequences of presidential elections. Justifiably unsatisfied with the current tempo of democratic change in Serbia, they continued to advocate the standpoint that 'any electoral change' is good, and did so with increasing aggressiveness". ${ }^{17}$

Following the election of president Nikolić, some EU officials noted that Serbia was "at a crossroads"; his victory "proved that the country's political landscape had become more complex and that the EU needs to be involved in an intensive dialogue with Serbian authorities and all political leaders from the very first moment". ${ }^{18}$ At home, while the panic surrounding government formation was going on, the newly elected president decided to pay his first visit abroad, to Russia. Although informal in official terms, this visit opened numerous questions about the politics of alternatives and whether the new Serbian leadership, contrary to the electoral campaign, was going to minimize its links with the West and move

15 Boris Tadić, "No Divisions in the Democratic Party”, Tanjug, 2011 [http://www.tanjug.rs/ news/27241/tadic--no-divisions-in-democratic-party.htm], 10 January 2013.

16 Zoran Stojiljković, "Izborna odluka", in Zoran Stojiljković (ed.), Zašto glasam, kako glasam, ako uopšte glasam, Beograd: Friedrich Ebert Stiftung, 2012, pp. 19-32: 30.

17 Žarko Korać, “The Time of Cohabitation”, Peščanik, 2012 [http://pescanik.net/2012/05/thetime-of-cohabitation/], 10 January 2013.

18 Miroslav Lajčák, "Serbia Faces Historic Turning Point", EUobserver, 2012 [http:// euobserver.com/opinion/116401], 18 January 2013. 
more towards the East. As reported, in Moscow, Russian president Putin started his welcome note by wishing Nikolić "to implement everything that was stated in [his] election program and to fulfill the Serbian people's expectations", that economic cooperation between the two "increased by almost $50 \%$ in the past year" and that Russians "see Serbs as [their] spiritual brothers". ${ }^{19}$ Based on Nikolić's response to Putin - that "Serbia is moving towards joining the EU" and that it will be built "in accordance with the rules of the EU", ${ }^{20}$ the informal talks in Moscow should not be interpreted as Serbian ambition to find an alternative and potentially give Russia priority over the EU.

Given the worrying economic situation at home, the newly established Serbian leadership has to explore opportunities that will eventually improve the living standard of the citizens of Serbia. While during the Cold War, the former Yugoslavia tried to preserve its economic relevance by deepening cooperation with the West, the impoverished post-Yugoslav Serbia is ready to receive investments from any geopolitical direction, even if sometimes this will not be possible due to the fluctuations in global economy. As Russia's deputy prime minister Dmitry Rogozin stated during his visit to Serbia, "[t]he difference between the EU's and Russia's approach is that Russia has the desire and money to invest in Serbia" and also underlined, something that is of crucial importance to pro-European forces, that "[t]here is no conflict of interest between Serbia's EU membership and friendship with Russia". ${ }^{21}$ For example, the South Stream project is seen as a big step forward: by having the pipeline passing through its territory, Serbia will get cheaper gas and Russia will secure access to a bigger European market and confirm its relevance in European Union affairs as the $21^{\text {st }}$ century is very much the century of energy politics. Additionally, a strong Serbian-Russian economic partnership could also lead to a strong political partnership, an upgrade that is surely facilitated by Nikolić's clear announcement in Moscow that "Serbia will never become a member of NATO" ${ }^{22}$

\section{Conclusion}

This paper has outlined some of the dominant issues affecting the overall progress of post-Milošević Serbia. Accordingly, the Kosovo question continues to represent a serious matter of concern. Although the Brussels administration has never said that it expects Serbia to give up its southern province in order to fully accede to the $\mathrm{EU}$, it has become difficult to believe that this will not be the case. When discussing

19 Kremlin, "Meeting with Serbian President-Elect Tomislav Nikolić", 2012 [http://eng. kremlin.ru/transcripts/3914], 18 January 2013.

20 Ibid.

21 Tanjug, "Rogozin: Russia is with Serbia”, 2012 [http://www.tanjug.rs/news/67723/rogozin-russia-is-with-serbia.htm], 18 January 2013.

22 Russia Today, "Serbia Says "nyet" to NATO Membership", 2012 [http://rt.com/politics/ serbia-russia-nato-eu-crisis-377/], 20 January 2013. 
Kosovo as a Serbian problem, it is important to note that the Belgrade authorities have supported the Kosovo Serbs to remain in Kosovo. However, one of the most alarming issues regards the presence of Serbian enclaves in the province that are still fully politically and economically integrated with Serbia. Thus, the question is how are these enclaves going to integrate within independent Kosovo and, secondly, who is responsible for this process? Still, when thinking about Kosovo as a European problem, there are also various aspects that deserve attention. For example, given the numerous criteria that any country seeking membership in the European Union must satisfy, ${ }^{23}$ it is objective to say that Kosovo is likely to face numerous obstacles. Even when negotiating the Kosovo status, the Brussels officials insisted on the policy of "standards before status", inaugurated by the third UN Mission in Kosovo chief, Michael Steiner of Germany, but once it had become obvious that standards were not going to be fulfilled any time soon, the policy was abandoned. In addition, Kosovo is formally recognized by 23 out of 28 Member States of the European Union. The remaining five states (Cyprus, Greece, Romania, Slovakia and Spain) do not intend to recognize Kosovo's independence, as their decision to do so could generate various problems at home.

It is worth mentioning that the most recent surveys conducted in Serbia have noted continuous drop of support for the country's EU membership, with data showing that " 59 percent of citizens do not believe that Serbia would access the EU in 10 or 15 years because nobody can guarantee this". ${ }^{24}$ Given that the volume of contacts, prospects for cooperation and promises exchanged between Serbia and Russia has remarkably increased since $2007,{ }^{25}$ it would be interesting to see if the continuous lack of pro-EU support has also to do with the intensified Russia-Serbia relations - a link that various members of the Serbian non-governmental sector see as groundless: "It is obvious that without Russia's involvement and without its support in certain informal centres, Serbia would not be in the situation in which it unfortunately finds itself today. Our elite naively believes that it is in Russia's interest to support

23 Any country seeking membership in the European Union must conform to the conditions set out by Article 49 and the principles laid down in Article 6 (1) of the Treaty on the EU. The relevant criteria were established by the Copenhagen European Council in 1993 and strengthened by the Madrid European Council in 1995. To join the EU, a new Member State must meet three criteria: political (implying stability of institutions guaranteeing democracy, the rule of law, human rights and respect for and protection of minorities), economic (implying existence of a functioning market economy and the capacity to cope with competitive pressure and market forces within the Union) and must accept the Community acquis (implying ability to take on the obligations of membership, including adherence to the aims of political, economic and monetary union; for the European Council to decide to open negotiations, the political criterion must be satisfied).

24 B92, "Support for the EU Plummets among Serbians", 2013 [http:/www.b92.net/eng/news/ politics-article.php?yyyy=2013\&mm=01\&dd=29\&nav_id=84394], 30 January 2013.

25 Žarko N. Petrović (ed.), Russia Serbia Relations at the Beginning of XXI Century, Belgrade: ISAC Fund, 2010. 
Serbia. It is a naïve way of looking at the world, bound up with the provincialism that imbues our perception of the world and what is happening around us". ${ }^{26}$

However, with the election of a new government in 2012, Serbia was once again exposed to the question of alternatives and speculations, but this time the situation seemed rather different, as the new government presented itself as fully aware both of the aforementioned uncertainties and Serbia's opportunities. With this in mind, there has not been much space left for the politics of alternatives. In contrast to the Djindjić government, which believed that Serbia did not have an alternative to the European Union, and the leadership that took over, which often struggled to confirm the previous view, leaving an impression that Serbia might have an alternative elsewhere, the Progressivists-dominated leadership is focused on potential benefits, regardless of the provider. Surely, the Russian federation is not an alternative at the moment, economically or ideologically. Economically, the EU is Serbia's biggest trade partner, accounting for 56 percent of domestic exports. ${ }^{27}$ Ideologically, although Titoist Yugoslavia was often proud of its similarity to the Soviet Union, the present-day Serbs are trying to be closer to the EU and the West in general rather than the Russians. In addition, Russia's decision not to recognize Kosovo's independence should not be necessarily associated with ideological proximity; it could also be perceived as its own ambition to be more relevant in EU and international politics. The desire for eventual membership in the European Union is a common denominator for all Western Balkan countries. It is an incentive to develop modern and effective legislation, and to reform and stabilize the political and economic environment. For example, in Serbia, corruption is recognized to be the biggest problem wherein political leaders are expected to solve them. The police and bureaucracy, while being the two elements with the greatest impact on our lives, "are the two most prevalent environments for 'corruption' simply because they are best positioned to leverage their power over common people". ${ }^{28}$ In contrast to the previous leadership, the 2012 elected government decided to tackle this problem first.

Still, without the full support from Brussels, there is little hope that Serbia and the Western Balkans will be able to shake off their existing reputation. The worstcase scenario would be to allow an increase in the already evident disproportion between the region and its neighbors who are further advanced in EU integration process. The (Western) Balkan question is a European question. So far, luckily, the Europeans have always confirmed their interest and willingness to assist the region, even if their involvement often entails taking responsibilities for acts in the past and calls for compromise.

26 Sonja Biserko, "Serbia'a Alternatives", Radio Slobodna Evropa, 12 December 2011.

27 Tanjug, "Delević: EU is Serbia's Main Trade Partner", 2012 [http://www.tanjug.rs/ news/36110/delevic--eu-is-serbias-main-trade-partner.htm], 18 January 2013.

28 Richard P. Farkas, Democratization in the Balkans: Prescription for a Badly Scarred Body Politic, Boston, MA: Northeastern University Press., 2007, pp. 80-81. 


\title{
Western Europe's approval of Europe's \\ Eastward enlargement - a starting \\ point for Europe's new future
}

\author{
Italy's attempts at integrating East-Central Europe \\ in a new continental balance: an early response to \\ the crisis of the Communist bloc (1989-1991)
}

Antonio VARSORI

\begin{abstract}
Since the late Nineteenth Century, Central Europe was regarded by Italy as an area where the new unified nation aimed at exerting political and economic influence. Such an ambition faded with Italy's defeat in the Second World War and especially as a consequence of the Cold War and the partition of Europe. In spite of that, Italy always paid attention to the developments in this part of the continent; especially the future of Yugoslavia was a concern of Italy's policy. In the 1970s at a local level some Italian regions took part to the creation of the "Alpe Adria" organization. During the second half of the 1980s with the impending crisis of the Communist régimes Italy tried to launch a new policy of cooperation with its neighbors. The pillars of this policy was on one hand the "Adriatic Initiative", which envisaged economic cooperation with Yugoslavia, and perhaps Albania, on the other the so-called "Quadragolare" which was formed by Italy, Yugoslavia, Hungary and Austria. Through the "Adriatic initiative" Italy hoped to counter the growing internal problems both Yugoslavia and Albania were facing, but the fall of Communism and the implosion of the Yugoslav Federation posed by far serious challenges to the Italian Government. As far as the "Quadrangolare", it appeared more successful and in a few yours Czechoslovakia and Poland joined the organization. Nevertheless Italy's ambitions were partly frustrated by the rapid and dramatic changes which characterized East-Central Europe after the fall of the Berlin wall which led to the creation of a new European balance.
\end{abstract}

Keywords: Italy, Central Europe, "Adriatic Initiative", "Quadrangolare”, Communism, European integration

In July 1989, after a long political crisis the Italian President of the Republic Francesco Cossiga appointed the Christian Democrat leader Giulio Andreotti President of the Council. Andreotti formed a five-party centre-left coalition government, a political formula which had characterized Italy's political scenario since the early 1980 s and had assured some stability to the country. ${ }^{1}$ The Prime

1 On Italy during the 1980s. See S. Colarizi, P. Craveri, S. Pons, G. Quagliariello (eds), Gli anni Ottanta come storia, Soveria Mannelli, Rubbettino, 2004; on Italy's international role 
Minister, who had led the Italian Foreign Ministry between 1983 and 1989 choose as his successor Gianni De Michelis, an emerging figure of Craxi's Socialist Party. In his inaugural speech in the Parliament De Michelis pointed out that, owing to the relevant political developments which were shaping the shaky Communist bloc Italy had the opportunity to renew friendly and fruitful relations with some of its eastern neighbors. ${ }^{2}$ In those days a non-Communist leader, the Catholic Mazowiecki, has been appointed Prime Minister in Poland, while in Budapest the Hungarian Communist Party was promoting a multi-party political system and was going to dismantle the so-called iron curtain along the Hungarian-Austrian border. ${ }^{3}$ De Michelis's statements expressed Italy's ambitions, which had deep roots in Italian foreign policy tradition. Since the Unification Italy had always regarded the Adriatic, the Balkan region and the Danube area as a privileged sphere of influence. Especially after the end of the First World War and with the collapse of the Austrian-Hungarian Empire Italy had strengthened its position in countries such as Austria and Albania, the latter became a sort of Italian protectorate. ${ }^{4}$ Close relations were established by the Fascist régime with Horthy's Hungary and Italy supported Budapest's revisionist policy. In spite of the bond with Hungary, Italy was able to develop good relations with Romania as well. As far as Yugoslavia was concerned, Mussolini constantly aimed at destroying the new South-Slav state in order to impose what US historian James Burgwyn has labeled "il Duce's Adriatic Empire", an attempt which characterized Fascist Italy's policy during the Second World War. ${ }^{5}$ Obviously such ambitions were frustrated by Italy's defeat.

see E. Di Nolfo (ed.), La politica estera italiana negli anni Ottanta, Manduria, Lacaita, 2003.

2 On De Michelis' experience as Foreign Minister see G. De Michelis, La lunga ombra di Yalta. La specificità della politica estera italiana, Venice, Marsilio, 2003. On Giulio Andreotti see the biography by M. Franco, Andreotti. La vita di un uomo politico, la storia di un'epoca, Milan, Mondadori, 2010, see also M. Barone and E. Di Nolfo (ed.), Giulio Andreotti, l'uomo, il cattolico, lo statista, Soveria Mannelli, Rubbettino, 2010.

3 On the developments which were taking place in Poland and in Hungary see for example: F. Fejto, La fin des démocraties poulaires. Les chemins du post-communisme, Paris, Seuil, 1992, pp. 253-274; P. Sebestyen, Revolution 1989 The Fall of the Soviet Empire, London, Phoenix, 2009, passim.

4 On Italy's policy towards Albania see for example P. Pastorelli, L'Albania nella politica estera italiana 1914-1920, Naples, Jovene, 1970; M. Borgogni, Tra continuità e incertezza. Italia e Albania (1914-1939). La strategia politico-militare dell'Italia in Albania fino all'operazione "Oltremare Tirana", Milan, Franco Angeli, 2007.

5 H. J. Burgwyn, L'impero sull'Adriatico. Mussolini e la conquista della Jugoslavia 19411943, Gorizia, Leg, 2006; see also M. Bucarelli, Mussolini e la Jugoslavia (1922-1939), Bari, Edizioni B. A. Graphics, 2006. On Fascist policy towards Eastern Europe see S. Santoro, L'Italia e l'Europa orientale. Diplomazia culturale e propaganda 1918-1943, Milan, Franco Angeli, 2005. On the relations between Italy and Romania see G. Caroli, La Romania nella politica estera italiana 1919-1965. Luci e ombre di un'amicizia storica, Milano, Edizioni Nagard, 2009 
In the immediate post-war period Republican Italy showed some interest in renewing traditional bonds with its eastern neighbors, but the Cold War provoked a sharp division of the European continent and Italy almost immediately choose to be a part of the western system through the adhesion to both the Marshall Plan and the Atlantic alliance, as well as the deep involvement in the integration process, which for at least forty years meant the integration of Western Europe. ${ }^{6}$ But since the second half of the 1980s, owing to Gorbachev's coming to power and the emerging of the so-called "Sinatra doctrine", new opportunities appeared to surface in EastCentral Europe. Actually, in spite of the division of the "old continent", especially since the 1970s, Italy had already focused its attention on its immediate neighbors, especially neutral Austria and Communist, but non-aligned Yugoslavia. For some time the relations with Vienna were negatively influenced by the South Tyrol question, but especially after the so-called package deal offered by Italy to the South Tyrolese German-speaking minority the relations with Austria improved. ${ }^{7}$ As far as Yugoslavia was concerned, for long time the relations with Belgrade had been poisoned by the peace treaty settlement of Italy's eastern border, especially by the "ethnic cleansing" that had compelled about 250,000 Italians to leave Yugoslavia; on the part of the Yugoslavs, they could not forget the bitter memories of the Fascist aggression. In the early 1970s however, the appearance of the Kosovo problem and the so-called "Croatian spring" rang an alarm bell in Rome about the stability of the Yugoslav federation. In 1975 Italy and Yugoslavia signed the Osimo treaty which definitively settled the thorny and still unsolved issues related to the Second World War and the peace treaty; the Italian governments began to support Yugoslavia as it was in Rome's interest to rely on a stable, non-aligned and prosperous neighbor in a period of renewed tensions between East and West. ${ }^{8}$

During the 1980s, especially after Tito's death, Yugoslavia experienced growing economic problems and political instability. The Italian authorities showed increasing concern about this state's future; so they went on supporting Belgrade's economy and favored the involvement of the European Community in the support

6 On Italy's foreign policy in the post-war period see A. Varsori, L'Italia nelle relazioni internazionali dal 1943 al 1992, Rome-Bari, Laterza, 1998. On Italy's attempt at developing an autonomous "Ostpolitik" see S. Tavani, L'Ostpolitik italiana nella politica estera di Andreotti, in M. Barone and E. Di Nolfo (eds), op. cit., pp. 243-304.

7 On the South Tyrol question see the traditional contribution by M. Toscano, Storia diplomatica della questione dell'Alto Adige, Bari, Laterza, 1968; see also the recent volume by G. Grote, The South Tyrol question, 1866-2010: from national rage to regional state, Oxford//Bern, Peter Lang, 2012; on the "package deal" see M. Marcantoni and G. Postal, Il pacchetto della Commissione dei 19 alla seconda autonomia del Trentino- Alto Adige, Trento, Fondazione Museo storico del Trentino, 2012. On the relationship between Italy and Austria see also M. Gehler and M. Guiotto (eds), Italien, Oesterreich und die Bundesrepublik Deutschland in Europa, Wien, Boehlau, 2012.

8 In general see M. Cattaruzza, L'Italia e il confine orientale, Bologna, il Mulino, 2007. 
to Yugoslavia's crumbling economic system; in 1985, for example Italy favored the grant by the EC of 480 million ECU to Belgrade. ${ }^{9}$ The Italian Foreign Ministry, which appeared already worried about the Kosovo too, did not disregard the possibility of creating some contact also with Albania, especially when with the approaching of Hoxha's disappearance the Albanian Communist régime appeared to show some early openings to the external world. ${ }^{10}$ Other incentives to more determined Italian efforts towards its eastern neighbors came from Italian local authorities. During the 1970s Italy's North East regions experienced a dramatic economic development and they became among the leading factors in Italy's industrial export system. Although Germany was Italy's main commercial partner, industrialists and local politicians from the Veneto and the Friuli began to look to their eastern neighbors as obvious commercial partners and promising new markets. In the mid-1970s some Italian regions - Lombardy, Veneto, Friuli and Trentino - had joined some regions of Germany, Austria and Yugoslavia in the creation of the "Alpe Adria" Community, whose main goal was the strengthening of economic and cultural relations of this geographic area. Although the "Alpe Adria" organization had no declared political ambitions it favored the setting-up of a transnational network and it concurred in helping Belgrade which appeared unable to solve its serious economic plights. ${ }^{11}$ On its part the Yugoslav leadership was looking to Italy as a partner which can offer some financial and political support. In early 1988 the Yugoslav authorities began to talk of an "Adriatic project" which would involve close economic cooperation between the two nations. Actually in that same year Italy granted various forms of financial support to Yugoslavia which amounted to 500 billion lire. ${ }^{12}$

In early 1989 the Italian Foreign Ministry began to elaborate on the project for an "Adriatic initiative". The plan was still a bit vague, but it envisaged close forms of economic cooperation between Rome and Belgrade; moreover it was thought

9 Archivio Storico Istituto Luigi Sturzo (hereafter ASILS), Archivio Giulio Andreotti (hereafter AGA), "Jugoslavia", box 542, memorandum "Nota informativa CEE-Jugoslavia" by the Italian Foreign Ministry, no date, but January 1985. In this connection I would like to thank Senator Giulio Andreotti for the permission to examine his papers, Dr. Flavia Nardelli, former secretary general of the Sturzo Institute for her kind support and Dr. Luciana Devoti, chief archivist at the Sturzo Insitute for her precious help.

10 On Italy's early concern about the Kosovo see for example ASILS, AGA, "Jugoslavia", box 542, memorandum "Yugoslavia - politica interna" by the Italian Foreign Ministry, no date, but early 1985. On the relations between Italy and Albania see ASILS, AGA, "Albania", box 329, tel. No. 407 Italian Embassy (Tirana) to the Italian Foreign Ministry, 12.12.1983. and tel. No. 90 Italian Embassy (Tirana) to the Italian Foreign Ministry, 1.3.1984.

11 On the Alpe-Adria organisation see the remarks in G. A, Pozzi, La cooperazione regionale, in F. Argentieri (ed.), Post comunismo terra incognita. Rapporto sull'Europa centrale e orientale, Rome, Edizioni Associate, 1994, pp. 134-135.

12 Asils, Aga, "Jugoslavia", box 542, memorandum "relazioni italo-jugoslave" by the Italian Foreign Ministry, no date, but early 1989. 
that such a project could be joined later by Albania. In the Farnesina's opinion the European Community would have to support the "Adriatic initiative" through its financial aid. ${ }^{13}$ Such a positive and optimistic view was strengthened by the appointment of Ante Markovic as federal prime minister and by its efforts to deal in a more effective way with the nation's economic crisis, especially the high rate of inflation of the Yugoslav currency. ${ }^{14}$ So the "Adriatic initiative" became the object of serious analysis on the part of both Italian and Yugoslav diplomats. In this period there was a further stimulus to Italy's taking the lead in creating forms of cooperation in the Adriatic/Balkan area. In spite of Markovic's efforts and of some positive result in the economic field Yugoslavia's political situation further worsened. Such a negative development was pointed out in spring 1989 by the Italian Ambassador to Belgrade, Sergio Vento in a report to Giulio Andreotti. In the Ambassador's opinion, the Yugoslav crisis could be solved through further economic support and a more determined effort by the European Community. ${ }^{15}$

The creation of the Andreotti government, especially the appointment of De Michelis as Foreign Minister had a relevant impact on Italy's policy towards their eastern neighbors. De Michelis came from an influential Venetian family and his political career has started in the Veneto region where he had his constituency and he maintained influential connections. So he was very much interested in Italy's economic and political projection towards East-Central Europe. As it has already stated, in his inaugural speech De Michelis pointed out the new government's interest in renewing Italy's bonds with its neighbors. Yugoslavia appeared to be the new Foreign Minister's major concern. In early August De Michelis and the President of the Italian Republic Francesco Cossiga had a meeting in Venice with the Federal Yugoslav President Drnovsek and the Yugoslav Foreign Minister Loncar. The Italian leaders pointed out Italy's interest in supporting the efforts by the Belgrade federal government in order to solve Belgrade's serious economic crisis. De Michelis suggested the implementation of the "Adriatic initiative": while the "Alpe Adria" had been limited to Slovenia and Croatia, in the opinion of the Italian Foreign Minister, the "Adriatic initiative" had to involve also the Southern and more backward republics from the South of the Yugoslav federation, especially Montenegro and Kosovo, as well as some southern Italian regions. ${ }^{16}$ The Italian authorities were more and more worried about the situation in the Kosovo region and they hoped that a wider plan of economic development could

13 Asils, Aga, "Jugoslavia", box 542, memorandum "Iniziativa adriatica - aspetti politici" by the Italian Foreign Ministry, no date, but early 1989.

14 On The early stage of the Yugoslav crisis see M. Glenny, The Fall of Yugoslavia. The Third Balkan War, London, Penguin Books, 1992. In general see J. Pirjevec, Le guerre jugoslave 1991-1999, Turin, Einaudi, 2001.

15 Asils, Aga, "Jugoslavia", box 542, letter No. 1187, S. Vento (Belgrade) to G. Andreotti (Italian Foreign Ministry), 10.4.1989.

16 G. De Michelis, op. cit., pp. 91-92. 
solve the problems which plighted the Yugoslav region inhabited by the Albanian community, so appeasing the ethnic and political rivalries which were characterizing this area. Moreover De Michelis informed his Yugoslav partners that there had been a proposal by the Hungarian government in order to held regular meetings at foreign ministers level among Italy, Austria, Hungary and Yugoslavia. This was the early idea of the "Quadrangolare" project; although Budapest had been at the origins of such a plan, Italy would play a central role. It was obvious that in this phase of quick democratization the Hungarian Communist leadership was looking for a strong western partner and Italy was the most obvious one. On their part the Italian authorities had followed with increasing interest the democratization process which was characterizing the Hungarian political scenario. ${ }^{17}$ In this same period the Bush administration was putting pressure on some EEC leading nations, especially Italy and France, in order to favor some determined economic effort in order to help both Poland and Hungary, which appeared the standardbearers of the liberalization process in East-Central Europe. ${ }^{18}$ Yugoslavia's reaction to Italy's suggestion was a positive one. Probably in those days few decisionmakers had noticed the big rally which in 1987 the new Serbian leader, Slobodan Milosevic, had organized at Kosovo Polje, an event which would have marked the path towards the implosion of the Yugoslav federation.

Nevertheless, in September 1989 the Italian and the Yugoslav governments organized an important bilateral conference which was held at Umago and Buje. The choice of these two small villages was a symbolic one, as they were located in the Istria peninsula, a disputed area between Rome and Belgrade, and on this occasion those localities had to become the symbol of reconciliation and renewed friendship between Italy and Yugoslavia. For Italy Andreotti and De Michelis took part to the conference, while for Yugoslavia Markovic and Loncar were present. On this occasion the two delegations released a joint statement which marked the official launching of the "Adriatic initiative". The project aimed at the economic development of the Adriatic area, through investments in transports, tourism and infrastructures. For example the project for building of a highway along the Adriatic coast of Yugoslavia was discussed. ${ }^{19}$ Moreover the two delegations agreed that the Albanian diplomacy had to be approached in order to ascertain Albania's interest in such an initiative. ${ }^{20}$ It may be wondered whether such a vague and long-term project could solve the growing problems which were affecting

17 Asils, Aga, “Ungheria”, box 675, letter No. 933, J. Nitti (Budapest) to G. Andreotti (Italian Foreign Ministry), 8.5.1989; tels. No. 1347 and 1348, Italian Embassy (Budapest) to the Italian Foreign Ministry, 9.10.1989. and 10.10.1989.

18 Asils, Aga, "Francia”, box 411, tel. G. Bush to G. Andreotti, 4.10.1989., secret.

19 On this conference see the records in Asils, Aga, "Jugoslavia", box 542.

20 On Italy's policy towards Albania see A. Varsori, Italy and the End of Communism in Albania, 1989-1991, in "Cold War History" vol. 12, No. 4, November 2012, pp. 615-635. 
Yugoslavia, but in this period nobody envisaged what would happen in a few years in East-Central Europe. Moreover the Italian authorities were optimist and they hoped that the "Adriatic initiative" could lead the European Community and other international organizations to grant further financial support to Belgrade. In this same period, for example, the Italian representative in the NATO Atlantic Council pointed out that western support to Yugoslavia was an important factor in order to stabilize the situation in the Balkan area. ${ }^{21}$ As far as the "Quadrangolare" was concerned, in the Italian authorities' opinion this organization would mainly have a political and wider goal, a way to fill the gap between western Europe and the former Communist bloc through regular meetings at Prime Ministers' and Foreign Ministers' level, while the "Adriatic initiative" through economic instruments aimed at stabilizing the Balkan area, mainly Yugoslavia and Albania. Yugoslavia would be a bridge between the two initiatives. Nevertheless also in the case of Hungary, the Italian government thought that economic and financial help would favor the democratization process and once again the Rome authorities hoped that in this connection it would be possible to mobilize the European Community. ${ }^{22}$

In a short while Italy's projects, which appeared to have a long-term character, would be largely influenced by the sudden acceleration of the dynamics in EastCentral Europe, so paving the way to the implosion of the Communist bloc. In November the fall of the Berlin wall, the perspective of a quick German reunification and the "velvet revolutions" which in few weeks wiped out the Communist régimes in East-Central Europe, as well as the crumbling of the Soviet Union radically changed the political scenario in East-Central Europe. Moreover between late 1989 and early 1991, as a consequence of the end of the Cold War, the Italian authorities were compelled to focus their attention on new more compelling issues such as the German reunification, the Gulf War and the political process which would lead to the Maastricht Treaty. Nevertheless the plans which aimed at renewing close contacts between Italy and the Balkan and Danube areas were not abandoned. Especially Hungary appeared interested in the plan for closer cooperation with Austria, Yugoslavia and Italy. An official declaration was signed in Budapest in mid-November 1989. As far as the Italian government was concerned, it hoped that such an agreement would favor both democratization and stabilization in Central Europe and it would be a boost to economic and technological cooperation. ${ }^{23}$ Such hopes were strengthened by the official visit paid by the Hungarian Foreign

21 Asils, Aga, "Jugoslavia”, box 542, tel. No. 1264, P. Fulci (NATO) to the Italian Foreign Ministry, 11.9.1989., strictly confidential.

22 Asils, Aga, "Ungheria", box 675, tels. 6338 and 6339 P. Calamia (Brussels EC) to the Italian Foreign Ministry. 22.9.1989. On the situation in Hungary see for example F. Argentieri, $L a$ breve stagione del governo Antall, in F. Argentieri (ed.), op. cit., pp. 107-126.

23 Asils, Aga, "Ungheria", box 677, memorandum "Iniziativa quadrangolare - Aspetti politici" by the Italian Foreign Ministry, no date, but late 1989. 
Minister, Gyula Horn, in Rome in January 1990. The evaluation by the Italian Foreign Ministry of the developments which were taking place in Budapest was a positive one and the Andreotti government appeared eager to strengthen further the contacts with the Hungarian régime. ${ }^{24}$ The Italian authorities were particularly interested in developing some form of economic aid to Budapest, which could represent the basis for future Italian investments in the former Communist country. ${ }^{25}$ Very early the countries involved in the "Quadrangolare" decided to widen the initiative to Czechoslovakia. In May 1990 on the occasion of a conference held in Vienna at Foreign Ministers level the "Quadrangolare" became officially the "Pentagonale" with Prague's adhesion. Italy got the first chairmanship of the "Pentagonale" and in August 1990 a summit was held in Venice. On this occasion it was agreed that every year there would be two meetings at Foreign Ministers' and Prime Ministers' level. Several working groups were created, which would deal with forms of cooperation in various fields: from tourism to transports, from environment to culture, from telecommunications to energy ${ }^{26}$ Although Italy played a relevant role in the "Pentagonale" initiative and the Rome authorities hoped to profit from this cooperation, especially in the economic field, the Farnesina regarded this organization mainly as a medium-term political instrument. In a memorandum drafted by the Italian Foreign Ministry it was stated that the "Pentagonale" would not substitute the existing European organizations, as well as the Atlantic Alliance, but it would be a way on one hand to avoid a dangerous instability in this area, on the other to favor the gradual involvement of former Communist régime in the structures of the European Community. ${ }^{27}$ In fact, if before the fall of the Berlin wall and the end of the Communist bloc some forms of cooperation with countries such as Italy could be regarded by Budapest, Prague and Belgrade as the obvious way to renew close bonds with western Europe, now the new post-Communist leaderships would directly appeal to Brussels and to the West in order to become full members of the western system, that is the European Community and NATO. Last but not least it became quickly obvious that a reunified Germany would become the most influential actor in Central Europe, so recovering the influence Berlin had exerted in countries such as Poland, Czechoslovakia and Hungary. In this context Italy would appear a minor partner if compared with Germany.

As far as the "Adriatic initiative" was concerned, that was a different matter, and Italy appeared to have some chance to influence the developments in Yugoslavia and

24 Asils, Aga, "Ungheria", box 677, memorandum "Ungheria - rapporti politici con l'Italia" by the Italian Foreign Ministry, no date, but early 1990.

25 Asils, Aga, "Ungheria", box 677, memoramdum "Oggetto: Ungheria - cooperazione allo sviluppo" by the Italian Foreign Ministry, no date but early 1990 .

26 Asils, Aga, "Ungherria", box 677, memorandum "Iniziativa esagonale" by the Italian Foreign Ministry, no date but early 1992.

27 Asils, Aga, "Ungheria", box 678, memorandum "Iniziativa Pentagonale" by the Italian Foreign Ministry, no date, but June 1990. 
Albania. Between 1990 and early 1991 for example Albania, where the Communists were still in power, showed a definite interest in developing close form of cooperation with Italy and they showed some willingness to be involved in the "Adriatic initiative" ${ }^{28}$ But in that same period the Yugoslav situation worsened and Italy's cautious policy, based on the support to the economic efforts by the federal authorities, appeared to become obsolete. The Andreotti government, especially De Michelis and the Farnesina obviously feared very much the implosion of Yugoslavia, in particular the perspective of a series of bloody civil wars, which would take place at Italy's doorstep. So they did every effort in order to support the moderate federal leaders and to avoid the declaration of full independence by Croatia and Slovenia. In March 1990 Andreotti and De Michelis paid an official visit in the US and they met President Bush and his advisers. On this occasion the Italian leaders still showed an optimist outlook about the "Quadrangolare", which was going to become the "Pentagonale", and the "Adriatic initiative" as well. ${ }^{29}$ Moreover in this same year a new declaration about forms of Adriatic cooperation was signed and it involved Italy, Yugoslavia, Greece and Albania. ${ }^{30}$ In early 1991 however, it became quite obvious that Slovenia and Croatia were heading towards a full independence and the federal authorities were becoming more and more weaker. In a dispatch he sent to the Farnesina in February 1991 Ambassador Vento sketched out a worrisome picture of the Yugoslav situation and he appeared to imply that both the "Pentagonale" and the "Adriatic initiative" would not be able to cope with a situation which was becoming very dangerous. ${ }^{31}$ The Slovenian and Croatian declaration of independence and the so-called Slovenian war were evidence of the impending implosion of Yugoslavia. In spite of that Italy still thought it was possible to save form of confederation and now the Italian authorities tried to favor the direct involvement of the European Community. The so-called EC troika, with the participation of De Michelis, appeared able in June to achieve some compromise between the federal authorities and the separatist republics. ${ }^{32}$ Moreover the Italian Government supported the initiative launched by the Austrian Foreign Minister, Alois Mock, in order to create an international committee formed by independent and well-known figures

28 A. Varsori, Italy ... cit., p. 622.

29 Asils, Aga, "USA", box 637, memorandum "Jugoslavia - nota riassuntiva", by the Italian Foreign Ministry, no date, but early March 1990; memorandum "Iniziativa Quadrangolare aspetti politici", no date but early March 1990; and memorandum "Iniziativa Adriatica aspetti politici", no date but early March 1990.

30 M. Bucarelli, La Slovenia nella politica italiana di fine Novecento dalla disgregazione jugoslava all'integrazione euro-atlantica, in M. Bucarelli and L. Monzali (eds), Italia e Slovenia fra passato, presente e futuro, Rome, edizioni Studium, 2009, pp. 116-117.

31 Asils, Aga, “Jugoslavia”, box 544, despatch No. 0855, S. Vento (Belgrade) to G. De Michelis (Rome), 27.2.1991.

32 For Italy's policy towards the Yugoslav question in this period see A. Varsori, L'Italia ... cit., pp. 137-144. 
who would deal with the Yugoslav crisis. ${ }^{33}$ In the meantime Poland would join the "Pentagonale", which would become the "Esagonale".July 1991, Italy did a last effort to resort to this organization in order to stabilize the Yugoslav situation; De Michelis convinced his Austrian and Hungarian colleagues to favor the convening of a top level meeting of the "Pentagonale" on the occasion of Poland's adhesion, but with the major goal of demonstrating that the Yugoslav federation was still alive. ${ }^{34}$ So an official conference of the "Pentagonale" was convened in Dubrovnik. The atmosphere of the conference was a surreal one, as both the representatives of the Yugoslav federal government and the separatist republics attended the meeting. Official statements were drafted and signed, and everybody appeared to believe that the conference had been a success. Actually in his memoirs Andreotti wrote that the meeting had been a complete failure. ${ }^{35} \mathrm{~A}$ few months later open hostilities were renewed and Dubrovnik would become the target of the federal artillery, which would have shelled the historical town. ${ }^{36}$ In that same period the Albanian Communist regime collapsed and flows of immigrants began to land on the Italian territory, creating new serious problems to the Italian authorities, problems which obviously neither the moribund "Adriatic initiative" nor the "Esagonale" could solve". ${ }^{37}$ Actually the Italian authorities still regarded the "Esagonale" as a useful instrument and in a memorandum drafted in late 1991 the Italian Foreign Ministry gave a positive evaluation of the organization, which appeared part of the flourishing of several forms of regional European cooperation -the Balkan cooperation, the Baltic Cooperation, the Nordic Cooperation, the Black Sea Cooperation. ${ }^{38}$ As far as the "Esagonale" was concerned, Italy's interest appeared to focus on the economic aspects; in a memorandum by the Farnesina which was drafted in December 1991 on the occasion of the visit to Rome by the Czechoslovak Prime Minister, the creation of close economic and financial links between the two states was highlighted and regarded as a positive starting point. ${ }^{39}$ Similar hopes emerged on the occasion of the

33 Asils, Aga, "Jugoslavia", box 544, message by fax, S. Vento (Belgrade) to the Italian Foreign Ministry, 8.6.1991., confidential.

34 Asils, Aga, "Jugoslavia", box 544, memorandum "Riunione dei ministri degli Esteri di Austria, Italia e Ungheria sulla situazione jugoslava" by the Italian Foreign Ministry, 9.7.1991.

35 G. Andreotti, De (prima) Re publica, Milan, Rizzoli, 1996, p. 255.

36 On the development of the Yugoslav conflict see M. Glenny, op. cit., passim.

37 See in general A. Varsori, Italy ... cit., passim.

38 Asils, Aga, "Calfa Marian primo ministro", box 364, memorandum "Cooperazione regionale europea" by the Italian Foreign Ministry, no date but December 1991. On Italy's economic interests see M. Guandalini, La presenza economica italiana all'Est, in F. Argentieri (ed.), op. ci., pp. 325-380.

39 Asils, Aga, "Calfa Marian primo ministro", box 364, memorandum "Appunto di sintesi" by the Italian Foreign Ministry, 10.12.1991. On the situation in Czechoslovakia see for example F. Leoncini, Cechi e Slovachi: dalla rinascita civile alla separazione, in F. Argentieri (ed.), op., cit, pp. 47-78. 
visit to Rome in July 1991 by the Hungarian Finance Minister ${ }^{40}$, Italy's aspirations were confirmed a few months later in some Foreign Ministry's documents dealing with the relationship between Italy and Hungary. ${ }^{41}$ Last but not least the "Esagonale" was regarded by the Italian authorities as an effective forum through which Italy and some countries from Central Europe could positively influence the Yugoslav crisis. ${ }^{42}$ Actually the "Esagonale" was not able to offer any viable solution to the implosion of the Yugoslav state. Nevertheless in the following years the organisation's membership steadily increased and it transformed itself into the Central European Initiative (CEI), a loose organization which now comprise 18 members, of which nine are part of the EU (Italy, Austria, Slovenia, Hungary, the Czech Republic, Slovakia, Poland, Romania and Bulgaria) and 9 are non-EU members (Serbia, Bosnia-Herzegovina, Croatia, Montenegro, Macedonia, Ukraine, Belarus, Albania, Moldova). Its mission, as it is stated in its official website is the promotion, through an international forum of "political, economic, cultural and scientific cooperation among its member states". Such cooperation would aim at favoring the future accession to the EU of its non-member states. ${ }^{43}$

In spite of the useful role which the CEI seems to play in favoring forms of dialogue and cooperation between the EU and the central-eastern European countries which are not full members of the EU, it is obvious that such an organization is something very different in both its goals and structures, from the plans the Italian governments had worked out in the late 1980s. Moreover, since 1992 Italy experienced a period of serious economic, political and institutional crisis and for some years its ability to play a leading international role was seriously threatened. The "Adriatic initiative" quickly collapsed as a consequence of Yugoslavia's violent implosion, while, besides Italy, for the other countries which had put forward the original "Quadrangolare", the adhesion to the EU was the main goal and in this connection a direct dialogue with Brussels, as well as other agreements, such as the Visegrad group, were more influential in favoring the accession by Austria, Poland, Hungary and Czechoslovakia to the European Union. ${ }^{44}$ So both the

40 Asils, Aga, "Ungheria”, box 677, memorandum "Ungheria” by the Italian Foreign Ministry, no date, but June 1991 and memorandum "Appunto" by the Italian Foreign Ministry, June 1990.

41 Asils, Aga, "Ungheria", box 677, memorandum "Ungheria", by the Italian Foreign Ministry, no date, but late 1991 .

42 Asils, Aga, "Ungheria” box 677, memorandum "Ristrutturazione dell'Esagonale a seguito della crisi jugoslava", by the Italian Foreign Ministry, no date, but late 1991 and tel. No. 1905, J. Nitti (Budapest) to the Italian Foreign Ministry, 19.11.1991.

43 See the information in www.cei.int. It must be pointed out that the secretariat of the Central European Initiative is located in Trieste.

44 On the enlargement process see for example L. Mattina (ed.), La sfida dell'allargamento. L'Unione Europea e la democratizzazione dell'Europa centro-orientale, Bologna, il Mulino, 2004; F. Carlucci and F. Cavone, La grande Europa. Allargamento, integrazione, sviluppo, 
"Adriatic initiative" and the "Quadrangolare" were quickly forgotten by both the Italian authorities and public opinion. Nevertheless these initiatives may be still recorded by historians as an early attempt by the Italian government at favoring a cautious and gradual integration of East-Central Europe in the European construction during a difficult phase of transition from the Communist system towards a stable post-Communist reality.

Milan, Franco Angeli, 2004; R. Scartezzini and J. O. Milanese (eds), L'allargamento dell'UE nello scenario geo-politico europeo, Milan, Franco Angeli, 2005. 


\title{
Germany and the EU-Eastern Enlargement
}

\author{
Wichard WOYKE
}

\section{History of Enlargement - overview}

The EU was founded as the ECSC in 1951 by the following six European countries: Belgium, the Netherlands, Luxemburg, France, Italy and Germany. 1957 followed the European Economic Community (EEC) and the European Atomic Energy Community (EURATOM), founded by the same countries. In 1967 the institutions of the three communities were combined. The development of these continental communities was very successful. That is the reason why other European countries became members of the European communities.

Five successive enlargements have followed since then:

- In 1973, Denmark, Ireland and the United Kingdom joined the European Community.

- In 1981, Greece became a Member State.

- In 1986, Spain and Portugal became members.

- In 1995, Austria, Finland and Sweden joined the EU.

- In 2004, the Czech Republic, Estonia, Cyprus, Latvia, Lithuania, Hungary, Malta, Poland, Slovakia and Slovenia joined. It was a historic enlargement which signified the re-unification of Europe after decades of division.

- On 1 January 2007 Romania and Bulgaria also joined, completing this historic process.

\section{The collapse of Communism}

In 1989/90 the communist/socialist world collapsed. This development was a tremendous challenge for the EC. Before the wall came down the EC had mainly dealt with the policies in Western Europe and was now preoccupied with postcommunist Eastern Europe. Meanwhile, the EU aimed to ensure political stability in Central and Eastern Europe to protect itself from the negative spillover consequences of instability. Furthermore, the EU had to fulfil the promises made in earlier times that, should geopolitical circumstances allow a membership of the EU. The question was no longer if the CEECs could become members of the EU but when these countries could enter the community. Within the EU countries began a process of reflection. Countries like France were at first hesitating when President Mitterrand proposed on the eve of the year 1990 a new "European Confederation", a loose grouping of states, with the CSCE members but without the big powers US and Soviet Union (c. Woyke 2010, p. 134 ff). 
President Mitterrand preferred to deepen the Community before taking on board new members, because the ratification of a deepened treaty made it harder for the CEECs to become member of the EU. But he did not get any support for his idea, either in the EU or in the CEECs. On the contrary most of the politicians in West- and Eastern Europe rejected his plan. The CEECs strived for membership in the EU. Also in Germany the idea of a European Confederation was rejected. So at last in 1993 the definitive decision was made that the place of these countries should be in the EU.

On the European Council in June 1993 in Helsinki the EU leaders decided that those countries could enter the community when they fulfilled the criteria. According to Article 49 of the Treaty on European Union, any European country which respects the principles of the European Union can in theory become a member of the Union:

In preparation for the fifth round of enlargement - the largest in the history of the EU (eastward enlargement) - the European Council formulated accession criteria in Copenhagen in 1993. The "Copenhagen Criteria", which were defined more precisely through the subsequent enlargement process, provide important orientation for candidate countries.

According to these criteria, accession candidates must fulfil the following requirements to become members of the $\mathrm{EU}$ :

- stable institutions to guarantee democracy, the rule of law, human rights and respect for and protection of minorities (political criterion);

- a functioning market economy and the capacity to cope with competitive pressure and market forces within the EU's internal market (economic criterion);

- the ability to take on all the obligations of membership, i.e. the entire body of EU law and policy known as the acquis communautaire, and adherence to the aims of political, economic and monetary union (acquis criterion).

The European Council in Copenhagen further emphasized that the Union's capacity to absorb new members, while maintaining the momentum of European integration, is also an important consideration of both the Union and the candidate countries. The EU's absorption capacity was long regarded as the "forgotten criterion" of Copenhagen. This condition, over which candidate countries themselves have little influence, grows in significance with each new round of enlargement.

\section{Germany and the Eastern enlargement}

With the coming down of the Wall the German question was back. The questions now became: What is going on with Germany? Will Germany stay in the European integration process? Would Germany drift away from the integration process and form a pan-European community centered on the eastern part of Europe? Or would there be a German-Russian dominion? In the 2+4 treaty from September 1990, a substitute for a German Peace Treaty, Germany was given its independence 
and the right to chooses alliances. But the United Germany continued mainly the foreign policy of the old FRG of Bonn and stayed in NATO and the European organisations. In the preamble of the German basics law, we can read: "Conscious of its responsibility before God and mankind, filled with the resolve to preserve its national and political unity and to serve world peace as an equal partner in a united Europe ...". Article 23 stresses the European dimension of the united Germany:

"(1) With a view to establishing a united Europe, the Federal Republic of Germany shall participate in the development of the European Union that is committed to democratic, social, and federal principles, to the rule of law, and to the principle of subsidiarity, and that guarantees a level of protection of basic rights essentially comparable to that afforded by this Basic Law. To this end the Federation may transfer sovereign powers by a law with the consent of the Bundesrat. The establishment of the European Union, as well as changes in its treaty foundations and comparable regulations that amend or supplement this Basic Law, or make such amendments or supplements possible, shall be subject to paragraphs (2) and (3) of Article 79.

(2) The Bundestag and, through the Bundesrat, the Länder shall participate in matters concerning the European Union. The Federal Government shall keep the Bundestag and the Bundesrat informed, comprehensively and at the earliest possible time.

(3) Before participating in legislative acts of the European Union, the Federal Government shall provide the Bundestag with an opportunity to state its position. The Federal Government shall take the position of the Bundestag into account during the negotiations. Details shall be regulated by a law. Furthermore the basic law makes it possible by Article 24 to transfer sovereign powers: "(1) The Federation may by a law transfer sovereign powers to international organizations.

(1a) Insofar as the Länder are competent to exercise state powers and to perform state functions, they may, with the consent of the Federal Government, transfer sovereign powers to transfrontier institutions in neighbouring regions.

(2) With a view to maintaining peace, the Federation may enter into a system of mutual collective security; in doing so it shall consent to such limitations upon its sovereign powers as will bring about and secure a lasting peace in Europe and among the nations of the world.

(3) For the settlement of disputes between states, the Federation shall accede to agreements providing for general, comprehensive, and compulsory international arbitration. ${ }^{1}$

In the united Germany, at the center of Europe after the end of the east-westconflict, was not only a hidden, but also a very open consensus between all the parties of the Bundestag, that the way of a united Germany is the membership in the European Communities, because Germany was and is one of the biggest

1 Law amending the Basic Law of 21 December 1992. 
beneficiaries of the integration process. And there was a new consensus too, that the CEECs should be integrated into the EC. Because of Germany's geographical position and its security and economic interests in Eastern Europe, it has always been clear that the eastern enlargement would be a "German-led enlargement" (Kolankiewicz 1994, 490). Already before the EU received a consensus about the enlargement strategy towards Eastern Europe, the united Germany had made an Eastern policy of its own. Chancelor Helmut Kohl and Foreign Minister Hans Dietrich Genscher argued already in 1991 in several speeches for the membership of Poland, Hungary and Czechoslovakia. In 1991/1992 there were concluded treaties with the neighbour states Poland, Czechoslovakia and Hungary in which Germany supported their EU-membership. Concerning the date of membership Germany's political leaders were very vague. From the Foreign affairs Office it was stated in 1992 that Poland, Hungary and Czechoslovakia could enter the Union around the year 2000. Germany tried to "Europeanize" the process of Eastern enlargement because Germany alone felt too weak to master the process of democratization in the CEECs. Enlargement would give the EU a greater collective presence in Eastern Europe, and would provide other West European countries with some leverage over German actions in Central and Eastern Europe.

Germany's government turned its attention after the final ratification and enactment of the Maastricht treaty in October 1993 to Eastern Europe. During its EU-presidency in the second semester of 1994, the German government declared the integration of Eastern Europe as a central priority. A major step in this process was the "pre-accession" strategy, approved by the European Council in Essen in December 1994. This strategy included the double promise of financial and infrastructural aid in the entering process into the Community. The pre-accession strategy was designed to prepare the candidate countries for future membership. It encompassed the following frameworks and mechanisms: Europe Agreements/ Association Agreements/Stabilisation and Association Agreements, Accession Partnerships/European Partnerships.

There were at least three major reasons for the German support of the widening process towards Eastern Europe. First, stabilisaty in the eastern area would increase German security too. Second, Germany could benefit economically from the membership of the CEECs in the EU. Third, moral reasons from history led to the support. Furthermore, membership was seen as an equivalent for the support of some CEECs in the unification process.

\subsection{Political and Military security}

Traditionally, Germany's security was a major concern. Throughout its history Germany has always paid the price in terms of war and insecurity of its central geographical position. Often, Germany or parts of it were objects of big powers 
surrounding the German Länder. During the cold war, West-Germany and EastGermany were as members of NATO and the Warsaw Pact respectively, located at the front. Two political and military systems bounced against each other. The situation from 1945-1989/90 was partly extremely unsecure. Nevertheless the two big military coalitions guaranteed a certain security in Europe. After the Wall came down and Germany was reunited, this country again became once again a geopolitical uncertainty to its east.

"From the standpoint of German security interests, EU enlargement would offer two primary benefits. First, it would move Germany from the eastern border of the EU to a more comfortable position to its middle. Thus it would have, in the form of Poland, the Czech Republic, Hungary, and possibly other postcommunist states the 'buffer zone' of allied and friendly countries that it has so often sought in the past, although through more unpleasant means" (Baun 1997, 5f.). Behind the ideas of the 'buffer zone' was the uncertain development of the Soviet Union/Russia, whose nationalism should concern the eastern European area.

The second big security benefit for Germany would be the political stability it would bring to Eastern Europe. Through enlargement - and already in the prospect of it -, the EU could export political stability which helped to guarantee its own security. A development which brought freedom and economic welfare in one part of Europe could not be maintained if there are open frontiers. The idea that the political system of liberal democracy would be widened up to the Polish/ Russian border increased the number of democracies in Europe and in the same way increased security as democracies do not tend to fight war against each other.

The third advantage lies in terms of internal security. Enlargement expands the area that enjoys liberty, security and the rule of law to embrace new member states. This enables them to strengthen the fight against organized and international crime. More effective measures can be taken to combat drug trafficking and trafficking of people as well as terrorism. Money laundering and financial crime too can be tackled more effectively. Asylum and refugee policies were standardized. Alongside equal reception conditions, common standards apply to asylum procedures and refugee status. With the support of EU states, shortcomings in the field of justice and domestic affairs in accession states can be remedied and suitable authorities and institutions put in place.

Enlargement is therefore a key transformational force, inspiring democratic change and economic liberalisation among those who wish to join. It is at the heart of the EU's soft power to extend the zone of peace, stability and prosperity on the continent. The appeal of the EU has been instrumental in the peaceful democratic transformation of Central and Eastern Europe and it remains the driving force for the reforms in the Western Balkans and in Turkey. It is in the EUs - and of course Germany's - vital interest to export stability into their neighbourhood rather than import instability from there. 


\subsection{German economic interests and the EU-enlargement}

"Just as Germany's geographical location makes it the most vulnerable member state to security threats from the east, it also makes Germany the country most likely to benefit from the economic opportunities afforded by postcommunist Europe" (Baun 1994. 6-7). First of all in Germany politicians thought to get a push in foreign commerce. And indeed trade between the applicant countries and later the new member countries doubled in a short time. The gross domestic product of Germany (and Austria) alone has risen by about $0.5 \%$ per annum thanks to enlargement. Rising exports to the accession states ensures higher economic growth in the EU member states and secures jobs there. Second, German companies can transfer their seats to Eastern and Central Europe, where the salaries and wages are much inferior to the salaries in Germany. Incidental wages are lower and, thus, companies are able to produce more cheaply. So they have a better situation on the world market. Since 1989 numerous German companies in sectors such as automobiles, chemicals and small manufacturing have established factories in the CEECs from which they supplied the EU and other markets. Private businesses from the old EU states can found branches in the new member states more easily and underpin their international competitiveness. Existing jobs are saved and new ones created. Enlargement makes possible extensive economic links with neighboring states in Eastern Europe. The former East Germany, in particular, can be expected to attract businesses engaged in trade with Eastern Europe. All in all, the EU's trade with the states of Central and Eastern Europe has quadrupled since 1989. Germany benefits particularly from this development. Today German companies sell more in the accession states than in the USA and Canada together.

Furthermore the CEECs have benefited tremendously from integrating their economies with the bigger and wealthier ones in Western Europe since the early 1990s. The objective of joining the EU served as an external anchor for reforms. As a result, these countries have gone from post-Communist chaos to orderly EU membership in less than fifteen years. And although the pace of reforms has slowed recently, the growth prospects in the region remain good. For the 'old' memberstates, the economic impact of enlargement has also been positive - although it has been much smaller, simply because the economies of the new members are so small. Some EU countries, in particular Austria and Germany, have done particularly well out of exporting to Central and Eastern Europe's fast-growing markets. And many West European companies have profited substantially from investing in retail, telecoms, energy or the media in the new Europe. But enlargement is changing the EU economy in a more profound way. Enlargement has allowed the emergence of a new, pan-European division of labour. This, in turn, will help the EU economy to stay competitive in a globalised world economy. 


\subsection{Moral interests}

Last but not least, Germany's interests in eastern enlargement derived from the attitude of the country in history. Not only the time of the Second World War burdened the German position towards the Eastern neighbours but also the time from the medieval age to the $20^{\text {th }}$ century shows many conflicts between German provinces and their eastern neighbours. The German feelings of moral duty and responsibility stem from the desire to atone for Germany's past aggression towards Eastern Europe. In the 90, leading politicians in West Germany realized more and more that the economic prosperity was also built on Soviet victimization of East Europeans and the erection of the iron curtain. The modernization process in the western part of Germany could be developed without being overstrained by claims from the east (cf. Pond 1966, pp. 32-33). But it was not only the historical dimension as one of the reasons for the promoton of the EU-enlargement. Furthermore, there was a debt of gratitude owed to the people of Eastern Europe, especially Hungarians, Poles and Czechs, who enabled the possibility of German unity in freedom and peace. In May 1989, it was Hungary opening the iron curtain for the first time at a pan European festival in Sopron. And in September the foreign minister Gyula Horn from Hungary cut with his Austrian homologue the iron curtain. In the German embassy in Prague, up to 5000 refugees from the GDR were supported by the Czech offices. There were deep feelings about the "gift of unification", which enabled the former GDR to automatically enter in NATO and the EU, while the other countries from the Warsaw Pact had to wait outside.

\section{The entrance of 12 countries 2004/2007}

On May $1^{\text {st }}$ in 2004 Poland, Hungary, Czech Republic, Estonia, Latvia, Lithuania, Slovakia, Slovenia, Malta and Cyprus became members of the EU. In 2007 followed Romania and Bulgaria as latecomers. It was the biggest enlargement ever, for the EU was nearly doubling its membership, increased its territory by 25 $\%$, its population by $20 \%$ and its GNP by ca. $5 \%$. But the membership of the new countries was not appreciated by all inhabitants in the old EU countries. This could be seen in a speech of former chancellor Schröder in the German Parliament on the occasion of the entray of these states. Schröder addressed the fears many Germans have about enlargement, saying he understood many people were worried about losing their jobs to lower wage competition in the new countries". The federal government takes seriously the concern that enlargement has increased pressure on the labor market", he said, justifying the employment restrictions Germany has implemented for new EU citizens. He also admitted globalization might cause some German companies to move jobs abroad, but added that such shifts could help strengthen their core business at home. "That can also lead to more 
employment in our own country... Together we have to make it clear that the opportunities outweigh the risks". Schröder indicated that Germany stood to gain much from enlargement by being once again at the heart of Europe. He pointed out that economic integration between old and new members was already underway and that Germany exported nearly as much to its eastern neighbors as it did to the United States. "The enlargement will not make us poorer, but rather richer", he said. However, he also renewed calls for harmonizing EU taxes, saying there could be no one-sided tax competition at the expense of those countries that are net contributors to the EU budget.

\section{EU-Enlargement today}

As the number of EU member states increases, the challenge of balancing enlargement with the capacity for and momentum of integration also grows. In recent years, the parameters of the EU enlargement policy have developed steadily. Within the framework of what is known as the "renewed consensus on enlargement", the EU has since 2006 focused on an enlargement strategy based on the following four principles.

- Consolidation: The EU meets its commitments and keeps the pledges it has made to accession candidates.

- Conditionality: Candidate countries must uphold the fair but rigorous criteria and conditions for accession.

- Communication: Greater transparency and improved communication are to ensure broad-based societal support for the enlargement process.

- Ensuring the EU is capable of absorbing new members: The EU must have the capacity to absorb and successfully integrate new member states without compromising its own ability to take action or its further development.

"The German Government is committed to these principles and is working to continue the enlargement process. At European level, it advocates a measured and judicious enlargement policy. Germany insists that the accession criteria be upheld in order to link enlargement with the process of internal EU consolidation. The German Government considers the EU's absorption capacity and the candidate countries' suitability for accession to be equally essential in decision-making" (auswaertiges-amt 2013).

At present, membership negotiations are underway with three countries: Croatia and Turkey opened negotiations with the EU in 2005, while talks with Iceland began in 2010. The Former Yugoslav Republic of Macedonia (FYROM) has been granted candidate status but has yet to begin formal membership negotiations. There are five further 'potential candidates' which have been recognised by the EU in the Western Balkans region of southeast Europe, meaning that they will be granted candidate status as soon as they fulfil the necessary requirements. These are: Albania, Bosnia and Herzegovina, Montenegro, Serbia and Kosovo. 
Treaty-based relations between the European Union and Turkeybegan already in 1963, when the Ankara Agreement, as it became known, was signed. By this signature Turkey was the second country, after Greece, to sign an Association Agreement with what was then the European Economic Community. The narrow cooperation of the EC with Turkey must be understood as cooperation with a NATO-member during the East-West-Conflict. The Agreement established close economic ties, which in 1995 developed into a customs union. Article 28 for the first time envisaged accession as a possible prospect: "As soon as the operation of this Agreement has advanced far enough to justify envisaging full acceptance by Turkey of the obligations arising out of the Treaty establishing the (European Economic) Community, the Contracting Parties shall examine the possibility of the accession of Turkey to the Community".

Having officially applied for EU membership in 1987, Turkey got candidate status by the European Council in Helsinki in 1999. Once the European Council had concluded in December 2004 that "Turkey sufficiently fulfils the Copenhagen political criteria", ${ }^{2}$ the way was clear to open accession negotiations on 3 October 2005. The negotiation talks between the EU and Turkey are not very easy because France's President Sarkozy (2007-2012) as well as Chancellor Angela Merkel (since 2005) in her role as party leader of the CDU, were against Turkish membership. They preferred a "privileged partnership" with Turkey. Officially, the German Government backed of course the opening of accession negotiations withTurkey and is in favour of conducting them as an open-ended process. But from the government it often emphasized that Turkey's accession to the EU is conditional on the country strictly fulfilling the Copenhagen criteria and implementing the Ankara Protocol in its entirety, as well as on the EU's capacity to absorb new members.

Of a total of 35 chapters under negotiation, only one, Science and Research, has been provisionally concluded to date. Since 2005, another twelve have been opened, the most recent being the chapter on Food Safety, Veterinary and Phytosanitary Policy, which was opened in June 2010. On 21 December 2012, Foreign Minister Westerwelle recommended opening negotiations on additional chapters during the first six months of 2013. For Westerwelle, Turkey had over the past decade made great progress. The country could build bridges to the Islamic world in Europe's neighbourhood. Political developments in the EU's and Turkey's common neighbourhood in the last years have underlined the value of closer liaison. In this context, the European Commission announced in October 2011 a Positive Agenda with respect to Turkey, which was welcomed by the Council of Ministers.

Thanks to its close political, cultural and economic ties with the country- there are nearly 2 mill. Turks living in Germany -, Germany has a special interest in

2 Brussels European Council 16/17 December 2004; Presidency Conclusions, 16238/1/04 REV 1, p. 4. 
Turkey moving closer to EU membership. Germany is also keen for it to keep up the momentum for reform, as this will have a major impact on its EU prospects. Turkey is crucial to stability in Europe's neighbourhood, as well as for the EU's energy supply. It likewise plays an important role in the intercultural dialogue between Europe and its neighbours in the Near and Middle East, as well as North. Nowadays, Germany is in favouring the consolidation of the EU. The last developments in the EU have shown that for most European peoples the enlargement process was too fast. Therefore, they are looking for more consolidation which must be suspected by the European governments.

\section{References}

http://www.auswaertiges-amt.de/EN/Europa/Erweiterung/Grundsätze_Erweiterungspolitik_ node.html (abgerufen am 7.5.2013).

Baun, Michael 1997: Germany and EU Enlargement", (Paper presented at the $5^{\text {th }}$ Biennial ECSA Conference, Seattle, May 29-June 1, 1997.

Kolankiewicz, George 1994: Consensus and Competition in the eastern Enlargement of the European Union, in: International Affairs, 70, pp. 477- 495.

Pond, Elizabeth 1996: Germany finds its Niche as a regional Power, in: The Washington Quarterly, 19, pp. 25-43.

Woyke, Wichard 2010: Die Außenpolitik Frankreichs. Eine Einführung, Wiesbaden. 


\title{
Hard Core Europe? Possible Scenarios for the Prospect of Differentiated Integration?
}

\author{
Georgiana CICEO
}

\begin{abstract}
The discussion on differentiated/flexible integration is far from novel. Ever since the first enlargement back in the 1970s a consistent literature started to develop in reaction to the increasing heterogeneity of the political, economic, social preferences and capabilities of the Member States. Differentiated integration received increased consideration in the $1990 \mathrm{~s}$ against the background of the forthcoming eastward enlargement. Back then, differentiated integration was designed as a possible solution for the loss of homogeneity occurred because of enlargement. Closer to our days, the differentiated integration has made a powerful comeback. The crisis has laid bare the flaws in the design of Economic and Monetary Union. As part of the solutions put forward, an even clearer distinction between euro and non-euro Member States came to dominate the discussions. However, the challenges posed by it are still to be explored especially in view of the ongoing discussion on the reform of the European Union. Proposals for a profound restructuring of the architecture of the EU's economic governance have intensified beginning with 2012 The present article analyses the challenges posed by differentiated integration to the countries remaining at the periphery of the core and to investigate whether they do not threaten to raise new frontiers.
\end{abstract}

Keywords: differentiated integration, EU reform, frontiers

The differentiated course of integration is considered suitable solution for easing the tension between the opposing demands for further deepening of integration and those for enlarging the EU membership. As such, it can be regarded as an useful tool for addressing the ever-growing heterogeneity of the Union: it offers convenient ways out for overcoming not only the discrepancies existing among the individual Member States in terms of economic power, their potential to pursue the deepening of integration or capacity of expanding it into new policy areas, but also their attitude towards the ultimate goals of the entire process of European. Although a commonly acknowledged definition of differentiated integration did not emerged yet, there is considerable overlapping among those put forward so far. For instance, Alex Warleigh considers that differentiated or flexible integration refers to 'the ability of Member States to choose not to participate in particular policies no matter how they are made'. ${ }^{1}$ As a result, it is 'all about allowing the creation of inequalities'. ${ }^{2}$ For Clara Brandi and Michael Wohlgemuth, differentiated

1 Alex Warleigh, Flexible integration. Which Model for the European Union?, New York: Sheffield Academic Press, 2002, p. 4.

2 Alex Warleigh, „Towards Network Democracy? The Potential of Flexible Integration”, in European Integration in the Twenty-First Century: Unity in Diversity?, eds. Mary Farrell, Stefano Fella and Michael Newman, London: Sage, 2002, p. 110. 
integration is a 'general term' employed for explaining 'the possibility of Member States to have different rights and obligations with respect to certain common policy areas'. ${ }^{3}$ It refers to the possibility of having temporary or permanently 'different levels of integration within the EU'. ${ }^{4}$ As far as Dirk Leuffen, Berthold Rittberger, Frank Schimmelfennig are concerned, they define the European 'system of differentiated integration' proceeding from the assumption that the EU refers not to "many Europes" "with task-specific jurisdictions each having their own organization', but to 'one Europe with an organizational and Member State core but with a level of centralization and territorial extension that vary by function'. ${ }^{5}$ It is an option that 'allows individual countries to remain at the status quo while others move ahead'. ${ }^{6}$

The discussion on differentiated/flexible integration is far from novel. Various modes of flexible integration have gained over the time considerable prominence in the political debate. Ever since the first enlargement back in the 1970s a consistent literature started to develop in reaction to the increasing heterogeneity of the political, economic, social preferences and capabilities of the Member States. Discussions on differentiated integration received increased consideration in the 1990s against the background of the forthcoming eastward enlargement. Back then, differentiated integration was designed as a possible solution for the loss of homogeneity occurred because of enlargement. Closer to our days, differentiated integration has made a powerful comeback. The crisis has laid bare the flaws in the design of Economic and Monetary Union. As part of the solutions put forward, an even clearer distinction between euro and non-euro Member States came to dominate the discussions.

Ever since its inception, the process of European integration determined the creation of a more or less visible network across the Member States. ${ }^{7}$ One of the major principles enshrined in the Treaty of Rome was that of equal rights and obligations for all member states. A vast 'body of common rights and obligations

3 Clara Brandi and Michael Wohlgemuth, Strategies of Flexible Integration and Enlargement of the European Union. A Club-theoretical and Constitutional Economics Perspective, Freiburg Discussion papers on Constitutional Economics (2006), p. 2, http://www.econstor. eu/handle/10419/4367 (accessed February 21, 2013).

4 Ibidem.

5 Dirk Leuffen, Berthold Rittberger and Frank Schimmelfennig, Differentiated Integration. Explaining Variation in the European Union, Basingstoke: Palgrave Macmillan, 2012, p. 10.

6 Frank Schimmelfennig, Dirk Leuffen, Berthold Rittberger, Ever looser union? Towards a theory of differentiated integration in the EU, EUSA Conference 2011, Boston, p. 12, http:// www.euce.org/eusa/2011/papers/9g_schimmelfennig.pdf (accessed February 21, 2013).

7 Cristina-Maria Dogoț, "How Permeable or Impermeable Could Be the Borders? Introduction", Eurolimes no. 13: Permeability and Impermeability of Socio-Economic Frontiers within the European Union, ed. Violaine Delteil, Cristina-Maria Dogot, Kozma Gabor and Jarosław Kundera, Oradea: Oradea University Press, 2012, pp. 5-8. 
which bind all the Member States together within the European Union'8 known as the acquis communautaire has been developed over the years. Nevertheless, in parallel another set of rules that concerns only a limited number of Member States has also paved its way and has come to raise vital questions about the nature and direction of the process of European integration. If thus far it was supposed that the differentiation is having just a temporary character, it becomes gradually more obvious that we are heading towards a situation where it contributes to the creation of permanent different standings inside the very same European family. Furthermore, differentiated integration additionally burdens the democratic credibility of European integration ${ }^{9}$ and generates fears of future inner borders inside the EU, 'separating people despite the fact that they are not physical'. ${ }^{10}$

Various modes of flexible integration have gained over time considerable prominence in the political debate. Alexander Stubb divided the existing political conceptions of differentiated integration into three principal categories/models: 1./ multi-speed, 2./ variable geometry and 3./ à la carte, by using three variables time, space and matter. ${ }^{11}$ Although each of the proposed models conveys a series of often subtle distinctions and implies different strategies for action, all stem from a similar diagnosis of the EU's malady: namely, that of seeking to apply excessively strict common goals and disciplines to countries, which in fact are strikingly diverse. Despite the fact that a certain number of variants of the above-mentioned models emerged in the mean time ${ }^{12}$, for the purpose of this discussion we will preserve Stubb's categorization.

The multi-speed model, the oldest among the three, whose origins stretch as far back as the beginning of the 1970s when the first enlargement round of the EC took place and consequently a debate on the need of solving the problem of growing heterogeneity of the EC started, proceeds from the assumption that while all the Member States want to reach the same integration goal, they do not have equal abilities and hence they reach this goal at different speeds. Some countries that are capable and willing to take a step forward in the integration reach the identified goal rather quickly whereas the other countries join

$8 * * *$, “Community acquis", http://europa.eu/legislation_summaries/glossary/community_ acquis_en.htm (accessed February 21, 2013).

9 Alex Warleigh, Democracy in the European Union: Theory, Practice and Reform, London: Sage, 2003, pp. 72-74.

10 Ioan Horga, Mircea Brie, "Europe between Exclusive Borders and Inclusive Frontiers", Studia Universitatis Babeş-Bolyai Studia Europaea, nr. 1, vol. LV (2010), p. 83.

11 Alexander C.-G. Stubb, "A categorization of differentiated integration", Journal of Common Market Studies, no. 2, vol. 34 (1996), pp. 283-295.

12 See for instance Warleigh, Democracy in the European Union, pp. 70-71. 
in later according to their capabilities and political will. ${ }^{13}$ From this perspective, the principal variable is time as differentiation in the level of integration of respective Member States is considered just an exceptional, temporary solution, not a permanent. The model revolves around a core - an 'avant-garde' ${ }^{14}$ or 'enhanced cooperation' or 'consolidated cooperation' group, consisting of those states which are willing and capable to integrate in a wider range of policies. For the sake of effective reaching of integration goals, they oblige themselves to a long-term sharing of common strategic and tactical interests. Different politicians envisaged different designs for this core, the most prominent remaining those put forward by Wolfgang Schäuble and Karl Lamers in $1994^{15}$ and Joshka Fischer in $2000^{16}$ as possible solutions for dealing with the accession of Central and Eastern European Countries to the European Union. The former shaped the center in the form of a 'hard-core' consisting of an elite club of Member States (France, Germany, Belgium, the Netherlands and Luxembourg), created with the aim of preventing the other, which are currently either unable or for some reasons hesitating, from hindering their determination to move ahead the process of integration. The other states could follow suit, but their admission in the inner circle remained dependent upon their capacity to assume the necessary obligations. The proposal generated immediately after its publication a wave of criticism equally from the supposed ins and outs. While the smaller countries inside the 'hard-core' felt themselves uneasy because of the Franco-German domination, those remaining outside regarded the proposal as too exclusivist because they feared that they might be treated as second-class members. The core in the vision of Joshka Fischer would resemble a 'centre of gravity' made of 'those states that want to cooperate more closely than others, as is already the case with the Economic and Monetary Union and with Schengen'. This group of states 'would conclude a new European framework treaty, the nucleus of a constitution of the Federation', on the basis of which 'the Federation would develop its own institutions, establish a government that within the EU should speak with one voice on behalf of the members of the group on as many issues as possible'. The 'center of gravity' would have to be the avant-garde, the driving force for the completion of political integration, and it should from the start comprise all the elements of

13 Stubb, p. 285.

14 Jacques Delors, An „Avant-garde” driving the European unification process forward. Speech at International Bertelsmann Forum „Europe without borders“, Berlin, January 19-20, 2001, http://www.eng.notre-europe.eu/ (accessed February 15, 2013).

15 Wolfgang Schäuble, Karl Lamers, Überlegungen zur europäischen Politik. Position Paper of the CDU/CSU-Bundestagsfraktion, September 1, 1994, http://www.cducsu.de/upload/ schaeublelamers94.pdf (accessed February 21, 2013).

16 Joshka Fischer, From Confederacy to Federation: Thoughts on the Finality of the European Integration, Berlin: Humboldt University, May 12, 2000. http://germanhistorydocs.ghi-dc. org (accessed February 15, 2013). 
the future federation' ${ }^{17}$ Neither this model did manage to break out without a good deal of criticism. However, it is necessary to be mentioned that around the center there is also a periphery which includes the countries that are either unable to achieve the level of integration of the core states (the laggards) or unwilling to do so (the opt-outs).

The model of variable geometry is based on the premise that the differences among the Member States could hamper EU's ability to achieve the necessary coherence. According to the definition of the European Commission, the term is 'used to describe the idea of a method of differentiated integration which acknowledges that there are irreconcilable differences within the integration structure and therefore allows for a permanent separation between a group of Member States and a number of less developed integration units'. ${ }^{18}$ This means that, on the one hand, there are Member States, which are not capable of reaching a particular level of integration. On the other hand, there are Member States for whom some policy areas are so sensitive in term of national interest that they are not willing to agree with expanding of integration into these policy areas. In a similar manner with the multi-speed model, the present one also takes into consideration the reality of a core and of a periphery, but in contrast with its challenger admits that there are differences with regard to the integration goals of individual Member States and the policy areas that they are ready to open for integration (not only with regard to their speeds of integration). Therefore, the model of variable geometry is considered as a compromise between the supranational and intergovernmental approach to the integration. It is often associated with the model of 'concentric circles' advanced in 1994 by the at that moment French Prime Minister, Edouard Balladur. In an interview for the French daily paper Le Figaro on August 30 of that year, he stated that Europe should consist of three concentric circles. ${ }^{19}$ The inner circle should comprise the Member States closely integrated in economic and monetary sphere as well as in the defense matters (EU core); a system of states based on existing Treaties (all the EU Member States) constitute another circle; and the third outer circle comprise other states of Europe that have established contractual relationship with the EU. A variant of the model concentric cir-

17 Fischer, pp. 9-10.

18 ***, "Variable geometry", http://europa.eu/legislation_summaries/glossary/variable geometry_europe_en.htm (accessed February 21, 2013).

19 The first to coin the term 'concentric circles' was Christopher Tugendhat, former British Commissioner and Vice-President of the European Commission, who, in a lecture delivered in 1984, considered this conception as a moderate version of variable geometry. See Christopher Tugendhat, Europe - What Matters Now, The Swinton Lecture, Cambridge, July 14, 1984, http://aei.pitt.edu/12017/1/12017.pdf (accessed February 21, 2013). Further, the idea was taken up by Jacques Delors and promoted in reaction to the events of 19891991. See Helen Wallace and William Wallace, Flying together in a larger and more diverse European Union, The Hague: The Scientific Council for Government policy, 1995, p. 62. 
cles would be the one of 'polycentric circles' that goes very much in the direction of a Europe à la carte.

The least orthodox of the three models of differentiated integration is the $a$ la carte one, designed for the first time by Ralf Dahrendorf in $1979^{20}$ in response to the stagnation that gripped integration throughout the 1970s. Based on the principles of intergovernmentalism, the model, as the metaphor of the menu of a restaurant from where it derives its name might suggest, considers that the Member States should be given the possibility of choosing from a variety of policy areas the ones in which they wish to participate (the matter of integration) by preserving a minimum of common goals ${ }^{21}$ - 'that is common policies where there are common interests without any constraint on those who cannot, at a given point of time, join them' ${ }^{22}$ After being opposed to any form of differentiated integration for the most part of the 1980s out of conviction that by preserving uniformity it could determine the speed of the entire integration process and would prevent it to 'spillover' into sensitive policy areas, UK shifted towards an à la carte model against the background of the negotiations on the Maastricht Treaty, not because it had completely abandoned its fears of losing influence if flexibility was to be considered a principle of EU governance, but because it wanted to counter the German concept of 'hard core' and the French one of 'concentric circles' ${ }^{23}$ In 1994, in a speech at the Leiden University, the then Prime Minister John Major, while recoiling from the idea of a Europe with a core and a periphery 'in which some would be more equal than others', stated his view according to which 'no Member State should lay claim to a privileged status on the basis of its participation' in some of the common policies or areas of close co-operation. ${ }^{24}$ On the contrary, only 'flexible arrangements allow countries freedom and choice on how they decide to participate in the pursuit of our shared aims'. ${ }^{25}$

$*$

The first treaty departure from the imperative of uniformity was made in the context of the Treaty of Maastricht in order to allow for the implementation of far reaching policies such as the monetary union. It was only with the Treaty of

20 Ralf Dahrendorf, A Third Europe? Third Jean Monnet Lecture, Florence: European University Institute, November 26, 1979, http://aei.pitt.edu/11346/2/11346.pdf (accessed February 21, 2013).

21 Under the minimum of common goals, an institutionalized economic cooperation (e.g. the common market) is mostly understood.

22 Dahrendorf, pp. 20-21.

23 Warleigh, Flexible integration, p. 15.

24 John Major, Speech at the William and Mary Lecture, Leiden University, September 7, 1994, http://www.johnmajor.co.uk/page1124.html (accessed February 21, 2013).

25 Ibidem. 
Amsterdam that flexibility was introduced as a principle of governance in the EU. The Treaty of Nice brought with it further clarifications with regard to the implementation of this principle. With the Treaty of Lisbon, a number of new avenues for advancing with the differentiated integration have been opened. At first, came the Charter of Fundamental Rights included in the Treaty, but not fully applicable to countries like Poland or UK. Then, gradually a number of other pieces of legislation came to supplement the already well-established enhanced cooperation in terms of foreign and security policy and justice and home affairs. For instance, only fourteen Member States adopted a Regulation on the right of international couples to choose which law to apply to their divorce at the moment of their marriage, thus preventing costly litigations, both economically and emotionally in $2010 .{ }^{26}$ In response to the fact that the existing legislation on a 'European patent' developed within the framework of the European Patent Office, was nothing more than the sum of the individual countries' patents, in 2012 a Regulation on a unitary patent ${ }^{27}$ was adopted after difficult negotiations by all EU Member States but Spain and Italy who opposed the document for linguistic reasons. ${ }^{28}$ Closer to our days, we have a highly divisive European Commission proposal for a tax on financial transactions that gathers the support of only 11 EU Member States and tends to become a test of 'how far groups of countries are willing to plough ahead on economic legislation and leave others behind' ${ }^{29}$ The proposed document does not enjoy even the support of all the euro zone countries despite the fact that taxation is so closely linked to member states' economies and could have an impact on non-participating countries.

Nevertheless, Economic and Monetary Union and the Schengen Agreement preserve a definite ascendancy over the various experiments in differentiated integration carried out so far. A comparative analysis about the impact of flexibility on 15 case studies from five policy areas undertaken by Alkuin Kölliker managed to highlight in an authoritative way the progressive advance of differentiated

26 European Commission, Lithuania is the 15th EU Member State to sign up to enhanced cooperation rules to help international couples, Press Release, November 20, 2012, http:// europa.eu/rapid/press-release_IP-12-1231_en.htm (accessed February 21, 2013).

27 European Parliament and the Council of the European Union, Regulation No 1257/2012 implementing enhanced cooperation in the area of the creation of unitary patent protection, December 17, 2012, http://eur-lex.europa.eu/LexUriServ/LexUriServ.do?uri=OJ:L:2012:36 1:0001:0008:EN:PDF (accessed February 21, 2013).

28 Carlo Maria Cantore, "We're one, but we're not the same: Enhanced Cooperation and the tension between unity and asymmetry in the EU", Perspectives on Federalism, Issue 3, Vol. 3 (2011): E - 13.

29 Ian Wishart, "The divisive tax", European Voice, February 21, 2013, http://www. europeanvoice.com/article/imported/the-divisive-tax/76473.aspx (accessed February 21, 2013). The 11 countries are: Austria, Belgium, Estonia, France, Germany, Greece, Italy, Portugal, Slovakia, Slovenia, Spain. 
integration from the mid-1980s to the end of the 1990s ${ }^{30}$ Moving the discussion forward to the present day, it turns out that the experience acquired up to now in differentiated integration indicates a certain preference for the multi-speed model, while there are still no notable examples for the use of the variable geometry model. In the practice of the European Union, it is also possible to find some examples converging towards the à la carte model or at least borrowing some of its features. Primarily it is the option of the so-called 'opt-out', or if you like, the option of negotiating an exemption from some policy provisions or even from the whole policies. According to Alex Warleigh ${ }^{31}$, one can sense a certain preference for the multi-speed model when it comes to policies with a predominant Community method of policy making because of the significant powers of the Commission and European Parliament, who tend to protect both small states and 'the general European interest' by preventing the emergence of a 'hard core'. At the other end of the spectrum there are the transgovernmental policies in the classification of Helen Wallace ${ }^{32}$ in which case the preferences have a tendency towards the à la carte model as usually clusters of member states agree to cooperate on various policy issues.

Apart from the legal provisions that open the possibility for differentiated cooperation in common foreign and security policy and justice and home affairs, there are a number of other possibilities for advancing in this direction. Firstly, we have the option of starting the integration outside the existing treaty framework and bringing it inside at a later point as it was the case with the Schengen Agreement. Secondly, it is possible to make use of the provisions of the Art. 114(4) Treaty on the Functioning of the European Union (TFEU), according to which 'if,[...], a Member State deems it necessary' can 'maintain national provisions on grounds of major needs referred to in Article $36^{33}$, or relating to the protection of the environment or the working environment'. Finally yet importantly, differentiated integration can proceed based on those provisions referring to enhanced cooperation. Art. 20(1) of the Treaty on the European Union (TEU) states that 'Member States which wish to establish enhanced cooperation between themselves within the framework of the Union's non-exclusive competences may make use of its institutions and exercise those competences by applying the relevant provisions of the Treaties'.

30 Alkuin Kölliker, Flexibility and European Unification: The Logic of Differentiated Integration, New York: Rowman and Littlefield, 2006.

31 Warleigh, Flexible integration, p. 12.

32 Helen Wallace, "An Institutional Anatomy and Five Policy Modes", Policy-Making in the European Union, eds. Helen Wallace, Mark A. Pollack and Alasdair Young, 6-th ed., Oxford: Oxford University Press, 2010, pp. 100-102.

33 Public morality, public policy or public security; the protection of health and life of humans, animals or plants; the protection of national treasures possessing artistic, historic or archaeological value; or the protection of industrial and commercial property. 
Over the years, differentiated integration came to be seen as a "way to find compromise and avoid log jam' ${ }^{34}$ and a useful 'tool for the management of diversity'. ${ }^{35}$ Despite the fact that according to Art. 20(1) TEU '[e]nhanced cooperation shall aim to further the objectives of the Union, protect its interests and reinforce its integration process' and that '[s]uch cooperation shall be open at any time to all Member States', differentiated integration cannot be regarded as a panacea for the problem of boosting the completion of the European construction. As a principle of EU governance, differentiated integration or flexibility remains divisive. Its proponents have to 'assuage the concerns of many actors at both EU and national levels and show that it can deepen (or at least not impede) integration' ${ }^{36}$

Differentiated integration generates anxiety as it opens a line of fracture with a long-established EU principle, namely, that of solidarity, which was part and parcel of the European project ever since its launch. It was generally considered that, if people are 'to give their full support to and participate fully in European integration', greater emphasis must be placed on 'their common cultural values and roots as a key element of their identity and their membership of a society' founded among other essential principles on solidarity. ${ }^{37}$ European solidarity can be read in many keys, but the most relevant for the present discussion is the one of constructing a lasting cross-national sense of unity. In this respect, the common policies, which lie at the heart of the European policy-making, are bound to 'give substance to the solidarity' that binds Member States' economies and currencies ${ }^{38}$. Now, restoring the credibility and integrity of the economic and monetary union has brought in sight the perspective of building up four unions- a banking union for the recovery of the financial stability, a fiscal union for achieving the goal of fiscal stability and for facing public finance challenges, an economic union to support growth, and a political union for redressing the long established problem of the democratic legitimacy. Out of the four proposed unions, the project of building a banking union is by far the most advanced. However, each of the four unions and the banking union in particular raise concerns that the line, which has

34 Alexander C.-G. Stubb, "The 1996 Intergovernmental Conference and the management of flexible integration", Journal of European Public Policy, no. 1, vol. 4 (1997), p. 47.

35 Warleigh, Democracy in the EU, p. 68.

36 Ibidem, p. 69.

37 European Parliament and the Council of the European Union, Decision No 1855/2006/EC establishing the Culture Programme (2007 to 2013), December 12, 2006, http://eur-lex. europa.eu/LexUriServ/LexUriServ.do?uri=OJ:L:2006:372:0001:0011:EN:PDF (accessed February 21, 2013).

38 Leo Tindemans, Report on the European Union, Bulletin of the European Communities Supplement 1/1976, http://aei.pitt.edu/942/1/political_tindemans_report.pdf (accessed February 21, 2013). 
been drawn since 2002 between the euro and non-euro area Member States, would lose its provisional character (as with the exception of the three opt-outs - United Kingdom, Denmark and Sweden, the other countries had an obligation to enter the euro area ${ }^{39}$ and become more entrenched and have implications with regard to the voting power and the influence of non-euro countries.

That is why in his speech on the State of the Union in 2012, the president of the European Commission felt himself compelled to emphasize that 'in Europe, we need no more walls dividing us! ${ }^{40}$ While insisting on the necessity of completing the economic and monetary union, which is essential to be supplemented by a genuine banking union and a fiscal union, the Commission President stressed that they would have to be properly equipped with institutional and political mechanisms. The inevitable reform of the treaty framework that can start after the 2014 European elections will have to provide the solutions for building a 'federation of states' in which ' $[\mathrm{n}] \mathrm{o}$ one will be forced to come along. And no one will be forced to stay out. The speed will not be dictated by the slowest or the most reluctant' ${ }^{41}$ Although the assurances are that 'there is only one European Union. One Commission. One European Parliament' ${ }^{42}$, the fact that according to Art. 20(1) TEU '[a]11 members of the Council may participate in its deliberations, but only members of the Council representing the Member States participating in enhanced cooperation shall take part in the vote' is generating the discomfort of those who will not participate in the decision making.

For instance, in a country like the United Kingdom whose government decided not to participate in the banking union, the House of Lords issued in conclusion of a long series of debates on the future of economic and monetary integration a report that states that ' $[\mathrm{w}] \mathrm{e}$ are deeply concerned that closer integration of an inner core of Member States could threaten the integrity of the single market'. ${ }^{43}$ As it is evident that the euro area would remain one of its key trading partners, the members of the UK Parliament could not afford to remain complacent with the current events and ignore the many legal and political intricacies of the project. The fear is that a certain 'degree of marginalization will be inevitable as the euro area (and possibly other Member States) take steps towards deeper integration' ${ }^{44}$ This feel-

39 Jacques Bourrinet, "L'évolution de la zone euro au travers de la plasticité de ses frontières", Eurolimes no. 8: Europe and its Economic Frontiers, ed. Luminița Şoproni, Angelo Santagostino and Ernő Molnar, Oradea: Oradea University Press, 2009, pp. 10-14.

40 José Manuel Durão Barroso, State of the Union 2012, Address to the Plenary session of the European Parliament, Strasbourg, September 12, 2012, http://europa.eu/rapid/press-release SPEECH-12-596_en.htm (accessed February 21, 2013).

41 Ibidem.

42 Ibidem.

43 House of Lords, European Union Committee, European Banking Union: Key issues and challenges, 7thReport of Session 2012-13, December 12,2012, http://www.publications. parliament.uk/pa/ld201213/ldselect/ldeucom/88/88.pdf (accessed February 21, 2013), p. 42.

44 Ibidem, p. 41. 
ing might be reinforced by the prospect that "euro area countries and other participating Member States will converge towards common positions in a number of areas. This may place an EU-27 single market under severe strain, in particular if a majority of non-euro Member States chooses to participate in banking union' ${ }^{45}$ The House of Lords Report cautions that the banking union proposals hide the risk of losing the cohesion of the European structure as this is now redesigned in the form of a construction with a variable geometry.

Especially the idea of creating a new institutional setup for the governance of the economic and monetary union meets with restraint within certain corners of the EU polity. Martin Schultz, the President of the European Parliament, was insisting that 'there is no need whatsoever to create new, parallel Unions and new, parallel institutions'. In the context of euro zone governance as well, 'the integrity of the Community institutions must be safeguarded'. When it comes to reforms, these will have to enable 'the 25 Member States which are keen to take part in all EU policies to do just that' ${ }^{46}$ His views are reinforced by the Thyssen Report, which considers it necessary 'to place the governance of the EMU within the institutional framework of the Union' and 'to proceed swiftly by maximizing the possibilities given by the existing Treaties and their elements of flexibility'. ${ }^{47}$

In the hitherto discussions on the creation of the banking union the concerns of the non-euro area countries have been largely assuaged. The proposed documents on the creation of the Single Supervisory Mechanism (SSM) and on the modifications to the functioning of the European Banking Authority contain important safeguards for the non-euro Member States. Accordingly, although the Treaty of Lisbon places the highest decision making authority in the European Central Bank (ECB) with the Governing Council in which the non-euro Member States have no vote, in the SSM, the decisions will be drafted by a Supervisory Board in which each participating state has one vote acting by simple majority ${ }^{48}$ and enter into force if the Governing Council of the ECB does not object them in a period of 10

45 Ibidem, p. 42.

46 Martin Schulz, Speech to the European Council, October 18, 2012, http://www. socialistsanddemocrats.eu/gpes/media3/documents/4057_EN_schulz_council_en_121018. pdf (accessed February 15, 2013).

47 Marianne Thyssen, Report with recommendations to the Commission on the report of the Presidents of the European Council, the European Commission, the European Central Bank and the Eurogroup "Towards a genuine Economic and Monetary Union”, A7-0339/2012, October 24, 2012, http://www.europarl.europa.eu/sides/getDoc.do?pubRef=-//EP// NONSGML+REPORT+A7-2012-0339+0+DOC+PDF+V0//EN\&language $=\mathrm{EN} \quad$ (accessed February 15, 2013), p. 18.

48 Council of the European Union, Proposal for a Council regulation conferring specific tasks on the ECB concerning policies relating to the prudential supervision of credit institutions, 17812/12, December 14, 2012, http://register.consilium.europa.eu/pdf/en/12/st17/st17812. en12.pdf (accessed February 15, 2013), Art. 19 (2ab). 
days. When a non-euro Member State objects an observation of the Governing Council to a draft proposal of the Supervisory Board, the Governing Council will, according to the current proposal, have to give an opinion on the reasoned disagreement expressed by the Member State and, stating its reasons to do so, confirm or withdraw its objection. ${ }^{49}$ The relations of the non-euro Member States with the proposed mechanism, as opt-ins with no voice in the Governing Council of the $\mathrm{ECB}$, are further detailed in many other articles of the future Regulation, which leads to the conclusion that even though the Treaty provides a 'relatively narrow basis for the involvement of the non-euro countries', yet it 'provides strong safeguards to protect' their interests. ${ }^{50}$

In the mean time, with regard to the next steps in the direction of the overall reform of the EU treaty framework, the opinions of the European leaders are split between the Angela Merkel's perceived need for greater 'Europeanization of national powers', David Cameron's aspiration towards denationalization of European powers, and François Hollande's vision of a stronger political union. ${ }^{51}$ Angela Merkel proceeds from the imperative of renewing the foundations of economic and monetary union. In order to dissipate the fears of those concerned of the prospect of a possible 'division between an EU of the 17 and of the 27, soon to be 28 ' she stresses that the renewed economic and monetary union is 'no closed club of euro countries' and 'does not lead to a two-speed Europe but, rather, creates a double-strength European Union'. However, she considers that there is necessary to decide 'whether only parliamentarians from the euro countries should be allowed to vote on such matters', but 'without establishing an additional parliamentary institution'. ${ }^{52}$ David Cameron, while mulling over the alternatives available for shaping the future of Europe, has come to the conclusion that any discussion will need to have as starting point the observation that 'we are a family of democratic nations, all members of one European Union, whose essential foundation is the single market rather than the single currency'. He agrees that at some stage in the next few years 'some big institutional changes' will become a must for 'the long term future of the Euro'. Yet, these will have to work fairly for those inside and outside the euro zone as it is 'a vital interest for us to protect the integrity and fairness of the single market for all its members'. The structure to be created will need to 'accommodate the diversity of its members' and to enable Europe 'to act with

49 Ibidem, Art. 6 (6ab).

50 Zsolt Darvas and Guntram B. Wolff, Should non-euro area countries join the SSM?, http:// www.eu-oplysningen.dk/upload/application/pdf/175b0f18/dkparlpaperformatted.pdf (accessed February 15, 2013).

51 ***, ,Charlemagne: Europe à l'Hollandaise. François Hollande's flawed vision for Europe”, The Economist, (February 9-15, 2013), p. 27.

52 Angela Merkel, Speech by Federal Chancellor Angela Merkel in the European Parliament, Brussels, November 07, 2012, http://www.bundesregierung.de/Content/EN/ Reden/2012/2012-11-07-merkel-eu.html (accessed February 15, 2013). 
the speed and flexibility of a network, not the cumbersome rigidity of a bloc'.$^{53}$ For François Hollande, Europe 'cannot be limited to a market, a budget, a currency, irrespective of their value', in the very same manner as it cannot be equated with a 'sum of treatises' or a 'compound of rules'. Neither can Europe survive as an 'accumulation of nations in which each of these comes to seek what is useful for itself and only for itself'. His solution lies in a 'differentiated Europe' which by no means is either a 'two speed Europe', because this would swiftly become imbalanced, or an à la carte Europe, because this would mean a divided Europe. With regard to the future institutional setting, the French vision is also relatively blurred. It is ready to accept the euro governance, new financial instruments and under certain conditions a budget for the euro zone, that will need to be connected to the budget of the European Union. ${ }^{54}$

As such, the British vision exposes little overlapping with both the German and in particular the French ones. However, it is obvious that all the three leaders agree that a new blueprint of the institutional framework is necessary and that a Europe with two speeds is not for the time being a convenient solution. 'The euro area is not likely to become a federal state in the traditional sense of the term in the near future'. ${ }^{55}$ Moreover, they find common ground with respect to the need for a democratic scrutiny of the institutions and decision-making processes by the European and national parliaments depending on the level of decision. In addition they favor a more efficient use of the mechanisms for enhanced cooperation already existing in the treaties as these perceived as tools for effective policy-making rather than tools for building a 'core Europe'. ${ }^{56}$ The overall decisions taking by now with regard to the banking union with its joint banking supervision and the and enhanced cooperation in fiscal and budgetary policy seem to reinforce this trend and add credibility to the political discourse on future reform irrespective of how elusive this might be right now.

Differentiated integration has been an important element of the political agenda and academic thinking on European integration for a long time. After the collapse

53 David Cameron, EU Speech at Bloomberg, January 23, 2013, www.number10.gov.uk/news/ eu-speech-at-bloomberg/ (accessed February 15, 2013).

54 François Hollande, Intervention devant le Parlement Européen, Strasbourg, February 5, 2013, http://www.relaunchingeurope.eu/sites/default/files/05\%2002\%2013\%20Discours $\% 20$ du $\% 20$ pr $\%$ C3\%A9sident $\% 20$ de $\% 201 \mathrm{a} \% 20 \mathrm{R} \% \mathrm{C} 3 \%$ A 9 publique $\% 20 \mathrm{au} \% 20$ Parlement $\% 20$ europ\%C3\%A9en\%20de\%20Strasbourg.pdf (accessed February 15, 2013), p. 5.

55 Francesco Paolo Mongelli, The Mutating Euro Area Crisis. Is The Balance Between "Sceptics" and "Advocates" Shifting?, Occasional Paper 144, February 2013, http://www. ecb.int/pub/pdf/scpops/ecbocp144.pdf (accessed 15 February 2013).

56 Funda Tekin and Wolfgang Wessels, Flexibility within the Lisbon Treaty: Trademark or Empty Promise?, EIPASCOPE, no. 1 (2008), p. 27. 
of the communist regimes in Central and Eastern Europe with the ensuing aspirations of these countries to become members of the European Union, the differentiated integration received increasing consideration, as it was perceived as a useful tool for handling diversity. In response to the forthcoming Eastern enlargement three designs of differentiated integration have come to gain prominence - multispeed, variable geometry and $a ̀$ la carte, each with a long established history behind and enjoying the preferences of one of the big Member States - Germany, France and United Kingdom, respectively. In response to the growing pleas for improving flexibility a number of ways were envisaged for allowing a group of countries to develop in a faster way their own process of integration in a determined policy area by leaving others behind. The most powerful of these remains by far that of enhanced cooperation introduced by the Treaty of Amsterdam and improved later by the treaties of Nice and Lisbon. Derogations from EU policies have been granted over time to many EU countries. However, the distinction between euro and noneuro area Member States has risen over the time concerns regarding the future position and voting power of the latter in the future. Against the background of the crisis, a number of overarching reforms have already been put in practice or just planned. While all non-euro area countries agree that the envisaged reforms offer a window of opportunity for consolidating a "genuine political integration", they fear losing their political influence in the reformed European Union and being sidelined at the border of the euro area. The analysis of the current discussion on differentiated integration and the measures already put in practice does not appear to reinforce the apprehension of the non-euro Member States. However, they have to bear in mind the fact that they cannot enjoy the same benefits from the mechanisms set in motion as the euro area countries even if they decide to participate in these.

\section{Bibliography}

Barroso, José Manuel Durão. State of the Union 2012, Address to the Plenary session of the European Parliament, Strasbourg, September 12, 2012. http://europa.eu/rapid/press-release_SPEECH-12-596_en.htm (accessed February 21, 2013).

Bourrinet, Jacques. "L'évolution de la zone euro au travers de la plasticité de ses frontières", Eurolimes no. 8: Europe and its Economic Frontiers, ed. Luminița Şoproni, Angelo Santagostino and Ernő Molnar. Oradea: Oradea University Press, 2009: 9-17.

Brandi, Clara; Wohlgemuth, Michael. Strategies of Flexible Integration and Enlargement of the European Union. A Club-theoretical and Constitutional Economics Perspective. Freiburg Discussion papers on Constitutional Economics, 2006, http:/www.econstor.eu/handle/10419/4367 (accessed February 21, 2013).

Cameron, David. EU Speech at Bloomberg, January 23, 2013. www.number10.gov.uk/news/ eu-speech-at-bloomberg/ (accessed February 15, 2013).

Cantore, Carlo Maria. "We're one, but we're not the same: Enhanced Cooperation and the tension betweenunity and asymmetry in the EU". Perspectives on Federalism, Issue 3, Vol. 3 (2011): E-1-21. 
Council of the European Union. Proposal for a Council regulation conferring specific tasks on the ECB concerning policies relating to the prudential supervision of credit institutions, 17812/12. December 14, 2012, http://register.consilium.europa.eu/pdf/en/12/st17/st17812. en12.pdf(accessed February 15, 2013).

Dahrendorf, Ralf. A Third Europe? Third Jean Monnet Lecture. Florence: European University Institute, November 26, 1979. http://aei.pitt.edu/11346/2/11346.pdf (accessed February 21, 2013).

Delors, Jacques. An „Avant-garde” driving the European unification process forward. Speech at International Bertelsmann Forum „Europe without borders“, Berlin, 19 - 20 January 2001. http://www.eng.notre-europe.eu/ (accessed February 21, 2013).

Dogoț, Cristina-Maria".How Permeable or Impermeable Could Be the Borders? Introduction”. Eurolimes no. 13: Permeability and Impermeability of Socio-Economic Frontiers within the European Union, ed. Violaine Delteil, Cristina-Maria Dogoț, Kozma Gabor and Jarosław Kundera, 5-8. Oradea: Oradea University Press, 2012.

European Commission. Lithuania is the 15th EU Member State to sign up to enhanced cooperation rules to help international couples, Press Release, 20 November 2012. http://europa.eu/ rapid/press-release_IP-12-1231_en.htm(accessed February 21, 2013).

European Parliament and the Council of the European Union. Regulation No 1257/2012 implementing enhanced cooperation in the area of the creation of unitary patent protection. December 17, 2012. http://eur-lex.europa.eu/LexUriServ/LexUriServ.do?uri=OJ:L:2012:36 1:0001:0008:EN:PDF (accessed February 21, 2013).

European Parliament and the Council of the European Union. Decision No 1855/2006/EC establishing the Culture Programme (2007 to 2013). December 12, 2006. http://eur-lex. europa.eu/LexUriServ/LexUriServ.do?uri=OJ:L:2006:372:0001:0011:EN:PDF (accessed February 21, 2013).

The Federal Trust for Education and Research. Flexible Integration and the European Constitution. European Policy Brief, nr. 12 (2005). http://www.fedtrust.co.uk (accessed February 15, 2013).

Fischer, Joshka. From Confederacy to Federation: Thoughts on the Finality of the European Integration, Berlin: Humboldt University, May 12, 2000. http://germanhistorydocs.ghi-dc. org (accessed February 15, 2013).

Hollande, François. Intervention devant le Parlement Européen, Strasbourg, February 5,2013. http://www.relaunchingeurope.eu/sites/default/files/05\%2002\%2013\%20Discours $\% 20$ du $\% 20$ pr $\%$ C3\%A9sident $\% 20$ de $\% 201 \mathrm{a} \% 20 \mathrm{R} \% \mathrm{C} 3 \%$ A 9 publique $\% 20 \mathrm{au} \% 20$ Parlement $\% 20$ europ\%C3\%A9en\%20de\%20Strasbourg.pdf (accessed February 15, 2013).

Horga, Ioan; Brie, Mircea. "Europe between Exclusive Borders and Inclusive Frontiers". Studia Universitatis Babeş-Bolyai Studia Europaea, nr. 1, vol. LV (2010): 63-87.

House of Lords, European Union Committee, European Banking Union: Key issues and challenges, 7th Report of Session 2012-13, December 12, 2012, http://www.publications.parliament.uk/pa/ld201213/ldselect/ldeucom/88/88.pdf (accessed February 21, 2013).

Kölliker, Alkuin. Flexibility and European Unification: The Logic of Differentiated Integration. New York: Rowman and Littlefield, 2006.

Leuffen, Dirk; Rittberger, Berthold; Schimmelfennig, Frank. Differentiated Integration. Explaining Variation in the European Union. Basingstoke: Palgrave Macmillan, 2012.

Major, John. Speech at the William and Mary Lecture, Leiden University, September 7, 1994. http://www.johnmajor.co.uk/page1124.html (accessed February 21, 2013).

Merkel, Angela. Speech by Federal Chancellor Angela Merkel in the European Parliament, Brussels, November 07, 2012. http://www.bundesregierung.de/Content/EN/ Reden/2012/2012-11-07-merkel-eu.html (accessed February 15, 2013). 
Schäuble, Wolfgang, Lamers, Karl. Überlegungen zur europäischen Politik. Position Paper of the CDU/CSU-Bundestagsfraktion, September 1, 1994. http://www.cducsu.de/upload/schaeublelamers94.pdf (accessed February 21, 2013).

Schimmelfennig, Frank; Leuffen, Dirk; Rittberger, Berthold. „Ever looser union? Towards a theory of differentiated integration in the EU”. EUSA Conference 2011, Boston. http://www. euce.org/eusa/2011/papers/9g_schimmelfennig.pdf (accessed February 21, 2013).

Schulz, Martin. Speech to the European Council, October 18, 2012.http://www.socialistsanddemocrats.eu/gpes/media3/documents/4057_EN_schulz_council_en_121018.pdf (accessed February 15, 2013).

Stubb, Alexander C.-G. "A categorization of differentiated integration". Journal of Common Market Studies, no. 2, vol. 34 (1996): 283-295.

Stubb, Alexander C.-G. "The 1996 Intergovernmental Conference and the management of flexible integration”. Journal of European Public Policy, vol. 4, no. 1 (1997): 37-55.

Tekin, Funda; Wessels, Wolfgang. Flexibility within the Lisbon Treaty: Trademark or Empty Promise?. EIPASCOPE, no. 1 (2008): 25-31.

Thyssen, Marianne. Report with recommendations to the Commission on the report of the Presidents of the European Council, the European Commission, the European Central Bank and the Eurogroup "Towards a genuine Economic and Monetary Union", A7-0339/2012, October 24, 2012. http://www.europarl.europa.eu/sides/getDoc.do?pubRef=-//EP// NONSGML+REPORT + A7-2012-0339+0+DOC $+\mathrm{PDF}+\mathrm{V} 0 / / \mathrm{EN} \&$ language $=\mathrm{EN} \quad$ (accessed February 15,2013).

Tindemans, Leo. Report on the European Union, Bulletin of the European Communities Supplement 1/1976. http://aei.pitt.edu/942/1/political_tindemans_report.pdf (accessed February 21, 2013).

Tugendhat, Christopher. Europe - What Matters Now, The Swinton Lecture, Cambridge, July 14, 1984. http://aei.pitt.edu/12017/1/12017.pdf (accessed February 21, 2013).

Wallace, Helen; Wallace, William. Flying together in a larger and more diverse European Union. The Hague: The Scientific Council for Government policy, 1995.

Wallace, Helen. "An Institutional Anatomy and Five Policy Modes", Policy-Making in the European Union. eds. Helen Wallace, Mark A. Pollack, Alasdair Young, 6-th ed., 69-107. Oxford: Oxford University Press, 2010.

Warleigh, Alex. Flexible integration. Which Model for the European Union?. New York: Sheffield Academic Press, 2002.

Warleigh, Alex. „Towards Network Democracy? The Potential of Flexible Integration”. In: European Integration in the Twenty-First Century: Unity in Diversity? eds. Mary Farrell, Stefano Fella and Michael Newman, 101-119. London: Sage, 2002.

Warleigh, Alex. Democracy in the European Union: Theory, Practice and Reform. London: Sage, 2003.

Wishart, Ian. "The divisive tax". European Voice, February 21, 2013. http://www.europeanvoice.com/article/imported/the-divisive-tax/76473.aspx (accessed February 21, 2013).

***, „Charlemagne: Europe à l'Hollandaise. François Hollande's flawed vision for Europe”, The Economist, (February 9-15, 2013), 27.

***. "Community acquis". http://europa.eu/legislation_summaries/glossary/community_acquis_en.htm (accessed February 21, 2013).

***. "Variable geometry". http://europa.eu/legislation_summaries/glossary/variable_geometry_europe_en.htm (accessed February 21, 2013). 


\title{
A Crisis of the European Model? Reflections and Projections
}

\author{
Iordan Gheorghe BÄRBULESCU \\ Andra-Maria POPA
}

\begin{abstract}
The multiple crises of the first two decades of the $21^{\text {st }}$ century had a great impact on the European Union. As a result, a thorough reflection on the design of the European model is required and a reassessment of its goals is needed. This paper argues that differentiated integration describes best the current model of European integration and that it is favourable for creating, on long-term, a more united Europe. After briefly explaining what the 'European model' stands for, the paper analyses the impact of the crises on the European economic governance framework - as the most decisively challenged dimension of the model - and presents some scenarios for the immediate future development of the European model of integration.
\end{abstract}

Keywords: the European model, differentiated integration, spill-over effects, the EU crisis, European economic governance

\section{Introduction}

The talk about the European model in the context of the crisis which has affected the European Union (EU) for the last 5 years is a debate about the future of the European Union (EU). Would this future mean 'more Europe', having competences in more policy fields (e.g. fiscal policy) and completing the political union or, on the contrary, would the crisis determine a pressure for returning competences to the national level? Would it be 'more Europe' for all member states or only for some? Both the late-2000s global financial crisis and the accompanying recession have hit Europe very hard and its countries quite differently. But the European sovereign debt crisis (better known as the Eurozone crisis), which started in 2010, has had the greatest impact on the EU as a community of states, putting its unity and solidarity to the supreme test. All these events happened on a background of diminishing trust of the public opinion within the member states both in EU institutions and in the EU project as a whole. ${ }^{1}$ This pushes for yet another reassessment of EU's boundaries and of its development model.

The traditional scholarly work regarding the future of the European integration (EI) process is mainly gathered around the key theories of EI and reflects a biased view emerging from the normative vision of the great EI theories. Thus, the federalists and neofunctionalists see, as an end result of the integration process, a

1 According to the Standard Euro-barometer (EComm 2012a, p. 14 - trust in the EU; EComm 2012b, pp. 59-63 - trust in EU institutions), the trust of the public in the EU has been declining since Spring 2007, a quite dramatically decrease in trust in the EU happening between Spring 2011 and Autumn 2011, when it dropped from $41 \%$ to $34 \%$. 
genuine political community of member states and believe the EU would slowly turn into a democratic European federation. The intergovernmentalists and liberal intergovernmentalists, on the other hand, see the EU as a group of strong national states, which cooperate with one another especially on low politics issues and make use of the EU institutional environment only to promote their domestic preferences and interests. Therefore, in their view, the EU is a special case of confederation.

The crisis has shown that there is no either-or answer to the question how would the EU model of integration look like in the future. The authors of this paper argue that differentiated integration describes best the current model of European integration and that it is favourable for creating a more united Europe. The main reason for promoting this argument would be that by creating closer cooperation between some member states on specific policy issues, it would trigger some sort of spill-over effect on other policy areas and this process would attract other member states as well. They believe that differentiated integration has the potential ${ }^{2}$ of slowly, but progressively, turning into unified integration by attracting more member states in the process and widening its policy coverage. Growing on this belief, the authors have chosen to write a conceptual paper on how the European model was affected by the crisis and try to make some assumptions on the direction in which the EU will develop in the near future. Their writing is based on the theoretical background of differentiated integration and the issue of the spill-over effect, which is detailed in the first part of the paper. The second part provides a conceptual delimitation of what the authors understand by the 'European model'. This is followed by a brief review of the impact of the crisis on this model, through analyzing its implications for the European economic governance model. ${ }^{3}$ And last, but not least, the authors state their views of the future development of the European model of integration.

\section{Theoretical background: differentiated integration and the spill-over effect}

Despite the vivid debates on the future of the EU, which take place between federalists and intergovernmentalists, reality has shown that the European project

2 As pointed out by Joschka Fischer in his speech "From Confederacy to Federation Thoughts on the finality of European integration" (2000, May 12, p. 8) at the Humboldt University in Berlin, "closer cooperation does not automatically lead to full integration"; deliberate political action is needed for completing the political union.

3 The authors chose to focus on analysing the impact of the crisis on the economic governance dimension of the European model, because they consider this component to be the most decisively challenged by the multiple crises of the late 2000s. They also acknowledge the fact that the crises have had an impact also on the social and political dimensions of the model, but they believe that the flaws in the economic governance pillar were the main causes which determined a spill-over onto the other two dimensions of the model. 
isn't going in either of the directions pointed out by these theories. It seems that it is rather the concept of differentiated integration which has the ability to encompass the current developments within the EU.

Differentiated integration has preoccupied both the scholarly and the political world for quite a while (ever since the $1970 \mathrm{~s}^{4}$ and especially after the $1990 \mathrm{~s}^{5}$ ), but their interest in this process has increased spectacularly due to the recent events associated with the Eurozone crisis. The literature on this issue is still quite poor, although there exists a plethora of conceptual work; the theoretical framework on the causes and effects of differentiated integration is still underdeveloped and data collection and analysis are nevertheless fuzzy. ${ }^{6}$

Also known as 'flexible integration", the concept of differentiated integration was formally introduced by the Amsterdam Treaty under the name of 'closer cooperation' describing the possibility for a group of member states to cooperate more closely in specific policy areas using the institutional framework of the EU. It was then slightly revised and renamed 'enhanced cooperation' by the Treaty of Nice in 2000. As Stubb" argues, differentiated integration "presents a paradigm shift, because traditional approaches to European integration such as federalism, functionalism, neo-functionalism and intergovernmentalism are all based on the traditional rigid model of integration", namely the unified integration model. Thus, it marks the acknowledgment of the fact that the current European integration process is not based on the 'Monnet method' anymore, but it results in a multitude of subgroups of EU member states which achieve higher levels of integration among themselves. Although Jean Monnet and the other EU founding fathers would have argued that this process is doing nothing but to destroy the integration process

4 The debate on this subject started with the launch of the Tindemans Report in 1975, but continued sporadically until the 1990s.

5 The talks on differentiated integration were revitalized in the 1990s once the German CDU/ CSU parties released in 1994 the study "Reflections on European Policy" (also known as the Lamers \& Schäuble Report).

6 Holzinger, Katharina; Schimmelfennig, Frank, "Differentiated Integration in the European Union: Many Concepts, Sparse Theory, Few Data", in Journal of European Public Policy, vol.19, no. 2, 2012, pp. 293, 302-303.

7 Alexander C-G. Stubb notes in his paper "The 1996 Intergovernmental Conference and the management of flexible integration" (Journal of European Public Policy, vol. 4, no. 1, 1997, p. 53) that there are three terms used for describing the same process: "differentiated integration [which] is often used in academic literature; flexible integration [...] used in political literature; and enhanced co-operation [...] used in politically correct literature [i.e. in the body of the Treaties]". Within this article, the authors use this terminological differentiation in order for the reader to understand better the object of reference.

8 Stubb, Alexander C-G., Negotiating Flexibility in the European Union, Basingstoke: Palgrave, 2002, p. 165.

9 See also Joschka Fischer's arguments for the replacement of the 'Monnet method' with differentiated integration in his speech given at the Humboldt University in May 2000. 
by fragmenting it, today's policy-makers and political scientists believe that this model allows for more integration, which "would otherwise be blocked by the lack of political will in some member states or by increasing heterogeneity among the members". ${ }^{10}$

In regard to the causes which determine differentiated integration, the most widespread explanations point to the great heterogeneity of the EU member states, as a result of the different enlargement rounds, but also to the design of the EU decision-making system. ${ }^{11}$ In an environment where the states have increasingly different preferences and capabilities, it is very hard to come to an agreement, given the EU institutional framework, where qualified majority and even unanimity are required in decision-making. Thus, the deadlock could be overcome by replacing the big 'integration for all' process with a bunch of smaller, but more profound 'integration for some' processes, between states with similar interests and economic performance.

The most widely accepted and used classification of the types of differentiated integration is provided by Alexander Stubb. ${ }^{12}$ He distinguishes between about 30 modes based on three criteria of differentiation: time, space and matter, and describes accordingly the three main categories of differentiated integration, namely multi-speed ${ }^{13}$, variable geometry ${ }^{14}$ and á la carte. ${ }^{15}$

Holzinger and Schimmelfennig ${ }^{16}$ observe well that Stubb's classification is somehow imprecise and redundant: it is obvious that all types of differentiation imply both a territorial and a sectoral matter, since there are only certain policy areas targeted by differentiated integration and, in every case, there are also states which don't participate in the integration. As an attempt to improve this classification, they suggest a set of six dimensions for assessing the modes of integration ${ }^{17}$ :

10 Holzinger, Schimmelfennig, p. 293.

11 Ibid., p. 299.

12 Stubb, "A Categorization of Differentiated Integration", pp. 283-295.

13 Stubb explains in "A Categorization of Differentiated Integration" (p. 287) that "multispeed' integration is being pursued by a group of member states willing and able to go further with the integration of some policy areas. The other states, which share the same common objectives, would follow later; thus the differentiation is just temporary.

14 Taking into consideration Europe's political, cultural and economic diversity, and therefore the impossibility of pursuing common goals valid for all member states, Stubb (ibid., pp. 287-288) says that this type of integration should allow permanent separation between a core of countries, which pursue deeper integration in some policy areas, and the less developed ones. This type of integration is based on opt-ins.

15 As the name says, member states should be able to choose, like from a menu, in which policy areas they want to go further with the integration, while they still maintain a minimum number of common objectives with all the other states; see Stubb (ibid., p. 288). It is rather based on opt-outs.

16 Holzinger, Schimmelfennig, p. 296.

17 Ibid., p. 297. 
“(1) permanent v. temporary differentiation;

(2) territorial v. purely functional differentiation;

(3) differentiation across nation states v. multi-level differentiation;

(4) differentiation takes place within the EU treaties v. outside the EU treaties;

(5) decision-making at EU level v. at regime level;

(6) only for member states v. also for non-member states/areas outside the EU territory".

Based on these dimensions, they also provide a very comprehensive overview of the distinct types of differentiated integration (see Table 1 below) which can find empirical evidence (all, except the Functional Overlapping Competing Jurisdictions - FOCJ), by giving some examples and indicating the literature on this issue.

An interesting approach on the different modes of differentiated integration within the EU is used by de $\mathrm{Neve}^{18}$, who introduces the metaphor of 'European Onion'19, which describes the EU as a multi-layered polity where overlapping subgroups of states achieve increasingly higher levels of integration and move slowly towards an 'ever closer Union'. Thus, de Neve ${ }^{20}$ distinguishes six 'layers' of the EU: the Association Agreements, the Stabilization and Association Agreements, the European Economic Area, the Schengen Agreement, the EU 27 and the Eurozone. The 'layers' are flexible since each state from a marginal layer is allowed to move towards the core, the core of the 'onion' having a centripetal effect on all external layers by pulling the member states to join a more advanced subgroup. ${ }^{21}$ The centripetal effect of the more integrated core combined with a spill-over effect on the connected policy fields would have the potential of attracting all member states to the 'finalité politique'. ${ }^{22}$

18 de Neve, Jan-Emmanuel, "The European Onion? How Differentiated Integration is Reshaping the EU", in European Integration, vol. 29, no. 4, 2007, pp. 503-521.

19 This model is quite similar to the one called 'Core Europe/Concentric circles' listed by Holzinger and Schimmelfennig in their classification.

20 de Neve, pp. 505-507.

21 Ibid., p. 512.

22 Ibid. 


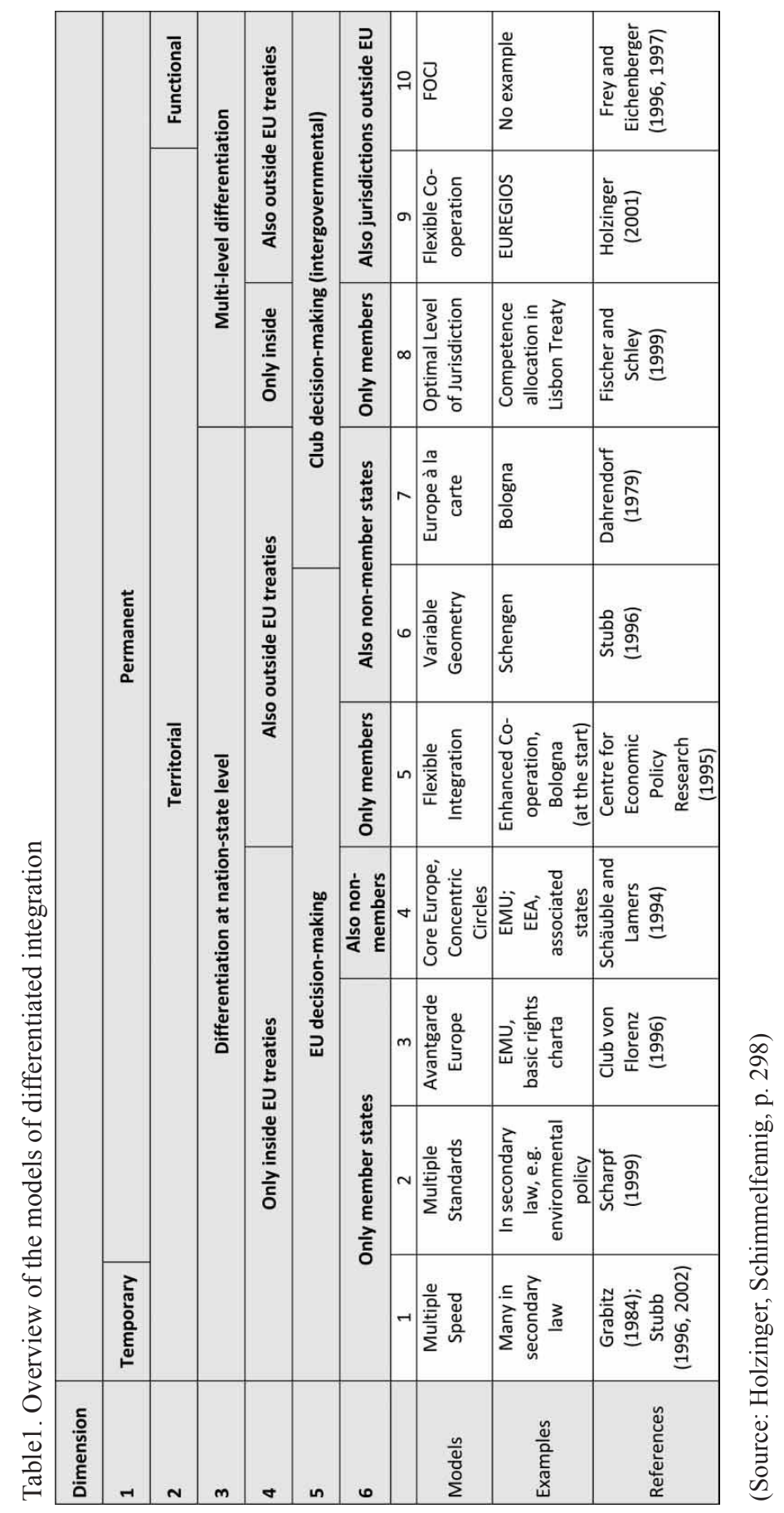


'Spill-over', the key concept of the neofunctionalist theory of European integration, was first defined by Ernst Haas and used for explaining how integrating one economic sector would create pressure for greater integration within that sector and in other economic and political activities, thus giving more authority to the EU level. ${ }^{23}$ Lindberg $^{24}$ describes the process as "a situation in which a given action, related to a specific goal, creates a situation in which the original goal can be assured only by taking further actions, which in turn creates a further condition and a need for more action, and so forth". This means that, once the political cooperation between member states has started in one activity, it has the potential to expand, in time, to other activities which weren't necessary intended in the beginning. As Niemann and Schmitter ${ }^{25}$ argue, some sectors are so interdependent that, when a problem arises on a particular policy issue, it can only be solved by integrating more policy areas.

The early neofunctionalist literature distinguished between two major types of spill-over (i.e. functional ${ }^{26}$ and political ${ }^{27}$ ) and later theorists added two more (i.e. cultivated ${ }^{28}$ and geographical/exogenous ${ }^{29}$ ).

23 Haas, Ernst B., The Uniting of Europe. Political, social and economic forces 1950 - 1957, Stanford: Stanford University Press, 1958.

24 Lindberg, Leon N., The Political Dynamics of European Economic Integration, Stanford: Stanford University Press, 1963, p. 10.

25 Niemann, Arne; Schmitter, Philippe C., "Neofunctionalism", in Wiener, Antje; Diez, Thomas (eds.), European Integration Theory, New York: Oxford University Press, 2009, p. 49.

26 'Functional spill-over' refers to the technical pressures, involuntarily generated by the integration of one sector of the member states' economies, which push for a wider integration also in the functionally related sectors. In other words, in order for the integration of one specific policy area to succeed, other, closely interconnected policy areas need to be integrated as well.

27 'Political spill-over' refers to the building-up of political pressure for more integration. This pressure is exert by national elites (governmental or non-governmental), which have come to move part of their activities and expectations to the European level, and based on their previous positive experiences, would now support further integration.

28 'Cultivated spill-over' involves the European Commission's role (or of other European institutions) in making European integration possible by 'cultivating' the national elites (both interest groups and national bureaucrats) in realising the EU objectives.

29 'Geographical spill-over' was the term used by Haas in his work The Uniting of Europe. Political, social and economic forces 1950 - 1957 (pp. 313-317) to explain UK's faltering to join the European Communities in the 1950s. Later on, Niemann and Schmitter (p. 62) in their contribution on neofunctionalism called this effect 'externalization' or 'exogenous spillover'. The cooperation between a group of states is believed to trigger horizontal integration (i.e. enlargement), since the excluded states would feel the pressure of joining the others in order to take advantage of the positive externalities of the integration process and not to experience the negative ones, if they decide to stay outside. Niemann and Schmitter (ibid.) argue that the need for enlargement can be explained by a spill-over effect, which doesn't determine integration of other policy areas, but calls for territorial expansion. 
According to Leuffen et. al. ${ }^{30}$, differentiated integration has two major manifestations: 'vertical differentiation' (European integration differs throughout the policy areas, some policies being more integrated than others) and 'horizontal differentiation' (European integration isn't uniformly applied to all member or nonmember states). In theory, it should be possible for these kinds of differentiations in the European integration process to be smoothened in time, with the help of the integrating pressure delivered through the different types of spill-over mentioned above.

\section{What is the European model?}

Since the paper talks so much about the 'European model', a conceptual delimitation is in order. In this context, the term 'model' can be understood in two ways:

1) "a thing used as an example to follow or imitate"

2) (according to the definition in social sciences) a "general sketch of the main features of some social phenomenon" 32 , which tries to abstractly represent and simplify reality by highlighting the relationships between its different aspects.

In line with the first understanding, the European model refers to the model of society the EU wants to develop inside its borders and export to the whole Europe and (maybe) to other regions of the world, as well. While focusing on both deepening and widening ${ }^{33}$, the authors believe the EU seeks to slowly develop into a political organization of federal inspiration and to explicitly extend its model of conflict resolution and generation of wealth throughout most of the states within the European continent and beyond it. The ultimate goal of this 'redefinition' ${ }^{34}$ of Europe is that, through its size, power and unity, it should become a global referential, a model for others, able to contribute to the peaceful management of the current globalized world. In the last 25 years, the model of the EU has quietly turned into a European

30 Leuffen, Dirk; Rittberger, Berthold; Schimmelfennig, Frank, Differentiated Integration: Explaining Variation in the European Union, Basingstoke: Palgrave Macmillan, 2012.

$31 \mathrm{http}: / /$ oxforddictionaries.com/definition/english/model, accessed on 15.02.2013.

32 Bealey, Frank; Johnson, Allan G., The Blackwell dictionary of political science: A User's Guide to Its Terms, Oxford, Massachusetts: Blackwell Publishing Ltd, 1999, p. 214.

33 For more comments on this binomial, see Bărbulescu, Iordan Gh., Uniunea Europeană: Extindere și aprofundare, București: Editura Trei, 2001.

34 When talking about the aim of this 'redefinition' of Europe, it recalls remembering that the EU's founding fathers had in mind, from the beginning, the creation of a federal Europe, open to all European states in search for integration. The on-going process of European integration seems to be moving quietly towards accomplishing their dream, although sometimes the pace is too slow or integration efforts are challenged by current developments in the world and in the EU member states (i.e. the global financial crisis, the recession and the Eurozone crisis) or by manifestations of Euroscepticism within EU leaders; thus the integration process has to adapt its methods to the current challenges (see above, the talk on the need to replace the 'Monnet method' with differentiated integration). 
model. Moreover, in terms of common awareness, Europe has been identified, more and more, with the EU; nowadays, even scientific analyses tend to identify the two entities, mainly due to the EU's high level of institutionalization and its policy area coverage..$^{35}$ These developments took place despite the Euroscepticism emerged in the 1970s, especially in the context of UK's accession, which believed the European Communities would remain just another free trade area. ${ }^{36}$

According to the second definition, the European model can be described as a set of unique characteristics which define the European model of society, mostly in comparison with the Nord-American model, based on the supremacy of markets. Thus, it refers to the specific EU model which promotes a balance between society, economy and politics, and, as Blanchard ${ }^{37}$ says, "combines economic efficiency and generous social insurance". While the Nord-American model includes economic growth and political liberty, but excludes social cohesion, the European model implies all three. The European model is based on a competitive social market economy, while the American one embraces a model of laissez-faire market economy. Economic growth of the American model proved to be more spectacular than in Europe, but not necessarily sustainable. Both value the individual freedom of choice and ownership and use competitive market mechanisms to allocate resources. It should be noted that these differences are presented in terms of the theoretical foundations of the two models, in reality the situation might be different, and the two models might have more things in common than arising from theory. ${ }^{38}$

35 Sawicki, Iwona, "Growing Regionalism in a Shrinking World", in European Policy Centre Working Papers, 2002.

36 This Euroscepticism periodically reappears, as it was in the case of the accession of the Central and Eastern Europe countries (CEECs). Even nowadays there are many scholars who argue that the heterogeneity of the 12 newest EU member states (13 since July 2013), together with the existing development gaps between them and the old members, would make the EU go back to being just a free trade area. The 'failure' in ratifying the Constitutional Treaty in France and the Netherlands in 2005 also contributed to the increase in Euroscepticism. At present, the Eurosceptics strike again and 'preach' the end of the Eurozone and of the EU as a whole, as the extended economic crisis and the sovereign debt crisis of the Eurozone countries only end up supplying these 'apocalyptic' predictions. As permanent Eurosceptic, the UK has once again expressed its thoughts on the future of the European model through the speech of its prime-minister, Mr. David Cameron, which is meant to clearly detach the UK from the group of member states wanting to build 'an ever closer political union', while pleading for a review of EU competences and the possibility of power to flow back to the member states (see Cameron, David, "David Cameron's EU speech in full", in The Telegraph, 2013, January 23).

37 Blanchard, Olivier, "Is there a viable European social and economic model?", in MIT Department of Economics Working Paper, no. 06-21, 2006.

38 See Alber, Jens, "The European Social Model and the United States", in European Union Politics, vol. 7, no. 3, 2006, pp. 393-419 and Alber, Jens, "What the European and American welfare states have in common and where they differ: facts and fiction in comparisons of 
The European model reflects a model of organizing economic and social relations, which meets the special combination of economy, state and society, which is specific for the EU. ${ }^{39}$ In terms of economy, the European model aims to combine the dynamics of growth within a market economy with the dialogue involving social partners; regarding state, it should be noted that, besides the fact that they function as liberal democracies, EU member states are welfare states, which supplement market action through redistribution, in order to mitigate social inequalities; in relation to society, in addition to creating opportunities for individuals, the model promotes solidarity between individuals, thus strengthening social cohesion. ${ }^{40}$

Over time, some important questions regarding the European model have been raised, some of which are still valid today:

- Will the model of the single market and of its four economic freedoms enhance in time or, on the contrary, will it disappear? We now have the EU with its 27 (soon 28) member states, supplemented by the EFTA ${ }^{41}$ countries, which leads to the remark that we are witnessing the institutionalization of all European countries, i.e. the gradual transfer of the European model in the entire European space, so that one comes to identify Europe with the EU and the European model with the model of the EU. All European countries are willing to be part of the EU or at least develop special relations with it.

- Could this economic model of the EU turn into a political one, which would eventually lead to the creation of the 'European Federation' the founding fathers were dreaming of? This goal can be achieved through extending the collective sovereignty to areas of high-politics, at least for a group of states, if not for all. The alternative would be the return to a classical - slightly changed - intergovernmental model, without strong common institutions and policies and without common laws. Nowadays, we can acknowledge that the European model has shown

the European Social Model and the United States", in Journal of European Social Policy, vol. 20, 2010, pp. 102-125.

39 See Alber, "The European Social Model and the United States", p. 394 and Luzzaraga, Francisco Aldecoa; Llorente, Mercedes Guinea, Europa viitorului. Tratatul de la Lisabona, Iaşi: Ed. Polirom, 2011, p. 125.

40 Alber, "The European Social Model and the United States", p. 395.

41 The European Free Trade Association (EFTA) is an international organization promoting free trade and consisting of four European countries: Iceland, Lichtenstein, Norway, and Switzerland. EFTA operates in parallel, but cooperates closely with the EU. Through the free trade agreement called the European Economic Area (EEA), created by the Porto Agreement in May 1992, EFTA countries are allowed to participate in the common market and its sectoral policies. Through the EU accession of Finland, Sweden and Austria in 1995, the EEA has lost its practical importance and is now serving only Liechtenstein, Norway and Iceland (Switzerland, although an EFTA member, still remains outside the EEA, having special agreements - such as 'communicating vessels' agreements - with the EU, in this way avoiding isolation from the community environment it lives in). 
the credibility of the 'shared sovereignty' method through successive institutional reforms and extension of competences.

- Can the European economic and social model - based on the principles of social market economy - which places the citizen in the centre of the triad of economy-state-society - become a genuine model of society in Europe? This model of welfare and growth is situated between the socialist-communist model, which aims to overcome social inequalities through abolishing the free market, and the classical model of laissez-faire liberalism ${ }^{42}$, in which the market is absolutely free and no state intervention is welcomed. Nowadays, one can say that the EU adopted this economic policy model through implementing specific actions and policies which define what is called the 'European social model'. Currently, all EU member states - including the UK - have their own social policies and, at the same time, they participate in common programs and projects on different social-related issues. The European Constitution took a step forward in this regard by institutionalizing this European model seen as EU's own distinctive economic and social model. The Lisbon Treaty also maintained this direction. Even in the current crisis, debates are not about abandoning the European model, but rather preserving it as a true 'heritage'.

- Are the EU and its member states able to have their 'own voice' in international affairs and, more specific, what are their commitments with already wellestablished organizations, such as NATO or Warsaw Pact ${ }^{43}$, or with neutral states? Can the EU - as an international actor - impose itself beyond the member states and progressively substitute them on issues of foreign policy? After 40 years, the EU has developed a common foreign and security policy, autonomous and compatible with both the one of NATO and the one of neutral states. Moreover, in its quest for developing a common voice on global scale, the EU has created a real European External Action Service and a true European Foreign Minister.

All these questions and their corresponding answers point to the fact that the model of the EU aims to become the European model. Therefore, it is a continental model which promotes a balance between society, economy and politics, and in which the citizen should play the central role.

\section{The impact of the crisis on the European model: what flaws} in the design of the model did the crisis highlight?

The multiple crises of the late 2000s, but especially the Eurozone debt crisis, have exposed some of the imperfections of the European model regarding its economic dimension and, to be more precise, the ones related to the economic governance

42 This model is representative for North American states.

43 The Warsaw Pact was designed in 1955 as a communist alternative to NATO and as military complement to the COMECOM. It was also led by the USSR and was dissolved in 1991. 
and structure of its Economic and Monetary Union (EMU). It is true that EU integration experts (mostly economists) have warned about some of them for some time and called for more political action to try to correct them. In this context, it is not the case to consider the European model to be fully wrong and completely abandon it. On the contrary, this gives EU leaders and 'designers' the opportunity to reflect upon the mistakes and try to come up with solutions to perfect the model and make it more sustainable.

The most significant and thus fundamental flaw in the European model is believed to lie in the institutional design of the European Economic and Monetary Union $^{44}$. Ever since its creation, specialists have argued that the EMU doesn't fulfil all the requirements for an optimal currency area (OCA).$^{45}$ Although the EU's internal trade amounts a considerable part of EU's trade ${ }^{46}$, labour mobility within the EMU seems to be limited ${ }^{47}$, making it impossible to balance economic shocks through labour migration. Although one might argue that the member states of the EMU have quite similar manufacturing structures ${ }^{48}$, they differ significantly in their basic economic structures. The main differences lie between the more tech-

44 See Dăianu, Daniel, "Euro zone crisis and EU governance: Tackling a flawed design and inadequate policy arrangements", in CASE Network Studies \& Analyses, no. 433, 2012.

45 According to Mundell's theory, presented in his paper "A Theory of Optimum Currency Areas" (The American Economic Review, vol. 51, no. 4, 1961, p. 657), an optimal currency area (OCA) is "a domain within which exchange rates are fixed" and in which factor mobility is indispensable and should be particularly high. Krugmann and Obstfeld define in their book International economics: theory and policy (Boston: Pearson, 2009, p. 581) OCAs as "groups of regions with economies closely linked by trade in goods and services and by factor mobility" and discuss the issue of Europe being an OCA, while examining whether the EMU has the four properties they believe define a genuine OCA: intra-regional trade, labour force mobility, similarity of economic structures, the degree of fiscal federalism (ibid., pp. 582-587).

46 According to Eurostat, intra-EU trade in goods accounts for around $60 \%$ of the total EU-27 trade. In 2011, the share of intra-EU exports was $64,3 \%$, with $3,7 \%$ less than in 2000 , and the share of the imports $61,4 \%$, with a slight decrease of $2,1 \%$ since 2000 (http://epp.eurostat. ec.europa.eu/tgm/refreshTableAction.do?tab=table\&plugin=1\&pcode=tet $00037 \&$ langua $\mathrm{ge}=\mathrm{en}$, accessed on 15.02.2013). This small drop in intra-EU trade since 2000 (after an incremental increase in the first 5-6 years, it started decreasing in 2007) can be attributed mostly to the recession which hit the EU member states, following the outbreak of the world financial crisis in 2007-2008 and the accompanying recession.

47 Although the EU and more specifically the EMU is based on the Single Market, which allows the free movement of goods, services, capitals and people, the residents of the member states are still quite reluctant to moving from one state to another. This appears to happen both due to the incompleteness of the Single Market (i.e. governments seem to continue to preserve some regulations regarding labour mobility) and other factors such as language and cultural differences or differences in social security systems.

48 Krugman and Obstfeld (p. 585) identify the intra-industry trade (i.e. the trade with similar products) within the EU as a sign of the similarity in manufacturing structures of its member states. 
nologically endowed, highly-skilled and capital abundant north and the less technologically equipped, poorer skilled and less capitalized south. Given EU's limited competences in the fiscal field and, therefore, its reduced budget, neither has the EU got enough funds to be able to rescue a member state in economic difficulties, nor does it have the (legally-based) ability to transfer resources from the wealthy economies to the 'less fortunate' ones, based on the principle of fiscal federalism.

Given the fact that the member states within the EMU have to uniformly apply the common monetary policy dictated by the European Central Bank (ECB), they no longer possess the ability to use monetary policy instruments to correct the imbalances within their national economies. In other worlds, national governments have less policy instruments to tackle domestic problems. As a result, asymmetric shocks are more likely to appear throughout the EMU, because member states are used to reacting differently to a specific issue and, therefore, the 'one size fits all' monetary policy might not produce the expected positive outcome in all states. The more heterogeneous the economies of the EMU are, the greater will the asymmetry of the macroeconomic shocks be. For 'smoothening' these shocks, Krugman and Obstfeld ${ }^{49}$ call for more flexibility on the labour markets - a domain which still remains of national competence - both regarding wages and mobility of the labour force.

Before adopting the Euro, member states are supposed to comply with the Maastricht convergence criteria ${ }^{50}$, but in order to make the Union work properly and avoid creating asymmetric shocks, it is highly important that the economies develop similarly, thus creating real convergence ${ }^{51}$ between them. Even when looking at the main indicator of real convergence for the 17 member states of the Eurozone, i.e. the GDP per capita, one can observe quite big differences among the states: in 2011, the GDP per capita within the Eurozone ranged from $9100 € /$ inhabitant in Estonia to $33300 €$ / inhabitant in the Netherlands or even $64900 €$ / inhabitant in Luxembourg. ${ }^{52}$ These figures are quite representative for the heterogeneity in the Eurozone and this gap even increases when comparing the Eurozone states with the other members of the EMU. This poor convergence in the EMU

49 Ibid., p. 588.

50 The criteria are listed in the art. 140, line 1 of the Treaty on the Functioning of the EU (2010, p. 108-109): price stability, public finance sustainability (both of the governmental budget deficit and of the public debt), exchange rates and long-term interest rates.

51 The real convergence of the member states' economies must be understood as convergence of the living standards throughout the Union. Some of the indicators for accessing the degree of this alignment are: the GDP per capita, the openness of the economy, the structure of the economy, the balance of payments and the labour costs (http://www.bnro.ro/Trecerea-laeuro-1251.aspx, accessed on 15.02.2013).

52 The numbers were taken from Eurostat: http://appsso.eurostat.ec.europa.eu/nui/ submitViewTableAction.do?dvsc $=6$, accessed on 15.03.2013. 
allowed tensions to appear between the states which have surpluses in their current account (i.e. Germany) and the ones running large deficits (i.e. Greece, Portugal). ${ }^{53}$

Regarding the issue of the insufficient institutional framework of the EMU, Dullien et al. ${ }^{54}$ identify three important points in the EU primary law which might have contributed to the outbreak and deepening of the crisis. They first note that the EU Treaty includes an explicit 'no bail-out clause' in its provisions - art. 125 of the Treaty on the Functioning of the European Union ${ }^{55}$ - which prohibits a member state to take over the liabilities of another one. This clause didn't succeed in fulfilling its purpose of teaching national governments to run prudent fiscal policies, but it made the bailing-out of Greece and the other countries very difficult (in many parts also illegal). The Treaty also forbids the ECB to 'directly' finance government budgets - art. 123 TFEU. ${ }^{56}$ On this issue, there was a strong debate whether the ECB is allowed or not to purchase government bonds of the indebted states on the secondary market, Germany being categorically against this action. ${ }^{57}$ Last but, not least, the Treaty left the supervision of the financial sectors to the member states and, since the coordination of national supervisors has been poor and there is no EU law regarding the liquidation of insolvent national or cross-border financial institutions, this situation allowed governments to bail-out banks at large scale and thus increase their debts. Dăianu ${ }^{58}$ also stresses out that the current EU arrangements for regulating and supervising the financial markets are fuzzy and inefficient; therefore, he highlights the need for "a common rulebook, more integrated supervision, and a common framework for crisis resolution". Dullien et al. ${ }^{59}$ sum up by saying that "the lack of a common resolution framework and a fiscal authority that would be able to pay in times of debt crisis explains some aspects of the euro crisis", such as the spread of the crisis to Italy and Spain.

To the above mentioned problems of the primary EU law framework, another one could be added: the lack of an 'exit clause' for the Eurozone ${ }^{60}$ Fahrholz and Wojcik $^{61}$ are in favour of introducing an 'exit clause' for the member states which

53 See Dăianu, p. 9.

54 Dullien, Sebastian; Fritz, Barbara; Mühlich, Laurissa, "Regional Monetary Cooperation: Lessons from the Euro Crisis for Developing Areas?", in World Economic Review, no. 2, 2013, p. 6.

55 EU 2010, p. 99.

56 EU 2010, p. 99.

57 See http://www.guardian.co.uk/business/nils-pratley-on-finance/2012/may/23/why-germany -doesnt-want-eurobonds, accessed on 15.02.2013.

58 Dăianu, p. 9.

59 Dullien, Fritz, Mühlich, p. 10.

60 According to the current primary law of the EU (i.e. the Treaty of Lisbon), there is no clause for member states' exiting the EMU, but only one regarding exist from the EU: art. 50 of the Treaty on the European Union (EU 2010, p. 43).

61 Fahrholz, Christian; Wójcik, Cezary, "The Eurozone Needs Exit Rules", in CESifo Working Paper Series, no. 3845, 2012, pp. 1-25. 
have trouble with their domestic finances, because in this way it would help in finding a quicker solution to the Eurozone crisis and foster stability across the EMU. After briefly presenting some possibilities for formulating this clause, they ${ }^{62}$ argue that introducing such a rule would strengthen the Eurozone by reducing the possibility of moral hazard, fostering domestic macroeconomic discipline, increasing the political bargaining power of the Eurozone vis-a-vis the indebted states and reducing uncertainty regarding the procedure and costs of a Eurozone exist. Lastly, they suggest that, given its political and economic feasibility, this 'exit clause' should be given serious thought when reforming the institutional framework of the Eurozone.

Another important issue revealed by the crisis regarding the EMU is the inability of the member states to respect the rules within the Stability and Growth Pact (SGP). Breaking the SGP rules is not a novelty, since it is well known that the very country that advocated for introducing these rules of budgetary discipline (i.e. Germany) has many times been among the countries which failed to respect them. ${ }^{63}$ A reason for the repeated infringement of these rules could be attributed to the SGP's modest and selective sanctioning capabilities and the insufficient authority of the Commission to enact them accordingly. It was not until the emergence of the Eurozone crisis when European leaders understood the importance of respecting the SGP provisions. Both due to the bailing-out of banks affected by the global financial crisis or big public spending, states have come to accumulate deficits and public debts above the limits allowed by the SGP, thereby endangering the stability of the Euro currency. Given the poor coordination regarding fiscal discipline accomplished through the SGP, Dăianu ${ }^{64}$ argues in favour of an EMU fiscal authority, which would be able to provide the necessary funds, mechanism and instruments to make fiscal transfers across the EMU possible. This would call for greater coordination between national governments on budgetary issues, the creation of a substantial common Eurozone budget and the issuance of common bonds through the $\mathrm{ECB}^{65}$, all these based on the principles of fiscal federalism.

As Krugman and Obstfeld ${ }^{66}$ note, if the EMU will be a successful project, it will promote the European model throughout the entire Europe and beyond its borders;

62 Ibid., p. 16-20.

63 As also reflected in the statistics of the European Commission (see http://epp.eurostat. ec.europa.eu/tgm/table.do?tab=table\&init=1\&language $=$ en $\&$ pcode $=$ tec $00127 \&$ plugin $=1$, accessed on 15.02.2013), during 2002 - 2005, both Germany and France repeatedly violated the rules on government deficits within the SGP, but no sanctions have been imposed on them (http://www.guardian.co.uk/world/2003/nov/27/qanda.business, accessed on 15.02.2013), thus creating a case of double standards (other states were either punished for the rulebreaking or have made great efforts to abide them) and, at the same time, endangering the economic stability and growth of the EMU.

64 Dăianu, p. 9.

65 Ibid., p. 10.

66 Krugman, Obstfeld, p. 587. 
but if it fails, the goal of the political unification of Europe will suffer some further setbacks. Thus, a good long-term durable solution has to be found for the problems within the EMU in order to be able to think about going further with the political integration of the EU member states and/or expanding the European model to other states or regions.

\section{Thoughts on future developments of the European model}

The Eurozone crisis has put the EU at a new crossroad; it has to choose now between different scenarios: deepening by increasing the number of EU competences, the return of some competences to the national level, differentiated integration, some states exiting the EU or even more states joining the EU.

As a response to the multiple crises that hit the EU since 2007-2008 and in an attempt to fix some of the flaws of the European model, EU leaders agreed to important reforms in the economic governance of its EMU. As Kunstein and Wessels ${ }^{67}$ note, these reforms were undertaken both within the EU Treaty framework $^{68}$, thus using the 'Community method', and outside the Treaty framework ${ }^{69}$, using the 'intergovernmental method'. As one can observe when looking at the measures taken after the crisis, all efforts concentrated on making the EMU - more precisely the Eurozone - more efficient and increase its cohesion, thus only sometimes allowing the non-Euro states to join the initiatives of the Eurozone members (like in the case of the Euro-plus Pact or the TSCG). The roadmap towards a genuine EMU, agreed upon in the European Council in December 2012 $2^{70}$, also focused

67 Kunstein, Tobias; Wessels, Wolfgang, "The New Governance of the Economic and Monetary Union: Adapted Institutions and Innovative Instruments", in Istituto Affari Internazionali Working Papers, vol. 13, no. 2, 2013, pp.1-13.

68 Kunstein and Wessels (p. 4) include in this category (1) the establishing of the European Systemic Risk Board and the European System of Financial Supervision in 2010 and the legislative proposal of creating the Single Supervisory Mechanism for an EU-wide supervision of banks; (2) the entry into force, in December 2011, of the 'Six-Pack' and of the 'Two-pack' in May 2013, a set of laws addressing fiscal and macroeconomic coordination and surveillance, and which partly use sanctions as a mode of coercion; they are meant to complement the SGP and the 'European Semester'; (3) the formalizing, in October 2011, of the Euro Summit, which gathers the Head of State or Government of the Eurozone states and meets at least two times a year.

69 The outside the Treaty reforms include, according to Kunstein and Wessels (p. 5): (1) the creation of the European Financial Stability Facility and of the European Stability Mechanism as temporary (in 2010), respective permanent (in 2012) internal crisis resolution mechanism; (2) the signing of the Euro-plus Pact, in March 2011, meant to improve the competitiveness of the signatory states (both Eurozone members and other EMU states); (3) the signing of the Treaty on Stability, Coordination and Governance (TSCG), in 2011, which aims at strengthening fiscal discipline at national level; the ratification process of this Treaty is still on-going.

70 See ECoun 2012 and van Rompuy, Herman, "Towards a genuine Economic and Monetary Union", Report presented in the European Council meeting in Brussels, 13-14 December 2012. 
on describing a step-by-step plan to achieve "deeper integration and reinforced solidarity" between the countries of the Euro area, as a sort of avantgarde of the EMU.

In today's context, Fischer's speech on the finality of European integration, held at the Humboldt University in Berlin in May 2000, returns to actuality. Fischer acknowledged the fact that the way to go further with the European model is through differentiated integration. $\mathrm{He}^{71}$ proposed that the states, which are determined to cooperate more closely than others, should be allowed to do so through enhanced cooperation, thus creating a more integrated core. This vanguardist group of states, formed of the Eurozone members ${ }^{72}$, is expected to develop into an economic and political union, having its own institutions and establishing a "new European framework treaty", putting the base for "the future federation". ${ }^{73}$ This core should be open to all member states and candidate countries, which would have to fulfil some requirements in order to join, but no member state could be forced to go further with the integration than it is able or willing to. For defining its idea of a closer integrated group of member states, Fischer used the term 'avantgarde', although he was referring to a 'Core Europe / Concentric circles' model of differentiated integration. ${ }^{74}$

Coincidentally or not, in his speech held in March 2012 at the Humboldt University in Berlin about the Euro crisis and the future of Europe, Piris ${ }^{75}$ also talked about the future of the EU in terms of differentiated integration, naming it 'two speed Europe', and proposing four scenarios. Among these scenarios, two referred to differentiated integration, having in centre the member states of the Eurozone: one in form of a de facto ${ }^{76}$ 'two speed Europe' and one of a de jure $e^{77}$

71 Fischer, pp. 7-8.

72 Although Fischer (p. 8) said that he had no answer to the question of which countries would form this core, his speech indicates that he had the Euro-states in mind.

73 Ibid.

74 According to Holzinger and Schimmelfennig's (p. 298) classification, the 'Avantgarde Europe' model applies only to EU members, but Fischer's model also talks about attracting candidate countries towards the more integrated centre, thus it would be more accurate to call it 'Core Europe / Concentric circles'.

75 Piris, Jean-Claude, "The Euro Crisis, Democratic Legitimacy and the Future Two-Speed Europe", Speech presented at the Humboldt University, Berlin, 2012, March 21.

76 Piris (pp. 8-9) notes that the closer political cooperation of the Euro-states should proceed within the current EU institutional and legal framework, taking advantage of the possibilities offered especially by art. 136 of the TFUE (EU 2010, p. 106) and for the rest, the group could use the intergovernmental method. Thus, he proposed some areas in which the group could decide to increase its cooperation within the Treaty's provisions (e.g. the coordination of national legislation on taxes and social policies; common measures regarding immigration policy; enhanced cooperation on judicial matters; permanent structured cooperation in the field of defence) and others in which it could close intergovernmental agreements (e.g. strengthening the ESM, the Euro-plus Pact; industrial cooperation).

77 The big difference to the other option is that the group would be legally established, through an international agreement. Piris (pp. 10-12) describes this arrangement as having a new legal basis, within which the states could establish new institutions (e.g. a smaller 
'two speed Europe'. Piris ${ }^{78}$ called for action towards a more integrated avantgarde Eurozone and stop complaining about a possible 'division of Europe', because he believes that deeper integration between the Euro-states is the only solution for the Eurozone and the EU as a whole. Although less convincing than Fischer, Piris noted that the more integrated core of the EU should be opened to accession by other EU member states ${ }^{79}$ under some conditions and that each EU member state should be allowed "to choose its own way and speed, in accordance with its needs and interests". 80

Based on the current developments within the EU and following the classification presented by Holzinger and Schimmelfennig, the authors see the EU moving towards a model of differentiated integration which has the Eurozone as a core and resembles to the 'Core Europe / Concentric circles' model of Holzinger and Schimmelfennig and the one of the 'European Onion' of De Neve. The authors believe that this type of integration within a small group of EU member states would extend to other policy areas and other member states of the EU or even to the candidate countries (the other 'layers') based on a functional and geographical / exogenous spill-over. Thus, in time, all the states in Europe would progressively be attracted towards the more integrated core of the EU (due to the benefits offered by the closer cooperation) and engage in more political cooperation, which could in the end lead to the creation of the European Federation.

But, it still remains arguable whether, on the long run, it is desirable for the EU to move towards the (pan-)European federation, or whether it ought to continue existing as an 'Unidentified Political Object' ${ }^{81}$ with its particular way of functioning and its community vision ${ }^{82}$ based on 'unity in diversity'. As President van

Commission; EU Council formations only for the Eurozone states, given that the Euro Summit already operates; a parliamentary assembly composed of representatives of the national parliaments concerned) and also broaden their area of cooperation (e.g. integrated system of macroeconomic surveillance and control; harmonizing tax and social legislation; increase cooperation on security and defence, but also regarding justice and home affairs, citizens' rights and mobility).

78 Ibid., pp. 13-14.

79 Here occurs a slight difference from Fischer's vision because Piris doesn't refer to candidate countries, thus describing with his de jure 'two speed Europe' (after the establishing of the new international agreement) an example of 'Avantgarde Europe', according to Holzinger and Schimmelfennig's (p. 298) classification.

80 Piris, p. 14.

81 Delors, Jacques, "Speech by Jacques Delors to the inaugural session of the Intergovernmental Conference, Luxembourg, 9 September 1985", p. 2.

82 This vision describes the EU as a group of associated nations sharing common interests or a common heritage, but each of these nations preserves its own specificity, while respecting the particularities of the others. For more on this subject, see Weiller, Joseph H.H., "Back to the Future: Europe as Community", in Collegium, no. 28, 2003, pp. 43-50. 
Rompuy $^{83}$ wrote in his report on the roadmap towards a genuine EMU: "More Europe' is not an end in itself, but rather a means for serving the citizens of Europe and increasing their prosperity". Thus, one can conclude that the goal isn't for the EU to develop into a state-like federation, but to deliver welfare to the peoples of Europe, may it occur through more political integration of all member states or only of some states willing to go further. Therefore, the authors agree with Kunstein and Wessels ${ }^{84}$ and predict a near future of 'more Europe' in terms of deeper political integration, but 'less Europe' in terms of the number of states pushing for more integration.

\section{Bibliography}

Alber, Jens (2006), "The European Social Model and the United States", in European Union Politics, vol. 7, no. 3, pp. 393-419.

Alber, Jens (2010), "What the European and American welfare states have in common and where they differ: facts and fiction in comparisons of the European Social Model and the United States", in Journal of European Social Policy, vol. 20, pp. 102-125.

Bărbulescu, Iordan Gh. (2001), Uniunea Europeană: Extindere și aprofundare, București: Editura Trei.

Bealey, Frank; Johnson, Allan G. (1999), The Blackwell dictionary of political science: A User's Guide to Its Terms, Oxford, Massachusetts: Blackwell Publishing Ltd.

Blanchard, Olivier (2006), "Is there a viable European social and economic model?", in MIT Department of Economics Working Paper, no. 06-21.

Cameron, David (2013, January 23), "David Cameron's EU speech in full” [online], in The Telegraph. Available online at http://www.telegraph.co.uk/news/worldnews/europe/ eu/9820230/David-Camerons-EU-speech-in-full.html accessed on 15.02.2013.

Dăianu, Daniel (2012), "Euro zone crisis and EU governance: Tackling a flawed design and inadequate policy arrangements", in CASE Network Studies \& Analyses, no. 433.

Delors, Jacques (1985, September 9), "Speech by Jacques Delors to the inaugural session of the Intergovernmental Conference, Luxembourg, 9 September 1985". Available online at http:// www.cvce.eu/content/publication/2001/10/19/423d6913-b4e2-4395-9157-fe70b3ca8521/ publishable_en.pdf accessed on 15.02.2013.

Dullien, Sebastian; Fritz, Barbara; Mühlich, Laurissa (2013), "Regional Monetary Cooperation: Lessons from the Euro Crisis for Developing Areas?", in World Economic Review, no. 2, pp.1-23.

Fahrholz, Christian; Wójcik, Cezary (2012), "The Eurozone Needs Exit Rules", in CESifo Working Paper Series, no. 3845, pp. 1-25.

Fischer, Joschka (2000, May 12), "From Confederacy to Federation - Thoughts on the finality of European integration", Speech presented at the Humboldt University, Berlin. Available online at http://www.cvce.eu/obj/speech_by_joschka_fischer_on the ultimate_objective_of european_integration_berlin_12_may_2000-en-4cd02fa7-d9d0-4cd2-91c9-2746a3297773. $\mathrm{html}$ accessed on 15.02.2013.

83 van Rompuy, p. 3.

84 Kunstein, Wessels, p. 11. 
Haas, Ernst B. (1958), The Uniting of Europe. Political, social and economic forces 1950 1957, Stanford: Stanford University Press.

Holzinger, Katharina; Schimmelfennig, Frank (2012), "Differentiated Integration in the European Union: Many Concepts, Sparse Theory, Few Data", in Journal of European Public Policy, vol. 19, no. 2, pp. 292-305.

Krugman, Paul R.; Obstfeld, Maurice (2009), International economics: theory and policy. 8th Edition. Boston: Pearson.

Kunstein, Tobias; Wessels, Wolfgang (2013), "The New Governance of the Economic and Monetary Union: Adapted Institutions and Innovative Instruments", in Istituto Affari Internazionali Working Papers, vol. 13, no. 2, pp. 1-13.

Leuffen, Dirk; Rittberger, Berthold; Schimmelfennig, Frank (2012), Differentiated Integration: Explaining Variation in the European Union, Basingstoke: Palgrave Macmillan.

Lindberg, Leon N. (1963), The Political Dynamics of European Economic Integration, Stanford: Stanford University Press.

Luzzaraga, Francisco Aldecoa; Llorente, Mercedes Guinea (2011), Europa viitorului. Tratatul de la Lisabona, Iaşi: Ed. Polirom.

Mundell, Robert A. (1961), "A Theory of Optimum Currency Areas”, in The American Economic Review, vol. 51, no. 4, pp. 657-665.

de Neve, Jan-Emmanuel (2007), "The European Onion? How Differentiated Integration is Reshaping the EU", in European Integration, vol. 29, no. 4, pp. 503-521.

Niemann, Arne; Schmitter, Philippe C. (2009), "Neofunctionalism", in Wiener, Antje; Diez, Thomas (eds.), European Integration Theory, New York: Oxford University Press.

Piris, Jean-Claude (2012, March 21), "The Euro Crisis, Democratic Legitimacy and the Future Two-Speed Europe", Speech presented at the Humboldt University, Berlin. Available online at http://www.whi-berlin.eu/tl_files/FCE/Rede-Piris.pdf accessed on 15.02.2013.

van Rompuy, Herman (2012, December 5), "Towards a genuine Economic and Monetary Union", Report presented in the European Council meeting in Brussels, 13-14 December 2012. Available online at http://www.consilium.europa.eu/uedocs/cms_data/docs/pressdata/ $\mathrm{RO} / \mathrm{ec} / 134355$.pdf accessed on 15.02.2013.

Sawicki, Iwona (2002), "Growing Regionalism in a Shrinking World", in European Policy Centre Working Papers.

Stubb, Alexaner C.-G. (1996), “A Categorization of Differentiated Integration”, in Journal of Common Market Studies, vol. 34, no. 2, pp. 283-295.

Stubb, Alexander C-G. (1997), "The 1996 Intergovernmental Conference and the management of flexible integration", in Journal of European Public Policy, vol. 4, no. 1, pp. 37-55.

Stubb, Alexander C-G. (2002), Negotiating Flexibility in the European Union, Basingstoke: Palgrave.

Weiler, Joseph H.H. (2003), "Back to the Future: Europe as Community", in Collegium, no. 28, pp. 43-50.

European Commission (EComm) (2012a), "Public Opinion in the European Union: First Results", in Standard Eurobarometer, no. 78. Available online at http://ec.europa.eu/public_opinion/archives/eb/eb78/eb78 first_en.pdf accessed on 15.02.2013.

European Commission (EComm) (2012b), "Public Opinion in the European Union: Annex", in Standard Eurobarometer, no. 78. Available online at http://ec.europa.eu/public_opinion/ archives/eb/eb78/eb78_anx_en.pdf accessed on 15.02.2013.

European Council (ECoun) (2012), Brussels European Council 13/14 December 2012. Presidency Conclusions, Brussels. Available on-line at http://www.consilium.europa.eu/uedocs/cms_data/docs/pressdata/en/ec/134353.pdf accessed on 15.02.2013. 
European Union (EU) (2010), Consolidated Treaties. Charter of Fundamental Rights, Publications Office of the European Union, Luxembourg. Available on-line at http://europa. $\mathrm{eu} / \mathrm{pol} / \mathrm{pdf} / \mathrm{qc} 3209190 \mathrm{enc}$ 002.pdf accessed on 15.02.2013.

http://www.guardian.co.uk/business/nils-pratley-on-finance/2012/may/23/why-germanydoesnt-want-eurobonds accessed on 15.02.2013.

http://epp.eurostat.ec.europa.eu/tgm/table.do?tab=table\&init=1\&language $=$ en $\& p \operatorname{code}=\mathrm{tec} 0012$ 7\&plugin=1 accessed on 15.02.2013. 


\title{
Integration as Disintegration. Some Remarks on the Romanian Case viewed by Emil Cioran
}

\author{
Ovidiu PECICAN
}

\begin{abstract}
The early writings of Emil Cioran, belonging to the years 1930, deal with the problem of the destiny of Romania. The rethinking and the reshaping of the country is configured by the young philosopher in the frame of the plans for disintegrating the old Europe in the views of a new, imperialist, integration of it. To interpret this tendency only taking into account the increasing totalitarian Europe of the 30es is not enough. The present analysis discovers other Romanian political tendencies in the same direction.

Keywords: Emil Cioran, Romania, integration, disintegration, Bismarck, Carol I, fascism
\end{abstract}

What could integration and of course, its reverse disintegration, mean for a young philosophy student and then to the temporary professor, temporary winner of a grant, from the inter-war period, who was passionate about the meditation on small and great cultures, on the western decline described by Ostwald Spengler, and on the lack of destiny of his own people? Whatever the answer to this question might be, the reference to the well-known philosopher of culture who wrote the successfull work Der Untergang des Abendlandes (1918, 1922-1923) ${ }^{1}$ is compulsory, because it offers the framework for the use - and the abuse - of the terms mentioned in the book of young Emil Cioran Romania's metanoia (written in 1935-1936, published in 1936). In this book, there is indeed not just more than one way of using the concepts of "integration" and "disintegration", but also an oxymoronic vision on them; a tensional, a contrasting vision. Actually, Emil Cioran conceives, paradoxically, the integration as a disintegration, a non-history

1 The Decline of the West (German: Der Untergang des Abendlandes), or The Downfall of the Occident, is a two-volume work by Oswald Spengler, the first volume of which was published in the summer of 1918. Spengler revised this volume in 1922 and published the second, subtitled Perspectives of World History, in 1923.

The book introduces itself as a 'Copernican overturning' and rejects the Euro-centric view of history, especially the division of history into the linear "ancient-medieval-modern" rubric. [1] According to Spengler the meaningful units for history are not epochs, but whole cultures which evolve as organisms. He acknowledges eight high cultures: Babylonian, Egyptian, Chinese, Indian, Mexican (Mayan/Aztec), Classical (Greek/Roman), Arabian, Western or "European-American". Cultures have a limited lifespan of some thousand years. The final stage of each culture is, in his word use, a 'civilization'. /.../

According to the theory, the Western world is actually ending and we are witnessing the last season - "winter time" - of the Faustian civilization. In Spengler's depiction, Western Man is a proud but tragic figure, for while he strives and creates, he secretly knows the actual goal will never be reached." (wikipedia, at: http://en.wikipedia.org/wiki/The_Decline_of_the_West) 
- as the famous thinking of Lucian Blaga reflected the historical vacuum from the Romanians destiny -, but also as a desertion from the historical and metaphysical mission that the Romanian people has to build or could build. Because the question is the following: if it really has the above mentioned mission, why doesn't it put it to work, following it scrupulously over a longer period of time? And if it doesn't, why doesn't it rise to the level of such a mission, as other people? Cioran thinks that the keeping into discretion, in an historical anonimity with no extraordinary facts, such as the great territorial conquests, or the great projects with long road traces, in other words the normal, average day-by-day organic development is the sure sign, on one hand, of the filution of the substance of a people, and on the other hand, the main symptom of a vocational castration, of a certain weakness in front of its mission. Such people will not acceed to edify a great civilisation, vanishing, step by step, from history.

Here are two of the important influences active in Cioran's thinking: the way Spengler conceives human civilisations and the way Lucian Blaga speaks about the mioritic space - namely, the metaphisical projection of the Romanian cultural relationship with the space of his own culture -, an opaque space, decayed from history, vague and ambiguous, which didn't let the traces of any capacity typical of a great culture able to give birth to an original civilisation.

Cioran's integration doesn't mean only the coming back to history and the insertion into the great history. For these were symptomatic, at that time, the approachement towards Hitler's Germany and, consequently, the entering into its gravity area, with the consequence of economic enslavement and of a strategic and military subordination to Berlin, for the longest part of the time of WW II. For the twenty four years old author, it also means the possibility of Romania's transformation into a unifying centre of the Balkans, more precisely into an inheriter of Constantinople ${ }^{2}$.

The idea is not as phantasmagoric as one could think. Its deepest roots can be traced back to the succession to the political power in the Byzantine Empire when, after 1204, Ioniță Caloian, the tzar of the Vlachs and the Bulgarians, tried it being eager to obtain for himself the basileus heritage. It can also be noticed the imperial and christian-orthodox ecumenic horizon in which some Romanian princes placed their approaches. I name, among those characters, Radu the Great - who brought Niphon, the Constantinopolitan patriarch, to Wallachia -, Neagoe Basarab, with

2 Ibidem, p. 230: “... fi-va România țara unificatoare a Balcanului, fi-va Bucureştiul Noul Constantinopol (subl. E.C.)?” / “... will Romania be the unifying country for the Balkan, will Bucharest be the New Constantinople?"/ Aspirațiile imperiale româneşti teoretizate de ideologii ortodoxişti ai Romei a IV-a oferă până astăzi cel mai flexibil şi mai adecvat model de înțelegere a unor fapte aparent disparate precum: daniile domnitorilor români la Muntele Athos, organizarea unui sinod cu ambiții ecumenice de către Vasile Lupu, la Iaşi (1642), implicarea României în războaiele balcanice şi Pacea de la Bucureşti (1913), acceptarea şi îndeplinirea de către România întregită a misiunii Antantei în Ungaria (1919), inițiativele legate de încropirea Micii Înțelegeri (1920) şi evenimentele din timpul conflagrației mondiale secunde. 
his dreams of greatness and imperial culture, Vasile Lupu, who hosted an ecumenic orthodox synod in Iassy, trying to stop the roman-catholic and calvinist propaganda inside Moldova together with the greatest theologians of his time. At his turn, Michael the Brave wanted, in the first period of his anti-Turkish military campaign (in the years 90 of the 16Ith century), to free the Balkans from the Ottoman domination. Closer, in the early 19th century, the idea of a confederation between the peoples from the lower Danube became visible in the political papers and projects of the small Romanian nobility (like the Federative Conspiration of Ioniță Tăutul).

With the coming of the German chancellor Otto von Bismarck's protegee, Charles I von Hohenzollern und Sigmaringen, on the Romanian principalities throne, the old project attended a revival, this time under Prussian protection. On the 20th of May, 1888, just six years after transforming the unified principalities into a Kingdom, Vasile Pogor, a valuable public personality, spoke about Charles I to his friend A. C. Cuza: "The German is much wiser than the country thinks. He suffers and keeps silent, following his plans in a wider prospective. /.../ Some people say that he dreams about founding a great Balkan state, in order to be its leader, and which would include into a confederation Bulgaria, Serbia, Romania etc." ${ }^{3}$ The fact was accomplished just partially, at the time of the Balkan wars. Their peace was negociated with Romania as arbiter, in Bucharest, in 1913.

As Ioan Petru Culianu has remarqued - in the third chapter of his unpublished monographyn, The unknown Mircea Eliade (written between 1982 and 1983) -, in the Romanian inter-war period culture, there is a certain intellectual tradition of the 4th Rome. Reading N. Iorga, Radu Dragnea, Nae Ionescu and Nichifor Crainic, ideologists of genuine and original Romanian orthodoxy, followed by the disciples of the philosopher Nae Ionescu, such as Mircea Eliade, Cioran (with Tears and Saints/ Lacrimi şi sfinți) and Constantin Noica (from a lot of the articles written in his younger years), I.-P. Culianu notices an attempt of putting together a common direction of thinking and acting in order to cover plural traditionalist directions: the orthodoxist nationalism of N. Iorga, the mistic "trăirism" of Nae Ionescu, the religiously orthodox coloured "gândirism" of Nichifor Crainic and also the spiritualist generationism from The Spiritual Itineray/ Itinerarul spiritual (1928) of Mircea Eliade (continued by Petre-Marcu Balş and the other authors of The White Lily Manifesto/ Manifestului Crinului Alb). Reconstructing briefly, but clearly, this structuring process of the dominant ideological mark of interwar Romania, Culianu went beneath the thinking of the schools from the time in a classical, monographic way, one at the time. Culianu remains, until now, the unique interpreter of that intellectual movement that subordinates to the imperial idea of orthodoxy taken from Byzance the different cultural traditionalist tendencies

3 A. C. Cuza, Innsemnări din viaţă şi documente omeneşti, ed. de Marian Ştefan, Bucureşti, Ed. Oscar Print, 2012, p. 15. 
of the time. He offered a plausible explanation frame to the Romanian political dynamics, insuficiently explained by the Greater Romania project and that was not explainatory - leaving aside the momentary understanding between Hitler and Antonescu -, looking for the Romanian army at Stalingrad in the time of the second world war. "Let us go, brothers, to a terrible and soaring crusade, against the human rottenness, against all the dead ideals which suffocate our impulses and against all the forms which press on our mission"4, says Cioran in the Romania's metanoia/ Schimbarea la față a României. The term "crusade" does not leave room for any ambiguity. It concentrates in itself christian militantism, militarism, conquest, and also a substantial trace of fanaticism. Cioran's Romania was called to integrate, even if only destructuring previously. And the way for meeting this goal was, for the young thinker, excess ${ }^{5}$.

Also about the "crusade" in connection with the second world war, spoke general Dwight Eisenhower right in the title of his memories. Applying the concept, as a follow-up of the American memorialist, to WW2, and, mainly, to the warrior initiative of the Axis, we can better understand that the perception on the revolutionary initiatives from the second inter-war decade was that it tried, to destroy for good the existent democratic environment, seen as a failure, and to replace it with a new, totalitarian, order. It seems that even WW1 was not a valuable lesson for this type of politics. Two decades later, marshall Ion Antonescu was going to war again, participating in the German adventure on the eastern front not only for regaining Basarabia from the Soviets, but also for finishing with the slavic race and getting rid of Russian orthodoxy for a Romanian one ${ }^{6}$. The old project of a Latin orthodox domination, namely a Romanian one, in this part of Europe, was not fading even if the reality was pretty complex.

Putting the meditation of Emil Cioran from Romania's metanoia in the shadow of the ideological line that dreamed about a Romanian power in the Balkans and even more than that, in all the Eastern Europe, "between Berlin and Moscow",

4 Cioran, "Tentația politicului şi a jertfii”, in Vremea, year VII, nr. 321, 14 January 1934, see Revelațiile durerii, ed. cit., p. 121.

5 "Pentru a înțelege spiritul Germaniei de astăzi, este absolut nevoie să iubeşti tot ceea ce este exagerat, tot ceea ce răsare dintr-o pasiune excesivă şi debordantă, să fii încântat de tot ceea ce este avânt irațional şi monumentalitate deconcertantă" /To understanding the spirit of Germany nowadays it is absolutely necessary to love the exaggerated, all that comes from an excessive and overflowing passion, to be enchanted by all that is irrational enthusiasm and disconcerting monumentality"/ (Emil Cioran, "Aspecte germane", în Vremea, an. VI, nr. 314, 19 noiembrie 1933, p. 9). "Dacă îmi place ceva la hitlerism este cultul iraționalului, exaltarea vitalități ca atare, expansiunea virilă de forțe, fără spirit critic, fără rezerve şi fără control" / If I like something about hitlerism is the cult of irrational, the exaltation of vitality as it is, the masculine expansion of forces, without critical spirit, without reserves and without control"/ (Emil Cioran, “Germania şi Franța sau iluzia păcii”, in Vremea, an. VI, nr. 318, Crăciun 1933).

6 Eduard Mezincescu, Mareşalul Antonescu şi catastrofa României, Bucharest, Ed. Artemis, 1993, pp. 51-53, 62-63, 139. 
allows one to align his work between the texts with a programmatic value for a certain Romanian expansionism comming from the Middle Ages, following the dream of an imperial legitimacy, which was manifesting itself as an imperialist modern fantasy, slightly grotesque for us. But not for young Cioran!

In Cioran's texts the integration of the eastern oecumene under Romanians - a dream mirrored later by the thinking of marshall Ion Antonescu - meant more than one thing. Without telling it expressly, he projected on to his own people the capacity and the ability to substitute itself, together with its orthodox vocation, to Moscow, the third Rome, becoming the centre of the eastern-christian religion from where the "light" was coming. But this type of mission was not to be done by the efforts of a "vegetable", passive, unclear in its plans. Therefore, the integration seen by Cioran also meant a moral and spiritual ressurection of the Romanians. He had in mind a real revolution. But "Națiunile mici nu pot face revoluții universale" /"Small nations cannot make universal revolutions"/7. He thinks that, "O revoluție trebuie să suprime un sistem general-valabil, existând, în forme diferite, în toate țările şi să întroneze altul, susceptibil de a fi primit pe întreg globul, indiferent de nivelul istoric al celorlalte națiuni" /"A revolution has to supress a generally accepted system that existed in different forms in all the countries and to install another one, susceptible of being accepted by the entire globe, no matter the historical level of the other nations"/8. Localised "Între Berlin şi Moscova, România este silită să-şi creeze un drum propriu" /"Between Berlin and Moscow, Romania is forced to create its own way $/ 9$. The problem is that "Orice revolutie natională este numai o treaptă /subl. E.C./. Ar putea spune cineva că fascismul şi hitlerismul sunt culmile istorice a două națiuni? Nu-mi vine a crede"/ "Any national revolution is only a step. Could one say that Fascism and Nazism are historical peaks of two nations? I can not believe it." $/ .^{10}$

Because Romanians need a boost, even despite their will, the way of totalitarianism is required as for granted, as in the case of Cioran. "I conceive dictatorship as a permanent revolution / E.C. /."11, "he says and: "In Romania only terror, brutality and endless anxiety could change something. All Romanians should be arrested and beaten, this being the only way for superficial people to make history ". ${ }^{12}$ Prudent, he thinks that "If the revolution of the nationalists does not bear fruit, they are not to blame, but the inherent flaws of our people". ${ }^{13}$

7 Ibidem, p. 167.

8 Ibidem, p. 167.

9 Ibidem, p. 229.

10 Ibidem, p. 168.

11 Cioran, Schimbarea la față a României, Bucharest, Ed. Humanitas, p. 191.

12 Cioran, letter to Petru Comarnescu, dated 27 December 1933, editet by Simona Cioculescu, in Manuscriptum, year XXIX, no. 1-2, 1998, p. 234.

13 Cioran, "În preajma dictaturii", in Vremea, year X, no. 476, 21 February 1937, p. 3. 


\title{
Future Scenarios for United Europe
}

\author{
Alberto GASPARINI
}

\begin{abstract}
In the paper the United Europe, in the shape of EU, is described, but also the "cracks" ongoing inside it: first of all the European economic crisis that does not allow to practice a positive internal "soft power", the lack of charismas of the EU élites, the mechanisms of government that weaken the capacity of EU to be effective (for example the rotation of the presidency, creeping internal colonialisms, and so on) are considered. Starting from this present scenario, scenarios for the future are worked out. We can define them in the following ways: 1) the pure catastrophic scenario: it sees the disappearance of the United Europe or this becomes an empty shell; 2) the realistic catastrophic scenario: it sees the United Europe to become an entity in which internal asymmetrical relations take form, completely open towards the strongest states and close enough (for the circulation and rules) towards the internal peripheral or smaller states or more little, operating a kind of colonialism; 3) the realistic ideal scenario: it sees that the United Europe keeps the "promises" made and the "premises" from which it is born, except that its member states are still strong and their "reserve of powers". Outwards the EU always remains and keeps the features of an International Organisation; 4) finally the pure ideal scenario: it sees the transformation of the EU in a federal state, in which the sovereignty of the federate state remains more and more soft so much that it disappears, at least in the aspects of general coordination and of the management of the EU general policies. The discussion of the four scenarios verifies which of them will be carried out in the future: after 10 years, 20 years, 30 years. 40 years. It is more likely that the fifth scenario occurs, that is a scenario that collects elements from each of the scenarios considered before and it assumes a further configuration with respect to those are forecast. Keywords: United Europe, scenarios, future, civil society, social integration
\end{abstract}

\section{Current scenario for the United Europe: problems and impasses}

The present-day is a Europe that offers many advantages, of course, but it also faces a number of problematic situations, all of which can be traced to a number of essential fixed points: the value of domestic peace but also of international peace, the original value of civil society extended to all societies in the manifestations of everyday life, the mixing of civil societies; a single political society which is not easy to construct because single states still exist, but also because this Europe displays a kind of addiction to a system, formerly bi-polar and now mono-polar, in which it has difficulty in identifying its post-imperial "wisdom".

The fusion of the above fixed points will produce the future Europe, but it will also produce the problems it must face and the opportunities that new and external developments will present it with. I shall now mention some of them.

1) The balance between the civil societies of each of the 28 nations and the civil society of the new European Union is fairly predictable and in some ways the element whose construction is most simple. The Union has a consolidated tradition of 
attention and action for standardising civil societies and opening them to dialogue. Community directives, and recommendations which become obligatory, have played a fundamental role in this construction - in the economy, the single currency, human and civil rights, culture, the widespread execution of public works that the poorest countries would otherwise be unable to achieve (in Portugal, Ireland, Greece, southern Italy and Spain), the devolution of central power to the (Euro)regions ${ }^{1}$, and the progressive weakening of national sovereignty, at least inasmuch as it impinges on civil society. There is no doubt that the entry of new countries in the EU - and subsequently of other candidates and candidates-to-be, all with a centralist, egalitarian and Communist history behind them - will pose enormous problems of harmonisation and require a great deal of time. ${ }^{2}$

2) The present European Union is a product of civil society, a collection of social groups, organisations and associations governed by the interests and rights of the individual, of all individuals. It must now be added that a national social system can maintain itself and its international relations (especially the most demanding ones) only if the various components of civil society give their consent to the political class which has made strategic choices for the country. The strategic choice in this case is to take the country into the European Union. What happens if the consent given to the political elite is removed? The result will be new governments, which may be populist or neo-Communist in character. This will produce the temptation, if not the actual move, to leave the united Europe. This is not a very likely scenario, because the accession of the former Communist countries was based on a sort of pact between their citizens and their governments and the EU: you make sure we get a good quality of life, full employment and self-fulfilment in the market through privatisation, and we shall succumb to the allure of being part of the New United Europe. ${ }^{3}$

3) What European civil society may arise from relations between the many old and new national civil societies, and therefore from the policies of the new European Union? Broadly speaking, the new countries exert a form of historical attraction on the societies of Mitteleuropa and Scandinavia, so they will to some extent strengthen their economic, cultural and social ties with countries of German or Scandinavian culture. This will cause imbalances among the various souls of Europe, with the reinforcement of the German-influenced Nordic soul at the expense of the Latin and Mediterranean souls, and to some extent even the English-speaking one. The result might be latent conflicts arising from the tendential formation of central and peripheral circles in the united Europe. This drives the marginal countries to pull into Europe not only the Balkan-Danube countries but also those of the Mediterranean area, starting with the now-consolidated

1 Gasparini, 2007, pp. 9-40; Gasparini, 2012, pp. 17-32.

2 Gasparini and Radojkovic, 1994; Petrovic and Russo, 1998; Puscas , 2006; Puscas, 2013; Kornai, 2008; Dolghi, Rouet and Radics, 2009.

3 Hughes, 1999; Baldocci and Gasparini, 2007; Sidjanski, 2007, pp. 87-110. 
Turkey and proceeding with the Arab and Maghreb countries in North Africa. The momentum will thus tend towards a further enlargement of Europe, which will in turn create new dynamics and new balances.

4) These political processes are made all the more complex by the lack of any precedent. It will take a long time for coalitions to form and consolidate, if they ever do. This complexity and the long-time scales involved in the preparation and taking of decisions (which also entail the time needed for the formation of consensus and convergence) absorb a great deal of energy and tension and too much attention, which works heavily to the detriment of the external role that the new European Union is called upon to play. And that handicap is further compounded by the fact that the European Foreign Minister is an entirely new figure, one whose independence from 28 national governments will have to be established. All this leads to the conclusion that for many years to come this European Union will unable to play an international role, one that would enact the consolidated values of the European peoples - that of peace as a basis on which to deal with conflicts (to be maintained at a virtual, sublimated level) and that of the "imperial wisdom" that Europe seems to have accumulated from its tragic imperialist past. ${ }^{4}$

\section{Scenarios in 2050 for a united Europe of civil societies}

Thus far we have outlined the present United Europe scenario, which is very similar to the neo-functionalist model conceptually developed by Haas ${ }^{5}$ and Lindberg ${ }^{6}$ and updated in the 1990s and the following decade by Gehring ${ }^{7}$ and Sandholtz and Stone Sweet ${ }^{8}$. Neo-functionalism "describes and explains the process of regional integration with reference to how three causal factors interact with one another: 1) growing economic interdependence between nations, 2) organizational capacity to resolve disputes and build international legal regimes, and 3) supranational market rules that replace national regulatory regimes. ${ }^{9}$

We have also identified the problems encountered by the scenario in maintaining Europe united in the immediate future, and in the deeper future of the next few decades. These futures are projected at times between 2020 and 2050. The first step is to define what the United Europe scenarios are, and then they are projected into the years comprised between 2020 and $2050 .{ }^{10}$

4 Rinaldi, 1995, pp. 327-350; Gasparini, 2004b, pp. 73-98; Balsocci and Gasparini, 2007.

5 Haas, 1958.

6 Lindberg, 1963.

7 Gehring, 1996, pp. 225-253.

8 Sandholtz and Stone Sweet, 1997, pp. 297-317.

9 Haas, 1961, pp. 366-392; Sandholtz and Stone Sweet, 1997, pp. 297-317.

10 Gruppo di Lisbona, 1994; Baletic, 1998; Hughes, 1999; Gasparini and Bregantini, 2004, pp. 264-305; Radermacher 2004, pp. 188-207; Bauman, 2005, pp. 269-293; Gasparini, 2011, pp. 149-180; Randers, 2013. 
There are four types of possible scenario, within one of which Europe may evolve in a linear and continuous fashion, but it may also pass from one to another, at times quite easily - as will be seen in an attempt in the next section to introduce the time variable into each of the four scenarios. Now for their definition.

Starting from a scenario analysis conducted in 2000 for countries yet to join the European Union, considered according to their degrees of openness to the outside $^{11}$, the scenarios may be denominated as follows:

1. Pure catastrophic scenario,

2. Realistic catastrophic scenario,

3. Realistic ideal scenario,

4. Pure ideal scenario.

In which

Catastrophic means a negative scenario contrasting with a previous positive situation and unable to produce a positive future, which thus becomes impossible.

Ideal means a positive scenario following a previous positive situation, able to produce a positive future, in fact tending to produce the best outcome.

Realistic means a scenario where the implementation of policies makes it possible to approach the best outcome, with use of sustainable resources. Such policies are pursued without subjecting the population to excessive sacrifices.

Pure means a scenario where the policies implemented make it possible to achieve the best outcome.

Each of the four scenarios is considered according to the following criteria:

1. Each scenario is dominated by a principle, which is conducive to the materialisation of one type of model.

2. In each scenario there is an economic balance/imbalance within the United Europe and its single states, with a specific internal soft power. ${ }^{12}$

3. The third criterion concerns European integration as contrasted with national integration, with intermediate forms of European areas.

4. The fourth criterion concerns the localisation of the "reserve of powers".

5. The fifth criterion concerns relations between public opinion, the population, elites and states, and their movements (which may or may not be migratory). ${ }^{13}$

6 . The sixth criterion concerns United Europe's relations with the outside world; it may behave as an international organisation, developing its own foreign policy according to the method of an external soft power. ${ }^{14}$

7. The seventh criterion emphasises the role of national civil societies and the United Europe.

Broadly following the above criteria, the four scenarios may now be defined.

11 Gasparini, 1999; Gasparini, 2004c; Ash , 2005, p. 203ss; Langer, 2011, pp. 31-60.

12 For example of Russia and China, see Wilson, 2012.

13 Scartezzini, 2002, pp. 377-400; Mon tanari, 2004, pp. 43-72.

14 Nye, 2005. 


\subsection{Pure catastrophic scenario or regression to states}

The principle dominating the catastrophic scenario is the reversion to original statehood. This is triggered by economic crisis, with a consequent plummeting of employment and incomes. The European Union is increasingly impoverished because the biggest and strongest states progressively reduce their budget contributions and the smaller and peripheral states therefore receive progressively fewer resources from the EU. National policies come to prevail over European policy and thus empty the United Europe of substance. Examples may be seen in the form of Hungary, the Czech Republic and the Poland of the Kaczynski brothers. The basic idea is "national is good", because the supranational EU is a source of discrimination and new vested interests. The latter include the European financial institutions, military power concentrated above all in French and British hands, internal alliances which further marginalise small states and make them increasingly insignificant. The ultimate "reserve of powers" is taken back by the states, including those which had already been devolved to the United Europe (previous non-compliance with the delegation of powers had been met with economic sanctions by the EU). European civil society fails, giving way to a reassertion of the overweening power of the civil societies of single states, and niche development as a consequence of national closure (whether imposed or chosen).

This scenario follows what Sandholtz and Stone Sweet ${ }^{15}$ and Rosamond ${ }^{16}$ call the intergovernmental model. This approach is based on the rationale that national states do preserve their core sovereignty while interacting among each other in search of results which satisfy their personal interests. National sovereignty represents the guarantee that common objectives and the integration process will respect the position of each member. Furthermore sovereignty constitutes a fundamental element for the existence of a national state. ${ }^{17}$ According this view the European Union should function as an ordinary international organisation in which the supranational power might exist in a weak form and in any case controlled by national interests.

In sum, this catastrophic scenario, more negative than the present scenario and unable to take a positive turn for the United Europe, is also pure because it is a reversion to single states after a time in which the United Europe model was believed in and experienced, only to be superseded by the frustration caused by its failure.

15 Sandholtz and Stone Sweet, 1997, pp. 297-317.

16 Rosamond, 2000, p. 132.

17 Albertini, 1997; Geertz, 1998, pp. 33-56; Acemoglu and Robinson, 2013. 


\subsection{Realistic catastrophic scenario or return to the Free Trade Area}

This scenario tends to empty the present United Europe of substance, turning into the North European idea of a Free Trade Area while preserving a simulacrum of United Europe, or perhaps a sort of "Dieta perpetua". ${ }^{18}$ In these conditions Europe's internal soft power, meaning the exercise of power by mediation and discussion, is unable to mediate the interests of EU member states and promote and equal and balancing integration of the diversities and differing levels of wealth of the European regions and social classes. Instruments such as free movement within the Schengen area, the Eurozone, structural projects, student exchanges and joint scientific research become increasingly exceptional in their adoption and effectiveness. In this scenario the EU also reduces integration and expands the accession of new states such as Belarus, the Ukraine, Moldova, Turkey, Balkan countries and states in the Mediterranean area. This leads to the creation of subareas of free trade: central-northern Europe (France, Benelux, Germany, Poland, the Czech Republic, Slovakia, Hungary), northern and Scandinavian Europe, south-eastern Europe (Balkan-Danube countries) and maritime southern Europe (Greece, Turkey, Italy, Spain, Portugal, Malta, Cyprus, the Middle East and North Africa). Norway becomes the reference model. The constraints of the United Europe are relegated to a discretional level, being adopted only according to national interests. The expansion of the Schengen area is stopped, partly because some countries refuse to take part (United Kingdom) and partly because others are refused entry to it, at least in the short to medium term. In external relations the United Europe behaves 1) as an international organisation in politics for lesser things (such as peacekeeping) and using international soft power in the economy and civil society; 2) as though it were non-existent for business of the greatest interest to the EU's stronger states - as in the cases of Libya and Mali. Lastly, national civil societies tend to maintain their current levels, with the class-based difference that European space is much easier to penetrate for elites (for study and tourism) and for the strongly empathetic poor, through immigration to European places representing the values that matter, than for autochthonous intermediate classes and the local poor, who remain in their national environments.

From a theoretical standpoint this scenario is more closely tied to the neo-functionalist approach already considered for the present scenario, highlighting the importance of regional integration and the pursuit of every national interest on the part of single states.

In sum, the realistic catastrophic scenario involves the disappearance of values, policies, global integration and economic balance, and the United Europe thus emptied is a shell within which a Free Trade Area takes shape. With the integration of the United Europe thus severely undermined, greater substance is taken on by

18 Ferraris, 2001, pp. 74-85. 
relations with non-EU countries and sub-areas within the present EU. The external borders of what is now the United Europe thus become weaker than they are now, whereas the borders between the sub-areas taking shape in the present EU become more rigid. Lastly, there occurs a split between national civil societies: those more closely identified with elites and poor non-European classes and young people who emigrate become (or remain) European civil societies, while those more identified with intermediate classes and the dignified autochthonous poor increasingly become national civil societies.

\subsection{Realistic ideal scenario or in equilibrium between political Europe in the short term and a federation in the long term}

The realistic ideal scenario rests on a principle which is ambivalent in terms of objectives to be pursued and dynamic over time. The aim is to take the present economic EU of civil societies towards a politically United Europe, beyond which is the more general objective of United Europe as a unitary state in the form of a confederation of states. This result is attempted through internal soft power, but its processes are too long for decisions which lead to radical changes, in particular in foreign policy (as shown by the cases of Iraq, Libya and Mali). Compared to the realistic catastrophic scenario, in this the variable geometries between EU countries (the current 27 plus Croatia) are less marked, because both the Schengen area and the Eurozone expand, and progressive European integration counteracts the formation of internal sub-areas (characterised by variable geometry). Favouring all this is the fact that discussions take place within established community bodies strengthened by cogent objectives. In addition, internal borders become increasingly redundant and virtual. By contrast, there is a marked tendency towards a rejection of the extension of the EU to countries still not in it, and a consequent hardening of neighbouring borders. Despite all the above, there remain strong contrasts between elements of public opinion (Europhiles against Eurosceptics) and their elites (more Euro-positive), and between states wanting greater integration and those wanting a loosening of internal integration and the common foreign policy.

In sum, the realistic ideal scenario has the positive orientation to enhance integration and limit the principle of variable geometries. The timescale for federation is still a long one and at times there are imbalances between elites favourable to Europe and national populations more interested in the practical benefits that the European Union can provide and the sacrifices it entails than the generic idea of a United Europe. On the other hand, the dominant model in the scenario is based on the syncretic paradigm. The "syncretic paradigm premised its assumptions about the dynamics behind regional change on ambivalence rather than certainty outcomes. The present standoff between the member states and those actors who steer 
the Community's supranational institutions simply could not be explained exclusively in realist or supranational terms". ${ }^{19}$

\subsection{Pure ideal scenario or a new federal state}

The strong guiding principle for this scenario is the aim of transforming the European Union into a federation of states. Recognising the internal powers of the federated states, the Union has the responsibility for the formation and imposition of general directives of economic, fiscal, monetary, environmental, transport, education, employment and foreign policy. The EU federal state is thus able to benefit from the time and resources previously devoted to decisions requiring a great deal of discussion, establishes a global society and free economies through internal soft power and also works through strong and effective international soft power. Territorial constraints (that is to say borders ${ }^{20}$ within the EU become increasingly administrative rather than political. Its external borders harden, but in these areas cooperation policies reduce the marginalisation of peripheral countries (with ECTCs, Euroregions, etc.). ${ }^{21}$ The EU establishes instruments which tend to reduce the marginalisation of areas and societies which may derive from the absence of national states which compensated for the differences within them. National states become regions in their present configuration and inherit their functions - in the case of medium-sized states they function as macro-regions, and small states are aggregated to their larger neighbours. The civil societies of single national states tend to fuse in a single European civil society through the achievement of a common and homogeneous integration of the human, civil and organisational rights of citizens belonging to the EU. Some specific characteristics peculiar to certain local and/or national societies continue to be recognised.

The pure ideal scenario ${ }^{22}$ achieves the ultimate and traditional aim of the United Europe of civil societies - a federal Europe, which is a single state but also a body of regional/state rights and duties which are perfectly recognised and implemented. The theoretical approach underlying this scenario is thus the federal one, which highlights "the priority to start making formal changes in political institutions and procedure as the key to securing social harmony and democracy. As a political doctrine, federalism has until quite recently always been more preoccupied by defining formal outcomes and recommending suitable institutional frameworks for balancing natural social diversity with the requirements for a just governance". ${ }^{23}$

19 O’Neill, 1996, p. 19ss.

20 Rifkin, 2002, p. 202.

21 Gasparini, 2012, pp. 17-32.

22 Bocchi, Ceruti and Morin, 1991, pp. 51-81; Fine, 2007, p. 48ss; Miglio and Barbera, 2008.

23 O’Neill, 1996, p. 19ss. 
The materialisation of this this scenario entails a high level of commitment to the objective but also to internal integration and equilibrium and a curtailment of the selfish interests of the single states making up the EU. It also requires the maintenance of a constant consensus based on practical responses to the needs and problems of civil societies. This scenario constitutes the realisation of the dream of a United Europe, the culmination of a process begun a long time ago by Spinelli24; but also Gatto ${ }^{25}$, De Gasperi, Monnet and Adenauer. We know, however, that the creation of this federation of states is not a final achievement, it is not a Europe united once and for all. History continues and the process of things goes on, so the commitment must be constant and efforts will have to be maintained to keep Europe united, modifying specific features and having to adapt to continually changing internal circumstances. Under these conditions the danger that this United Europe could enter into crisis and see the beginning of its decline is always present. It hardly needs to be said that such events have been seen many times in the past.

\section{The four scenarios in the temporal process from 2010 to 2050}

The four scenarios illustrated above represent the concluding point of a given period, which may be postulated to finish in 2050. It may also be considered as the reference point for a process of actions and policies which are introduced to modify the current scenario, the state of things as they now stand. As is well known, the business of prediction is not a utopian exercise. What is important in prediction is how the predicted future is constructed, that is to say the collection of actions and policies which in a given period are successively adapted in order to reach the desired (normative) prediction. By contrast, how a utopia is achieved matters little - what counts is the final state, which must be a perfect and unchangeable condition. ${ }^{26}$

If at the end of the given time-frame the four scenarios prove not to match the predictions made, this will be because more attention has been devoted to the process (the how mentioned above) than to the perfection of the predicted final state. In these conditions the future takes different forms, and is varyingly predictable, according to the times considered (the distance between $t_{0}$ and $t_{1}$ ). A prediction is more reliable if the time is short (a survey drawing on a short time-frame gives a more "certain" prediction), while a prediction is more uncertain and generic when time-frames are longer. In the case of United Europe four times are considered; over short time-frames the environment (context) is stable and the endogenous United Europe variables are more effective - the opposite is the case when the prediction times are longer.

24 Spinelli, 2010, pp. 39-72.

25 Gatto, 1995.

26 See Gasparini, 2000, pp. 2224-2233. 
For United Europe the operational environments for the four time-frames considered ${ }^{27}$ are as follows:

$-2020 \rightarrow$ stable environment,

$-2030 \rightarrow$ an environment with "creaks" and "noises", that is to say with modifications that produce some secondary effects of outward and inward adjustment for United Europe,

$-2040 \rightarrow$ an environment undergoing changes, some of which are radical,

$-2050 \rightarrow$ an environment with unpredictable radical changes.

The extreme scenarios (pure catastrophic and pure ideal) may be described as "movementist"; since they are orientated towards radical internal change in comparison with the current scenario (2010) and require strong and continual intervention policies. The first scenario of regression to states (pure catastrophic) is the result of the centre's inability to adopt community policies and the adoption by states of strong self-interested policies. The fourth scenario of the new federal state (pure ideal) is the result of "extreme" highly targeted community policies. But it is above all the result of policies leading to internal changes: United Europe's internal structure changes radically with the disappearance of the European Council and its representation of state decision-making power and with the establishment of the Euro as the state currency.

In these conditions the intermediate scenarios are more realistic, in that: 1) they entail fewer sacrifices for states (above all financial, connected to the criteria to which they have to conform) and for some social and particularly economic classes, which should face a number of "pressing" directives; 2) they are subject to ambivalent policies (or even contradictory between state and community level), unclear policies subject to discretional application and policies which may become contradictory in their sequencing over time. The latter contradiction is due to the fact that over time these scenarios are subject to policies which take varying lengths of time to be implemented or have to be adjusted or supplemented over time with other policies.

Another cause of these difficulties may be that strong (or central) states want certain policies and weaker ones (in terms of economy and status) want others. Or there may be a clash between the United Kingdom, the Czech Republic and Hungary (for example), which want a weakly united Europe, and other states which want a stronger United Europe more generous with money and investment and more open to free movement.

The following question may also be asked: what happens when the federal state of Europe has been achieved, even before the forty-year timescale has elapsed? It has already been seen that such an institutional arrangement is unlikely to be perfect, since the differing viewpoints of the states composing it are not likely to disappear. Even admitting that such a federation is established,

27 See Gasparini, 1983, pp. 203-228. 
what sort of future lies in store for it? The new variables putting the European federation to the test may include radical and unexpected changes in the environment, the consolidation of national economic interests previously softened by the commitment needed to maintain the new state, unstable internal balances which may bring variable geometries back to differentiate between parts of Europe, attractions to external neighbours such as the US for Britain, Russia for central Europe, the Mediterranean basin for southern Europe, the maintenance of states' right of secession - but above all a collaboration fatigue, a tiredness of being together. ${ }^{28}$

Such fatigue has played an important role in previous administrative and political unions. Town councils which have united have subsequently wished to regain their autonomy; parts of provinces (such as Imperia in Italy) have wanted their own autonomy. The same may happen with regions and states set up on the basis of aggregations subsequently considered to be unnatural, artificial and shortterm. There is no doubt that countervailing forces attenuate this tiredness of being together: the inertia deriving from the habit of living together, the fact of having regulated co-existence with efficient and effective institutions, and a system of infrastructure providing close connection. But there are examples in Europe of states which have broken up, and therefore failed, after a time of co-existence: Czechoslovakia, Yugoslavia and the Soviet Union. Others are tempted to break up, such as Belgium, Britain, Spain and even Italy, with ambitions of varying degrees of credibility for a Free State of Trieste, a Padania of the Northern League and an independent Sardinia and Friuli.

At any rate, in the federated Europe the fatigue of living through a common experience starts to produce destructive effects when things (above all the economy, producing problems of identity and neo-nationalism) go wrong and there begins a process, whose speed will depend on external variables, leading to the break-up of the United Europe. Processes similar to the development of tiredness with a Europe too peaceful, too bourgeois, too Belle Époque, led to a desire for social and cultural novelty and a new society at the turn of the $19^{\text {th }}$ century, which in turn led to the enthusiasm greeting the outbreak of the First World War as the beginning of the rebirth of moribund social orders and societies.

Having factored in the times of the four scenarios, we may now rationalise the process whereby they may evolve from 2020 to 2050, postulating (merely for conventional purposes) that until 2040 the environment external to the United Europe remains basically static.

The table below is a schematic presentation of the possible development of the four United Europe scenarios over forty years of prediction.

28 Chiti-Batelli, 2004, pp. 573-589. 


\begin{tabular}{|c|c|c|c|c|}
\hline $\begin{array}{l}\text { Year } \\
\text { of pre- } \\
\text { diction }\end{array}$ & $\begin{array}{l}\text { Return to states } \\
\text { (Pure catastrophic } \\
\text { scenario) }\end{array}$ & $\begin{array}{l}\text { Return to Free } \\
\text { Trade Area (Rea- } \\
\text { listic catastrophic } \\
\text { scenario) }\end{array}$ & $\begin{array}{l}\text { Equilibrium between } \\
\text { the political Europe } \\
\text { in the short term and } \\
\text { a federation in the } \\
\text { long term (Realistic } \\
\text { ideal scenario) } \\
\end{array}$ & $\begin{array}{l}\text { New federal state } \\
\text { (Pure ideal scenario) }\end{array}$ \\
\hline 2020 & \begin{tabular}{|l|} 
- Economic Eu- \\
rope and of civil \\
societies, \\
- European cen- \\
tral institutions \\
(technocratic/ \\
rigid-contested)
\end{tabular} & $\begin{array}{l}\text { - Political and eco- } \\
\text { nomic Europe and } \\
\text { of civil societies } \\
\text { - European central } \\
\text { institutions }\end{array}$ & \begin{tabular}{|l|} 
- Economic Europe \\
and of civil societies \\
- European central \\
institutions
\end{tabular} & $\begin{array}{l}\text { - Economic Europe } \\
\text { and of civil societies } \\
\text { - European cen- } \\
\text { tral institutions in } \\
\text { consolidation }\end{array}$ \\
\hline 2030 & $\begin{array}{l}\text { - Dialogues among } \\
\text { states } \\
\text { - European cen- } \\
\text { tral institutions in } \\
\text { demobilisation }\end{array}$ & $\begin{array}{l}\text { - Economic Eu- } \\
\text { rope and of civil } \\
\text { societies } \\
\text { - European cen- } \\
\text { tral institutions in } \\
\text { demobilisation }\end{array}$ & $\begin{array}{l}\text { - Political and eco- } \\
\text { nomic Europe and } \\
\text { of civil societies, but } \\
\text { partial } \\
\text { - European central } \\
\text { institutions }\end{array}$ & $\begin{array}{l}\text { - Political and eco- } \\
\text { nomic Europe and of } \\
\text { civil societies } \\
\text { - European central } \\
\text { institutions, with } \\
\text { political powers } \\
\end{array}$ \\
\hline 2040 & $\begin{array}{l}\text { - States revert to } \\
\text { separate status } \\
\text { - Mainly economic } \\
\text { Europe with inter- } \\
\text { nal colonialism }\end{array}$ & $\begin{array}{l}\text { - Europe of civil } \\
\text { societies } \\
\text { - European cen- } \\
\text { tral institutions in } \\
\text { demobilisation }\end{array}$ & $\begin{array}{l}\text { - Political and eco- } \\
\text { nomic Europe and of } \\
\text { civil societies } \\
\text { - European central in- } \\
\text { stitutions with internal } \\
\text { soft power functions }\end{array}$ & $\begin{array}{l}\text { - Europe as a federal } \\
\text { state } \\
\text { - European central } \\
\text { institutions in a fed- } \\
\text { eral state }\end{array}$ \\
\hline \multicolumn{5}{|c|}{ The United Europe environment becomes less static, indeed radical events occur } \\
\hline 2050 & $\begin{array}{l}\text { Return to a new } \\
\text { united Europe }\end{array}$ & $\begin{array}{l}\text { Strengthening of } \\
\text { European central } \\
\text { institutions }\end{array}$ & $\begin{array}{l}\text { Experience of new in- } \\
\text { ternational and federal } \\
\text { state soft power }\end{array}$ & $\begin{array}{l}\text { Negative epilogue of } \\
\text { the federal state vs. } \\
\text { Strengthening of the } \\
\text { federal state }\end{array}$ \\
\hline
\end{tabular}

\section{Evolution of the scenarios}

Observed over the next thirty years $(2020,2030,2040)$, the four scenarios are highly linear in their sequence, comprised between the two extremes of a reversion to states, which at the most are joined in a Free Trade Area (Pure catastrophic scenario), and the formation of a federal state (Pure ideal scenario), with the crucial element of internal soft power which frees resources for international soft power, whose methods and potential the Europe of civil societies has already experienced. These two scenarios are explained and represented by an intergovernmental model $^{29}$ and at the opposite extreme a federal approach ${ }^{30}$, a model of bottom-up political change in which enlightened elites and their populations build a grand European project. In these models a central role is played by the civil societies of

29 Sandholtz and Stone Sweet, 1997, pp. 297-317; Rosamond, 2000.

30 O’Neill, 1996. 
individual states and of United Europe (global civil society), in which elites and the population as a whole are inextricably linked.

Beyond these two extremes, what is much more likely is the emergence of a scenario combining a number of characteristics of the two realistic scenarios (the second and the third, catastrophic and ideal). We may consider it as a fifth scenario, a realistic synthesis of the two intermediate ones.

Although everything is predicted to happen between 2010 and 2040, the plausibility of the dynamics and timescales in the scenarios is based and developed in the present United Europe, in physiological enlargement or in reduction.

These internal scenarios assume a basically static external environment in which all movements occur in accordance with predicted rules, at least without radical or violent external changes. But this cannot be taken for granted, since recent years have seen an unforeseen change in the form of the 2008 financial crisis generated by the United States. It has produced turmoil in the economies and globalisation processes of the United Europe and its banking systems, an increase in government bond yield spreads and an impoverishment of the lower-middle classes, in southern and Danubian Europe in particular. Further changes may also occur in the next $30-40$ years, and their unpredictability is at the root of crises which may strike at the process of integration of the European Union.

To such changes, which are unpredictable at least in their practical manifestations, the addition of at least another two may be postulated: 1) profound economic, political and power-relationship changes between some emergent nations (China, India, Brazil and the new Russian Federation) and the United Europe, which is increasingly marginalised along with the United States and Japan; 2) a profound subversion of Europe by Islamic fundamentalism and possible terrorism coming from north and sub-Saharan Africa. The first countries to be involved are in southern Europe.

These events, and others not now foreseeable, produce strong impulses in two directions - the dissipation of this new United Europe's energy and reorganisation and close integration within it. As a synthesis we project the four above scenarios to 2050, ten years after 2040, when the United Europe was designing its future based on its own strength and internal processes in a static external environment.

As seen in the schematic presentation above, 2050 shows some profound changes in the United Europe: in the pure catastrophic scenario there is a reversion to single European states; in the pure ideal scenario the United Europe is at a fork - in one direction is a negative epilogue of the break-up of the federation and in the other the strengthening of the federal state to face new external challenges threatening the disintegration of a United Europe which is no longer federal but a single unitary state. 


\section{In the end will this United Europe be achieved or will there be other united Europes?}

The above question may also be expressed as follows: in a hundred years (from 1950 to 2050) the United Europe has produced a basic imprint which in the first 50 years (from 1950 to 2000) we desired and sought. Will it last for the next 50 years (from 2000 to 2050)? Or will this United Europe collapse and follow a new reunification process because (say) the last 50 years have seen the dominance of some EU states such as Germany, or Germany and France, which is unacceptable to medium-small states, who see it as a new colonialism hiding behind the standardised rules of the European institutions?

The construction of a United Europe takes a long time because it involves states which each have their own long political history. However, there are two observations which run counter to this long-term factor. The first is that this United Europe was conceived and began to be built sixty years ago (formally in 1957), so a great many unifying factors have already been put in place. Secondly, before any political government, Europe is united by national civil societies which are increasingly standardised to a European norm. This points to a radically new future direction, towards the possible demise of the present United Europe and towards the emergence of new possible future models of United Europes.

Previous united Europes entered into crisis, and then collapsed, when their principal social structures (feudalism, and then the bourgeoisie) fell into decline. In the present United Europe the principle social structures are its civil societies, whose outlook has extended beyond their national cocoons since national traditions began to lose their hold in the 1970s.

Until the early 1990s the principal social structure of this United Europe of civil societies was hampered by a series of factors: 1) the existence of many frontiers, some of which were hard; 2) a less international dimension in relations between organisations; 3) civil societies were still largely nation-centred; 4) there was still a gap between cosmopolitan elites and the rest of the population, which was localist; 5) there were two types of cosmopolitanism, one excessively orientated towards the US, the other excessively orientated towards the USSR.

In the subsequent decades these civil societies became less national and more European, firstly because the financing and directives of the ECSC, EEC and EU progressively promoted the standardisation of national societies, states and European civil society. Secondly, national identities have not been a particularly difficult obstacle because they have been overlaid by the new European identity, including that of belonging to cross-border areas.

In the future of what is now a United Europe it is thus unlikely that Europeorientated civil societies and the European civil societies will decline as did the feudal system and 18th- and 19th-century bourgeois society. 
On the contrary, this European civil society (and its outward-looking national civil societies) is opening up and absorbing new dimensions based on the values of peace (referred to above), social justice, human rights and openness to the outside but also from the outside to the inside. There is also an increasing awareness of the value of protecting populations which manage to adapt to new situations, but also of the value of protecting populations which are poor and marginalised because of migration and marginalised and impoverished by "development models" old and new. ${ }^{31}$

\section{References}

Acemoglu, Daron and Robinson, James A., (2013), Perchè le nazioni falliscono, Milano, Il Saggiatore

Albertini, Mario, (1997), Lo stato nazionale, Bologna, Il Mulino.

Ash, Timothy Garton, (2005), Free World. America, Europa e il future dell'Occidente, Milano, Mondadori

Baldocci, Pasquale Antonio and Gasparini, Alberto, (2007), L'Europa in bilico/ L'Europe en suspens, Quaderni di Futuribili, no. 9.

Baletic, Zvonimir, (1998), "Europa unita, un lungo cammino", in Petrovic, Rade and Russo, Francesco (eds.), L'altra Europa, Napoli, Edizioni Scientifiche Italiane, 225-230.

Bauman, Zygmunt, (2005), La società sotto assedio, Roma, Laterza.

Bocchi, Gianluca, Ceruti, Mauro and Morin, Edgar, (1991), L'Europa dell'era planetaria, Milano, Sperling and Kupfer.

Censis, (1991), L'Europa del sociale. Un processo di integrazione dal basso, Milano, Angeli.

Chiti-Batelli, Andrea, (2004), "Perplessità sull'avvenire dell'Unione Europea", in Affari Esteri, no. 143 .

Dolghi, Dorin Joan, Rouet, Gilles and Radics, Zsolt, (eds.), (2009), "Europe and the neighborhood", in Eurolimes, vol. 7.

Ferraris, Luigi Vittorio, (2001), "La "Dieta perpetua" come congresso permanente di diplomatici", in Futuribili, no. 1-2, 74-85.

Fine, Robert, (2007), Cosmopolitanism, New York, Routledge.

Galtung, Johan, (1994), "L'emergente super-nazionalismo europeo", in Futuribili, vol. 1, no. 1, 129-143.

Gasparini, Alberto, (1983), Ambiente operativo e azienda agricola, Milano, Angeli.

Gasparini, Alberto, (ed.), (1999), Scenari di conflittualità futura. Assetti geopolitici e gestione della crisi nei prossimi dieci anni, Roma, Cemiss

Gasparini, Alberto, (2000), "Prediction and futures studies", in Borgatta, Edgar Frances and Montgomery, Rhonda, (eds.), Encyclopedia of sociology, New York, MacMillan, 2224-2233.

Gasparini, Alberto, (ed.), (2002), "Disoccupazione. Il lato oscuro dello sviluppo", in Futuribili, no. 3.

Gasparini, Alberto, (ed.), (2004a), Gli Europei e la Costituzione ci sono, a quando l'Europa?! The Europeans and the Constitution are in place - when will Europe be?, Quaderni di Futuribili, no. 5.

Gasparini, Alberto, (2004b), "Significati d'Europa", in Gasparini, Alberto, (ed.), Gli Europei e la Costituzione ci sono, a quando l'Europa?'/ The Europeans and the Constitution are in place - when will Europe be?, Quaderni di Futuribili, no. 5, 73-98.

31 Gasparini, 2002. 
Gasparini, Alberto, (2004c), "La previsione. Modi e temi italiani”, in Futuribili, no. 3.

Gasparini, Alberto, (2007), "Euroregione e confini virtuali. Luoghi internazionali in cui si elabora l'integrazione europea", in Baldocci, Pasquale Antonio and Gasparini, Alberto (eds.), L'Europa in bilico/ L'Europe en suspens, Quaderni di Futuribili, no. 9, 9-40

Gasparini, Alberto, (2011), Società civile e relazioni internazionali, Bologna, Il Mulino.

Gasparini, Alberto, (2012), SWOT 3. Cross-border co-operation in Europe. A comprehensive overview, Strasbourg, Council of Europe.

Gasparini, Alberto and Bregantini, Luca, (2004), "Scenari al 2010 per i paesi di recente entrata e di prossima candidatura nell'Unione Europea”, in Futuribili, no. 3, 264-305.

Gasparini, Alberto and Radojkovic, Miroljub, (eds), (1994), "Oltre le guerre balcaniche. Cosa può succedere quando i piccoli dei hanno grandi sogni”, in Futuribili, vol. 1, no. 2.

Gatto, Ludovico, (1995), Il federalismo, Roma, Newton Compton.

Geertz, Clifford, (1998), Mondo globale, mondi locali, Bologna, Il Mulino.

Gehring, Thomas, (1996), "Integrating integration theory. Neo-functionalism and international regimes", in Global Society, vol. 10, no. 3, 225-253.

Giubboni, Stefano, (2004), "L'Europa sociale ed il Trattato costituzionale. Luci e ombre", in Gasparini, Alberto, (ed.), Gli Europei e la Costituzione ci sono, a quando l'Europa?/ The Europeans and the Costitution are in place - when will Europe be?, Quaderni di Futuribili, no $5,99-116$.

Gruppo di Lisbona, (1994), I limiti alla competitività, Roma, Cnel.

Haas, Ernst, (1958), The uniting of Europe, Stanford, Stanford University Press.

Haas, Ernst, (1961), "International integration. The European and the universal process", in International Organization, vol. 15, no. 3, 366-392.

Hughes, Barry B., (1999), International futures. Choice in the face of uncertainty, Boulder Col., Westview Press.

Kornai, János, (2008), From socialism to capitalism, Budapest, Central European University Press.

Langer, Josef, (2011), "Europe 2030: anticipating nation, border and society", in Langer, Josef, (ed.), Analysis and visions for Europe, Frankfurt am Main, Peter Lang GmbH, 31-60.

Lindberg, Leon, (1963), The political dynamics of European integration, Stanford, Stanford University Press.

Miglio, Gianfranco and Barbera, Augusto, (2008), Federalismo e secessione, Milano, Libero

Montanari, Arianna, (2004), "L'identità europea e i valori occidentali", in Gasparini, Alberto, (ed.), Gli Europei e la Costituzione ci sono, a quando l'Europa?/ The Europeans and the Constitution are in place - when will Europe be?, Quaderni di Futuribili, no. 5, 43-72.

Nye, Joseph, (2005), Soft power, Torino, Einaudi.

O’Neill, Michael, (1996), The politics of European integration, New York, Routledge.

Petrovic, Rade and Russo, Francesco, (eds.), (1998), L'altra Europa. L'Europa centrale e $i$ Balcani verso l'Unione Europea, Napoli, Edizioni Scientifiche Italiane.

Puşcaş, Vasile, (2006), European negotiations. A case study: Romanian accession to the European Union, Quaderni di Futuribili, no. 7.

Puşcaş, Vasile, (2013), EU accession negotiations (A handbook), Vienna, Hulla and Co. Human Dynamics KG.

Radermacher, Franz Josef, (2004), Balance or destruction, Vienna, Oekosoziales Forum Europa.

Randers, Jorgen, (2013), 2052. Scenari globali per i prossimi quarant'anni, Milano, Edizioni ambiente.

Rifkin, Jeremy, (2004), Il sogno europeo, Milano, Mondadori. 
Rinaldi, Niccolò, (1995), "L'immagine dell'Europa nel mondo", in Bettin Lattes, Gianfranco, (ed.), La società degli Europei, Bologna, Monduzzi, 327-350.

Rosamond, Ben, (2000), Theories of European integration, Houndsmills, MacMillan

Sandholtz, Wayne and Stone Sweet, Alec, (1997), "European integration and supranational governance", in Journal of European Public Policy, no. 4, 297-317.

Scartezzini, Riccardo, (2002), "Cittadinanza europea e identità nazionali”, in Bettin Lattes, Gianfranco, (ed.), Bologna, Monduzzi, 377-400.

Shelley, Monica and Winck, Margaret, (eds.), (1995), Aspects of European cultural diversity, New York, Routledge.

Sidjanski, Dusan, (2007), Une vision futurible de la Constitution federative européenne", in Baldocci, Pasquale Antonio and Gasparini, Alberto, (eds.), L'Europa in bilico/ L'Europe en suspens, Quaderni di Futuribili, no.9, 87-110.

Spinelli, Altiero, (2010), “Gli Stati Uniti d'Europa e le varie tendenze politiche”, in Spinelli, Altiero and Rossi, Ernesto, (eds.), Il Manifesto di Ventotene, Milano, RCS, 39-72.

Wilson, Jeanne L., (2012), Soft power. A comparisons of discourse and practice in Russia and China. Working Paper Series, SSRN eLibrary (http://ssrn.com/abstract=2134457). 


\section{Table of Contributors}

\section{Nicolas BADALASSI}

Post-doctoral researcher, Université Sorbonne Nouvelle - Paris (France)

\section{Iordan Gheorghe BÄRBULESCU}

President of the Romanian Association of International Relations and European Studies

Professor of International Relations and European Studies, Dean of the Department of International Relations and European Intergration, National University of Political Studies and Public Administration, Bucharest (Romania)

\section{Gérard BOSSUAT}

Professor Emeritus, Université de Cergy- Pontoise (France)

\section{Georgiana CICEO}

Associate professor of European Studies, Faculty of European Studies, BabeşBolyai University Cluj-Napoca (Romania)

\section{Georgi DIMITROV}

Professor Dr. Habil., European Studies Department, St. K1. Ohridski University of Sofia (Bulgaria)

\section{6. Łukasz DWILEWICZ}

Lecturer, Department of Economic and Social History, Warsaw School of Economics (Poland)

\section{Gergely FEJERDY}

Associate Professor of Contemporary History, Pázmány Péter Catholic University, Budapest (Hungary)

Senior Research Fellow, Hungarian Institute of International Affairs (Hungary)

\section{Alberto GASPARINI}

Professor of Urban and Rural Sociology, University of Trieste (Italy)

\section{Michael GEHLER}

Professor for Modern German and European History, University of Hildesheim (Germany) 
Chairman of the Historical Commission of the Austrian Academy of Sciences in Vienna (Austria)

\section{Vladimir GONĚC}

Professor of European Construction, Institute of Political Sciences of Slovak Academy of Sciences (Slovakia)

\section{Marius JUCAN}

Professor of American Studies, Department of International Relations and American Studies, Faculty of European Studies, Babeş-Bolyai University ClujNapoca (Romania)

\section{Janusz KALIŃSKI}

Professor, Department of Economic and Social History, Warsaw School of Economics (Poland)

\section{Jerzy $Ł A Z O R$}

Assistant Professor, Department of Economic and Social History, Warsaw School of Economics (Poland)

\section{Lucian LEUȘTEAN}

Associate professor, Faculty of History, Alexandru Ioan Cuza University of Iași (Romania)

\section{Wilfried LOTH}

Professor of Modern and Contemporary History (Chair), University of DuisburgEssen (Germany)

Chairman of the EU Liaison Committee of Historians

\section{Wojciech MORAWSKI}

Dean of Undergraduate Studies, Warsaw School of Economics (Poland)

\section{Valentin NAUMESCU}

Associate Professor of Comparative Politics, Security Studies, and Foreign Policy and Diplomacy, Department of International Relations and American Studies, Faculty of European Studies, Babeş-Bolyai University Cluj-Napoca (Romania)

\section{Michael O'NEILL}

Jean Monnet Professor of European Politics, Nottingham Trent University (United Kingdom) 


\section{Nicolae P $\breve{A U N}$}

Professor Jean Monnet Ad Personam of European Integration

Dean of the Faculty of European Studies, Babeş-Bolyai University Cluj-Napoca (Romania)

\section{Ovidiu PECICAN}

Professor of European Studies, Faculty of European Studies, Babeş-Bolyai University Cluj-Napoca (Romania)

\section{Ioan-Aurel POP}

$\mathrm{PhD}$ Professor, Member of the Romanian Academy

Rector of Babeș-Bolyai University Cluj-Napoca (Romania)

\section{Andra-Maria POPA}

$\mathrm{PhD}$ Student, Department of International Relations and European Intergration, National University of Political Studies and Public Administration, Bucharest (Romania)

\section{Roumiana PRESHLENOVA}

Associate Professor, Institute of Balkan Studies with a Center for Thracology, Bulgarian Academy of Sciences, Sofia (Bulgaria)

\section{Branislav RADELJIĆ}

Senior Lecturer in International Politics, School of Law and Social Sciences, University of East London (United Kingdom)

\section{Sylvain SCHIRMANN}

Professor of Contemporary History, Université Robert Schuman, Strasbourg Director of Institut d'Etudes Politiques de Strasbourg (France)

\section{Ewa SZCZEPANKIEWICZ-RUDZKA,}

Professor Assistant, Institute of Political Studies and International Relations of the Jagiellonian University, Cracow (Poland)

\section{Sara TAVANI}

Research fellow, University of Perugia (Italy)

\section{Antonio VARSORI}

Professor of History of International Relations, University of Padua (Italy)

Deputy-Chairman of EU Liaison Committee of Historians 
29. Wichard WOYKE

Professor emeritus of political sciences, Westfalian Wilhelms University, Münster (Germany)

30. Benedetto ZACCARIA

$\mathrm{Ph} . \mathrm{D}$. candidate in "Political Systems and Institutional Change", IMT Institute for Advanced Studies Lucca (Italy) 


\section{Publications of the European Union Liaison Committee of Historians}

- Poidevin, Raymond (dir.), Histoire des débuts de la construction européenne, mars 1948-mai 1950 - Origins of the European Integration, March 1948-May 1950, Actes du colloque de Strasbourg, 26-30 novembre 1984, Publications du Groupe de liaison des historiens auprès des Communautés européennes, vol. 1, Bruylant: Bruxelles/ Giuffré: Milano/ LGDJ: Paris/ Nomos Verlagsgesellschaft: Baden- Baden, 1986.

- Schwabe, Klaus (Hrsg.), Die Anfänge des Schuman-Plans, 1950/51 - The Beginnings of the Schuman-Plan. Contributions to the Symposium in Aachen, May 28-30, 1986, Publications of the European Community Liaison Committee of Historians, vol. 2, Nomos Verlagsgesellschaft: Baden-Baden/ Giuffré: Milano/ LGDJ: Paris/ Bruylant: Bruxelles, 1988.

- Serra, Enrico (a cura di), Il rilancio dell'Europa e i Trattati di Roma - La relance européenne et les Traités de Rome - The relaunching of Europe and the Treaties of Rome, Actes du colloque de Rome, 25-28 mars 1987, Publications of the Euro- pean Community Liaison Committee of Historians, vol. 3, Bruylant: Bruxelles/ Giuffré: Milano/ LGDJ: Paris/ Nomos Verlagsgesellschaft: BadenBaden, 1989.

- Trausch, Gilbert (Hrsg.), Die Europäische Integration vom Schuman-Plan bis $z u$ den Verträgen von Rom - The European Integration from the Schuman-Plan to the Treaties of Rome. Contributions to the Symposium in Luxembourg, May 17-19, 1989, Publications of the European Community Liaison Committee of Historians, vol. 4, Bruylant: Bruxelles/ Giuffré: Milano/ LGDJ: Paris/ Nomos Verlagsgesell- schaft: Baden-Baden, 1993.

- Dumoulin, Michel (dir.), Plans de temps de guerre pour l'Europe d'après guerre, 1940-1947 - Wartime plans for Postwar Europe, 1940-1947, Actes du colloque de Bruxelles, 12-14 May 1993, Publications of the European Community Liaison Committee of Historians, vol. 5, Bruylant: Bruxelles/ Giuffré: Milano/ LGDJ: Paris/ Nomos Verlagsgesellschaft: Baden-Baden, 1995.

- Trausch, Gilbert (dir.), Le rôle et la place des petits pays en Europe au XXe siècle

- Small countries in Europe: Their role and place in the XX ${ }^{\text {th }}$ Century, Publications of the European Community Liaison Committee of Historians, vol. 6, Nomos Ver- lagsgesellschaft: Baden-Baden, 2005. 
- Deighton, Anne/ Milward, Alan (eds.), Widening, Deepening and Acceleration: the European Economic Community, 1957-1963, Publications du Groupe de liaison des professeurs d'histoire auprès des Communautés européennes, vol. 7 , Nomos Verlagsgesellschaft: Baden-Baden/ Bruylant: Bruxelles, 1999.

- Loth, Wilfried (ed.), Crises and compromises: the European Project, 19631969, Publications du Groupe de liaison des professeurs d'histoire auprès des Commun- autés européennes, vol. 8, Nomos Verlagsgesellschaft: Baden-Baden/ Bruylant: Bruxelles, 2001.

- Varsori, Antonio (ed.), Inside the European Community. Actors and Policies in the European Integration from the Rome Treaties to the Creation of the 'Snake' (1958-1972), Publications of the European Community Liaison Committee of Historians, vol. 9, Nomos Verlagsgesellschaft: Baden-Baden, 2005.

- Bitsch, Marie-Thérèse/ Bossuat, Gérard (dir.), L'Europe Unie et l'Afrique. De l'idée d'Eurafrique à la convention de Lomé I, Publications du Groupe de liaison des professeurs d'histoire auprès des Communautés européennes, vol. 10, Nomos Verlagsgesellschaft: Baden-Baden, 2005

- Harst, Jan van der (ed.), Beyond the Customs Union: The European Communitys' Quest for Deepening, Widening and Completion, 1969-1975, Publications du Groupe de liaison des professeurs d'histoire auprès des Communautés européennes, vol. 11, Bruylant: Bruxelles/ LGDJ: Paris/ Nomos Verlagsgesellschaft: Baden- Baden, 2007.

- Loth, Wilfried (ed.), Experiencing Europe. 50 years of European construction 1957-2007, Publications du Groupe de liaison des professeurs d'histoire auprès des Communautés européennes, vol. 12, Nomos Verlagsgesellschaft: Baden-Baden, 2008.

- Anjo G. Harryvan / Jan van der Harst, Max Kohnstamm. Au European's Life and Work, Publications of the European Union Liaison Committee of Historians, vol. 13, NomosVerlagsgesellschaft: Baden-Baden, 2011.

- Johnny Laursen (Ed.), The Institutions and Dynamics of the European Community, 1973-83, Publications of the European Union Liaison Committee of Historians, vol. 14, NomosVerlagsgesellschaft: Baden-Baden, 2013.

- Claudia Hiepel (Ed.), European Integration in a Globalizing World, 1970-85, Publications of the European Union Liaison Committee of Historians, vol. 15, NomosVerlagsgesellschaft: Baden-Baden, 2014. 